DOE/EIA-0348(95)/2

Distribution Category

UC-950

\title{
Electric Power Annual 1995 Volume II
}

\section{December 1996}

\section{Energy information Administration}

Office of Coal, Nuclear, Electric and Alternate Fuels

U.S. Department of Energy

Washington, DC 20585-0650

\section{MASTER}

\section{DISTALBITION of THUS DOCWMENT is unewted}

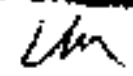

This report was proparad by the Enargy Information Administration, the fadependent statiaticel and analytical epency within the Departinent of Energy. The information contained here in should not bo construed as advoceting or reflacting any pollcy poshlion of the Department of Erargy or any other organizalion. 


\section{Contacts}

Questions regarding this report may be directed to:

Energy Information Administration. EI-52

Coal and Electric Data and Renewables Division

U.S. Department of Energy

1000 Independence Avenute, S.W.

Washington, D.C. 20585-0650

Questions of a general nature should be directed 10:

Howard Walion (202/426-1156)

Internet E-Mail: hwalton oeia.doe.gov

Ditector, Coal and Electric Data

and Renewables Division

Contributions to this report were provided by the tollowing employees of the Coal and Electric Data and Renewables Division (fax number 202/426-1 308):

Volume II Publication Coordinator:

Linda Bromley (202/426-1164),

Internet E-Maì: lbtomley eia.doe.gov;

The U.S. Electric Power Industry at a Glance:

Larry Prete (202/426-1161),

Channele Donald (202/426-1270);
U.S. Electric Vtility Retail Sales and Revenue;

Linda Bromley (202/426-1164),

Channele Donald (202/426-1270);

\section{U.S. Electric Utility Financial Satistics:}

Jerome A. Sanderson (202/426-1162) Investor, Thomas S. Wiltiams (202/426-1267) Investor, Charlene Harris-Russell (202/426-1 ]63) Pablic;

U.S. Electric Utility Environmental Statistics:

John G. Colligan (202/426*1174);

U.S. Electric Power Transactions:

John Makens (202/426-1165);

U.S. Electric Utility Demand-Side Management:

Linda Bromley (202/426-1164),

Channele Donald (202/426-1270);

U.S. Nonutilify Power Producers:

Betty Williams (202/426-1269),

The Energy Information Administration is committed to quality products and quality service. To ensure that this report meets the highest standards for quality, please forward your comments or suggestions about this publication to Linda Bromley at (202/426-1164) or Internet E-Mail: lbromley @eia.doe.gov.

For general inquiries about energy data, please contact the National Energy Information Center at (202/586-8800). Intectet users moy contact the centes at this address: infoctr oeia.doe.gov, 


\section{DISCLAMMER}

Portions of this document may be illegible in electronic image products. Images are produced from the best available original document. 


\section{DISCLAMER}

This report was preparted as in account of work apansorad by an apency of the United States Government Neither the United States Governmeat nor any osency thereof, nor eny of their employes, mukes any wartenty. expecss $\alpha$ implied, of asumes any iegal leabitity of responsibility for the acuency, completeness, of use-

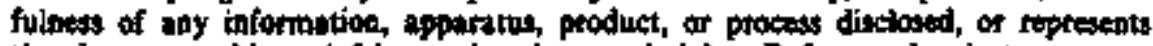
that its we would not infinge privately owaed rights Reference bextits to any specific commercial proctuct, process, ar service by trede name tndimark, manufac-

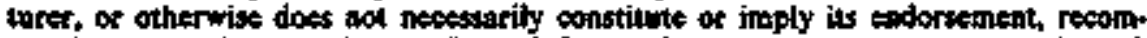
mendatios, or favoring by the Unitud Siates Governmest or any stency thereof. The viows and opinions of authors expressed hereid do not necessarily suate of riflest those of the Utited Statos Governened on iny atemby thereof. 


\section{Preface}

\section{Two-Volume Approach to the Electric Power Annual}

The Electric Power Annual is pubtished in two volumes, first released in 1995 . Volume I, released July 1996, focuses on U.S. electric utility data on net generation, fosal fuel consumption, stocks, receipts, and cost. Volume I also contains preliminary data on generating unit capability and planned additions, as well as estimated retail sales of electricity, associated revenue, and average revenue per kilowatthour of electricity sold. Also included in Volume $I$ is information on net generation and assaciated generating capability from renewable energy sources and the estimates for national-[evel nonutility data.

Volume II presents annual summary stalistics for the electric power industry, including information on both electric utilities and nonutility power producers. Included are the preliminary data for electric utility retail sales of electricity, assocjated revenue, and average revenne per kilowatthour of electricity sold and for electric utility fínancial statistics, environmental statistics, power transactions, and demand-side management. Final data for U.S. nonutility power producers on installed capacity and gross genetation, as well as supply and disposition information, are provided in Volume II.

The Eleciric Power Annual 1995, Volume II presents a oummary of electric power industry statistics at national, regional, and State lovels. The objective of the publtcation is to provide industry decisionmakers. government policymakers, analysts, and the general public with historical data that may be used in undetstanding U.S, electricity markets. The Electric Power Annual, Volume II is prepared by the Coal and Electric Data and Renewables Division; Office of Coal, Nuclear, Electric and AIternate Fuels; Energy Information Administration (EIA); U.S. Department of Energy.

In the private sector, the majority of the users of the Electric Power Annual, Volume II are researchers, analysts, and individuals with policymaking and decisionmaking responsibilities in electric utility compantes or other energy concerns. Other users include financial and investment institutious, economic development organizations, special interest groups, lobbyists, electric power associations, and the news media.

In the public sector, users include anajysts, researchers, statisticians, and other professionals with regulatory, policy, and progtam responsibitities for Federal, State, and local goveruments. The Congress and other legistative bodies are also interested in general trends related to electricity at Stale and national levels. Data in this report can be used in analytic studies 10 evaluate new legislation. Public service commissions and other special government groups share an interest in State-level statistjcs.

In Volume II, the section titled "The U.S. Electric Power Industry at a Glance" highlights key statistics for the year. Subsequent sections present data on electric utility retail sales and revenue, electric utility financial statistics, electric utility environmental statistics, electric power transactions, electric utility demand-side management, and nonutility power producers. Each section contains related text and tables and refers the reader to the appropriate publication that contains more detailed data on the subject matter. Monetary values in this publication are expressed in nominal terms.

Data published in the Electric Power Annual, Volume II are compiled from six forms filed annually by eleciric utilities and one form filed annually by nonutility power producers. These forms are described in detail in the "Technical Notes." 


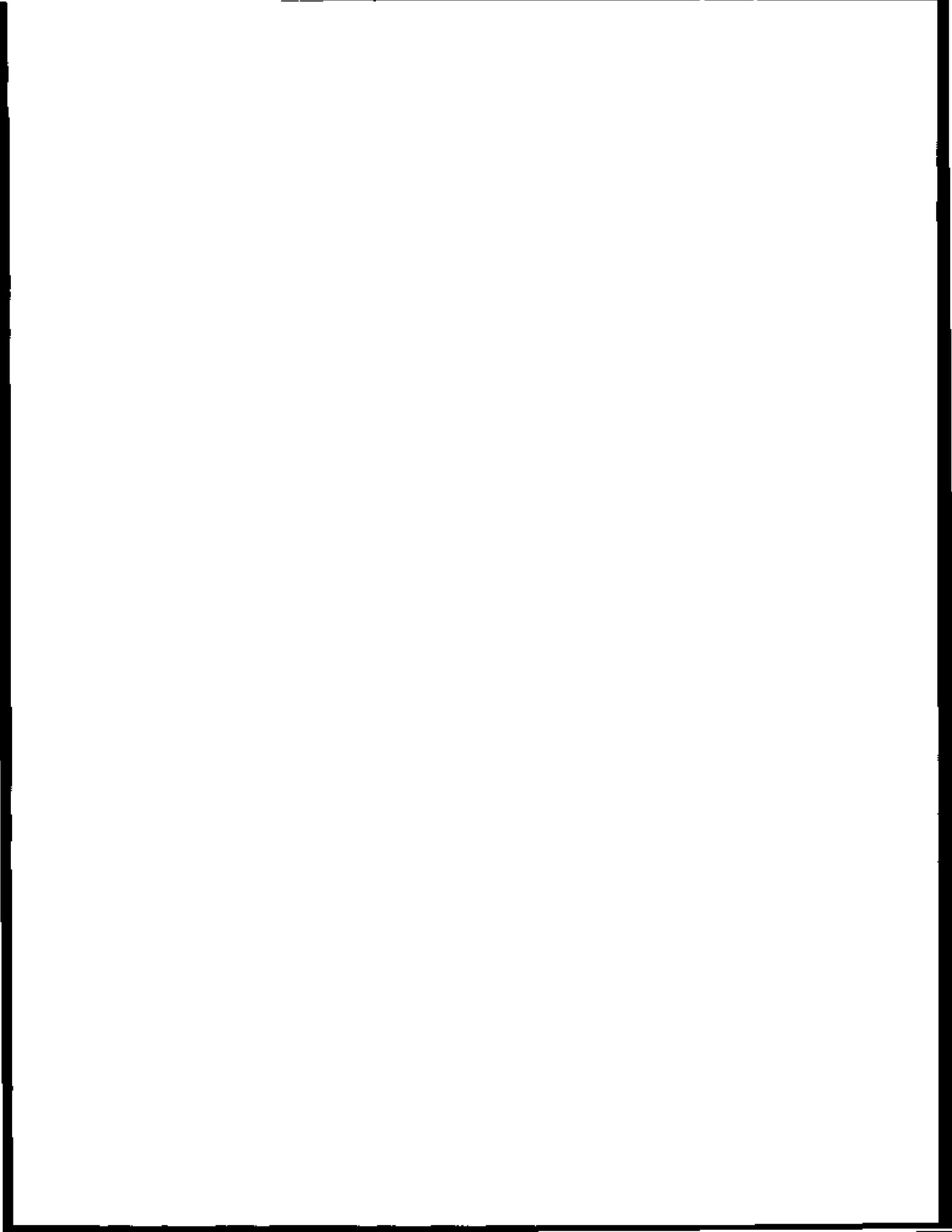




\section{Contents}

Poge

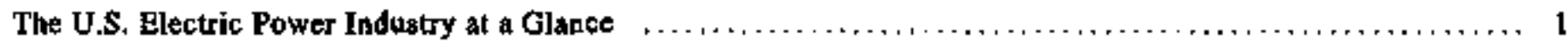

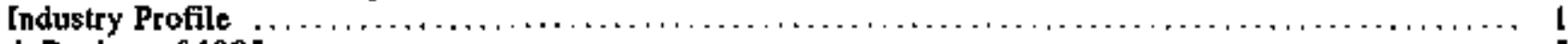

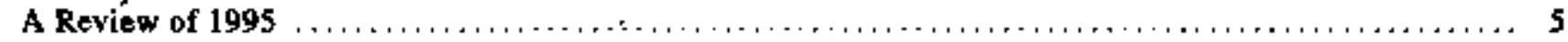

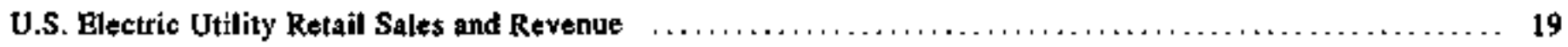

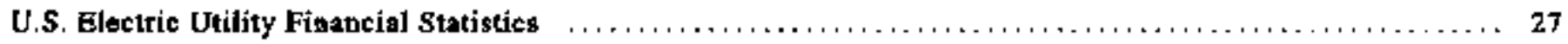

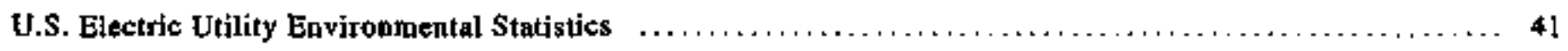

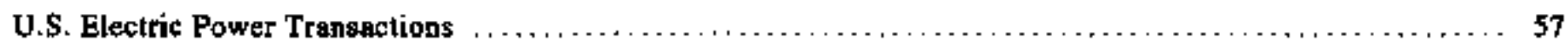

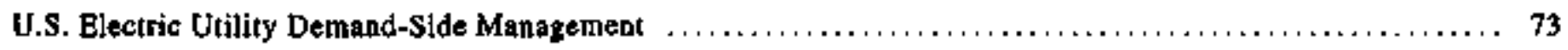

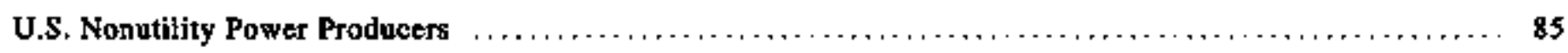

Appendices

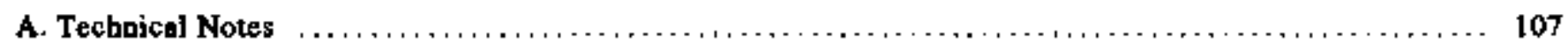

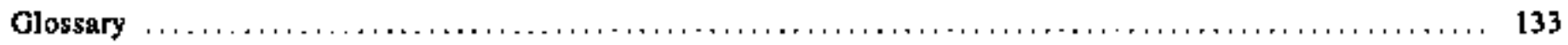




\section{Tables}

Page

1. Electric Power Industry Summary Statistics for the United States, 1994 and 1995 . . . . . . . ..... 15

2. U.S. Electric Utility Sales to Ultimate Consumers and Associated Revenue by Sector, 1991 Through

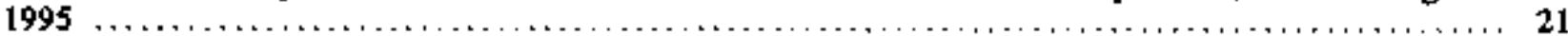

3. Average Revenue per Kilowatthour for U.S. Electric Utitities by Sector, 1991 Through $1995 \ldots \ldots \ldots .22$

4. U.S. Electric Uijity Sales to Ultinate Consumers by Sector, Cedsus Division, and State, 1994 and 199523

5. Number of Ultimate Consumers Served by U.S. Electric Utilities by Sector, Census Division, and State, 1994 and 1995

6. Revenue from U.S. Electric Utility Sales to Ultimele Consumers by Sector, Census Division, and State. 1994 and 1995

7. Average Revenue per Kilow atthour for U.S. Electric Utilities by Sector, Census Division, and State, 1994 and 1995

8. Composite Statement of lncome for Major U.S. lnvestor-Owned Electric Utilities, 1991 Throngh 1995

9. Composite Balance Sheet for Major U.S. Investor-Owned Electric Utilities, 1991 Through 1995

10. Composite Financial Indicators for Major U.S. Investor-Owned Electric Utilities, 1991 Through 1995

11. Revenue and Expense Statistics for Major U.S. Investor-Owned Electric Utitities, 1991 Through 1995

12. Revenue and Expense Percentages for Major U.S. Investor-Owned Electric Utilities, 1991 Through 1995

13. Average Operating Expenses for Major U.S. Investor-Owsed Electric Utilities, 1991 Through 1995

14. Composite Statement of Income for Major U.S. Pubjicly Owned Geverator Electric Utilities, 1991 Through 1995

15. Composite Balance Sheet for Major U.S. Publicly Owned Generator Electric Utilities, t 991 Through 1995

16. Composite Financial Indicators for Major U.S. Publicly Owned Generator Electric Utilities, 199I Thrọgh 1995

17. Revenue and Expense Statistics for Major U.S. Publicly Owned Generator Electric Utilities, 199 : Through 1995

18. Composite Statemenl of Income for Major U.S. Publicly Owned Nongenerator Electric Utilities, 1991 Through 1995 5 (1) 4 3 .

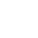

19. Composite Balance Sheet for Major U.S. Publicly Owned Nongenerator Electric Utilities, 1991 Through 1995

20. Composite Financial Indicators for Major U.S. Publicly Owned Nongenerator Electric Utilities, 1991 Through 1995

21. Revenue and Expense Statistics for Major $U . S$. Publicly Owned Nongenerator Electric Utilities, 1991 Through 1995

22. Estimated Emissions from Fossi]-Fueled Steam-Electric Generating Units al U.S. Electric Utilities, 1991 Through 1995

23. Ntimber and Capacity of Fossjl-Fueled Steam-Electric Generators for U.S. Eleciric Utilily Plants with Environmental Equipment, 1991 Through 1995

24. Estimated Emissions from Fossit-Fueled Steam-Electric Generating Units at U.S. Electric Utilities by Census Division and State, 1994 and 1995

25. Estimated Emissions from Fossil-Fueled Steam-Electric Generating Units at U.S. Electric Utilities by Fossil Fuel, Census Division and State, 1995

26. Number and Capacity of Coal-Fired Steam-Electric Generators for U.S. Electric Utility Plants with Environmeatal Equipment by Ceusus Division and State, 1995

27. Number and Capacity of Petroleum- and Gas-Fired Stean-Electric Generators for U.S. Electric Utility Plants with Envitonmental Equiptnent by Census Division and State, 1995

28. Average Quality of Fossil Fuels Burned at U.S. Electric Utilities by Census Division and State, 1994

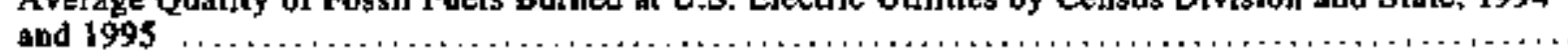

29. Avezage Flue Gas Desulfurization Costs at U.S. Electric Utilities by Census Division and Siate, 1991

30. Flue Gas Desulfurization (FGD) Capacity in Operation at U. $\mathbf{S}$. Electric Utility Plants as of December 1999

31. Sousces and Disposition of Electricity at U.S. Electric Utilities, 1991 Througb 1995

32. Net Genetation from U.S. Electric Utilities by North American Electric Reliability Council Region and Hawaij, 199] Through 1995 
33. U.S. Electric Utility Sales to Ultimate Consumers by Sector, North Ametican Electric Reliability Council Region, and Hawaii, 1991 Through 1995

34. Generating Capability at U.S. Electric Utilities by North Ametican Electric Reljability Council Region and Hawaji, as of December 1991 Through 1995

35. Noncoincidental Peak Load at U.S. Electric Utilities by North American Electric Reliability Counci] Region and Hawaii, 199! Through 1995

36. U.S. Electric Utility Recejpts by North American Electric Reliability Council Region and Hawaii, 199? Through 1995

37. U.S. Electric Utility Deliveries by North American Electric Reliability Council Region and Hawaii, 1991 Through 1995

38. U.S. Electrie Uiility Net Energy Flow by Nortb American Electric Retiability Council Region and Haweit, 1991 Through 1995

39. U.S. Electric Utility Purchases of Nonutility Generated Electricity by North American Electric Reliability Council Region end Hawaii, 1991 Through 1995

40. Net Imports at U.S. Electric Utilities by North American Electric Reliability Council Region and Hawati, 1991 Through 1995

Imports to U.S. Electric Utilities by North American Electric Reliabilily Council Region and Hawaii, 1991 Through 1995

42. Exports from U.S. Electric Uiiljties by North American Electric Reljability Council Region and Hawaij, 1991 Through 1995

U.S. Electric Utility Demand-Sjde Management Program Energy Savings, Actual and Potential Peak

Load Reductions, and Cost, 1991 Through 1995

44. U.S. Electric Utiljty Actual Peak Load Reductions by North American Electric Reliability Council Region and Hawaii, by Demand-Side Management Program Category, 1991 Through 1995

45. U.S. Electric Utility Demand-Side Management Program Annual and Incremental Effects by Program Categoty, 1995

46. U.S. Electric Utility Demand-Side Management Program Annual and Incremental Effects by Sector, I995

47. U.S. Electric Utitity Potential Peak Load Reductions by Direct Load Control and Interruptible Load and by North Annerican Electric Reliabijity Conncil Region and Hawaii, Selected Years

48. U.S. Electric Utility Demand-Side Management Energy Sovings by North American Electric Reliability Council Region and Hawaii, Selected Years

49. U.S. Electric Utility Demand-\$lde Management Cost by North American Electric Reliability Council Region and Haw aij, Solected Years

50. U.S. Electric Utility Demand.Side Management Direct and Indirect Cost, Selected Years

51. Number of U.S. Electric Utilities with Demand-Side Management Energy Efficiency Programs by End Uses and Program Types by Sector, 1995

52. Summary Statistics for U.S. Nonutility Power Producers, 1991 Through 1995

53. Installed Capacity at U.S. Nonutility Generating Facilities by Fossil Fuels, Renewable Enetgy Sources, and Census Division, 1991 Through 1995

54. Instalied Capactty at U.S. Nonutility Generating Facilities by Energy Source and Census Division, 1991 Through 1995

55. Installed Capacity at U.S. Nonutility Generating Facilities by Energy Source and State, 199] Through 1995

56. Installed Capacty at U.S. Nonutility Genetating Facilitjes by Qualifying Facility Stans and Census Division, 1991 Through 1995

Installed Capacity of U.S. Nonutilities Attribated to Major Industry Groups and Census Divisions, 1991 Through 1995

58. Gross Generation for U.S. Nonutility Power Producers by Energy Source and Census Division, 1991 Throught 1995

Gross Generation for U.S. Nonutility Power Producers by Energy Source and State, 1991 Through 1995

60. Gross Generation at U.S. Nonutility Generating Facilities by Qualifying Facility Status and Consus

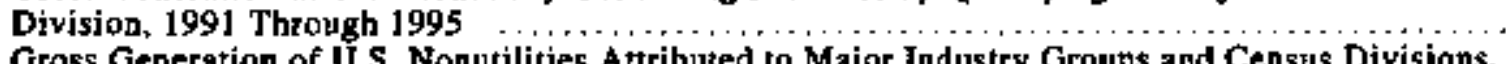
1991 Through 1995

62. U.S. Nonutility Electricity Supply and Disposition for Facilities by Census Division and State, 1995

A1. Installed Capacity at U.S. Nonutility Generating Facilities by Producing Energy Group and Census Division, 1993 Through 1995

A2. Gross Generation by U.S. Nonutitity Generating Facilities by Producing Eaergy Group and Census Division, 1993 Through 1995

A3. SuJfur Dioxide, Nitrogen Oxide, and Carton Dioxide Enission Factors

A4. Carbon Dioxide Emission Factors for Coal by Rank and State of Origin

A6. Unit-of-Measure Equivalerts 


\section{Illustrations}

Page

1. U.S. Electric Utility Sales to Ultínate Consumers by Class of Ownership. $1995 \ldots \ldots \ldots \ldots \ldots \ldots \ldots 10$

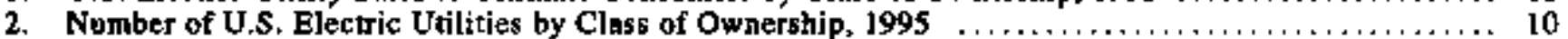

3. Number of Ultimate Consumers Served by U.S. Electric Utilities by Class of Ownership. 1995 ...... 11

4. Revenue from U.S. Electric Utility Sales to Ultimate Consumers by Class of Ownership, $1995 \ldots \ldots$. $\ldots$

5. U.S. Electric Utility Sales for Restale by Class of Ownership, $1995 \ldots \ldots \ldots \ldots \ldots \ldots \ldots \ldots \ldots, 12$

6. Revenue from U.S. Electric Utility Sales for Resale by Class of Ownership. $1995 \ldots \ldots \ldots \ldots \ldots \ldots$. 12

7. U.S. Electric Utility Sales to Ultimate Consumers by Sector, $\mathbf{1 9 9 5} \ldots \ldots \ldots \ldots \ldots \ldots \ldots \ldots \ldots \ldots \ldots$

8. U.S. Electric Utility A verage Revenge per Kilowathour by Sector, $1995 \ldots \ldots \ldots \ldots \ldots \ldots \ldots \ldots, 13$

9. Installed Capacity at U.S. Nonutility Generating Facilities by Type of Facility, $1995 \ldots \ldots \ldots \ldots \ldots$. 14

10. Planned Capacity Additions for U.S. Nonutility Generating Facilities by Energy Source, as of

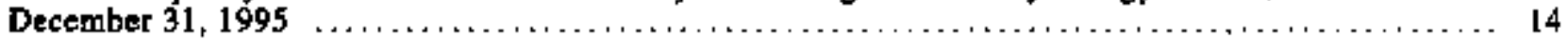

11. Aljocation of the Revenue Dollar from Electric Operations for Major U.S. Investor-Owned Electric Utilities, 1995

12. Electric Operating Expenses for Major U.S. Investor-Owued Electric Uujlities, 1995

13. Average Operating Expenses of Fossi]-Fueled and Nuclear Steam-Electric Plants for Major U.S. Investot-Owned Electric Utilities, 1995

14. North American Electtic Reliability Council Regions for the Contiguous United States and Alaska .... 60

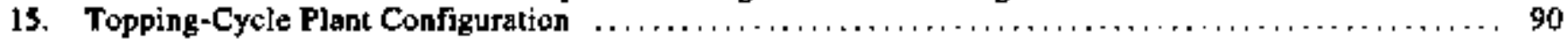

16. Bottoming-Cycle Plant Confguration $\ldots \ldots \ldots \ldots \ldots \ldots \ldots \ldots \ldots \ldots \ldots \ldots \ldots \ldots \ldots \ldots, \ldots \ldots \ldots$ 


\section{The U.S. Electrlc Power Industry at a Glance}

The ftrst section of this chapter provides a profite of the electric power industry in the United States. The second section summarizes pertinent statistics on various aspects of the U.S, electric power industry for the year and includes a graphic presentation.

\section{Industry Profile}

The U.S. electric power industry is composed of tradjtional electric utilities; nontraditional electricityproducing companies, also known as nontulilities; and, dwe to restructuring of the industry, new industry particjpants such as power marketers and brokers. The traditional electric utitities, investor-owned, publicly owned, cooperative, and Federal ulilities, ate generally companies tbat provide generation, transmission, distribution, and/or energy services for all customers in a designated service territory. In addition to the traditional electric utilities, there are new nontraditional entities in the electric power industry such as noujtility powet prodocers, power marketers, and power brokers.' The electric power industry in the Unjted States historically has been a highly regulated, monopolistic indestry. However, with passage of Federal legislation in recent years, the industry is in the process of becoming less regulated and more competitjve. Signifjcant changes are taking place as the industry transitions from the traditional monopolistic structure to a competitive structure. Conlipuing deregulation of the industry at both the Federal and State levels has the potential to jncrease competition and change the nature of the way electricity is priced. traded, and marketed in the United States.

\section{Tradlitional Electric Utilltes}

Investor-Owned Electric Utilitiles. Investor-owned electric utilities currently account for more than 75 percent of all U.S. electric utility generating capability, generation, sales, and revenue. Investor-owbed utilities operate in all States except Nebraska. Like al] private businesses, investor-owned electric utilities bave the objective of producing a teturn for their investors. They elther distribute their profits to stockholders as djvidends or reinvest these profits. They are granted service monopoites and are obligated to serve all cuslomers in their service areas. As franchised monopolies, these electric utilities are regulated and requited to charge reasonable and comparable prices to similar classifications of consumers and to give consumers access to services under similar conditions. Most investor-owned electric utilities are operating companies that provide basic services for the generation, trapsuitssion, and distribution of electricity. The majority of jnvestor-owned electric vitilities perform all three functions. As the industry becomes competitive, utilities are organizing generation, transmission, distribution, and energy services into separate business units, and prices for these fitnctions are being unbundled.

I In this report, the following defluttiont are used to disttogulsh between the traditional olectric tiility and nonuliltiy power producer: \&n electric utibly is any person, corporalion, municipaltty. Stute, polteical subdivision or agency, iczlgation project, Federal power adminia-

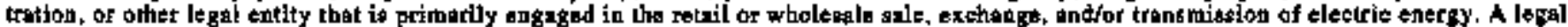

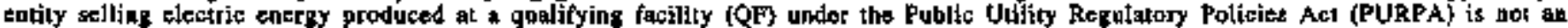

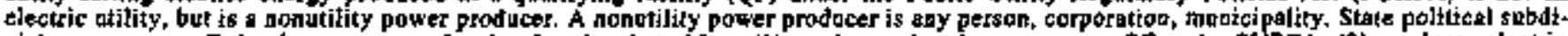
vision or arency. Federal aseney, or other lepal enbly that eicher: (1) produces electrite energy as a QP under PURPA. (2) prodaces electrie energy bat is primarily engaged in business aclivities other tban the salo of electric enercy, snch as apriculture, mintog, manufacturing.

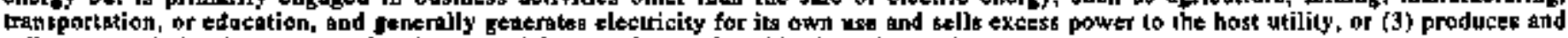
sells power wholtsalo at nocregulated rales and does not have a fraschised aervice territory. 
Publicly Owned Electric Utilities. Publicly owned electric utilities in the United States are nanprofit local government agencies ostablished to serve their communities and nearby consumers at cost. remrniog excess funds to the consumer in the form of commuaity contributions, econontic and efficient facilities, and reduced rates. Publicly owned electric utilities include municipals, public power districts, State authorilies, irrigation distriets, and other State otganizations. Most municipal electric utilities simply distribute power, although some large ones produce and transmit electricity as well. They obtain their fiancing from municipal treasuries and from revenue bonds secured by proceeds from the sale of electricity. Public power districts and projects are concentrated in Nebraska, Washington, Oregon, Arizona, and California. Voters in a public power district eleat commissioners or directors to govern the district, independent of any municipal government. State authoritios, like the Power Authority of the State of New York or the South Carolina Public Service Authority, are agencies of their respective State goveroments. Itrigation districts may have still other forms of organization. In the Salt River Project Agricultural Improvement and Power District in Arizoca, for example, votes for the Boerd of Ditectors are apportioned according to the size of landholdings.

Cooperative Electric Utilities. Cooperative electric utilities in the United States are owned by their members and are established to provide electricity to those members. The Rural Utilities Service (formerly the Rural Electrification Administration in the U.S. Department of Agriculture was established under the Rural Electrification Act of 1936 with the purpose of extending electric service to small rural communities (usually fewer than 1,500 consumers) and farms where it was relatively expensive to provide service. Cooperatives are incorporated under State law and are ustally directed by an elected board of directors, which in turn selects a manager. The National Rural Utilities Cooperative Finance Corporation, the Federal Fitrancing Bank, and the Bank for Cooperatives are the most important soturces of debt financing for cooperatives. Cooperatives operate in all States except Connecticut, Hawait, and Rhode Istand and the District of Columbia.

Foderal Electric Lthities. Federal electric utilities are primarily producers and wholesalers of electric power and do not produce any profit. As required by law, preference in purchasing the electricity produced is given to publicly owned and cooperative electric utilitjes and to other nonprofjt entities. Wholesale Federal producers include the U.S. Army Corps of Engineers, the U.S. Bureau of Reclamation, and the International Boundary and Water Commission. Power produced by these Fedetal entities is marketed by Federal power marketing administrations in the U.S. Department of Energy: Bonneville, Southeastern, Soutbwesterm, and Western Area. The Federal power marketing auministrations operate in all areas except the Noriheast, upper Midwest, and Hawati. The largest producer of Federal electricity, the Tennessete Valley Authority, markets its own power. The Alaska Power Administration operates and distributes power from its own jrojects; also, it markets both the wholesale and retail electricity. On Navember 28,1995 , the President signed a bill avthorizing the sale of the Alaska Power Administration's projects. Final transfer of title to the State of Alaska and three utilities is anticipated in November, 1997. 


\section{The Changing industry}

The electric power industry, spurred by the passage of several bills including the Public Utility Regulatory Policies Act of 1978 (PURPA) and the Energy Policy Act of 1992 (EPACT), is evolving from a highly regulated, monopolistic industry to a less regulated, competitive industry. This evolving industry includes new participants such as exempt wholesale generators (EWG's) and power marketers.

PURPA facititated the emergence of a group of nonutility electricity-producing companies called qualifying facilities (QF). Qualifying facilities receive certain benefits under PURPA. Under PURPA for small power producers and conenerators to receive status as a $\mathrm{QF}$, the facitity must produce electric and snother form of useful thermal energy through the sequential use of energy, and must moet certsin ownership, operating, and efficiency requirements established by the Federal Energy Regulatory Commission (FERC). The facility must generate electricity with at least 75 percent total emergy input from biomass, renewable resoarces, or geothermal energy as the primary source. Cogenerators are generating facilities that produce electricity and another form of useful thermal energy, usually beal or steam, for industrial processes or heating or cooling purposes. Qualifying facilities receive certein benefits under PURPA. ${ }^{2}$

Also considered nonutilities in the United States are independent power producers. These entities are wholesate electricity producers and are unaffiliated with the franchised utilities in the area in which they sell power. Unlike traditional electric utilities, IPP's do not possess transmission facilities and to nol bave retail sales of power. By definjtion, a facility that has QF status under PURPA is not an IPP.

The Energy Policy Act of 1992 (EPACT) moditied the Public Utility Holding Company Act (PUCHA) and created another class of nonutilities, exempt wholosale generators (EWG). ${ }^{3}$ EPACT exempted EWG's from the corporate and geographic restrictions that PUHCA imposed. With this modification, public utiljty holding companies ate allowed to develop and operate independent power projects anywbere in the world.

The EPACT also amended the Federal Power Act (FPA) such that any electric utility can apply to the FERC for an order requitring another electric utility to provide transmission services (wheeting). Prior to EPACT, the FERC could not mandate an electric utility provide wheting services for wholesale electrie trate. This change in the law permits owners of electric gentrating equipmeat to sell wholesale power (sales for resale) to noncontiguous vtilities. More recently, the Federal Energy Regulatory Commission (FERC) issued two final orders, 888 and 889, jimplementing EPACT's provisions for open access to transmission lines. Otder 888 addresses equal access to the transmission grid for atl wholesale buyets and sellers, transmission pricing, and the recovery of stranded costs. Stranded costs are the investments made by utijities under the regulated environment that may not be recoverable in market-based rates in a competitive eovironment. Order 889 requires jurisdictional utilities that owa or operate transmission facilities to establish olectronic systems to share information bout their available transmission capacities. In response to these rulemakings, utilities are proposing to form Independent System Operators (ISO) to operate the transmission grid, form regional transmission groups, and develop open aceess same-time information systems (OASIS) to inform all competitors of the ayailable capacity on their lines.

The provision for open transmission access in EPACT has also facilitated the tale of new particlpants in the electric power industry, power marketers and power brokers. Power marketers are entities engaged in buying and selling wholesale electricity and fall under the jurisdiction of the FERC, since they take ownership of electricity and are engaged in interstate trade. Power brokers, who do not take ownership of electricity, are not regulated by the FERC. A growing number of power matketers have filed with the FERC and had their rates approved. These power marketers generally do not possess geperation or transmission facilities or sell power to retail castomers. However, with the continuing deregulation of the industry, and the existence of pilot programs for retail choice that some States are initialing, power marketers are beginning to enter retail electricity markets. Due to deregulation, power marketers are increasing their presence in the electric power industry.

Additionally, State legislatures and the Congress are considering legisiation that wilt allow competition in retaj] sales of electric power. At least two States, Rhode Island and California, have passed bills that will altow end-use custoners in their States to begin choosing among competilive genetation suppliers by 1998. Transmission and distribution will remain regulated functions with rules to assure open access to lines for all competitors. Continuing deregulation st both Federal and State levels is transformtug the historically monopolistic electric power industry into a competitive industry that will eveniually increase competition in the genteration and service components of the efectric power industry, and change the nature of the way electricity is priced, odded, and marketed in the United States.

\footnotetext{
I See the chnpter "Nowutility Power Producera" for a doscription of these benefits.

1 EWG's are nat contidered ejectric atilites wader PUHCA; they are restricted to selling wholesake power to electric utilites and muaicipolites. For this report. EWG's are classified as nonutilities. However, EWG't were considered to be eloctric ptilities under the Pederal Power Act.
} 


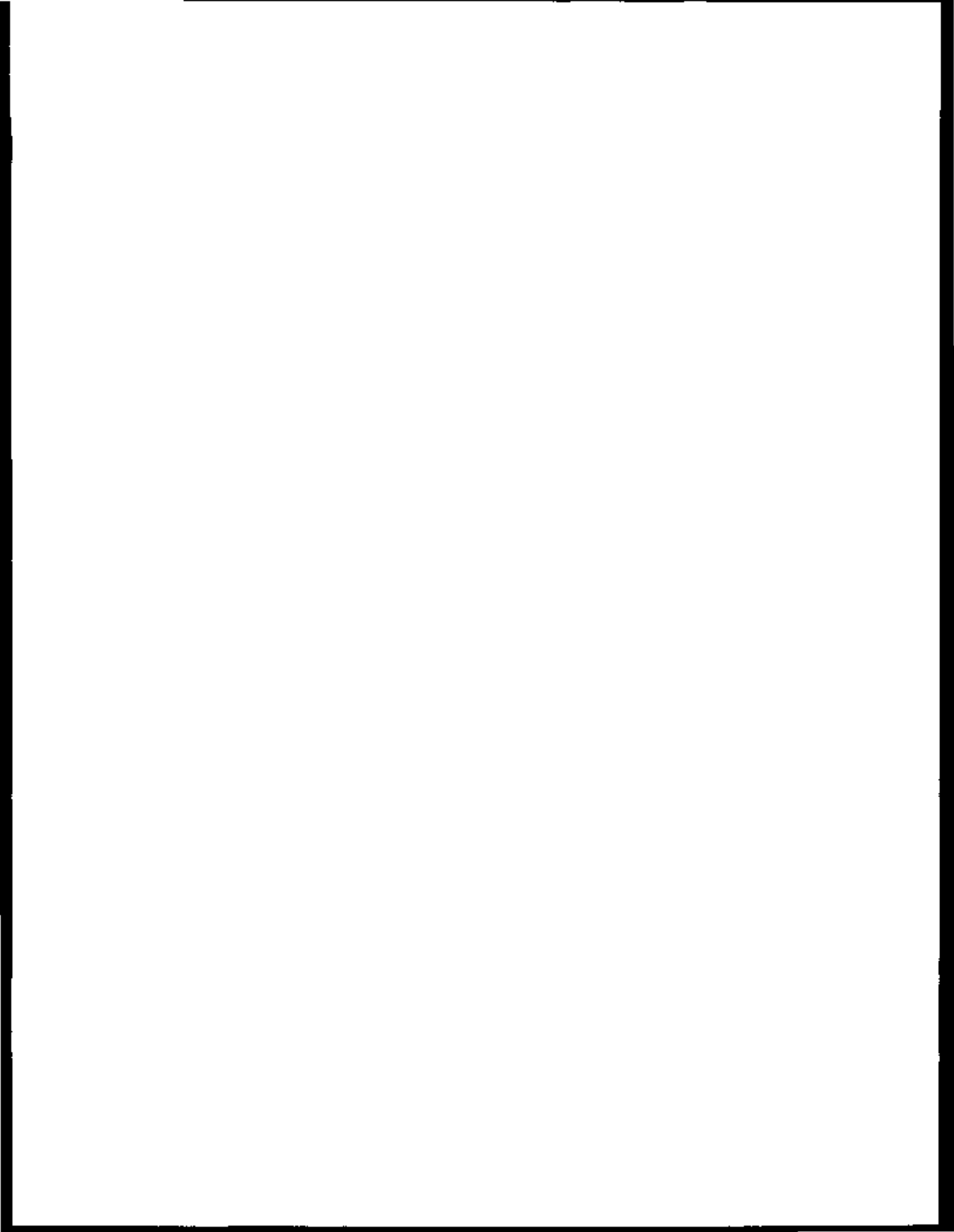




\section{A Review of 1995}

A graphic presentation (Figures I through 10) on the U.S. electric utjlity industry includes: retajl sates of electricity, associated tevenue, and average revenue per kitowatthour sold by class of ownership; number of ultimate consumers served and number of electric utilities by class of ownership; sales for resale and associated revenue by class of ownership; net sales and average revenue per kilowatthour by sector; and nonutility installed and planned capacity. These data are collected and compiled from various sousces, as indicated in the Preface.

\section{U.S. Electric Uillity Statistles}

Retall Sales and Revenue. In 1995, sales of electricity to ultimate consumers increased to 3,013 billion kilowatthours, approximately 2.7 percent more than the 2,935 billion kilowatthours recorded in 1994 . Revenue from retail sales increased from $\$ 203$ bitlion in 1994 to $\$ 208$ biltion in 1995, a 2.5-pertent increase (Table 1). Average revenue per kitowalthour decreased slightly, from 6.91 cents is 1994 to 6.89 cents in 1995 .

Residential sales increased by 3.4 percent to 1,043 billion kilowatthours; commercial by 5.2 percent 10 863 billion kilowatthours and industrial by 0.5 percent 10 1,013 billion kilowatthours; other decreased 2.5 percent to 95 billion kilowatthours. Revenue frori residential consumers increased 3.6 percent to $\mathbf{5 8 8}$ billion and commercial increased 4.7 percent to $\$ 66$ billion; industrial revenue decreased 1.9 percent to $\$ 47.2$ billion; and other remained steady at $\$ 7$ billion. The decrease in industrial revenue and increase in sales is indicative of the trend of falling industrial rates. This can be attributed to utilities sbifling con. sumers between the industrial and commercial sectors and a willingness to negotiate with industrial consumers for lower rates in response to rising competition in the electric power industry.

Average revente per kilowatthour was 8.40 cents in the residential sector, 7.69 cents in the commercial sector, 4.66 cents in the industrial sector, and 6.88 in the other sector. Average revenue for the residential sector is generally higher than for the other sectors, due in part to the relatively snall consumption level per consuner and the relatively low load factor. The load factor is average load expressed as a percentage of the peak load. Generally, a consumer whose average load is low relative to its maximum demand is more costly to serve than a consumer whose load factor is bigh. Residential consumers typically have a lower losd factor than industrial consumers.

Among the ownership classes, in vestor- $\alpha$ wned electric ptilities account for more than 75 percent of all retail sales and revenue, with publicly owned and cooperative electric utilities providing the remainder.
Federal electric utilities are primarily wholesalers of electricity. Sales to ultimate consumers increased in 1995 for electric vtilities in all ownership classes: investor-owned, by 2.5 percent to 2,292 billion kilowatihours; pobjicly owned, by 2.4 percen to 432 billion kilowatthours; cooperatives, by 5.0 percent to 240 billion kilowatthours; and Federal, by 6.0 percent to 50 billion kilowatthours. Revenue likewise increased for all ownership classes: investor-owned, by 2.6 percent to $\$ 164$ billion; publicly owned, by 1.1 percent to $\$ 26$ billion; cooperatives, by 3.7 pereent to $\$ 17$ billion; and Federal, by 3.2 percent to $\$ 1$ billion.

Average revenue per kilowatthour decreased for all ownersbip classes except investor-owned electric utilities that increased slightly in 1995 to 7.15 cents from 7.14 cents in 1994. For publicly owned electric util\$fies, the average revenue per kilowatthour decreased from 6.10 cents to 6.02 cents; cooperatives from 7.01 cents to 6.92 cents; and for Federal electric utilities from 2.76 cents in 1994 to 2.69 cents in [ 993 .

Federal electric utilities generally have the lowest average revenue per kilowatthour because they have access to relatively low-cost financing and generally utilize facilities that are relatively inexpensive to operate. Because publicly owned electric utilities also have access to relatively low-cost financing and are nonprofit entities, they have lower average revenue per kilowathow than investor-owned electric utilities. Although cooperative tlectric atilitits have economic advantages similar to those of publicly owned electric utilities, they generally serve sparsely populated areas and provide service to a higher percentage of rural residential customers than other classes of electric utilities. As a conseguence, cooperative electric utiljlies generally have a higher average revenue per kilowatthour than do publicly owaed electric utijities.

Financisl. In 1995 , the major investor-owned olectric utilities had electric utility operating revenues of $\$ 183.7$ billion. Electric operating expenses $\$ 150.6$ billion) increased by only 1.3 percent resulting in an increase of $\mathbf{\$ 2 . 4}$ billion (7.9 percent) in operating income. Electric generating and maintenance expenses excluding fuel went down $\$ 1.5$ billion in 1995 from 1994. Net income ( $\$ 22.0$ billian) showed an increase of 10.9 percent from 1994. Earnings available to common stock increased by $\$ 2.2$ billion or 12.2 percent. Earnings available per average common share were $\$ 3,04$, continuing its sleady increase.

In 1995, investment in the major inyestor-owned segment of the industry was $\$ 578.9$ billion, an increase of $\$ 4.4$ billion from 1994 . Electric utility construction work in progress (CWIP) was \$13.5 billion, a decrease of 21.1 percent from 1994 and a decrease of 34.5 percent from 1992. The total asset enrnover ratio (operating revenues divided by total assets) remained aboul the same at 0.35 . Total capitatization of $\$ 365.8$ biltion increased by $\$ 1.0$ billion from that in 1994. The percent of long-term debt to total captlalization stood at 47.5 . down from the ratio of 48.1 in the previous year. 
In 1995, the major publicly owned generator electric utilities had electrict utility operating revenue of $\$ 20.8$ down by 11.9 percent. Generator electric utility operating expenses decreased by $t 1.6$ percent, resulting in an increase in net income (\$0.1 bi]lion) of 14.9 percen1. Total assets for publicly owned generator electric utilities decreased 14.8 percent to $\$ 99.5$ billion. The Electric Utility Plant per Dollar of Revenue ratio was 4.0 in 1995.

In 1995, the major publicly owned nongenerator electric utilities had electric utility operating revenue of $\$ 8.4$ billtion, a 4.4-percent growth over 1995. Nongenerator electric utility operating expenses increased by 4.4 percent to end the year at $\$ 7.9$ billion. Net income for nongenerators remained \$0.4 billion. Total assets for nongenterator electric ytilities increased by 14.4 percent to end the year at $\$ 11.8$ billion. The Electric Utility Plant per Dollat of Revenue ratio was $\$ .2$ in 1995.

Environmental. In 1995, air emissions from electric utility operated fossil-fueled steam electric plants were estimated at less than 12 million tons of sulfur dioxide $\left(\mathrm{SO}_{2}\right) ; 7$ million tons of nitrogen oxides $(\mathrm{NO})$; and 1,968 million tons of carbon dioxide $\left(\mathrm{CO}_{2}\right)$. There was a decrease in the $\mathrm{SO}_{2}, \mathrm{NO}_{\mathrm{x}}$ and $\mathrm{CO}_{2}$ emissions for 1995 from the previous year. The most signifficant was for $\mathrm{SO}_{2}$ emissions, a decrease of more than 19 pereent. This decrease is mostly due to power plants that must comply with restrictions on $\mathrm{SO}_{2}$ emissions specified in Phase I of the Clean Ais Acl Amendments of 1990 (CAAA-90), which became effective in January 1995. The electric utilities owning the 110 power plants targeted to reduce $\mathrm{SO}_{2}$ emissions (onder Phase I provisions) selected from several of the strategies available to them to meel those goals. The strategy elected by many of the utilities was relying on the consumption of lower sulfur coal to meet the requirements. Some utilities added pollution abatement equipment to boilers, retired or reworked boilers, or used a combination of strategies including tarned or purchased aliowances to meet the enissions standards.

Flue gas desulfurizations (FGD) sometimes referred to as scrubbers use chemicals such as liate to remove sulfur oxides from the combustion gases of boiters before the gases are discharged into the atmosphere. In 1995, there were 177 generators connected to scrubbers at U.S. power plants, compared with $16 B$ in [9\$4 and 137 in 1985, a 5- and 29-percest incresse, respectively. The average sulfur content of coal detivered to all U.S. electric utility plants decreased from 1.17 percent by weight in 1994 to 1.08 percent by weight in 1995.

Power Transactions. On a netional level, wholesale power receipts (purchased power plus excbanges received and wheling received) increased to 2,020 biljon ki]owatthours in 1995 fom 1,927 billion kilowatthours in 1994. Each year, however, as total trade increased, the exchange-received components decteased. This pattern reflects a structural change in the wholesale trade sector of the electric power incustry. From a national total of 241 billion kilowatthours jn 1991 to 159 billion kilowatthours in 1995, exchanges received fell nearly 80 billion kilowatthours. The electric power industry has shifted away from in-kind exchanges of electricity to purchesed power transactions as increased price competition has become apparent among traditional electric utikities."

In 1995, the noncoincidental peak load at electric utillites in the contiguous U.S. showed an increase of 6 percent growth from the prior year to 621 million kilowatts for the sumamer pertod. The winter peak hoad period reversed its decline from the prior year and increased 26 million kilowatts, to 545 million kilowatts for the contiguous U.S.. By the year 2000 , the contiguous U.S. winter and summer peak loads are expected to grow to 585 and 661 million kilowatts, respectively.

In 1995, United States imports of electricity dropped to 47 billion kilowathours of electricity from Canada and Mexico and exports increased to over 9 billion kilowatthours. More than 23 billion kilowatthours entered the Uniled States at the northeastern border, while over 7 billion kilowatthours entered througb Washington State for consumption in the West. More than three-fourths of the the electricity exported was transmitted from the Western Systems Coordinaling Council (WSCC).

\footnotetext{
4 In 1990, the Federal Energy Regulatory Commit tow (FERC) changed its treatment of one wholegale trade accosut. The definition for

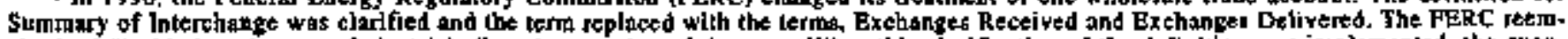
phasjzed "in-find excfianges of electriefly" as the nentibt of the term. When this clarification of the defiaitroa was implemented, the quantity of etectricity reported traded in this category dropped trearly in half, from 427 billiav kilowathours in 199010241 billion kilowathours in 1991 .
} 
Demand-Side Management. Most States are actively considering proposals for restructuring the electric power industry, including options for deregulating the the teneration segment of the industry and providing retaij access. A few States, such as Caljfornia, have enacted statutes and/or adopted poljcies that will create a competitive retail access market. Such changes are affecting utility demandside management (DSM) activities and could significantly change the financing, structure, and detivery of end use energy services.

Traditionally, utility DSM programs have been developed through an integrated resource planning process which compared the cost of DSM programs to the cost of other resources and are approved by State Public Utilities Commissions. In a competitive market, regulated utilities may not retain their obligation to provide generation serviees and regulatory oversight of theit DSM programs. Additionally, competition is creatiog pressure for utilities to eut costs. In some instances, this has resulted in a reduction in planned DSM expenditures and a shift away form eustomer rebate prograrts. Forther, to the extent vtility generation revenues ultimately may be based on competitive market prices, a conflict could emerge between the interests of generation owning utilities in higher generation prices and the effects of some DSM programs to reduce demand and possibly to help hold down competitive prices for generation. These factors could contribute to slower growth in energy savings from DSM progrants.

New retalling activities are emerging as competition grows in the electric power industry. These activities include increased utility attention to marketing and those of new brokers and energy service companies. These new energy retailers can be expected to offer customers packages of services that include electricity (and in some cases natural gas), financial secvices to hedge price uncertainty, and expanded energy management services designed to allow consumers to adjust their energy usage to shanging electricity prices. Demand-side services will be competitively marketed as a means of helping consumers manage their energy bills. These services may include automated energy management linked to comnupications system that provides consumers and their energy management systems access to changing hourly electricity prices.

Regulators and legislators in some States are likely to set aside funds collected from all consumers connected to the distribution system to support energy efficiency programs. The California restructuring legislation bas used this approach to require utilities to purchase energy efficiency savings under standard offers.

Utilities in the Pacific Northwest and New England bave formed consortiums to support energy efficiency market transformation, programs that attempt to create lasting changes in markets for energy efficient products. Such efforts may represent a more economical way to achieve long-term energy savings.

Also, 1995 incremental savings from energy efficiency programs nearly matched the jevel of incremental sayings achieved in 1994. This suggests that efficiency programs are continuing to play a significant role in the Nation's resource mix. oven as it changes to reflect the development of a mote competitive electric power industry.

In 1995. I,053 of the 3,199 electric utilities in the United Stales reported having DSM programs, an increase of 2.2 percent over 1994 . Of these 1.053 utilitjes, 470 are classified as small and 583 as large. ${ }^{5}$ The 1,053 utilities accaunt for 85 percent of the tota! tetail sales of electricily in the United States.

Energy savings for the 583 large electric utilities increased to 57,421 million kilowatthours, 4,938 militon kilowatthours over 1994. These energy savings represent 1.9 percent of annual electric sales of $3,013,41$ million kilowatthours, to ultimate con. sumers in 1995 .

Actual peak load reductions for large utilities increased 18.2 percent from 25,001 megawatts in 1994 to 29,561 megawatts is 1995 . These actual peak load reductions are approximately 4 percent of total peak load in the United States. Potential peak load reductions increased 9.6 percent from 42,917 megawatts in 1994 to 47,029 megawatts in 1995 .

DSM costs decreased from $\$ 2.71$ billion in 1994 to $\$ 2.42$ billion. This is the second consecutive year that DSM costs have decreased from a high of $\$ 2.74$ billion in 1993.

Incremental effects are thase cansed by new programs and new participants in existing programs for the current reporting year. For 1995, incremental energy savings for large utilities were 8.242 million kilowatthours, incremental actual peak load reductions were 4,636 megawatts, and incremental potential peak load reductions were 6.539 megawatts.

\footnotetext{
s I arge otilities are those reportiag gales to wlimate consamers or soles for resale grealer than or equal to 120,000 megawatibours. These

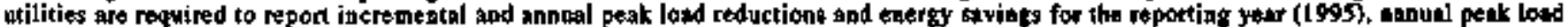

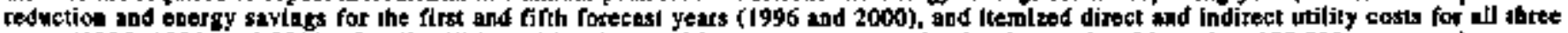

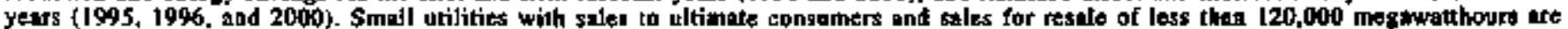
only required to export incremental emergy savings and peak load reduction, and tatal vijlity, total nonttility, end tolal DSM corta for the reporting year and for the first and fifth forecast years.

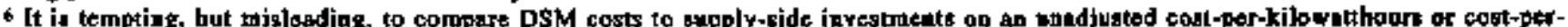

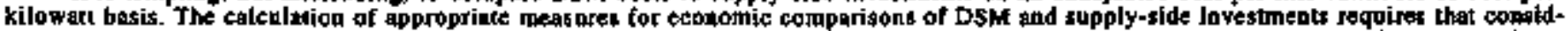
erntion of the life-cycle cost of the aptions betin companed be addressed on an lategrated bosis (l.e., the iateraclion of the change in tadtale

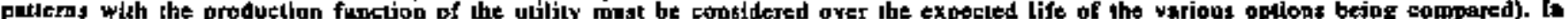

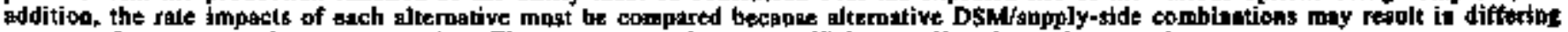
puterns of revenute requiremenls ovee time. The data pregented ane not aufficiept to allaw for soch comparison.
} 


\section{U.S. Nonullity Power Producer Statistics}

Generation, In 1995, U.S. nonutility power producers with facilities having an inslalled capacity of 1 megawalt or more generated 374 billion kilowathours of electricity. U.S. nonutility power producers received 90 billion kilowatthours from and delivered 232 billion kilowathotss to electric utilities and other end users. Nonutility power producers delivered approximately 61.9 percent of their gross generation to elecitic utilities and other end users and used 232 billion kilowatthours for power plant operation and for industrial processes. The highest [evel of nonutility production of electricity occurred in California and Teras, with 63 and 55 bislion kilowatthours, respeclively.

Gross generation for nonutility power producers (with an installed capacity of I megawatt or more) was 5.5 percent higher in 1995 than a year earlier. Slightly more than half of the generation by nonutility power producers was gas-fired, with generation from cokl accounting for 15.4 percent of the total. Of the total nonulility generation, 315 biltion kilowatthours were from qualifying facilities, more than five times the quantity from nonqualifying facilities. (See the Chapter titled "Nonutility Power Producers" for a definition of these facilities.) The Jargest share of gross generation was produced by facilities in the West South Central Census Division, followed by the Pacific Census Division. The manufacturing sector domisales electricity generation and is concentrated in the West South Central and Middle Atlantic Census Divisions, where there is a large potential for cogeneration in both the refining and the paper and pulp industries.

Capacify. The total isstalled capacity of nonutility power producers with an installed capacily of 1 megawatt or thore was 70,254 megawats at the end of 1995. The installed capacity for facilities of 1 megawatt of more increased by 2.6 percent from 1994. Nonutility capacity in 1995 was equivalent to 9.3 percent of the traditional U.S. electric atility installed capacity.

Of all energy sources, gas accounted for the largest amount $\{29,272$ megawatts) of nonutility capacity. The West South Central Census Dirision accounted for 37.3 percent of that gas-fired capacity. The second largest share of nonutifity capacity was provided by petroleun, followed by coal. The largest volume of petroleum capacity $(3,755$ megawatts) was located in the South Atlantic Census Division. Cogeneration accounts for 78.2 percent of nonutility capacity (68.4 percent qualifying facility capacity and 9.8 percent nonqualifying facility eapacity). Small power producers and independent power producers accounl for 13.7 and 7.9 percent, respectively, of nonutility capacity.

The greatest number (539) of nonutility generating facilities was in the Pacific Census Division, and most of the capacity (13,891 megawatts) was in the West South Centsal Census Division. In the Pacific Census Bivision, California dominated because the State actively promoled alteroalive energy sources in the 1970 's and 1980's by providing incentives to nontraditional electricity producers. Many of these incentives have since expired of been rescinded, but they served to assist in the development of nonutility generation. In the West South Central Census Divisjon, Texas dominated mainly because of the large potential for cogeneration in the petroleum refining industry, where thermal and electric losd requirements are co-located.

Nontuilities are not subject to 'rate base' as the basis of the price setting process and, therefore, the economic regulation regarding tecovery of the investmeats of nonutilities is generally established on a different basis from that of a regulated public utility that is subject to 'avoided cost' based pricing. pricing that is a direct result of negotiations between the parties, 'market bastd' pricing, and others. As a result of this exception, a shorter lead time exists for the types of contracts signed by the nonutlities with their constructors (turnkey and other incentive based construction contracts). This type of contract had not been the historical practice of the utility industry, but under current conditions, clearly utilities and nonutilitjes alike will avail themsetves of whatever contracr provisions will allow the shortest lead time and lowes! cost. The utility and nonutility are both looking at the need for and timing of new capacity in very similar ways. The NERC Reliabiljty Assessment 1996-2005 states that in the later years of the ten-year assessment period, a number of Regions and subregions are no longer reporting generation capacity additions needed to salisfy regional etiteria, although they do recognize such needs. However, it does signal an increased reljance on short lead-tine resources that allow commilments to be delayed until required and reflects a shift toward a market-driven supply where customers choose the quantity and level of supply appropriate for their purposes. Nonutilities plan approximately 9 gigawatus of capacity additions; 5 gigawatts through 1998 with 11 gigawats (generalor nameplate capacity) planned for the same period by electric utilities. Electric vtilities have ptanned 48 gigawatts (generator nameplate capacity) in capacity additions for the 10-year period, 1996 through 2005 . Of the nonutility planned capacity, 20.0 percent is petroleum and/or gas-fired. Coal-fired capacity represents 11.7 percent of the total planned nonutility additions.

Consumption. In 1995, consumptios by nonutilities of 1 megawatl or more included $2.31 \mathrm{l}$ billion cubic feel of natural gas, 48 million short tons of coal, and 39 million barrels of petroleum. Compared to 1994. consumption decreased 3.4 percent for petroleum, 8.4 percent for coal, and increased 7.5 percent for gas. Natural gas was the fuel most used by nonutilities.

Emissions, In 1995, estimaled air emissions from nonutility facilities of 1 megawatt or more were 1,217 thousand short tous in $\mathrm{SO}_{2}, 1,440$ thousand short tons of $\mathrm{NO}_{x}$ and 556,324 thousand shorl tons of $\mathrm{CO}_{2}$. This

7 Energy Information Adminjstration, inventery of Power Ptants in the United States 1993, DOEEIA.0095(93). 
is a 14.5 percent decrease of $\mathrm{SO}_{3}$ endissions from the previous year. The decrease of $\mathrm{SO}_{2}$ efnissions was due to lower sulfur content of fuel consumed from the pre. vious year.

\section{Renewable Energy Resources}

Section 171 of Public Law 102-486, the Energy Policy Act of 1992, requires the Administrator of the Energy Information Administration to annually collect and publish the results of a survey of electricity production from domestic renewable onergy resonjces. This requirement includes reporting data on electricity proouction (it kilowatchours) and totaf installed capacity. Renewable energy resources in Table 1 , "Electric Power Industry Summary Statistics for the United \$tates, 1994 and 1995," are reported in detail in the Renewable Energy Annual, 1995. 
Flgure 1. U.S. Electrle Utility Sales to Uithade Consumers by Class of Ownerahlp, 1995

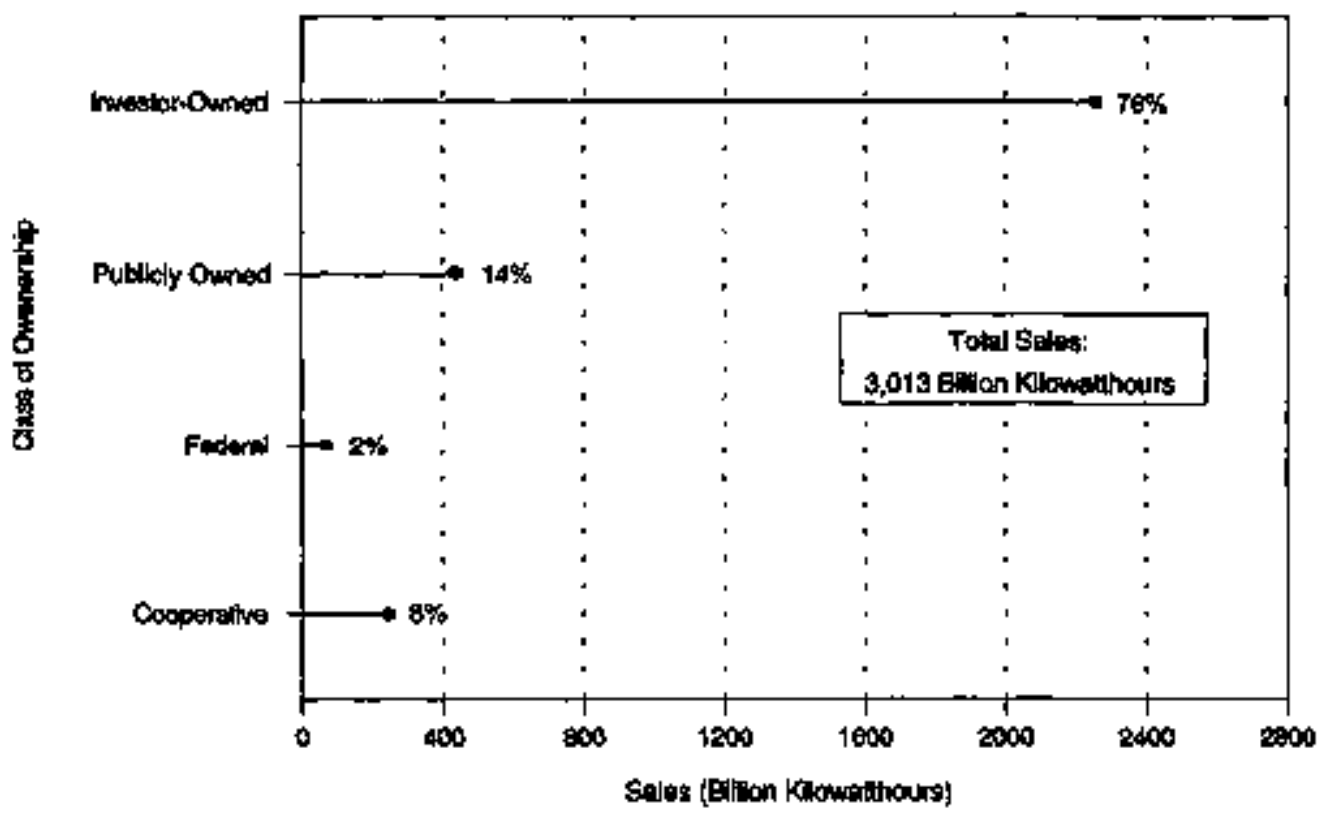

Notes: -Data are pretminary. - Totals may not equal sum of camponents because of independant rounding.

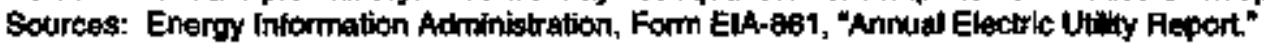

Figure 2. Number of U.S. Eectrle Utilliea by Class of Ownership, 1995

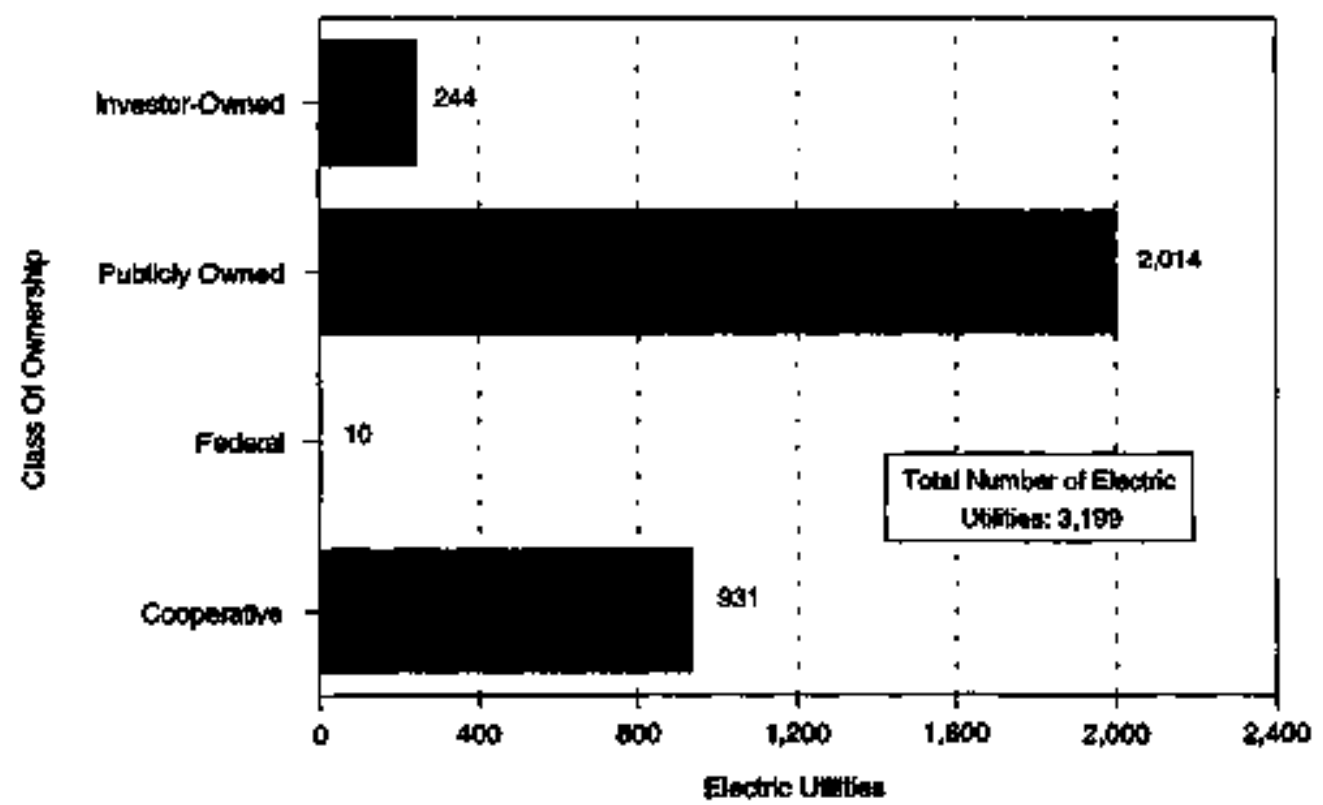

Noter *Data are proliminary. *Fower Marketers are nok sturwh this year.

Solrce: Energy mlormation Adminigtration, Form EIA-861, "Anmual Eloctric Litility Report." 
Flgure 3. Number of Ultimate Consumers Served by U.S. Electic Utilitias by Clant of Owmarahlp, fogs

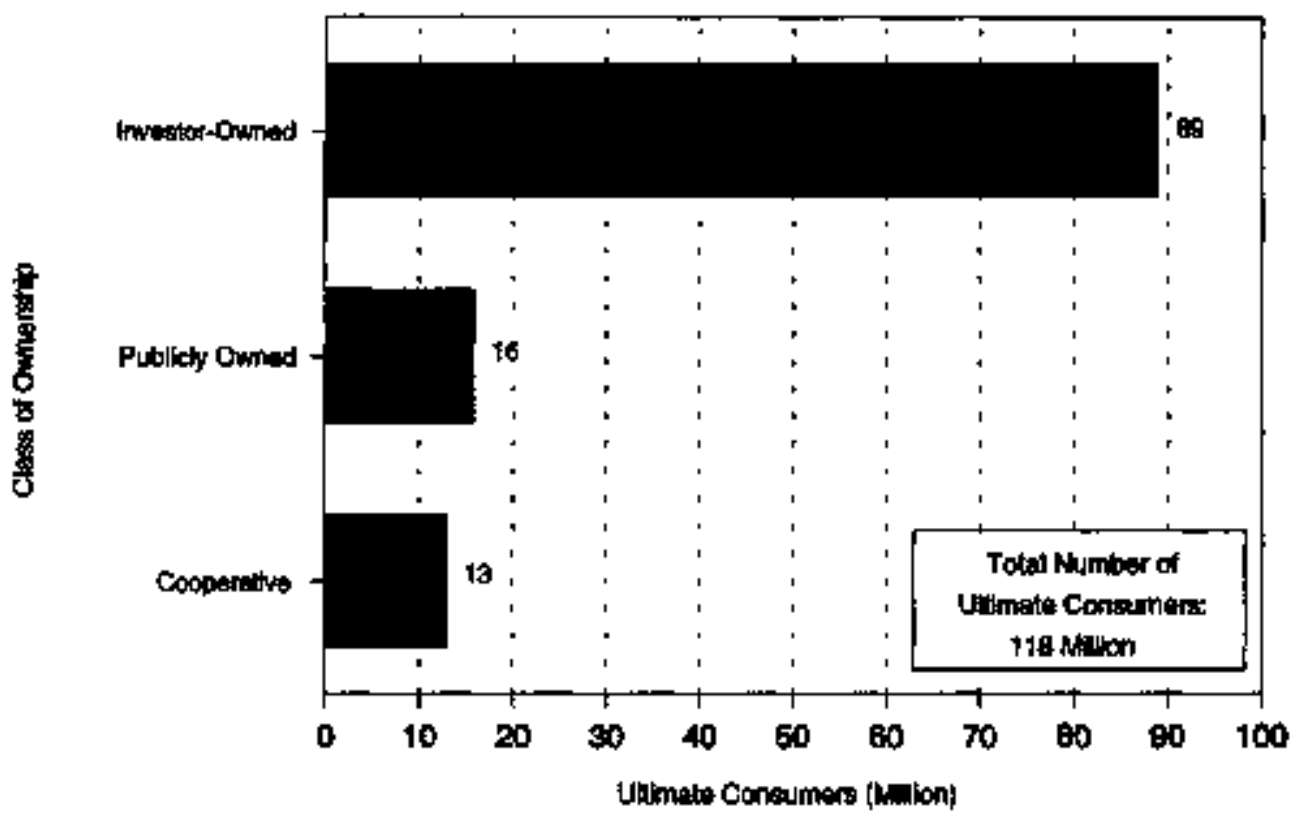

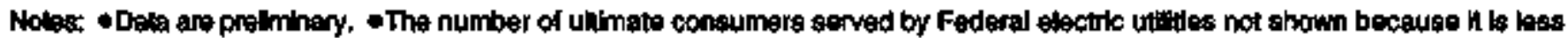
then 1 milon. The number of utimete conesumers is an average of the number of coneumers at the chase of each month. $\bullet$ Totals maty not toqual sum of components because of independent rounding.

Source: Energy intormation Administrailon, Form ElA-s\$1, "Annual Electric Utility Report."

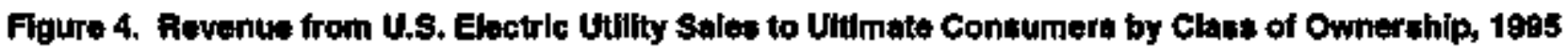

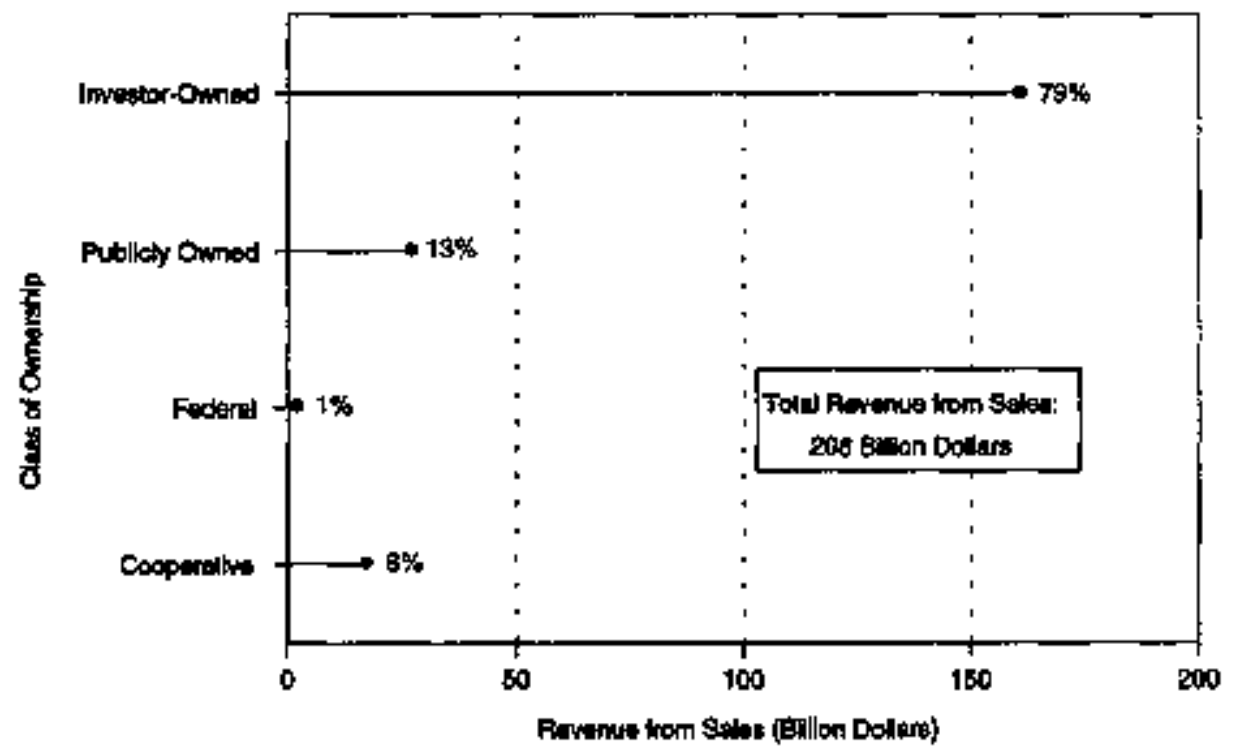

Notes: -Date are prealminary. -Tokak may not equal sum of components because of hdependent rounding.

Source: Energy Inlormation Admintstration, Form ElA-661, "Amual Electric Utilly Preport." 
Figure 5. U.S. Electrle Utifty Sales for Rosale by Clasa of Ownerahip, 1905

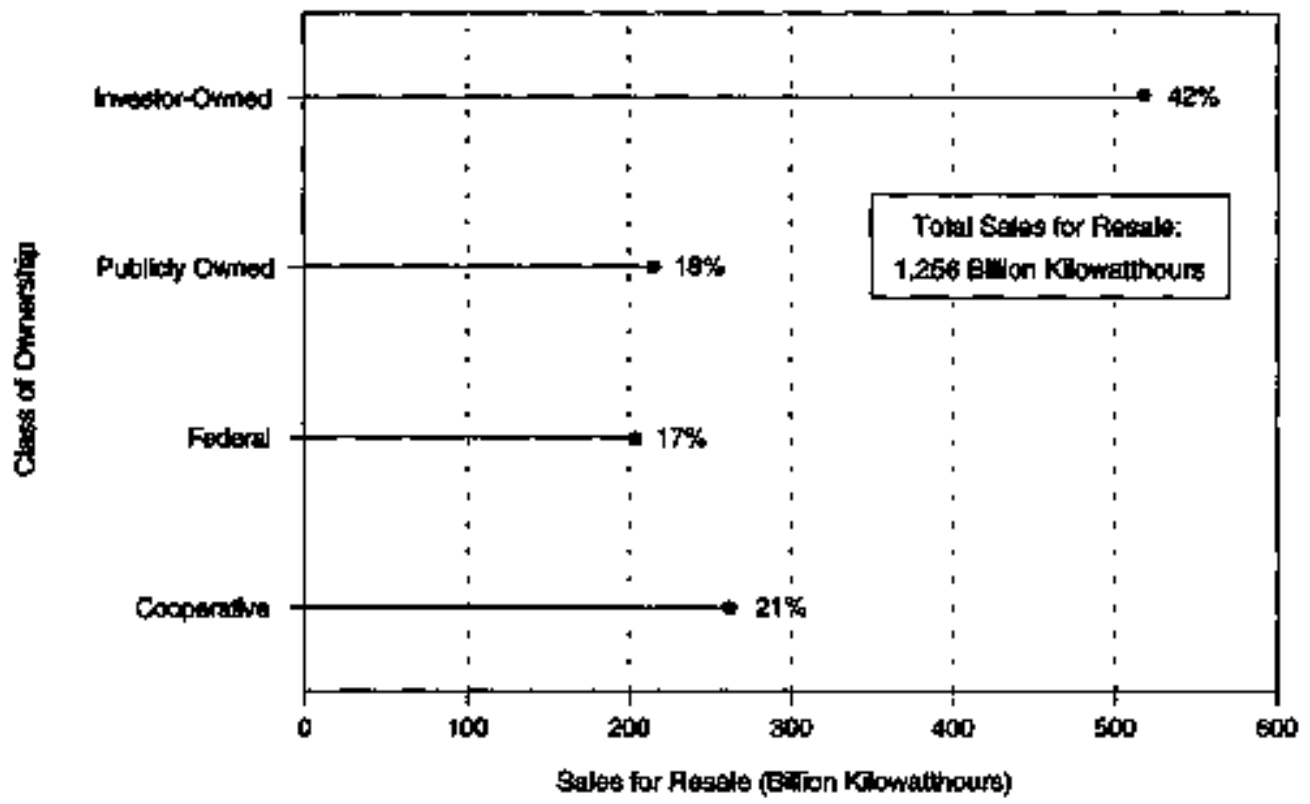

Notes: Data are prelenhary. *Tokats may not equal sum of components because of independent rounding. *Power Marketers are not shown this year.

Source: Energy Infonnation Administration, Form ElA-861, "Annural Elactric Utility Report."

Figure 6. Revenue from U.S. Electric Utillty Sales for Resale by Class of Ownership, 1995

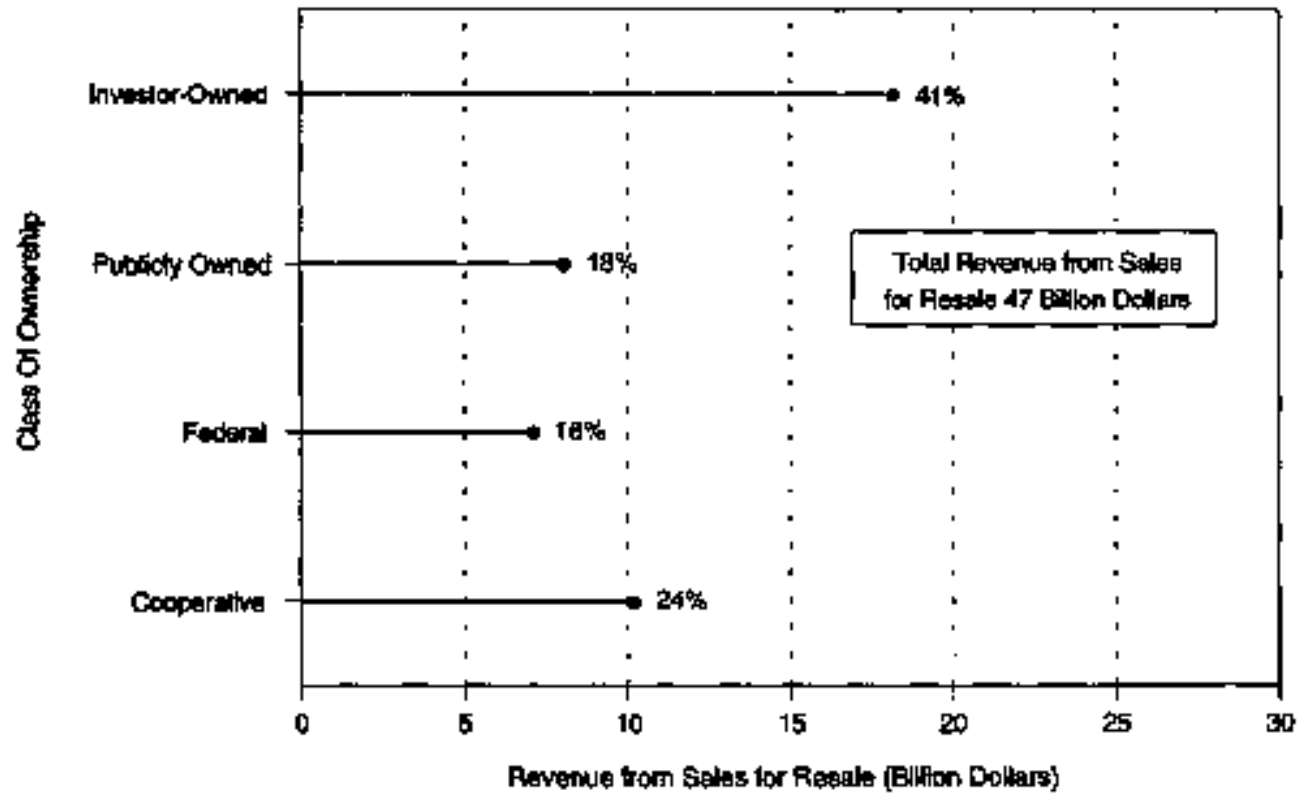

Notes: •Data are prelininary. -Totals mey not equal sum of components because of independent rounding. -Power Marketers are not shown this year.

Source: Energy intormatton Administration, Form EIA-661, "Annual Electric Ulility Report." 
Figure 7. U.S. Electric Utility Sales to Ulitimate Consumers by Sector, 1995

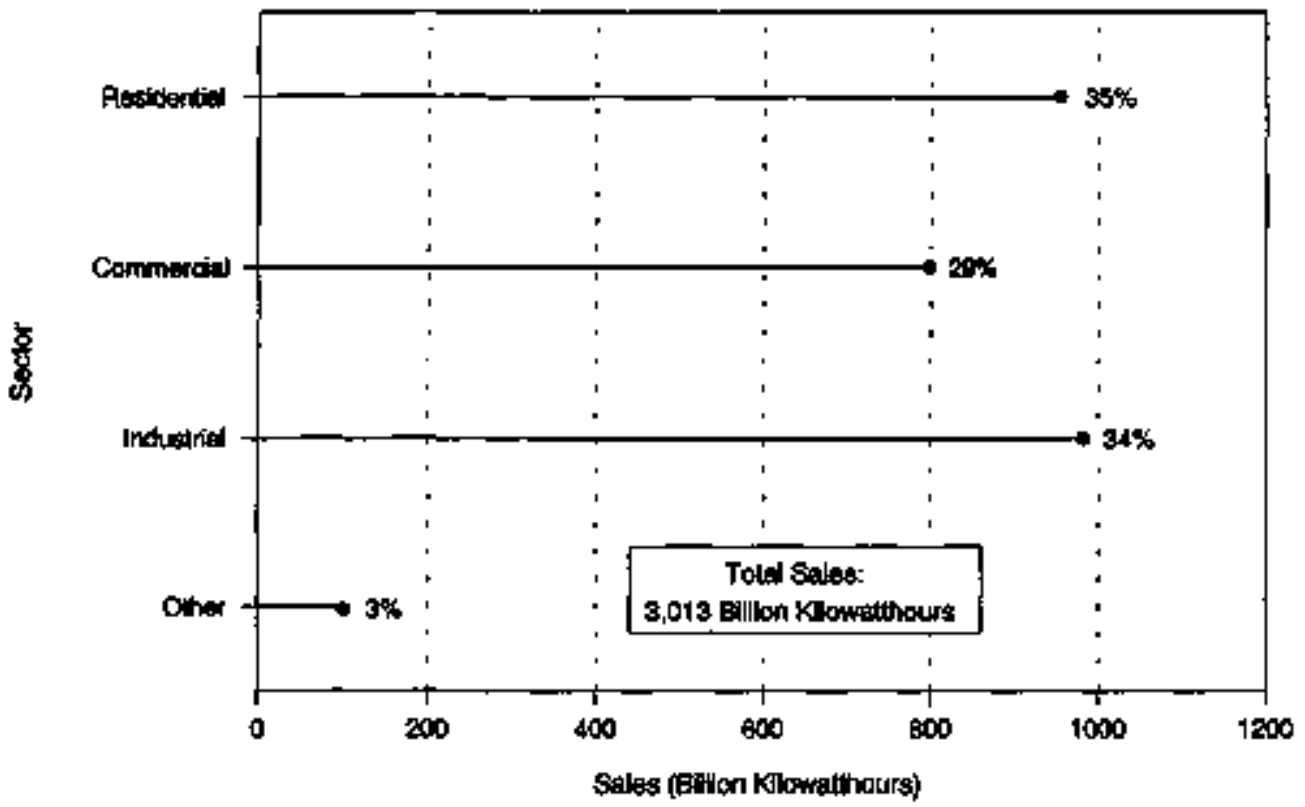

Notes: Other includes seles for public street and Wghway lighting, other sales to public authorities, sales to relroads and

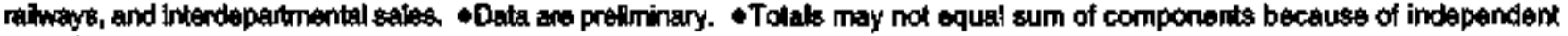
rounding.

Source: Energy Information Adrinistration, Form ElA.861, "Anmuad Electrle Uti"'ly Report"

Flgure 8. U.S. Electric Utllity Averege Rovenue per Kilowatthour by Sector, 1905

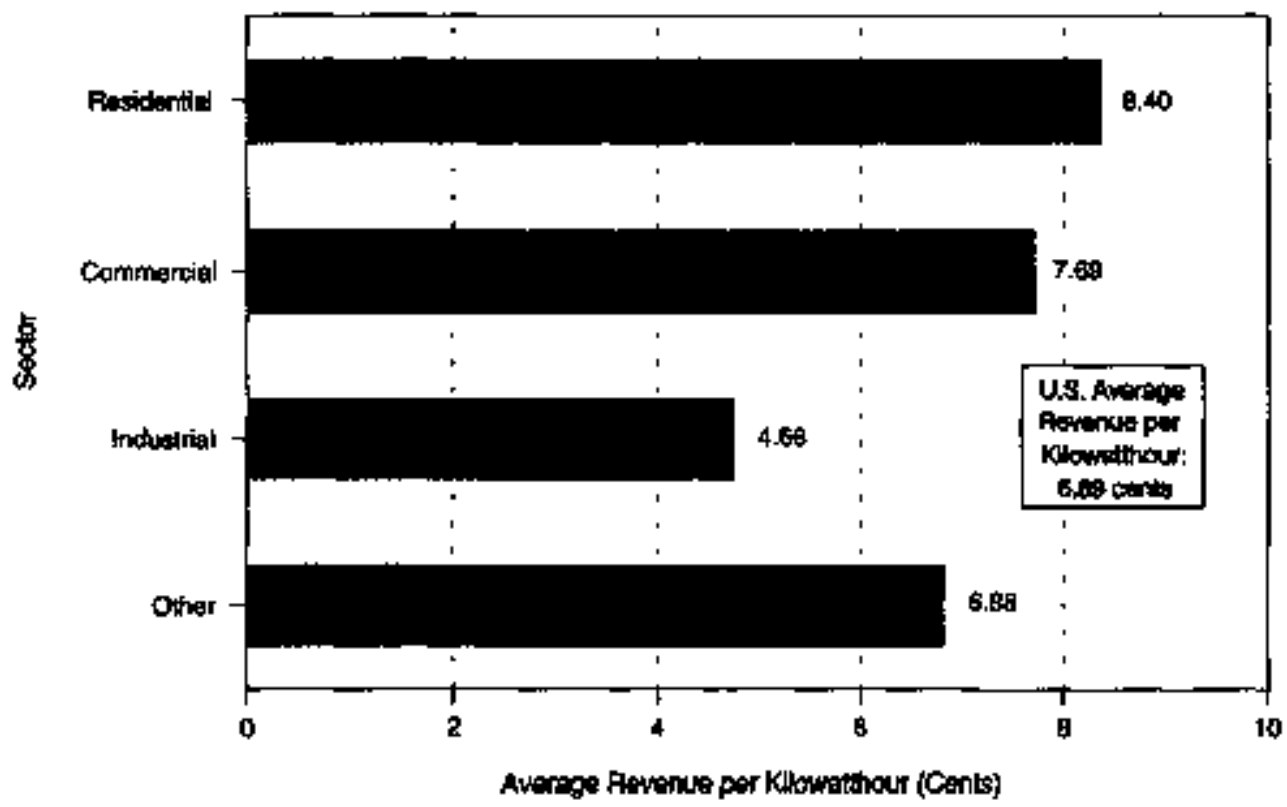

Notas: * Other tholudes sales for puble street and highway lighting, other sales to puble authortles, sales to railroads and rallways, and interdopartmental saldes. Daie are prelminary.

Source: Energy intormation Administration, Form ElA-861, "Annuad Electric Utility Report." 
Figure 9. Installed Capeclty at U.8. Nomutility Cenerating Faellitles by Type of Facillty, 1996

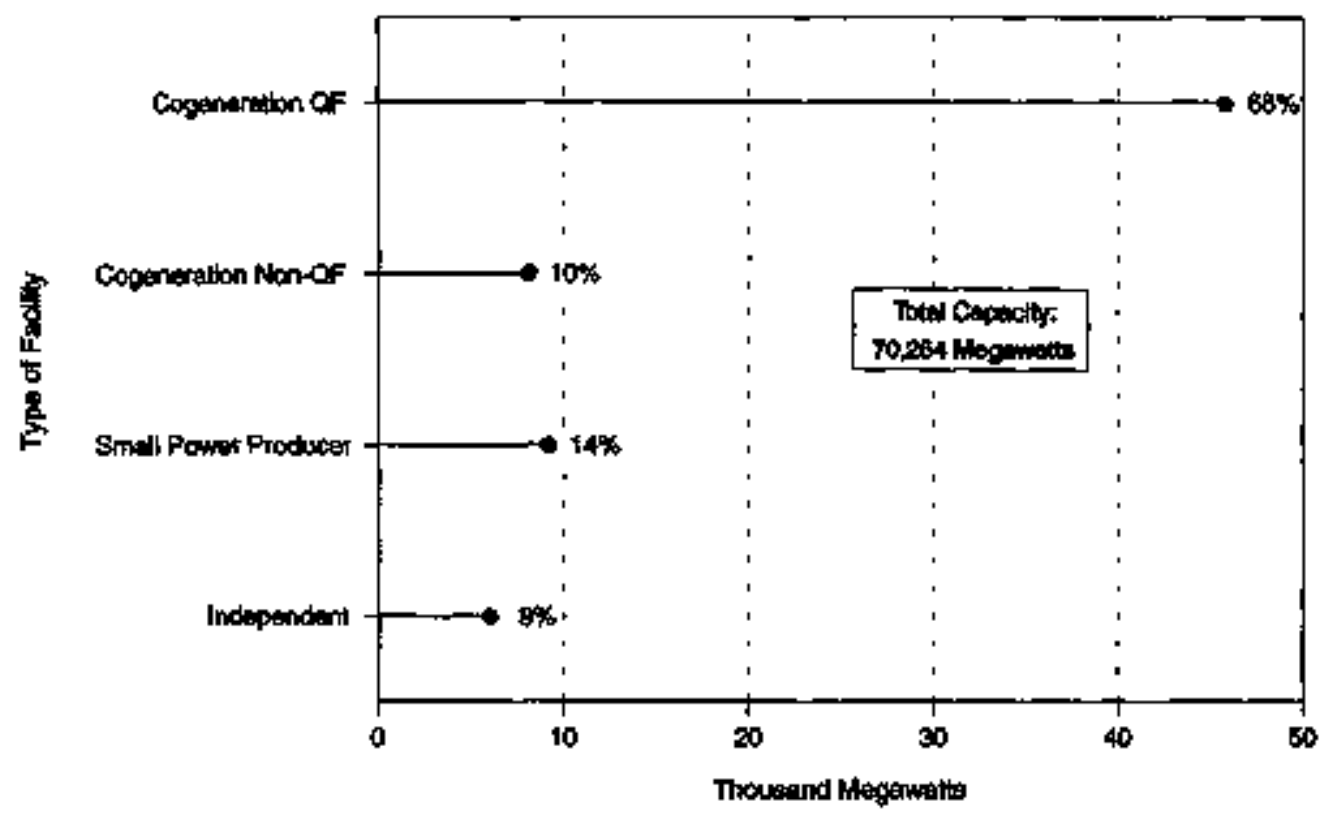

$Q F=$ Qualifying Faciuty.

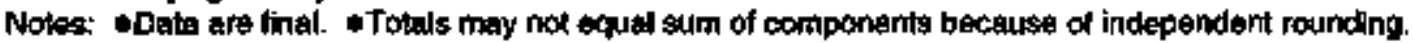
Source: Energy Informalion Adminlstration, Form ElA.\&\%7, "Annual Norublity Power Froducer Report."

Figure 10. Planned Capacly Additions for U.S. Nonutilly Generating Faclitios by Energy Souroe, at of December $3 t, 1996$

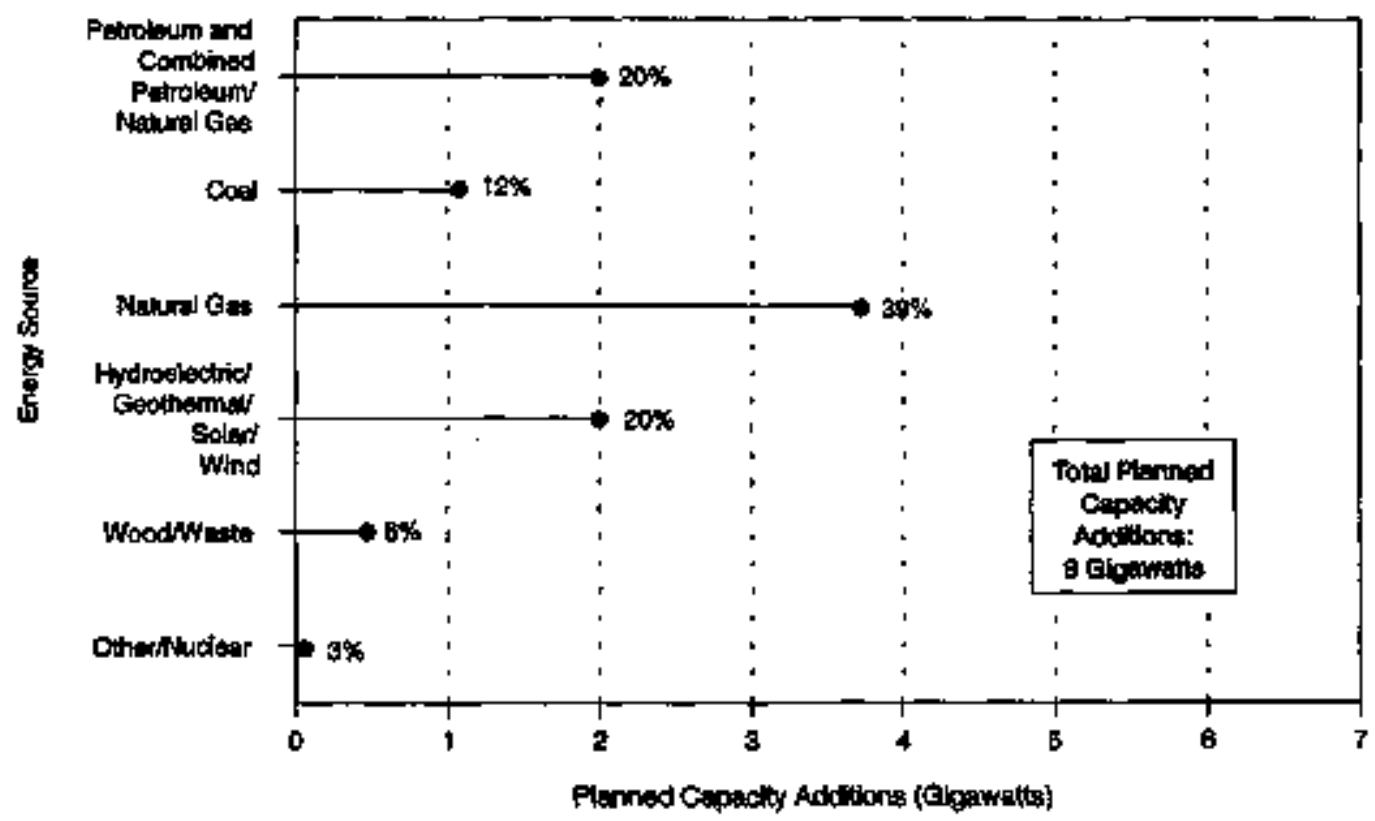

Notes; -Tokals may not equal sum of components because of independent rounding. ECther inciudes hydrogen, sutfur,

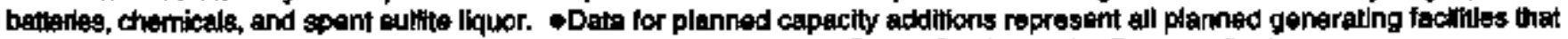
moel one or more of trres critenta presented in Chapier 6, "Nonutility Power Producers." - Date are final.

Source: Enorgy Intomation Administration, Form ElA-897, "Annual Nonutliy Power Frodubur Report." 
Fable 1. Electric Power Industry Summary Statistics for the Unlted States, 1994 and 4995

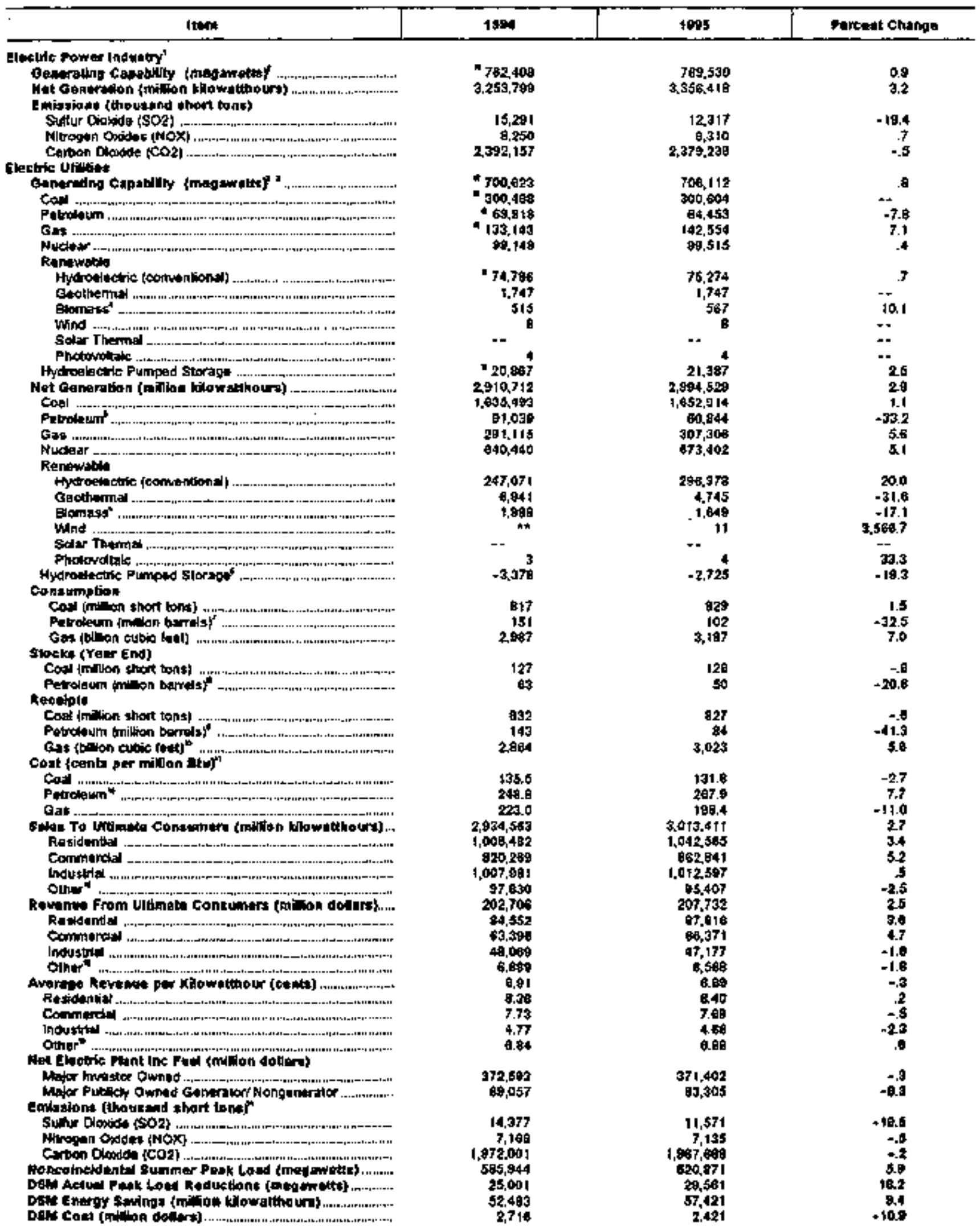


Toble 1. Electric Power Industry Sunmary Statistles for the United States, 1994 and 1995 (Contimued)

\begin{tabular}{|c|c|c|c|}
\hline $\operatorname{lin}$ & 194 & 19s5 & Priment Change \\
\hline 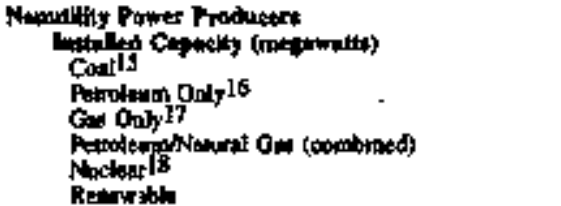 & $\begin{array}{r}68,461 \\
10,372 \\
2,262 \\
28,055 \\
9,820 \\
-\end{array}$ & $\begin{array}{l}70,254 \\
10,454 \\
2,358 \\
20,272 \\
10,479 \\
-\end{array}$ & $\begin{array}{r}26 \\
8 \\
42 \\
43 \\
67 \\
-\end{array}$ \\
\hline 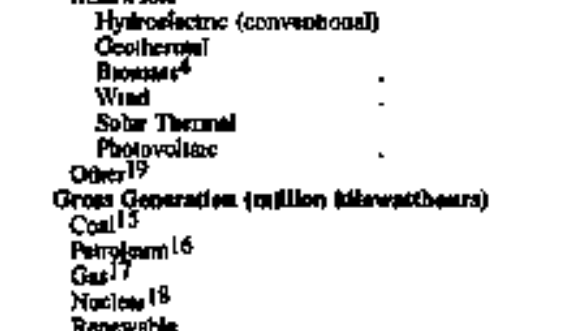 & $\begin{array}{r}3,364 \\
1,335 \\
10,364 \\
1,737 \\
354 \\
594 \\
594,925 \\
59,035 \\
13,069 \\
192,214 \\
34\end{array}$ & 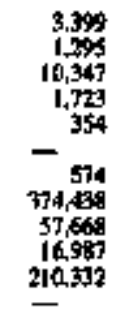 & $\begin{array}{r}10 \\
-30 \\
-21 \\
-8 \\
-8 \\
-70 \\
-35 \\
53 \\
-23 \\
127 \\
94 \\
-\end{array}$ \\
\hline 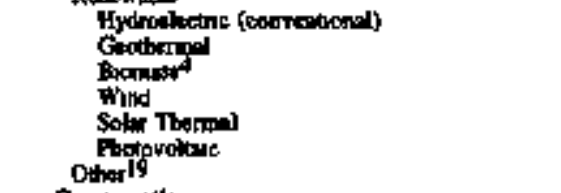 & $\begin{array}{r}13,227 \\
10.122 \\
5,392 \\
3,402 \\
-824 \\
-3,504\end{array}$ & $\begin{array}{r}14,774 \\
4,912 \\
56,975 \\
3,185 \\
824 \\
3,700\end{array}$ & $\begin{array}{l}117 \\
-2] \\
-7 \\
-85 \\
=7\end{array}$ \\
\hline 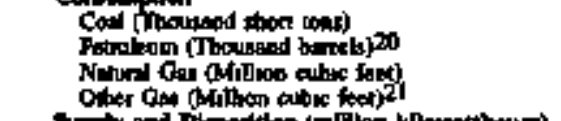 & $\begin{array}{r}5,261 \\
40,460 \\
2,149,246 \\
1,586,185\end{array}$ & $\begin{array}{r}4,849 \\
30,675 \\
2,311,797 \\
1,604,427\end{array}$ & $\begin{array}{r}-84 \\
-34 \\
75 \\
13\end{array}$ \\
\hline 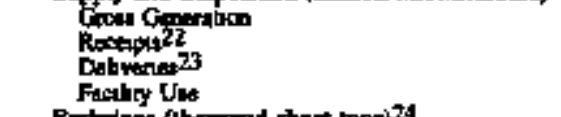 & $\begin{array}{r}354,9,25 \\
94,166 \\
12,3,315 \\
226,775\end{array}$ & $\begin{array}{r}374,438 \\
89,919 \\
23,049 \\
232,478\end{array}$ & $\begin{array}{r}55 \\
-45 \\
44 \\
24\end{array}$ \\
\hline 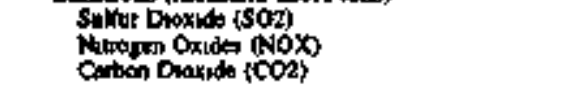 & $\begin{array}{r}1,424 \\
1,3,75 \\
5,781\end{array}$ & $\begin{array}{r}1,217 \\
1,4,60 \\
5,56,324\end{array}$ & $\begin{array}{r}-145 \\
79 \\
-19\end{array}$ \\
\hline
\end{tabular}

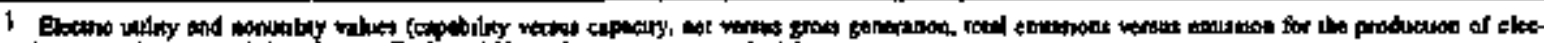

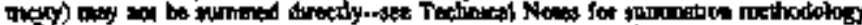

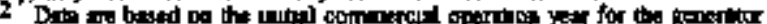

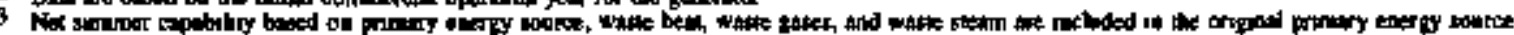

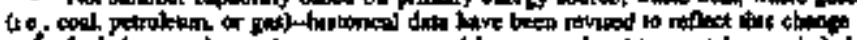

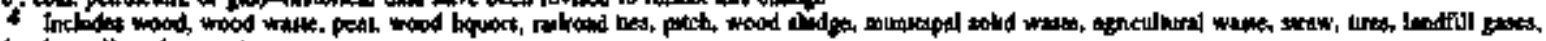

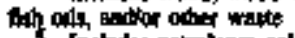

I. Inelodes patroleon coks

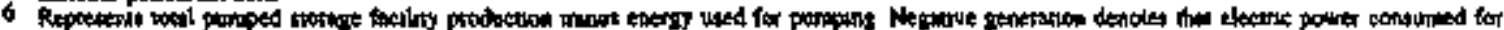

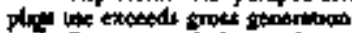

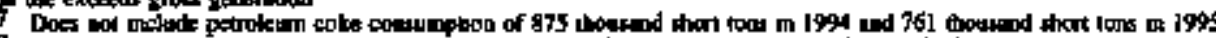

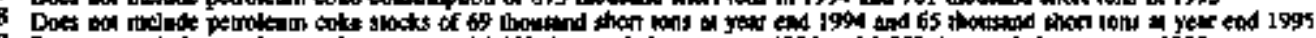

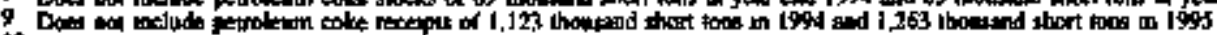

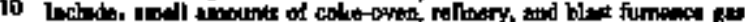

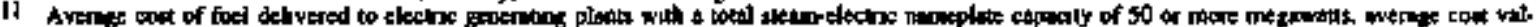

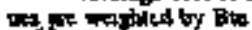

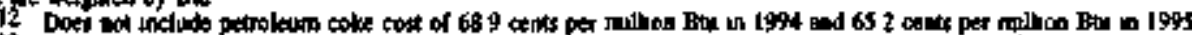

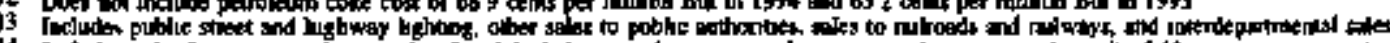

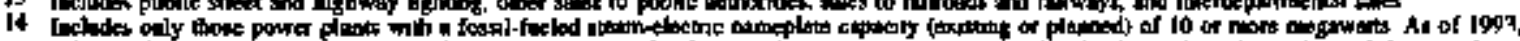

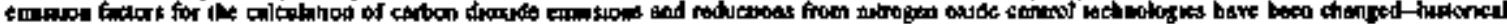

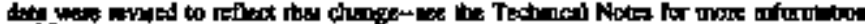

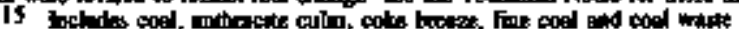

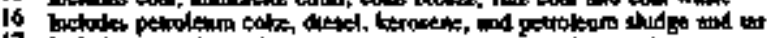

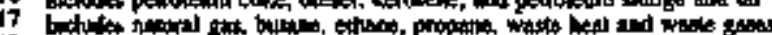

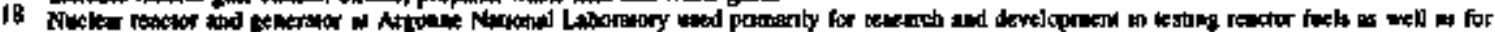

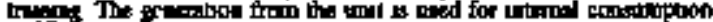

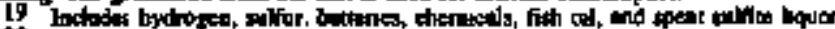

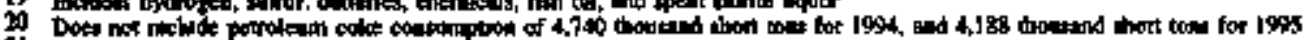

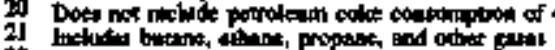

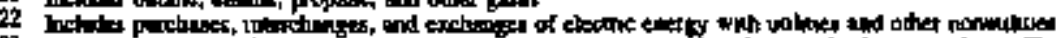

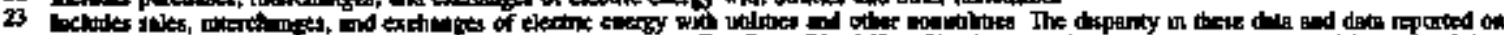

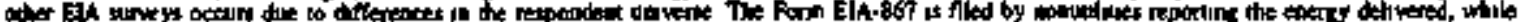

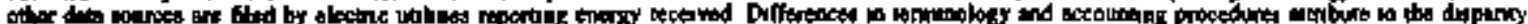

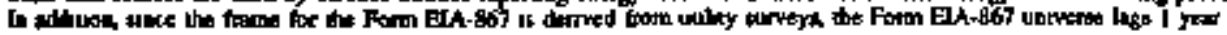




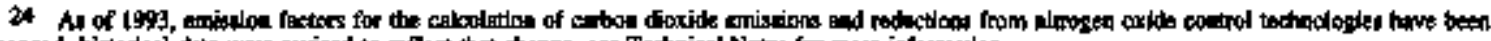

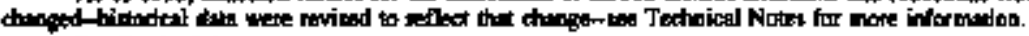

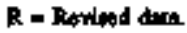

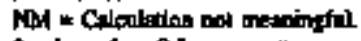

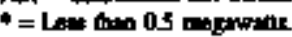

ot - Lesu tho 0.5 million Hlopmentours.

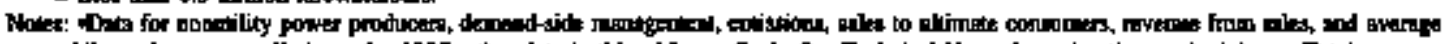

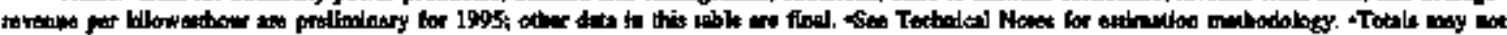

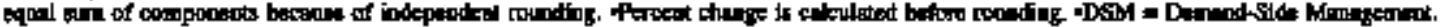

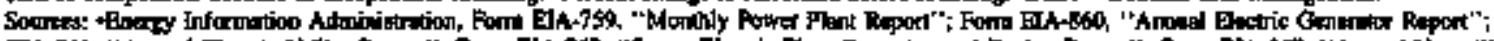

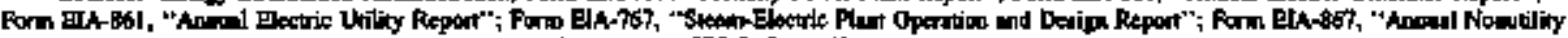

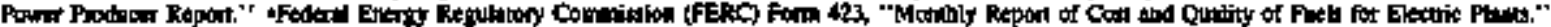

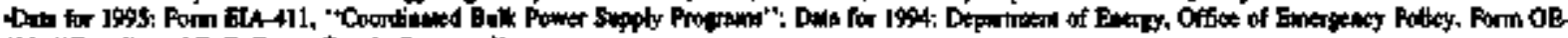
411. "Cocidiented Bure Power Sopply Propan.". 


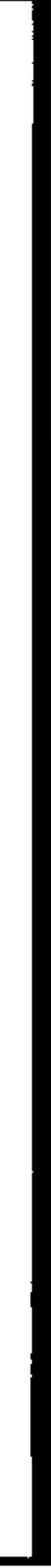




\section{U.S. Electric Utility Retail Sales and Revenue}

This chapter provides summary statistics on the sale of electricity to ultimate consumers, associated revenue, and average revenue per kilowatthour sold at the national, Census division, and State levels.

\section{Background}

Because eloctricity itself cannot be stored, it must be generated, Iransmitted to the consumer, and consumed instantaneously. Electric utility companies were formed to provide these services. An electric system consists of: generating plants (stations) to convert different forms of ebergy to electric power; transformers to taise the voltage in order to reduce losses in transmitting the power; transmission lines to transmit the power to the general vicinity of coosumption; transformers to lower the voltage; and distribution lines to distribute the power to the ultimate consumers. The entite system of generating stations, transformers, transmission lines, and distribution lines is a power system. Electric utilities bistorically build, design, and operate power systems. Most large investorowned electric utilities own and operate entire power systens: the generation, transutis\$ion, and distribution functions. Many small companies are distribution companies, purchasing their electricity from gensration strpliers, which can include traditional electric utilities, nonutility power producers, and power marketers. In anticipation of competition in the electric power industry, electric utility companies are forming separate business units for generation and customer service apart from transmission and distribution.

U.S. electric utilities are high-investment businosses and historically have been treated as monopolies because duplicale facilities, particularly transmission and distribution lines, would be jnefficient. Thus, franchises are granted to lectric utilities for given geograpbical areas by regulatory officials. To oblain a fradchłse, electric utilitios must provide service to all consumers in their territories at a reasonable cost. As the electric power industty transitions to a competitive environment, transmission and distribution will likely remain as regulated and noncompettive functions. However, the generation function is now competitive at the wholesale tradt lovel, and somb States are planniog to injtiate competition at the retail leve].

The service tetritory of an electric utility genetally has many different classifications of consumers. Electric utifities determine consumer classifjcation by various factors such as dearand, rate schedule, Standard Industrial Classification (SIC) code, distribution voltage, accounting methods, end-use applica- tions, and other social and economic characteristics. Electric utilities use consumer classifications far planning purposes (e.g. load growth and peak demands) and for deriving their rate schedules, often with the approval of a government regolatory agency.

\section{End-Use Sectors}

Consumers within the service territory of an electric utility are grouped into end-use sectorst residential, commercial, industrial, and othet. The electric utility determines the criteria for end-ase sector classification based on its service territory, size, location, ownership, and regulatory structure.

The residential sector includes private housebolds and apartment buildings, where energy is consumed prjmarily for spece heating, water heating, air conditioning. ligbting, refrigeration, cooking, and clothes arying. The commercial sector includes nonmanufacturing business establishments, sucb as hotels, motels, restaurants, wholesale businesses, and retail stores, and bealth, social, and educational instilutions. The industrial sector includes manufacturing, construction, mining, agriculaure, fishing, and forestsy establishments (SIC codes I through 39). Electric utilities may elassify their commercial and industrial service based on demand or annual usage falling within a range speciffed by the utility, such as classjfying a light manufacturer as commercial. The other sector includes public street and highway Ijghting, transportation, municipalities, divisions or agencies of State and Federal governments under special contracts or agterements, and other utillity departments as defined by the pertinent regulatory agency and/or electric utility.

\section{Aevenue Requirements}

The revenue requirements of an electric utility are set to reimburse the utility for providing electric service. Revenue requitements are the anticipated costs of providing services for some period of time in the future, usually one yoar. Revenue requirements are based on operating expenses, depreciation expenses, taxes, and return on the rate base (profit of the electric utility). The process of determining electricity prices generally follows three stages: (1) identification of revenue requirements, (2) allocation of the requirements for different classes of service (sectors), and (3) establishment of rate schedules for each sector. In the future, competition at the retail level may change the way rates are sel and by whom. In a deregulated environment, generation prices will be market-based rather than cost-based as under the current regulated 
systed. Rates will be "unbundled," and bills will include a list of services and the associated rates and chares such as energy, transmission, djstribution, metering, and other charges. Transmission and distribution, being natural monopolies, will likely remain regulated. Under open access rules allowing competjtion for wholesale generation, some costs that are currently collected in rate schedules for generation assets may becoma stranded. This means that the costs of the generation asset may not be recoverable at marketbased rates in a competitive environment for generation. The tecovery of stranded costs is an issue that will aeed resolution as the industry undergoes deregolation. These stranded costs may be recovered in nonbypassable charges in the form of a rate per kilowathour paid by all consumers in the jurisdictional distribution utility.

Currently, under a regulated environment, the rate schedules to gonerate revenute requirements for electric utilities, which are unique to each utility, are developed using a cost-based methodology and are stubject to approval by the appropriate authority based on the ownership class epplicable to the utility. Fot example, investor-owned electric utilities are regulated by State public service commissions and the Federal Energy Repulatory Commission (FERC). Under new FERC rutes, transmission of wholesale power will remain regulated to ensure open access to transmission systems in a competitive envitonment, while wholesale rates for generation will become deregulated. State public utility commissions will continue to regulate retail sales and distribution. However, some States are considering retail competition for generation that will allow market-based rates for energy, while regulating distribution rates. Public electric utilities, in most States, are controlled through localiy elected or appointed officials, and are not under the jurisdiction of FERC. Their rate schedules will, however, possibly be affected by any changes in State regulations addressing retai] competition. A detaiłed discussion on utility classes of ownership and the emerging competitive environment are included in the "Industry Profile" section of the first chapter of this publication.

A rate schedute is a statement that the utility will provide service to a particular class of consumer at a certain price. Prices for different sectors vary based on the objectives of the utility. These objectires include the need to altocate the various costs incurred in providing service, to mainatin the existing consumer base of the utility, and to promole new business.

\section{Average Revenue per Kilowathour}

The arerage revoute per kilowatthour of electricity sold by electric utilities is calculated by dividing the annual revenue from retail sales by the annual retail sales for each sector and State. The resulting measurement is the cost (pat kjlowatlhour of electricity sold) for providing service to a sector, given the rate schedule of the electric utility for that particular sector. The average revenue per kilowatthour is calcu- lated for all consumers and for each sector (residential, commercial, industrial, and other sajes). Utilities typicalty employ a number of rate schedules within a single sector. These alternative rale schedules reflect the varying consumplion levels and patterns of dif. ferent consumers and the associated impacts on the cost to the electric utility for providing electrical service. The average revenue per kilowatthour by sector reported in this publication represents a weighted average of revenue and sales from ultimate consumers within that sector and across sectors for all consumers.

The electric revenue used to derive the average revenue per kilowathour is the operatitig revenue reported by the electric utility. Operating revenue fncludes energy charges, demand charges, consumer service charges, environmental surcharges, fuel adjustments, and other miscellaneous charges.

Utility operating revenues cover, among other costs of service. State and Federal taxes assessed on the utility. State and local authorities tax the value of plants (property taxes), the amount of revenues (gross receipts taxes), parchasts of materials and services (sales and use taxes), and a potentially long list of other items that vary extensively by taxing authority. The Federal component of these taxes are, for the most part, "payroll" taxes. Taxes deducted from employees' pay such as Federal income taxes and employees' share of social security taxes are not a part of the utility's "tax costs," but ate paid to the taxing authorities in the mame of the employees. These taxes are included in the utility's cost of service (i.t. revenue requirements) and in the amounts recovered from consumers in rates. Therefore, such taxes are reported as operating revenues.

Electric utilities, like many other business enterprises, are required by various taxing authorities to collect and remit taxes assessed on its consumers. In this regard, the utility serves as an agent for the taxing authority. Taxes assessed on the consumer but collected by the utility, such as gross receipts tax, sales tax, or environmental surcharges, are called "passthrough" taxes. These taxes do not represent a cost of the utility and are not recorded in the operating revenues of the utility. However, taxing authorities differ in whether a speciftc tax is assessed on the utility or the consumer, a difference that in turs determines whether or not the tax is included in the electric utility's operating revenue.

Average reveoue per kilowathour for the residential sector is generally higher than for other sectors. This is primarily due to the higher costs associated with serving many constmers who use relatively small amounts of electricity. These costs include direct-logd costs (such as those for distribution lines, transformets, and meters) in addition to cousumer or administrative costs. The industrial sector generally bas the lowest average revenue per kilowatthour because of the ecouomies of serving a few consumers who nse relatively large amounts of electricity.

Federal electric utilities generally have the lowest average revenue per kilowatthour among the owor- 
ship classes because they bave access to relatively low-cost financing and mosily utilize inexpensive hydrotlectric facjlities. Because publicly owned electric utjlities also have access to relatively low-cost financing and are nonprofit entities, they have lower average revenue per kilowatthour than investor-owned electric utilitjes. Although cooperat tve electric utilites have economic advantages similar to those of publicly owned electric utilities, cooperatives gonerally serve sparsely populated areas; as a consequence, cooperatives generally have higher average revenue per kilowatthour than publicly owned utilities.

Becaltse of the type and availability of capacity and the cost of fuel, the average revenue per kilowathour differs across U.S. Census divisions. The New Engtand and Middle Atlantic Census Divtsions tend to have an average revenue per kilowattbonr that is bigher than the national average because of their reliance on petroleutm; whereas, the East and West South Ceniral Census Divisjons rely on gas-fired generation and the East North Centrat and South Atlantic Census Divisions rely on coal-fited generation. Petroleum is generally a more expensive energy source than coal and natural gas. Because the Mountain Census Divi- sion relies on inexpensive hydroelectric generation, the average revenue per kilowathonr in this region is usually below the national average for all clesses of consumers. The Census divisions where Pederal hydroelectric facilities provide sjgnificant amounts of electricity, such as the East South Central Census Division, also bave low average revenue per kilowatthour.

\section{Source of Data}

Summary statistics on relail sales of electricity by electric utilities and average revenue are provided in the following tables. These data were obtrined from the Form EIA-86!, "Anntial Electric Utility Report." The form is an annual census of electric utitities (approximately 3,200) that own and/or operate facilithes within the United States, ts territories, and Puerto Rico." Data colfected include the generalion, transmission, distribution. sales, and assocjated revenue of electric energy and is primarily used by the public. More detailed statisttcs on sales, average reverue, and revenue per kilowathour are published annually in the Electric Sales and Revenue"

Table 2. U.S. Electric Utility Sales to Ultimate Consumers and Associated Revenue by Sector, 1991 Through 1995

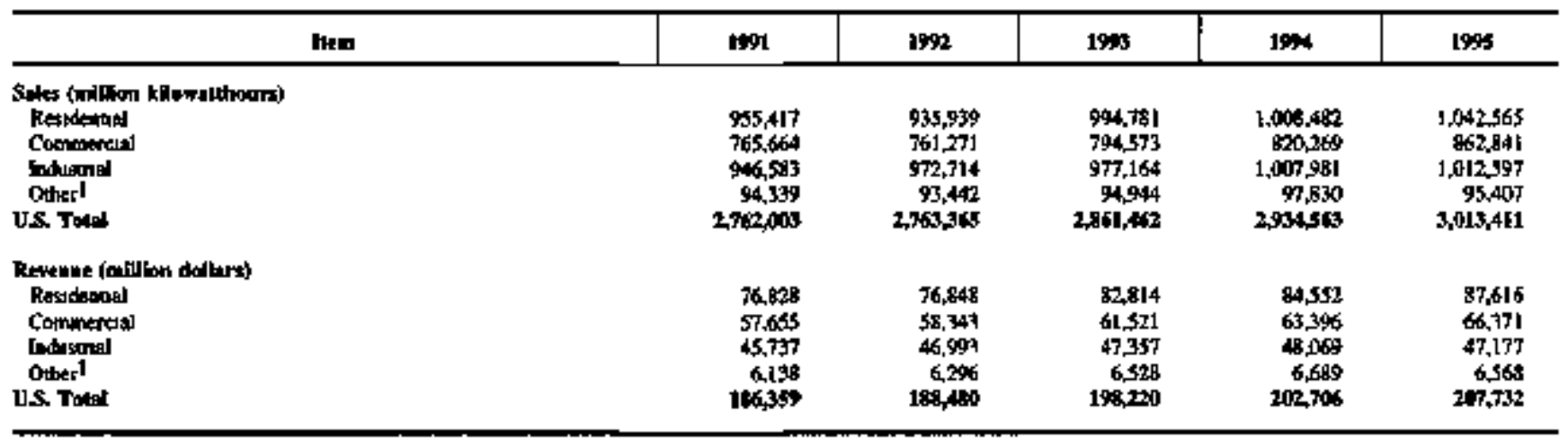

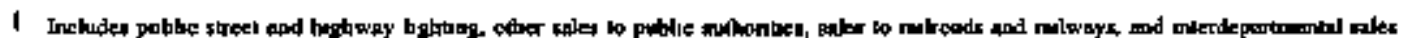

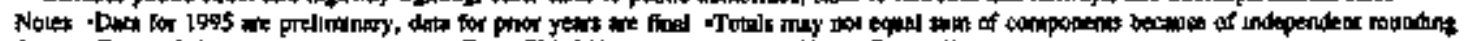

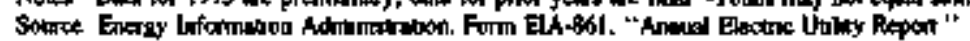

\footnotetext{
3 Summary data In Ihys pubication are for the Ubited States only and do aot include Puerio Rico and the US Serntories

9 For detaled dat, meluding date for the powor authorities of Gund, Paerto. Rice. Amencan Samoa, and the Vitgis Islands, sec the Electrc Sales and Revenue, DOEJEIA-0540, poblished annoally by the Enersy Informatıpa Administrabon
} 
Thble 3. Average Revenare per Kilowattham for U.S. Electric Utilitica by Sector, 1991 Throogh 1999 (Cents)

\begin{tabular}{|c|c|c|c|c|c|}
\hline 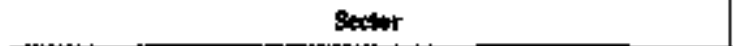 & 1951 & $5 x$ & 194 & Ithe & tos \\
\hline 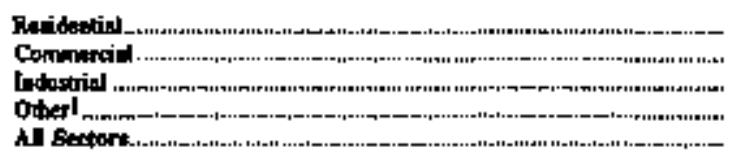 & 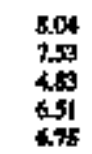 & $\begin{array}{l}8.21 \\
7.66 \\
4.83 \\
6.74 \\
4.6\end{array}$ & $\begin{array}{l}8.31 \\
7.74 \\
4.35 \\
6.60 \\
6.3\end{array}$ & $\begin{array}{l}9.98 \\
7.73 \\
4.77 \\
6.84 \\
6.91\end{array}$ & $\begin{array}{l}8.00 \\
7.60 \\
4.66 \\
6.88 \\
6.8\end{array}$ \\
\hline
\end{tabular}

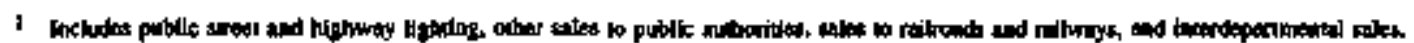

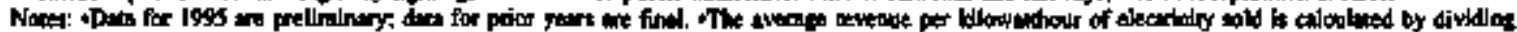

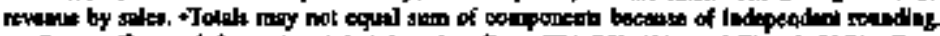

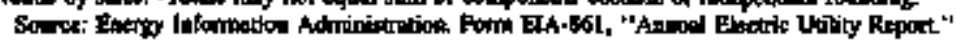


Tahle 4. U.S. Klectric Utifity Sales to Ultimpte Consumers by Sector, Ceasts Division, and Strte, 1994 and 1995

(Million Kilowatthours)

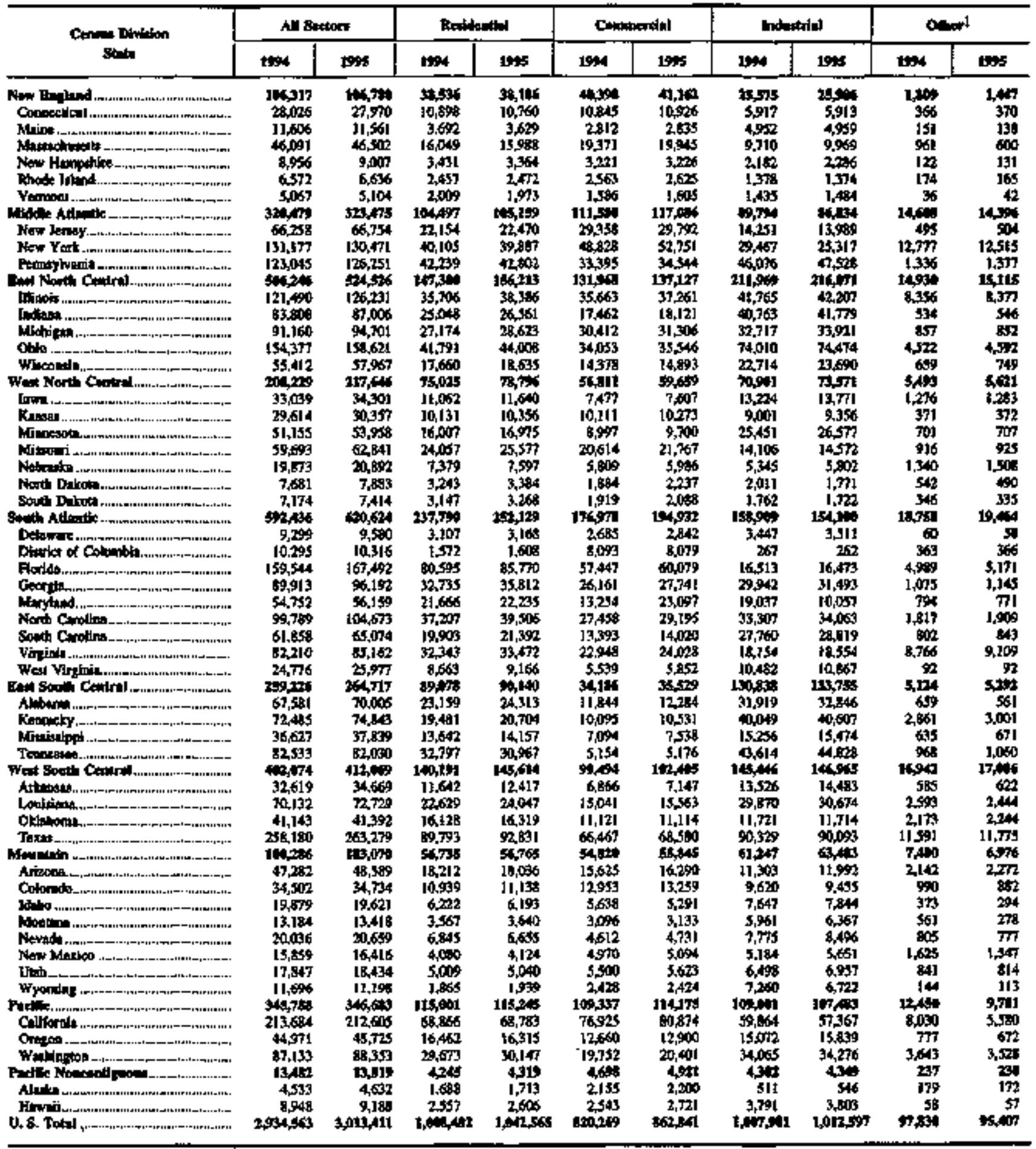

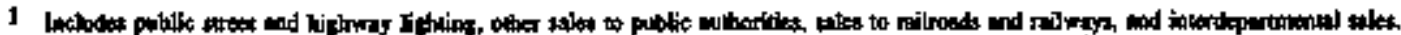

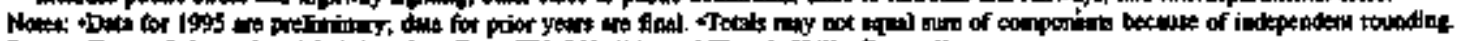

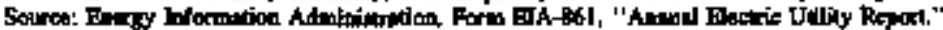


Tabie 5. Number of Ultmate Consumers Served by U.S. Electric Utilltes hy Sector, Census Divtsion, and State, 1994 and 1995

(Thousands)

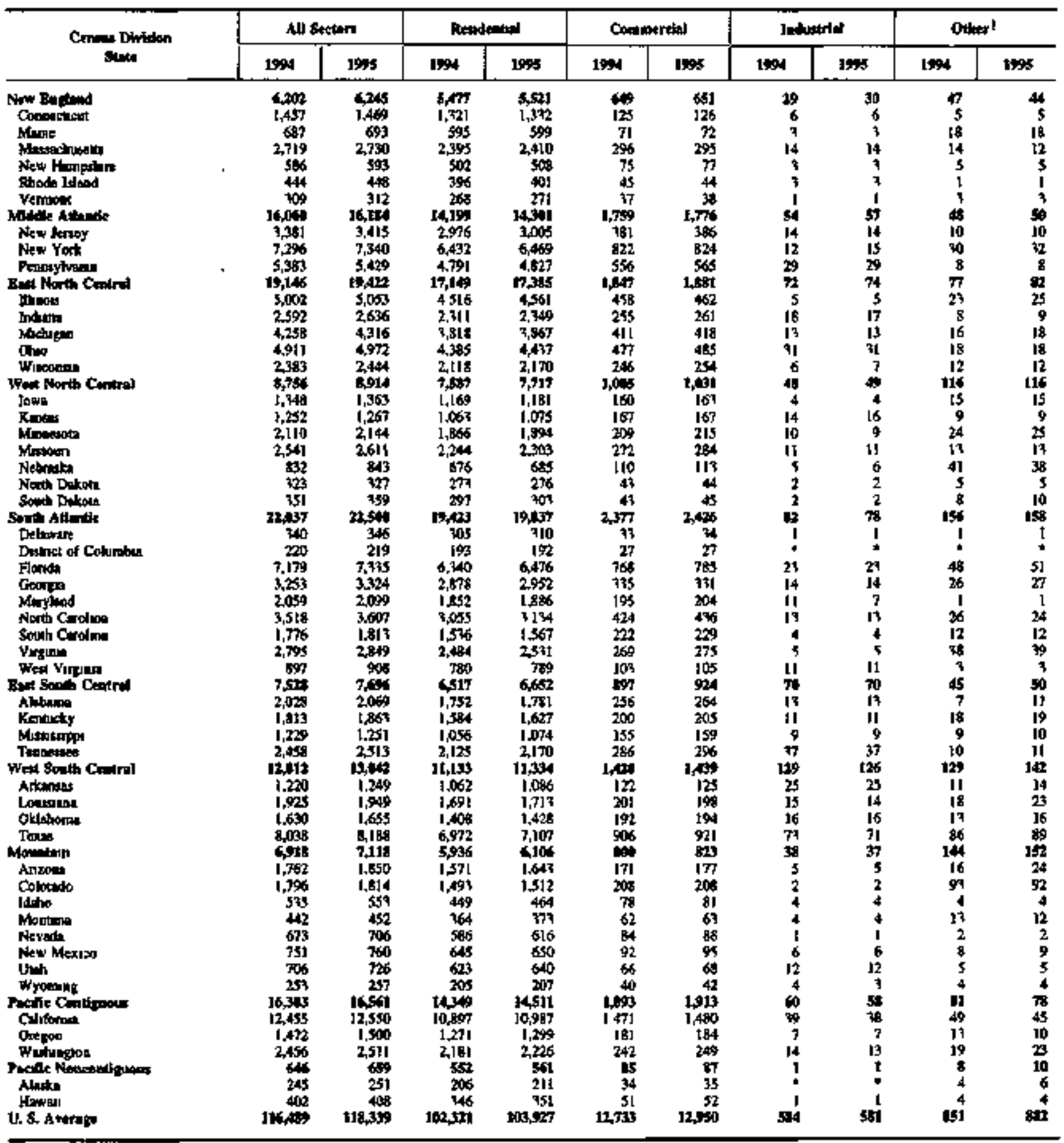

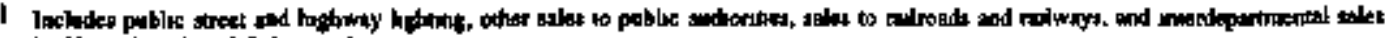
tralpe kes ling 05 thourind

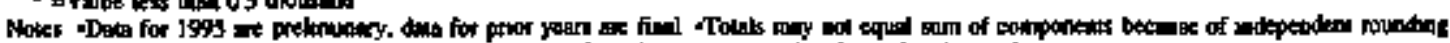

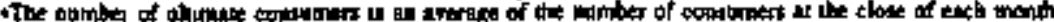

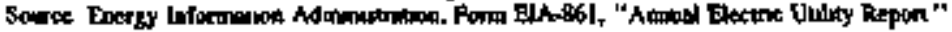


Table 6. Revenue from U.S. Electric Utility Sales to Ultmate Cownmers by Sector, Censug Division, and State, 1994 and 1995

(Million Dollars)

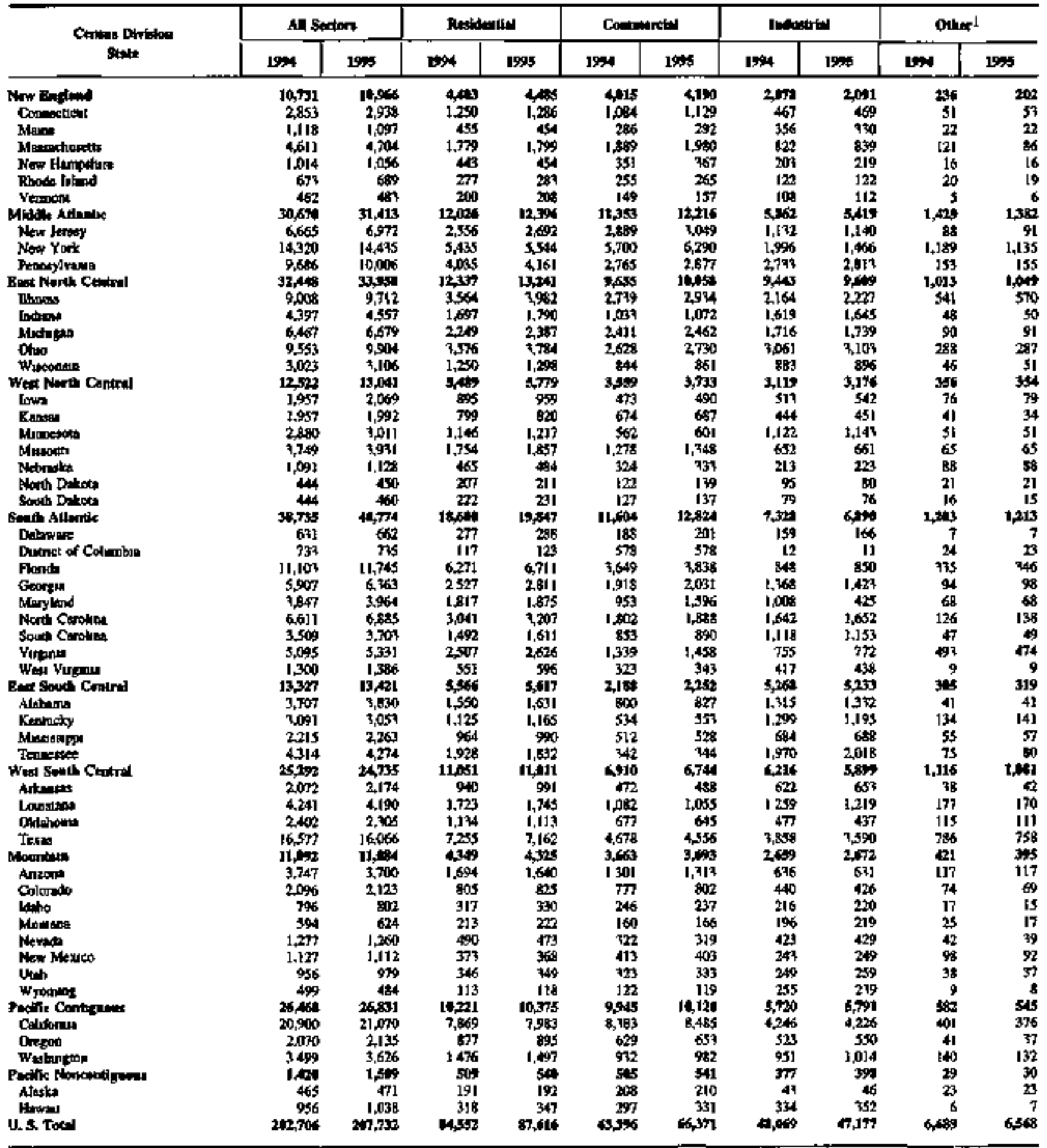

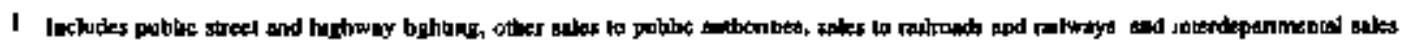

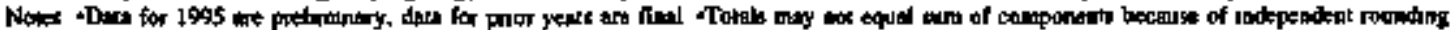

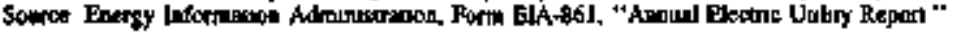


Table 7. Average Revenote per Kilowatthour for U.S. Electric Utiltites by Sector, Census Division, and Stute, 1994 and 1995 (Cents)

\begin{tabular}{|c|c|c|c|c|c|c|c|c|c|c|}
\hline \multirow{2}{*}{ 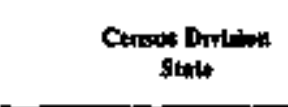 } & \multicolumn{2}{|c|}{ Al Sechom } & \multicolumn{2}{|c|}{ 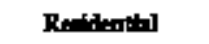 } & \multicolumn{2}{|c|}{ Ceneriala } & \multicolumn{2}{|c|}{ Indin|r|r| } & \multicolumn{2}{|c|}{ Oulet } \\
\hline & 150 & ind & 19) & $\operatorname{teg}$ & $19=4$ & $1 \% 8$ & 192 & Les & 1724 & thes \\
\hline 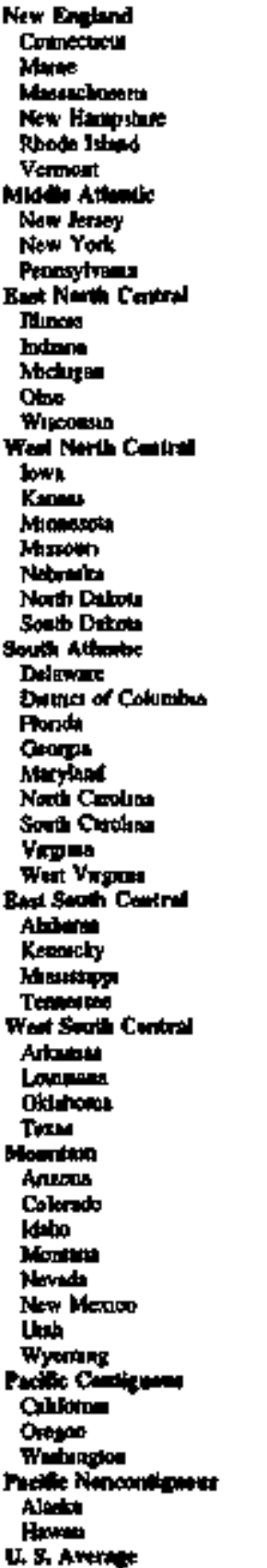 & 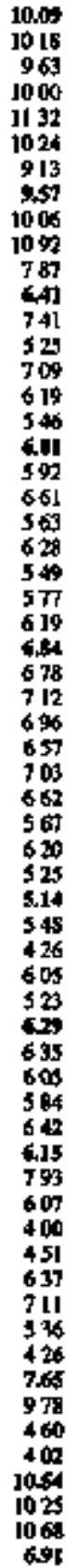 & 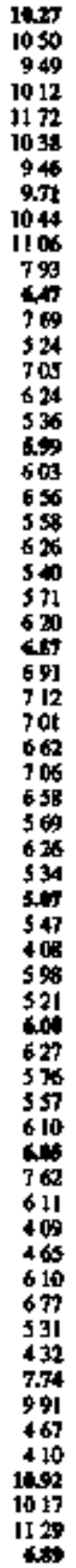 & 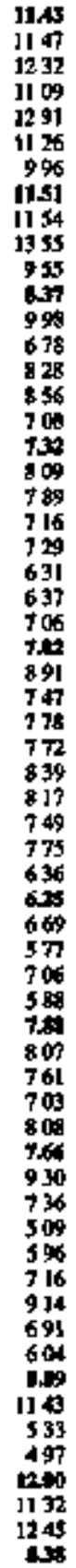 & 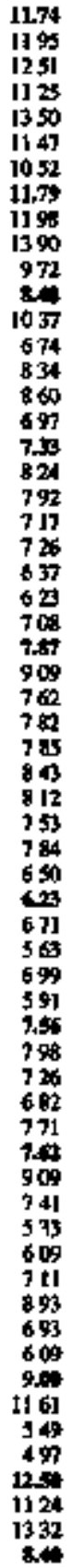 & 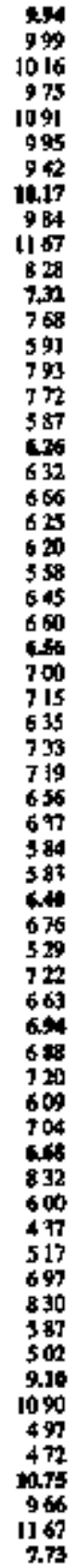 & 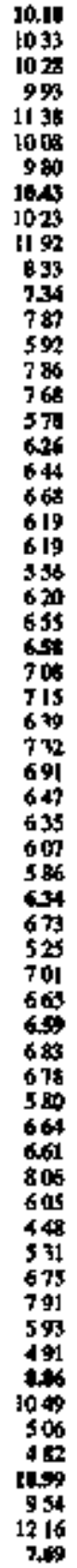 & 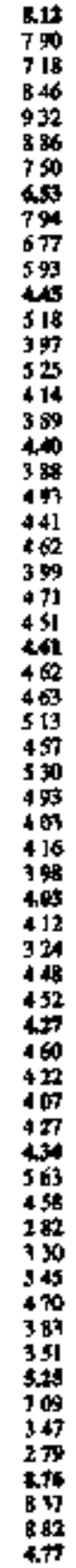 & $\begin{array}{l}815 \\
794 \\
665 \\
842 \\
930 \\
887 \\
756 \\
624 \\
915 \\
579 \\
592 \\
445 \\
528 \\
394 \\
513 \\
417 \\
975 \\
437 \\
394 \\
482 \\
430 \\
154 \\
384 \\
430 \\
443 \\
447 \\
472 \\
436 \\
516 \\
452 \\
423 \\
485 \\
400 \\
416 \\
403 \\
391 \\
405 \\
294 \\
441 \\
450 \\
401 \\
451 \\
397 \\
373 \\
394 \\
421 \\
526 \\
451 \\
281 \\
344 \\
505 \\
440 \\
372 \\
355 \\
539 \\
737 \\
147 \\
296 \\
946 \\
338 \\
927 \\
446\end{array}$ & 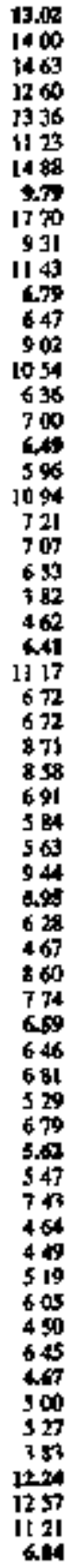 & 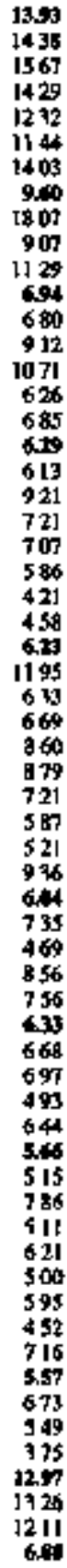 \\
\hline
\end{tabular}

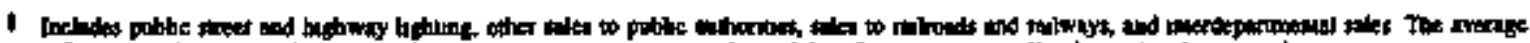

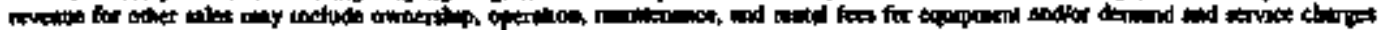

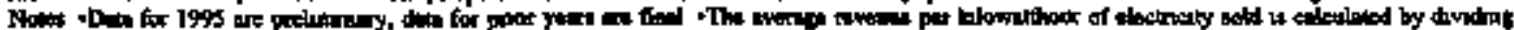

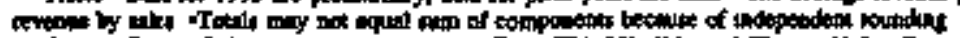

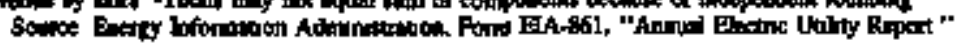




\section{U.S. Electric Utility Financial Statistics}

This chaptet presents data on the financial results of operations for major U.S. investor-owned and publicly owned electric utilities. Composite financial data on other segonents of the U.S. etectric utility industry ${ }_{+}$for example, Federal electric utilities and rural electric cooperatives, afe not included. The data exhibited consist of the Composite Statement of Income, the Composite Balance Sheet, Composite Financial Indicators, and Raventie and Expense Statistics. Hjstorical data are provided for a 5-year period on major U.S. investor-owned and U.S. publicly owned electric utilities. Statisties on the average operating expenses for all plants owsed by major U.S. investot-owned electric utilities are also provided.

\section{Background}

Today, virtualy all investor-owned electric utilities ard subject to State and Federal regulatory jutisdiction. State commissions have the authority to regulate electric rates of utilities engaged in providing service to ultimate consumers (retail saless) and to oversee the issuance of mortgage bonds, debentures, notes, preferred stock, and common stock. The Federal Energy Regulatory Commission (FERC) regulates, among other things, electric rates for interstate wholesale transactions. The ratemaking process eets rates at levels that cover all operating expenses and taxes with a remaining balance that will enable a stility to pay a fair return on funds invested by the stockholders.

A compontent of any economic regulatory activity is the determination of financing and accounting rales. As a consequence of regulatory jurisdiction, regulations for fitancing and accounting are more eritical to the electric power industry than to most other nonregulated industries. Both FERC and State commissions normally ose quasi-judicial proceedings for financial and accounting regulation.

Many of the publicly owned electric utilities are selfregulated (for example, the City of Dover, Delaware), while some fall under the jurisdiction of the public utility commission within the Stale( $\theta)$ where they provide electricity to ultimate consumers (as in the State of Ohio . Because of the absence of any requirement for reporting to a spectfic regulatory body, the accounting practices and policies of publiely owned electric utilities vary greatly. Many publicly owned electric utilities use the FERC Uniform System of Accounts or variations of this (and other) accounting systems. As a result, the composite statistics provided must be viewed with an appropriate degree of caution.
Electric utilities must submit data for a 12-manth period (which does not necessarily end on December 31) and show consistency in their methoos and reporting dates. Because of the respondent burden in preparing this information, publicly owned electric utilities are permitted to nse the year-end period on which thejir fiscal practices are based. Data are provided for the major publicly owned electric utjlities by generator and nongenerators.

\section{Composite Statement of income}

This statement provides a summary of the revenue collected from consumers in return for services rendered within the reporting period; reflects the conts incurred by the electric utility in the production and delivery of electricity; and reports the ntt income or proftl that remains for the owners of the business. Because of the uniqute nature of regolated electric utilitjes, the income statement that is standard to ather nonregulated industries bas been recast to reflect the reporting convertions in the electric power industry. For example, accounting for capital used in construction requires additional reporting on the income statement because of the perpetual nature of construction work in progress. Also, on occasion, electric utilities are required to defer the recovery of cettain costs and earnings from consumers until a futore period. This introduces additional accounting requirements, which must be reflected on all financial statements.

\section{Composhe Balance Sheot}

The balance sheet represtents an accounting at a particular time. For this section, the composite balance shets are presented for major investor-owned electric utilities at the end of a calendar year and for major publicly owned electric utilities for the 12-month fiscal year ending in 1995. A summary of plant, property, and cash beld by the electric utilities, as well as the receivables of the electric utilities, are represented as assets on the composite balance sheet. Future funds obligated by the electric utilities to acquire assets are shown as liabilities and any increasted investment by stockholders is shown as capital on the balance sheet. The standard batance sheet used in the electric power industry emphasizes capital intensity while the balance sheet used by nonregulated industries empbasizes líquidity. 


\section{Composite Financial Indicators}

The financial statement accounts presented in this chapier represent compiled statistics resulting from the activity of the selected electric utilitios. The moasurement of how well the electric utility industry performs in different areas can be approximated by comparing some of the asset and income accounts to other relevant accounts. Using the financial statement information, some basic indicators that can be used to analyze or assess the financial condition of the industry are provided. The method used 10 derive these selected financiat indicators is ratio analysis.

Activity ratios of the investor-owned electric utillties evaluale bow assets are managed. The electric utility industry is one of the most capital intensive industries in the Unjted States, and activity ratios are paramount indicators of the magnitude of this capital intensity. These ratjos detnonstrate the financial relationship that exists between the assets and the revente, sales, and income that these fixed and total assets generate. The tatios on electric-fixed-asset (net plans) turnover and total-asset turnover assess the efficient use of assets in the generation of income.

Leverage rutios of the investor-owned electric utilities sumourize the overalt debt burden and debt structure. In addition, these ratios indicate the financial ability to meet debt service requirements and how well management uses leverage to increase the value of the slockholders' investment. The financial soundness of an industry is directly related to the ability of the industry to raise capital and to provide a reasonable return on the capital invested. To measutre the ability to do this, a number of indicators are used. Current assets to current liabilities is a measure of liquidity. For example, do the investor-ow'bed electric utilitjes have sufficient cash and other assets (current) that can be quickly converted to eash to cover maturing obligations (current liabilities)? Long-term debt to capitalization, preferred stock to capitalization, and common-stock equity to capitalization portray the financial structure and higblight the exlent to which debt and other fixed obligations are used to finsnce operations. Total debt to total assets shows the amount of debc that has been incurred in relationship to the tolal assets possessed. As the value of this ratio increases, the financial risks atso become groaler and more apparent. Common-stock equity to total assets evaluates financial strength. As pet worth increases in relationship to total assets, the debt portion is decreased and financial risks are lowered, Interest coverage before taxes without AFUDC (Allowance for Funds Used During Construction), a noncash source of income, is an indicator of the ability of the investor-owned electric utility to ensure its payment of annual interest costs and maintain its credit ratings.

Profitability ratios of the investor-owned electric utidities indicale operating effectiveness and are used to further evaluate the management of income. The profit margin is equal to net income divided by revenue. This widely used ratio represents the overall measure of income performance. Return on averagecommon-stock equity measures the rate of teturn on equity capital invested. Since one of the main objectjves of nanagement is to earn the bighesi return permissible, this ratio is the best single mensure of the effectiveness of management from the perspective of the stockholders. Return on investment measures the overall rate of return that has been earned on assets. This ratio, determined by dividing total assets into net income, provjdes an indicator of overall financial performance.

Ratios on the pablicly owned electric utilities are provided to assist in understanding the financial performance of the publicly owned segment of the industry. Six ratios are cajculated from the statement of income. Electric wtility plant per dollar of revenue bighlights the capital intensity of the utility. Current assets to current liabilities provides a measure of the ease by which the utility can meet its current obligations. Eleciric urility plant as a percent of total assets represents the total gross invesument in electric plant divided by the total assets. A significant variation in this ratio should signal a relatively fundamental change in the activicies of the electric ntility. Net electric utility plant as a percent of total assets represents the remaining book value and a significant variation should signal a change for the electric utility. Debt as a percent of total liabilities represents the amount of debt compared to total liabilities and other credits. Accumulated provision for depreciation as a percent of total electric plant measures the cost of recovery of the use of the assets over a pertiod of time for an electric utility; an increase indicates that plant asset life is being used up. Five ratios are calcalated from the balance sheet. The ratios of electric operating and maintenance expenses, electric depreciation and amortization, saxes and eax equivalents, and interest on long-ierm debt to electric operating revenue are indicators of how resources were used to produce income. Net income per dollar of revenue provides the amount of the revenue dollar that exceeds expenses and deductions.

Because a number of initiatives are being considered to promote increased competition in the electric power industry, three operating ratios that measure specific costs associated with the sale of each kilowathour of electricity have been included. $P u r$. chase Power Cents Per Kilowatrhour is the ratio of the cost of purchased power to the number of kilowatthours purchased. This ratio neasures the purchased power component of power supply cost. Generated Cents Per Kilowathour is the ratio of the cost of labor, materials used and expenses incurred in the production of electric generation. This ratio measures the generation component of production expenses. Total Power Supply Per Kilowatihour Sold is the ratio of the total cost of powet supply to total sales to both ultimate and restale consumers. This ratio measures all power supply costs, jncluding generation and purchase power, associated with the saie of each kilowatthour of electricity. 


\section{Revenue and Expense Statlatics}

Summary revenue and expense statistics are basic to any analysis of the opetating soundness of an electric utility. To conduct this analysis, it is necessary to separate the electric utility revenue and expense information from other utility reventue and expense tata. Emphasis is placed on total electric operating expenses. Data are presented so that operating costs are separate from maintenance, depreciation, and taxes. For comparative purposes, the ratio of income from utjlity aperations is also included.

\section{Electric Operating Expenses}

Before consumers can be provided with electricity, it first must be either produced (generaled) or purchased, then transmitted to the general area where it will be consumed, and finally distributed to the indjvidual consumer. Hence, electric utilities separate their costs of providing power into four functional areas: generation, transmission, distribution, and administration. Costs incurred at the geseration site for the production of electricity are generally referred to as operating expenses.

Operating expenses include recurring expenses to operste and maintain the physical condition or operating efficiency of the plant. These expenses include wages and benefits of the operators, plant maintenance, security, supervision, toaterials (such as spare parts), and supplies (except fuel consumed during plant operation and maintenance). Fuel expenses include the costs of purchasing, handling. preparing, and transporting fuel. Operating expenses do not include capital cartying costs, such as interest on debi, return on equity, depreciation, amortization expenses, and associated taxes. Capital carrying costs must be added to the operating expenses to obtain lotal generation expenses.

Investor-owned electric utilities are the major sources of total electricity generation, accounting for sbout 80 percent of total utility generation in the United States in 1995. Publicly owned electric utilities were respossible for about io percent of the total U.S. utility geoeration, while the remainder was accounted for by Federal and cooperative electric utilities. Operating expenses per unit of output (kitowathour) for the major investor-owned electric utilities from 1991 through 1995 are provided grouped into the following calegories: fossil-fueled steam, nuclear, hydroelectric, and other (jncludes gas turbine and small scale tlestric plants).

\section{Data Sources}

Financial Statistics. The financial slatistics reported in this chapter on the investor-owned electric utilities are compiled from data oxtacted from the FERC Form 1, "Annual Report of Major Electric Util. ilies, Licensees and Otbers." This suryey is a restricted-universe ceasus used annually to collect detailed accounting, financial, and operating data from major investor-owned electric utilities having, in each of the last 3 consecutive years, sales or transmission service that exceeds one or more of the following:

- 1 million megawatthours of total annual sales

- 100 megawatthours of anbual sales for resale

- 500 megawatthours of annual power exchanges delivered

- 500 megawatthours of annual wheeling for others (deljveries plus losses).

Of the 244 investor-owned electric utilities, the 179 major utitities ate required to submit the FERC Form 1. These major invesior-owned electric utjlitjes represent about three-fourths of all investor-owned electric utilities. The electric utilities are required to follow the Uniform System of Accounts prescribed by the FERC (in cooperation with the National Association of Regulatory Utility Commissioners). Detailed financial statistics on investor-owned electric vtilities are published in the Financlal Statistics of Major U.S. Investor Owned Electric Uritities. ${ }^{10}$

The financial statistics on the publicly owned electric utilities are compiled from data extracted from the Form EIA-4 12, "Annual Report of Public Electric Utilities." This form is a restricted-universe census used annually to collect detailed accounting financial, and operating dala from major publicly owned electric utilities having, is each of the last 2 consecutive years, sales that exceed either of the following:

- 120,000 megawatthours of sales to ultimate con. sumers

- 120,000 megawatthours of sales for resale.

Approximately 500 publicly owned electric utilities are required to subrait the Form EIA-412. These major publicly owned electric utilities represent about onefourth of all publicly owned electric utilities and more than 80 percent of total sales by publicly owned elec. tric utilitjes to ultimate consumers. These electric utilities are requested, but not required, to follow the FERC Uniform System of Accounts, Detailed financial statistics on public electric utilities, Federal electric utilities, and rural electric cooperatives are publisbed in the Financial Stotistics of Major U.S. Publicly Owhed Electric Utilties. ${ }^{11}$

10 Energy Information Adminisuratton (EIA), Financial Statistics of Majter U.S. Investor. Owred Electric Utlities. DOEEIA-0A37(94)1

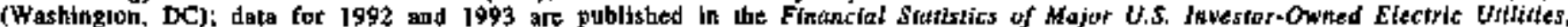

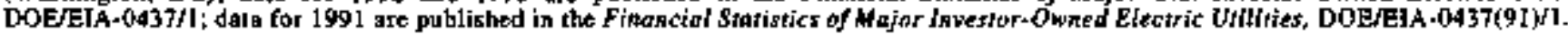

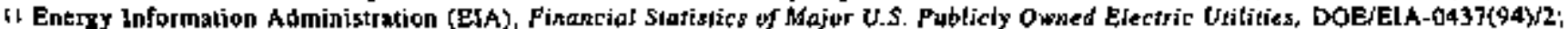

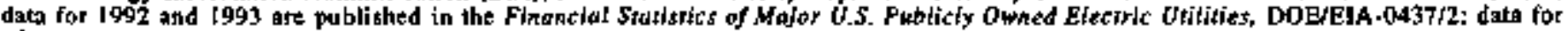
[99] are published in the Financial Sraristics of Major Publichy Onwed Electric Utitities, DOEREIA-0437(99)/2. 
Table 8. Composite Statement of Income for Major U.S. Investor-Owhed Electric Utilities, 1991 Throwgh 1995

(Thousand Dollass)

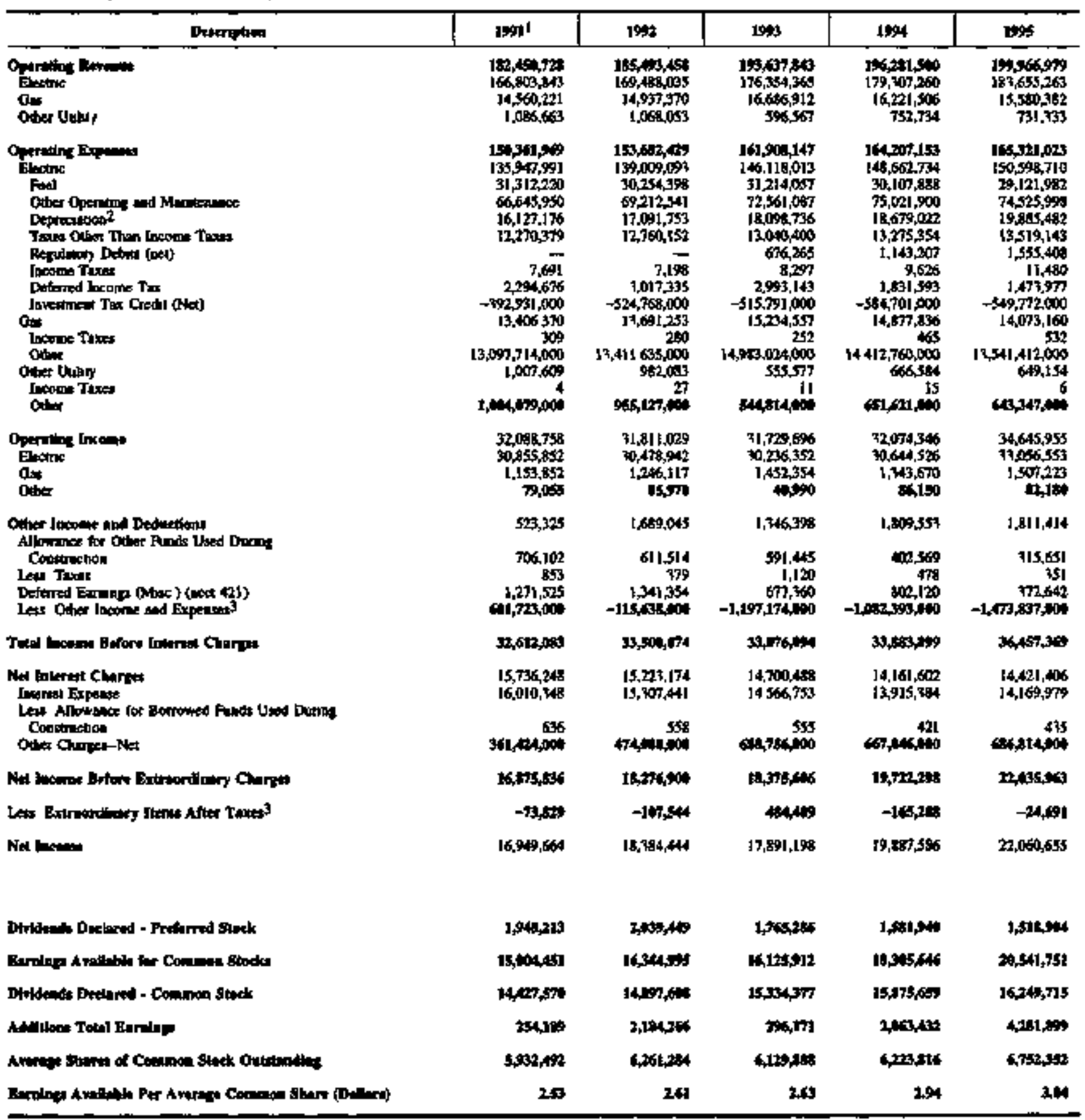

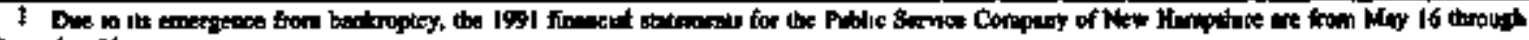
Dutmbit 31

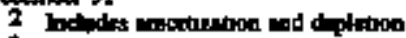

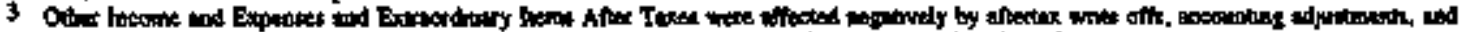

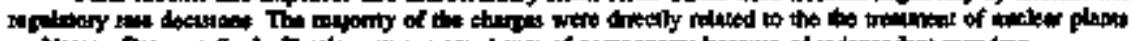

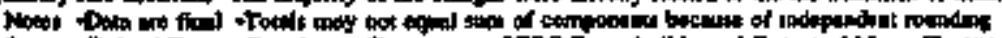

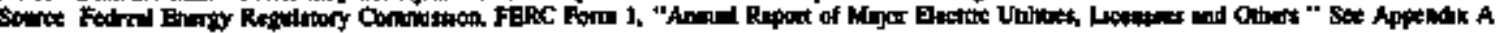

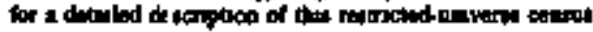


Table 9. Conposite Balance Sheet tor Major U,S. Investor-Owned Electric Utitities, 1991 Through 1995

(Thousand Dollars)

\begin{tabular}{|c|c|c|c|c|c|}
\hline Detactimatimat & $19 \$ 1$ & 192 & $16-3$ & $1 * 4$ & Fis \\
\hline \multicolumn{6}{|l|}{ Arab } \\
\hline 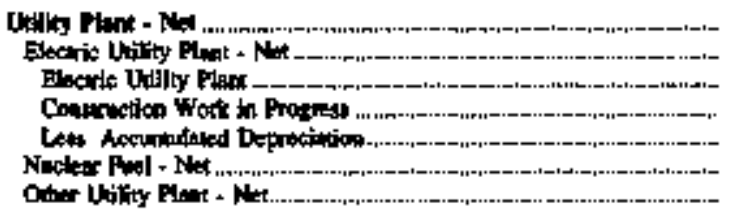 & $\begin{array}{r}376,771,743 \\
349,611,005 \\
479,842,279 \\
18,477,211 \\
140,280,414 \\
6,911,640 \\
20,249,033\end{array}$ & 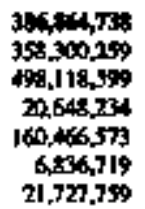 & $\begin{array}{r}39,209,243 \\
34,929,459 \\
319,207,367 \\
18,048,849 \\
173,426,756 \\
1,964,178 \\
24,005,606\end{array}$ & $\begin{array}{r}397,12,254 \\
366,936,417 \\
5,928,343 \\
17,148,353 \\
186,140,318 \\
5,656,878 \\
5,218,959\end{array}$ & 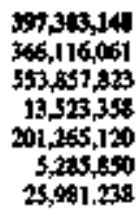 \\
\hline 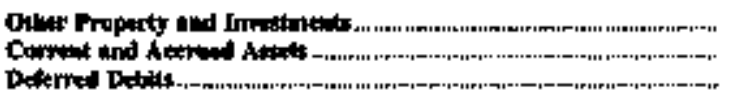 & 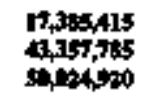 & 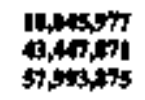 & 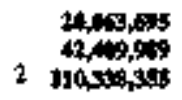 & 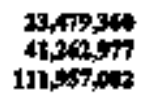 & 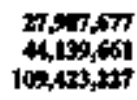 \\
\hline 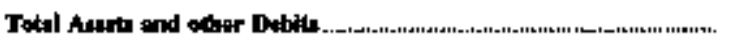 & 4750123 & 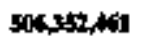 & stactitit & $574,511,673$ & $\sin 33_{3}, \pi$ \\
\hline \multicolumn{6}{|l|}{ Capilnation and Liablitides } \\
\hline 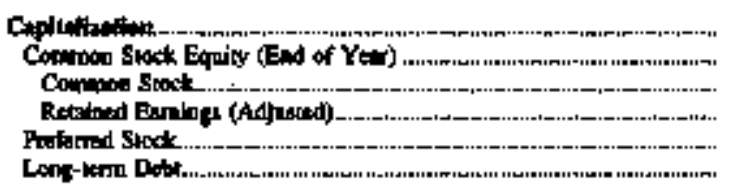 & 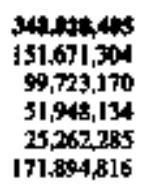 & 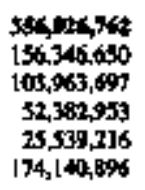 & 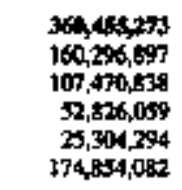 & $\begin{array}{r}36,524,736 \\
164,492,824 \\
109,52,036 \\
54,560,728 \\
24,859,833 \\
175,382,079\end{array}$ & $\begin{array}{r}3,6,76,716 \\
170,497,137 \\
111,391,825 \\
39,195,307 \\
21,597,105 \\
173,708,479\end{array}$ \\
\hline 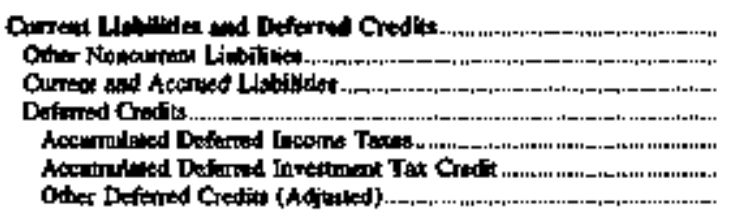 & $\begin{array}{r}13,715,414 \\
6,991,199 \\
49,357,466 \\
28,422,789 \\
59,198,294 \\
14,689,786 \\
14,544,706\end{array}$ & 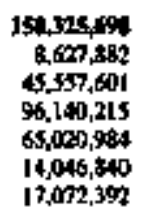 & $\begin{array}{r}206,19 \times, 010 \\
11,478,313 \\
49,879,976 \\
145,828,731 \\
104,964,189 \\
13,428,995 \\
27,4,8,549\end{array}$ & $\begin{array}{r}20,736,097 \\
13,452,636 \\
49,035,058 \\
148,799,743 \\
107,054,667 \\
12,754,415 \\
26,460,160\end{array}$ & $\begin{array}{r}213,161,438 \\
14,352,102 \\
49,529,408 \\
148,877,493 \\
108,615,175 \\
12,138,902 \\
28,12,375\end{array}$ \\
\hline 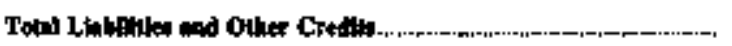 & 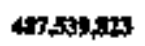 & 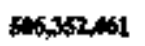 & 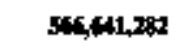 & 574511,173 & $5 \%, 933,714$ \\
\hline
\end{tabular}

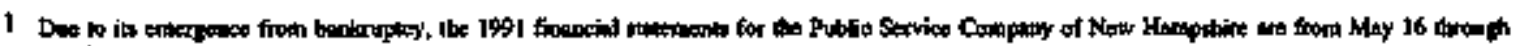
Docember $\$ 1$.

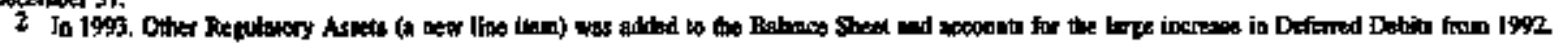

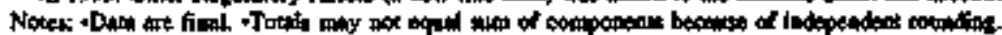

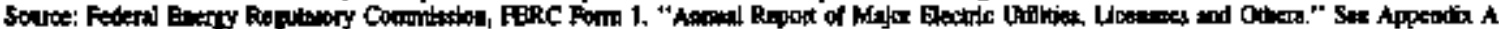

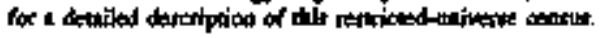


Figure 11. Alocetion of the Revenue Dollar from Electric Operatlons for Major U.S. Investor-Ownod ElectricUtillties, 1995

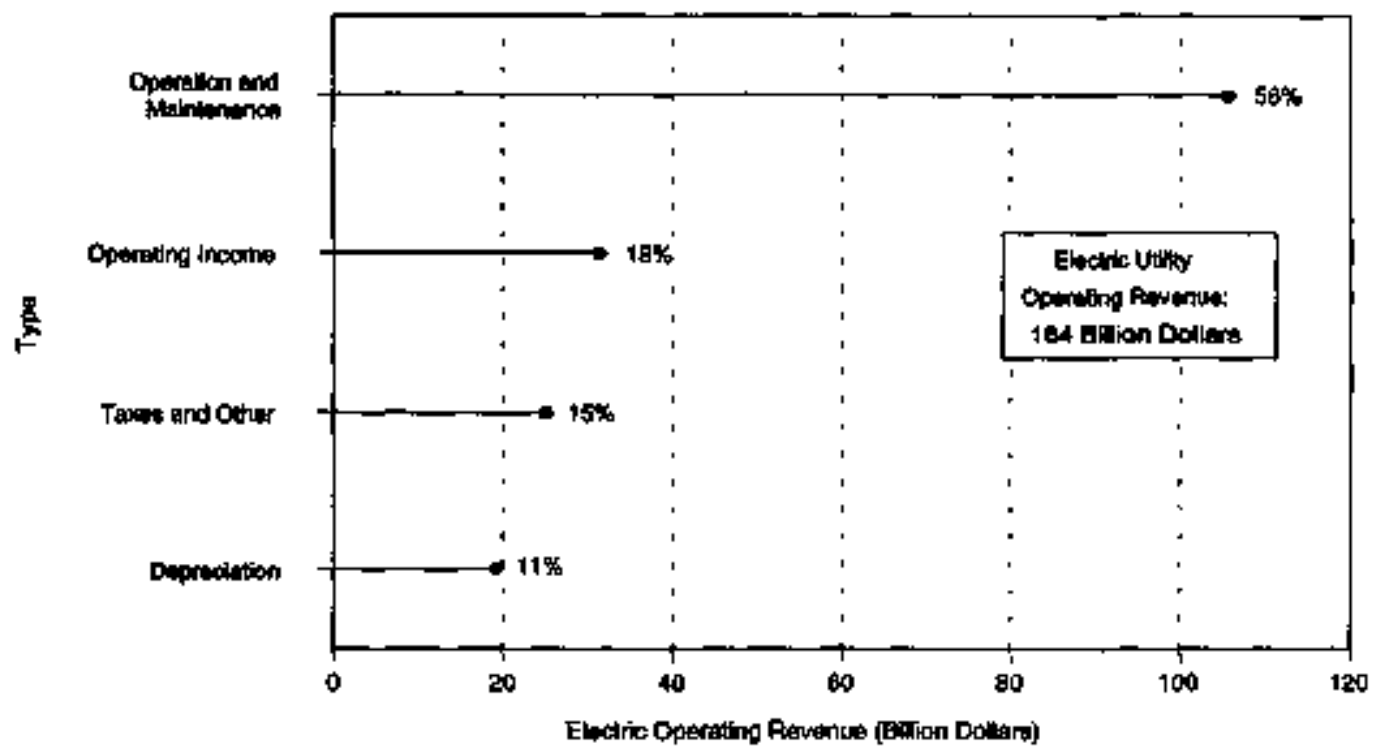

Notes: -Depreciation includos amortizalion and deptetion. -Totals may not equal sum of components bectuse of independen: rounding. Data are final.

Source: Federal Energy Regulaiory Comrileston, FERC Form 1, "Annual Repon of Major Electric Uth"ibes, Leensees and Others," See Appendix A kor a detailed description of this restricted unverger census.

Figure 12. Elactric Operating Expenuas for Major U.S. Investor-Owned Electrle Utilitian, 1996

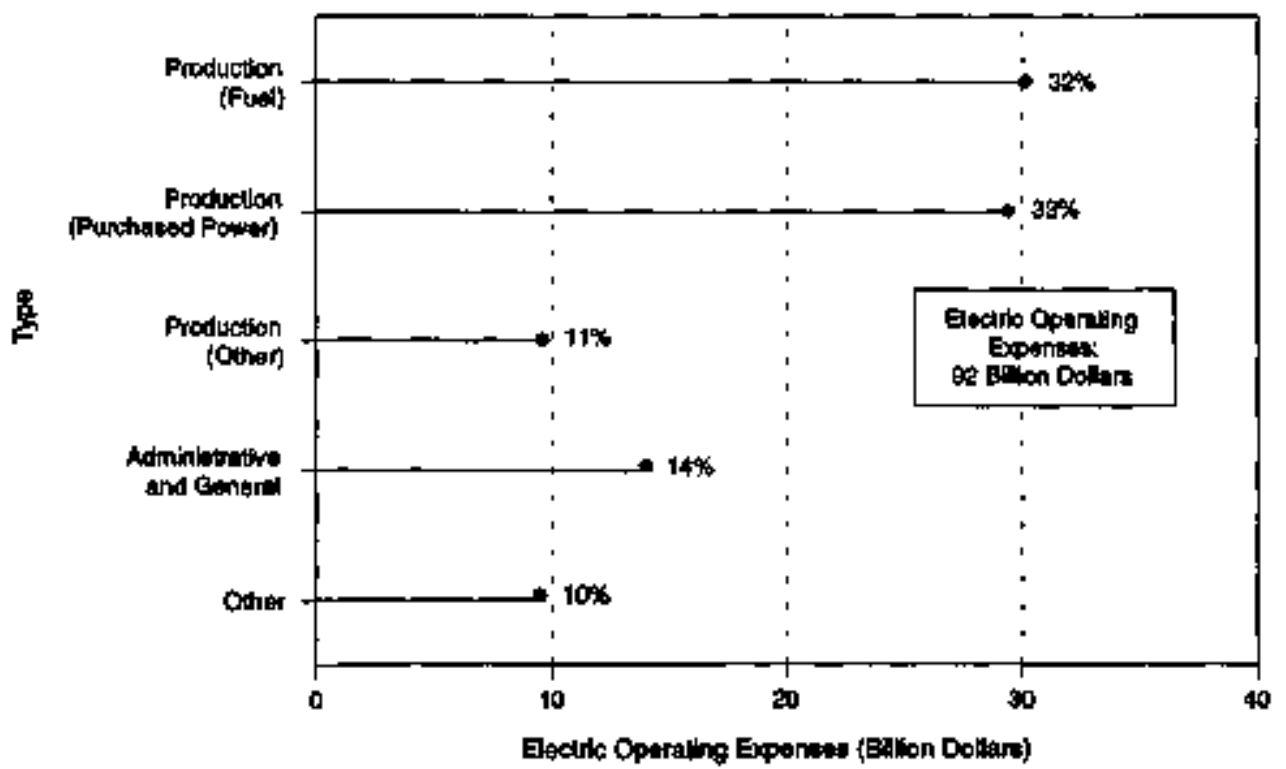

Notes: •Other inchudes transmiesion, distebution, customer account, customer semite, and sales. -Tokals may not equal sum of components because of hideperdent rounding. -Data are final.

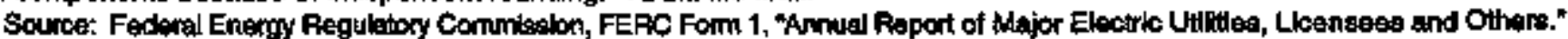
Seo Appendix A for a detailed deecription of this restrleted-universe census. 
Table 10. Composite Financial Indicators tor Mafor U.S. Investor-Owned Electric Utilities, 1991 Through 1995

\begin{tabular}{|c|c|c|c|c|c|}
\hline Dmerlpting & $199^{2}$ & $19 \%$ & $\operatorname{trgs}$ & $19 \%$ & 1945 \\
\hline 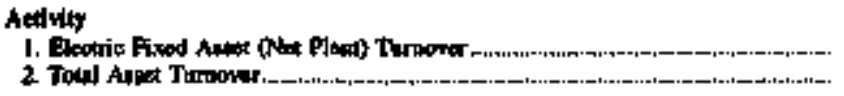 & $\begin{array}{r}0.49 \\
37\end{array}$ & $\begin{array}{r}0.75 \\
37\end{array}$ & $\begin{array}{r}0.49 \\
.94\end{array}$ & $\begin{array}{r}0.49 \\
34\end{array}$ & $\begin{array}{r}0.50 \\
.35\end{array}$ \\
\hline 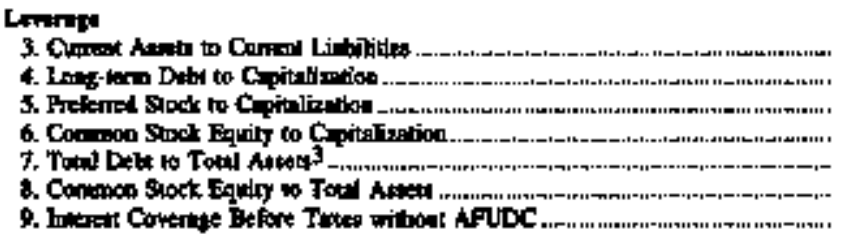 & $\begin{array}{r}1.00 \\
49.28 \\
7.24 \\
43.48 \\
36.69 \\
31.11 \\
2.49\end{array}$ & $\begin{array}{r}.95 \\
48.91 \\
7.17 \\
43.91 \\
36.13 \\
30.48 \\
2.62\end{array}$ & $\begin{array}{r}.87 \\
4.51 \\
7.02 \\
44.47 \\
32.48 \\
28.29 \\
2.78\end{array}$ & $\begin{array}{r}86 \\
48.09 \\
6.82 \\
43.10 \\
32.35 \\
28.63 \\
3.10\end{array}$ & $\begin{array}{r}498 \\
47.49 \\
590 \\
46.61 \\
31.89 \\
29.45 \\
3.37\end{array}$ \\
\hline 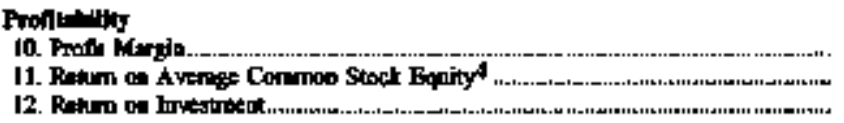 & $\begin{array}{r}9.29 \\
11.33 \\
3.48\end{array}$ & $\begin{array}{r}9.91 \\
11.94 \\
\mathbf{1 . 6 3}\end{array}$ & $\begin{array}{r}9.24 \\
11.30 \\
3.16\end{array}$ & $\begin{array}{r}10.13 \\
12.24 \\
3.46\end{array}$ & $\begin{array}{r}11.63 \\
13.17 \\
3.81\end{array}$ \\
\hline
\end{tabular}

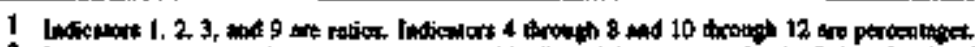

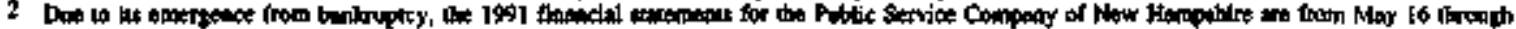
Decentien 31

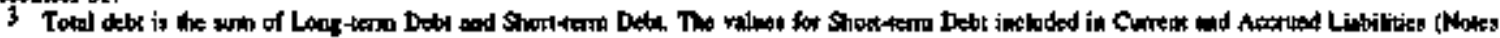

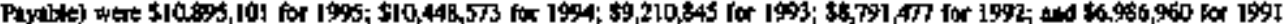

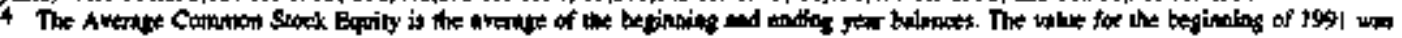
$5146,547,683$.

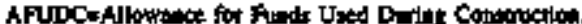

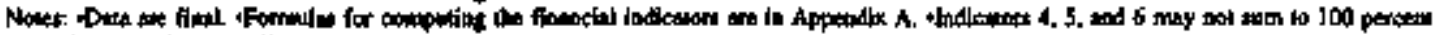
becing of indipantem roupding

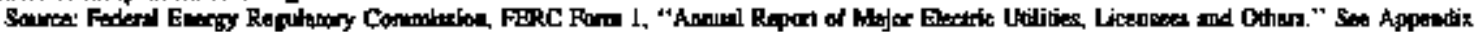

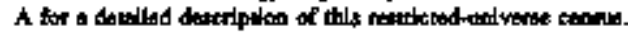


Table 11. Revenue and Expense Stotistics for Major U.S. Investor-Owned ERectric Utilities, 1991 Throush 1995

(Thousand Dallars)

\begin{tabular}{|c|c|c|c|c|c|}
\hline Deseripatan & J99:1 & 192 & 1955 & tris & bis \\
\hline 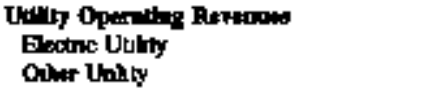 & $\begin{array}{r}182,400,728 \\
164,810,843 \\
15,646,894\end{array}$ & $\begin{array}{r}16,43,46 \\
168,488,435 \\
16,105,423\end{array}$ & $\begin{array}{r}13, \mathbf{x}, 546 \\
176,354,365 \\
17,283,479\end{array}$ & $\begin{array}{r}19,281,500 \\
179,307,260 \\
16,914,210\end{array}$ & $\begin{array}{r}199,34,975 \\
193,655,763 \\
16,311,715\end{array}$ \\
\hline 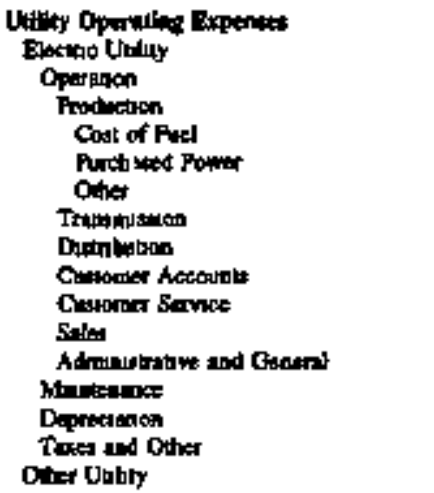 & $\begin{array}{r}151,361,999 \\
13,947,991 \\
84,933,743 \\
64,101,328 \\
31,312,200 \\
24,169,252 \\
10,620,056 \\
1,247,286 \\
2,530,490 \\
3,263,212 \\
1,451,507 \\
209,230 \\
11,196,490 \\
12,024,427 \\
16,127,176 \\
21,062,645 \\
14,413,979\end{array}$ & 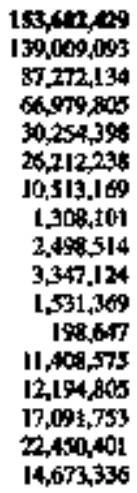 & $\begin{array}{r}161,942,147 \\
146,11 \pm, 013 \\
91,328,230 \\
68,730,003 \\
31,244,057 \\
27,715,512 \\
9,851,274 \\
1,354,058 \\
2,595,023 \\
3,418,487 \\
1,832,267 \\
203,291 \\
13,124,300 \\
12,446,914 \\
18,098,736 \\
24,244,133 \\
15,796,134\end{array}$ & $\begin{array}{r}164,207,153 \\
148,662,734 \\
93,107,998 \\
69,269,652 \\
30,107,868 \\
29,213,464 \\
9,947,680 \\
1,361,060 \\
2,581,409 \\
3,546,489 \\
1,955,991 \\
231,589 \\
14,162,789 \\
12,021,790 \\
18,679,022 \\
24,853,924 \\
15,544,420\end{array}$ & 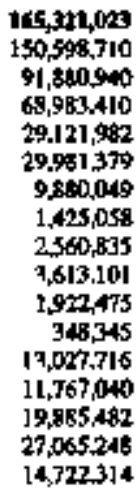 \\
\hline 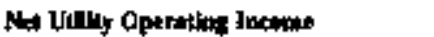 & $540,0,705$ & MAll,009 & $31,72,404$ & $32,074,346$ & 34,4t5,95s \\
\hline
\end{tabular}

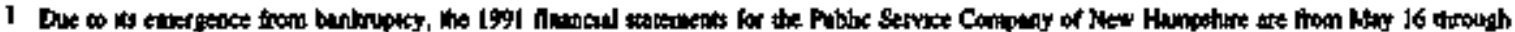
Depantion ?1

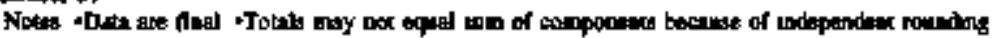

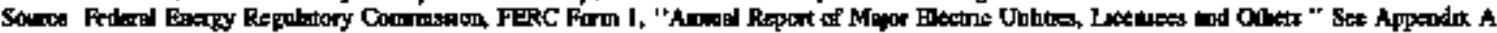

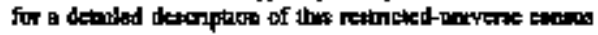

Table 12. Revenue and Expense Percentages for Major U.S. Investor-Omned Electric Utillties, 1991 Through 1995

\begin{tabular}{|c|c|c|c|c|c|}
\hline Descruptow & 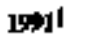 & $\ln$ & 1908 & $1+4$ & 19s5 \\
\hline 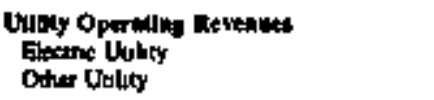 & $\begin{array}{r}100 \\
914 \\
86\end{array}$ & $\begin{array}{r}100 \\
974 \\
86\end{array}$ & $\begin{array}{r}19 \\
81 \\
89\end{array}$ & $\begin{array}{r}149 \\
914 \\
86\end{array}$ & $\begin{array}{r}1000 \\
918 \\
92\end{array}$ \\
\hline 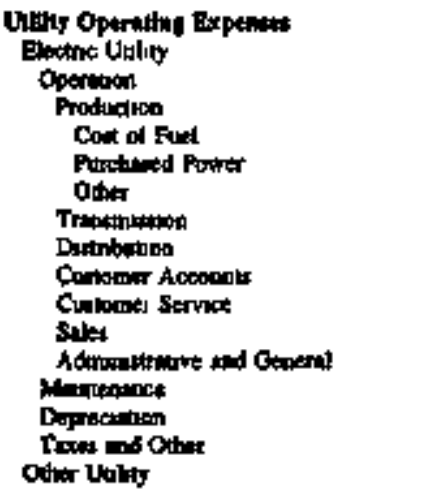 & $\begin{array}{r}64 \\
745 \\
41 \\
362 \\
172 \\
132 \\
58 \\
7 \\
14 \\
18 \\
8 \\
1 \\
61 \\
68 \\
88 \\
120 \\
79\end{array}$ & $\begin{array}{r}629 \\
749 \\
470 \\
361 \\
163 \\
141 \\
57 \\
7 \\
13 \\
18 \\
8 \\
1 \\
62 \\
66 \\
92 \\
121 \\
79\end{array}$ & $\begin{array}{r}80.6 \\
755 \\
472 \\
355 \\
161 \\
143 \\
51 \\
7 \\
13 \\
18 \\
10 \\
1 \\
68 \\
64 \\
93 \\
125 \\
42\end{array}$ & $\begin{array}{r}137 \\
757 \\
474 \\
353 \\
153 \\
149 \\
51 \\
7 \\
13 \\
18 \\
10 \\
1 \\
72 \\
61 \\
55 \\
127 \\
39\end{array}$ & $\begin{array}{r}81.7 \\
757 \\
459 \\
143 \\
146 \\
150 \\
49 \\
7 \\
13 \\
18 \\
10 \\
2 \\
65 \\
59 \\
99 \\
135 \\
74\end{array}$ \\
\hline 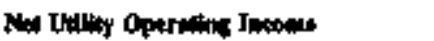 & 17,6 & I7.1 & 16.4 & 16.3 & 17.3 \\
\hline
\end{tabular}

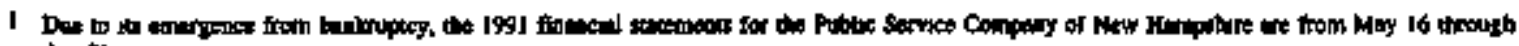
Dexperior 3)

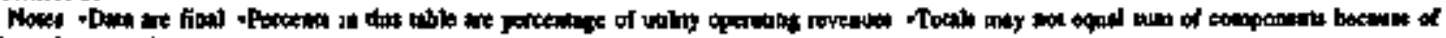

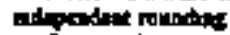

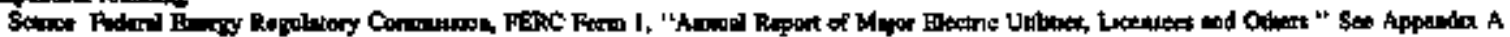

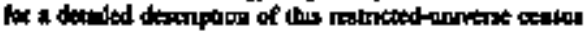


Twhle 13. Averape Operallne Expenes for Major U.S. Investor-Owed Electric Ut:litios, 1991 Through 1995

(Mitls per Kilowatthour)

\begin{tabular}{|c|c|c|c|c|c|}
\hline PIn $T_{\boldsymbol{X}}$ & 201 & 1902 & 5 & $15 \% 4$ & 194 \\
\hline & \multicolumn{5}{|c|}{ Oparesere } \\
\hline \multirow[t]{2}{*}{ 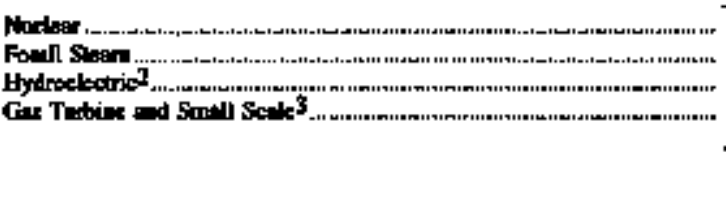 } & $\begin{array}{r}10.49 \\
2.29 \\
3.68 \\
9.61\end{array}$ & $\begin{array}{r}10.43 \\
2.38 \\
4.33 \\
10.18\end{array}$ & $\begin{array}{r}10.20 \\
2.37 \\
3.42 \\
6.7\end{array}$ & $\begin{array}{l}9.79 \\
2.32 \\
4.53 \\
4.58\end{array}$ & $\begin{array}{l}9.43 \\
2.38 \\
3.69 \\
3.57\end{array}$ \\
\hline & \multicolumn{5}{|c|}{ 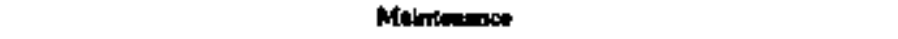 } \\
\hline \multirow[t]{2}{*}{ 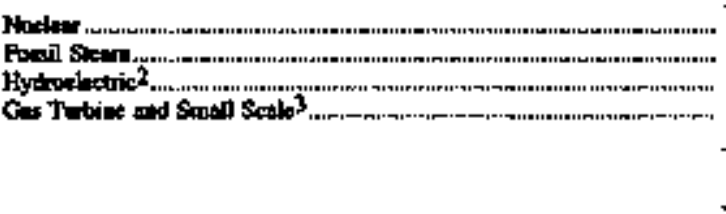 } & $\begin{array}{r}1.50 \\
2.95 \\
2.89 \\
1290\end{array}$ & $\begin{array}{r}5,53 \\
2,55 \\
3,30 \\
1215\end{array}$ & $\begin{array}{l}5.73 \\
296 \\
2.65 \\
7.52\end{array}$ & $\begin{array}{l}5.20 \\
2.82 \\
2.90 \\
5.39\end{array}$ & $\begin{array}{l}5.21 \\
2.65 \\
2.19 \\
4.28\end{array}$ \\
\hline & \multicolumn{5}{|c|}{ Fad } \\
\hline 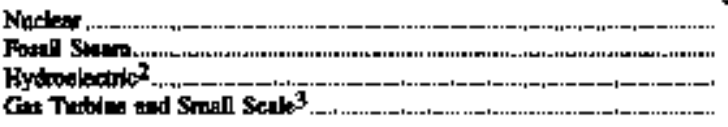 & $\begin{array}{r}6.71 \\
17.91 \\
30.96\end{array}$ & $\frac{17.12}{17.49}$ & $\frac{589}{17.65}$ & $\begin{array}{r}5.87 \\
16.67 \\
2.79\end{array}$ & $\frac{5.75}{16.47}$ \\
\hline & \multicolumn{5}{|c|}{ Toualt } \\
\hline 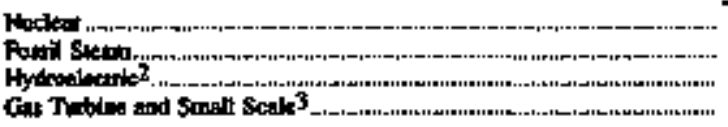 & $\begin{array}{r}22.70 \\
23.17 \\
6.76 \\
53.51\end{array}$ & $\begin{array}{r}22.48 \\
22.83 \\
7.63 \\
50.92\end{array}$ & $\begin{array}{r}21.80 \\
22.97 \\
6.4 \pi \\
10.38\end{array}$ & $\begin{array}{r}20.86 \\
21.00 \\
7.43 \\
32.16\end{array}$ & $\begin{array}{r}20.39 \\
21.11 \\
5.69 \\
25.67\end{array}$ \\
\hline
\end{tabular}

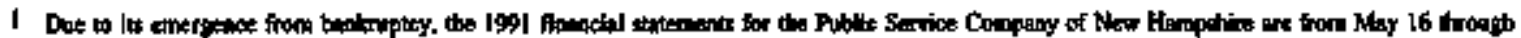
Deperiber 2 ?.

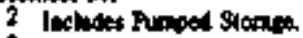

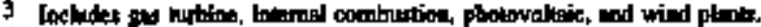

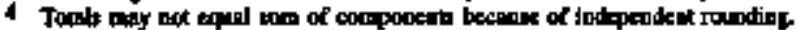

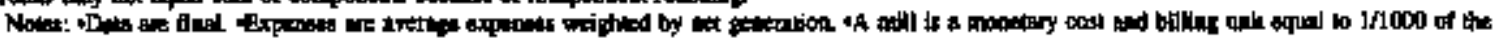
US. dollew (equetyalent to IfHO of I serk).

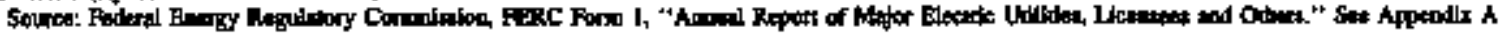

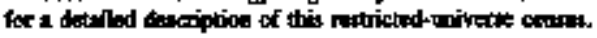


Figure 13. Average Operating Expenses of Fosst-Fueled and Nuelaer Stearm-Electric Pianto for Major U.S. Inveptor-Owned Electric Utilltiol, 1995

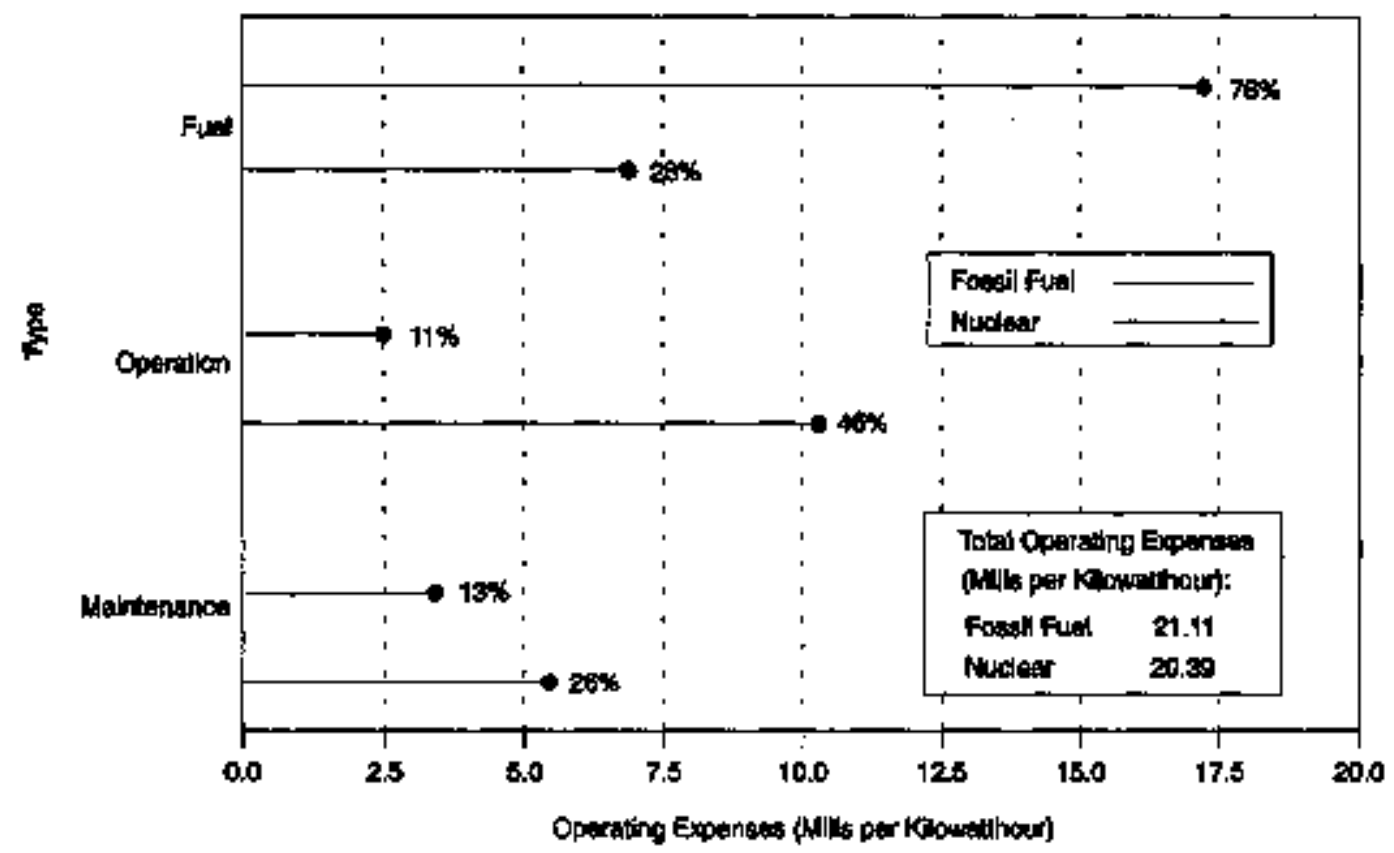

Notes: Data are final. -Totals may not equal sum of components because of independent rounding.

Source: Federal Energy Regulatory Commission, FERC Fotmt, "Annual Report of Major Electric Uulities, Licensees and Others." See Appendix $A$ for a detailed description of this restricted-universe census. 
Table 14. Compaitte Statement of Income for Mojor U.S. Pablicty Owned Generator Electric Utiltitex, 1991 Through 1995

(Thousand Dollars)

\begin{tabular}{|c|c|c|c|c|c|}
\hline Denchiption & $19 \$ 1$ & 169 & 1903 & 1094 & 1994 \\
\hline Oparath Rme:ce - Electrik & 21,482, mo & $21,686,349$ & $2,521,047$ & $20,3,6,696$ & 20 , \\
\hline 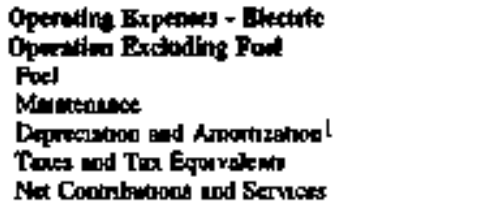 & $\begin{array}{r}14,846,421 \\
9,0082917 \\
3,072,159 \\
1,446,295 \\
2,300,532 \\
595,719 \\
389,300\end{array}$ & $\begin{array}{r}17,190,647 \\
9,408,002 \\
3,119,477 \\
1,564,792 \\
2,417,279 \\
6,1,140 \\
-\end{array}$ & $\begin{array}{r}18,162,164 \\
9,807,647 \\
3,437,920 \\
1,565,297 \\
2,596,099 \\
759,209 \\
7\end{array}$ & $\begin{array}{r}10,64,698 \\
10,191,897 \\
3,285,718 \\
1,594,444 \\
1,720,560 \\
76,068 \\
-\end{array}$ & $\begin{array}{r}16,714,140 \\
9,6,27156 \\
2,794,299 \\
1,962,497 \\
2,574,064 \\
756,144 \\
-\end{array}$ \\
\hline 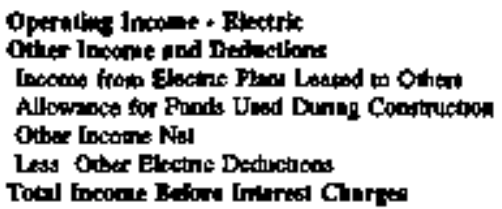 & $\begin{array}{r}4,1+4,949 \\
1,8013,761 \\
5,942 \\
71,025 \\
1,890,138 \\
127,345 \\
40,710\end{array}$ & $\begin{array}{r}4,45,763 \\
1,068,544 \\
15,129 \\
24,183 \\
1,839,484 \\
249,852 \\
6,124,644\end{array}$ & $\begin{array}{r}4,35,65 \\
1,319,798 \\
23,576 \\
28,476 \\
1,455,984 \\
28,323 \\
5,579,392\end{array}$ & $\begin{array}{r}4,617,997 \\
1,00,521 \\
30,242 \\
7,872 \\
1,237,067 \\
176,259 \\
5,116,920\end{array}$ & $\begin{array}{r}40,949 \\
251,380 \\
14.714 \\
9,145 \\
1,050,092 \\
222,573 \\
4921,328\end{array}$ \\
\hline 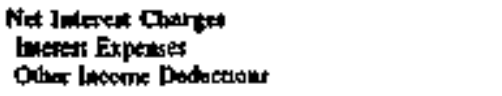 & $\begin{array}{r}5,20,5,79 \\
4,775,009 \\
470,796\end{array}$ & $\begin{array}{r}5,025,758 \\
4,757,587 \\
268.175\end{array}$ & $\begin{array}{r}4,682,103 \\
4,433,6,67 \\
248,946\end{array}$ & $\begin{array}{r}4,651,141 \\
4,332,296 \\
348,845\end{array}$ & $\begin{array}{r}3,896,654 \\
7,540,396 \\
7,56261\end{array}$ \\
\hline 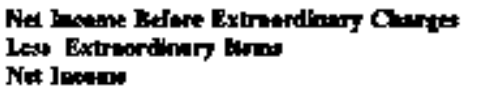 & $\begin{array}{r}.33,51 \\
7544 \\
78967\end{array}$ & $\begin{array}{r}1,099,889 \\
115,275 \\
953,613\end{array}$ & $\begin{array}{l}297,360 \\
214,27 \\
903,14\end{array}$ & $\begin{array}{r}1,035,779 \\
124,211 \\
911,500\end{array}$ & $\begin{array}{r}1,024,611 \\
-22,75 \\
1,047,43\end{array}$ \\
\hline
\end{tabular}

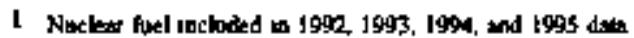

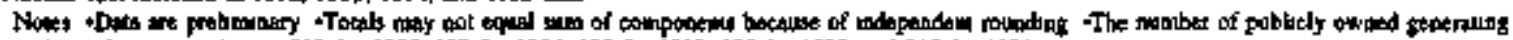

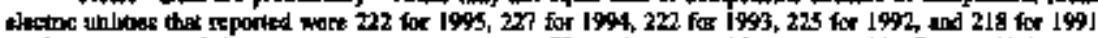

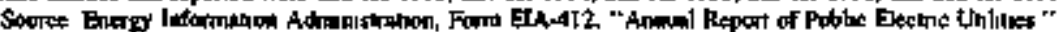

Table 15. Composite Balance Sheet for Major US. Publicly Owned Generator Electric Utilities, 1991 Through 1995

(Thousand Dollars)

\begin{tabular}{|c|c|c|c|c|c|}
\hline Desciption & 1991 & $\operatorname{lom}$ & 19\%5 & $19 \%$ & 1395 \\
\hline 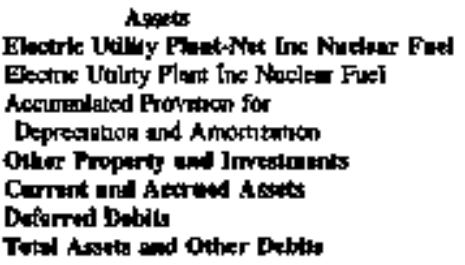 & 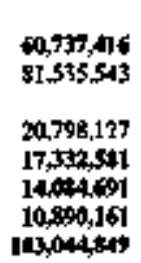 & 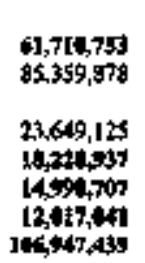 & 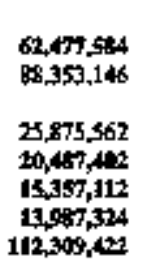 & $\begin{array}{l}63,576,114 \\
92,044,066 \\
28,461,981 \\
24,973,9646 \\
15,787,291 \\
13,913,754 \\
114,246,146\end{array}$ & $\begin{array}{l}57,0,49,368 \\
84,113,584 \\
7,044,277 \\
18,894,421 \\
11,944,255 \\
10,543,805 \\
99,501,869\end{array}$ \\
\hline 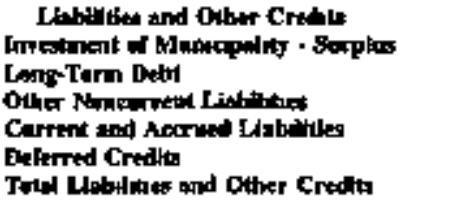 & 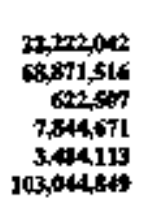 & 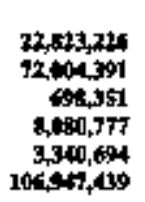 & 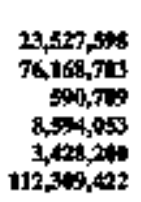 & $\begin{array}{r}24,51 d, 261 \\
76,15,149 \\
701,446 \\
1,913,155 \\
9,26,4,415 \\
114,246,146\end{array}$ & 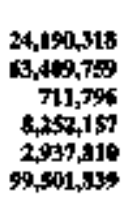 \\
\hline
\end{tabular}

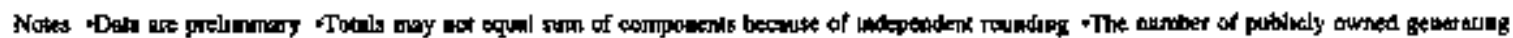

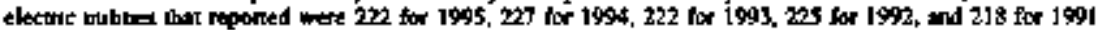

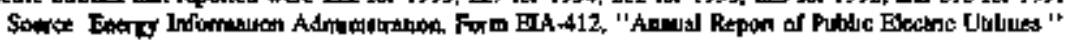


Tabje 16. Composite Financial Indichtors for Major US. Pablicly Owned Generator Electric Utulittes, 1991 Through 19\%s

\begin{tabular}{|c|c|c|c|c|c|}
\hline Descriptin & 1401 & $\mathbf{1 0 2}$ & $1 * \$$ & $1 \%$ & 1548 \\
\hline 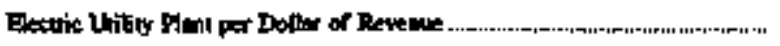 & 3.9 & 3.9 & 3.9 & 4.0 & 40 \\
\hline 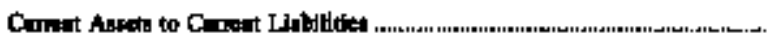 & 18 & 1.9 & $\mathbf{1 . 8}$ & $\mathbf{I . E}$ & t.6 \\
\hline 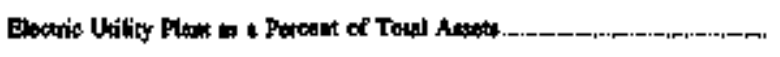 & 79.1 & 79.8 & 78.7 & 80.6 & s4.5 \\
\hline 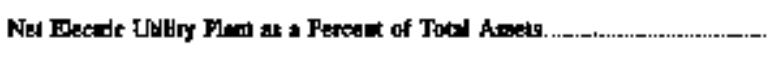 & 58.9 & 37.7 & 55.6 & $\$ 5.6$ & 57.4 \\
\hline 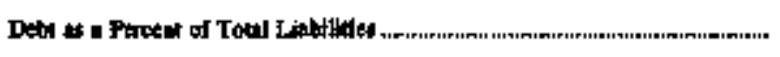 & 74,4 & 74.9 & 75.5 & 75.0 & 72.0 \\
\hline 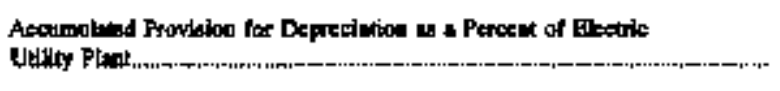 & 25.5 & 23.? & 29.3 & 30.9 & 32.2 \\
\hline 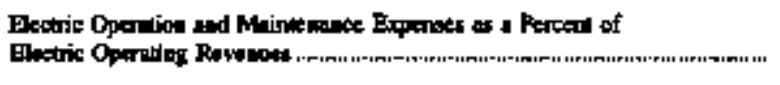 & 645 & 65 & 65.7 & $4 \mathbf{5} 2$ & 64,4 \\
\hline 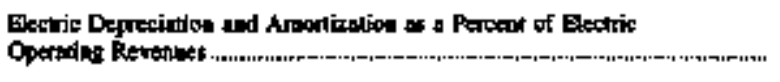 & 109 & 10.5 & $\mathbf{I 0} \&$ & II.I & 11.8 \\
\hline 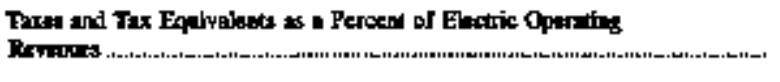 & 28 & 3.1 & 34 & $\mathbf{3 . 3}$ & 3.6 \\
\hline 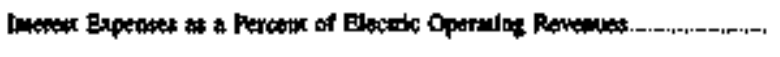 & 326 & 21.9 & 19.7 & 18.6 & 17.0 \\
\hline 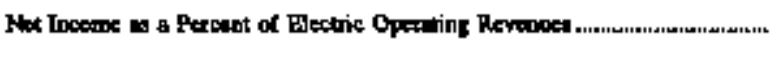 & 3.6 & 4.5 & 3.0 & 3.9 & 5.0 \\
\hline 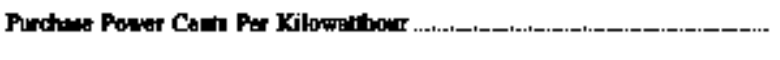 & 3.8 & 3.7 & 3.6 & 9.6 & 3.9 \\
\hline 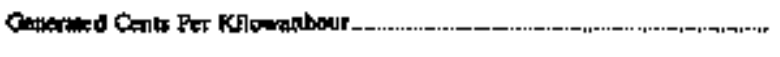 & I.t & 1.9 & 1,9 & 19 & 1.6 \\
\hline 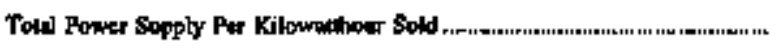 & 2.6 & 26 & 2.6 & 26 & 2.3 \\
\hline
\end{tabular}

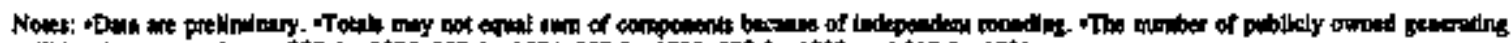

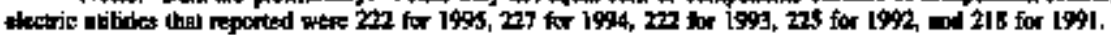

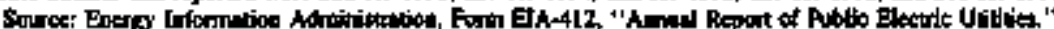

Table 17. Revenue and Expense Statistles for Majoc U.S. Publich Owned Generotor Electric Utilities, 1991 Thronct 1995

(Thousand Dollars)

\begin{tabular}{|c|c|c|c|c|c|}
\hline Dataripilon & 190t & $\sin$ & Itos & tys & 199 \\
\hline 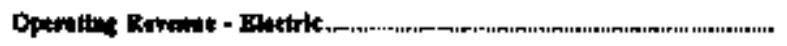 & 21, & 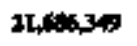 & $\mathbf{3 2 , 5 2 1 , 5 4 7}$ & 13,20640 & $24,7+4,06$ \\
\hline 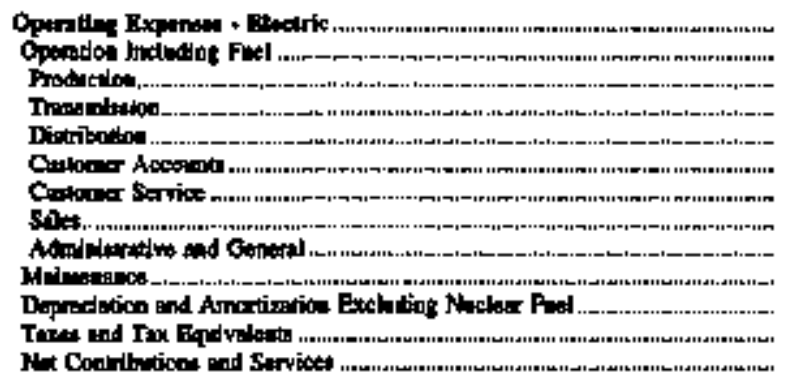 & 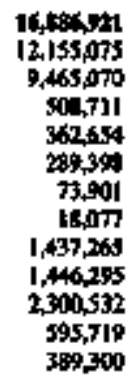 & $\begin{array}{r}17,13,47 \\
12,527,435 \\
9,712,324 \\
534,512 \\
388,703 \\
29,309 \\
62,731 \\
17,545 \\
1,92,411 \\
1,961,792 \\
2,285,647 \\
691,140 \\
-\end{array}$ & $\begin{array}{r}18,162,194 \\
13,211,567 \\
10,254,701 \\
379,635 \\
408,335 \\
314,992 \\
94,069 \\
17,210 \\
1,573,005 \\
1,561,293 \\
2,41,3927 \\
759,205 \\
-\end{array}$ & 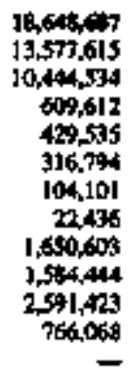 & $\begin{array}{r}16,114,144 \\
12,021,149 \\
9,390,795 \\
289,108 \\
121,667 \\
321,790 \\
101,684 \\
19,617 \\
1,467,778 \\
1,362,485 \\
2,415,672 \\
754,144 \\
-\end{array}$ \\
\hline Incte & 4hesen & $40 ; \pi, \pi$ & 4,3sings & $46 \operatorname{lng}$ & 4,0 s,ses. \\
\hline
\end{tabular}

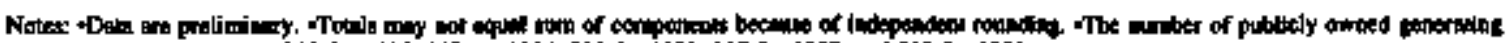

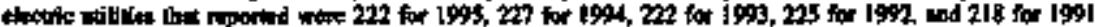

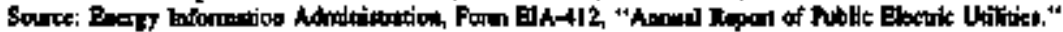


Table 18. Composite Statement of Income for Major US. Poblicly Owned Nongenerator Electric Utilties, 1991 Through 1995

(Thousand Dollars)

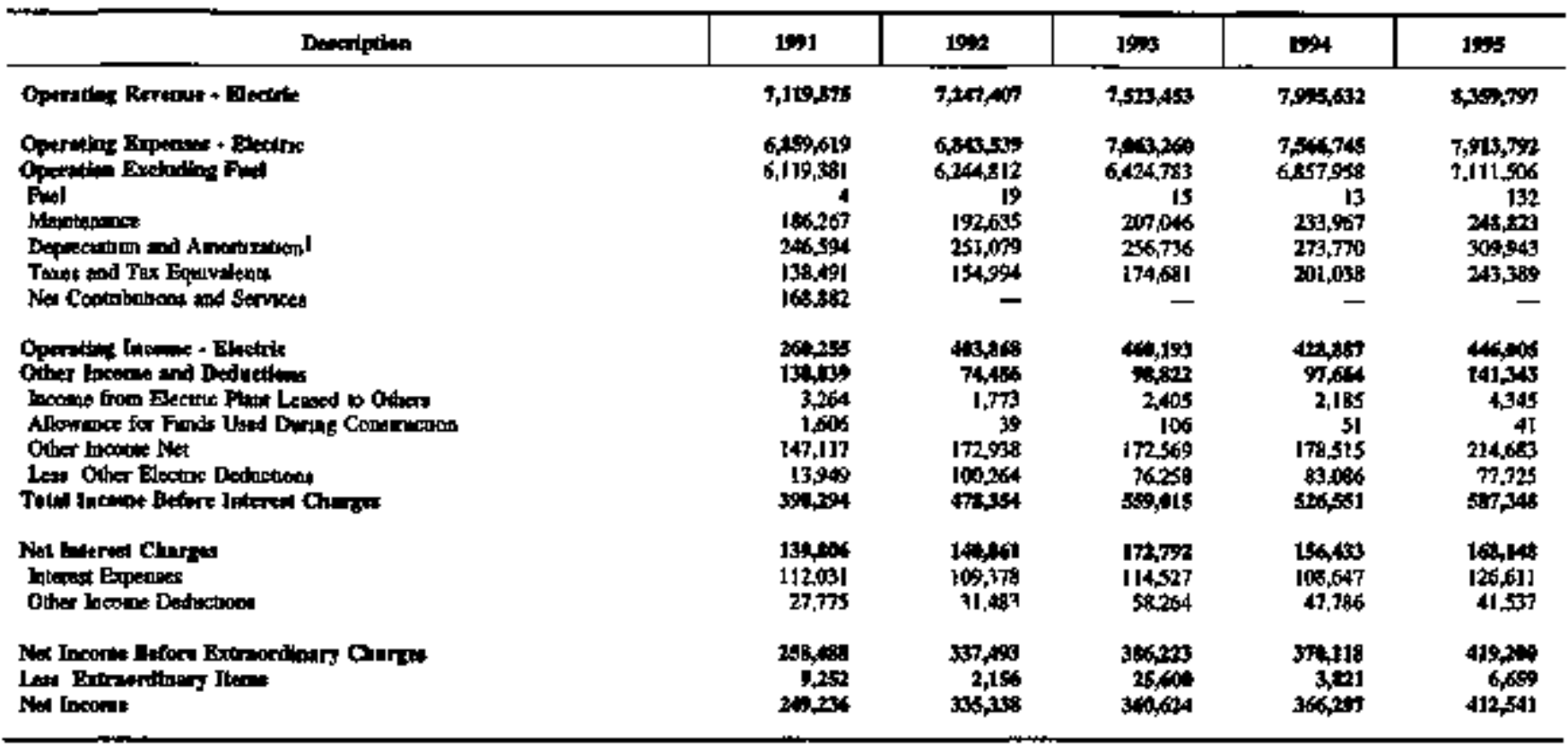

I Nodew fucl indaded in 1992, 1993, 1994, and 1999 da

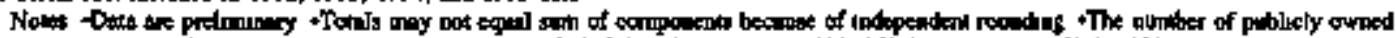

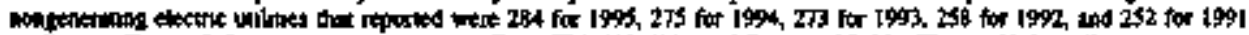

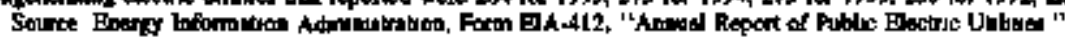

Table 19. Composite Balance Sheet for Major U.S. Publicly Owned Nongenerator Electric Utilities, 1991 Throngh 1995

(Thousand Dollars)

\begin{tabular}{|c|c|c|c|c|c|}
\hline Dtecrtpiln & 1981 & $16 \% 2$ & $16 / 5$ & 1904 & $19 \%$ \\
\hline 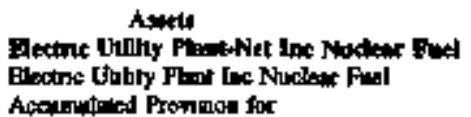 & $\begin{array}{l}464,421 \\
7,318,688\end{array}$ & $\begin{array}{l}4,811,003 \\
7,733,037\end{array}$ & $\begin{array}{l}5,244,229 \\
8,317,096\end{array}$ & $\begin{array}{l}\text { 5,46,1690 } \\
8,759,850\end{array}$ & $\begin{array}{l}\text { c.x35:47 } \\
9.871,670\end{array}$ \\
\hline 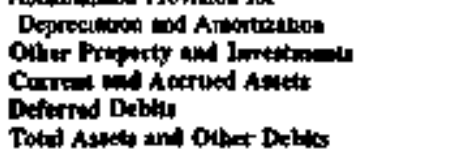 & $\begin{array}{r}2,656,267 \\
1,84,6,647 \\
2,1,4,131 \\
324,440 \\
+, 948,440\end{array}$ & $\begin{array}{r}2,852,034 \\
1,894,401 \\
2,2,9,404 \\
34,263 \\
9,384,501\end{array}$ & 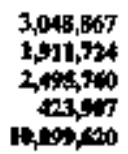 & 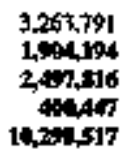 & $\begin{array}{r}7,676,323 \\
2,189,561 \\
2,162,823 \\
160,946 \\
11,774,918\end{array}$ \\
\hline 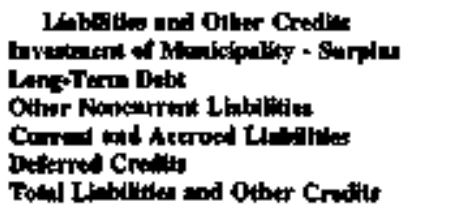 & 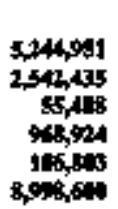 & 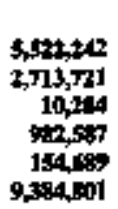 & 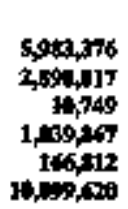 & 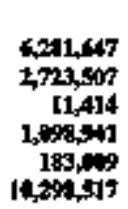 & 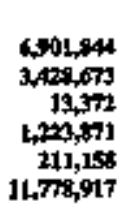 \\
\hline
\end{tabular}

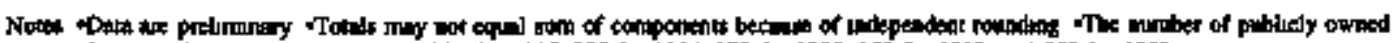

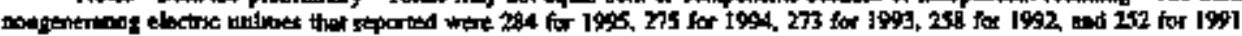

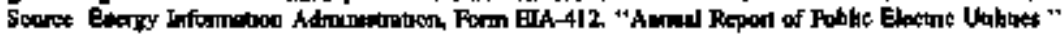


Table 20. Composite Financial Indicators for Mujor U.S. Publicly Owned Nongenerator Electric Uallities, 1991 Through 1995

\begin{tabular}{|c|c|c|c|c|c|}
\hline Destiptiog & 19y 1 & $\sin$ & $\operatorname{sins}$ & $\operatorname{ses}$ & 1995 \\
\hline Blectec Uldhey Plapd ger Dollus of Roreace & 10 & $1 \mathbf{1}$ & I I & ] I & I 2 \\
\hline 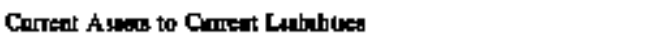 & 22 & 23 & 24 & 23 & 23 \\
\hline 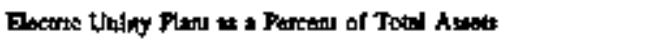 & 81 3 & 724 & 824 & [S ] & 836 \\
\hline 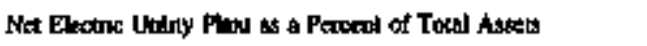 & 518 & 520 & 322 & 594 & 329 \\
\hline Debt as a Pereend of Total lublulbes & 390 & 394 & 390 & 31 & 795 \\
\hline 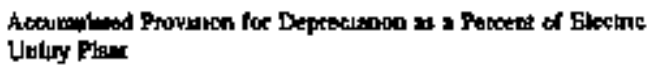 & 363 & 369 & 167 & 舟 & 36.8 \\
\hline 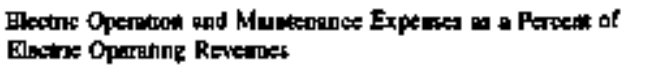 & 886 & 128 & 881 & $\mathbf{3 0} 7$ & 880 \\
\hline 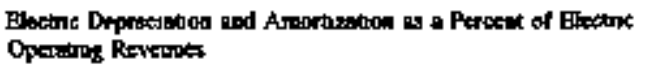 & $\$ \$$ & 14 & 34 & 14 & $\$ 7$ \\
\hline 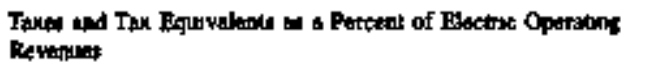 & 19 & 21 & 27 & 25 & 29 \\
\hline 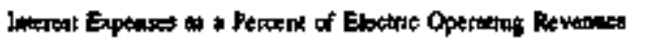 & $\$ 6$ & 15 & is & 14 & 19 \\
\hline 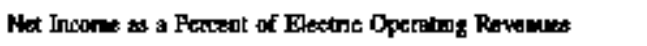 & 15 & 46 & 48 & 46 & 49 \\
\hline 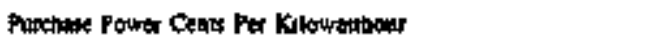 & 41 & 41 & 41 & 41 & 42 \\
\hline
\end{tabular}

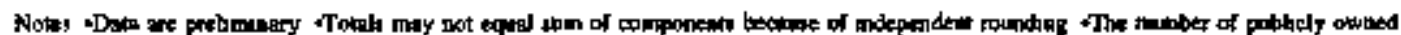

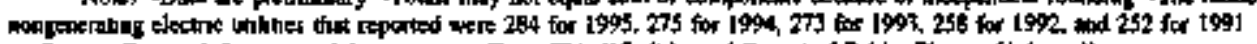

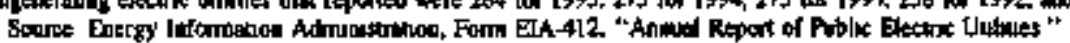

Table 21. Revenue and Expense Statestics for Major U.S. Publicly Owned Nongenerator Electric Utirities, 1991 Through 1995

(Thousand Dollars)

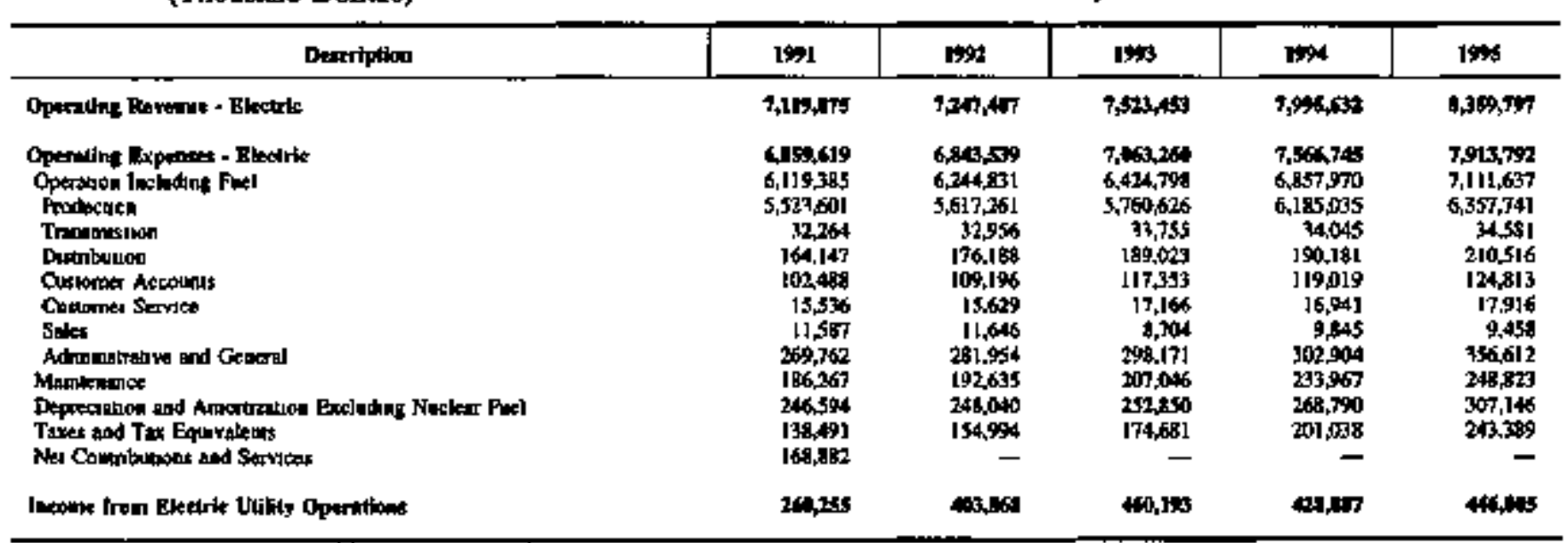

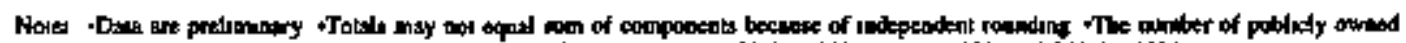

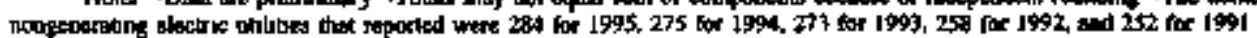

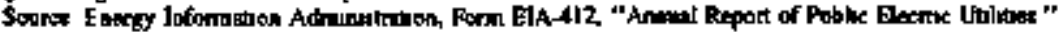




\section{U.S. Electric Utility Environmental Statistics}

\begin{abstract}
When fossil fuels are buined in the production of electricity, a variety of gases and particulates are formed. If these gases and particulates are not captured by some pollution control equipment, they are released into the atmosphere. This chapter provides a brief summary of the gaseous emistions from U.S. electric utilities and the methods employed to reduce or eliminate their release into the atmosphere.
\end{abstract}

\section{Background}

Among the gases emitted during the burning of fossil fuels are sulfur dioxide $\mathrm{SO}_{2}$, nitrogen oxides $\mathrm{NO}_{n}$ and carbon dioxide $\mathrm{CO}_{3}$. Coal-fired generating units produce more $\mathrm{SO}_{2}$ and $\mathrm{NO}_{x}$ than other fossil-fuel unjts for two reasons. First, because coal generally contains more sulfur than other fossil fuels, it cteates more $\mathrm{SO}_{2}$ when burned. Second, there are more $\mathrm{NO}_{x}$ emissions from coal-fired plants because more coal-fired capacity than other fossi]-fueled capacity is in use.

Sulfur is an element that is present in almost all coal, although some kinds of coal contain more sulfur than others depending on the geographic location of the coal mine and the type of coal being mined. Western coal has less sulfur than eastern coal. More than onehalf of the coal mined in the West is subbituminous coal that is low in stufur content (about 0.5 percent) and contains approximately 9,000 Bty per pound. Bituminous eastern coal can exceed both a 5-percent sulfur content and a beat content of 12,000 Btu per pound. The average pereent of sulfur contained in cosl ranges from 0.3 percent in the West to approximately 2.5 percent in the East. Duting combustion, the sulfur combines with the oxygen in the air to form $\mathrm{SO}_{2}$. As the $\mathrm{SO}_{2}$ mixes further with oxygen and trace substances in the air, a variety of sulfate compounds emerges. How these transformations take place, and in what proportions, is a subject of vigorous research. The behavior of $\mathrm{SO}_{2}$ emissions depends partly on the type of coal used and bow it is burned. In addition, the presence of light, moisture, and other pollotants in the atmosphere may also be important in triggering the complex changes that $\mathrm{SO}_{2}$ emissions undergo. To a lesser degree, sulfur is also contained in pettoleum and varies according to the type of petroletrm (for erample, light oil, heavy oil, ete.). Petrolem burued at utility power plants ranges frorn containing almost no sulfur 10 about 3,5 percent sulfur. The weighted average percent of sulfur contained in petroleum consumed by utility plants ranges from about .5 percent in western plants to about 1.4 percent for plants in New England. The amount of sulfur contained in natural gas is insignificant.

\begin{abstract}
Nitrogen is a colorless, odorless gas that trakes up about 78 perceat of the atmosphere. Nitrogen in the atmosphere during the combustion process (burning of fuels at the plant) combints with oxygen and water to form several $N O_{x}$ Also, a small amount of nitrogen in the coal is converted to $N O_{r}$. The otost important is nitrogen djoxide, one of the compounds that gives photochenical smog its characteristic yellowishbrown color. Only about 10 percent of the nitrogen compounds in the air aro the result of human activity. The rest are formed by natural processes, such as the decay of organic matter. However, since the humanmade 10 percent is enitted mostly in industrial urban areas, concentration there can become high enough to cause concern.
\end{abstract}

$\mathrm{SO}_{2}$ and $\mathrm{NO}_{2}$ are called precursors to acid deposition, because, under the right set of conditions, they react with otber chemicals in the atmosphere to form. sulfuric acid and nittic acid, respectively. These two acids do not accumulate in the atmosphere, but are absorbed by rain droplets, thus cleansing the atmosphere but discharging the acid onto the earth in the form of "acid rain." In addition, sulfuric acid may form microscopic droplets that can be deposited directly onto the ground. This form of deposition, as well as the direct capture of $\mathrm{SO}_{2}$ by vegetation, is refersed to as dry deposition.

$\mathrm{CO}_{2}$ is a colorless, odorless, nontoxic gas formed by the combustion of carbon and carbon compounds found in coal, perroleum, and gas. Currently, the only Way to limit the emission of $\mathrm{CO}_{2}$ when burning fossil fuels is extremely expensive. $\mathrm{CO}_{2}$ is normally removed from the atmosphere by green plants and absorbed by the ocesa. The increased use of tossil fuels in recent years, as well as extensive deforestation, has caused a bujldup of $\mathrm{CO}_{2}$ in the atmosphere. This increase of $\mathrm{CO}_{2}$ causes the atmosphere to absorb infrared radiation reflected from the earth that would otherwise have been dissipated into space. This phenomenon could increase average global temperature. It is called the "greephouse" effect because it is similas to the trapping of the sun energy in a greenhouse. These potential increases in temperalures are of concern because they could catse significant elimatic changes, shifts in agricultural zones, and partial melting of the polar ice caps resulting in flooding of coastal areas. However, significant uncertainties exist regarding global warming. and no conclusions can be drawn regarding future warming based on past temperature records.

Efforts are underway to determine what methods can be employed to reduce or eliminate the release of $\mathrm{CO}_{2}$ from power plants. Tail gas cleanup ( $\mathrm{CO}_{2}$ scrubbing) is curently the only technological option. This option 
would require the adsptation by the electric utility industry of acid gas removal technologies used by the petroleum and pelrochemical industries. Because of the potential expense involved and the uncertajnty concerning the jmpacts of emissions from the gas, no emission standards or required reductions exist.

Additionally, the Department of Energy is developing clean cosi technologies (such as pressurized fluidized-bed combustion) for tow plants and repowering applications. Due to the increased conversion efficiencies of these technologies, $\mathrm{CO}_{2}$ emissions are reduced.

\section{Emission Standards}

To respond to concerns about emissions of $\mathrm{SO}_{2}$ and NOx as well as several other air pollutants, Congress passed the Clean Air Act (CAA) in 1963. It was not until 1970, however, that the Environmental Protection Agency was empowered to set enforceable air quality standards. In 1971, this Agency established New Source Performsnce Standards (NSPS) that required coal-fired utility boilers built after Angust 17, 1971 , to emit no more than 1.2 pounds of $\mathrm{SO}_{2}$ per million Btu of heat ingut. Requirements for $\mathrm{NO}_{2}$ were more complex $x_{1}$ with allowable limits ranging from 0.2 pounds per million Btu to 0.8 pounds per million Btu. depending on the type of fuel burned and the combustion devtce used.

In 1977, Congress amended the CAA to require States to set limits on existing sources in regions not attaining goals established in the Act. In 1979, the Environmental Protection Agency established the Revised New Source Performance Standards (RNSPS). The new standards retain the 1971 NSPS of 1.2 pounds of $\mathrm{SO}_{2}$ per million $\mathrm{Btu}$ of beat isput, bus require $\mathrm{SO}_{2}$ emissions from all new or modified (post 1978) boilers to be reduced by at least 90 percent ualess 90-percent removal reduces emissions to less than 0.6 pounds per million Btu. If emissions fall below that level, reductions between 70 asd 90 percent are permitted, depending on the sulfur content of the cod. RNSPS for $\mathrm{NO}_{\mathrm{z}}$ are complex and, as with NSPS, set linits varying from 0.2 to 0.8 pounds per mitlion Btu, depending on the type of fuel burned and combustion device used. RNSPS for $N O_{x}$ differ from NSPS in the number of categories of combustion into which they are divided.

The primary goals of the Clean Air Act Amendments (CAAA) of 1990 that affect generators of electricity are a 10 -million-1on reduction in $\mathrm{SO}_{2}$ emissions and a 2 -million-ton reduction in $\mathrm{NO}_{x}$ emissions from 1980 levels. The reduction in $\mathrm{SO}_{2}$ is to occur in two phases that begin in 1995 and 2000 , respectively. The CAAA establisbed an innovative marketable omission allow. ance program. It also contains a list of the allowances to be issued in Phase 1 , and the Environgmental Protection Agency published a preliminary list of Phase 2 allowances in June 1992.

\section{Emlssion Reductions}

Sulfur Dioxide. One method avallable to reduce the $\mathrm{SO}_{2}$ emitted when burning coal is to switch to a coll that has a lower sulfur content. Emissions of sulfur djoxide may also be redaced by using less polluting fuels, particularly gas. Another approach is to instal] equipment designed to remove $\mathrm{SO}_{2}$ from the gas (tilue gas) released through the flues of the plant. Addjtional methods for reducing emissions of $\mathrm{SO}_{2}$, which include converting boilers to the fluidized-bed combustion process and employing the technology of integrated-gasification combined cycle, are currently under study and not in extensive use.

Nitrogen Oxides. Formation of $\mathrm{NO}_{2}$ is less dependent on what type of fuel is burned than on how the fuel is burned. Apart from the nitrogen content of the fuel, the extent of nitric-oxide formation depends primarily on the combustion temperature. NO, emissions can be reduced by low excess-air firing: lowcombustion temperatures; use of low-nitrogen fuels (such as natural gas and light distillate oil); staged conbustion in which localized fuet-rich conditions are created where both therbial and fuel $N O_{x}$ are mini-

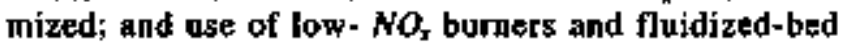
combustion.

\section{Environmental Equipment}

While not the only kind of environmental equipment instalied at power plants. flue gas desulfurization unjts, particulate collectors, and cooling towers are the most signjficant. In a flue gas desulfurization unit (scrubber), the gases resulting from combustion are passed through tanks containing a material that captures and neutralizes the $\mathrm{SO}_{2}$. Particulate matter is most freguently removed fram the combustion gases by either filtering (a series of filter bags that trap the ash and dust much as a household vacuum cleaner does) in a baghouse or witb an electrostatic precipitator. In the latter, the particulates are given an electric charge and collected. Particulate collection is mainly centered on coal combustion because of the large percentage of ash that coal contajns. Petroletum has very little ash, and natural gas has practically none.

For a fossil-fueled steam-electric generating untt, about two-thirds of the heat produced by buming the fuel is relesesed to the environment, and only about onte-third is used to produce electricity. Most waste heat (contained in the cooling water) is dissipated into a body of water, such as a river, lake, or bay. Cooling towers are instalted where there is insufficient cooling water and where the waste heat discharged into the cooling water affects plants or matine life. A cooling tower is a structure for transferring heat in the water to the atmosphere. The rast common type is the wet towe, also called the evaporative tower. In a wet tower, cooling is caused mainiy by evaporation of the water and partly by direct-heat transfer.

Environmental equipment can represent a significant part of the cost of a power plant. This cost includits 
the initial capital cost of installation and the recurring operation and maintenance (O\&M) costs. Capital costs are given as a cost per kilowatt of installed nameplate capacity.

\section{Data Sources}

Estimates are provided in the following tables for $\mathrm{SO}_{3}$. $\mathrm{NO}_{2}$, and $\mathrm{CO}_{2}$ emissions from fossil-fueled steamelectric generating anits. The methodology for computing emission estimates is described is Appendix A. Additional detailed information on emissions from electric utilities can be obtained in Chapter 6 of the Annwal Energy Outlook.12 Also presented in the following tables are the number and capacity of fossilfueled steam-electric generators with environmental equipment (scrubbers, particulate collectors, and cooling towers). Becouse power plants can have more than one type of environmental equipment, the gener. ators at these plants can be included in more than one category. Asso, bot all utility plants have environmental equipment. Data regarding the quality of fossi] fuels used to produce slectricity by electric utilities, including heat, sulfur, and asb content, are also provided in the following tables. Lastly, average flue gas desulfurization costs (that is, operation and maintenance costs per kilowatthour of generation and installation costs per kijowatt of nameplate capacity) are presented.

These estimates were ejther derived or obtained directly from the Form ELA-767, "Steann-Electric Plant Operation and Design Report." This fotm is a restricted-universe census used lo collect boilerspecific data from almost 900 U.S. electric utility power plants with organic or puclear-fueled steanelectric nameplate capacity of 10 or more megawatts operated by more than 300 electric utilities. The entire form, including data on euvironmenta] equipment, is filed by about 700 power plants with a nauneplate capacity of 100 or more megawatts. Information on power plents with a rameplate capacity between 10 and 100 megawatts is submitted only for fuel consumption and flue gas desulfurization equipmest. There are 67 nuclear power plants in the Fotm EIA-767 respondent universe. 
Table 22. Esthmated Embsions from Foosll-Futled Steam-Electric Generating Units at U.S.

\section{Electric Utllities, 1991 Through 1995}

(Thousand Short Toos)

\begin{tabular}{|c|c|c|c|c|c|}
\hline Enimilon & $1 \% 1$ & $1+2$ & 193 & 1934 & loss \\
\hline Solfu Doxde (s02) & 15,513 & 13,175 & 15,014 & $14, \pi 7$ & 11,571 \\
\hline 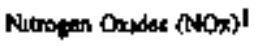 & 7,433 & 7,188 & 7,378 & 7.160 & 7.135 \\
\hline Chan Drande (C02pl] & 1.907 .612 & $1.902,884$ & $1,970,193$ & $1,512,001$ & $1,967,669$ \\
\hline
\end{tabular}

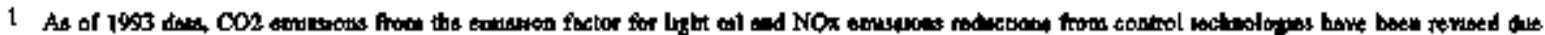

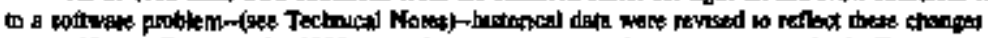

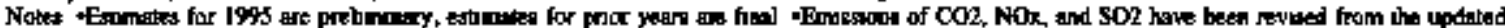

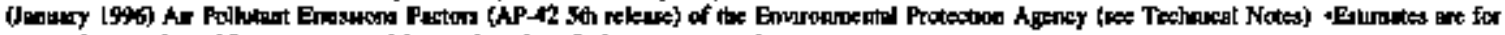

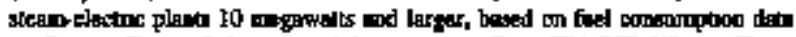

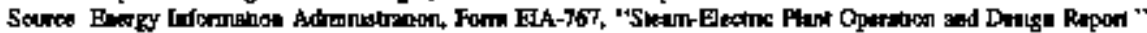

Table 23. Number and Capacity of Fossil-Fueled Stenm-Electric Generators for US. Electric Utillty Plants with Environmental Expuipment, 1991 Through 1995

\begin{tabular}{|c|c|c|c|c|}
\hline \multirow{2}{*}{$\begin{array}{l}\text { Emlrominatal } \\
\text { Equipant }\end{array}$} & \multicolumn{2}{|c|}{ Sanblers } & \multicolumn{2}{|c|}{ Pentiperiake Collectors } \\
\hline & $\begin{array}{l}\text { Numier of } \\
\text { Gowimbrat }\end{array}$ & 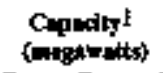 & $\begin{array}{l}\text { Muber of } \\
\text { Geiterstiond }\end{array}$ & 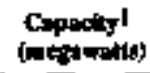 \\
\hline \multirow[t]{3}{*}{$\begin{array}{l}1991 \\
1991 \\
1993 \\
1994 \\
1995\end{array}$} & $\begin{array}{l}155 \\
155 \\
154 \\
168 \\
175\end{array}$ & $\begin{array}{r}70,734 \\
71,531 \\
71,906 \\
8,617 \\
84,260\end{array}$ & $\begin{array}{l}1,173 \\
1.164 \\
1.151 \\
1.135 \\
1,139\end{array}$ & $\begin{array}{l}352,910 \\
353,365 \\
330,908 \\
351,180 \\
350,700\end{array}$ \\
\hline & \multicolumn{2}{|c|}{ Cocklus Tourerg } & \multicolumn{2}{|c|}{ Totd? } \\
\hline & $\begin{array}{l}\text { Namber of } \\
\text { Ceminaloss }\end{array}$ & 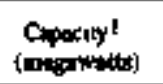 & Nomber of & 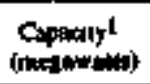 \\
\hline $\begin{array}{l}1991 \\
1992 \\
1993 \\
1994 \\
1995\end{array}$ & $\begin{array}{l}455 \\
494 \\
4 \% 6 \\
4 \$ 0 \\
41\end{array}$ & $\begin{array}{l}164,632 \\
165.050 \\
164,807 \\
165,452 \\
165,012\end{array}$ & $\begin{array}{l}1,359 \\
1,345 \\
1,330 \\
1,309 \\
1,295\end{array}$ & $\begin{array}{l}378,883 \\
37,9,034 \\
376,831 \\
376,899 \\
375,408\end{array}$ \\
\hline
\end{tabular}

I Nameplate capacity

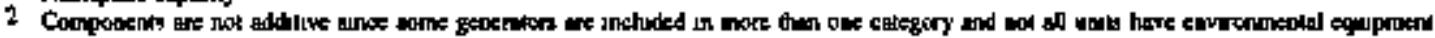

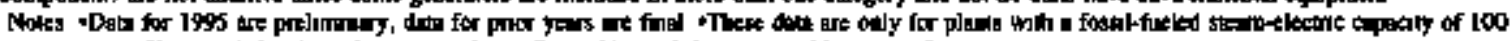

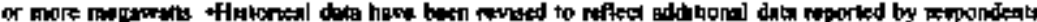

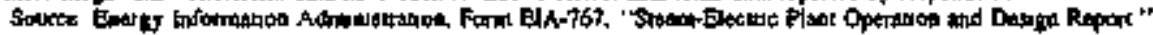


Table 24. Estinated Emissions from Foss:-Fueled Steam-Electric Generating Units at U.S. Electric Utillties by Census Divislon and State, 1994 and 1995

(Thousand Short Tons)

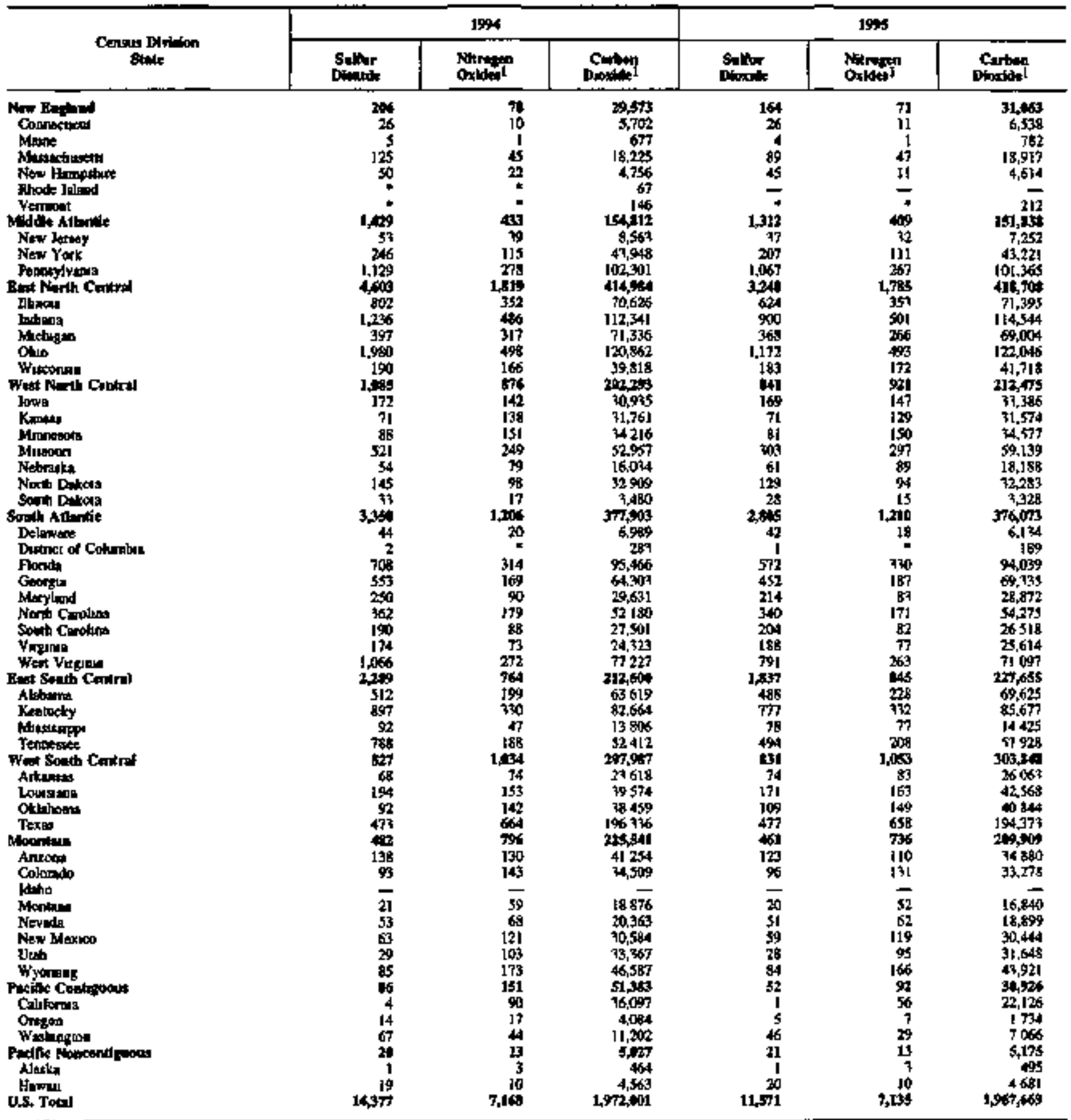

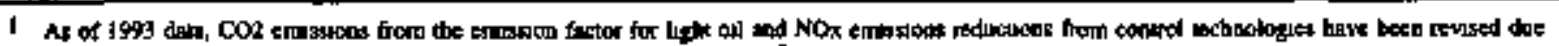

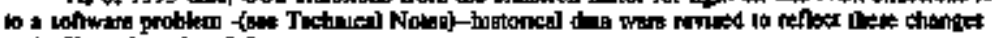

$*$ Vohe leat thin 05

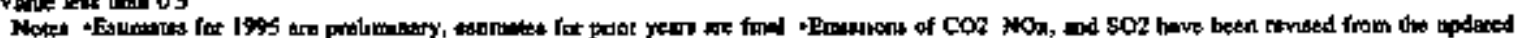

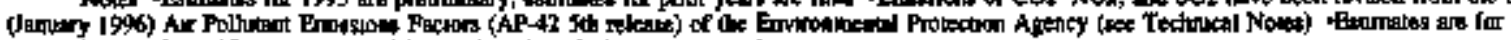

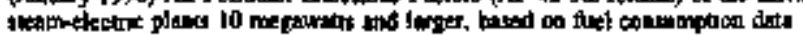

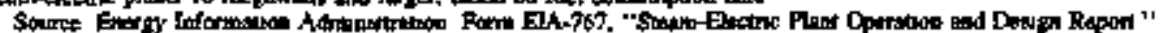




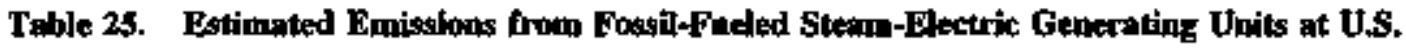
Electric Utilities by Fossil Fuel, Census Divliton, and State, 1995 (Thousand Short Tous)

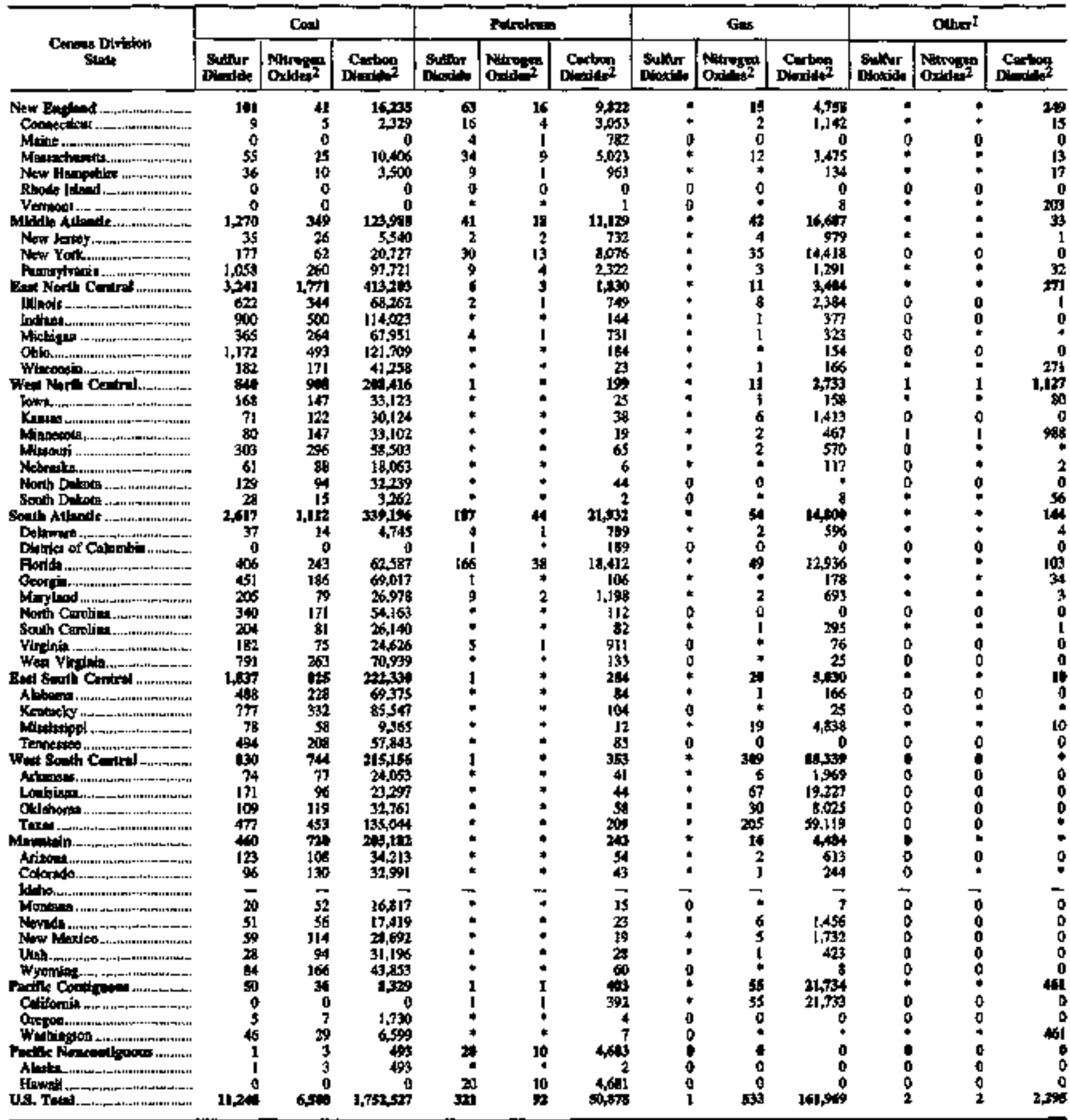

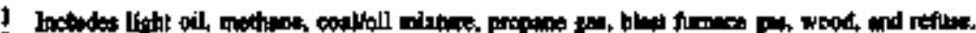

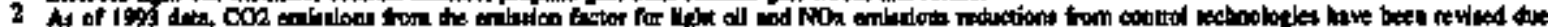

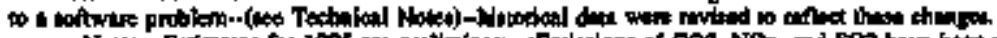

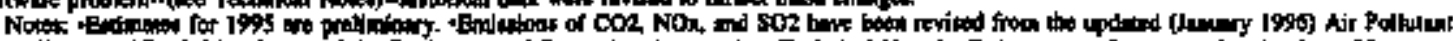

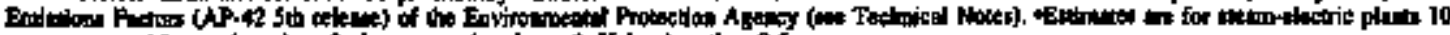

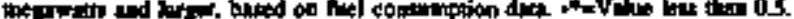

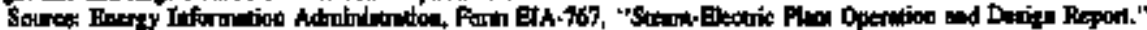


Tahle 26. Nonber and Capecity of CoalFired Steam-Electric Generators for U.S. Electric Utitity Plents with Environmental Equipment by Cences Division and State, $19 \% 3$

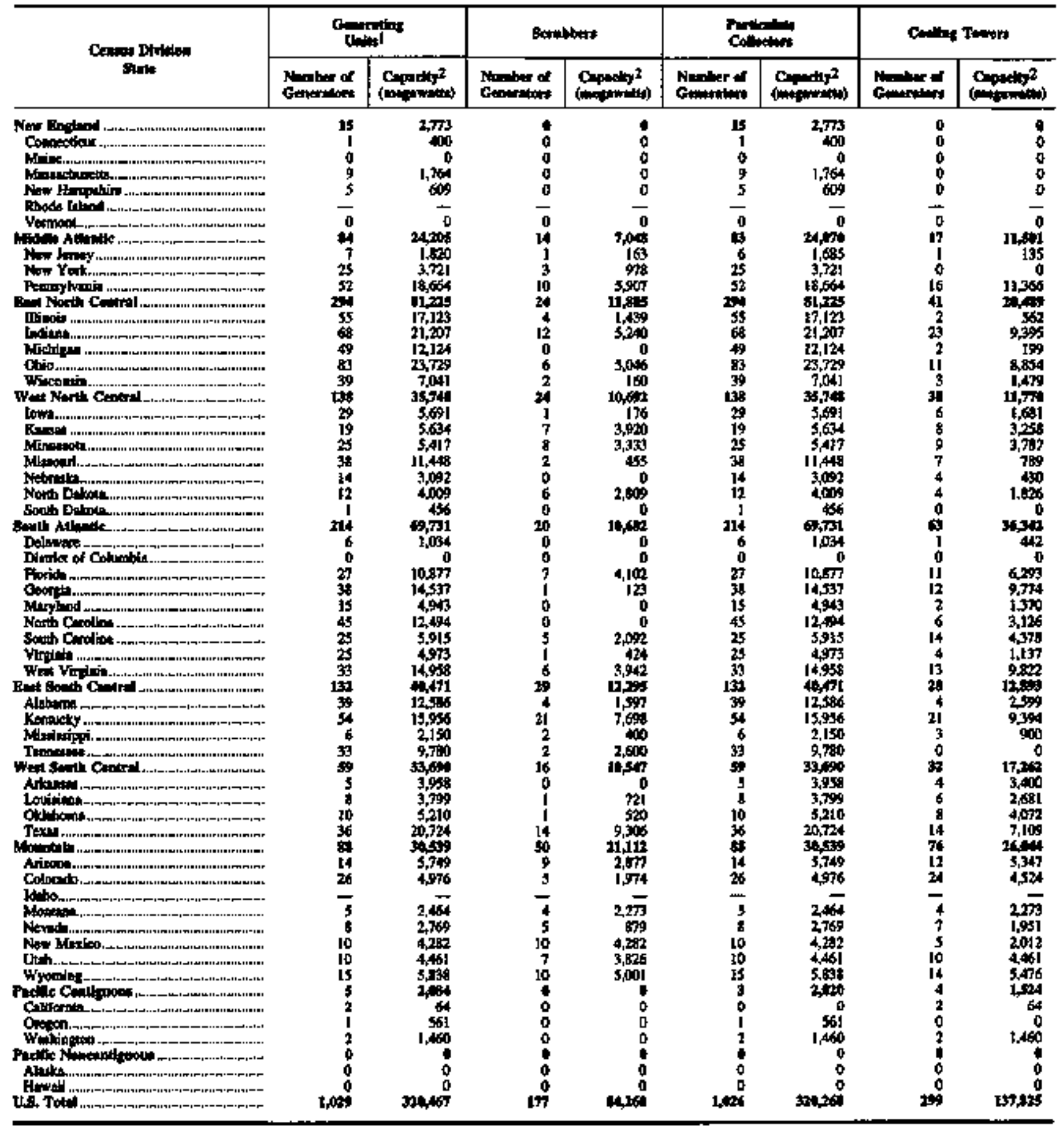

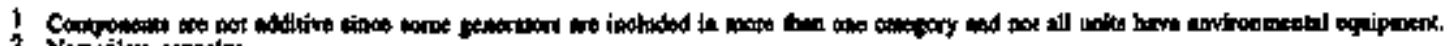
7 Nimpin capedy.

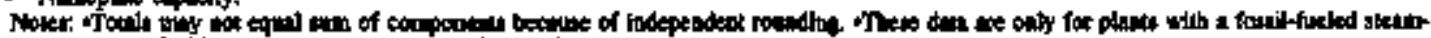

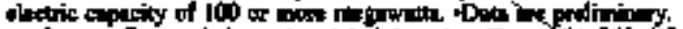

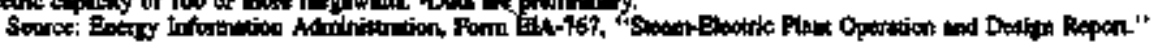


Table 27. Number and Capacty of Petroleom- and Gas-Fired Stenn-Electric Generators for U.S. Electric Udtity Plants whth Envhrommental Equipment by Census Division and State, 1995

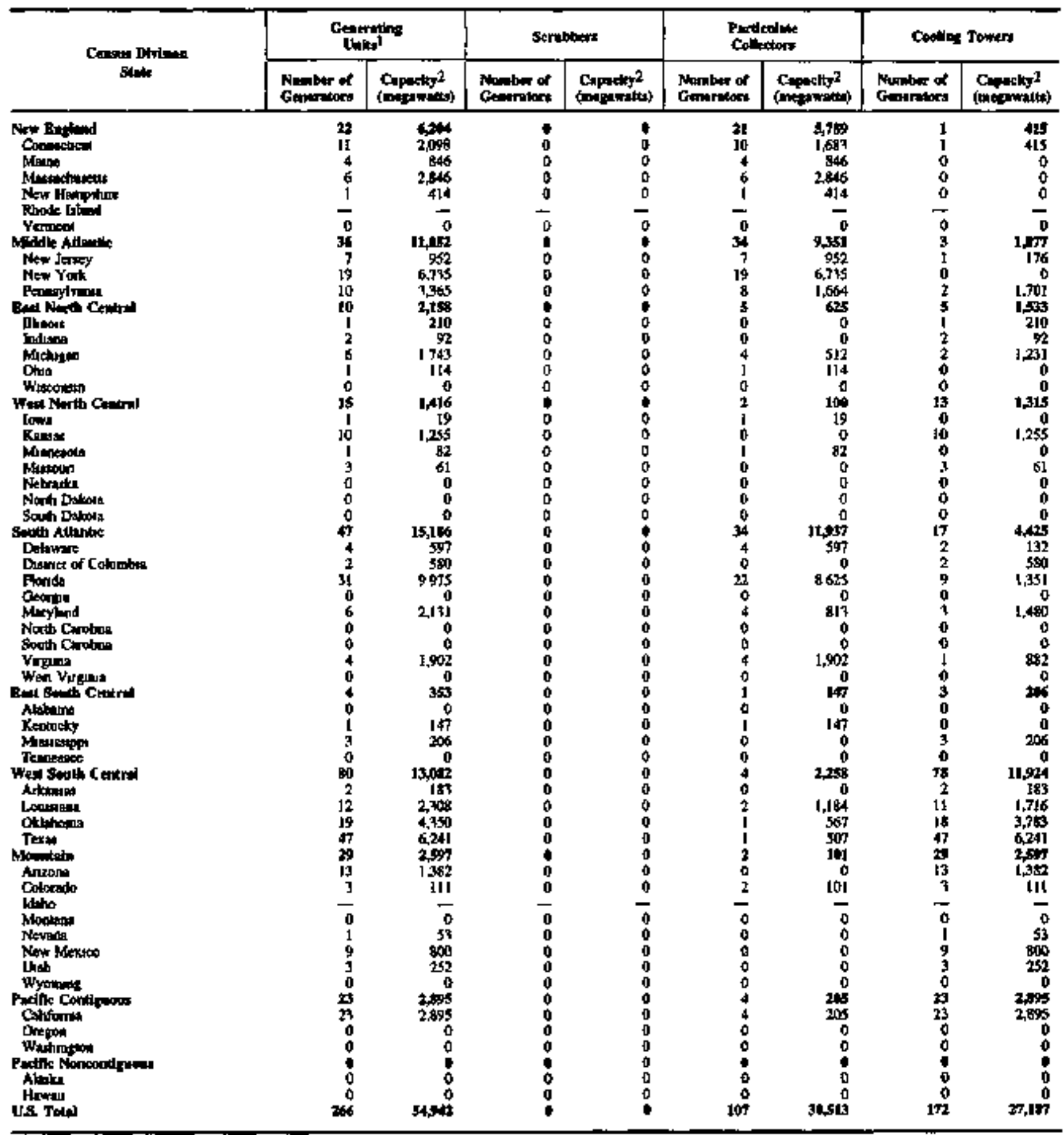

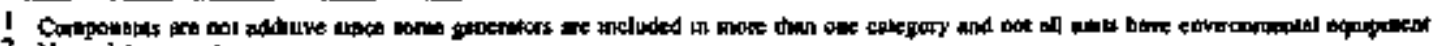
2 Nincoplela capeaby

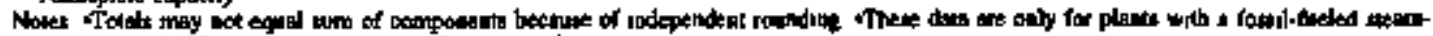

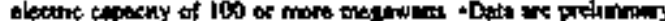

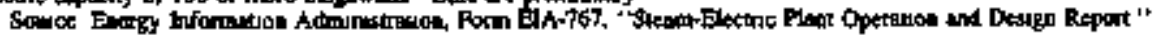


Table 28. Average Quality of Foosil Fuels Burned at U.S. Electrle Utilities by Censas bivision and Strite, 1994 and 1995

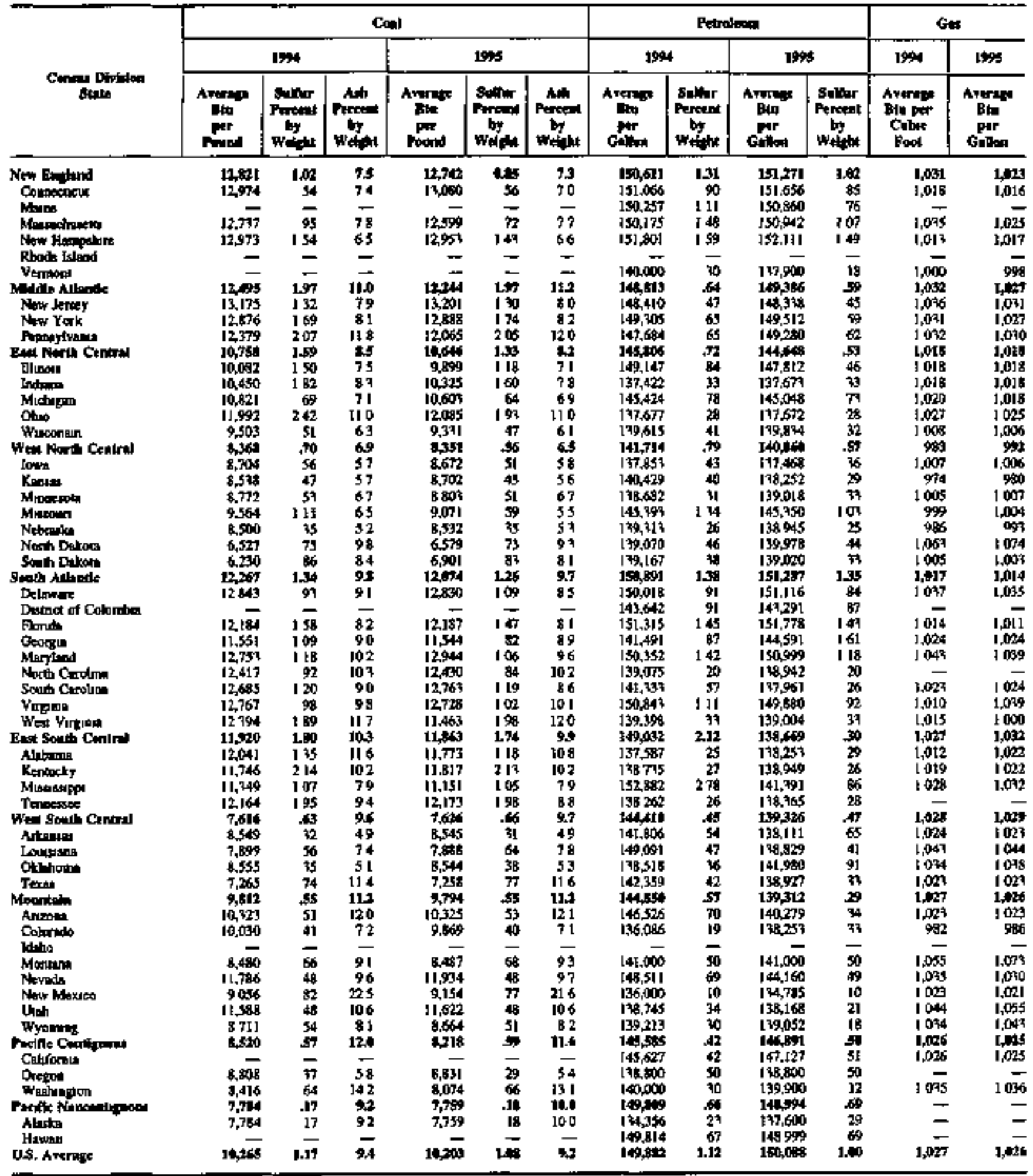

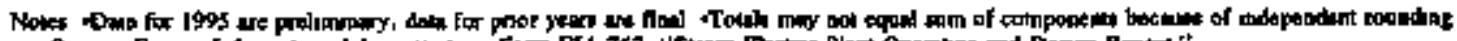

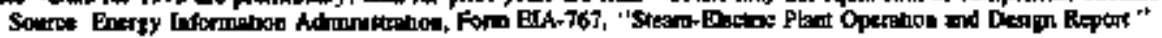


Table 29. Average Flne Gas Desulfurbation Costs at U.S. Flectric Ut'lities by Census Divklon and State, 1991 Throngh 1995

\begin{tabular}{|c|c|c|c|c|c|c|c|c|c|c|}
\hline \multirow{2}{*}{$\begin{array}{c}\text { Crafra Dividon } \\
\text { Sind }\end{array}$} & \multicolumn{5}{|c|}{ 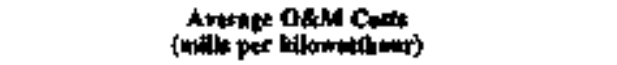 } & \multicolumn{5}{|c|}{ 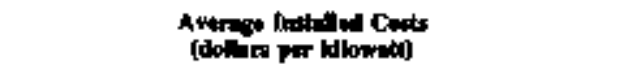 } \\
\hline & J99] & $\operatorname{lin}$ & $19=5$ & Ind & I\% & $19 \%$ & 195 & $19 m$ & I94 & I9ES \\
\hline ..,, $, \ldots, \ldots$ & - & - & - & $m$ & - & - & - & - & - & - \\
\hline Compectoll.,-, & - & - & 一 & 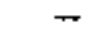 & - & - & - & - & - & - \\
\hline 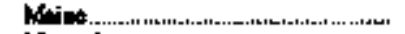 & - & - & - & - & - & - & - & - & $\longrightarrow$ & - \\
\hline 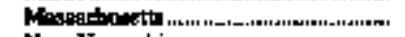 & - & - & - & - & - & - & - & - & - & - \\
\hline New Hempobin:.............-_-_-...... & - & - & - & - & - & - & - & 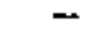 & $\rightarrow$ & - \\
\hline Rhodo filtid...................................- & - & 一 & 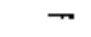 & - & - & - & - & - & - & - \\
\hline thatie_, & $\bar{s} \bar{u}$ & $4 \overline{91}$ & $\mathbf{3 . \overline { 4 }}$ & $2 \bar{a}$ & $3 \overline{48}$ & $\overline{17 \pi}$ & $\overline{1 / 3}$ & $\overline{184}$ & $\overline{1} \overline{s i}$ & $\overline{1-4}$ \\
\hline New Jowey & - & $\mathbf{N M}$ & $\mathrm{NM}$ & NM & 3.36 & - & 396 & 39 & 398 & 398 \\
\hline 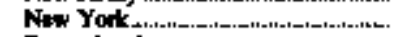 & I.T.7 & 1.09 & 1.09 & I.03 & 1.18 & 319 & 319 & 331 & 331 & 331 \\
\hline 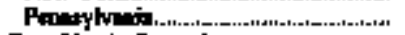 & 6.20 & 604 & 4.65 & 296 & 3.40 & 149 & 157 & 357 & 157 & ISA \\
\hline Eow North Comiral & 2.16 & LW & 1.94 & 245 & I.F & $13 \%$ & In & 130 & 127 & 124 \\
\hline 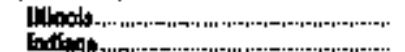 & 259 & 247 & 232 & 271 & 2.51 & 197 & 197 & 143 & IAI & 147 \\
\hline 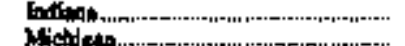 & 2.12 & 158 & I5F & ISI & 152 & 133 & 149 & 143 & 10 & 144 \\
\hline 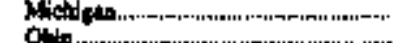 & - & $\vec{x}$ & - & - & - & - & - & - & - & - \\
\hline 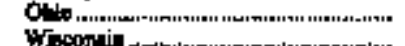 & 2.09 & 2,06 & 225 & 292 & 1.93 & $\$ 3$ & 5.3 & 83 & $\mathbf{8 B}$ & 88 \\
\hline Wreponqin & - & - & - & 2.06 & 1.08 & - & - & - & 16 & I5 \\
\hline Wet Noeth Central & .72 & .75 & A & $\infty$ & so & 75 & $\mathbf{k}$ & 84 & 4 & 78 \\
\hline 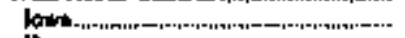 & 283 & 2.42 & 1.87 & 153 & 156 & 202 & 2002 & 202 & 202 & $20 \%$ \\
\hline Kentakn & 59 & - & 49 & .40 & 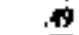 & 71 & $\boldsymbol{n}$ & 72 & 7 & 6) \\
\hline 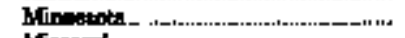 & .40 & $\boldsymbol{\omega}$ & $\Delta 3$ & .39 & .37 & 73 & 7 & 7 & 73 & 73 \\
\hline 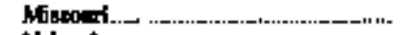 & 1.85 & 2.12 & 1.86 & 1.35 & 1.20 & 87 & 87 & 87 & 87 & so \\
\hline 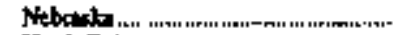 & - & $\vec{a}$ & - & - & - & $\rightarrow$ & - & - & - & - \\
\hline 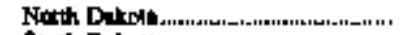 & 81 & .74 & $\$ 1$ & .79 & .74 & 7! & 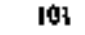 & 192 & 102 & 100 \\
\hline 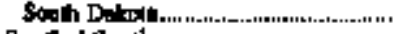 & - & $\overline{-}$ & - & - & $=$ & - & $=$ & $=$ & $=$ & $=$ \\
\hline & 1.69 & Lt: & st & 1.16 & ss & 144 & 143 & 16 & 115 & 12. \\
\hline $\begin{array}{l}\text { Delnwast } \\
\text { Dintrict of Columbinth }\end{array}$ & 29.62 & NM & - & - & & 1,385 & 1,385 & 一 & - & 二 \\
\hline & $\bar{x}$ & $1 . \overline{15}$ & $\overline{78}$ & $\overrightarrow{10 t}$ & 8 & $\vec{\sigma}$ & $\frac{6}{69}$ & $\overline{69}$ & $\overline{6}$ & $\overline{73}$ \\
\hline Goostin & - & - & - & - & 5.13 & - & - & - & - & $\mathbf{N} \mathbf{M}$ \\
\hline Maphind. & - & - & - & - & - & - & - & - & - & - \\
\hline 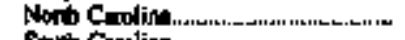 & $\bar{z}$ & $\bar{c}$ & - & $\bar{z}$ & - & - & - & $=$ & $\bar{n}$ & 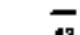 \\
\hline 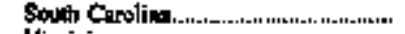 & 60 & .64 & 5 & .60 & . 48 & 43 & $\$$ & 43 & 49 & 43 \\
\hline Artinit & $2 \bar{s}$ & $\overrightarrow{223}$ & 200 & 233 & $1 . \overrightarrow{4}$ & 20 & $\overline{200}$ & $\overline{217}$ & $\overline{200}$ & $\overrightarrow{216}$ \\
\hline 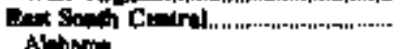 & 151 & 1.5 & 1.46 & 1.45 & Les & 150 & 10 & 137 & 14 & 14 \\
\hline 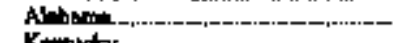 & .94 & 9.00 & 69 & .62 & 57 & 82 & 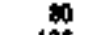 & 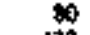 & $\mathbf{\infty}$ & $\infty$ \\
\hline 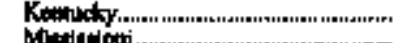 & 1.70 & 1.91 & 1.76 & 1.60 & 1.58 & 155 & 135 & I⿳2口了2 & 140 & 100 \\
\hline 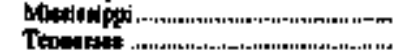 & NM & NH & $\mathrm{MM}$ & 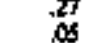 & .35 & 202 & 200 & 196 & 204 & 204 \\
\hline 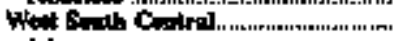 & I.1. & 1.3 & $1 . \$ 1$ & tw & 31 & 6 & 73 & 74 & 76 & 4 \\
\hline Alonowl & $\mathrm{NM}$ & NM & NWM & Nhd & Nod & $\overline{7 s}$ & $\overline{75}$ & $\overline{75}$ & $\bar{x}$ & $\overline{7}$ \\
\hline Oldhom & $\ln 20$ & Nin & 4 & .90 & .99 & 9 & 92 & 9 & 92 & 92 \\
\hline 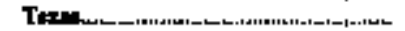 & $\$ .200$ & 1.26 & 1.03 & I.1I & 9 & 67 & 72 & 73 & 75 & 30 \\
\hline 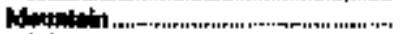 & $\pi 9$ & $\$$ & $\infty$ & 73 & $\Rightarrow$ & 19 & IAs & 146 & too & $\mathbf{1 5 0}$ \\
\hline 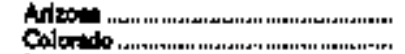 & 6 & .68 & 67 & 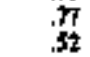 & .88 & 175 & 175 & 160 & 175 & 179 \\
\hline 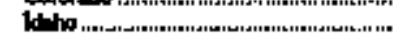 & - & - & ח & 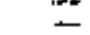 & 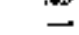 & $=$ & - & - & - & s \\
\hline 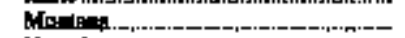 & .94 & so & $\$ .10$ & 1.11 & 1.14 & 274 & 274 & 274 & 274 & 274 \\
\hline 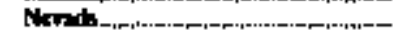 & 3.80 & .93 & 99 & .74 & 1.57 & 126 & 126 & 126 & 126 & 126 \\
\hline Ladilon & 1.14 & 1.68 & 1.07 & $i_{0}$ & 1.03 & 167 & ixs & 165 & I荷 & I65 \\
\hline 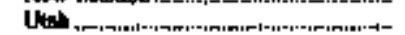 & 56 & 48 & $\$ 7$ & 41 & .47 & in & $\underline{\eta}$ & 少 & 101 & 101 \\
\hline Fyound & 67 & .\$\$ & $\$ 4$ & 6 & 61 & 139 & 137 & 139? & 137 & is \\
\hline 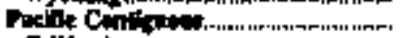 & - & - & - & - & - & - & - & - & - & - \\
\hline 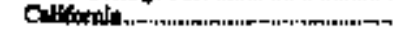 & - & - & - & - & - & - & - & - & - & - \\
\hline " & - & - & - & - & - & - & - & - & - & - \\
\hline 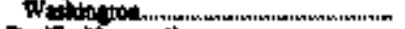 & - & - & - & - & - & - & - & 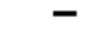 & - & - \\
\hline 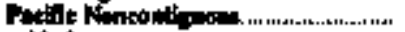 & - & - & - & - & \% & - & - & - & - & - \\
\hline 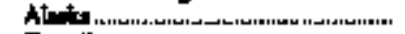 & - & - & - & - & - & - & - & - & - & - \\
\hline 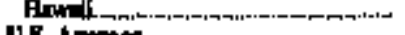 & $=$ & $\overline{\mathbf{n}}$ & $\pi$ & $\overline{14}$ & $\bar{x}$ & $\overline{7}$ & $=$ & $\bar{z}$ & $\overline{1}$ & $\overline{-}$ \\
\hline 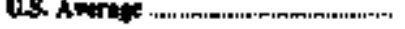 & Int & 10 & $1.1 \%$ & $1-14$ & 1.16 & $13 \mathbf{0}$ & H3: & 125 & 177 & 125 \\
\hline
\end{tabular}

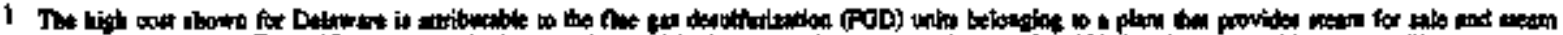

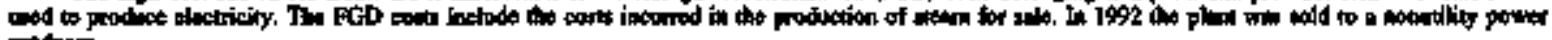
proderer.

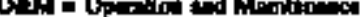

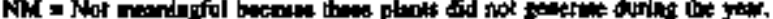

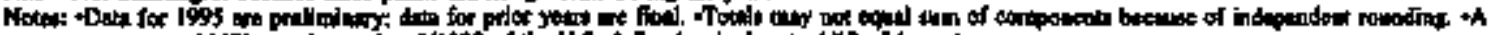

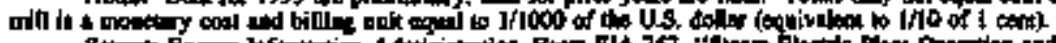

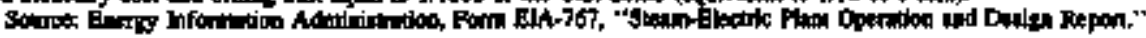




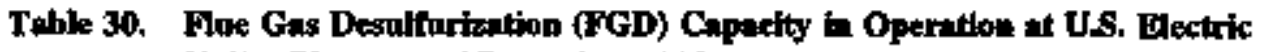
Utility Fants as of Decemater $195 \mathrm{~s}$

\begin{tabular}{|c|c|c|c|c|c|c|c|}
\hline \multirow{2}{*}{ Jidly } & \multicolumn{2}{|c|}{ Capinking } & \multirow{2}{*}{ 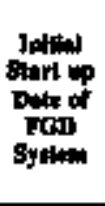 } & \multirow{2}{*}{ 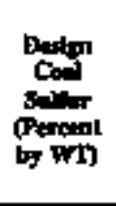 } & \multirow{2}{*}{ reto ThN } & \multirow{2}{*}{ Sortend } & \multirow{2}{*}{ 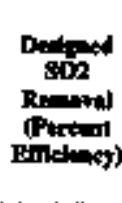 } \\
\hline & $\underset{r t a x}{b y}$ & 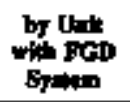 & & & & & \\
\hline 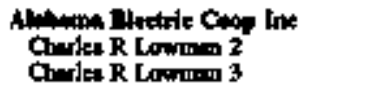 & 530 & 236 & 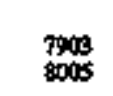 & $\begin{array}{l}1.90 \\
1.90\end{array}$ & $\begin{array}{l}\text { Sproy } \\
\text { sproy }\end{array}$ & Lones: & $\begin{array}{l}85.0 \\
850\end{array}$ \\
\hline 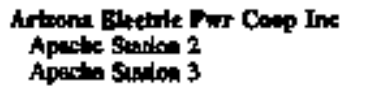 & 464 & 193 & $\begin{array}{l}7901 \\
7901\end{array}$ & .70 & $\begin{array}{l}\text { Packod } \\
\text { Pactiod }\end{array}$ & 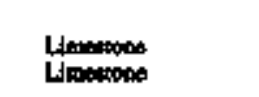 & $\begin{array}{l}55.0 \\
85.0\end{array}$ \\
\hline 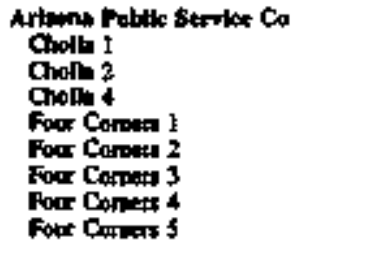 & $\begin{array}{l}1,105 \\
= \\
\pm, 2 \pi 0 \\
= \\
=\end{array}$ & $\begin{array}{l}114 \\
299 \\
414 \\
190 \\
190 \\
253 \\
818 \\
818\end{array}$ & $\begin{array}{l}712 \\
7300 \\
8100 \\
7201 \\
7201 \\
7201 \\
8501 \\
8501\end{array}$ & $\begin{array}{l}1.00 \\
1.20 \\
1.30 \\
.80 \\
80 \\
80 \\
80 \\
80\end{array}$ & 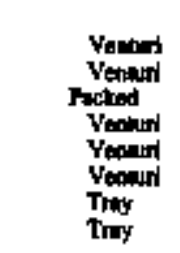 & 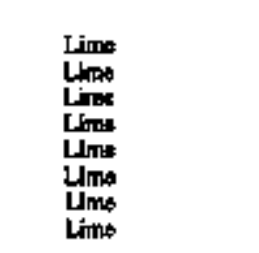 & $\begin{array}{l}80.0 \\
90.0 \\
90.0 \\
7.0 \\
720 \\
720 \\
72.0 \\
720\end{array}$ \\
\hline 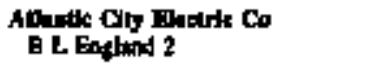 & 176 & 163 & 9501 & 3.20 & Spray & Limationed & 93.6 \\
\hline 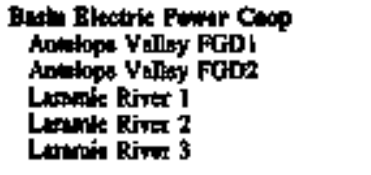 & $\begin{array}{l}870 \\
1.710 \\
=\end{array}$ & $\begin{array}{l}45 \\
435 \\
570 \\
510 \\
510\end{array}$ & 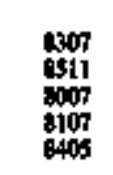 & $\begin{array}{r}1.20 \\
1.20 \\
.00 \\
.00 \\
.00\end{array}$ & $\begin{array}{l}\text { Sproy Dry } \\
\text { Epray Dry } \\
\text { Sproy } \\
\text { Spriy } \\
\text { Sphry Dry }\end{array}$ & 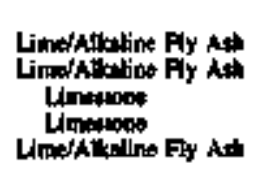 & $\begin{array}{l}81.0 \\
81.0 \\
90.0 \\
90.0 \\
\mathbf{B 1 . 0}\end{array}$ \\
\hline 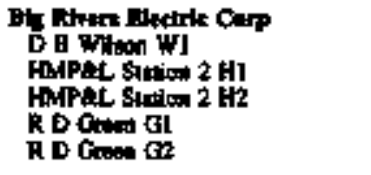 & $\begin{array}{l}309 \\
365 \\
5 \\
5\end{array}$ & $\begin{array}{l}509 \\
100 \\
105 \\
264 \\
204\end{array}$ & $\begin{array}{l}8511 \\
9506 \\
9506 \\
7912 \\
0101\end{array}$ & $\begin{array}{l}180 \\
1.20 \\
4.20 \\
1.00 \\
400\end{array}$ & $\begin{array}{l}\text { Spray } \\
\text { Troy } \\
\text { Troy } \\
\text { Sprey } \\
\text { Sprity }\end{array}$ & 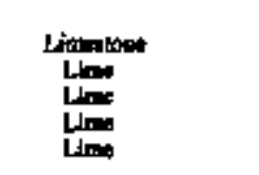 & $\begin{array}{l}90.0 \\
950.0 \\
9500 \\
90.0 \\
90.0\end{array}$ \\
\hline Noin Sinpord 2 & - & - & 9511 & .90 & Crasting Dry & 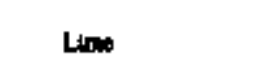 & 920 \\
\hline 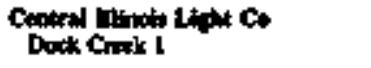 & 41 & 41 & 7607 & 3.40 & Vemonit & LJmeatom & $\$ 6.0$ \\
\hline 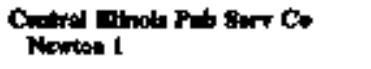 & 1,235 & 617 & 7912 & 400 & $s_{p a r p}$ & Sodium Carbonete & 90.0 \\
\hline 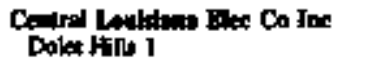 & 721 & 721 & 8604 & .7 & Sproy & 넘olione & 76.0 \\
\hline 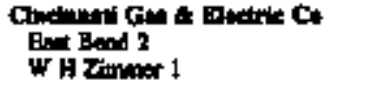 & 1,426 & $\mathbf{6 , 4 2 6}$ & $\begin{array}{l}6100 \\
9100\end{array}$ & $\begin{array}{l}5.20 \\
4.50\end{array}$ & Sprey Dry & Lims & $\begin{array}{l}99,0 \\
99,0\end{array}$ \\
\hline 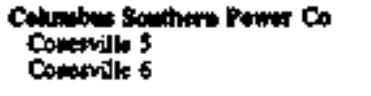 & 2,175 & 44 & $\begin{array}{l}770 S \\
700\end{array}$ & $\begin{array}{l}7.90 \\
7.90\end{array}$ & Spary & Limb & $\begin{array}{l}89.7 \\
89.7\end{array}$ \\
\hline 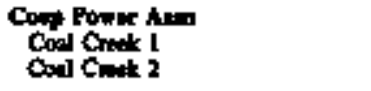 & 1,012 & $\begin{array}{l}506 \\
506\end{array}$ & $\begin{array}{l}7906 \\
10 \%\end{array}$ & 1.00 & Spmy & Limk & $\begin{array}{l}90.0 \\
90.0\end{array}$ \\
\hline Denere Controtion a Tran Coop & 400 & 400 & 0606 & .50 & spon & Limatrose & 95.0 \\
\hline 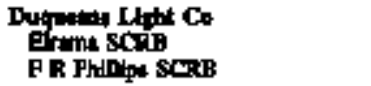 & $\begin{array}{l}510 \\
411\end{array}$ & $\begin{array}{l}510 \\
411\end{array}$ & $\begin{array}{l}76009 \\
7406\end{array}$ & $2 \leqslant 0$ & $\begin{array}{l}\text { Yenturi } \\
\text { Yenturi }\end{array}$ & $\begin{array}{l}\text { Lime } \\
\operatorname{Lim} 10\end{array}$ & $\begin{array}{l}83.0 \\
83.0\end{array}$ \\
\hline
\end{tabular}

Sat foctingats al atd of table. 
Table 30. Floe Gas Desulfurtzation (FGD) Capactty in Operatton at U.S. Electric Utility Plants as of December 1995 (Cantinned)

\begin{tabular}{|c|c|c|c|c|c|c|c|}
\hline \multirow{2}{*}{ Phor and ToD Nat } & \multicolumn{2}{|c|}{ 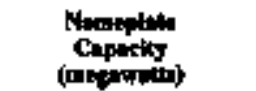 } & \multirow{2}{*}{ 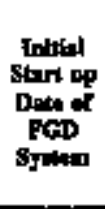 } & \multirow{2}{*}{ 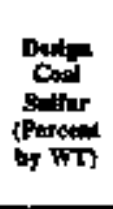 } & \multirow{2}{*}{ FGI Typ } & \multirow{2}{*}{ Sorbend } & \multirow{2}{*}{ 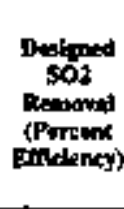 } \\
\hline & $\ln _{\ln =0}$ & $\begin{array}{l}\text { Wy that } \\
\text { whe FGD } \\
\text { Syeten }\end{array}$ & & & & & \\
\hline 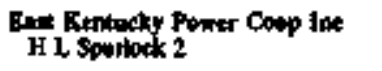 & 814 & $\operatorname{sis}$ & $\mathbf{B}=6$ & 360 & Spry Dy & Lime & 900 \\
\hline 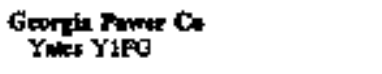 & 1,488 & 13 & 9210 & 250 & 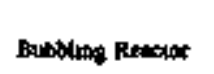 & Limantime & 900 \\
\hline $\begin{array}{l}\text { Grand Bmes Chy of } \\
\text { J B Sins } 3\end{array}$ & 78 & 58 & 8308 & 280 & $\operatorname{Tan}$ & Late & 900 \\
\hline 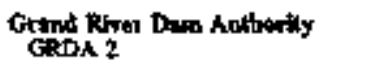 & 1,010 & 524 & 8604 & 150 & Sproy Dry & 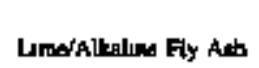 & 850 \\
\hline 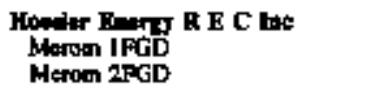 & 1,060 & 540 & 8200 & 300 & $\begin{array}{l}\text { Sproy } \\
\text { Sproy }\end{array}$ & $\begin{array}{l}\text { Lunertosu } \\
\text { Lumestooce }\end{array}$ & 900 \\
\hline 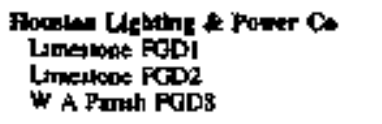 & 1,627 & $\begin{array}{l}813 \\
813 \\
615\end{array}$ & $\begin{array}{l}8511 \\
9611 \\
B 212\end{array}$ & $\begin{array}{l}310 \\
510 \\
50\end{array}$ & $\begin{array}{l}\text { Spruy } \\
\text { Sphry } \\
\text { sprwy }\end{array}$ & 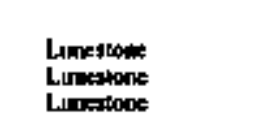 & $\begin{array}{l}900 \\
900 \\
850\end{array}$ \\
\hline 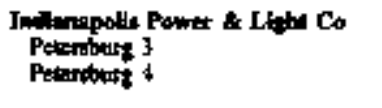 & 1,873 & 574 & $\begin{array}{l}711 \\
6609\end{array}$ & $\overline{-}$ & $\begin{array}{l}\text { Tray } \\
\text { Sproty }\end{array}$ & the & $\begin{array}{l}850 \\
950\end{array}$ \\
\hline 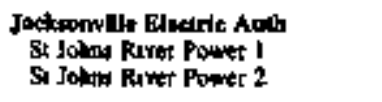 & 1,395 & 679 & $\begin{array}{l}\sin 1 \\
\operatorname{son}\end{array}$ & 220 & $\begin{array}{l}\text { Spray } \\
\text { Spray }\end{array}$ & Lamescose & $\begin{array}{l}900 \\
900\end{array}$ \\
\hline 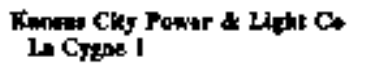 & 1,579 & 893 & 7306 & 540 & Venturn & Lumeatom & 800 \\
\hline $\begin{array}{l}\text { Kortucky vililies Co } \\
\text { Goet I } \\
\text { Grem Rivel I }\end{array}$ & 2,226 & 597 & $9 \$ 12$ & $\begin{array}{l}150 \\
180\end{array}$ & Spray & 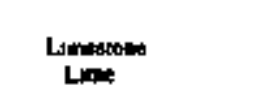 & 950 \\
\hline 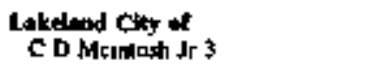 & $\$ 93$ & 264 & 8200 & 180 & spras & Lamestowe & 850 \\
\hline 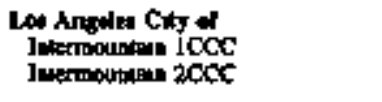 & 1,640 & $\begin{array}{l}829 \\
820\end{array}$ & $\operatorname{seg} 7$ & $\begin{array}{l}90 \\
30\end{array}$ & Spray & 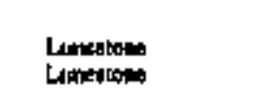 & 900 \\
\hline 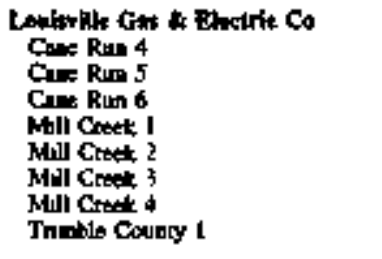 & $\begin{array}{r}792 \\
= \\
1.717 \\
= \\
=\end{array}$ & $\begin{array}{l}167 \\
205 \\
272 \\
336 \\
356 \\
\$ 63 \\
544 \\
565\end{array}$ & $\begin{array}{l}7612 \\
7805 \\
7904 \\
8112 \\
10012 \\
8110 \\
8207 \\
9012\end{array}$ & $\begin{array}{r}350 \\
950 \\
350 \\
600 \\
600 \\
500 \\
630 \\
450\end{array}$ & $\begin{array}{l}\text { Peclos } \\
\text { Spray } \\
\text { Tray } \\
\text { Spray } \\
\text { Spray } \\
5 \text { pray } \\
\text { Spry } \\
\text { Sproy }\end{array}$ & 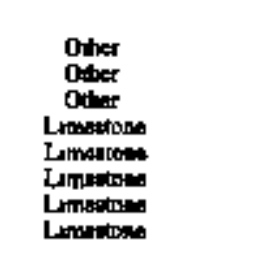 & $\begin{array}{l}550 \\
850 \\
900 \\
900 \\
900 \\
900 \\
900 \\
907\end{array}$ \\
\hline $\begin{array}{l}\text { Lener Colwada Fiver Ambority } \\
\text { Sam Seymont }\end{array}$ & 1,690 & $\$ 0$ & 504 & 170 & Spray & Lumbaton & 900 \\
\hline 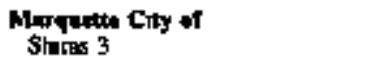 & 40 & 40 & ByOH & so & Sproy Dig & Lmetwot & 800 \\
\hline 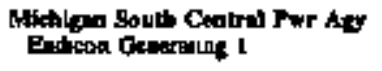 & $s$ & 50 & 8708 & 430 & spay & Lunextowe & 00 \\
\hline 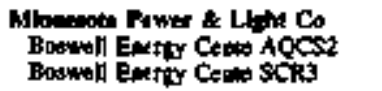 & 1, 677 & 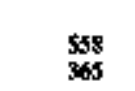 & $\frac{8004}{7362}$ & 100 & $\begin{array}{l}\text { spiny } \\
\text { spryy }\end{array}$ & Alletles Fly Adh & $\begin{array}{l}532 \\
254\end{array}$ \\
\hline
\end{tabular}

sed foochous a tad of the 
Table 30. Flae Gas Desulfurization (FGD) Capaclty in Operation at U.S. Electric Utility Pinti, as of December 19ss (Continoed)

\begin{tabular}{|c|c|c|c|c|c|c|c|}
\hline Iilly & Py & 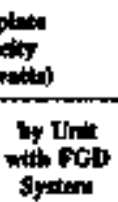 & 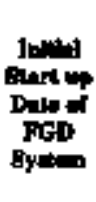 & 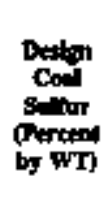 & FGD Typ & Soctber & 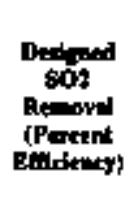 \\
\hline 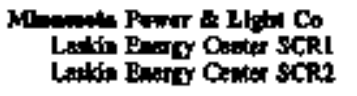 & 116 & $\begin{array}{l}5 \$ \\
58\end{array}$ & $\begin{array}{l}7105 \\
7105\end{array}$ & $\begin{array}{l}100 \\
1.00\end{array}$ & $\begin{array}{l}\text { Spiny } \\
\text { Spoty }\end{array}$ & 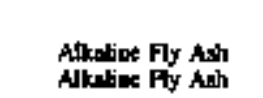 & $=$ \\
\hline 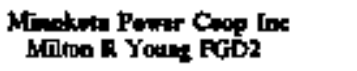 & 734 & 477 & $\pi 06$ & 1.20 & Spray & Lute/hlouline Fly Ash & 77.9 \\
\hline 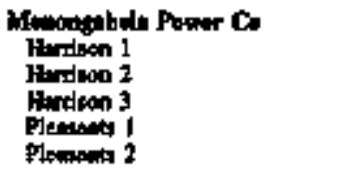 & $\begin{array}{r}2,052 \\
= \\
= \\
+2,465\end{array}$ & $\begin{array}{l}634 \\
644 \\
684 \\
684 \\
684\end{array}$ & $\begin{array}{l}9411 \\
9411 \\
9411 \\
3003 \\
8012\end{array}$ & $\begin{array}{l}400 \\
1,00 \\
400 \\
4,00 \\
450\end{array}$ & $\begin{array}{l}\text { Sprity } \\
\text { Spaty } \\
\text { Spray } \\
\text { Truy } \\
\text { Tray }\end{array}$ & $\begin{array}{l}\text { Line } \\
\text { Line } \\
\text { Line } \\
\text { lime } \\
\text { Lime }\end{array}$ & $\begin{array}{l}98.0 \\
98.0 \\
98.0 \\
90.0 \\
90.0\end{array}$ \\
\hline 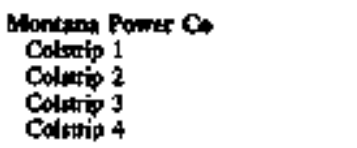 & $\begin{array}{r}2733 \\
= \\
=\end{array}$ & $\begin{array}{l}35 \% \\
35 \% \\
776 \\
78\end{array}$ & $\begin{array}{l}T S 11 \\
760: 4 \\
8401 \\
8604\end{array}$ & $\begin{array}{l}80 \\
80 \\
80 \\
.80\end{array}$ & $\begin{array}{l}\text { Venturi } \\
\text { Venhuri } \\
\text { Ventur } \\
\text { Venturi }\end{array}$ & 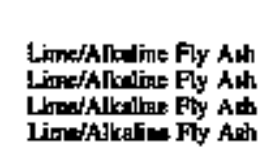 & $\begin{array}{l}58.8 \\
58.8 \\
95.0 \\
95.0\end{array}$ \\
\hline 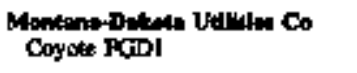 & OSOSO & 450 & BLOS & .90 & Sprop Dry & Lime/alketilue Py Ash & $\pi 0.0$ \\
\hline Mhestite Ots of & 276 & 176 & sosos & 3.20 & Sprots & Linotitione & 960 \\
\hline 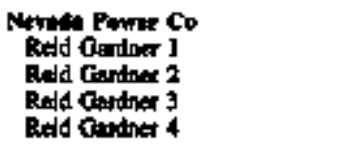 & $\begin{array}{r}612 \\
- \\
- \\
-\end{array}$ & $\begin{array}{l}\text { I14 } \\
114 \\
114 \\
200\end{array}$ & $\begin{array}{l}7604 \\
7404 \\
7407 \\
8007\end{array}$ & $\begin{array}{l}50 \\
50 \\
50 \\
.90\end{array}$ & $\begin{array}{l}\text { Spray } \\
\text { Spring } \\
\text { Spray } \\
\text { Spray }\end{array}$ & 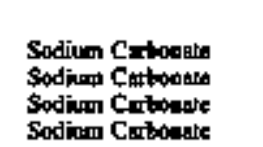 & $\begin{array}{l}90.5 \\
90.5 \\
90.5 \\
85.0\end{array}$ \\
\hline 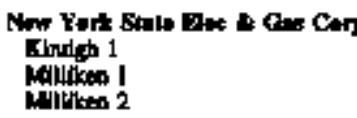 & $\begin{array}{r}\mathbf{6 5} \\
32 \\
=\end{array}$ & $\begin{array}{c}655 \\
155 \\
157\end{array}$ & $\begin{array}{l}8000 \\
9000 \\
9001\end{array}$ & $\begin{array}{l}3.60 \\
3.20 \\
3.20\end{array}$ & $\begin{array}{l}\text { Sproy } \\
\text { Spity } \\
\text { Sproy }\end{array}$ & 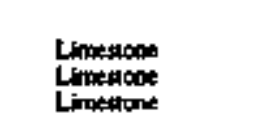 & $\begin{array}{l}\$ 0.0 \\
\$ \$ .0 \\
95.0\end{array}$ \\
\hline 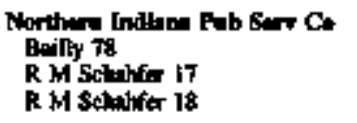 & 1,943 & $\begin{array}{l}616 \\
424 \\
424\end{array}$ & $\begin{array}{l}9206 \\
9604 \\
8002\end{array}$ & 3.20 & $\begin{array}{l}\text { Paplod } \\
\text { Spray } \\
\text { spoyy }\end{array}$ & $\begin{array}{l}\text { Unestome } \\
\text { Olar } \\
\text { Ollwar }\end{array}$ & $\begin{array}{l}90.0 \\
90.0 \\
900\end{array}$ \\
\hline 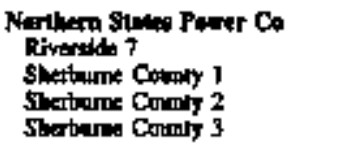 & $\begin{array}{r}104 \\
2,129 \\
=\end{array}$ & $\begin{array}{l}165 \\
660 \\
660 \\
809\end{array}$ & $\begin{array}{l}9101 \\
7605 \\
7704 \\
8711\end{array}$ & $\begin{array}{r}1.30 \\
.90 \\
90 \\
90\end{array}$ & $\begin{array}{l}\text { Spraty Dry } \\
\text { Yerloni } \\
\text { Sprey } \\
\text { Spray Dry }\end{array}$ & 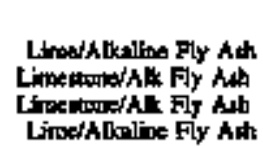 & $\begin{array}{l}70.0 \\
50.0 \\
50.0 \\
72.3\end{array}$ \\
\hline 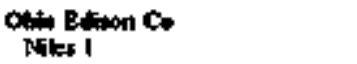 & 266 & 266 & 9510 & $\$, 00$ & \$pray & Lunedpe & 950 \\
\hline $\begin{array}{l}\text { Oid Powar Ce } \\
\text { Gen J M Gavin I } \\
\text { Gen I M Gewn } 2\end{array}$ & 2,500 & $\begin{array}{l}1,300 \\
1,300\end{array}$ & $\begin{array}{l}9412 \\
9505\end{array}$ & $\begin{array}{l}3.50 \\
3.50\end{array}$ & $\begin{array}{l}\text { Spry } \\
\text { Spray }\end{array}$ & $\begin{array}{l}\text { Litho } \\
\text { Limite }\end{array}$ & $\begin{array}{l}950 \\
950\end{array}$ \\
\hline 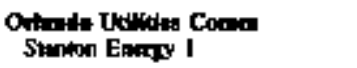 & 520 & 463 & ston & 3.50 & Spray & Linfalcne & 90.0 \\
\hline 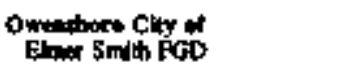 & 416 & 415 & 9411 & 350 & Spray & Lineateme & $\mathbf{\%} .0$ \\
\hline 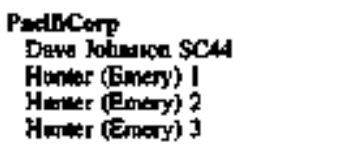 & $\begin{array}{r}817 \\
1,399 \\
-\end{array}$ & $\begin{array}{l}360 \\
446 \\
446 \\
466\end{array}$ & $\begin{array}{l}7200 \\
7006 \\
9006 \\
8306\end{array}$ & $\begin{array}{l}.40 \\
.60 \\
.60 \\
.60\end{array}$ & $\begin{array}{l}\text { Ventur } \\
\text { Spray } \\
\text { Spryy } \\
\text { Spray }\end{array}$ & $\begin{array}{c}\text { lime } \\
\text { Lime } \\
\text { Lime } \\
\text { Lroctone }\end{array}$ & $\begin{array}{l}\mathbf{0 0 . 0} \\
\$ 0.0 \\
90.0\end{array}$ \\
\hline
\end{tabular}

Sec footonotias a end of uble 
Table 30. Fue Gas Desalforization (FGD) Capacity in Operation at U.S. Electric Ut"lity Flants as of December 1995 (Cominnaed)

\begin{tabular}{|c|c|c|c|c|c|c|c|}
\hline \multirow{2}{*}{ 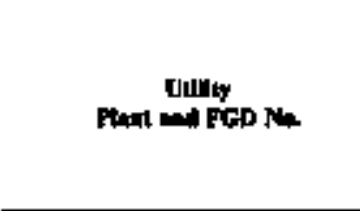 } & \multicolumn{2}{|c|}{ Capedy } & \multirow{2}{*}{$\begin{array}{l}\text { Ining } \\
\text { Sart op } \\
\text { Dated } \\
\text { Sitiden }\end{array}$} & \multirow{2}{*}{ ipis } & \multirow{2}{*}{ FUD Ty" } & \multirow{2}{*}{ Sorte-1 } & \multirow{2}{*}{ 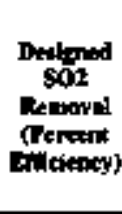 } \\
\hline & by & 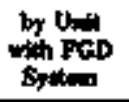 & & & & & \\
\hline 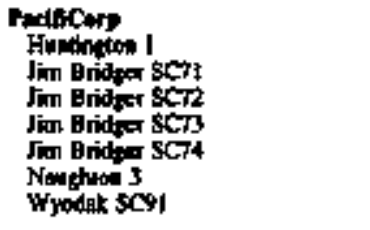 & 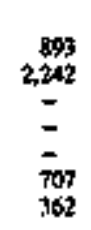 & $\begin{array}{l}446 \\
561 \\
561 \\
561 \\
561 \\
326 \\
362\end{array}$ & $\begin{array}{l}7902 \\
9009 \\
8609 \\
8009 \\
7911 \\
8110 \\
8612\end{array}$ & $\begin{array}{r}0.60 \\
1,00 \\
1,00 \\
1.00 \\
1.00 \\
.00 \\
.00\end{array}$ & $\begin{array}{l}\text { Spry } \\
\text { Traty } \\
\text { Truy } \\
\text { Truy } \\
\text { Tryy } \\
\text { Tryy } \\
\text { Spmy Dy }\end{array}$ & 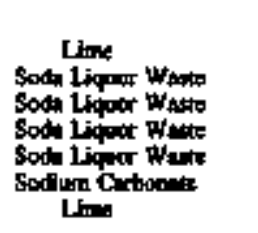 & $\begin{array}{l}80.4 \\
86.4 \\
86.4 \\
86.4 \\
91.0 \\
70.0 \\
752\end{array}$ \\
\hline 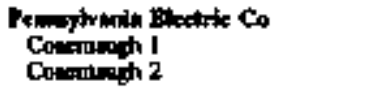 & $\stackrel{5}{5} 872$ & $\begin{array}{l}936 \\
936\end{array}$ & $\begin{array}{l}9412 \\
9511\end{array}$ & $\begin{array}{l}2.20 \\
2.20\end{array}$ & Spray & limention & 95.0 \\
\hline 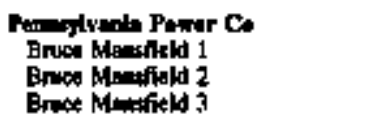 & $\begin{array}{c}2,741 \\
= \\
-\end{array}$ & $\begin{array}{l}914 \\
914 \\
914\end{array}$ & $\begin{array}{l}7604 \\
7010 \\
000\end{array}$ & $\begin{array}{l}4.00 \\
4.00 \\
4.00\end{array}$ & $\begin{array}{l}\text { Yeaburl } \\
\text { Vexpourl } \\
\text { Sinty }\end{array}$ & $\begin{array}{l}\text { Lime } \\
\text { Lims } \\
\text { Lime }\end{array}$ & $\begin{array}{l}92.1 \\
92.1 \\
9.1\end{array}$ \\
\hline 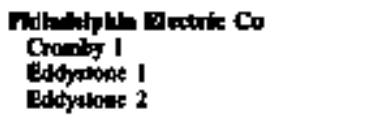 & $\begin{array}{c}1,48 \\
-\end{array}$ & $\begin{array}{l}1 \pm 8 \\
354 \\
354\end{array}$ & $\begin{array}{l}\mathbf{2} 212 \\
\mathbf{v 2 1 2} \\
\mathbf{2} 212\end{array}$ & $\begin{array}{l}3.60 \\
2.60 \\
2.60\end{array}$ & $\begin{array}{l}\text { Spiny } \\
\text { sinimy } \\
\text { Spminy }\end{array}$ & 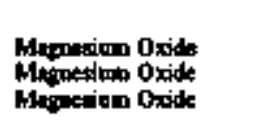 & $\begin{array}{l}93.0 \\
92.0 \\
92.0\end{array}$ \\
\hline 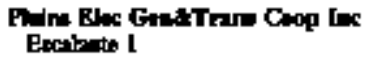 & 293 & 233 & $\$ 12$ & .80 & Spry & Lineswoes: & 95.0 \\
\hline 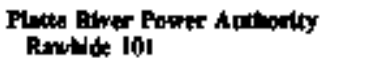 & 285 & 255 & 404 & .30 & Spat Dey & 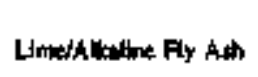 & 80.0 \\
\hline Polk Snrrka Ce of Collento & 710 & $\mathbf{3 5 0}$ & Dos & .40 & Spmy Dry & Other & 26.0 \\
\hline 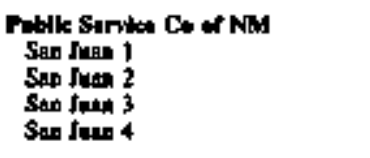 & $\begin{array}{c}1 . m 9 \\
= \\
=\end{array}$ & $\begin{array}{l}365 \\
350 \\
544 \\
534\end{array}$ & $\begin{array}{l}7004 \\
7008 \\
7003 \\
2004\end{array}$ & $\begin{array}{l}1.30 \\
1.30 \\
1.30 \\
1.30\end{array}$ & $\begin{array}{l}\text { Tray } \\
\text { Tray } \\
\text { Thing } \\
\text { Thy }\end{array}$ & $\begin{array}{l}\text { Oher } \\
\text { Ohiter } \\
\text { Ohinter } \\
\text { Ohe }\end{array}$ & $\begin{array}{l}90.0 \\
900 \\
90.0 \\
90.0\end{array}$ \\
\hline 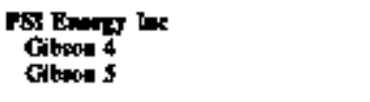 & $\stackrel{3,340}{-}$ & $\begin{array}{l}668 \\
668\end{array}$ & $\begin{array}{l}9501 \\
\$ 210\end{array}$ & $\begin{array}{l}3.50 \\
1.40\end{array}$ & Sproy & 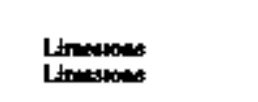 & $\begin{array}{l}92.0 \\
86.0\end{array}$ \\
\hline 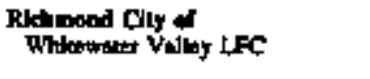 & - & $\neg$ & 9410 & 2.10 & Sprity Drt & Lingorim & 72.5 \\
\hline 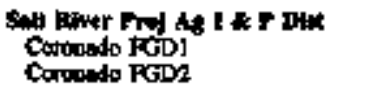 & 827 & 411 & $\begin{array}{l}7912 \\
8011\end{array}$ & $\begin{array}{l}1.00 \\
1.00\end{array}$ & Spny & $\begin{array}{l}\text { Ltanestoes } \\
\text { Limestouse }\end{array}$ & 82.5 \\
\hline Sed Antenlo Chy of & 346 & 546 & 9212 & .60 & Sproy & Lreatons: & 70.0 \\
\hline 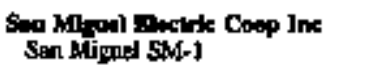 & 410 & 410 & 201 & 3.00 & Spay & Lomperse & 860 \\
\hline 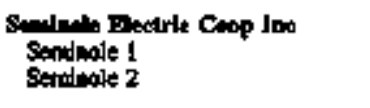 & $\stackrel{1,429}{=}$ & $\begin{array}{l}715 \\
715\end{array}$ & 84012 & $\begin{array}{l}3.00 \\
3.00\end{array}$ & Sway & Linemente & $\begin{array}{r}86.0 \\
86.0\end{array}$ \\
\hline 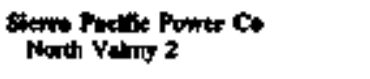 & 521 & 267 & $\mathbf{s o p}$ & $\infty$ & $S_{\text {Fray }}$ Dry & ume & 70,0 \\
\hline 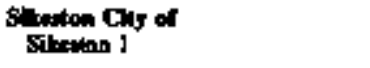 & 261 & 261 & siii & 200 & Venond & Limontone & 75.5 \\
\hline
\end{tabular}

Sect bomoces to end of loblo. 
Table 30. Flue Gas Deanlfortzation (FGD) Capacity in Operation at U.S. Flectric Utility Plants as of Dexember 1995 (Continued)

\begin{tabular}{|c|c|c|c|c|c|c|c|}
\hline \multirow{2}{*}{ 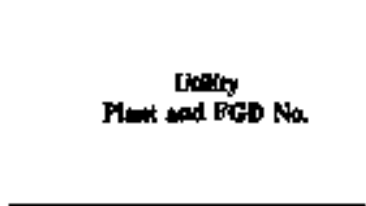 } & \multicolumn{2}{|c|}{ 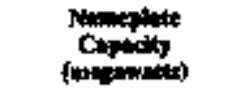 } & \multirow{2}{*}{ 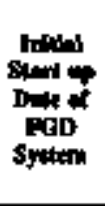 } & \multirow{2}{*}{ 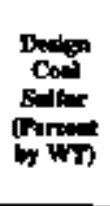 } & \multirow{2}{*}{ PGD Typ: } & \multirow{2}{*}{ Sertent } & \multirow{2}{*}{ 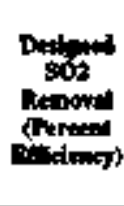 } \\
\hline & Fing & 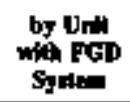 & & & & & \\
\hline 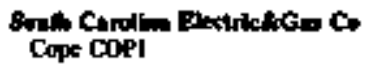 & 413 & 417 & 9511 & 1,90 & Sproy Dry & lime & 95.0 \\
\hline 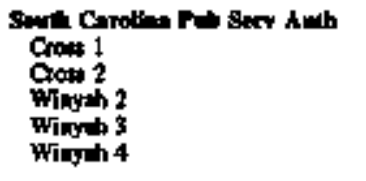 & $\begin{array}{l}1,143 \\
1, \overline{260} \\
= \\
=\end{array}$ & $\begin{array}{l}\text { s91 } \\
555 \\
315 \\
315 \\
315\end{array}$ & $\begin{array}{l}2505 \\
5912 \\
7007 \\
8006 \\
8111\end{array}$ & $\begin{array}{l}1.10 \\
1.60 \\
1.10 \\
2.30 \\
1.70\end{array}$ & 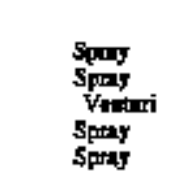 & 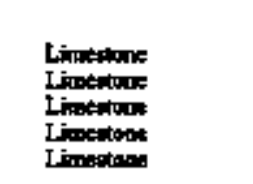 & $\begin{array}{l}90.0 \\
81.4 \\
45.0 \\
900 \\
90.4\end{array}$ \\
\hline 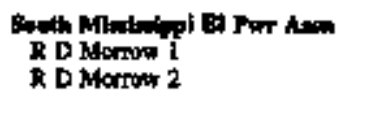 & $\stackrel{400}{-}$ & $\begin{array}{l}200 \\
200\end{array}$ & 7909 & $\begin{array}{l}1.50 \\
1.50\end{array}$ & $\begin{array}{l}\text { Spray } \\
\text { Spryy }\end{array}$ & 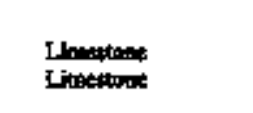 & $\begin{array}{l}52.7 \\
52.7\end{array}$ \\
\hline Mirrou 4 & 272 & 173 & 7904 & 4.40 & Vasom & Limestone & 89.4 \\
\hline 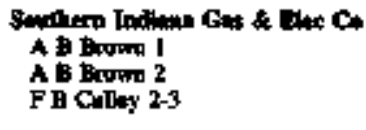 & $\begin{array}{l}530 \\
515\end{array}$ & $\begin{array}{l}265 \\
265 \\
369\end{array}$ & $\begin{array}{l}7904 \\
3002 \\
9501\end{array}$ & $\begin{array}{l}4.50 \\
4.90 \\
3.50\end{array}$ & $\begin{array}{l}\text { Spay } \\
\text { spry } \\
\text { spry }\end{array}$ & 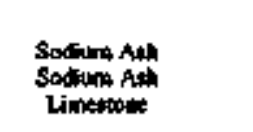 & $\begin{array}{l}\$ 5.0 \\
90.0 \\
95.0\end{array}$ \\
\hline 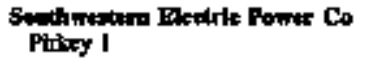 & 72 & 721 & 8501 & 1.00 & Sprom & 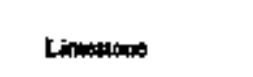 & $\$ 5.0$ \\
\hline 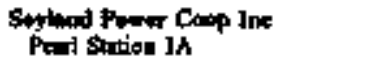 & 22 & 22 & TE:I & 3,40 & Yenturi & Onlwer & It 8 \\
\hline 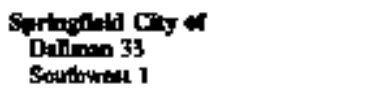 & $\begin{array}{l}368 \\
194\end{array}$ & $\begin{array}{l}207 \\
194\end{array}$ & $\mathrm{~m}_{\mathrm{nod}}^{8012}$ & $\begin{array}{l}330 \\
3.00\end{array}$ & $\begin{array}{l}\text { Pached } \\
\text { Tray }\end{array}$ & Lilistone & $\begin{array}{l}950 \\
570\end{array}$ \\
\hline 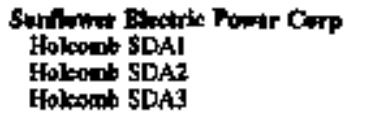 & $\begin{array}{l}349 \\
- \\
-\end{array}$ & $\begin{array}{l}349 \\
349 \\
349\end{array}$ & $\begin{array}{l}8900 \\
83080 \\
8308\end{array}$ & $\begin{array}{l}1.00 \\
1.00 \\
100\end{array}$ & $\begin{array}{l}\text { Swry Doy } \\
\text { Spry Dry } \\
\text { Spryy Dry }\end{array}$ & 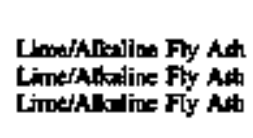 & 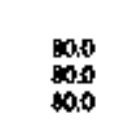 \\
\hline 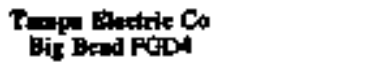 & 2,823 & 486 & 8502 & $3 \leqslant 0$ & sprony & Limetrone & 900 \\
\hline 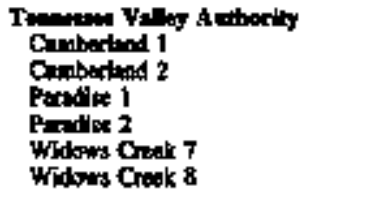 & $\begin{array}{l}2,600 \\
2,568 \\
- \\
1,969 \\
-\end{array}$ & $\begin{array}{r}1,300 \\
1,300 \\
704 \\
704 \\
575 \\
5 \$ 0\end{array}$ & $\begin{array}{l}9501 \\
9501 \\
8509 \\
8312 \\
8112 \\
7801\end{array}$ & $\begin{array}{l}4.00 \\
4.00 \\
3.20 \\
3.2 \\
4.00 \\
4.50\end{array}$ & $\begin{array}{l}\text { Spray } \\
\text { Sproy } \\
\text { Sprity } \\
\text { Sproy } \\
\text { Spany } \\
\text { Inyy }\end{array}$ & 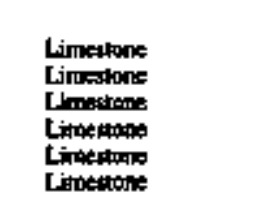 & $\begin{array}{l}95.0 \\
95.0 \\
84.2 \\
84.2 \\
83.4 \\
80.0\end{array}$ \\
\hline 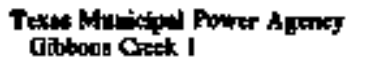 & 444 & 441 & 830 & 234 & Spray & Lbmettone & 900 \\
\hline 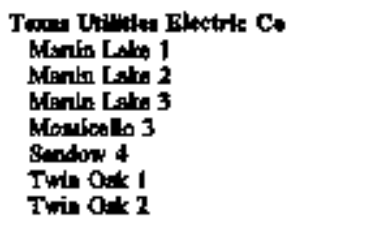 & $\begin{array}{c}2,390 \\
= \\
\overrightarrow{1} \\
1,980 \\
591 \\
1,602 \\
=\end{array}$ & $\begin{array}{l}793 \\
793 \\
793 \\
793 \\
591 \\
8901 \\
301\end{array}$ & $\begin{array}{l}7705 \\
7806 \\
7904 \\
7006 \\
8105 \\
304 \\
504\end{array}$ & $\begin{array}{l}.90 \\
.90 \\
.90 \\
1 \leqslant 0 \\
1.00 \\
1.00 \\
1.60\end{array}$ & 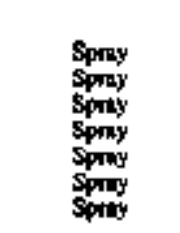 & 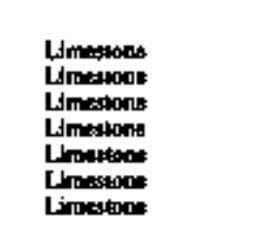 & $\begin{array}{l}91.0 \\
91.0 \\
910 \\
740 \\
23.5 \\
89.0 \\
080\end{array}$ \\
\hline 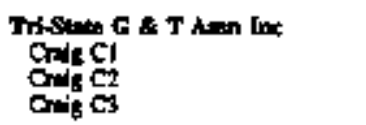 & $\begin{array}{c}1,339 \\
= \\
=\end{array}$ & $\begin{array}{l}446 \\
446 \\
446\end{array}$ & $\begin{array}{l}8010 \\
8005 \\
8410\end{array}$ & $\underset{40}{40}$ & $\begin{array}{l}\text { Sproy } \\
\text { Spray } \\
\text { 5pray Dry }\end{array}$ & 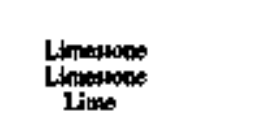 & $\begin{array}{l}85.0 \\
85.0 \\
85.0\end{array}$ \\
\hline
\end{tabular}

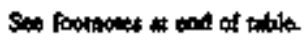


Table 30. Fue Gas Desalfurlzatlon (FGD) Capacity in Operatlon at U.S. Electric Utility Plants as of December 1995 (Contibued)

\begin{tabular}{|c|c|c|c|c|c|c|c|}
\hline \multirow{2}{*}{ 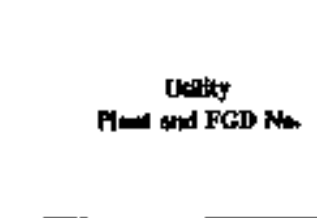 } & \multicolumn{2}{|c|}{ (1) } & \multirow{2}{*}{ 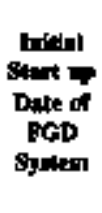 } & \multirow{2}{*}{ 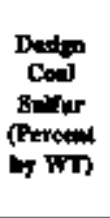 } & \multirow{2}{*}{ PGD TJ" } & \multirow{2}{*}{ Sorbeit } & \multirow{2}{*}{ 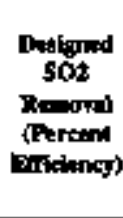 } \\
\hline & $\ln _{\text {lint }}$ & $\begin{array}{l}\text { with FGD } \\
\text { Spatem }\end{array}$ & & & & & \\
\hline $\begin{array}{l}\text { Twenin Electrle Power C. } \\
\text { Springervile I } \\
\text { Springorvile ? }\end{array}$ & $\begin{array}{r}\mathbf{5 0} \\
-\end{array}$ & 425 & $\begin{array}{l}\mathbf{8 6 0 6} \\
\mathbf{9 0 0 6}\end{array}$ & $\begin{array}{r}6.70 \\
.70\end{array}$ & $\begin{array}{l}\text { Sprty Dry } \\
\text { Spray Dry }\end{array}$ & 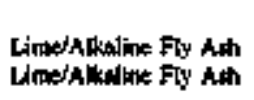 & $\begin{array}{l}61.3 \\
61.3\end{array}$ \\
\hline $\begin{array}{l}\text { Chiled Power Atm } \\
\text { Ek RJwet I } \\
\text { Sinnton } 10\end{array}$ & 17 & $\begin{array}{c}46 \\
172\end{array}$ & $\begin{array}{l}8903 \\
8306\end{array}$ & $\bar{x}$ & $\begin{array}{l}\text { Spray Dry } \\
\text { Spany Dry }\end{array}$ & $\begin{array}{l}\text { Lins } \\
\text { Limk }\end{array}$ & $\begin{array}{l}900 \\
70.0\end{array}$ \\
\hline 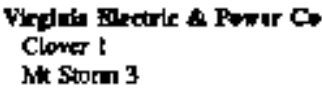 & 1,648 & $\begin{array}{l}424 \\
322\end{array}$ & $\begin{array}{l}9010 \\
9001\end{array}$ & $\begin{array}{l}2.00 \\
2.00\end{array}$ & $\begin{array}{l}\text { Spry } \\
\text { Spryy }\end{array}$ & $\begin{array}{l}\text { Limasuode } \\
\text { Limesnode }\end{array}$ & $\begin{array}{l}90.0 \\
90.0\end{array}$ \\
\hline $\begin{array}{l}\text { Weft Penn Puwer Co } \\
\text { MHintoll I5 }\end{array}$ & $\$ 49$ & 299 & 2008 & 400 & Sptaly & Line & 95,0 \\
\hline 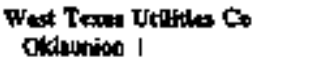 & 720 & 720 & 8612 & 40 & Spray & Linestone & 86.8 \\
\hline 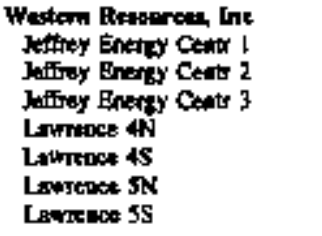 & $\begin{array}{r}2,160 \\
- \\
- \\
604 \\
= \\
=\end{array}$ & $\begin{array}{l}720 \\
720 \\
720 \\
114 \\
114 \\
403 \\
409\end{array}$ & $\begin{array}{l}7807 \\
8005 \\
6306 \\
6906 \\
6906 \\
7105 \\
7105\end{array}$ & $\begin{array}{l}.30 \\
.30 \\
.30 \\
.90 \\
.90 \\
.90 \\
.90\end{array}$ & 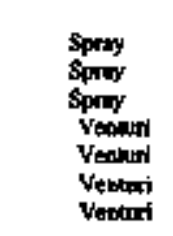 & 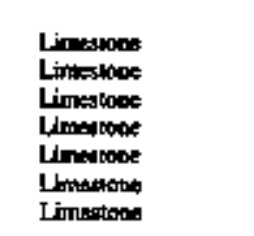 & $\begin{array}{l}60.0 \\
50.0 \\
60.0 \\
73.0 \\
73.0 \\
520 \\
520\end{array}$ \\
\hline 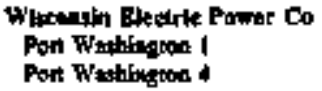 & $\begin{array}{r}328 \\
-\end{array}$ & $\begin{array}{l}80 \\
80\end{array}$ & $\begin{array}{l}9308 \\
9408\end{array}$ & $\begin{array}{l}1.20 \\
1.20\end{array}$ & Sprty & 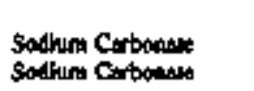 & $\begin{array}{l}50.0 \\
50.0\end{array}$ \\
\hline
\end{tabular}

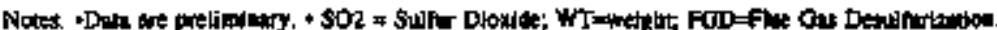

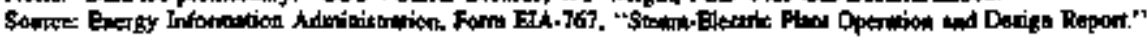




\section{U.S. Electric Power Transactions}

This chapter provides stummary information for the U.S. electric power industry on its operations and wholesale electricity trade at the international (Canada and Mexico), pational, and North American Electric Reliability Council (NERC) region levels. ${ }^{43}$ Oenerating capability, generation from utility and nonutility sources, and end-user consumption are also presented.

\section{Background}

An electric power system is a group of generation, transmission, distribution, communication, and other facilities that are physically connected and operated as a single unit under one control. Transmission and distribution lines and associated facilities are used to transmit electricity from its point of origin (the generator) to the ultimate consumer. Although, due to its physical characteristics, electricity tlows along all available paths, it follows the path of least resistance. The flow of electricity must be closely monitored to onsure that sufficient generating capacity is available and on-call to satisfy all demand (load) for electricity placed on the power system. In addition, for system standardization and reliability purposes, the flow is maintained at a frequebcy of 60 cycles per second.

The flow of electricity within the system is maintained and monitored by dispatch centers having control and security responsibilities. Historically, the dispatch center inventoried and prioritized all generating capacily available to it. tracked transactions involving the buying or selíng of either electric power or capacity, monitored current load, and anticipated future load on the system. In the future, this responsibility may be handled differently. How, is now being detemined by participants in the new elec. tric power industry.

It is the responsibility of the dispatch center to match the suppty of electricity with demand. The demand for electricity is not constant in nature. That is, load requirements fluctuate continurously, based on such factors as time of day, season of the year, and the characteristics of territory served by the system. Nonetbeless, the dispatch center must be ready to
Ineet the highest level of load placed on the systefm. The dispatch center must accommodate the loss of generating facilities (both planned and unexpected). In addition, the center must monitor transmission lines to determine whether the flow of electricity is approaching the carrying limits of the lines. In order to carry out its responsibilities in a timely fashion, the dispatch center is autborized to buy and sell electricity based on system requirements.

Authority for these transactions has been preapproved under interconnection agreements (contracts) that have been signed by all the electric utilities that are physically interconnected and/or have coordination agreements with other utilities not physically interconnected. (All these agreements are subject to regulatory approval.) These apreements inc]ude transaction categories for purchases, sales for resale, exchanges, and wheeling of energy. In the near flature, a competitive power market will address this allocation of resources through the open buying and selling of electricity and the independent pricing of system operating costs which were bundled into the total charges for electricity.

Purchase transactions involve buying power from electric utilities and nonutility producers of elecIricity. Sales for resale transactions refer to power sold by one electric utility or powet marketer to other electric utilities for distribution. (Direct interstate wholesale sales to retail customers by power marketers are not authorized.) Some transactions involving the trade of electric energy are based on availability of excess generating capacity or diversily in load requirements. For example, if one electric utility has its lowest load during the winter season, it may arrange to offer its available excess generating capacity in exchange for excess generating capacity available at a facility with low summer load. This type of arrangendent is an exchange transaction. However, the repayment or replacement of exchange energy may have extended over several years. The use of exchange transactions is disappearing. Spot and futures markets will eventually replace this type of transaction. Whecling transactions are the movenent of electricity from one utility to another utility over the transmission facilities of one or more intervening utilities.

19 The NERC is aA orpantzation established by the electuic utility indastcy for msinlaining. coordieating, and promoting reliability among the interconnecied sysiens of Nont America. 


\section{Electric Utilty Transactions}

Electric power transactions (wholesale electricity trade) allowed electric utilities to acguire power, to share resources, and to provide mutral assistance in times of potential and actual need. They allowed the utility systems to provide lower cost service to their consutners by taking advantage of the load diversity of each utilty. These transactions also allowed each utility to conserve its own resonrces, to share the benefits of reduced operating costs with its consumers, to receive emergency energy support from other utilities, and to reduce the cost of its own requirements for operating reserve. Competitive markels (spot and futures) are expected to be substituted as the electric utility industry continues to change from monopoly based siructure. However, due to the complexity of electric power transactions involving the specifics of coniracts, simultaneous energy transactions, the unintended receipt and delivery of energy (ibadvertent ffow), and losses, the teporting of both the classification and quantity of each transaction among otilities is expected to be inconsistent in the future as well.

Electric utilities originally became interested in energy transactions because of the savings gatned from reduced or avoided prodaction costs. They sYoided building expensive additional tapacity by obtaining power from other sources. Purchasing power from other utilities hejped utilities meet peak logd wthout using expensive oil- or gas-fited turbines. Similarly, utilities benefited from being able to delay or stagger construction of additional baseload plants. Electric utilities have also delayed or replaced new plant construction by purchasing electricity from nonutility generators under long-term contracts. Now, opportunities are developing for price based decisioss.

\section{Power Pool Transactlons}

In addition to dealing to ofte-time purchase and sale uransoctions, many electric utilities have joined together and formed power pools to achieve better operating efficiencies and to gain additional support for maintaining a functional alectrical system. Thus, they share the benefits achieved by joint planning, coordinated use of genterating and transmission facilities, and/or common coverage of facility outages. This coordination also provides the opportunity to acbieve short-term saving. largely from varying fuel prices and the costs associated with different mixes of capacity. The future of this type of agreement will hinge on the full implementation of the Federal Energy Regulatory Commission (FERC) Orders that directed changes be made to these agretements.

Power pools can be made up of two electric ubilities, like the Michigan Electric Coordinated Systemn (Detroit Edison Company and Consumer Power Company), include all the major investor-owned utilities within a State (the New York Power Pool), or cross State lines (the PJM Power Pool includes parts or all of Penssylvania, New Jersey, Maryland, and Delaware).
Power pools may run under a single-gystem dispatch to meet combined-load requiremonts and maintepance programs, or they may just share the benefits of planned or hourly wholesale sales of power and energy among the member utilities. They may also have responsibility for coordinating flow within the geographic area of the interconnected systems. In any case, they are bound by the operating standards established by the electric power industry. These atandards require the coordination and maintenance of gystem stability and reliable service on a regional basis. In the future, if the concept of an independent system operator takes hold, many power pools may reinvent themselves and operate under a new structure of rules.

\section{NEAC Profile}

The North American Electric Reliability Council (NERC) consists of 9 regional reliability councils whose memberskips comprise essentially all of the electric utility 'systems in the contiguous United States, Canada, and Baja Calífornia Norte, Mexico. Part of the State of Alaska operates togtther and is an affiliate nember; sometimes referenced as the tenth council. The regional councils are responsible for maintajning and setting standards for the reliability and stability of the electricity flowing within the three power grids (the Eastem Power Grid, the Western Power Grid, and the Electric Reliability Council of Texas Power Gud) present in the contiguous United States. The data for NERC regions in this publication are based upon the assignment of all electric utilities to an individual region and are for the U.S. portion of the regions only (Figure [4).

\section{Regulation of U.S. Electric UtIIty Traneactions}

The Federat Energy Regulatory Commission (FERC) is responsible for regulating interstate wholesale transwetions. U.S. electric utilities and potential power marketers (registration and rate structure) file with the FERC for approval of proposed rate schedules for transmission services and charges, and for wholesale transactions. Historicaliy, transmission filings covered the allocation of electric power flows on the transmission line systems. Other calegories described in the filings usually include the responsibilities of the utilities to one another during normal and omergency conditions, operating-reserves, support, diversity exchanges, and unscheduled or inadvertent-energy flows. Recendly, new atthority was granted the FERC by the Energy Policy Act of 1992 to ensure that any wholestale generator--electric utility or nonotility--can access the transmission grid to reach its markets. After application, the FERC con order electric atilities to grovide transmission (wheling) services, provided that the proposed transaction is in the public interest and meets key criteria related to pricing, reliabjlity. and self-dealting.

Wholesale transactions include capacity sales, energy sales, and energy exchanges. Wholesale transactions 
are Eurther divided by duration of the sale and the type of capacity and energy sold. The length of the sale can the for an hour, a day, a week, a month (or several months), a season, several years, or some combination of these time periods.

Capacity sales are nsualty considered firm sales (that it, associated energy may be taken, or the capacity must be paid for if the energy is not taken; and the delivery is scheduled during normal system operating condlions). This capacity may be made available from the entire system or from an identified geperating unit. The capacity offered in these transactions may be available only during a set period of a given seasen, for an off-peak time of the day, or from a gea. crator fired by a particular fuel that is curtently not fully utilized. The energy associated with this capacity sale, if required, has a separate cost schedule from the capacity charge attached to each kilowatt of power.

Nonfirm sales, sometimes called energy, economy, or interruptible sales, do not include a demand or capacity charge in the price of the transaction. These transactions are subject to curtailment or cessation of delivery by the suppliet in accordance with prior agreements or under specified conditions. The sales are often based on splitting the benefits gained by the parties involved. They are used to gain operational savings, for example, by avoiding the use of more expensive fuels, or by selting electricity generated by the spillage of excess reservoir water.

Energy exchanges involve transfers of energy to other systems at no monetary charge. The energy must be returned in kind at a later date agreed upon by both parties. Otherwise, the receiving party pays for the energy received. The incidental miscellaneous transfer of energy and inadvertent flow are also handled in the same manner. In total, these wholesale transactions have becoune very important tools used by the U.S. electric utility industry to reduce costs and avoid expensive now capacity.

\section{Other Wholesale Electrlcity Trade Concerns}

Environmental issuer associated with air, solid-waste disposal, water quality, and aguatic babital have received increasing attention from utility and power plant operators. Plant operating restrictions caused by air and water emissions bave altered or restricted the dispatching of some facilities and in certain cases, plant cooling water soures have been contaminated or shut down due to aquatic organtsms. Ttansmission line right-of-way and projected line cobstruction are also being affected because of concerns linked to generated electromagnetic forces surrounding the trans. mission lines. The issue of who will butld new transmission lines in the future is uncertain. Changing responsibjilities in the electric power industry may make it difficult to jostify new construction in one State that address requireneats for new transtrission capability or reliability support coming from another State.

Legislative and regulatory initiatives have been implemented to address emissions at power plants. For example, the Clean Air Act Amendments of 1990 established emission allowances for njtrogen oxides, sulfur dioxide, and carbon dioxide for power plants based on historical levels, (The implementation occurs in two phases: 1995 for an identified set of utility plants and 2000 for at] others.) The cost of compli. ance is expected to change the cost of the output of some existing plants, alter construction spproaches to new facilities, cause changes to the fuel tose of other power plants, and cause an reexamination by powerplant operators of what can be done to reduce omissions. The impact of the changes will affect the tuture availability of power from power plants entit. ting high levels of these gases and increase the attractiveness of acquiting power from other facilitios and electrical systems emitting low levels. In addition, traditional wholesale trade patterns are going to be attered by changing practices in the new electric power industry. Cost issues will change to one of price. Availability of electrical energy will change to issues concerning more effective capacity utilization and that may mean more use of high emission source generators.

\section{International Transactions}

U.S. electric utilities and power marketers bave taken advantage of being able to entes into international trade agreements to acquire energy from Canada and Mexico. These trade agreements between Canadian utilities and U.S. participants in the electric power industry cover a variety of transaction options. The options include purchasing nonfirm energy from relstively inexpensive rentewable resources (hydroelectric from Conada and geothermal from Mexico); acquiring additional generating capability to support contracted tequirements for supply; the holding of purchased electricity (as reservoir water) to be reacquired when needed; and sharing the benefits of coordinated operations pianning for the electrical systems. In some instances, constumers can be served more officiently if they are connected to foreign transmission lines, because they are geographicalty closer to those lines.

\section{Data Sources}

Statistics on electricity transactions among U.S. electric ntilities and on international electricity trade (including the United States, Canada, and Mexico) are presented in the following tables. These data were obtained from the Form EIA+861, "The Annual Electric Utility Report"; the Form EIA-860, "Annual Eleetric Generator Report"; the Form EIA-411. "Coordinated Bulk Power Supply Program Report"; and the Department of Energy, Office of the Assistant Secretary for Fossil Energy, Form FE-781R, "Annual Repott of International Electric Exportilmport Data." 


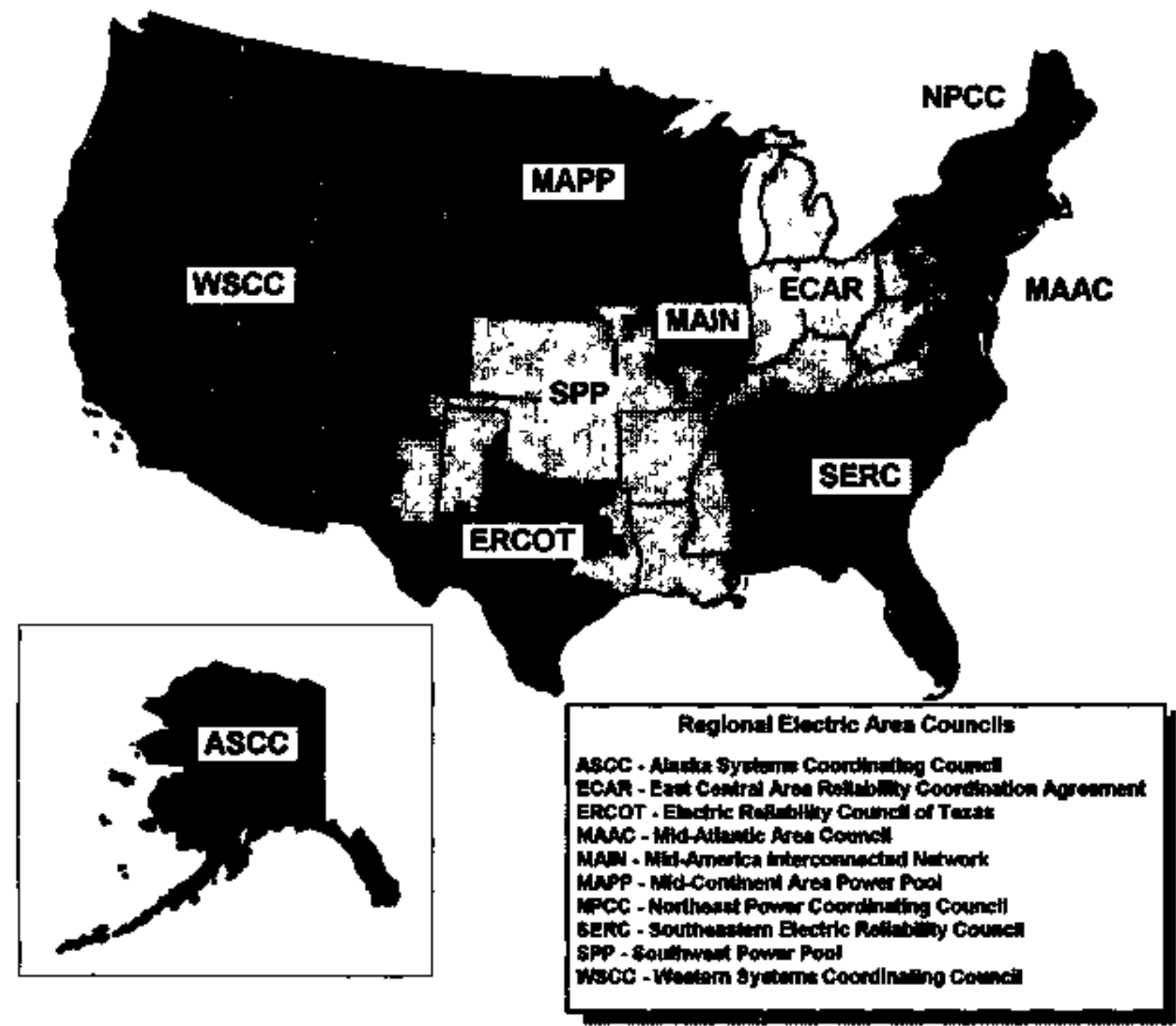

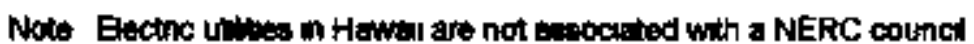

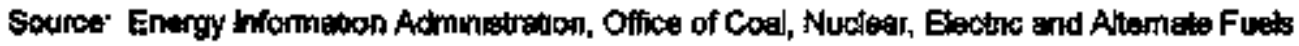


Tabje 31. Sources and Disposition of Electricity at U.S. Blectric Ut0itles, 1991 Through 1995 (Million Kulowathours)

\begin{tabular}{|c|c|c|c|c|c|}
\hline Gem & I991 & 1992 & $10 s$ & 1994 & 199 \\
\hline \multicolumn{6}{|l|}{ Sourat } \\
\hline 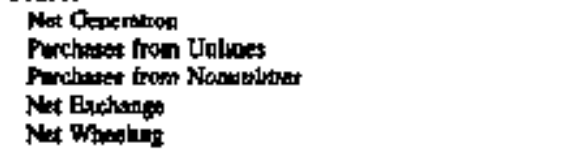 & $\begin{array}{r}2,8,35,379 \\
1,127,659 \\
139,436 \\
1,172 \\
4,969\end{array}$ & $\begin{array}{r}2,605,092 \\
1,1,46,320 \\
166,283 \\
-3,504 \\
5,756\end{array}$ & $\begin{array}{r}2897,815 \\
1.716,892 \\
185,537 \\
-2,725 \\
4,668\end{array}$ & $\begin{array}{r}2,924,961 \\
1,276,814 \\
2,28,779 \\
-7,549 \\
4,205\end{array}$ & $\begin{array}{r}3,004,538 \\
1,20,2,677 \\
22,115 \\
129 \\
7,016\end{array}$ \\
\hline \multicolumn{6}{|l|}{ Deperikon } \\
\hline 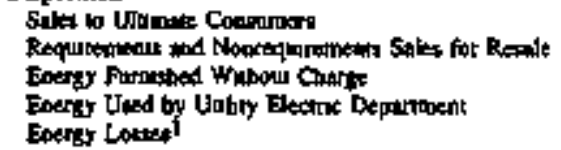 & $\begin{array}{r}2,762,003 \\
1,116,655 \\
4,210 \\
15,154 \\
210,596\end{array}$ & $\begin{array}{r}2,763,365 \\
1,119,948 \\
4,409 \\
15,651 \\
216,592\end{array}$ & $\begin{array}{r}2,851.462 \\
1,200,047 \\
5,007 \\
14,245 \\
226,415\end{array}$ & $\begin{array}{r}2,934,563 \\
1,385,152 \\
4,762 \\
15,498 \\
220,948\end{array}$ & $\begin{array}{r}7,013,451 \\
1,25 \%, 518 \\
5,343 \\
12,457 \\
22,0,049\end{array}$ \\
\hline
\end{tabular}

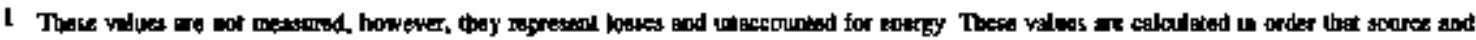
hrporalood of abergy ane equmaled

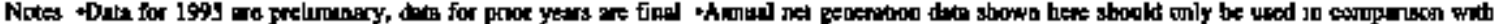

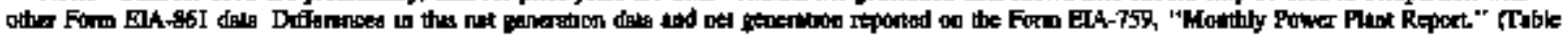

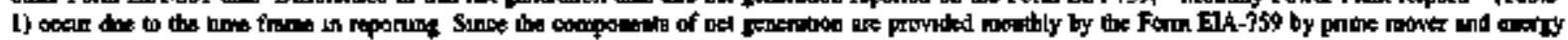

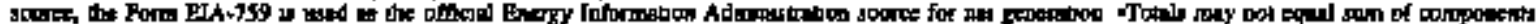

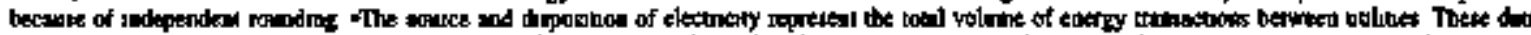

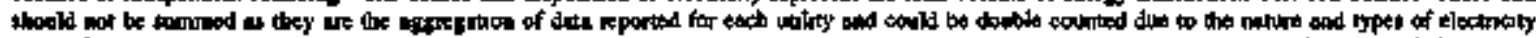

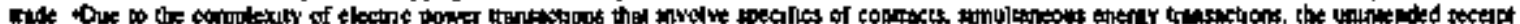

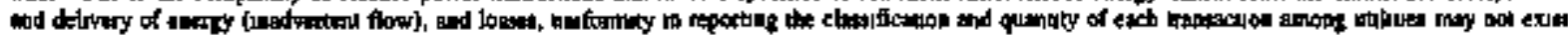

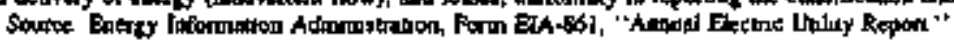

Table 32. Net Generation trom U.S. Electric Utilitled by North American Electric Rellability Councll Region and Hawall, 1991 Throngh 1995

(Mitlion Kilowathours)

\begin{tabular}{|c|c|c|c|c|c|}
\hline 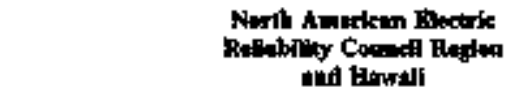 & $19 \$ 1$ & 1942 & Isss & 1901 & thes \\
\hline 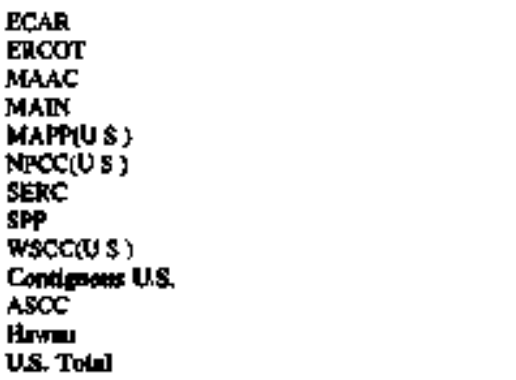 & 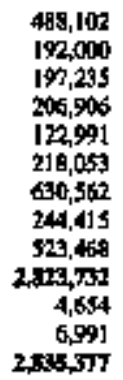 & 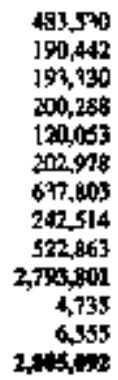 & $\begin{array}{r}494,602 \\
195,18 ? \\
205,552 \\
21 \pm, 284 \\
124,600 \\
195,140 \\
667,464 \\
256,901 \\
527,428 \\
2907,360 \\
4,660 \\
5,790 \\
20,47,815\end{array}$ & 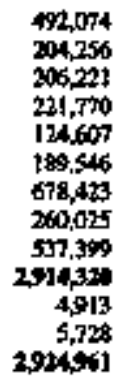 & 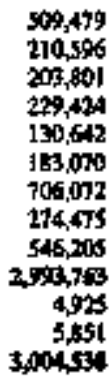 \\
\hline
\end{tabular}

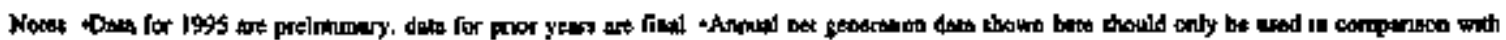

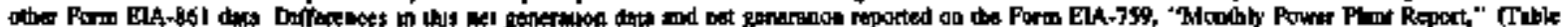

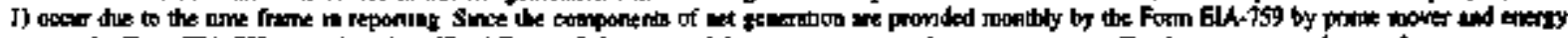

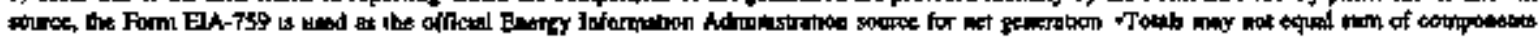
becture of mdependeol reunding

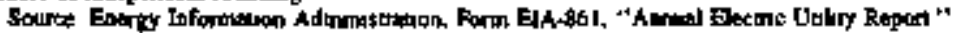


Table 33. U.S. Eloctric Utility Sales to Ultimate Comoners by Sector, North American Electric Relisolity Council Region, and Howalt, 1991 Through 1995 (Milluon Kilowarthours)

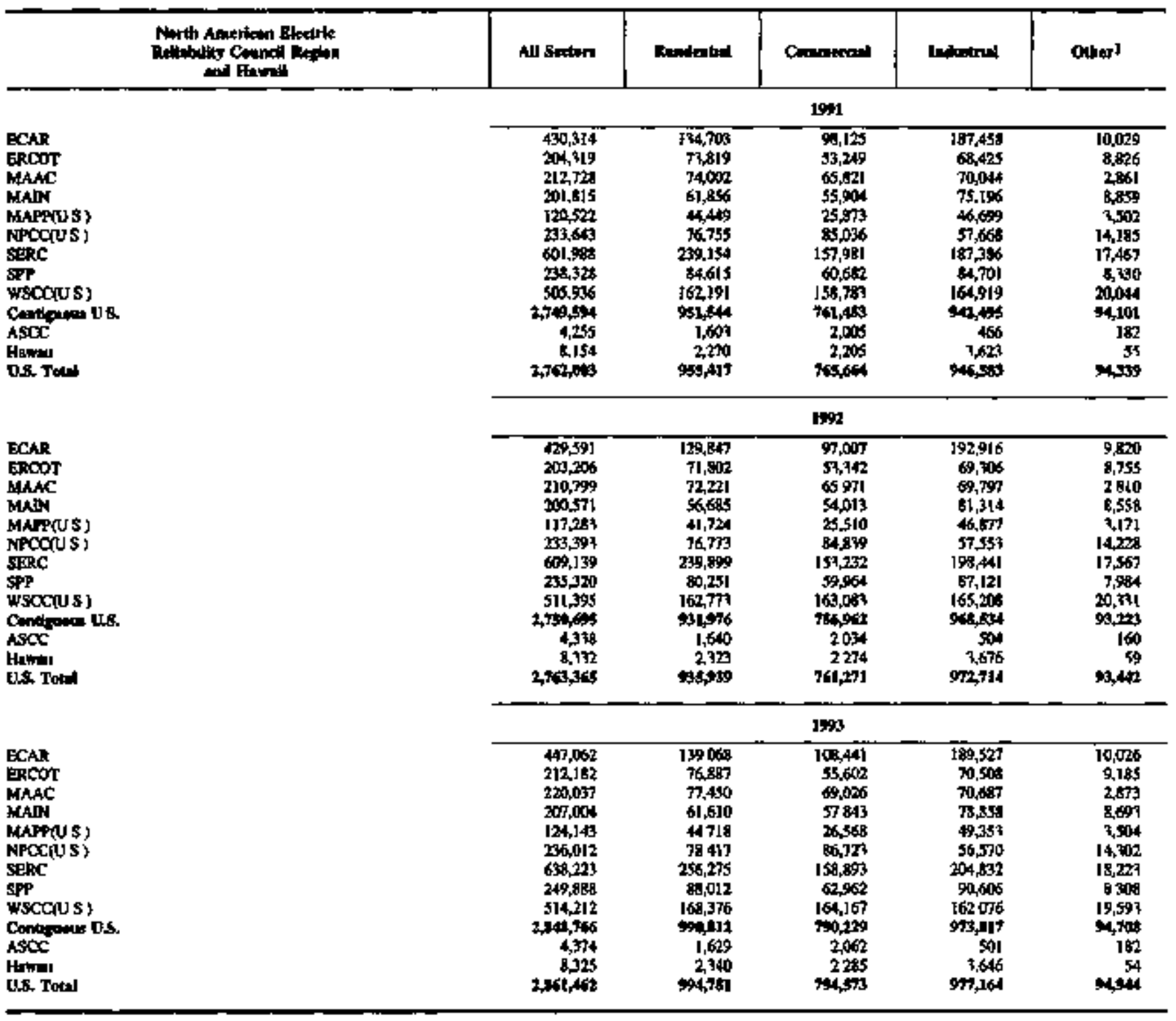

See rogitomes at end of wolle 
Thale 33. U.S. Electric Utility Sules to Eitinate Consoness by Sector, North American Electric Reliability Coancil Regioll, and Howait, 1991 Throngh $1 \% 95$ (Continoed)

(Million Kilowatttours)

\begin{tabular}{|c|c|c|c|c|c|}
\hline 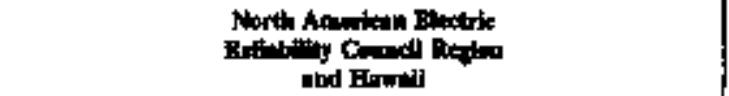 & Allscitory & Bodilonital & Coconiretel & |atritat & Oberl \\
\hline & \multicolumn{5}{|c|}{ then } \\
\hline 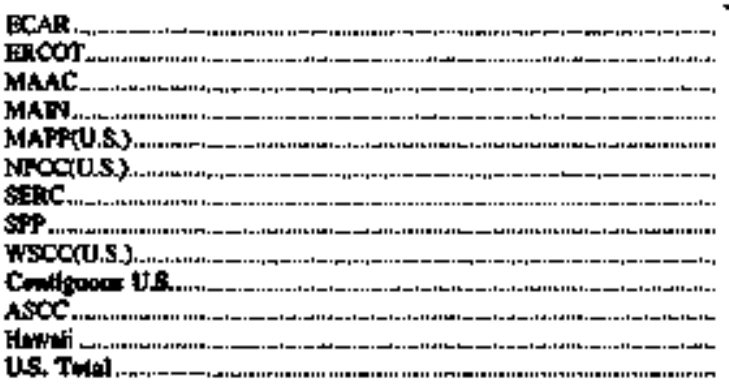 & 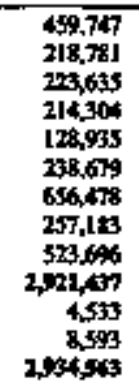 & 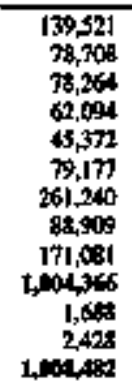 & $\begin{array}{r}111,731 \\
5,209 \\
75,475 \\
60,0 \% 6 \\
29,015 \\
19,591 \\
164,290 \\
65,485 \\
163,782 \\
115,644 \\
2,155 \\
2,451 \\
12,269\end{array}$ & $\begin{array}{r}198,793 \\
73,216 \\
66,999 \\
83,056 \\
51,776 \\
55,255 \\
212,424 \\
94,302 \\
167,957 \\
1,43,811 \\
511 \\
3,659 \\
1,47,541\end{array}$ & $\begin{array}{r}9,701 \\
9,615 \\
2,897 \\
9,068 \\
3,771 \\
14,656 \\
18,524 \\
8,498 \\
20,876 \\
9,596 \\
179 \\
56 \\
97,034\end{array}$ \\
\hline & \multicolumn{5}{|c|}{ Ines } \\
\hline 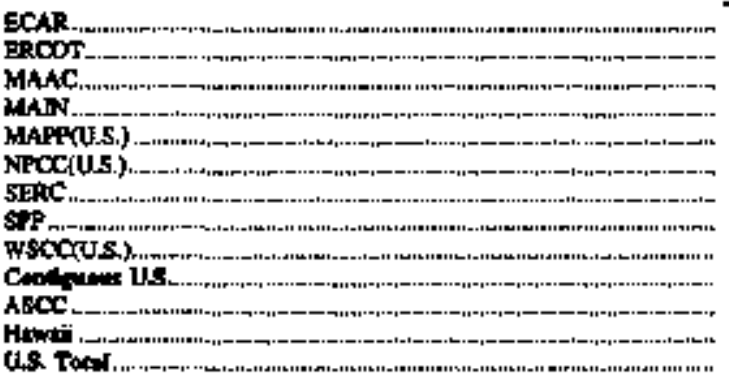 & 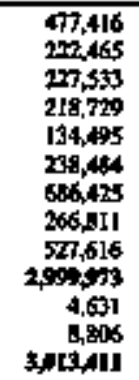 & 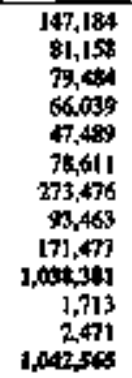 & $\begin{array}{r}116,093 \\
59,068 \\
86,667 \\
62,617 \\
29,530 \\
94,236 \\
172,427 \\
67,387 \\
169,779 \\
640,117 \\
2,200 \\
2,605 \\
762,041\end{array}$ & 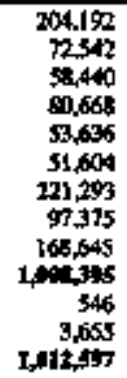 & $\begin{array}{r}9,946 \\
9,700 \\
2,924 \\
9,204 \\
3,839 \\
14,034 \\
19,234 \\
\$, 586 \\
17,715 \\
95,174 \\
172 \\
55 \\
99,407\end{array}$ \\
\hline
\end{tabular}

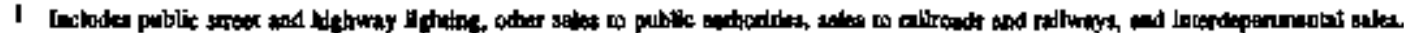

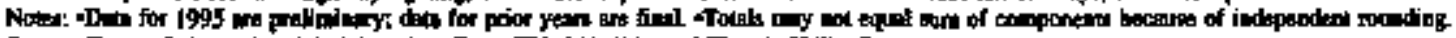

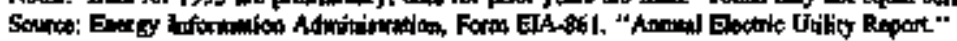

Table 34. Generating Capobility at U.S. Blectric Utlltes by North Amerienm Elactric Reliability Counct Refion and Flawall, as of December 1991 Through 1995 (Megawatts)

\begin{tabular}{|c|c|c|c|c|c|}
\hline 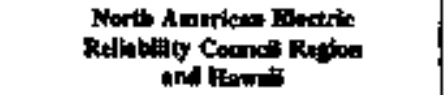 & $\| \boldsymbol{s}^{\mathrm{R}}$ & $1+x^{n}$ & $19 y^{8}$ & $1944^{R}$ & Isest \\
\hline 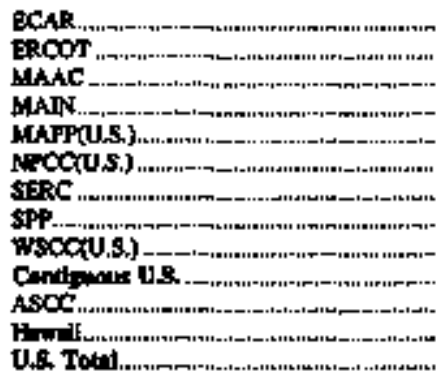 & 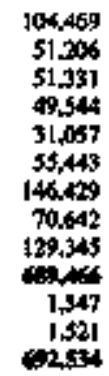 & 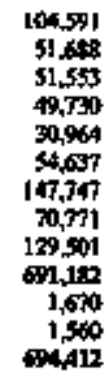 & 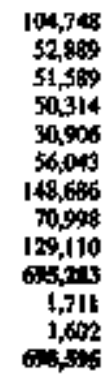 & $\begin{array}{r}104,535 \\
51,948 \\
51,494 \\
50,852 \\
31,357 \\
55,956 \\
150,214 \\
71,085 \\
128,794 \\
67,267 \\
1,737 \\
1,602 \\
70,611\end{array}$ & $\begin{array}{r}104,426 \\
53,400 \\
52,083 \\
51,4 \$ 0 \\
31,311 \\
55,567 \\
153,434 \\
11,375 \\
125,752 \\
702,779 \\
1,732 \\
1,602 \\
706,111\end{array}$ \\
\hline
\end{tabular}

Q a Revied data

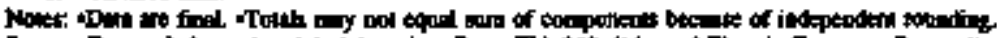

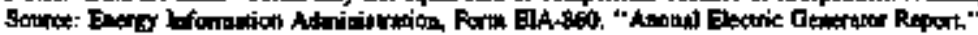


Table 35. Noncoincidental Peak Laad at U.S. Electic Utilites by North American Electric Rellabilty Conncil Region and Fawall, 1991 Tbrough 19\%

(Megawats)

\begin{tabular}{|c|c|c|c|c|c|}
\hline \multirow{2}{*}{ 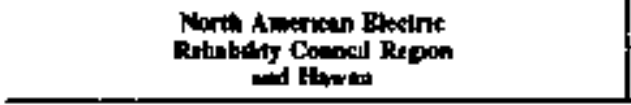 } & \multicolumn{5}{|c|}{ Acted } \\
\hline & $\$ 1$ & $1+2,2$ & 1993 & 1994 & cons \\
\hline \multirow{3}{*}{ 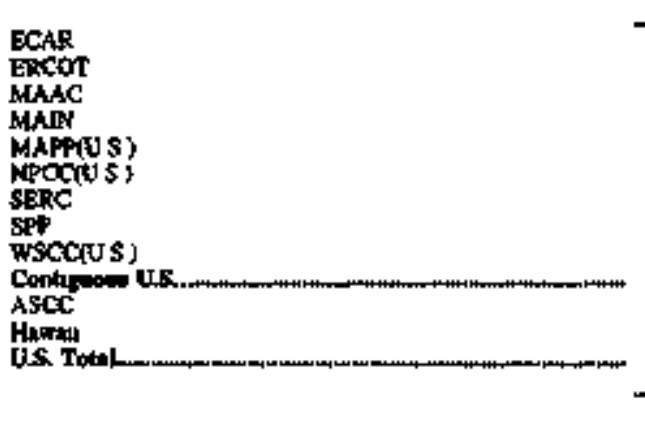 } & \multicolumn{5}{|c|}{ Sumber } \\
\hline & 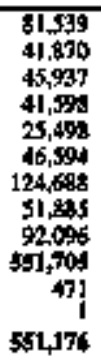 & 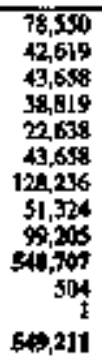 & 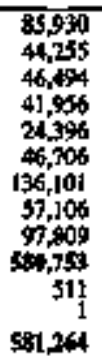 & $\begin{array}{r}87,165 \\
14,162 \\
46,019 \\
12,562 \\
27,000 \\
47,581 \\
132,584 \\
56,035 \\
102,212 \\
515,320 \\
524 \\
54,04\end{array}$ & 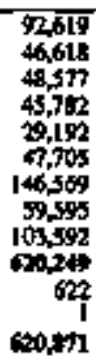 \\
\hline & \multicolumn{5}{|c|}{ Whinter } \\
\hline \multirow[t]{4}{*}{ 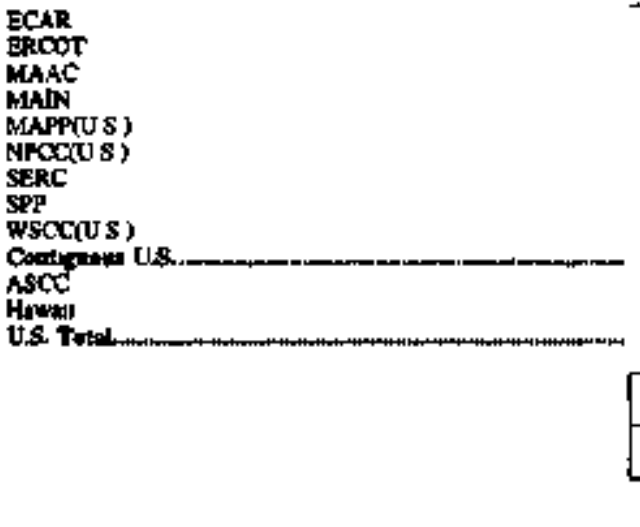 } & 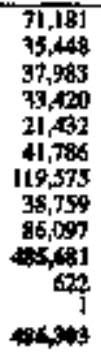 & $\begin{array}{r}72,835 \\
35,055 \\
73,915 \\
31,259 \\
21,966 \\
41,128 \\
121,250 \\
39,912 \\
91,686 \\
47,945 \\
635 \\
1 \\
40,618\end{array}$ & 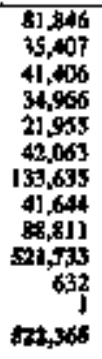 & $\begin{array}{r}73,6589 \\
36,180 \\
40,659 \\
13,999 \\
23,019 \\
42,547 \\
132,661 \\
42,505 \\
91,097 \\
510,290 \\
641 \\
510,994\end{array}$ & 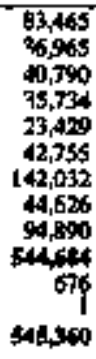 \\
\hline & \multicolumn{5}{|c|}{ Protoched } \\
\hline & 154 & $19 \mathrm{f}$ & Es: & 2ano & 2005 \\
\hline & \multicolumn{5}{|c|}{ Bonim } \\
\hline \multirow[t]{2}{*}{ 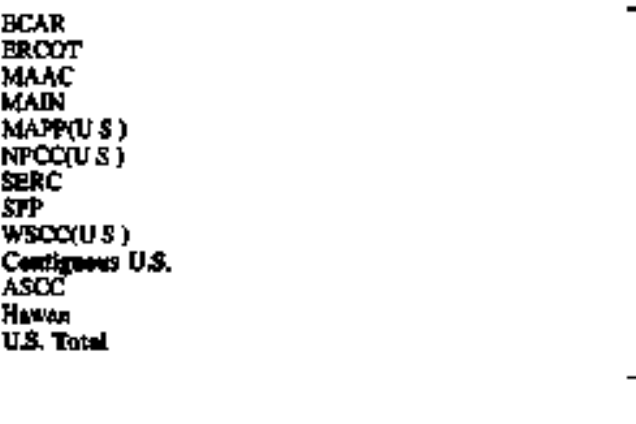 } & 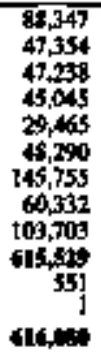 & 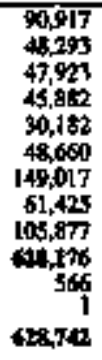 & 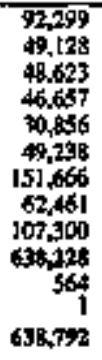 & 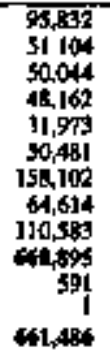 & 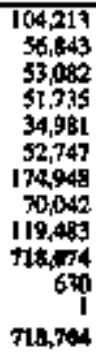 \\
\hline & \multicolumn{5}{|c|}{ Wmiter } \\
\hline 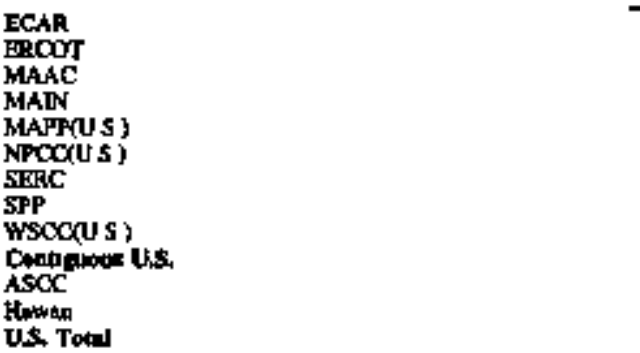 & $\begin{array}{r}8+, 901 \\
3,026 \\
41,491 \\
35,496 \\
24,065 \\
49,420 \\
139,214 \\
44,397 \\
96,647 \\
\$ 4,061 \\
710 \\
1 \\
545,77\end{array}$ & 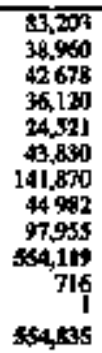 & $\begin{array}{r}84,738 \\
79,406 \\
47,301 \\
76,812 \\
25,066 \\
44,401 \\
145,294 \\
45,566 \\
99453 \\
564,157 \\
727 \\
1 \\
564,579\end{array}$ & 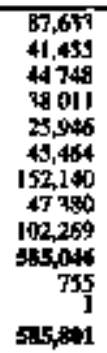 & $\begin{array}{r}92,646 \\
46,530 \\
47,413 \\
40951 \\
28,168 \\
47,609 \\
167,459 \\
51,775 \\
110,445 \\
632,736 \\
806 \\
1 \\
63,52\end{array}$ \\
\hline
\end{tabular}

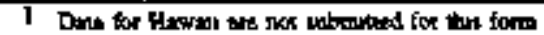

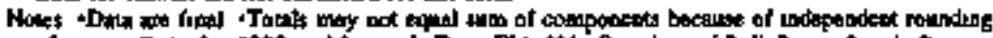

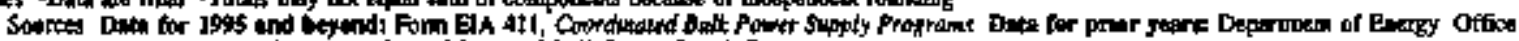

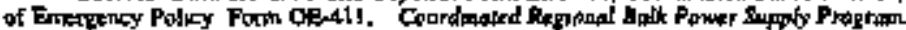


Table 36. U.S. Electric Ut'ity Recelpts by North American Electric Relbbilly Council Region and Hawall, 1991 Throupt 1995

(Million Kilowatthours)

\begin{tabular}{|c|c|c|c|c|c|}
\hline & 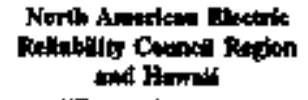 & Twald & $\begin{array}{c}\text { Purchesed } \\
\text { Penter }\end{array}$ & $\begin{array}{l}\text { Exchantas } \\
\text { Recelintd }\end{array}$ & $\begin{array}{l}\text { Whectha } \\
\text { Rectiped }\end{array}$ \\
\hline & & \multicolumn{4}{|c|}{$19 \% 1$} \\
\hline \multirow[t]{2}{*}{ 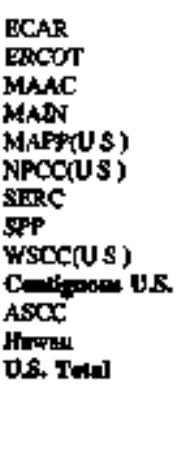 } & . & $\begin{array}{r}195,606 \\
127,343 \\
84,599 \\
30,405 \\
114,659 \\
211,379 \\
3 \$ 1,671 \\
150,048 \\
503,361 \\
1,97,64 \\
2,875 \\
1,605 \\
1,981,541\end{array}$ & $\begin{array}{r}151,284 \\
57,845 \\
61,395 \\
48,165 \\
78,176 \\
140,964 \\
321,277 \\
122,420 \\
2 \$ 1,676 \\
1,143,162 \\
2,343 \\
1,601 \\
1, \pm 17,166\end{array}$ & $\begin{array}{r}14,076 \\
48,603 \\
17,752 \\
6,420 \\
26,999 \\
17,242 \\
31,957 \\
5,477 \\
77,218 \\
241,278 \\
20 \\
4 \\
24,5404\end{array}$ & 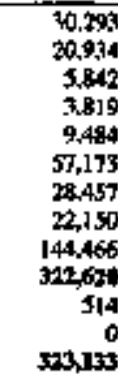 \\
\hline & & \multicolumn{4}{|c|}{1992} \\
\hline \multirow[t]{2}{*}{ 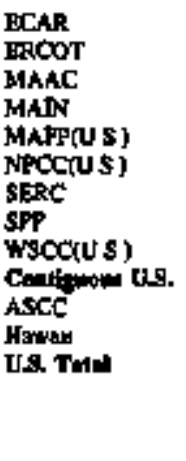 } & i & 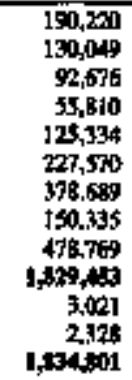 & $\begin{array}{r}1,55,564 \\
59,661 \\
7,675 \\
52,108 \\
81,610 \\
163,419 \\
325,039 \\
123,644 \\
275,031 \\
1,39,750 \\
2,531 \\
2,324 \\
1,312,648\end{array}$ & $\begin{array}{r}7,853 \\
46,311 \\
1], 134 \\
219 \\
32,062 \\
7,464 \\
26,439 \\
4,943 \\
76,224 \\
203,643 \\
13 \\
4 \\
200,645\end{array}$ & $\begin{array}{r}31,803 \\
24,077 \\
9,868 \\
7,4 \$ 9 \\
11,661 \\
60,657 \\
27,211 \\
21,749 \\
127,514 \\
318,069 \\
478 \\
0 \\
311,438\end{array}$ \\
\hline & & \multicolumn{4}{|c|}{109} \\
\hline 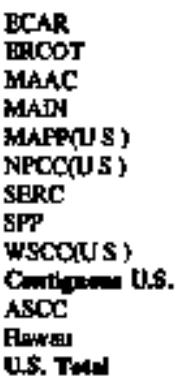 & ' & 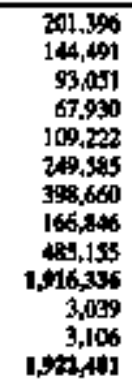 & $\begin{array}{r}167,278 \\
67,523 \\
76,663 \\
62,519 \\
89,875 \\
178,147 \\
31,176 \\
535,037 \\
287,564 \\
1,401,743 \\
2,582 \\
3,109 \\
1,407,419\end{array}$ & 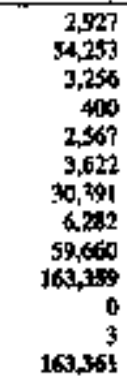 & $\begin{array}{r}31,191 \\
26,716 \\
13,132 \\
5,018 \\
16,781 \\
57,815 \\
27,132 \\
25,528 \\
194,931 \\
151,244 \\
4 \$ 6 \\
0 \\
351,701\end{array}$ \\
\hline
\end{tabular}

Sec toomocen at ood of ablo 
Table 36. U.S. Electric Utility Recelpts by North Amerken Electric Reliability Countil Regtan and Alawali, 1991 Throegh 1995 (Contionted)

(Million Kiłowathours)

\begin{tabular}{|c|c|c|c|c|}
\hline 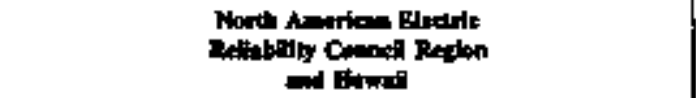 & 1 & 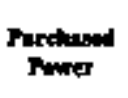 & $\begin{array}{l}\text { Buebeng } \\
\text { Beakined }\end{array}$ & $\begin{array}{l}\text { Whedlaty } \\
\text { Rectived }\end{array}$ \\
\hline & \multicolumn{4}{|c|}{ ton } \\
\hline 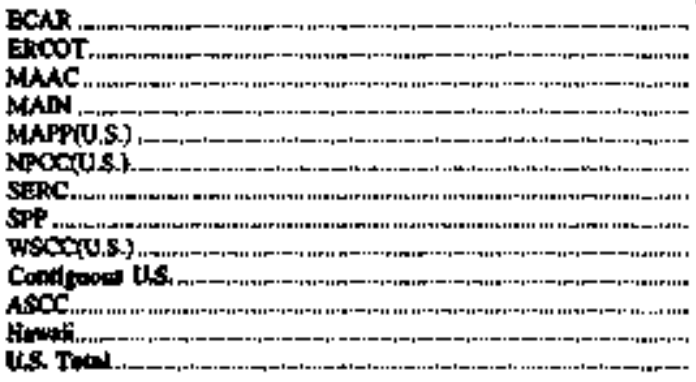 & $\begin{array}{r}199,000 \\
141,092 \\
94,910 \\
6,5,558 \\
109,957 \\
267,251 \\
397,661 \\
172,119 \\
47,009 \\
1,919,7,71 \\
9,952 \\
3,444 \\
1,917, \pm 67\end{array}$ & 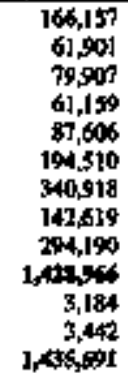 & 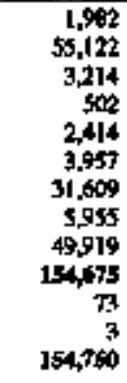 & 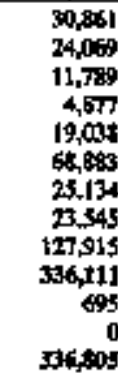 \\
\hline & \multicolumn{4}{|c|}{195} \\
\hline 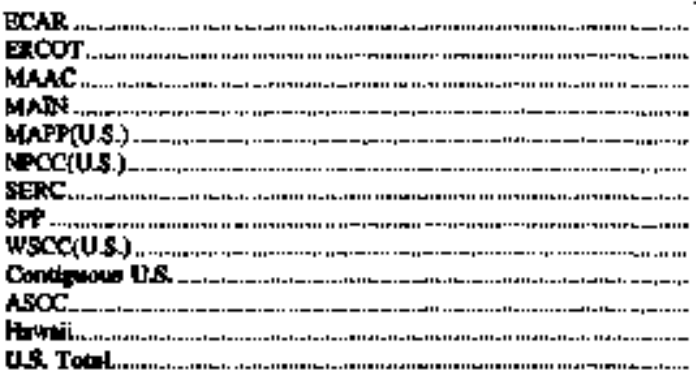 & $\begin{array}{r}24,659 \\
145,439 \\
114,217 \\
67,367 \\
112,723 \\
26,0,040 \\
424,578 \\
175,992 \\
484,169 \\
2412,175 \\
4,21\} \\
3,512 \\
2,19,015\end{array}$ & $\begin{array}{r}185,967 \\
61,215 \\
98, \pi 74 \\
60,707 \\
92,089 \\
199,071 \\
35 \%, 399 \\
146,965 \\
297,932 \\
1,97,973 \\
3,301 \\
3,518 \\
1,504,792\end{array}$ & $\begin{array}{r}2,158 \\
30,420 \\
528 \\
3,99 \\
2,826 \\
4,060 \\
41,590 \\
5,525 \\
11,6,39 \\
199,145 \\
137 \\
15,249\end{array}$ & $\begin{array}{r}33,534 \\
33,795 \\
14,915 \\
6,270 \\
17,816 \\
59,800 \\
30,769 \\
23,502 \\
134,604 \\
355,944 \\
719 \\
0 \\
355,574\end{array}$ \\
\hline
\end{tabular}

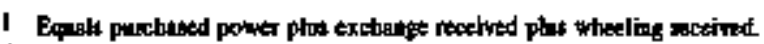

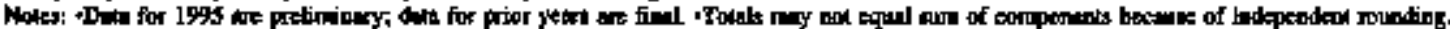

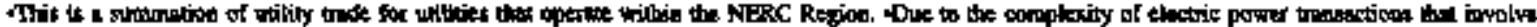

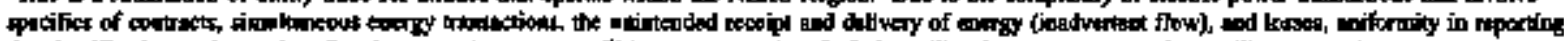

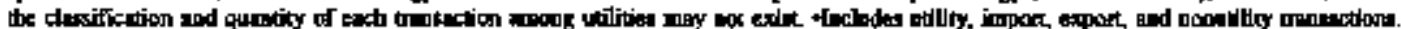

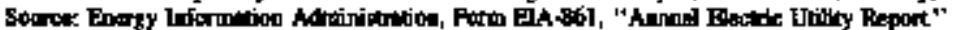


Table 37. US. Electric Utility Deliveries by North Anerican Electric Reliability Conncit Requon and Fowait, 1991 Through 1995

(Milion Kilowarthours)

\begin{tabular}{|c|c|c|c|c|}
\hline 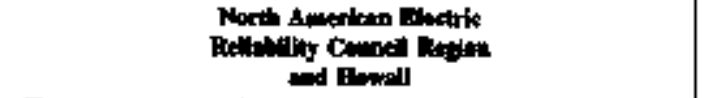 & Delltofit:s & 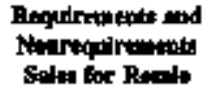 & $\begin{array}{l}\text { Ducharise } \\
\text { Detiverad }\end{array}$ & $\begin{array}{l}\text { Wheelns: } \\
\text { Delivernd }\end{array}$ \\
\hline & \multicolumn{4}{|c|}{1991} \\
\hline 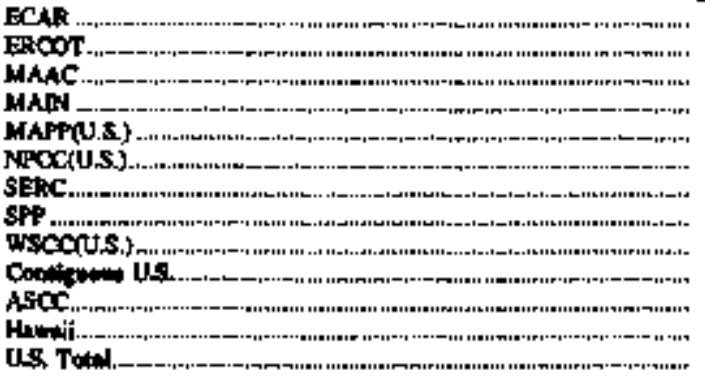 & $\begin{array}{r}221,435 \\
101,790 \\
51,239 \\
40,267 \\
106,020 \\
177,039 \\
364,167 \\
136,561 \\
465,535 \\
1,47,140 \\
2,849 \\
1,97,4,54\end{array}$ & 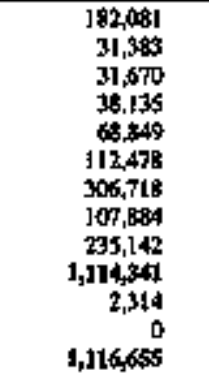 & $\begin{array}{r}9,193 \\
49,470 \\
13,776 \\
6,392 \\
29,235 \\
7,695 \\
30,001 \\
6,600 \\
87,8001 \\
241,100 \\
21 \\
2010 \\
20,130\end{array}$ & $\begin{array}{r}30,161 \\
20,937 \\
5,842 \\
3,739 \\
7,935 \\
56,925 \\
27,447 \\
22,078 \\
142,592 \\
31,4,466 \\
514 \\
0\end{array}$ \\
\hline & \multicolumn{4}{|c|}{158} \\
\hline 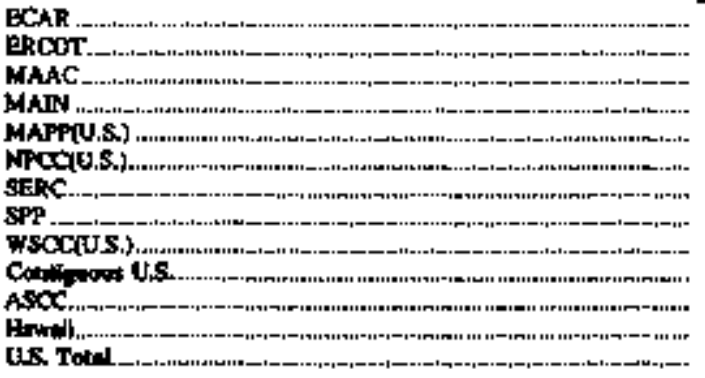 & 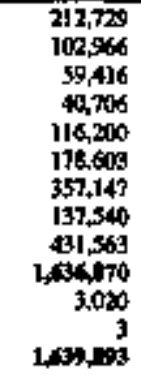 & $\begin{array}{r}178,224 \\
32,299 \\
48,364 \\
31,240 \\
71,447 \\
116,451 \\
300,696 \\
109,595 \\
27,114 \\
1,117,411 \\
2,524 \\
0 \\
1,119,94\end{array}$ & $\begin{array}{r}2,887 \\
46,577 \\
1,272 \\
62 \\
33,906 \\
1,657 \\
31,053 \\
5,306 \\
83,426 \\
27,146 \\
14 \\
3 \\
207,162\end{array}$ & $\begin{array}{r}31,618 \\
24,690 \\
9,719 \\
1,404 \\
10,947 \\
60,495 \\
25,408 \\
21,039 \\
125,023 \\
\$ 12,304 \\
475 \\
0 \\
\$ 12,7172\end{array}$ \\
\hline & \multicolumn{4}{|c|}{193} \\
\hline 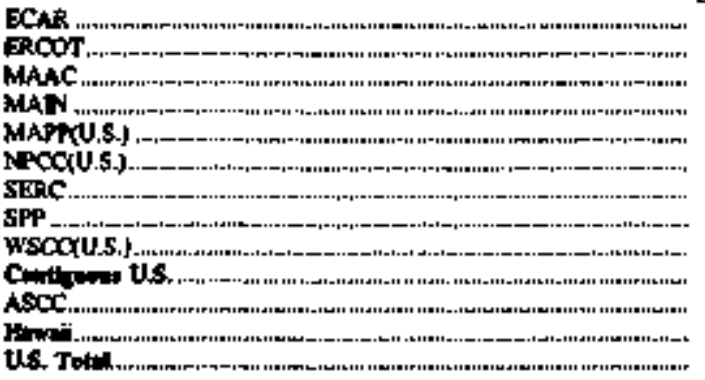 & 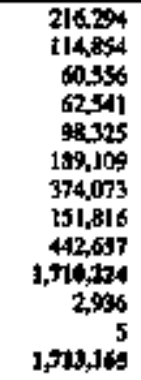 & $\begin{array}{r}182,147 \\
33,760 \\
47,525 \\
51,410 \\
71,043 \\
119,632 \\
321,445 \\
119,353 \\
289,351 \\
4,191,549 \\
2,400 \\
0\end{array}$ & $\begin{array}{r}3,153 \\
54,409 \\
1 \\
180 \\
4,251 \\
1,923 \\
27,394 \\
7,044 \\
67,816 \\
166,141 \\
0 \\
5 \\
t 66,145\end{array}$ & $\begin{array}{r}30,994 \\
26,686 \\
13,030 \\
4,951 \\
16,130 \\
67,55,7 \\
25,7,744 \\
25,419 \\
1,36,489 \\
346,576 \\
4566 \\
0 \\
347,032\end{array}$ \\
\hline
\end{tabular}

Seo fooknoter at and of uble. 
Tablo 37. U.S. Eleatric Otility Deliveries by North American Eiectric Reliebllity Counefl Region and Hawati, 1991 Through 19\%5 (Continued)

(Million Kilowathours)

\begin{tabular}{|c|c|c|c|c|}
\hline 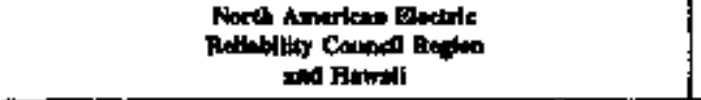 & Tollid & 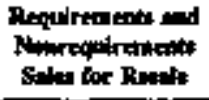 & $\begin{array}{l}\text { Redenes: } \\
\text { Dillnered }\end{array}$ & 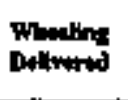 \\
\hline & \multicolumn{4}{|c|}{1594} \\
\hline 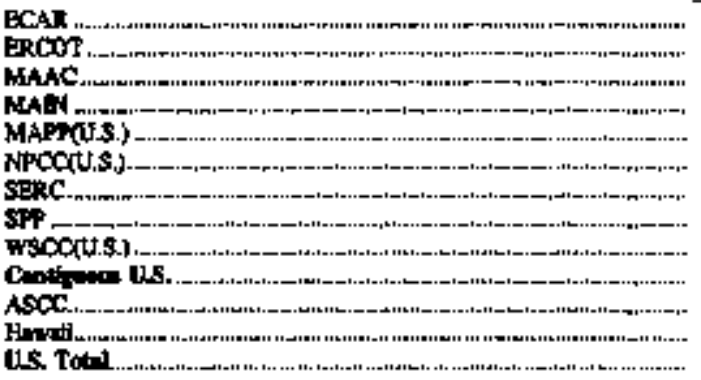 & 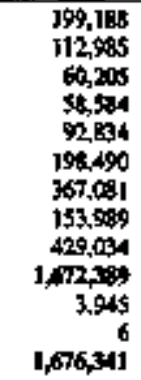 & $\begin{array}{r}16,6,045 \\
33,536 \\
48,483 \\
53,490 \\
70,181 \\
128,171 \\
312,497 \\
124,9,92 \\
244,474 \\
1,16,160 \\
3,172 \\
0 \\
1,185,152\end{array}$ & 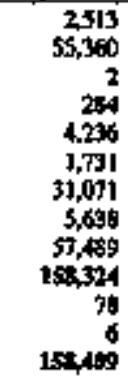 & 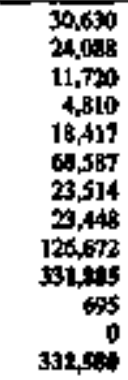 \\
\hline & \multicolumn{4}{|c|}{165} \\
\hline 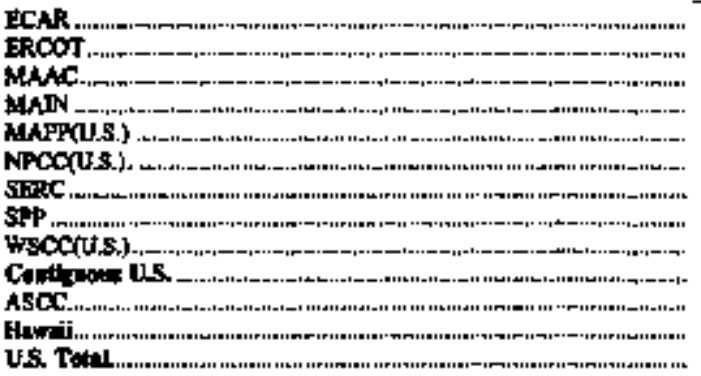 & $\begin{array}{r}27,034 \\
118,456 \\
71,251 \\
61,427 \\
95,275 \\
185,496 \\
393,583 \\
161,207 \\
449,416 \\
1,70,424 \\
4,138 \\
11 \\
1,760,540\end{array}$ & $\begin{array}{r}186,465 \\
34,017 \\
5,5,900 \\
5,5,044 \\
74,394 \\
124,588 \\
327,697 \\
132,687 \\
26,5,945 \\
1,26,768 \\
3,250 \\
0 \\
1,155,515\end{array}$ & $\begin{array}{r}2,270 \\
50,644 \\
9 \\
209 \\
4,755 \\
2,267 \\
37,116 \\
5,113 \\
57,0 \% 0 \\
159,0 \% 7 \\
109 \\
11 \\
159,127\end{array}$ & 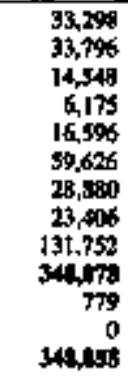 \\
\hline
\end{tabular}

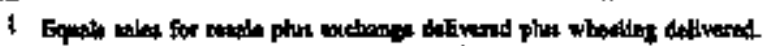

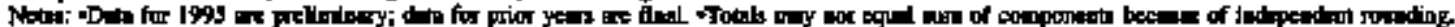

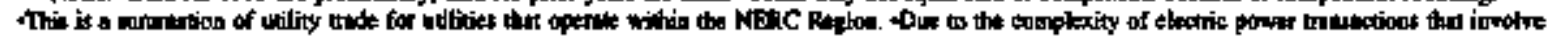

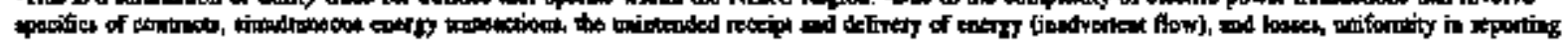

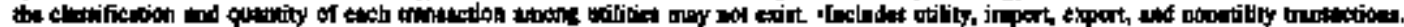

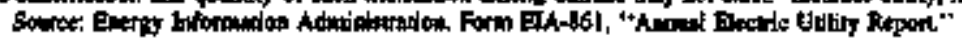


Table 38. U.S. Electric Utiliky Net Eneray Fow by North Americtn Electric Reliability Coancil Region and Hawail, 1991 Through 1995

(Million Kilowatthours)

\begin{tabular}{|c|c|c|c|}
\hline & 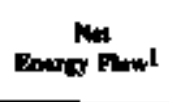 & Bestptor & Dellverko3 \\
\hline \multirow{3}{*}{ 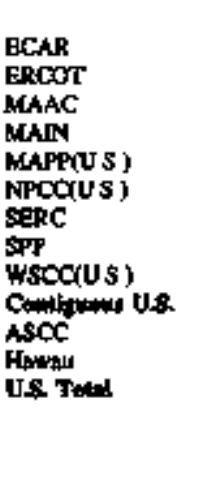 } & \multicolumn{3}{|c|}{ E21 } \\
\hline & 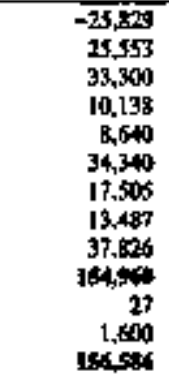 & 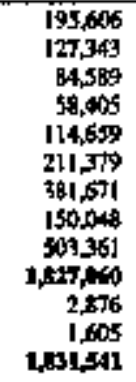 & $\begin{array}{r}21,435 \\
101,790 \\
11,299 \\
48,267 \\
106,020 \\
177,038 \\
364,167 \\
176,561 \\
465,535 \\
1,67,100 \\
2, \$ 49 \\
5 \\
1,97,958\end{array}$ \\
\hline & \multicolumn{3}{|c|}{$n$} \\
\hline \multirow[t]{2}{*}{ 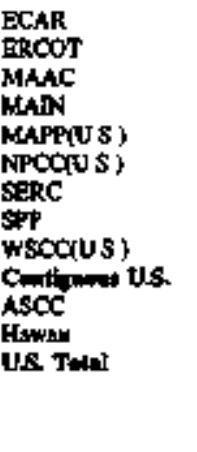 } & $\begin{array}{r}-72,509 \\
27,082 \\
3,260 \\
15,105 \\
9,134 \\
48,967 \\
21,542 \\
12,795 \\
47,206 \\
1,96,545 \\
1 \\
2,325 \\
134,46\end{array}$ & 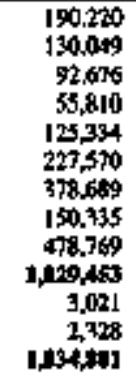 & $\begin{array}{r}212,729 \\
100,966 \\
59,416 \\
40,706 \\
116,200 \\
175,609 \\
357,147 \\
177,540 \\
471,569 \\
1,46,470 \\
3,020 \\
3 \\
1,090,43\end{array}$ \\
\hline & \multicolumn{3}{|c|}{193} \\
\hline 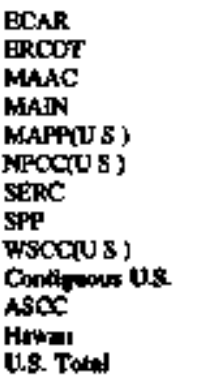 & 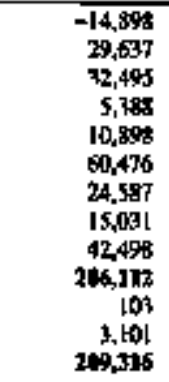 & 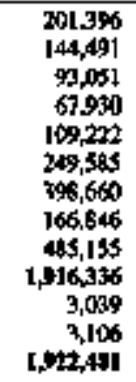 & $\begin{array}{r}216,294 \\
16,854 \\
60,596 \\
62,541 \\
98,325 \\
189,109 \\
174,073 \\
151,816 \\
442,651 \\
1,710,224 \\
2,936 \\
5 \\
1,7 t 3,145\end{array}$ \\
\hline
\end{tabular}

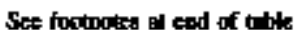


Table 38. US. ERectric Utlity Net Gaerw Flow by North Anerican Electric Reliability Cooncil Region and Hownif, 1991 Through 1995 (Continued)

(Million Kilowatthours)

\begin{tabular}{|c|c|c|c|c|}
\hline \multicolumn{2}{|c|}{ 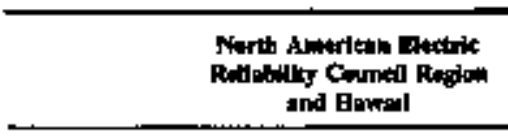 } & Prot & 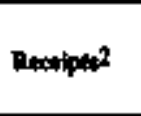 & \multirow[t]{2}{*}{ 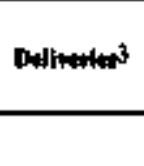 } \\
\hline & & & $19 \times 4$ & \\
\hline \multirow[t]{2}{*}{ 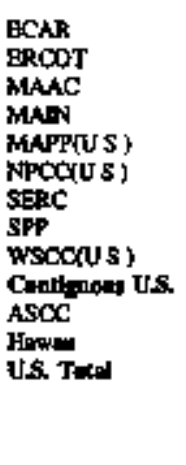 } & & 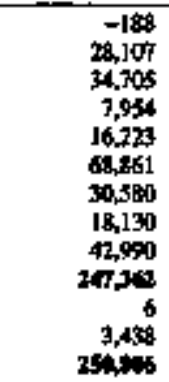 & $\begin{array}{r}199,000 \\
141,092 \\
94,910 \\
66,518 \\
109,097 \\
267,351 \\
397,661 \\
172,119 \\
472,095 \\
1,919,751 \\
3,952 \\
3,44 \\
1927,14\end{array}$ & $\begin{array}{r}199,180 \\
112,965 \\
60,205 \\
36,584 \\
92,834 \\
198,490 \\
367,081 \\
133,989 \\
429,634 \\
1,67,360 \\
3,945 \\
6 \\
1,676,441\end{array}$ \\
\hline & & \multicolumn{3}{|c|}{1985} \\
\hline 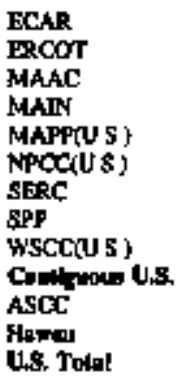 & . & $\begin{array}{r}2,625 \\
26,574 \\
42,860 \\
5,940 \\
17,448 \\
76,544 \\
30,495 \\
14,795 \\
34,751 \\
292,671 \\
79 \\
3,512 \\
265,42\end{array}$ & $\begin{array}{r}224,659 \\
145,430 \\
114,217 \\
67,367 \\
112,723 \\
269,010 \\
424,576 \\
175,992 \\
484,169 \\
2012,175 \\
4,217 \\
3,522 \\
2,019,910\end{array}$ & $\begin{array}{r}223,034 \\
118,456 \\
71,357 \\
61,427 \\
95,275 \\
106,476 \\
393,489 \\
161,207 \\
149,418 \\
1,76,356 \\
4,138 \\
11 \\
1,763,503\end{array}$ \\
\hline
\end{tabular}

I Equis recelple nanis delivaras

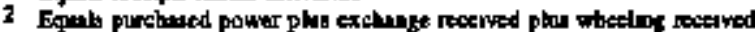

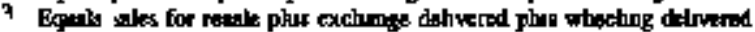

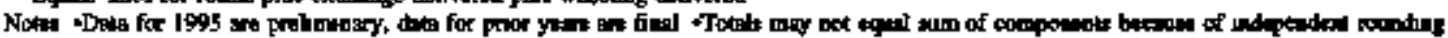

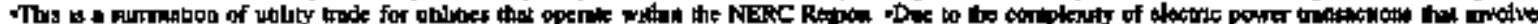

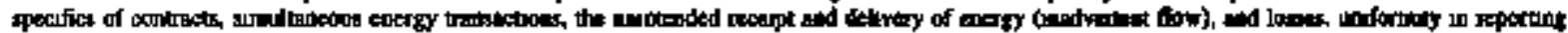

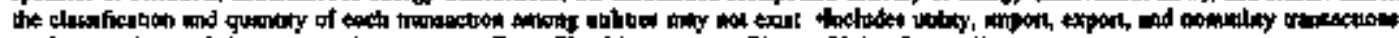

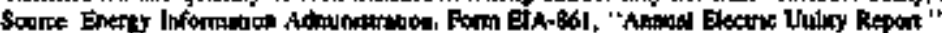

Tabłe 39. U.S. Electric Utlity Purcheses of Nonotility Generated Electricity by Nortb American Electric Relibillty Coundl Rejion and Hawall, 1991 Through t995

(Million Kilowathours)

\begin{tabular}{|c|c|c|c|c|c|}
\hline 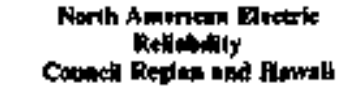 & $1 \% 9$ & {$[\boldsymbol{s} ;$} & 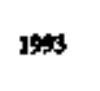 & $35 \times 4$ & lisis \\
\hline 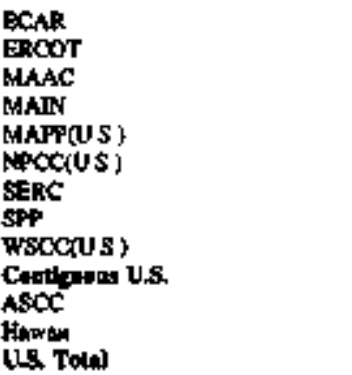 & $\begin{array}{r}8,649 \\
20,036 \\
13,721 \\
273 \\
1,563 \\
2,2,220 \\
12,914 \\
5,705 \\
49,951 \\
138,053 \\
1 \\
1,402 \\
139,436\end{array}$ & $\begin{array}{r}10,420 \\
24,666 \\
16,433 \\
347 \\
576 \\
36,116 \\
15,304 \\
3,457 \\
5,637 \\
16,967 \\
1 \\
2,924 \\
14403\end{array}$ & 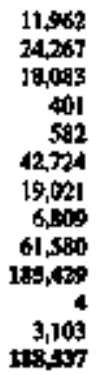 & $\begin{array}{r}12,409 \\
23,264 \\
20,911 \\
392 \\
595 \\
9,348 \\
24,020 \\
6,356 \\
67,297 \\
206,337 \\
3,442 \\
24,758\end{array}$ & $\begin{array}{r}13,131 \\
22,603 \\
23,870 \\
447 \\
595 \\
57,513 \\
29,184 \\
5,343 \\
65,869 \\
215,500 \\
7 \\
3,578 \\
273,113\end{array}$ \\
\hline
\end{tabular}

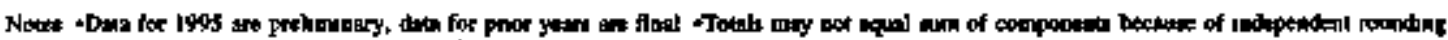

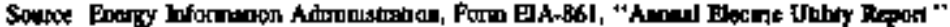


Table 40. Net Imparts at U.S. Electric Uthlities by North Anerican Electric Repabtity Council Reglon and Howail, 1991 Trough 1995

(Thousand Kilowatthours)

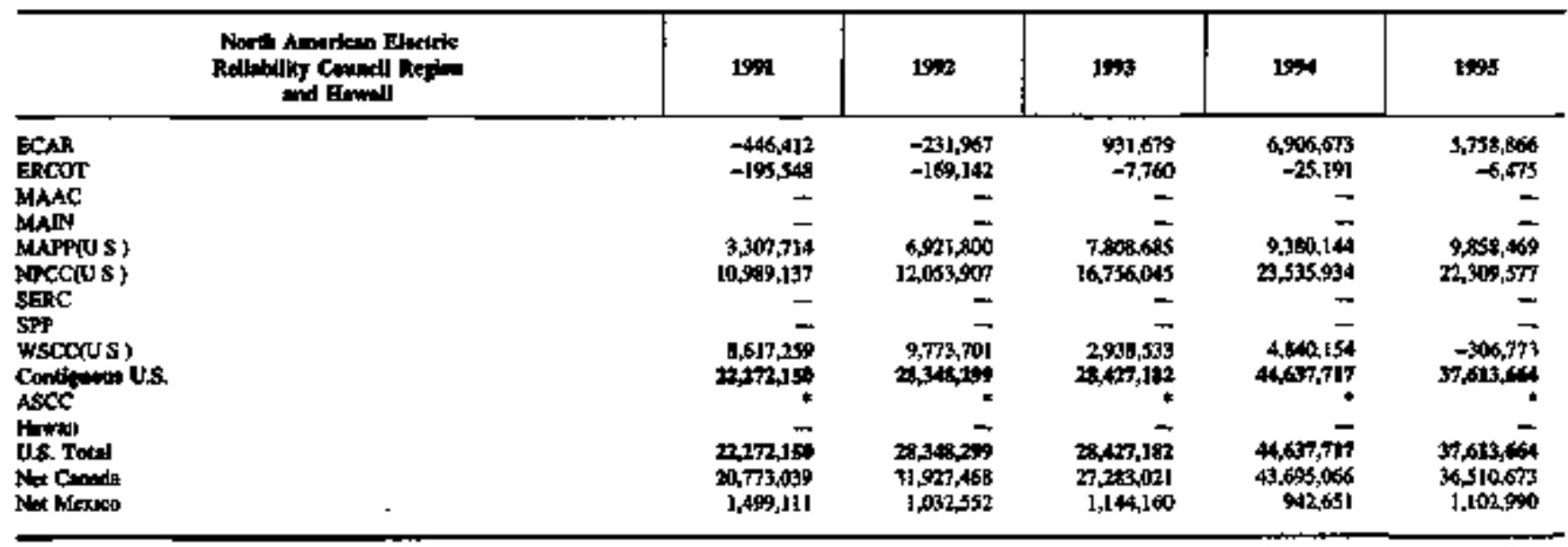

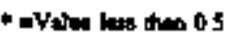

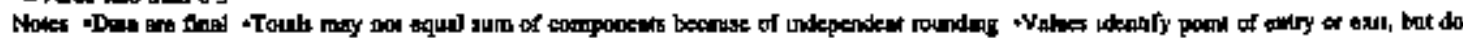

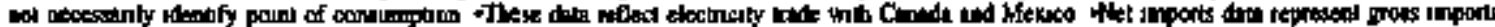
nima gropa exporil

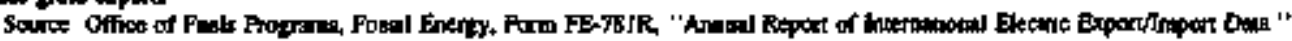

Tuble 41. Inports to U.S. Elechis Utilftes by North Anerican Electric Reliablity Council Reglion and Hawalk, 1991 Through 1995

(Thousand Kilowathours)

\begin{tabular}{|c|c|c|c|c|c|c|}
\hline & 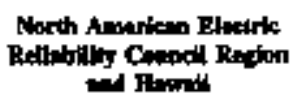 & Iנפ & I & Les & 1994 & 1995 \\
\hline $\begin{array}{l}\text { ECAR } \\
\text { ERCOOT }\end{array}$ & & 106 ses & 82.151 & 959.746 & $6,909,5,58$ & $5,7 \times 8,94$ \\
\hline MAAC & & 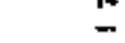 & $=$ & 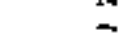 & - & - \\
\hline MAIN & & $=$ & - & - & - & - \\
\hline 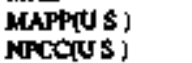 & - & $\begin{array}{l}1,700.073 \\
13,051,529\end{array}$ & $\begin{array}{r}8,573,651 \\
14,699,638\end{array}$ & $\begin{array}{l}10,767,276 \\
18,741,212\end{array}$ & $\begin{array}{l}10,130,216 \\
25,0080,505\end{array}$ & $\begin{array}{l}10,3,2,319 \\
23,4] 7,069\end{array}$ \\
\hline SERC & & - & - & $\Rightarrow$ & $\rightarrow$ & $\neg$ \\
\hline SPP & & - & - & $=$ & $\vec{x}$ & - \\
\hline $\begin{array}{l}\text { wscciU S ) } \\
\text { Contilum us }\end{array}$ & & $\begin{array}{l}12,905,049 \\
34,1612,265\end{array}$ & $\begin{array}{l}13,848,735 \\
37,744,176\end{array}$ & $\begin{array}{r}8,613,566 \\
\$ \$, 011,514\end{array}$ & $\begin{array}{l}10,109,276 \\
52,229,691\end{array}$ & $\begin{array}{r}7,215,641 \\
4,760,74\end{array}$ \\
\hline Asce & & $\bullet$ & • & $\bullet$ & 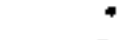 & 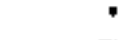 \\
\hline Hrim & & $\pi$ & $=$ & - & $=$ & $\bar{z}$ \\
\hline US, Total & & $30,12,24$ & $3 \pi, 24,176$ & $30,0,1, \$ 14$ & $52,125,488$ & 46,760374 \\
\hline Prom Campan & & $28,696,527$ & $35,181,753$ & $37,0058,496$ & $50,218,347$ & 44,502962 \\
\hline Froen Marucs & & 2115.73 & $2,022,419$ & $1,993,327$ & $2,031,319$ & $2,257,411$ \\
\hline
\end{tabular}

- moltin leat than os

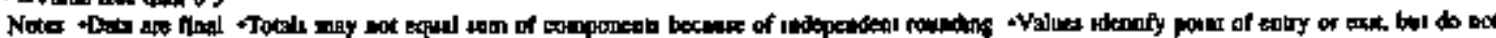

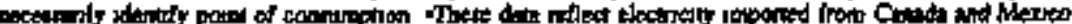

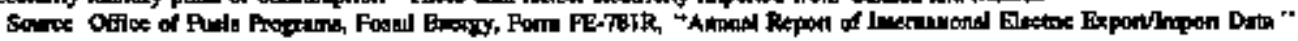


Tabie 42. Exports from U.S. Electric Uilhties by North American Electric Retiabilty Councll Regton and Hawali, 1991 Throngh 1995

(Thousand Kilowarthours)

\begin{tabular}{|c|c|c|c|c|c|}
\hline 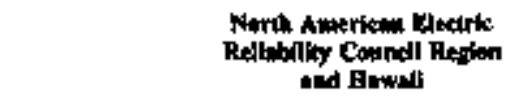 & $19 m$ & 1932 & 1959 & 154 & 19s \\
\hline $\begin{array}{l}\text { ECAR } \\
\text { EROOT }\end{array}$ & $\begin{array}{l}\$ 53,018 \\
195,562\end{array}$ & $\begin{array}{l}314,118 \\
149,142\end{array}$ & $\begin{array}{r}28,067 \\
7,774\end{array}$ & $\begin{array}{r}2,025 \\
25,261\end{array}$ & 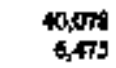 \\
\hline MAAC & $=$ & - & - & $\vec{a}$ & - \\
\hline MABN & - & $=$ & $=$ & $=$ & $=$ \\
\hline $\begin{array}{l}\text { MAPN(U S) } \\
\text { NECCUS ) }\end{array}$ & $\begin{array}{l}1,401,061 \\
2,062,686\end{array}$ & $\begin{array}{l}1,651,252 \\
2,640,731\end{array}$ & $\begin{array}{l}2,958,591 \\
1,95,167\end{array}$ & $\begin{array}{r}750,072 \\
1,544,571\end{array}$ & $\begin{array}{r}74,290 \\
1.102,92\end{array}$ \\
\hline SERC & - & 4 & - & $\longrightarrow$ & - \\
\hline SPP & - & $\Rightarrow$ & $=$ & - & $=$ \\
\hline 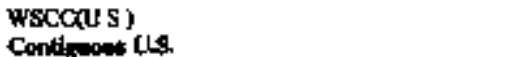 & $\begin{array}{l}4,927,289 \\
5,54,1] 6\end{array}$ & $\begin{array}{l}4073,034 \\
\text { sotstint }\end{array}$ & $\begin{array}{r}1,675,033 \\
10.654431\end{array}$ & $\begin{array}{l}5.269,122 \\
7.501,851\end{array}$ & $\begin{array}{l}7,50,414 \\
1,1,751\end{array}$ \\
\hline$A S C C$ & & 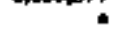 & 1. & 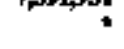 & \\
\hline Hawn & & - & & $=$ & \\
\hline $\begin{array}{l}\text { US. Toder } \\
\text { Jo Cantede }\end{array}$ & $\begin{array}{l}\$, 844,1114 \\
7,923,488\end{array}$ & $\begin{array}{l}8045,577 \\
3,254,289\end{array}$ & $\begin{array}{r}10,654,652 \\
9,005,465\end{array}$ & $\begin{array}{l}7,31,55 t \\
6,523,283\end{array}$ & $\begin{array}{l}9,161,710 \\
7,992,399\end{array}$ \\
\hline To Astapeso & 616,628 & 999,867 & 84,16 & $1,058,665$ & $1,154,421$ \\
\hline
\end{tabular}

- avan kas the 09

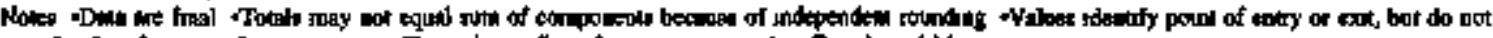

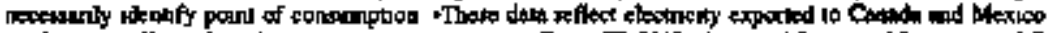

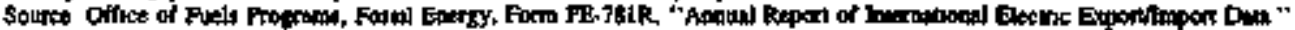




\section{U.S. Electric Utility Demand-Side Management}

U.S. electric utilities have come to realize that a flexible and diverse management strategy provides the greatesi opportunily for success in the competitive and uncertain environment in which they operate. An important component of this strategy has been the incroasing reliance on demand-side management (DSM) programs to modify the growth in demand for energy use, to cost-effectively meet customer energy service requirements, to selectively expand customer services, and to and optimize the use of generating resources. This chapter provides a brief description of the key elements of electric utility DSM programs in the United States.

\section{Background}

DSM consists of electric utiljties planning, jmplementing, ant monitoring activitjes that are designed to encourage consumers to modify their level and pattern of electricity usage. The primary objective of most DSM programs has been to provide cost. effective energy and capacily resources to help defer the need for new sources of power, including generating facilities, power purchases, and transmission and distribution capacity additions. Identifying the right mix of DSM options can be mutually beneficial to the utility, the consumer, and society. The utility can benefit from lowered costs of service, improved operating efficjency, reduced capital requirements, and enhanced consumer service. Consumers can benefit from reduced costs and improved value of service. Society can benefit from reduced emissions and the conservation of energy sources. With the changes that are occurring within the electric utility industry, there is a great deal of uncertsinty about the direction of utility sponsored DSM programs. Some ulilities are moving toward energy service companies, while other utilities are making bo changes to theit DSM programs.

In many states DSM programs are still a key component of the integraled resource plass (IRP) of a number of electric utilities. The IRP process differs from traditional utility planoing practices primarily in its increased attention to DSM programs and its integration of supply- and demand-side resources into a flexible resource portfolio. Utilities and some State regulatory commissions use the IRP process to assess a variety of resource options that meet consumer energy-service requirements, while being responsive to external changes stich as economic conditions, resource prices, new lechnologies, and changes in regulatory and tax policy. In addition to balanced consid. eration of supply- and demanid-side options, the IRP process includes consideration of risk and diversity of supply, maintenance of system reliability, and in some instances the apptication of specific values to reflect environmental and other external impacts.

\section{Identity Program Alternatives}

The types of DSM programs that utilities seiect to alter the timing and level of demand for electricity will vary significantly depending on their overall organization and market environment, strategic objectives, and system operating characteristics. DSM programs generally promote one of four basic objectives that differ in their intended effects on electricity use (measured in kilowathours) and demand (measured in kilowatts). First, energy efficiency, or conservation, programs are aimed at reducing the energy used by specific enduse devices and systems through the promotion of high-efficiency equipment and building design. typically reducing energy consumption throughout many hours of the year. Such hight efficiency measures gencrally use less electricity to provide consumers an equivalent or greater level of electric energy services (light, heat, cooling, or drive power). Second, load management programs are aimed at reducing or shifting demand at certain criticsl times (such as summer or winter peak), and are focused on changing the timing of electricity demand. These program types usually have only a minor ffect on the amount of annual electricity consumption. For example, residential and commercial aír conditioners or water beaters may be allowed to operate unimpeded during off-peak demand hours, but are cycled on and off by direct control of the utility during a few peakdemand houts. Third, flexible load shepe programs provide consumers a ptice signal or incentive to modify their consumption in response to changes in the utility's cost of providing power. Real time pricing is an example of this type of program. Fourth, strategic load growth or electrification progtams are designed to increase electricity consumption typtcally by building usage during valleys of low consumption or introducing new, efficient electrotechnologies. Such programs may facilitate the efficient operation of baseload generating units, reduce rates, and help customers meet environmentat requirements, enhance prodnct quality, or lower costs by replacing less efficient energy sources.

The energy savings and peak load reductions reported by electric utilities to ElA fall into one of six DSM program types.

Energy Efficiency - Energy efficiency programs are aimed at reducing the energy used by speciftc end-use devices and systems, typically without reducing the 
level of energy services provided. These programs often target high-use seasons or times of day. Whils they reduce overall electricity constumption over many hours during the year, the largest impacts of these programs often coincide with periods of peak usage. Savings are generally achieved by substituting technically more advanced equipment to produce the same level of end-tse services (e.g-r lighting, beating. motor drive) with less electricity. Examples include bigh-efficiency appliances, efficient lightiog, highefficiency heating, ventilating and air conditioning (HVAC) systems or control modifications, efficient building design, advanced electric motors and drive systems, and heat recovery systems. Energy efficiency programs frequently incorporate rebates, financing or other financial incentives for participation, rather than relying primarily on alternative rate structures as do some other program categories.

Birett Load Control - This category represents the consumer load that can be interrupted during the periods of peak load by direct control of the ulility system operator. This type of control primarily involves residential consumers.

Interruptible Load - This category accounts for the consumer load that, in accordance with contractual arrangements, can be interrapted during periods of peak load either by the direct control of the utility system operator or by the action of the consomer at the direct request of the system operator. It usually affects large-volume commercial and industrial consumers.

Other Load Management - This category refers to programs other than direct load control apd interruptible load that limit peak Ioads, shift peak load from on-peak to off-peak lime periods, or encourage customers to respond to changes in the utility's cost of providing power. The category includes technologies that primarily shift all or part of a load from one timeof-day to another and secondarily may have on impact on energy consumption. Examples inclorde space heating and water beating storago systems, cool storage systems, and load limiting devices in energy management systems. This category also includes programs that aggressively promote tine-of-use (TOU) rates and other innovative rates such as real-time pricing. These rates are intended to reduce consumer bills and shift hours of operation of equipment froth on-peak to off-peak, or high-cost to low-cost periods. through the application of time-differentiated rates.

Other Demand-Side Manngement Protram - This residual category capiures the effects of DSM programs that cannot be meaningfully included in any of the other program categorles. The energy effects attributable to this category represent the net effects of all the residual programs. Programs that promote consumer substitution of other energy types for elec. tricity and self-genteration of electricity for consumers' own use are included. ${ }^{\text {t* }}$

Load Bullding - This category represents programs that are aimed at increasing the usage of existing olectric equipment or the addition of electric equipment. Examples include industrial technologies such as induction heating and metting, direct arc fornaces and infrared drying; cooking for conamercial establishments; and heat pumps for residences. Load Building includes programs that promote the substitution of electricity for other fuels. ${ }^{\text {is }}$

\section{Planning and Solection of Programs}

The key elements of the DSM program pianning and selection process are to identify and evaluate key consumer characteristics that influence acceptanco and response to DSM programs and key atility considerations affecting resonrce requiremeats and the cost of alternative resource options. Among the consumer characteristics that influence a program's success are demographics, income, knowledge and awareness, attitude and motivation, discount rate, and price experjence. External influences such as economic condijtions, energy prices, tecbuologies, regulation, and tax credits also influence consumer's decisions regarding fuel and appliance choices, appliance and equipment efficiency, and appliance use. The utility's considerations are usually fockused on the interaction of load shape changes and supply-side resource options, transmission and distribution effects, and regulatory compliance.

To compere DSM programs to other demand- and supply-side resources, regulators have developed standardized benefit-cost tests. Five benefit-cost tests are widely used in planning to identify cost-effective DSM prograns. For each test, the net present value and benefit-cost ratio can be determined. The present value equals total benefits of the program less total costs; the benefit-cost ratio is the ratio of total benefjts to total costs. Basted on these values, the utility can prioritize DSM prograns to determine which, if any, should be implemented.

The Utility Cost Test measures the net benefits or costs of progrants based on costs incurred by the utility and revenue requirements of the utility (i.e., the test excludes participant costs). It determines if the utility's cost for DSM programs is less than the avoided supply cost.

The Participant Test measures the quantifiable benefits and costs to consumers who participate in the DSM progran. It attempts to answer whethet the participant is better off with the DSM technology and likely to participale in futore programs.

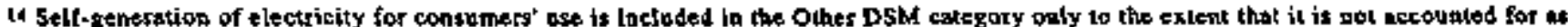
beckup generatiots ith Otber Load Managentent or leterruptible Lodd categories. Also, self-generation in the Other DSM category inciedes

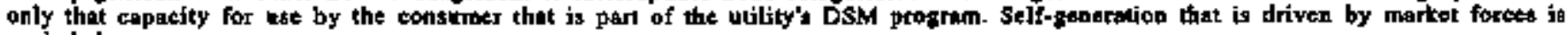
excluded.

Is Load bujlding. althongh collected on the Form EIA-86I, Schedule $V$, is not iacluded in the discussion of data fa this pobliention.
} 
The Rate Impact Measnre Test captures the present value irapact on all consumers' average rates due to the DSM program. It evaluates whether average rates for consumers (including nomparticipants) will go up or down ot remain unaffected.

The Tutal Resource Cost Test shows the net benefits or costs of a DSM program as a resource option based on the total costs of the program, including both participant and utility costs (the Soeietal Cost Test is a variant of this test that incorporates externalities and excludes tax credits). The Total Resources Cost Test determines if the total cost of DSM to participants and non-participants is less than the supply cost for an equivalebt amount of capacity and energy.

The Societal Test takes the broadest point of view, including the total tesource cost and external costs and benefits, such as environmental impacts. It determines if the total cost of the DSM program is less than the aliernative supply cost (including environmental costs).

The inclusion of environmental externalities in planning generally affects DSM options favorably. For example, if only traditional costs are considered is the planning process, a supply-side option might appear more aftractive than a particular energy efficiency progrant.

However, traditional costs seldom reflect the full cost to society of utility activities that adversely affect the environment. In assessing supply- and demand-sidt oplioas for planning purposes, regulators have been moving to consides broad jmpacts of utility resource ecquisition on society. including environmeneal and other externalities. Environmental externalities are real impacts on the probuction or utility functions of others, including impacts on heallh and property values, which are not reflected in the prices of goods and services." ts Under traditional command-andcontrol air quality regulation, the additional emissions associzted with operating a polluting facility for more hours do not increase the production costs of the source. Thus, many residual air emissions are classified as externalities. Externalities also may include national security costs associated with reliance on foreign oil or transition costs associated with local economic dislocations. Environmental externalities have become a part of the criteria for comparison and selection of utility resource options in 26 States and the District of Columbia. 17

\section{Program Implementetion}

Another component of DSM program development is the marketing plan to implement a package of costeffective programs through customer education, direct contact, cooperation with trade ally (for example, building contractors and appliance dealers), advertising/promotion, allernative pricing. incentives. financing, and direct installation. The programs differ in the types of services offered to consumers. For example, general information programs attempt to inform consumers about DSM options through such mechenisms as brochures, bill stuffers, television and radio advertisements, and workshops. Direct installation programs involve installation of energy efficiency measures in the facilities of participating consumers by the vtility ar its contractors. These programs generally cover low-cost messures, such as water-heater wraps and compact fluorescent tamps. Energy audits provide information on the physical and operating characteristics of a building and its energy uses and processes. Audit services vary from simple walk-througbs to building management training programs and cito-specific process and efficiency evaluations. Incentive programs offer cash or noncash awerds to manufacturers of energy efficient electric equipment, deliverers of energy products or services such as applitance and oquipment dealers, building contractors, and architectural and engineering firms, or directly to consumers to encourage consumer participation in a DSM program and adoption of recommended measures. Appliance rebates and zero- or low-interest loans are common examples of incentive programs. Lastly, utilities offer alternative-rate programs, such as discounts or refunds on montbly eleccric bills, in return for consumer participation in programs designed to reduce peak demand or to modify the load shape.

Most DSM programs ate aimed at specific subsets of the utility population, typically by consumer classes and market segments. For example, the residential sector is often subdivided by housing type (for example, single-unit, multi-unit, mobile home). Residential sector programs ty pically consider the relative similarity of end uses and consumption patterns to identify load-sbape modification opportunities with relatively predictable outcomes. Because per-unit electricity consumption in the residential sector is iess than that of the commercial and incustriat sectors, residential DSM programs are usually designed to achieve high participation rates in order to significantiy alter the load curve of the utility system.

Most conmereial electricity consumption is for lighting, air conditioning, and space beating. However, the relative importance of the different end uses varies significanlly across consumer types. Office buildings, tetail establishments, schoots, super* markets, and restaurants exhibit distiactly differemt patterns of electricity consumption. Recently, utilityp. 17.

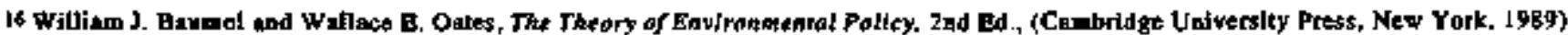
17. (Wushingtoo, D.C., 1993). 
sponsored efforts to develop DSM potential in the commercial sector have increased significantly, with program activities focusing on energy-management assistance, cool storage, lighting, heating and air conditioning, and water heating inprovenents.

DSM program development in the industrial sector has been slow compared to its development in the resjdential and commercial sectors. The wide variety of industrial processes use indtially hindered the design of DSM programs tailored to the industrial sector. Utilities traditionally telied on alternative rate-desigo approaches, such as interruptible service and time-of-use rates to achieve DSM objectives in the industrial sector. Utilitjes have broadened their DSM approach to include incentive and financing grograms for industrial lighting, thermal storage, electrotechnology, advanced motors and drive systems, compressed+air systems, ana other processenergy uses that have the potential to meet onergyefficiency and load-management objectives. A number of utilities bave also developed flexible costom measure programs that atlow industrial energy users and utilities to work together to identify cost-effective measurtips.

\section{Monttor and Evaluate Programs}

Electric utilities must tely on systematic measurement, statistical analysis, and engineering expertise to evaloate the operation and performance of DSM programs by verifying DSM results, assessing the effectiventess of the progran, providing feedback on the results that are essential for future decisions about DSM programs. Utilities report DSM-program results in 2 number of ways, depending largeiy on the load modification objectives of their programs. For example, otilities interested in peak clipping typically measure program success in terms of total peak load reduction or its reduction per consumer. Utilities interested in reducing overall energy consumption measure both peak load reduction and total energy savings. When evaluating program suceess, utilities typically determine the level of load-and-entrgy reductions, program costs per unit of energy and/or demand savings, and program patticipation tates.

While the consumplion of electricity can be measured in a variety of ways (such as monthly electric bills. special short-term metering. whole-building loadresearch data, or end-use load monltoring) the saving of electricity--the difference between actual consumption and what would bave occutred in the absence of a DSM program--can only be estimated based on engineering data or statistical analysis.

The asalytical procedures applied to estimate tlectricity and load changes involve a variety of techbiques. These techniques include using engineering estimates to detive the energy-saving effect per instal- lation of each energy-efficient device, monitoring electricity use for selected consumers before and after participation in a DSM activity, and contrasting the aggregated effects of DSM program participants and nonparticipants.

Evaluation and verification to determine whether DSM programs achieve their stated objectives are essential because (1) utilities are scheduled to invest billions of dollars in DSM programs, (2) utilities are counting on the sayed electricity as one way to met expected incroases in future electricity demand, (3) State regulators are increasingly allowing utilities to collect fitancial incentives and recover cost revemues based on the results of DSM programs, (4) the results of conservation prograpss may be recognized for porposes of environmental compliance, and (5) utilities and regulaters need to know what mix of DSM technologies and techniques yields the most cost-effective enetgy savings. ${ }^{18}$

As utility DSM budgets have grown, exceeding \$2.4 billion in 1995, it has become ittcreasingly important to know what DSM programs have accomplished. This bas led to more sophisticated efforts to measure and evaluate an increased number of programs. Nevertheless, delailed impact and process evaluations have been completed on only a small fraction of all DSM programs. These evaluations vary with respect to the methodologies employed, the issues and types of progsams studied, and the purposes for which evaluations were conducted. Because pracices vary substantially from one utility to the nexi, it is difficult to generalize regarding the quality of the dats supporting the estimates of energy savings and peak reductions reported to EIA or the extent to which such estimates have been subject to after-the-fact verification. ${ }^{\text {is }}$

\section{Data Sources}

The data in the following tables were collected on Schedule V, "Demand-Side Management Information," of the 1995 Form EIA-861,"Anbual Electric Utility Report," Schedule V collects utility information on actual and potential peak load reductions and energy savings for six program categories (Entergy Efficieacy, Direct Load Control, Interruptible Load, Other Load Management, Other DSM Programs, and Load Building) by four majot consumes sectors (resideutial, commercial, industrial, and other). Utilities provide information for the reporting year (1995) and the first and fifth forecast years (1996 and 2000 ).

Both anmual and incremental energy savings and peak load reductions are collected for the reporting year. Ansual effects are the total effects in energy use and peak load caused by afl new and prior-year participants in the DSM programs that are in place during a given year. It includes all participants in existing and

I8 General Accounting Office, Electricity Suppiy, Utility Dentand-Side Managentent Prngrants Cas Reduce Electricity Ust, GAORCED-92-13 (Waskington, DC, Octobter $\$ 991$ ).

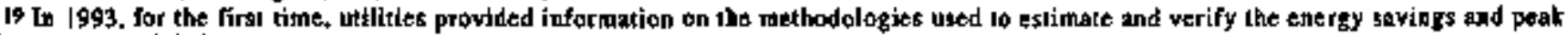
logd redoetions of tholr DSM programs. 
new programs (those implemented during the given year). Incremental effects are the annual effects in energy use and peak load calused by new participants in DSM programs during a given year. Incremental effects ate annualized to indicate the program effects that would have occurred had these participarts been in the program on January 1 of the guven year.
DSM costs are reported in one of three categories. If the cost can be tracked to a specifjc program category (energy efficieacy, direct load control, etc.), it is reported as a direct utility cost under that program category. If the cost cannot be tracked to a program category, it is reported as an indtrect utility cost under the appropriate accounting category (administratjve, marketing, monitoring and evaluation, or other). Total nonutility cost is also reported.

Table 43. U.S. Electric Utility Demond Side Managenent Progran Energy Saymogs, Actual and Potential Peak Load Reductions, and Cost, 1991 Through 1995

\begin{tabular}{|c|c|c|c|c|c|}
\hline Ilin & 19;1 & 1992 & 1945 & 1594 & 1908 \\
\hline 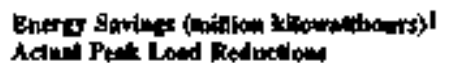 & 24,848 & 15,563 & 4,294 & 52,489 & 57,421 \\
\hline 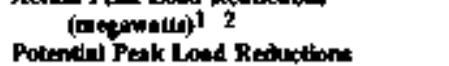 & 15,619 & $17,20 \mathrm{~d}$ & 29,069 & 25,001 & 29,561 \\
\hline 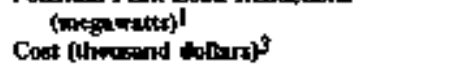 & $1,003, m$ & $\begin{array}{r}32,422 \\
2,348,094\end{array}$ & $\begin{array}{r}39,5088 \\
2,241,533\end{array}$ & $\begin{array}{r}42,917 \\
2,715,657\end{array}$ & $\begin{array}{r}4 \pm, 029 \\
2,421,204\end{array}$ \\
\hline
\end{tabular}

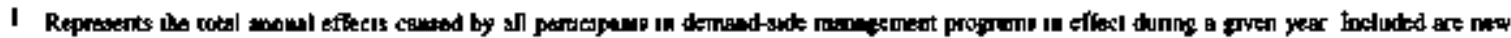

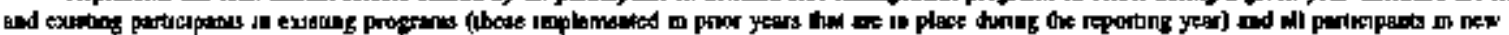

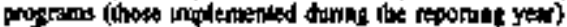

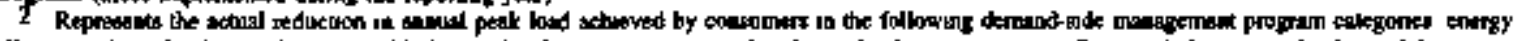

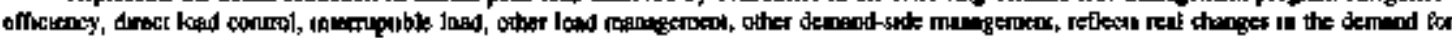

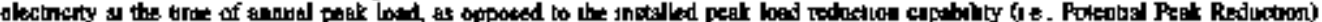

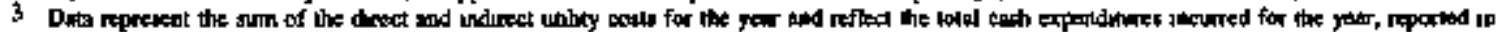

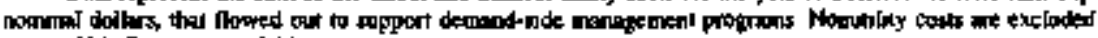
NAl Dema apt artaleble

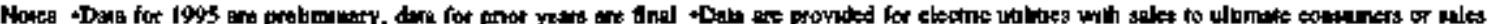

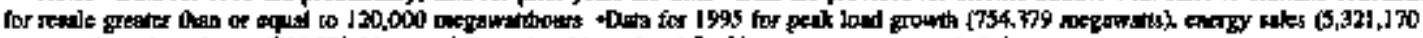

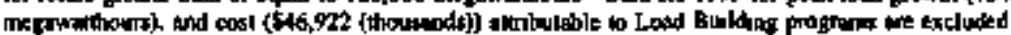

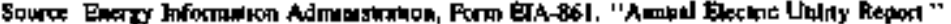

Table 44. U.S. Electric Utility Actual Peak Load Reductbons by North American Electric Rellablity Council Region and Howall, by Demand-Side Manegement Program Category, 1991 Through 1995 (Megawatts)

\begin{tabular}{|c|c|c|c|c|}
\hline 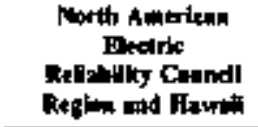 & 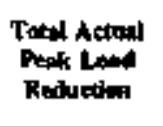 & $\begin{array}{l}\text { Dirsct Loed } \\
\text { Control }\end{array}$ & $\begin{array}{l}\text { Inimreptible } \\
\text { Land }\end{array}$ & 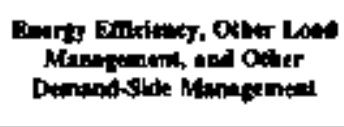 \\
\hline & \multicolumn{4}{|c|}{$19 \% 1$} \\
\hline 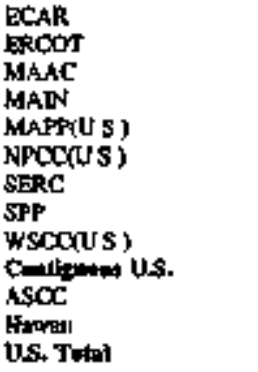 & $\begin{array}{r}1,401 \\
311 \\
1,484 \\
762 \\
1,424 \\
1,497 \\
4,876 \\
1,159 \\
2669 \\
15,574 \\
3 \\
40 \\
15,615\end{array}$ & $\begin{array}{r}319 \\
68 \\
573 \\
64 \\
902 \\
215 \\
2,030 \\
506 \\
414 \\
5,04 \\
1 \\
0 \\
5,453\end{array}$ & $\begin{array}{r}615 \\
10 \\
667 \\
369 \\
305 \\
343 \\
602 \\
420 \\
287 \\
3,446 \\
3 \\
25 \\
3,644\end{array}$ & $\begin{array}{r}467 \\
213 \\
244 \\
329 \\
217 \\
935 \\
2,244 \\
221 \\
6.967 \\
6157 \\
0 \\
15 \\
4,50\end{array}$ \\
\hline
\end{tabular}

Sec footinktes at end of bable 
Table 44, D.S. Electric Utility Actual Peall Laed Reductions by North American Electric Relisbility Council Region and Elawath, by Demand-Side Munagenent Progran Category, 1991 Through 1995 (Continued)

(Meqawatts)

\begin{tabular}{|c|c|c|c|c|c|c|}
\hline & 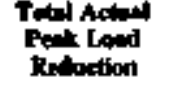 & tiruet Lat & Taterruptits & Enolys & Otbo Lot & 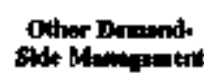 \\
\hline & \multicolumn{6}{|c|}{199} \\
\hline \multirow[t]{2}{*}{ 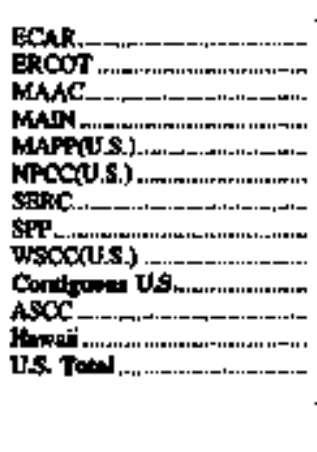 } & $\begin{array}{r}661 \\
592 \\
1,677 \\
140 \\
1,542 \\
1,796 \\
5,559 \\
624 \\
3,902 \\
17,194 \\
7 \\
17,244\end{array}$ & 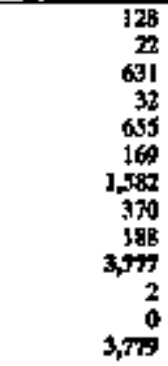 & $\begin{array}{r}49 \\
131 \\
317 \\
464 \\
420 \\
323 \\
684 \\
117 \\
1,074 \\
3,574 \\
0 \\
3,579\end{array}$ & $\begin{array}{r}379 \\
309 \\
216 \\
323 \\
270 \\
1,597 \\
2,639 \\
85 \\
2,351 \\
7,40 \% \\
7,89\end{array}$ & $\begin{array}{r}101 \\
68 \\
512 \\
20 \\
190 \\
48 \\
47 \\
6 \\
237 \\
1,469 \\
4 \\
146\end{array}$ & 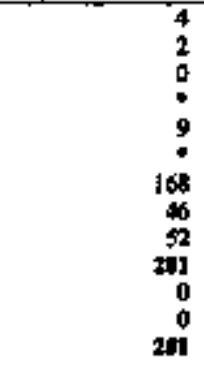 \\
\hline & \multicolumn{6}{|c|}{ te9d } \\
\hline \multirow[t]{2}{*}{ 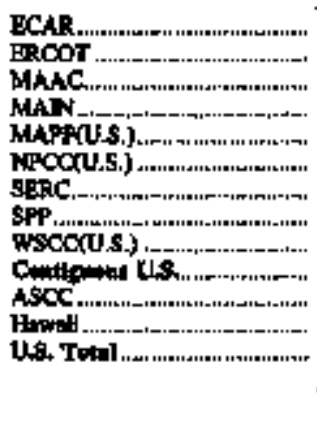 } & 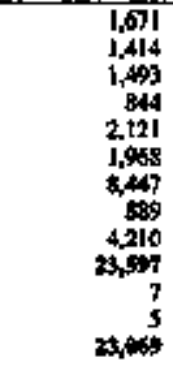 & 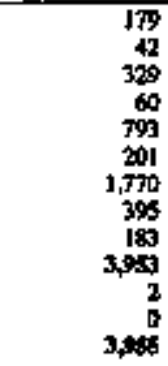 & $\begin{array}{r}773 \\
114 \\
516 \\
247 \\
632 \\
218 \\
2792 \\
323 \\
1,003 \\
6,624 \\
0 \\
0\end{array}$ & $\begin{array}{r}573 \\
949 \\
301 \\
4,44 \\
413 \\
1,520 \\
3,370 \\
111 \\
2,671 \\
14,369 \\
5 \\
14,34\end{array}$ & 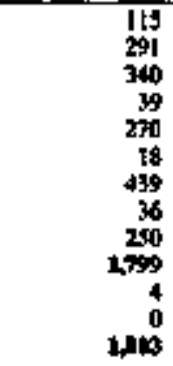 & $\begin{array}{r}31 \\
17 \\
7 \\
12 \\
115 \\
73 \\
104 \\
315 \\
0 \\
0\end{array}$ \\
\hline & \multicolumn{6}{|c|}{304} \\
\hline \multirow[t]{2}{*}{ 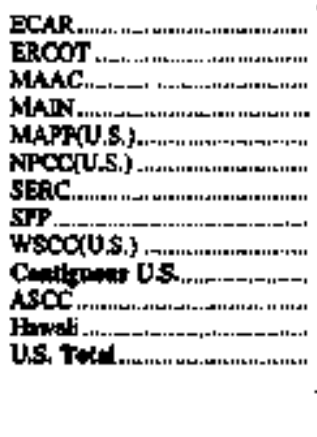 } & 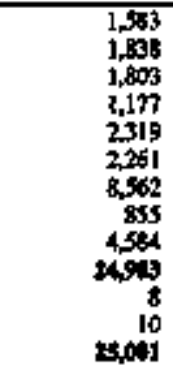 & $\begin{array}{r}200 \\
20 \\
343 \\
26 \\
933 \\
90 \\
2116 \\
242 \\
205 \\
4176 \\
2 \\
417 \%\end{array}$ & $\begin{array}{r}634 \\
77 \\
676 \\
323 \\
656 \\
194 \\
2,736 \\
2,99 \\
996 \\
6,745 \\
0 \\
0 \\
6,70\end{array}$ & $\begin{array}{r}631 \\
1,420 \\
414 \\
576 \\
505 \\
1,958 \\
3,02 \\
1,7 \\
2,950 \\
11,650 \\
1 \\
6 \\
11,465\end{array}$ & $\begin{array}{r}109 \\
301 \\
356 \\
46 \\
211 \\
16 \\
494 \\
185 \\
374 \\
240 \\
0 \\
204 \\
4\end{array}$ & $\begin{array}{r}15 \\
19 \\
4 \\
6 \\
14 \\
1 \\
192 \\
13 \\
57 \\
391 \\
4 \\
0 \\
376\end{array}$ \\
\hline & \multicolumn{6}{|c|}{ 198 } \\
\hline 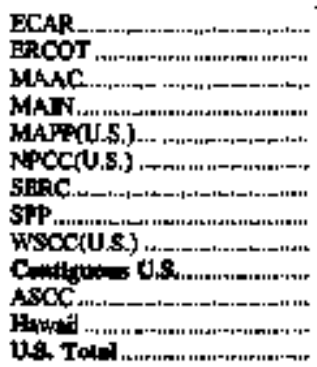 & 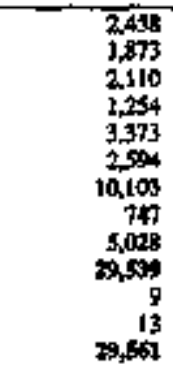 & 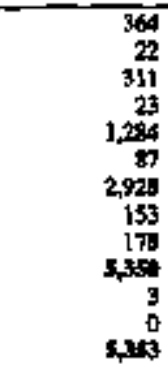 & $\begin{array}{r}1,083 \\
94 \\
751 \\
505 \\
1,198 \\
301 \\
9,314 \\
203 \\
947 \\
8,41 \\
0 \\
0 \\
8,41\end{array}$ & $\begin{array}{r}539 \\
1,447 \\
671 \\
6,51 \\
661 \\
2,178 \\
3,134 \\
269 \\
3,415 \\
13,243 \\
2 \\
13,212\end{array}$ & $\begin{array}{r}107 \\
306 \\
362 \\
59 \\
215 \\
28 \\
498 \\
172 \\
424 \\
2,168 \\
0 \\
0 \\
2,158\end{array}$ & $\begin{array}{r}60 \\
4 \\
13 \\
9 \\
15 \\
292 \\
19 \\
67 \\
416 \\
5 \\
6 \\
45\end{array}$ \\
\hline
\end{tabular}

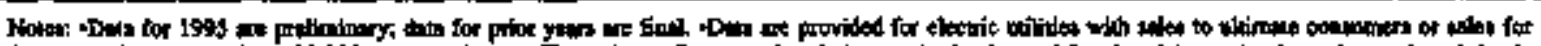

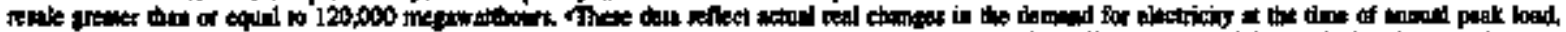

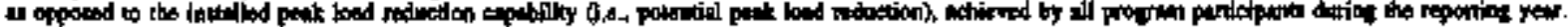

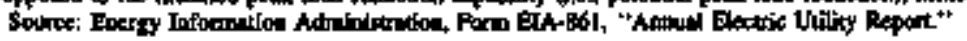


Table 45. U.S. Electric Utility Demand-Slde Management Propram Annaal and Incrementel Effects by Propram Category, 1995

\begin{tabular}{|c|c|c|c|}
\hline Propiting & 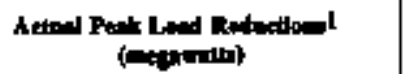 & 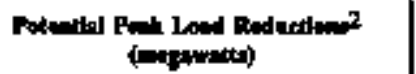 & $\begin{array}{l}\text { Enorgy Saving } \\
\text { (m:ter lowallheart) }\end{array}$ \\
\hline \multirow[b]{2}{*}{ 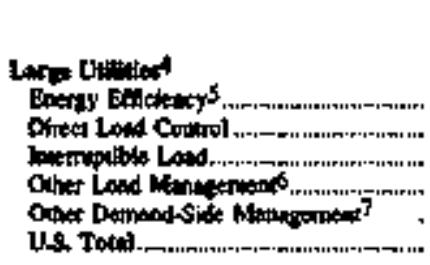 } & \multicolumn{3}{|c|}{ Annow Btfets } \\
\hline & $\begin{array}{r}13,212 \\
5,359 \\
8,401 \\
2,168 \\
196 \\
19,361\end{array}$ & $\begin{array}{r}13,212 \\
9,057 \\
21,820 \\
2,485 \\
416 \\
47,009\end{array}$ & $\begin{array}{r}55,325 \\
133 \\
434 \\
297 \\
1,329 \\
57,421\end{array}$ \\
\hline & \multicolumn{3}{|c|}{ Incremed Enects } \\
\hline 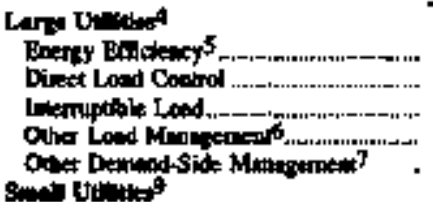 & $\begin{array}{r}1,561 \\
582 \\
2,200 \\
246 \\
32\end{array}$ & $\begin{array}{r}1,561 \\
9,58 \\
3,574 \\
355 \\
43\end{array}$ & $\begin{array}{r}7,901 \\
12 \\
56 \\
60 \\
193\end{array}$ \\
\hline 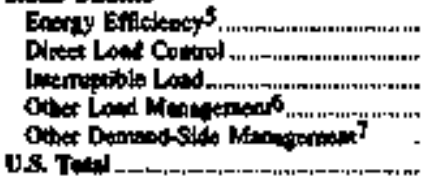 & $\begin{array}{r}7 \\
20 \\
4 \\
3 \\
2 \\
4,696\end{array}$ & $\begin{array}{r}7 \\
28 \\
6 \\
5 \\
2 \\
6,539\end{array}$ & $\begin{array}{r}16 \\
2 \\
1 \\
8,242\end{array}$ \\
\hline
\end{tabular}

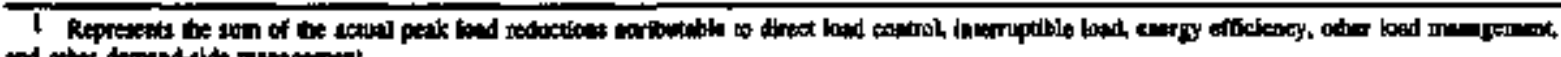

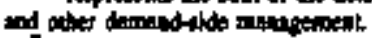

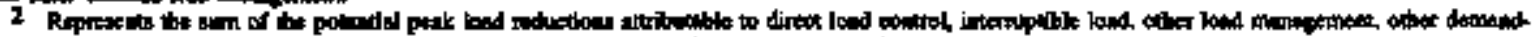

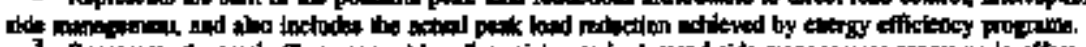

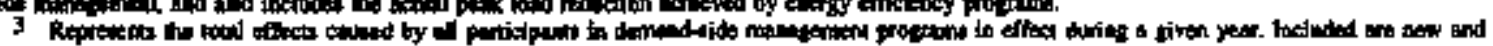

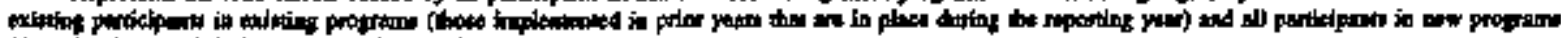

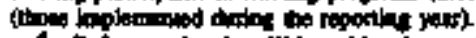

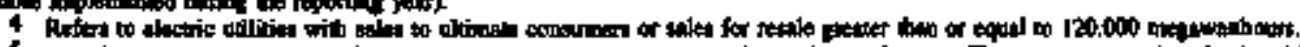

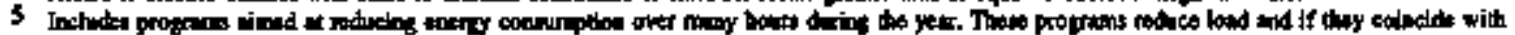

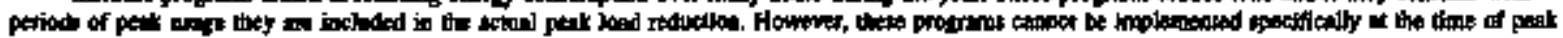
itat.

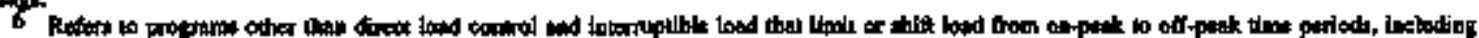

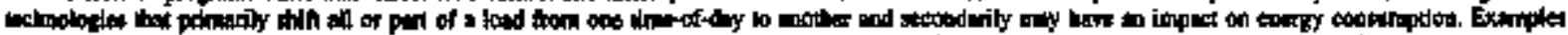

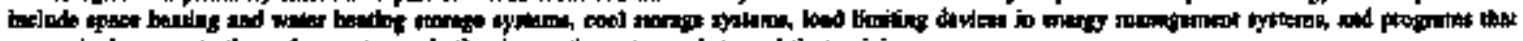

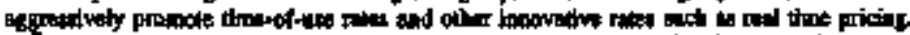

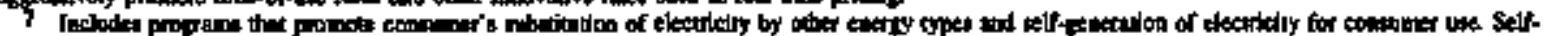

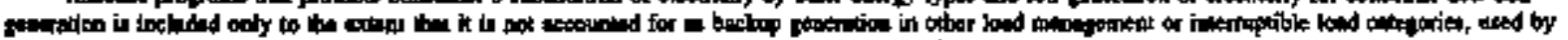

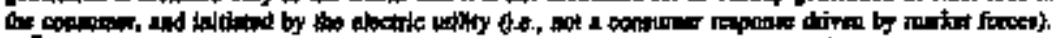

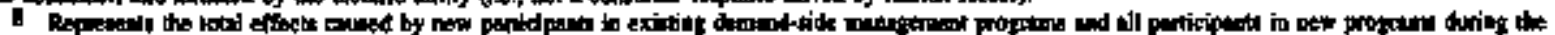

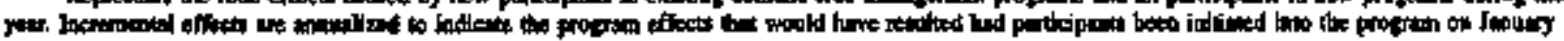

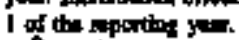

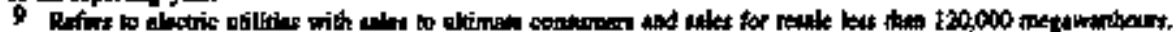

- aviles les lo.s.

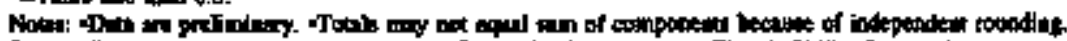

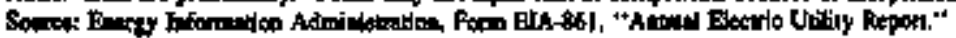


Table 46. U.S. Electric Utillty Demond-Ste Management Program Amanal hnd Jucremental Effects by Sector, 1995

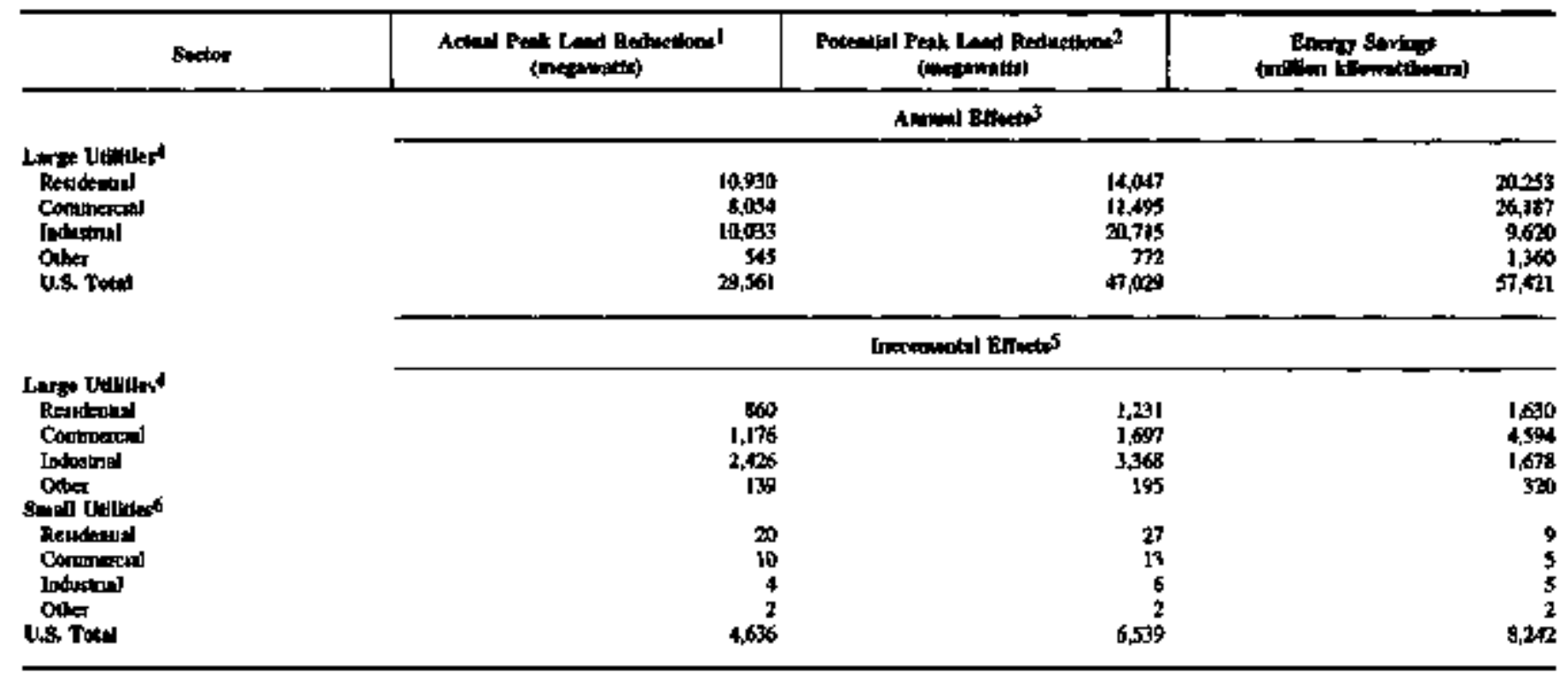

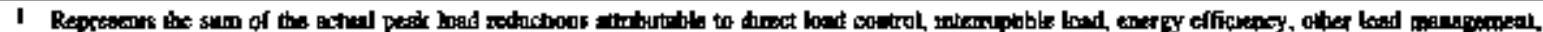

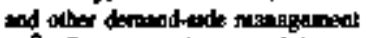

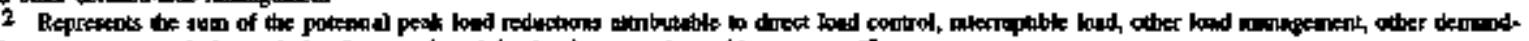
sode mongrefor

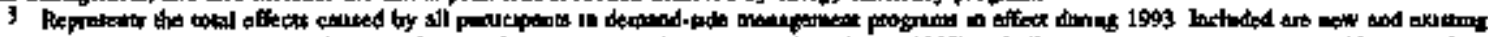

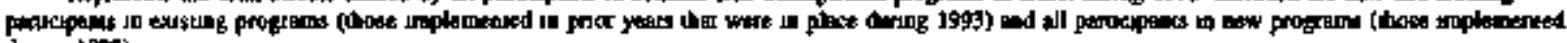
durns (1993)

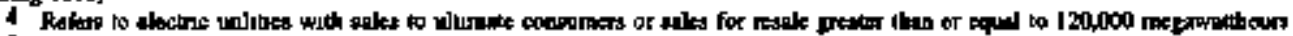

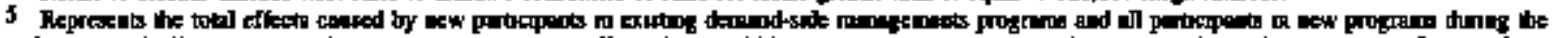

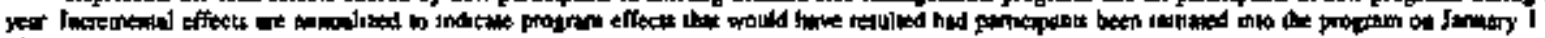

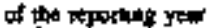

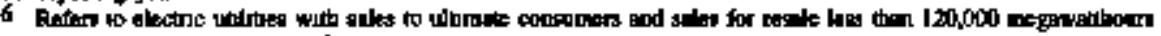

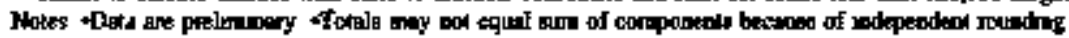

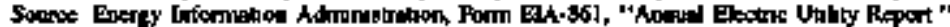


Table 47. U.S. Electric Utllity Potential Peak Load Reductions by Direet Loed Control and Imterruptible Logit and by North American Electric Reliability Coencil Region and Howail, Seleeted Years

(Megawatts)

\begin{tabular}{|c|c|c|c|c|c|c|c|}
\hline \multirow{2}{*}{ 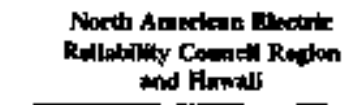 } & \multicolumn{5}{|c|}{ Htorked Itedertion } & \multicolumn{2}{|c|}{ Projeteted Rtdpatidits } \\
\hline & 1999 & 1901 & $19 \%$ & $19-4$ & Los & 1596 & 2000 \\
\hline \multirow{15}{*}{ 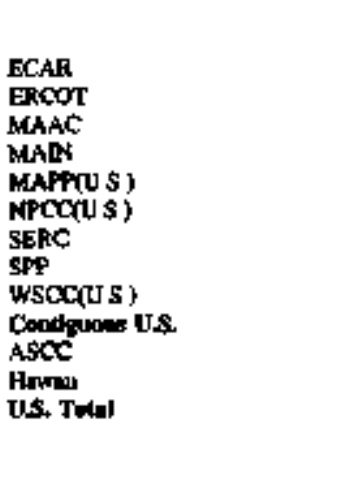 } & \multicolumn{7}{|c|}{ Dinet lowd Condrol } \\
\hline & 337 & 22 & 227 & 247 & 413 & $44 \overline{7}$ & $\overline{655}$ \\
\hline & 68 & [2] & 164 & $\operatorname{lon}$ & 215 & 2018 & 220 \\
\hline & 756 & 933 & 1,033 & 1,260 & 1,206 & $1.22 t$ & 1,074 \\
\hline & 64 & 147 & 190 & 211 & 169 & 234 & $\$ 06$ \\
\hline & 1,020 & 3,054 & 1,252 & 1,368 & 1,676 & 1,948 & $2,2 T$ \\
\hline & 222 & 188 & 219 & 104 & 111 & 100 & 107 \\
\hline & 3,271 & 3,814 & 3.950 & 4,339 & $4,0,0 ?$ & 4,149 & 4,951 \\
\hline & 569 & 53 & 615 & 424 & 121 & 329 & 348 \\
\hline & 731 & 612 & 612 & 724 & 627 & 627 & e95 \\
\hline & $T, 030$ & 7,624 & $1,2 \times 3$ & tatsos & 9,034 & 9,20 & 11,203 \\
\hline & & & 2 & & 3 & 3 & 3 \\
\hline & & & & & & & 0 \\
\hline & 7,04 & 700 & 0,266 & ats & 9,037 & 5,267 & 11,237 \\
\hline & \multicolumn{7}{|c|}{ 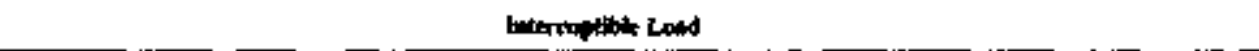 } \\
\hline ECAR & 1,036 & 1,214 & 1.456 & 1,643 & 2230 & 2,581 & 2.659 \\
\hline BRCOT & 1,293 & 1.736 & 1,968 & 1,80, & J,9]\$ & 2919 & 2.233 \\
\hline MAAC & 724 & 638 & 1,157 & 1,614 & 1,781 & 1.736 & $20 t 8$ \\
\hline MAN & 735 & $86 \%$ & 80,1 & 1,116 & 1.202 & 1,931 & 1.431 \\
\hline MAPPU S\} & 682 & 789 & 8 & 971 & 1,326 & 1,360 & 1,674 \\
\hline NPCC(US ) & 379 & 371 & 358 & 245 & 349 & 258 & 349 \\
\hline$\$ \mathbf{S R C}^{2}$ & 2,759 & 1,204 & 6,624 & 6,816 & 7,621 & 7,625 & $8,0 \div 0$ \\
\hline SPP & 813 & I,IBI & 2.041 & 2,004 & 1.964 & 2.130 & 2,497 \\
\hline wscc(us s & 3,038 & 3,353 & 2,997 & 3,167 & $1,13 t$ & 7.157 & 7,097 \\
\hline Cendlyoon LS. & 11,45 & Mass & 10,203 & 15,300 & $21 \$ 40$ & 24,195 & 24,059 \\
\hline$A S C C$ & & & & o & 0 & 0 & \\
\hline Hlnwan & & & 12 & & 0 & 4 & \\
\hline US, Trtal & 11,467 & 14564 & 10,239 & ID:844 & 21,320 & 2,102 & 24,45 \\
\hline
\end{tabular}

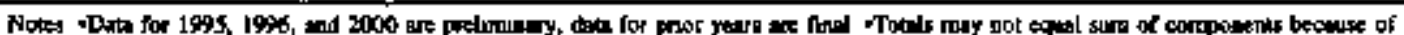

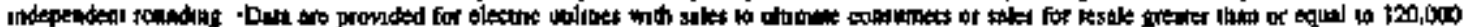

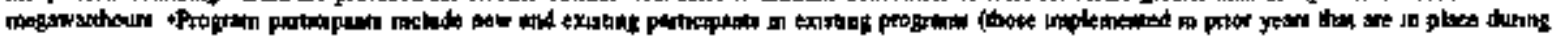

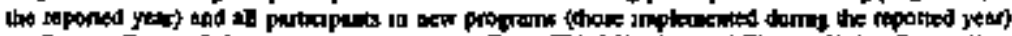

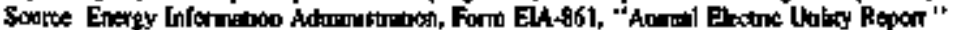

Table 48. U.S. Electric Utility Demand-Side Montgenant Energy Savings by North American Electrtc Reliability Council Region and Eowaii, Selected Years

(Million Kilowatthours)

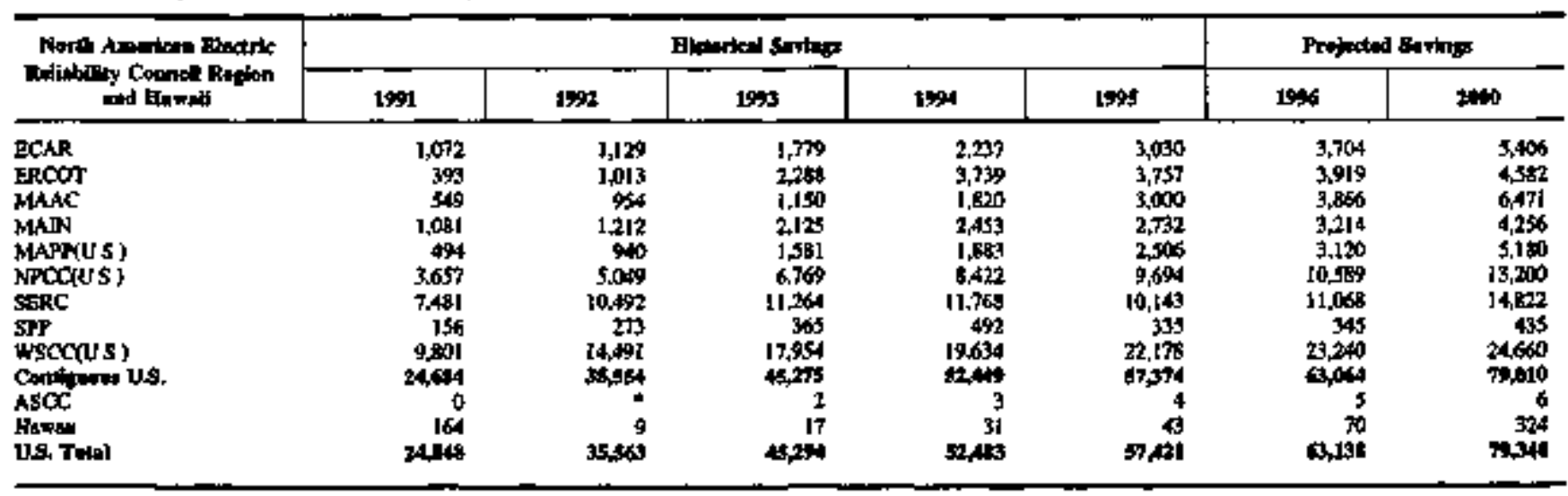

- Jighe losa than oS

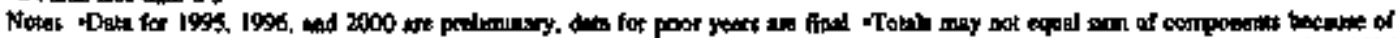

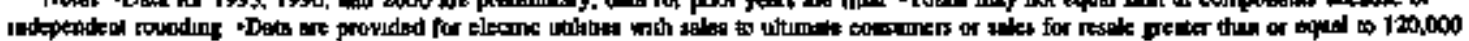

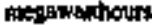

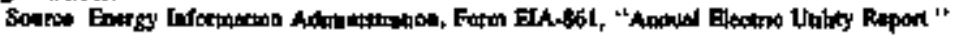


Table 49. U.S. Electric Ctilty Deanand-Side Manggenent Cost by North American Electric Reliability Couscil Region and Hawni, Selected Years

(Thousind Dollars)

\begin{tabular}{|c|c|c|c|c|c|c|c|}
\hline \multirow{2}{*}{ 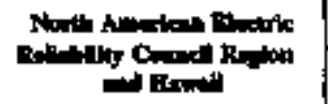 } & \multicolumn{5}{|c|}{ Estatim; } & \multicolumn{2}{|c|}{ Projicted } \\
\hline & 195 & 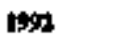 & 15:3 & 164 & 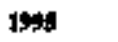 & noss & 204 \\
\hline 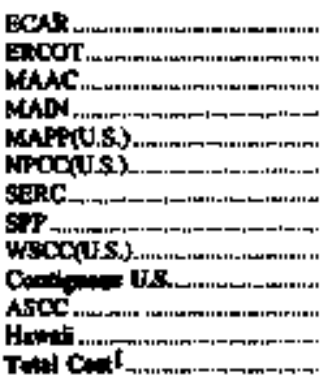 & 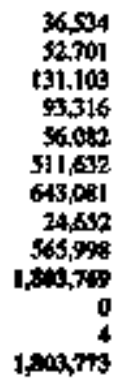 & $\begin{array}{r}130,903 \\
55,675 \\
178,420 \\
13,610 \\
53,021 \\
542,227 \\
510,469 \\
30,927 \\
679,752 \\
2,34,079 \\
315 \\
760 \\
2,348,404\end{array}$ & 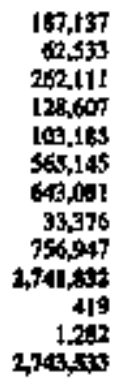 & 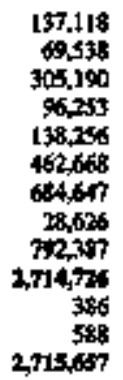 & 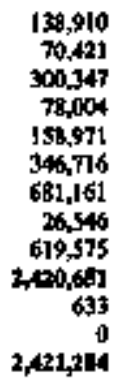 & $\begin{array}{r}121,684 \\
61,547 \\
22,717 \\
78,317 \\
12,963 \\
323,480 \\
667,942 \\
25,944 \\
549,711 \\
2,231,500 \\
789 \\
11,104 \\
2,26,13\end{array}$ & $\begin{array}{r}94,445 \\
57,341 \\
342,329 \\
98,875 \\
149,347 \\
268,694 \\
782,813 \\
26,660 \\
411,215 \\
1731,724 \\
999 \\
25,990 \\
2,254,64\end{array}$ \\
\hline
\end{tabular}

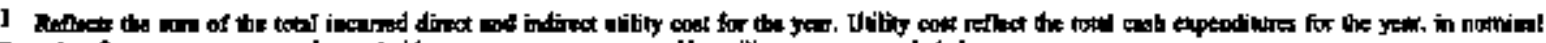

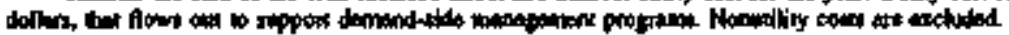

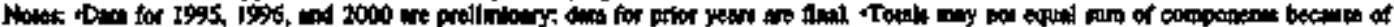

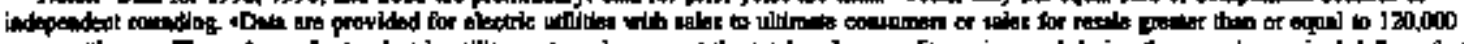

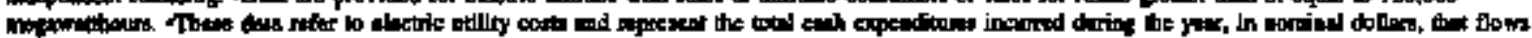

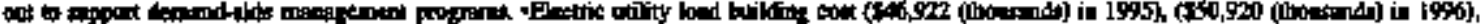

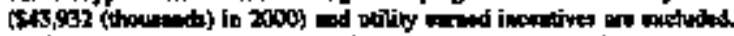

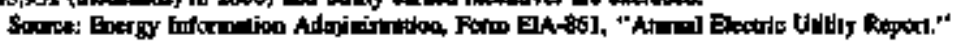

Table 50. U.S. Electric Utility Demand-Sldo Management Direct and Indirect Cost, Selected Yeary (Thousand Do:lars)

\begin{tabular}{|c|c|c|c|}
\hline \multirow{2}{*}{ 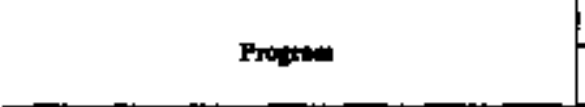 } & 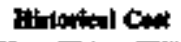 & \multicolumn{2}{|c|}{ Profulad Con } \\
\hline & 19 & 1 19:5 & 2000 \\
\hline 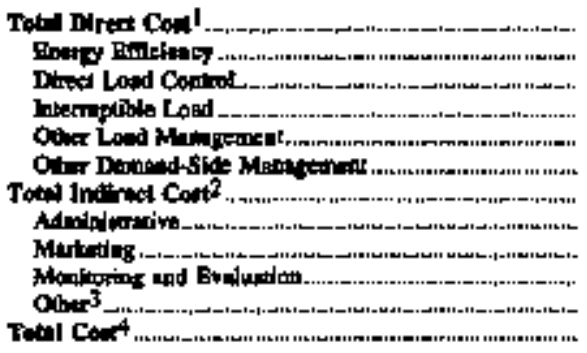 & 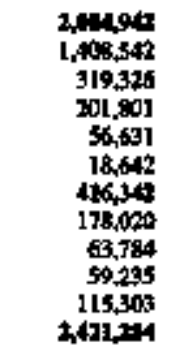 & 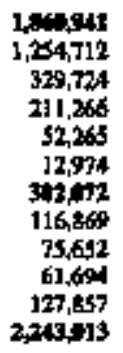 & 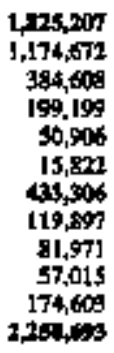 \\
\hline
\end{tabular}

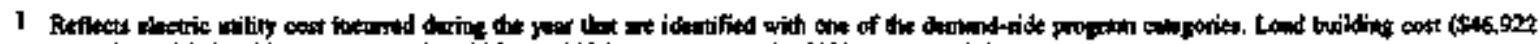

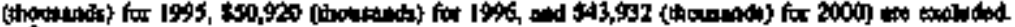

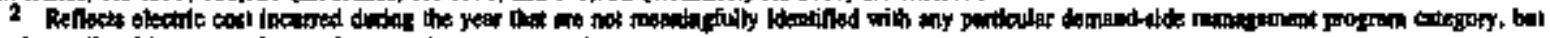

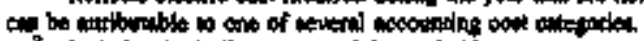

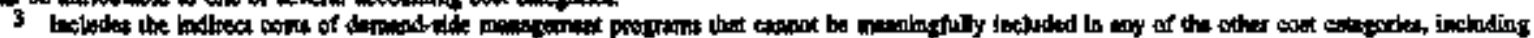

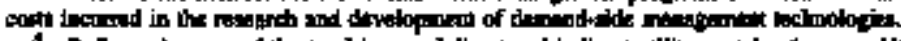

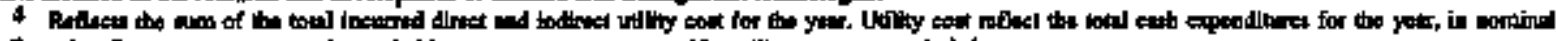

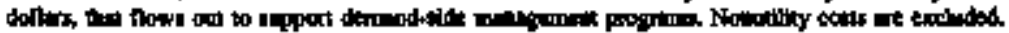

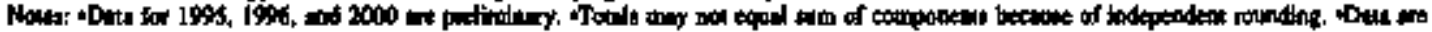

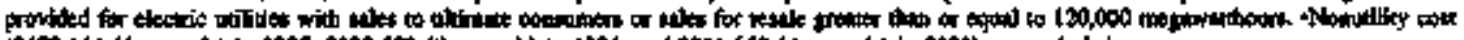

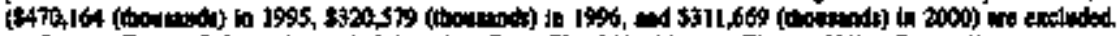

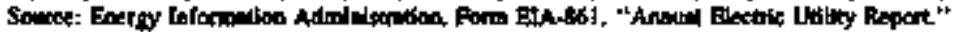


Table 51. Number of U.S. Elettrite Utllties with Demand-Side Maningement Enerzy Bfficieacy Proprams by Fnd Uses and Program Types by Sector, 1995

\begin{tabular}{|c|c|c|c|}
\hline 14to & 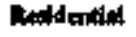 & 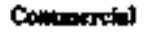 & Industrial \\
\hline 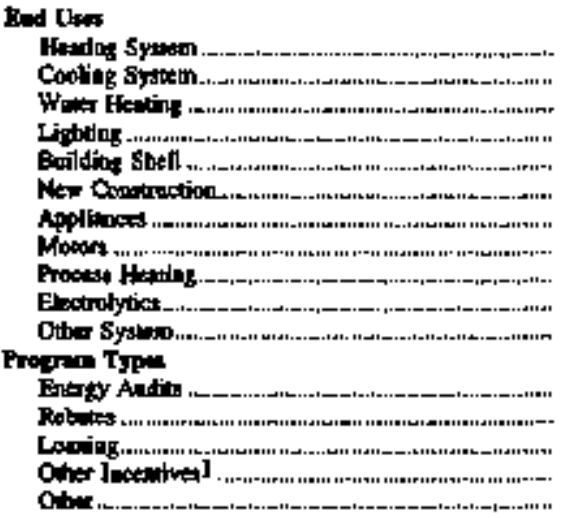 & $\begin{array}{c}367 \\
384 \\
421 \\
243 \\
219 \\
245 \\
178 \\
= \\
= \\
= \\
61 \\
187 \\
385 \\
177 \\
143 \\
141\end{array}$ & $\begin{array}{r}244 \\
280 \\
213 \\
285 \\
134 \\
159 \\
66 \\
177 \\
51 \\
9 \\
34 \\
936 \\
275 \\
108 \\
99 \\
99\end{array}$ & $\begin{array}{r}133 \\
164 \\
149 \\
223 \\
100 \\
114 \\
51 \\
191 \\
96 \\
24 \\
44 \\
\\
251 \\
194 \\
74 \\
81 \\
74\end{array}$ \\
\hline
\end{tabular}

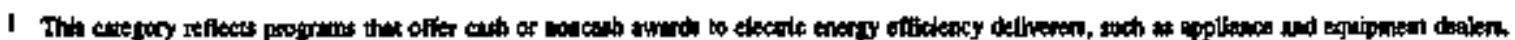

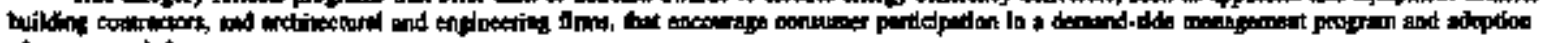
of rocoitureadod bethost.

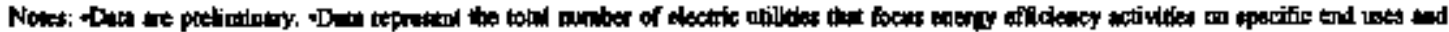
proporm types.

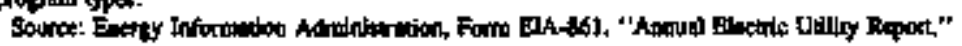





\section{U.S. Nonutillty Power Producers}

This chapter provides an overview of U.S. conutility power producers, and their generating technologies, together with statistical data on capacity, generation, sales, consumption and emissions for 1991 through 1995. These data are aggregated at the U.S. Census division level. Since nonutility data are confidential, the EIA implemented information disclosure rules. See "Nondisclosvre of Data" in Appendix A. In 1989, the Energy Information Administration (EIA) began collecting nonutility electricily generation data on the Form ELA-867, "Annual Nonutility Power Producers Report." This survey enables the EIA to suppiement tits data on electric utility production and to fill the information gap on this growing source of electric power. The initial survey was developed to include capacity, fuel consumption, generation, and deliveries of electricity to traditional utilities. Due to the sensitivity of the data on costs and reliability expressed by representatives of the nonutility power producters, these data were excluded from the survey. See "Forrt EIA $-867^{\text {th }}$ in Appendix A.

\section{Background}

Early in the 20th century, more than balf of all electricity produced in the United States came from industrial firrts. However, during the first half of the 20th century, atajor changes occursed in the industry: econonies of scale in gemeration, decreased rates, and gteatly inproved reliability made electricity inexpensive and dentand soared. Most industrial plants shifted away from generating their own power and opled to purchase electricity fron their local utijities. By 1950, the electric utility jndustry was serving virtually all electricity demand, except for a few industries that generated small amounts for their own use. Electricity was inexpensive, capacity growth appeared to be limitless, and electric utilities were strictly regulated to protect the consumers. During the 1970's, however, the electric utility industry changed from one characterized by decreasing marginal costs to one of increasing cosis. Inflation, the energy erises, environmental concerns, and the tising costs of nuclesr power led to increased electricity rates and reduced growth in cepacity.

In the late 1970 's, changing economic condjtions and legislation made nonutility generation attractive again for thany industrial facilities and power project devel. opers. In addition, oil-price shocks in the 1970's led to a dramatic rise in energy prices, while high interest rates and stricter Federal air quality regulations increased the cost of building power plants. A nonutility power producing facility soekiag to establish an interconnected operation with an electric utility faced three major obstacles. First, utilitjes were seldom willing either to purchase the electric power output of nonutility producers or pay a fair rate for that output. Second, some utilities charged high rates for backup services to nonutility power producers. Third, facilities that provided electricity to a atility connected to the grid risked being considered a public utility and subject to extensive State and Federal regulation.

In the 1970's, inflation, the energy crises, environmental concerns, and the rising costs of nuclear power raised electricity rates and reduced investment in new capacity. These factors led to a re-examination of alternatives such as nonotility electric power, which prompted the passage of the Public Utility Regulatory Policies Act (PURPA) of 1978. Congress acted to relieve a nationwide energy crisis by enacting the National Eaergy Act of 1978, which encompassed PURPA and four other laws: the National Energy Conservation Policy Act, the Powerplant and Industriat Fuel Ust Act, the Natural Gas Policy Act, and the Energy Tax Acl. PURPA provided for increased conservation of energy and incressed efficiency in the use of facifities and resources by electric utilities. It called for State regulatory authorities to encourage conservation and otitity efficiency and to provide for equitable rates. Some of the provisions of PURPA were designed to encourage the development of cogeneration and small power production by loosening the economic, regulatory, and institutional barriers that discouraged cogeneration and the use of renewable energy resources.

PURPA makes a distinction between facilities that qualify for benefits, referred to as qualifying facilities (QF's), and other generating facilities. The QF's inclade certain cogenerators, small power producers, and other nonutility generators. Cogeneration is an energy efficient technology, while small power production is defined in PURPA as a technology that primarily uses renewable energy sources. Other generatiog facilities include industrial and commercial gentrators and independent power producers without a designated franchised service area. The Federal Energy Regulatory Commission (FERC) is respon. sible for the implementation of PURPA and has established tules to encourage the development of cogenerators and strall power production facilities. In addition, each State regulatory authority is required to implement such rules for each electric utility under its rate-making authority. The rules for the FERC program that define QF's are published in the Code of Federal Regulations, Title 18, Part 292. 
Under FERC sules, cogeseration and small power production facilities may be designated as QF's if they meet specific ownership, 20 operating, and efficlency criteria. A facility may fite an information report, known as a "self qualifying notice," with the FERC if it areets the requirements of FERC pablished rules, or it may apply to the FERC for certification as a QF under PURPA. QF's are guaranteed that electric utilities will purchase their output at the utility's avoided cost, which is the incremental cost that an electric utility would incur to produce or purchase an amount of power equivalent to that purchased from QF's. Additionally, $Q F$ 's are gusranteed that electric utilities will provfde back up strvice at prevailing (non discriminatory) rates.

The Eatrgy Policy Act of 1992 (EPACT) amended the Public Utility Holding Company Act (PUHCA) of 1935. PUHCA was designed to discourage holding companies from structuring their operations in ways that would prevent effective State regulation.

These are provisions of EPACT that are potentially sffecting the nonutility industry. The creation of exempt wholessle generators (EWG's), corporate entities that are engaged exclusively in the business of wholesale electric generation and that ase exempt from corporate organizational restrictions under PUHCA. Entities that are currently subject to PUHCA (tegistered holding companies and exempt utility holding companies) and entities that are not currently subject to PUHCA (nonutilities and non-bolding company utilities) are permitted to own EWG's without limitation. Registered holding compasies, must obtain approval from the Securities Exchange Commission to finance EWO's and service sales and construction cobtracts jnvolving EWG's. The EPACT removes obstacles to wholesale power cortpetition in the PUHCA by allowing both utilities and nonutilities to form EWG's withoul triggering the restrictions of PUHCA.

Allowiug FERC to order upon application the wholesale, but not retail, transmission access on a case-bycase basis and transmission service by utilities, subject to certain protection.

The establishment of a program for providing Federal support on a competitive basis for renewable energy technologies. It also expends the progrem to promote the export of these renewable energy technoloties to emerging markets in developing copntries.

\section{Recint Legislative and Rogulatory Actlvities}

Recent goverbment activity that will affect nonutility power producers are largely motivated by the EPACT electricity provistons, the FERC and several States have beet working to develop open-access transmisston systems, restructure the wholesale power generation market, and reform the ratemaking process. However, regalators are moving cautiously until the competitive effects of changes in utility cost structure and bosiness practices are thoroughly studied. For example, the pricing provistions in wholesale powet supply and transmission service contracts are undergoing review as the electricity industry moves closer to a market-based priciog regime. Artificial market support mechonisus, sucb is PURPA's avoided cost and guaranteed market provisions, are being reviewed as well.

In April of 1996, FERC issued two notable Federal actions to foster competition. These actions were the Finat Rules and a notice of proposed rulemaking (NOPR). Open Access Non-discrintinatory Transmission Services by Public Utilities (Docket No. RM95-8-(00) or Order No. 888, and Open Access Same-time Information System and Standards of Conduct (Docket No. RM95-9-900) or Order No. 889. The Order $\mathbf{8 8 8}$ would require that all utilities file open access transmision tariffs for wholesale electricity transmission services. These services would have to be nondiscriminatory in the sense that terms and conditions for service were comparable to those available to utilities. The Order $\mathbf{8 8 9}$ requires jurisdictional utili. ties that own or operate transmission facilities to establtsh electronic to systems to share information about the available transmission capacity. It also established a standard of conduct for utilities. The NOPR issued by FERC proposes implementation of new electronic systems for utilities to use in reserving capacity on its and other companies ${ }^{+}$transmission systems.

PURPA is under review for streamlining or repeal of certain key provisions. The FERC issued a Final Rule in Janusry 1995 that modified requirements for QF determination. ${ }^{21}$ Key modifications incluted (1) allowing facilities to meet operating and efficienxy standards on a 12- -ronth basis (rather than calendaryear basis) to account for stautap difficulties, (2) clarifying the "sequential-ose-of energy" requirement"2, (3) removing the 80 -megawatt size limitation for qualifying Small Power Producers (a temporary removal of the limitation was instituted by Congress in 1991), and (4) streamlining the $Q F$ determination process for facilities that use waste energy inputs. A1 the legislative level, a bill was introduced before the U.S. Senate that repeals Section 210 of PURPA. Known as the Electric Utility Ratepayer Act (S.708), the bill would eliminate the requirement that atilities must offer to purchase power from QF's. Proponents

20 FEAC raler sequire that QF's be lest than 50 percent gwatd by eloctric utilities.

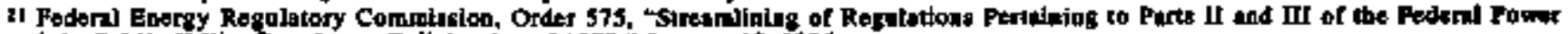
Act and the Public Uijlity Regolatory Policies Act of 1975." Jannay 13, I95.

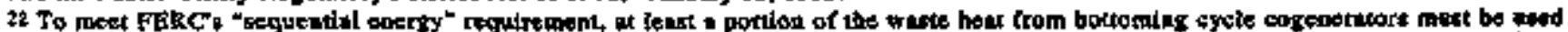

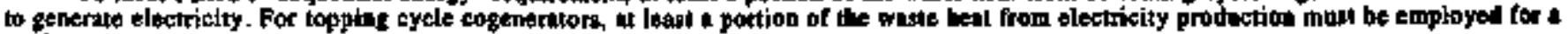
useful thermat purpout. 
of the bill argue that the QF power purchase mandate is anticompelitive and costly. Opponents of the bill maintain that the mandate is a necessary check against utility monopoly power. The Electricity Competistion Act of $1996(S .1526)$ would require states to implement retail competition by 2010, grant FERC anthority to permit recovery of all stranded costs, and repeal PURPA Section 210. House legislation $H . R$. 2562, The Ratepayer Protection Act would repeal Section 210 of PURPA and require FERC 10 issue a regulation to "assure that no utility shall be required directly or indirectly to absorb the costs associated with purchases from a qualifying factlity. "The provision does not specifically indicate whether any regulation assuring recovering of qualifying facjlity cost would be limited to the term of the contract between the cuslomer and the utility.

State public service combrissions (PUC's) are coping with new regulatory responsibilities resulting from various EPACT provisions. New standards have been establisbed, or are now being considered, for addressing jurisdictional responsibility for wholesale power market transactions. For the nonutility power market, an issue has been whether PUC's should intervene in disputes involving negotiated wholesale power purchases. Other new regulatory responsibilities include oversight of EWG's and the reevaluation of power purchase, supply, and demand-side management practices.

Regulators are also investigatiog ways to mitigate the adverse financial impacts on utilities' regulated assets caused by competition, while at the stame time providing consumers with lower-cost power purchase alternatives. Among the options advanced by PUC's are incentive rates for deferring cogeneration or bypass by industrial customers, performance-based rates (price-cap and other flexible pricing plans), approval of utility-operated, on-site industrial power generation projects, and allowing independent power producers to repower existing utility generating plents.

\section{Nonutility Classifleatlons}

Cogeneration. The major technology used is nonutility generation is known as cogeneration. Cogeneration is the conbined production of electric power and another form of useful energy (such as heat or stean) through the use of one energy soutce. The process can begin either with hest or steam profuction or with electricity generation. The unused enetgy from the first process is used as input to the second prosess. The primary energy source is generally a fossil fuel (coal, petroleum, or natural gas), although renewables are also used, particularly wood and waste. To receive QF stalus under PURPA from FERC, a cogenerating facility must meet the operating criteria by producing electric energy and "another form of useful thermal energy through the sequential use of energy." In addition, depending on the technology of the cogeneration facility, it must meet specific efficiency criteria.
Cogeneration uses a number of technologies 10 produce both electric power and another form of useful energy. The technology selected depends on the requirement for processed steam. Cogenerating technologies are classified as "topping-cycle" and "bottoming-cycle" systems, depending on whether electrical or thermal energy is produced first. In a typical topping-cycle system (Figure 15), the energy input to the system is first transformed into electricity by using high-temperature, high-pressure steam from a boiler to drive a turbine to generate electricity. The waste heat, or the lower pressure steam exhatusting from the turbine, is used as a source of processed heat. Topping-cycle systems are the most common and are used in commercial, rural, and industrial applications. The two configurations in Figure 15 represent most topping-cycle facilities.

In a bottoming-cycle system (Figure 16), hightemperalure thermal energy is produced first for applications such as reheat furnaces, glass kilns, or aluminum metal furnaces. Heat is extracted from the hot exhaust stream and transferred (throvgh one or mare mediums) to drive a turbine. Bottoming-cycle systems are generally used by industrial processes that require very high temperature heat, thus makieg it economical to recover the waste heat.

Fossil-fueled steam turbine systems are used in most industrial cogenertiting processes, while gas-turbine systems are used in most other processes. Gas-turbine systems use combustion gases to drive a turbine to produce electricity and recover heat from the exhaust gases for waste-beat boilers. Compared with gas tarbine systems, diesel engine systems are limited in application since they provide less useable processed heat per unit of eleetric power output. In a diesel system, the engine is cooled with water. The heated water is then used for processed steam, beat. or hot water applications. Exhaust gases can be used in a similar manner. Diesel systems are attractive to smalt cogenerating applications that need an instantaneous supply of electricity where the electric power requirement is generally greater than the heet requirement. With diesel systems, unlike some technologies, bojler warmup time is not nectessary.

Small Power Production. To be fesignated as a small power producet under the 1978 PURPA regujations, a facility was linited to a capacity no greater than 80 megawatts and had to generalo electricity using renewable energy as a prinary source. In 1990 , for specific energy sources (biomass (waste), soles, geothermal, and wind), the size restriction to qualify as a small power producer was removed. Fossil fuels can be used, but 75 percent or IDore of total energy consumption must be derived from renewable resources and the aggregate of fossil fuel usage cannol exceed 25 percent of total energy input during any calendar year. Reliance on these technologies can reduce the need to consume fossil fuels to generate electrix gower.

Renewable energy includes solar, wind, biomass, geothermal, and water (hydrsulic). Solar thermal technology converts solar energy through bigh concen- 
tration and heat absorption into electricity or process energy and is mainly used in the Pacific Contiguous Census Division. Wind geserators produce mechanical energy firectly through shaft power. Windmills rotating parallel or perpendjcular to the ground are the most common haruesses used in wind technology and are mainly concentrated in the Pacific Contiguous and West South Central Census Divisions. Biomass enetgy is derived from a variety of sources. The biomass resource base potentially includes hundreds of plant species, various agricultural and industrial residues and processing wastes, municipal solid waste and sewage, and animal wastes. Industrial wood and wood waste is tho form of biomass energy most commonly used by nonutilities. When economic to do so, the industries that produce paper, wood, and agricultural products are increasing their use of biomass to improve efficiency of their operations and to contribute to their on-site energy requirements. These industries are indigenous to the South Atlantic and Pacific Contiguous Census Divisions. Geothermal technologies convert heat naturally present in the oarth into beat energy and electricity by tapping into high- and low-temperature flujds and by extracting steam. Hydropower is derived by converting the potential energy of water to electrical energy using a bydraulic turbine connected to a generator. Hydropower and geothermal technologies are mainly concentrated in the Pacific Contiguous Census Division.

Other Nonutility Generators. In addition to faciljties that are classified as qualifying cogenerators and small power producers, other nonutility companies produce electric power for their own use and for sale to electric utilities. They include independent power producers (IPP's), nonqualifying cogenerators, and other commerciel and industrial establishments. These nonutility companies are built mainly to supply and sell power to electric utilities. They do not qualify under PURPA because of the ownership, operating, or efficiency criteria established by FERC. IPP's are defined by FERC as producers of electric powet other than QF's that are unaffiliated with franchised utilities in the IPP's market area and that for other reasons lack significant market power. IPP's may lack market power due to site or access to transmission.

\section{Nonutility Oparations}

Business Classiffication. The nobutility power producint industry operates in various sectors of the U.S. economy and is classified according to the Standard Industrial Classifjcation (SIC) Manual of the Office of Management and Budget. The main classifications are:

\author{
Agriculture, Foresiry, and Fishing \\ Mining \\ Construction \\ Manufacturing \\ Transportation and Public Utilities \\ Wholesale and Retail Trade
}

Finance, Insurance, and Real Estate

Services

Public Administration

Other.

A list of the categories of peimary business activity within each classification is contained in Appendix A.

The nonutility power producing industry includes business entities that transform materials or substances into new products using mechanical or chemical processer. In some processes, the energy is transformed into steam for generating both electricity and another useful thetraal output. This thermal output can be used directly in a manufacturing process such as paper production and indirectly for beating buildings or by other end users. The manufacturing sector uses the most energy (i.e. is the most energy intensive) because it creates new products using mechanical or chemical processes. It is therefore more cost-effective to produce one's own energy in this sector than in sectors that only require energy for space conditioning and lighting, such as the nonmanufacturing sectors.

Energy Sources, Mosl nonutility power producers use fossil fuels in their production processes. Many of thers are able to switch from one fossil fuel to another when fuel supply is interrupted or when there is a price advantage in switchiog to another fuel. For example, they may switch from gas to oil in winter when their gas supplies are diverted to residential use, or from oil to coal when oil prices rise. Otber nonutility power producers use various tenewable enexgy sources. Increasingly, many firms ate also able to switch from fossil tuels to renewable fuels. Many nonutility power producers use combustors that are able to burn two or more different fuels simulaneously, in varying combinations, to generate the desired heat output. Other nonutility power producers can only burn one fuel at a time, but their combustors can be converted to bum different fuels. Pinally, many producers have multiple combustors that use different fuels to supply heat or power. Thus, the adaptability of nonutility power producers to using nutiple fuel sources depends primarily on the type of generating equipment available and on economic conditions. A nonutility power producer with many options as to fuel choice has a great economic advantage over a producer tied to only one fuel source.

\section{Data sources}

Summary statistics on nonutility capacity, generation, sales, and emissions in the United States are provided in the following tables. All data are final. These data were obtained from the Form ElA-867, "Annual Nonotility Power Producer Report." The Form EIA-867 is a mandatory survey of all existing and planned nonutility electric generating facilities in the United States with a total generator nameplate capacity of 1 or more megawatts. In 1992, the repportiog threshold of the Form ELA-867 was lowered to include alt facilities with a conbined nameplate capacity of 1 or more 
megawatts. Previously, data were collected every 3 years from facilities with a nameplate capacity between 1 and 5 megawatts. Planned generators are defined as a proposal by a company to install electric genesating equipment at an existing or planned facility. The proposal is based on the owner baving obrained (1) all environmental and regulatory approvals, (2) a signed contract for the electric energy, or (3) financial closure of the facility. Nonutilities generalty iastall small, turn-key packaged generatiog facilities with minimal regulatory requirements which result in considerably less lead time to finance and build, as compared to traditional electric utility facilities, Data on planned nonutility capacity additions as of December 31, 1995, are presented by energy source in Figure 10. These data represent all nonutility planned generating facilities that meet one or more of the criteria defided earlier.

Some nonutility power producers of I or moro megawatts use only fossil fuels; some use only renewable energy; and some use a combination of both fossil fuels and renewable energy sources. Although the majority of aonutility power producers generate electric power using fossil energy, those using renew able energy represent a large portion of capacity. Because of the consumption of multiple energy sources by some generating units, capacity and generation wetre allocated by energy source. The algoritbms used to allocate insiatled capacity and generation by cnergy source are discussed in the Technical Notes (Appendix A).

The other energy saurces in Tables 52, 54, 55, 58 and 59 include bydrogen, sulfur, batteries, chemicals, fish oil and spent sulfite liquor.

The number of facilities shown for 1995 includes operational facilities in 1994 and new facilities or planned facilities that became operational during that year.

The total capacity for 1991 through 1995 (Table 52) includes all operable genesating unils including units not normally used bot on standby with little or no genteration, and units oul of service for the entire reporting year that are expected to be returned to service in the future. Units on standby and out of service represented 7 percent of the total nonutility generatiog eapacity in 1995. 
Figuro 15. Two Topping Cyclo Pint Conilguration:
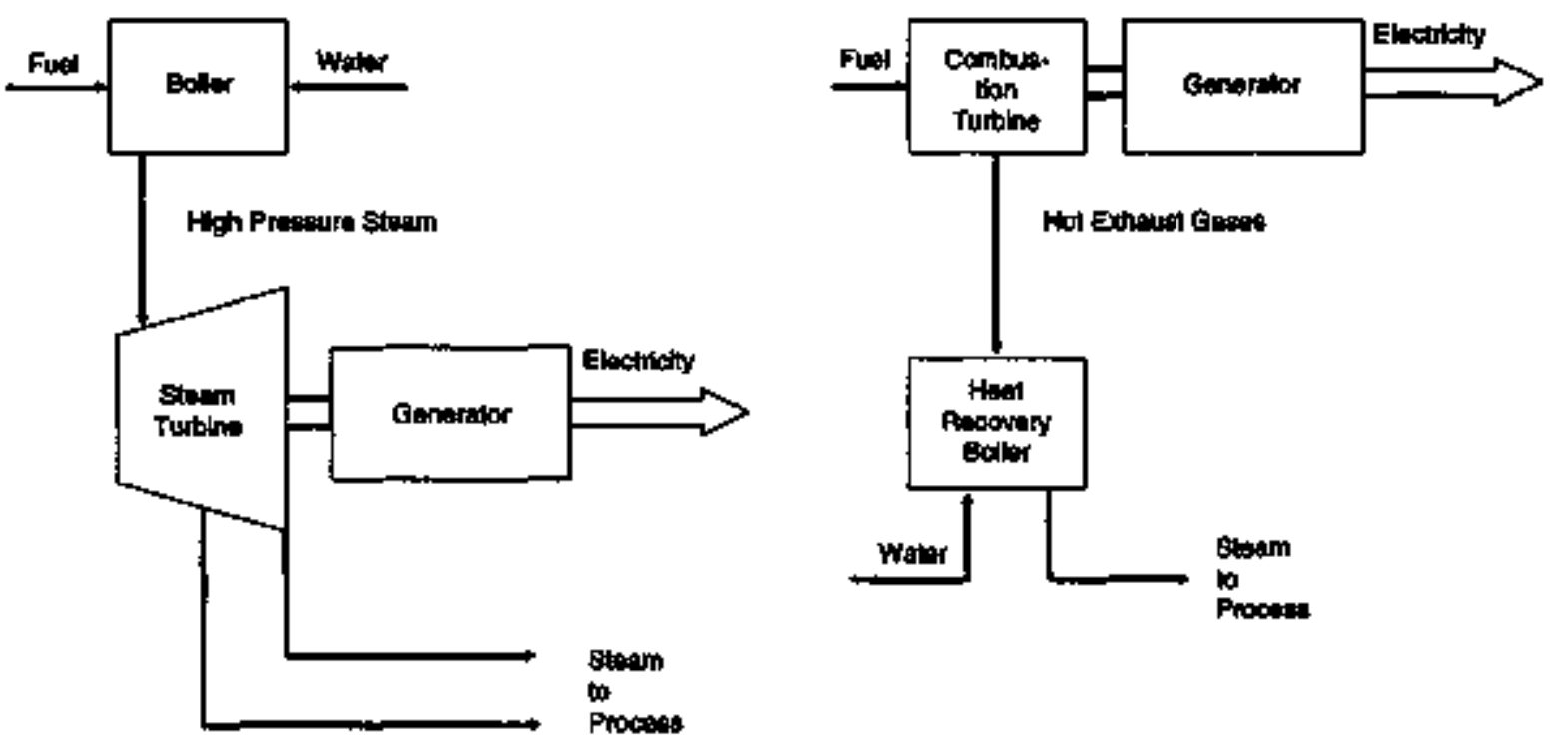

1. A boller protucse stew lo ponwer a wibhegunerator to produce electallty. The turbine stown laving the turtine is lesed in themal applcetion: such at apace heding or food preparation.
2. A combustion turting or tiesel enpine bums tuel to epin a that cormected to a genestator to produce electrifty. Wasta hata from the buining tud ta recaptured in a wasto-hed neconery boiner and Is usest for drect heofing or is used to produce stoen tor themingl applications.

Source: Federal Energy Rigulatory Commisotion, Cogeneration, 1985. 
Flawn 16. Bottoming-Cycle Plant Confipuration

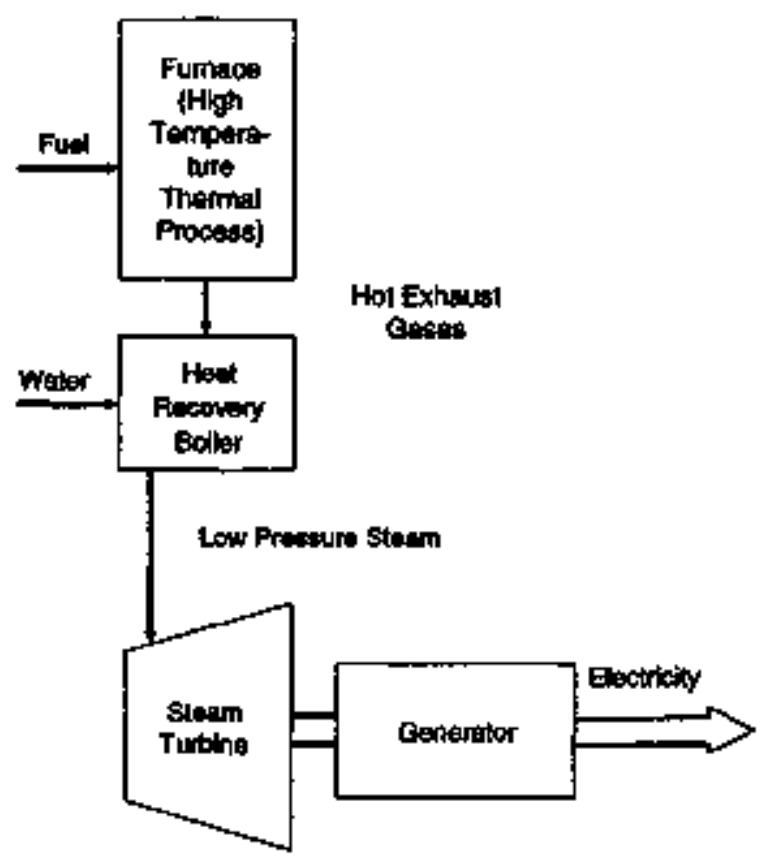

A tumece bo used in a binding or forming procese. A waste-hapel recowery boller recaptures the unused energy

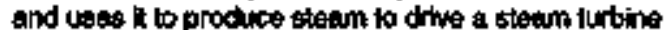
genertitor to produce alectricity.

Source: Foderal Energy Regulatory Commission, Cogeneration, 1995. 
Table 52. Summary Statistles for U.S. Nonutility Power Prodacers, 1991 Through 1995

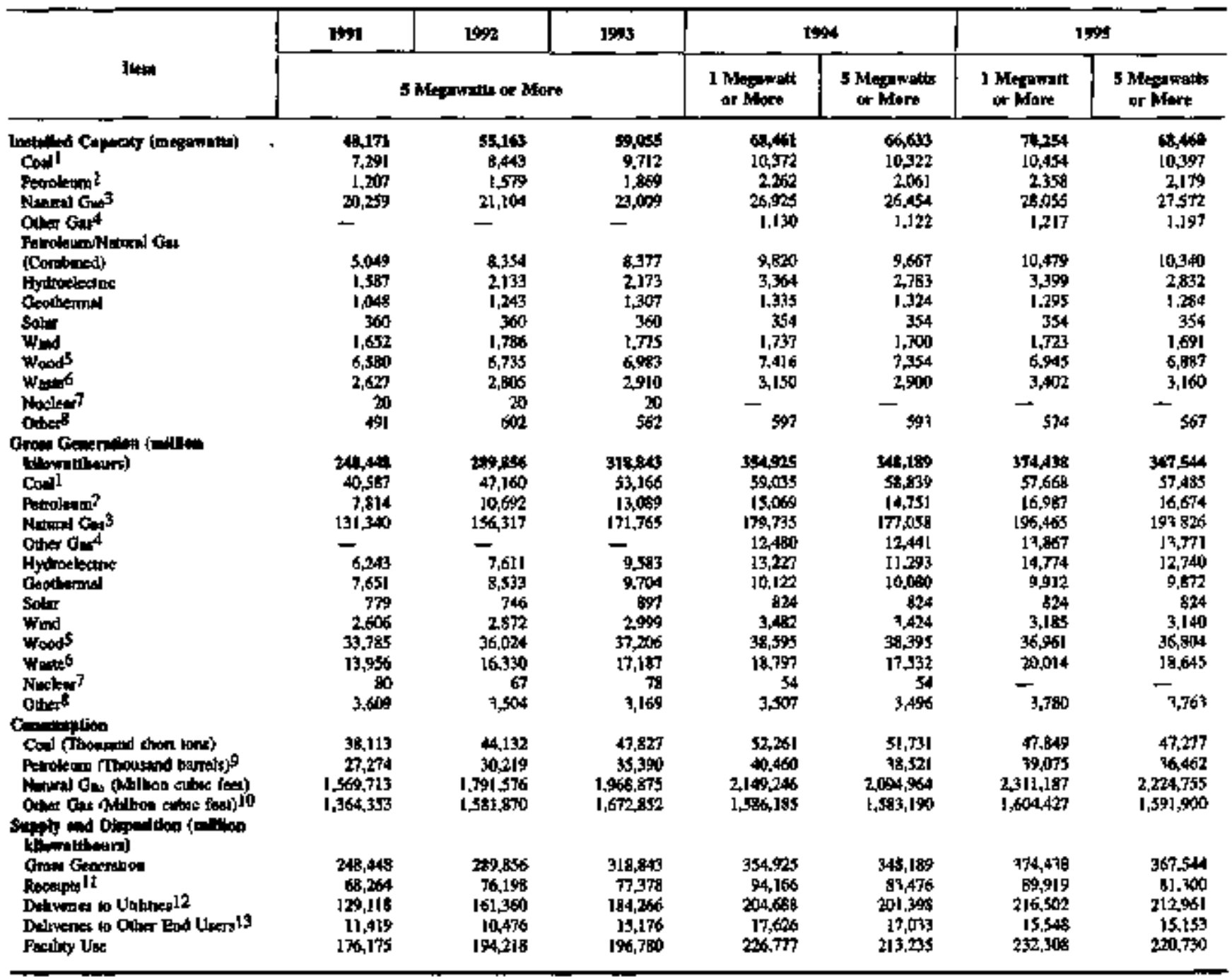

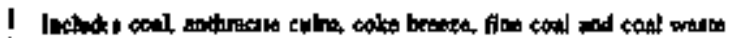

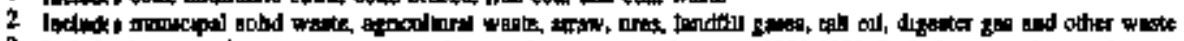

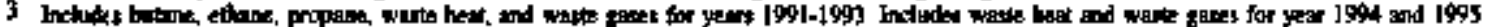

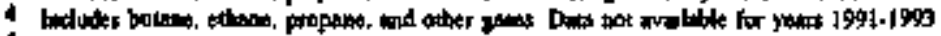

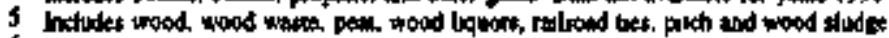

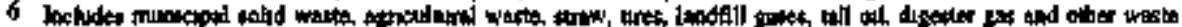

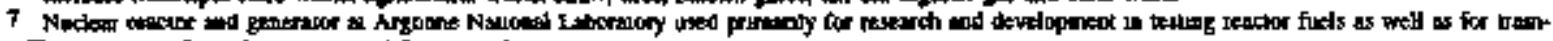

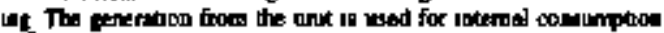

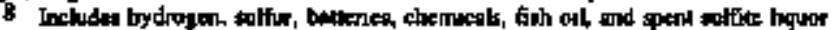

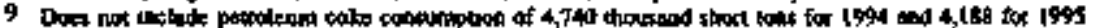

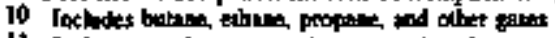

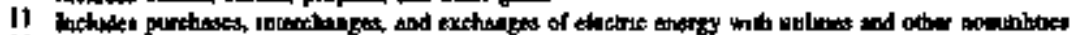

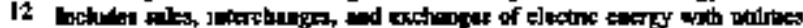

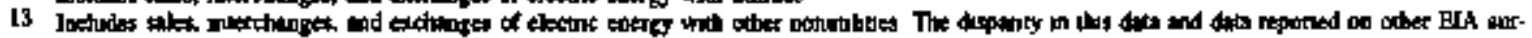

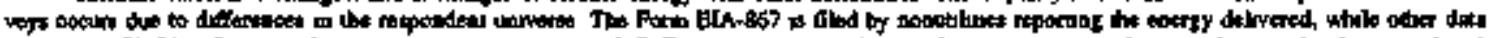

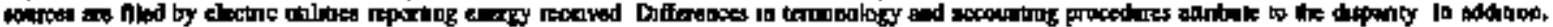

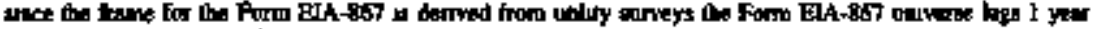
NA = Not woloste

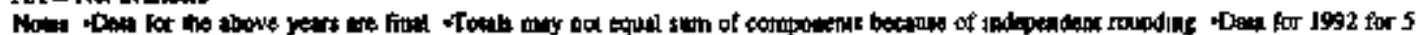

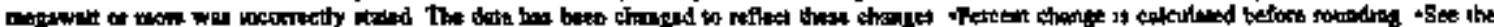

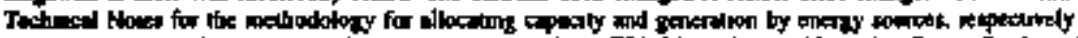

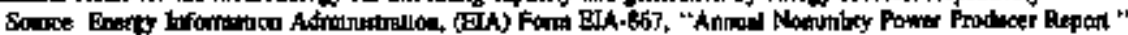


Table 54. Installed Capacity at U.S. Nonntiliky Generating Facilities by Enerty Source and Cenoue Division, 1991 Through 1995 (Megawatts)

\begin{tabular}{|c|c|c|c|c|c|c|c|}
\hline 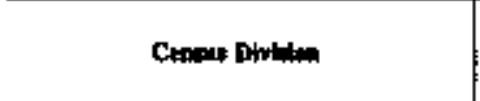 & Conll & Natent & 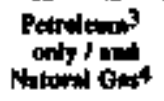 & 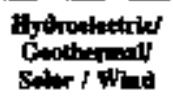 & Prows I & Other 7 & Tratul \\
\hline & & & 199t & leghwatif in Mor & & & \\
\hline \multirow[t]{2}{*}{ 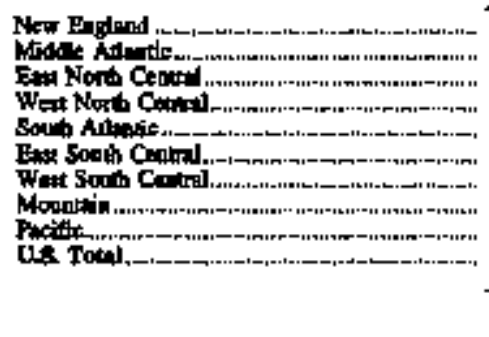 } & $\begin{array}{c}353 \\
1,328 \\
1,095 \\
4 \\
2,114 \\
276 \\
16 \\
162 \\
7,201\end{array}$ & 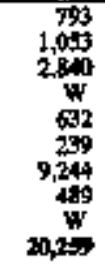 & 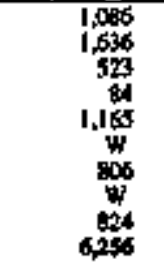 & $\begin{array}{c}432 \\
239 \\
59 \\
55 \\
155 \\
- \\
+ \\
363 \\
3343 \\
447\end{array}$ & $\begin{array}{r}1,192 \\
654 \\
577 \\
104 \\
2809 \\
874 \\
1,197 \\
199 \\
1,658 \\
1247\end{array}$ & 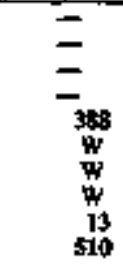 & $\begin{array}{r}3,56 \\
4,040 \\
5,033 \\
1,100 \\
7,269 \\
1,096 \\
1,06 \\
1,792 \\
1,138 \\
4,171\end{array}$ \\
\hline & \multicolumn{7}{|c|}{ 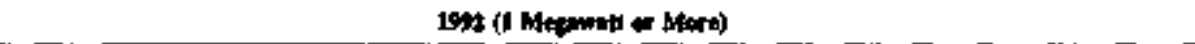 } \\
\hline \multirow[t]{2}{*}{ 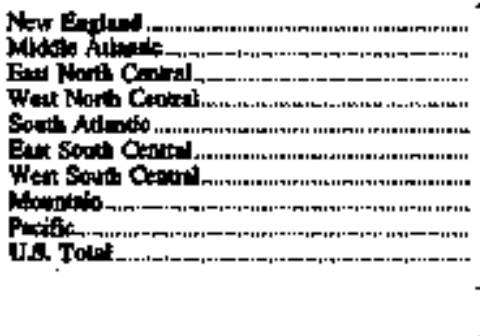 } & 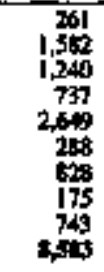 & & 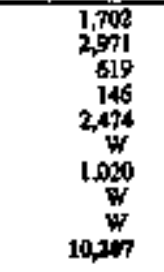 & 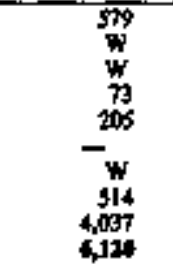 & 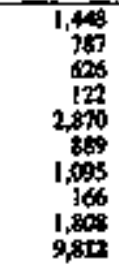 & $\begin{array}{c}-w \\
-w \\
-w \\
w \\
w \\
w\end{array}$ & $\begin{array}{r}4,404 \\
7,379 \\
9,449 \\
1,224 \\
9,449 \\
1,935 \\
12,690 \\
1,0,49 \\
12,844 \\
56,14\end{array}$ \\
\hline & \multicolumn{7}{|c|}{ 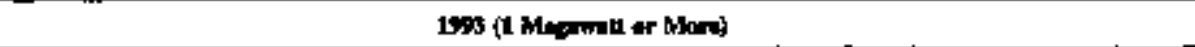 } \\
\hline \multirow[t]{2}{*}{ 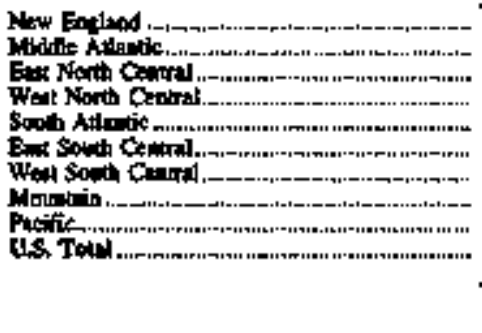 } & 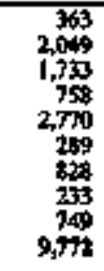 & 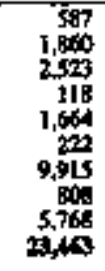 & 10.780 & 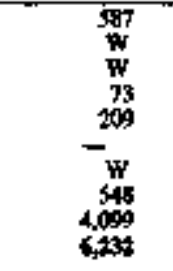 & 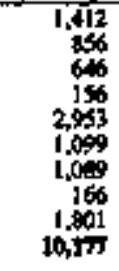 & $\begin{array}{c}w \\
\mathbf{w} \\
\mathbf{w} \\
\mathbf{w} \\
\mathbf{w} \\
\mathbf{w} \\
\mathbf{w}\end{array}$ & $\begin{array}{r}4,739 \\
8,730 \\
5,548 \\
1,261 \\
10,300 \\
1,734 \\
13,069 \\
2,020 \\
13,345 \\
4,796\end{array}$ \\
\hline & \multicolumn{7}{|c|}{ 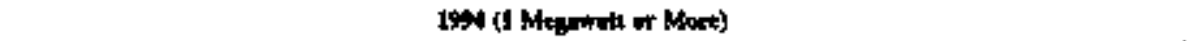 } \\
\hline \multirow[t]{2}{*}{ 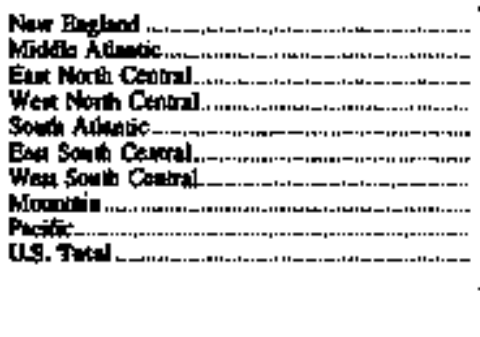 } & $\begin{array}{r}353 \\
2,302 \\
2,057 \\
729 \\
2771 \\
323 \\
827 \\
238 \\
771 \\
10,74\end{array}$ & 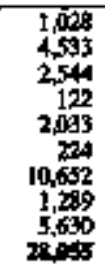 & 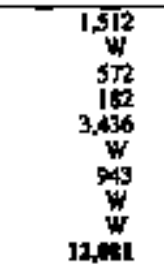 & $\begin{array}{r}595 \\
411 \\
115 \\
95 \\
968 \\
w \\
w \\
551 \\
4,059 \\
6,509\end{array}$ & $\begin{array}{r}1,416 \\
088 \\
658 \\
168 \\
3,197 \\
1,264 \\
1,125 \\
1,57 \\
1,692 \\
16,446\end{array}$ & $\begin{array}{c}-w \\
-w \\
-w \\
\mathbf{w} \\
\mathbf{w} \\
\mathbf{w} \\
\mathbf{w} \\
\mathbf{w}\end{array}$ & $\begin{array}{r}4,895 \\
11,751 \\
5,947 \\
1,296 \\
12,394 \\
2,080 \\
13,764 \\
2,682 \\
13,644 \\
6,461\end{array}$ \\
\hline & \multicolumn{7}{|c|}{ 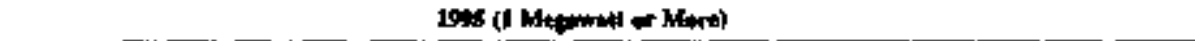 } \\
\hline 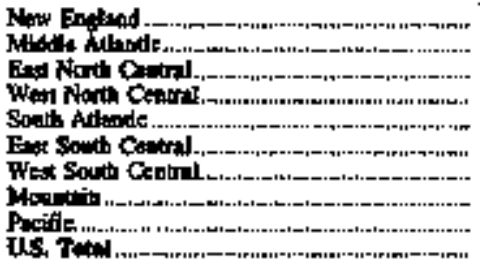 & & 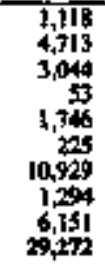 & 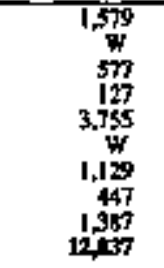 & 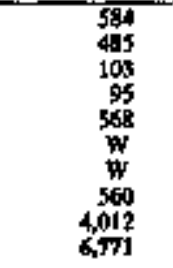 & $\begin{array}{r}1,404 \\
973 \\
6,90 \\
176 \\
3,010 \\
1,254 \\
1,145 \\
1,53 \\
1,50 \\
1,947\end{array}$ & $\begin{array}{c}-w \\
w \\
w \\
w \\
w \\
w \\
w\end{array}$ & $\begin{array}{r}5,037 \\
12,477 \\
5,917 \\
1,232 \\
12,995 \\
2,008 \\
13,891 \\
2,757 \\
13,040 \\
70,4\end{array}$ \\
\hline
\end{tabular}

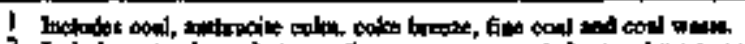

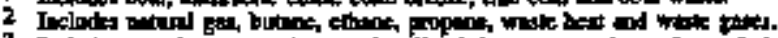

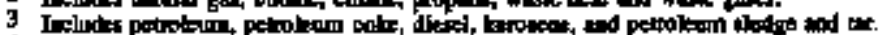

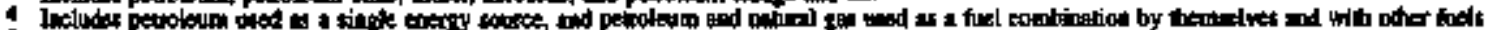

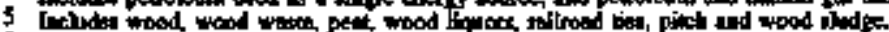

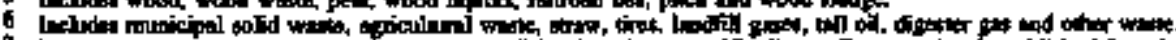

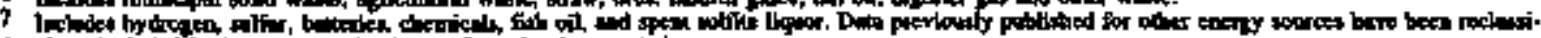

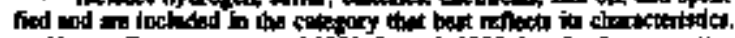

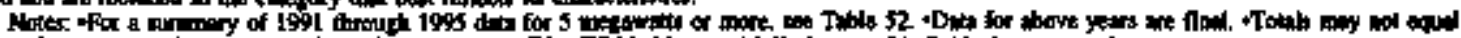

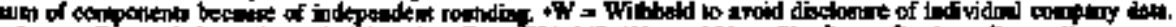

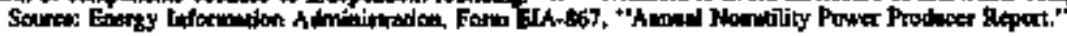


Tuble 55. Installed Copwity at U.S. Nonutility Generotint Facilitio by Energy Soarce and States 1995 (Megrawatts)

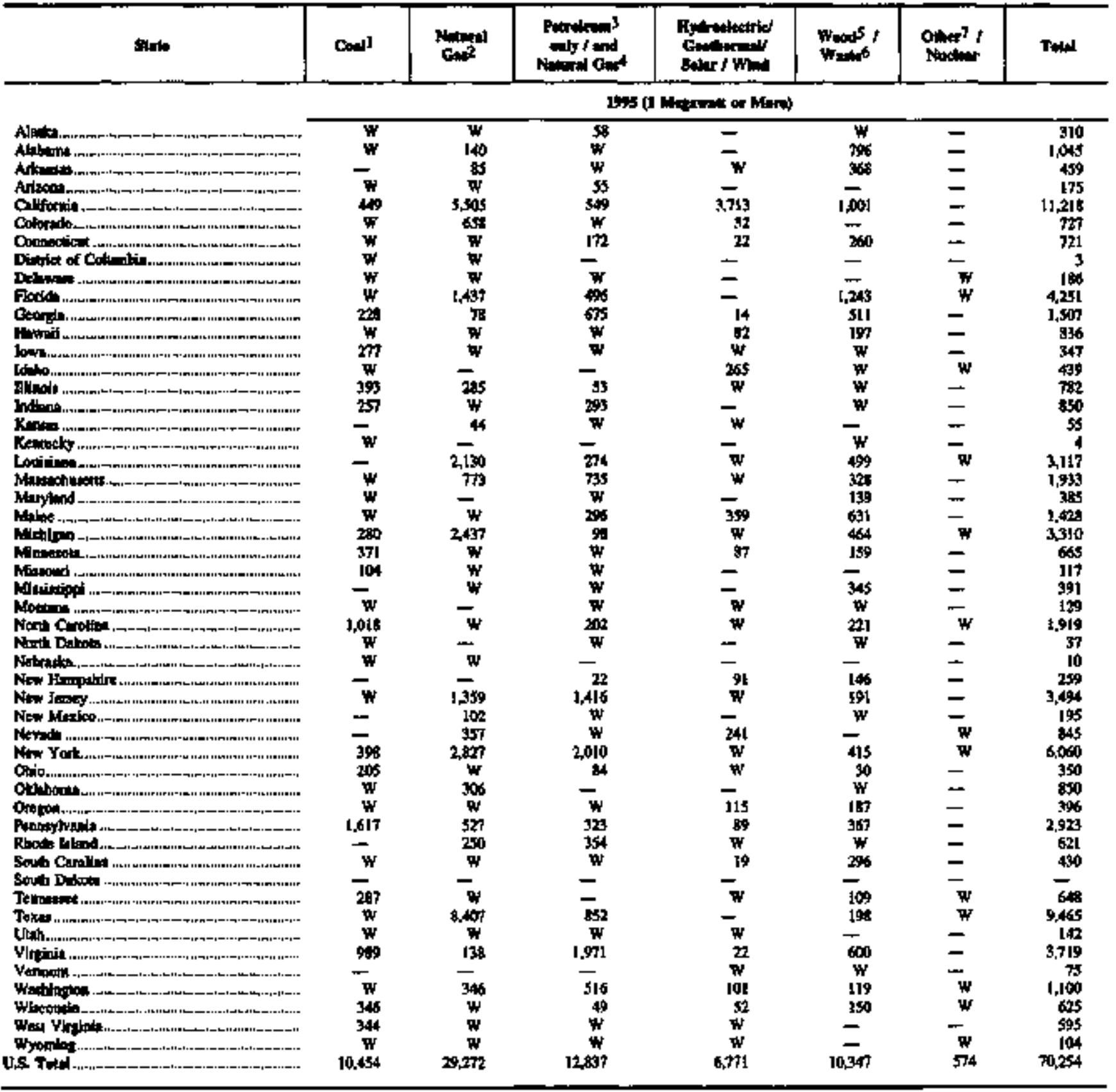

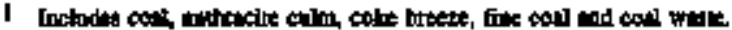

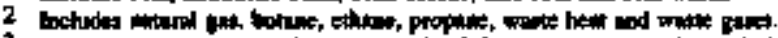

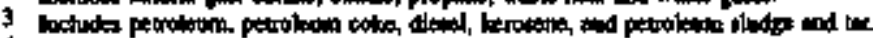

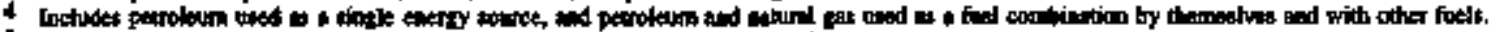

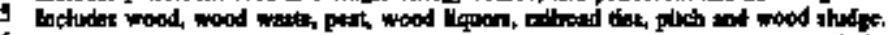

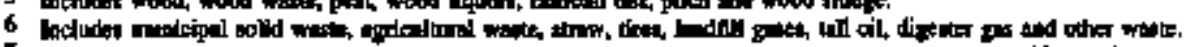

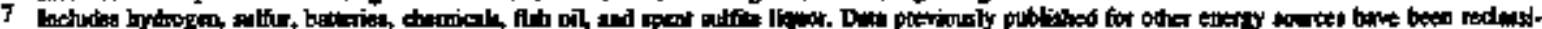

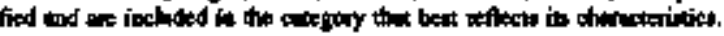

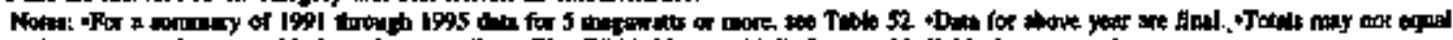

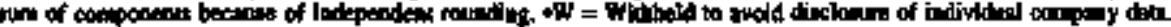

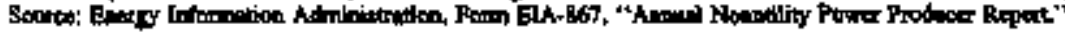


Tabte 56. Installed Capacity at U.S. Nonut"lity Generating Faclitites by Qualifying Facillty Stotus and Census Division, 1991 Through 1995

(Megawatis)

\begin{tabular}{|c|c|c|c|c|c|c|}
\hline \multirow[b]{2}{*}{ Ceth:ex Dhtelan } & \multicolumn{2}{|c|}{ QP Coputits } & \multicolumn{2}{|c|}{ Wan-QF C-incity } & \multicolumn{2}{|c|}{ Tacel Cequents } \\
\hline & Fealditat & 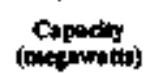 & Phen of & 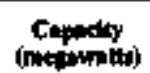 & ren of & 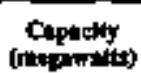 \\
\hline & \multicolumn{6}{|c|}{ to1 (5 Meynetis or More) } \\
\hline \multirow[t]{2}{*}{ 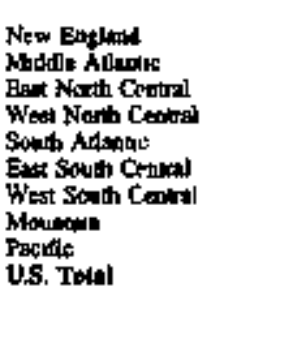 } & $\begin{array}{r}69 \\
105 \\
38 \\
14 \\
86 \\
16 \\
87 \\
28 \\
276 \\
719\end{array}$ & 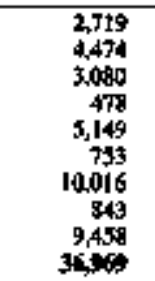 & $\begin{array}{r}28 \\
17 \\
52 \\
22 \\
47 \\
17 \\
30 \\
15 \\
86 \\
308\end{array}$ & $\begin{array}{r}1,137 \\
467 \\
1,954 \\
625 \\
2,153 \\
736 \\
2010 \\
449 \\
1,681 \\
11,245\end{array}$ & $\begin{array}{r}91 \\
122 \\
90 \\
36 \\
133 \\
33 \\
117 \\
43 \\
362 \\
1087\end{array}$ & $\begin{array}{r}3,056 \\
4,940 \\
5,033 \\
1,103 \\
3,263 \\
1,489 \\
12,056 \\
1,292 \\
1+, 131 \\
2,191\end{array}$ \\
\hline & \multicolumn{6}{|c|}{ 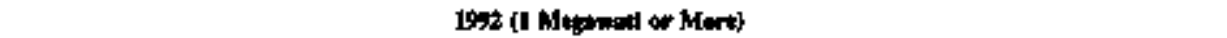 } \\
\hline \multirow[t]{2}{*}{ 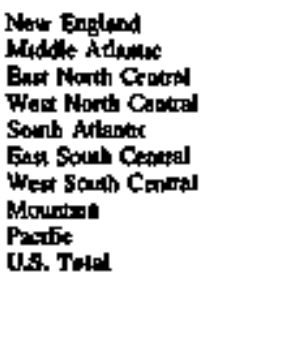 } & $\begin{array}{r}117 \\
211 \\
95 \\
23 \\
127 \\
23 \\
107 \\
13 \\
409 \\
1,17 \%\end{array}$ & $\begin{array}{r}3,0 \pi \\
6,924 \\
3,341 \\
505 \\
6,256 \\
827 \\
10,551 \\
1,313 \\
10,972 \\
41,760\end{array}$ & $\begin{array}{l}75 \\
48 \\
99 \\
44 \\
95 \\
23 \\
49 \\
37 \\
149 \\
637\end{array}$ & $\begin{array}{r}1,327 \\
435 \\
2,108 \\
720 \\
3,187 \\
713 \\
2,128 \\
540 \\
1,876 \\
13,44\end{array}$ & $\begin{array}{r}196 \\
299 \\
194 \\
67 \\
222 \\
46 \\
166 \\
110 \\
549 \\
1040\end{array}$ & $\begin{array}{r}4,404 \\
7,379 \\
5,449 \\
1,224 \\
9,443 \\
1,545 \\
12,680 \\
1,852 \\
12,848 \\
6,3414\end{array}$ \\
\hline & \multicolumn{6}{|c|}{1993 (1 Megowatt or Mera) } \\
\hline \multirow[t]{2}{*}{ 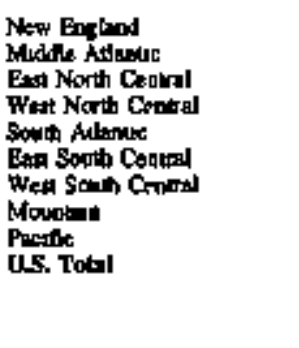 } & $\begin{array}{r}116 \\
230 \\
90 \\
25 \\
139 \\
24 \\
107 \\
91 \\
412 \\
1202\end{array}$ & $\begin{array}{r}3,404 \\
8,351 \\
3,401 \\
512 \\
7,011 \\
801 \\
11,159 \\
1,446 \\
1,506 \\
4,774\end{array}$ & $\begin{array}{r}73 \\
\$ 4 \\
101 \\
49 \\
97 \\
30 \\
60 \\
38 \\
142 \\
04\end{array}$ & $\begin{array}{r}1,325 \\
375 \\
2,143 \\
749 \\
3,291 \\
559 \\
1,910 \\
574 \\
1,716 \\
13,44\end{array}$ & $\begin{array}{r}199 \\
274 \\
199 \\
74 \\
236 \\
54 \\
167 \\
119 \\
554 \\
1,464\end{array}$ & $\begin{array}{r}4,725 \\
8,730 \\
5,546 \\
1,261 \\
10,303 \\
1,714 \\
13,069 \\
2,000 \\
13,345 \\
6,7134\end{array}$ \\
\hline & \multicolumn{6}{|c|}{ vg4 (1 Mezmunit or Mara) } \\
\hline \multirow[t]{2}{*}{ 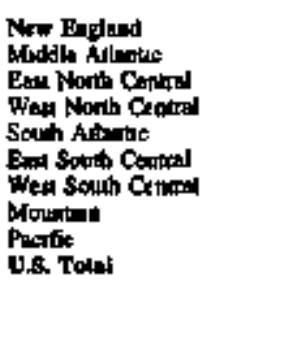 } & $\begin{array}{r}117 \\
248 \\
101 \\
26 \\
131 \\
24 \\
107 \\
85 \\
408 \\
1257\end{array}$ & $\begin{array}{r}3,420 \\
11,350 \\
3,448 \\
534 \\
8,300 \\
930 \\
11,546 \\
1,905 \\
11,926 \\
6,561\end{array}$ & $\begin{array}{r}75 \\
48 \\
118 \\
51 \\
129 \\
35 \\
51 \\
31 \\
146 \\
741\end{array}$ & $\begin{array}{r}1,475 \\
400 \\
2,490 \\
760 \\
4,683 \\
1,159 \\
1,917 \\
776 \\
1,628 \\
14,009\end{array}$ & $\begin{array}{r}162 \\
2 \% 6 \\
219 \\
77 \\
260 \\
39 \\
168 \\
123 \\
354 \\
1,964\end{array}$ & $\begin{array}{r}4895 \\
11,752 \\
5,947 \\
1,298 \\
12,784 \\
2,080 \\
13,764 \\
2,682 \\
13,654 \\
68,461\end{array}$ \\
\hline & \multicolumn{6}{|c|}{ 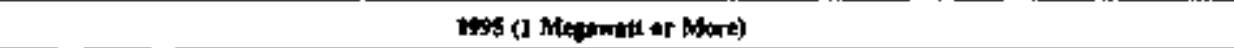 } \\
\hline 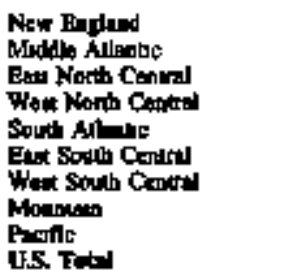 & $\begin{array}{r}119 \\
248 \\
112 \\
28 \\
160 \\
25 \\
109 \\
85 \\
400 \\
1.29\end{array}$ & $\begin{array}{r}3,478 \\
12,057 \\
3,712 \\
575 \\
9,066 \\
1,143 \\
12,165 \\
1,990 \\
11,940 \\
56,245\end{array}$ & $\begin{array}{r}79 \\
45 \\
110 \\
52 \\
125 \\
31 \\
58 \\
39 \\
199 \\
54\end{array}$ & $\begin{array}{r}1,560 \\
390 \\
2,205 \\
658 \\
3,929 \\
9,75 \\
1,726 \\
1,970 \\
1,920 \\
14,100\end{array}$ & $\begin{array}{r}192 \\
306 \\
122 \\
80 \\
245 \\
59 \\
167 \\
129 \\
539 \\
1,973\end{array}$ & 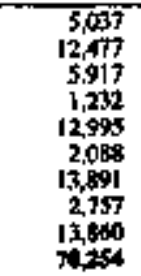 \\
\hline
\end{tabular}

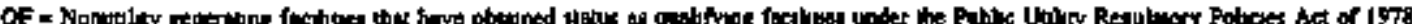

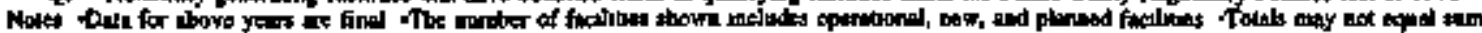

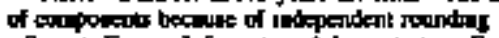

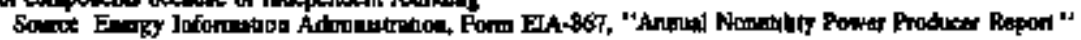




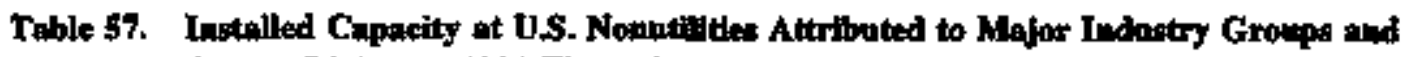
Census Divisions, 1991 Through 1995

(Megawatts)

\begin{tabular}{|c|c|c|c|c|c|c|c|}
\hline Caind Divition & 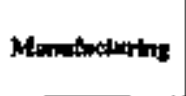 & 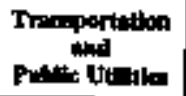 & Berridon & Matiot & & Dithy & Toutet \\
\hline & \multicolumn{7}{|c|}{ 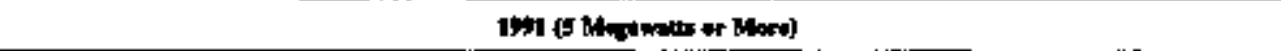 } \\
\hline \multirow[t]{2}{*}{ 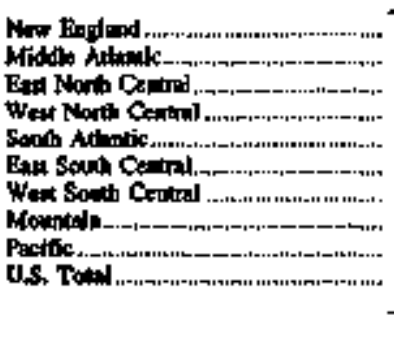 } & $\begin{array}{r}1,525 \\
3,326 \\
4,677 \\
607 \\
5,474 \\
1,466 \\
11,291 \\
493 \\
3,348 \\
1+767\end{array}$ & I98 & $\begin{array}{r}33 \\
184 \\
193 \\
130 \\
524 \\
-W \\
w \\
w \\
w 111\end{array}$ & 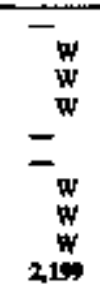 & $\begin{array}{l}-w \\
-w \\
-w \\
-w \\
w \\
w\end{array}$ & 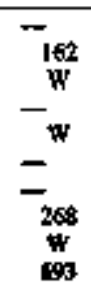 & $\begin{array}{r}3,166 \\
4,940 \\
5,053 \\
1,103 \\
7,369 \\
1,489 \\
12,066 \\
1,292 \\
11,136 \\
4,171\end{array}$ \\
\hline & \multicolumn{7}{|c|}{ 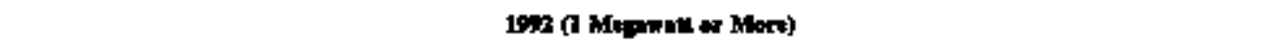 } \\
\hline \multirow[t]{2}{*}{ 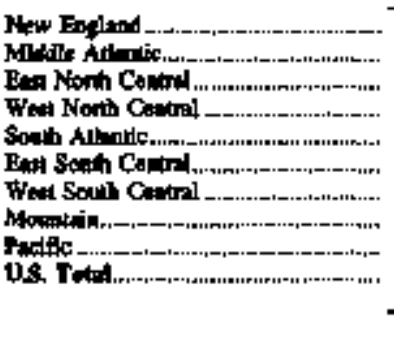 } & $\begin{array}{r}2,1,20 \\
5,112 \\
4,864 \\
695 \\
6,371 \\
1,497 \\
11,665 \\
746 \\
4,342 \\
\$ 7,412\end{array}$ & $\begin{array}{c}2,167 \\
1,395 \\
253 \\
7,804 \\
472 \\
4,740 \\
13,051\end{array}$ & $\begin{array}{c}W \\
470 \\
239 \\
138 \\
150 \\
17 \\
193 \\
157 \\
203\end{array}$ & $\begin{array}{c}w \\
w \\
w \\
w \\
w \\
w \\
190 \\
197 \\
1,560 \\
2,13\end{array}$ & 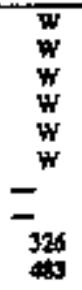 & 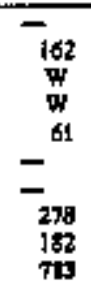 & $\begin{array}{r}4,404 \\
7,379 \\
5,449 \\
1,224 \\
9,443 \\
1,535 \\
12,600 \\
1,852 \\
12,848 \\
5,414\end{array}$ \\
\hline & \multicolumn{7}{|c|}{ 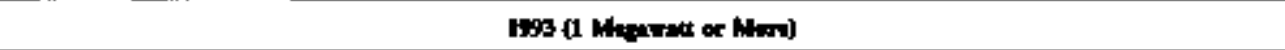 } \\
\hline \multirow[t]{2}{*}{ 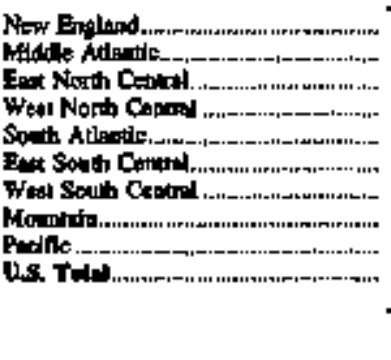 } & $\begin{array}{r}2,248 \\
5,807 \\
4,851 \\
702 \\
6,925 \\
1,676 \\
12,245 \\
772 \\
4,678 \\
39,904\end{array}$ & $\begin{array}{r}2, \overline{363} \\
1,969 \\
301 \\
184 \\
2,914 \\
18 \\
442 \\
566 \\
5,532 \\
14,349\end{array}$ & $\begin{array}{c}w \\
511 \\
211 \\
165 \\
159 \\
w \\
203 \\
150 \\
324 \\
1004\end{array}$ & $\underset{m}{w}$ & 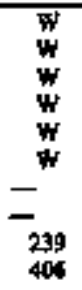 & $\begin{array}{l}- \\
225 \\
w \\
w \\
- \\
269 \\
2173 \\
1,005\end{array}$ & $\begin{array}{r}4,729 \\
8,750 \\
1,546 \\
1,261 \\
10,303 \\
1,734 \\
13,069 \\
2,020 \\
13,385 \\
0,748\end{array}$ \\
\hline & \multicolumn{7}{|c|}{ 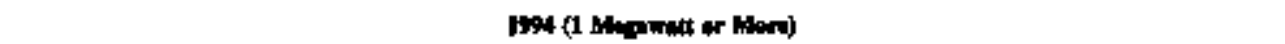 } \\
\hline \multirow[t]{2}{*}{ 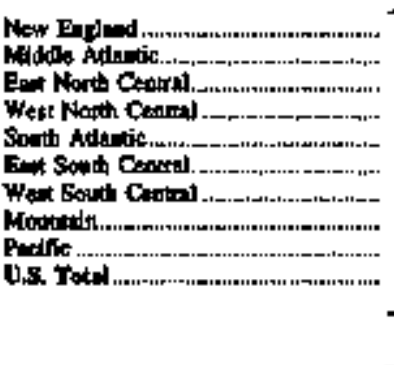 } & $\begin{array}{r}2,267 \\
8,509 \\
5,129 \\
706 \\
8,180 \\
2,009 \\
12,940 \\
835 \\
1,086 \\
4,67\end{array}$ & $\begin{array}{r}2,49 \\
2,168 \\
373 \\
213 \\
3,867 \\
18 \\
442 \\
7799 \\
5,307 \\
10,416\end{array}$ & $\begin{array}{l}W \\
516 \\
287 \\
166 \\
116 \\
202 \\
139 \\
433 \\
207\end{array}$ & $\begin{array}{c}-w \\
w \\
w \\
w \\
180 \\
245 \\
2409 \\
3,258\end{array}$ & 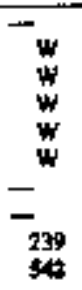 & 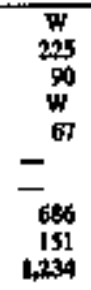 & $\begin{array}{r}4,695 \\
11,752 \\
5,947 \\
1,206 \\
12,784 \\
2,088 \\
13,764 \\
2,642 \\
13,654 \\
43,461\end{array}$ \\
\hline & \multicolumn{7}{|c|}{ 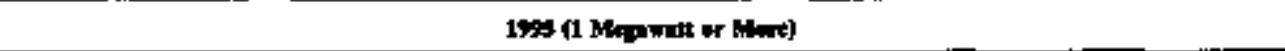 } \\
\hline 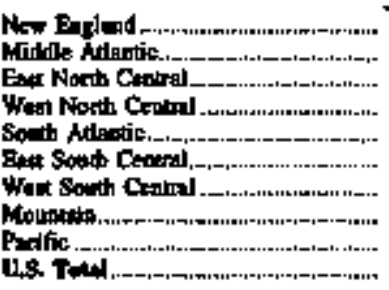 & $\begin{array}{r}2,201 \\
9,282 \\
5,066 \\
755 \\
8,842 \\
2,027 \\
13,257 \\
\$ 65 \\
5,250 \\
4,604\end{array}$ & $\begin{array}{c}2,502 \\
2,074 \\
356 \\
104 \\
3,704 \\
5,258 \\
15,144\end{array}$ & $\begin{array}{c}W \\
353 \\
353 \\
164 \\
169 \\
W \\
202 \\
132 \\
436 \\
2,140\end{array}$ & $\begin{array}{c}- \\
W \\
w \\
W \\
w \\
w \\
17 \\
245 \\
2,49 \\
34\end{array}$ & $\begin{array}{c}-w \\
w \\
w \\
w \\
w \\
w \\
-w \\
-w 4\end{array}$ & $\begin{array}{c}w \\
225 \\
w \\
w \\
204 \\
-w \\
692 \\
176 \\
1,36\end{array}$ & $\begin{array}{r}5,037 \\
12,477 \\
3,917 \\
1,292 \\
12,995 \\
2,088 \\
13,891 \\
2,757 \\
13,860 \\
70,234\end{array}$ \\
\hline
\end{tabular}

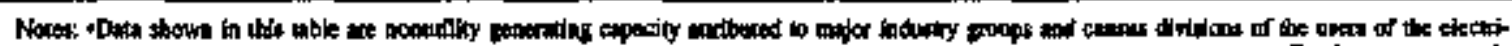

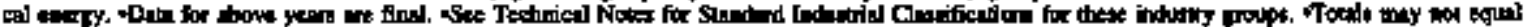

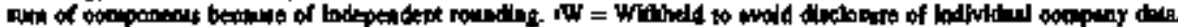

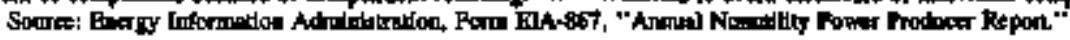


Table 58. Gross Generation for U.S. Nonutility Power Producers by Binergy Source and Census Division, 1991 Throngh 1995

(Million Kilowathours)

\begin{tabular}{|c|c|c|c|c|c|c|c|c|}
\hline Congen Divitum & Canl & Purrolemente & 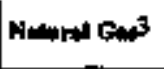 & Sylimeletetris & 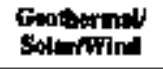 & $\begin{array}{l}\text { Foud } \\
\text { Thats }\end{array}$ & 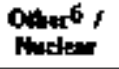 & Theld \\
\hline & \multicolumn{8}{|c|}{ 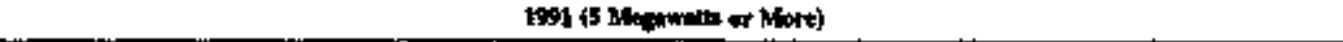 } \\
\hline \multirow[t]{2}{*}{ 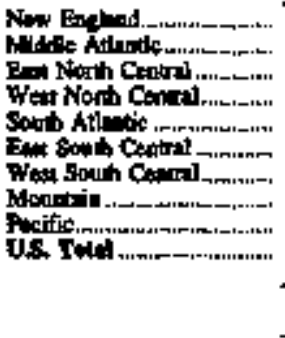 } & $\begin{array}{r}2,557 \\
7,741 \\
5,456 \\
1,841 \\
11,504 \\
2,065 \\
5,459 \\
1,044 \\
3,409 \\
4,047\end{array}$ & 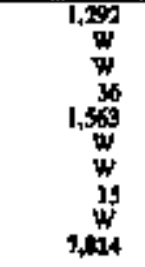 & $\begin{array}{r}6,710 \\
11,050 \\
12,173 \\
745 \\
3,706 \\
2,192 \\
50,095 \\
1,932 \\
32,796 \\
51940\end{array}$ & $\begin{array}{l}2.264 \\
877 \\
266 \\
227 \\
760 \\
= \\
-511 \\
1,357 \\
6,140\end{array}$ & 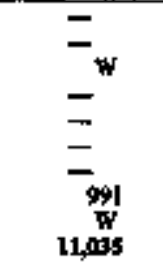 & $\begin{array}{r}7,553 \\
3,933 \\
3,004 \\
466 \\
12,991 \\
4,735 \\
5,404 \\
755 \\
8,850 \\
7,741\end{array}$ & 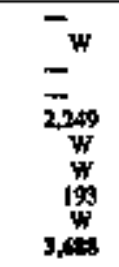 & $\begin{array}{r}20,347 \\
24,686 \\
21,424 \\
3,316 \\
32,773 \\
9,013 \\
73,444 \\
5,48 \\
57,443 \\
240,448\end{array}$ \\
\hline & \multicolumn{8}{|c|}{ 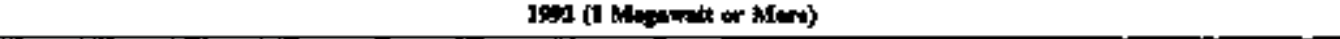 } \\
\hline \multirow[t]{2}{*}{ 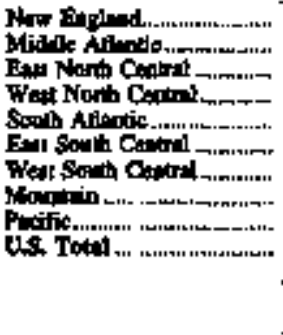 } & 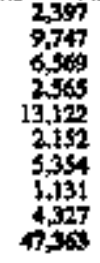 & $\begin{array}{r}1,506 \\
7 \\
510 \\
50 \\
2,354 \\
W \\
2,129 \\
40 \\
3,017 \\
10,046\end{array}$ & $\begin{array}{r}11,056 \\
22,504 \\
13,349 \\
749 \\
5,266 \\
2,401 \\
62,469 \\
3,430 \\
37,354 \\
15,74\end{array}$ & 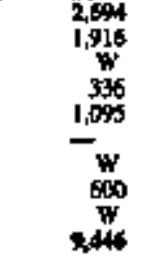 & $\begin{array}{l}\bar{z} \\
= \\
= \\
\bar{z} \\
1,214 \\
1,0,246\end{array}$ & $\begin{array}{r}5,416 \\
5,241 \\
3,566 \\
670 \\
14,996 \\
5,163 \\
5,406 \\
816 \\
9,407 \\
5,007\end{array}$ & 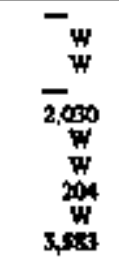 & $\begin{array}{r}26,071 \\
40,850 \\
24,358 \\
4,371 \\
3,504 \\
9,060 \\
77,000 \\
7,453 \\
67,040 \\
29,411\end{array}$ \\
\hline & \multicolumn{8}{|c|}{ 19es (I Mngand at Mort) } \\
\hline \multirow[t]{2}{*}{ 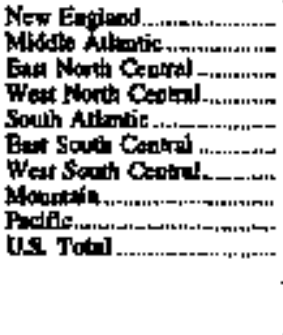 } & $\begin{array}{r}2,417 \\
10,950 \\
7,138 \\
2,652 \\
15,466 \\
2,289 \\
5,798 \\
1,317 \\
5,940 \\
50,364\end{array}$ & $\begin{array}{r}1,764 \\
67 \\
63 \\
2,774 \\
1,279 \\
112 \\
2,905 \\
13,344\end{array}$ & $\begin{array}{r}12,460 \\
18,381 \\
14,274 \\
687 \\
7,486 \\
2,170 \\
6,3,077 \\
4,638 \\
10,706 \\
17,2,7\end{array}$ & 1.526 & $\begin{array}{l}\bar{z} \\
= \\
= \\
= \\
\overline{150} \\
12110\end{array}$ & $\begin{array}{r}9,062 \\
5,714 \\
3,602 \\
737 \\
14,821 \\
6,019 \\
5,001 \\
767 \\
9,270 \\
5 \$, 744\end{array}$ & ${ }_{w 1,}^{w}$ & $\begin{array}{r}2,279 \\
48,705 \\
26,211 \\
4,675 \\
49,620 \\
10,741 \\
80,073 \\
9,572 \\
73,400 \\
\$ 4,724\end{array}$ \\
\hline & \multicolumn{8}{|c|}{ J) 4 (f Meponta or Mer) } \\
\hline \multirow[t]{2}{*}{ 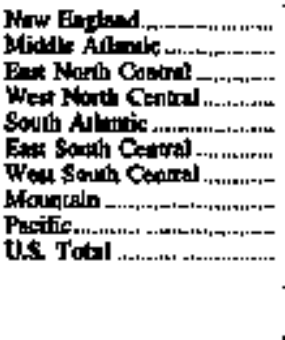 } & 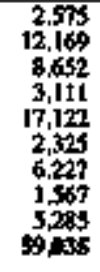 & $\begin{array}{r}1,557 \\
2,213 \\
317 \\
W \\
3,369 \\
174 \\
1 \% \\
115 \\
3,114 \\
15,196\end{array}$ & $\begin{array}{r}13,917 \\
34,176 \\
15,139 \\
726 \\
11,340 \\
2,246 \\
64,768 \\
6,131 \\
43,762 \\
12,214\end{array}$ & 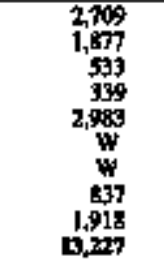 & $\begin{array}{l}\overline{-} \\
-w \\
= \\
-w \\
12752\end{array}$ & 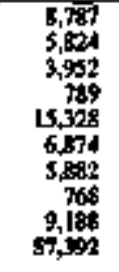 & 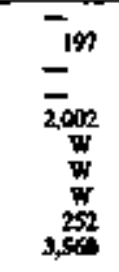 & $\begin{array}{r}39,925 \\
36,457 \\
25,993 \\
5,077 \\
52,152 \\
12,756 \\
81,999 \\
11,273 \\
76,271 \\
35,125\end{array}$ \\
\hline & \multicolumn{8}{|c|}{ 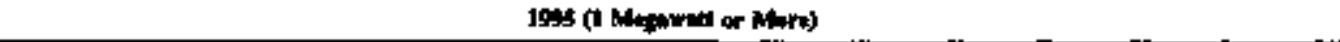 } \\
\hline 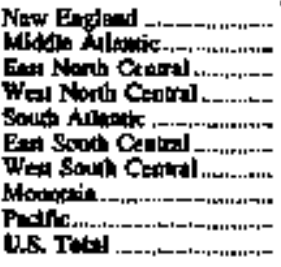 & $\begin{array}{r}2,400 \\
14,603 \\
6,619 \\
2,600 \\
18,891 \\
2,775 \\
3,786 \\
1,511 \\
4,404 \\
57,64\end{array}$ & $\begin{array}{r}2,112 \\
1,781 \\
685 \\
w \\
1,729 \\
125 \\
w \\
179 \\
169 \\
w\end{array}$ & $\begin{array}{r}1,, 418 \\
45,181 \\
16,061 \\
690 \\
15,735 \\
2,181 \\
66,547 \\
6,624 \\
43,692 \\
210,402\end{array}$ & 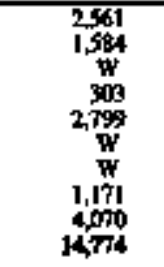 & $\begin{array}{l}= \\
= \\
= \\
= \\
12,205 \\
1304\end{array}$ & 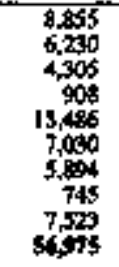 & 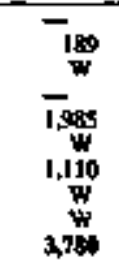 & $\begin{array}{r}29,350 \\
69,768 \\
28,430 \\
4,702 \\
57,624 \\
12,700 \\
23,172 \\
12,703 \\
76,415 \\
374,43\end{array}$ \\
\hline
\end{tabular}

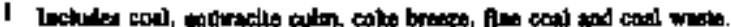

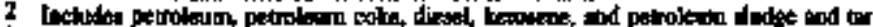

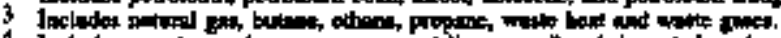

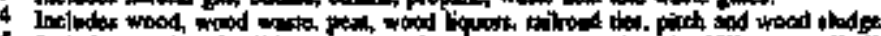

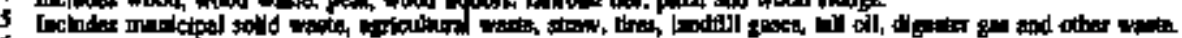

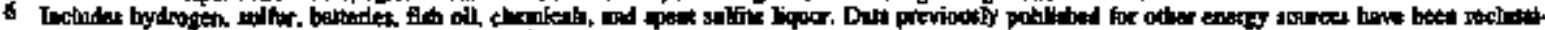

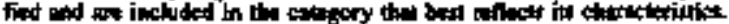

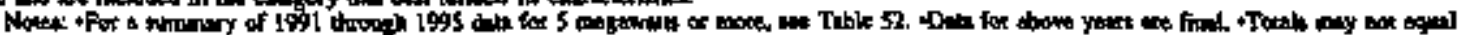

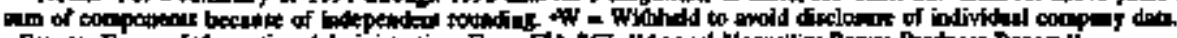

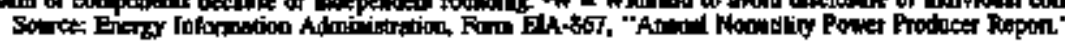


Table 59. Groas Generation for U.S. Nonotilty Power Prodwers by Energy Soarce and State, 1995

(Million Kilowathours)

\begin{tabular}{|c|c|c|c|c|c|c|c|c|}
\hline State & $C_{1+1}$ & Fetrelen=2 & Nond Gar & Ej-inulestric & 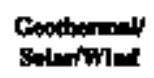 & woodst & 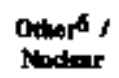 & Troul \\
\hline & \multicolumn{8}{|c|}{ 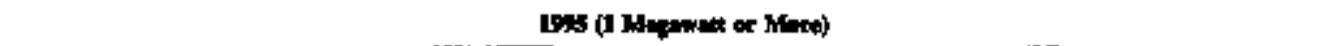 } \\
\hline Alth & $\mathbf{W}$ & 139 & $\bar{F}$ & $\Rightarrow$ & - & w & ש. & $1 \overline{239}$ \\
\hline 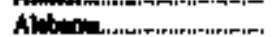 & 565 & 106 & 1,240 & - & - & 4318 & - & 6,260 \\
\hline 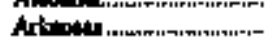 & $W$ & $w$ & 912 & $\overline{-}$ & - & 9,634 & - w & $2,6 \pm$ \\
\hline 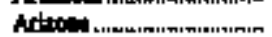 & w & 20 & 477 & - & - & $W$ & - & 578 \\
\hline 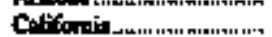 & 2,979 & 1,904 & 3056 & $w$ & 11.948 & 5,253 & $w$ & 62832 \\
\hline 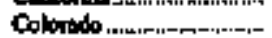 & W & W & 2,665 & $\$ 25$ & - & W & - & $3,06 ?$ \\
\hline 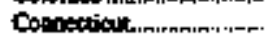 & $\boldsymbol{w}$ & 189 & 1.57 & $w$ & ـ & $1.60 \%$ & - & 4812 \\
\hline Dithist of Colbitbit , & - & - & - & - & - & - & $m$ & $=$ \\
\hline 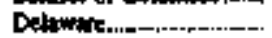 & $w$ & $\boldsymbol{W}$ & $\boldsymbol{w}$ & 一 & - & 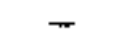 & $w$ & 750 \\
\hline 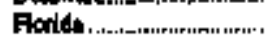 & 4,153 & 640 & 8064 & 一 & 一 & 5.839 & 1,702 & 21.197 \\
\hline Geactit. & 1.120 & 665 & 1,304 & 51 & - & 3,133 & - & 6,285 \\
\hline 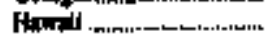 & W & 1,755 & $w$ & $\mathbf{6}$ & $\mathbf{W}$ & 693 & W & 4,327 \\
\hline 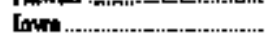 & 1,002 & 9 & int & $\mathbf{W}$ & - & 男 & - & 1,177 \\
\hline 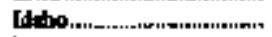 & $\mathbf{W}$ & w & $w$ & $\$ 96$ & - & sti & $\mathbf{w}$ & 1,823 \\
\hline 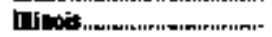 & I & $w$ & 1,504 & $\mathbf{W}$ & - & $w$ & - & 3,950 \\
\hline 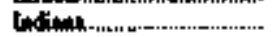 & $\$ \$ 0$ & $\mathbf{w}$ & 3,100 & - & - & $\mathbf{w}$ & - & 4.281 \\
\hline 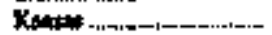 & - & W & 18) 1 & $\boldsymbol{w}$ & 一 & - & مـ & 195 \\
\hline 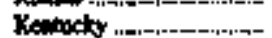 & - & $\boldsymbol{w}$ & - & $-"$ & 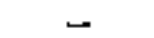 & $\mathbf{W}$ & - & 4 \\
\hline Lotididne & $\mathbf{w}$ & $\mathbb{w}$ & 14,034 & $\%$ & en & 2915 & $w$ & 20,196 \\
\hline 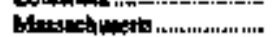 & $\boldsymbol{w}$ & 200 & 8,310 & $\mathbf{w}$ & - & 2,156 & - & 11,02 \\
\hline 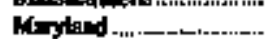 & W & $w$ & $W$ & - & - & 108 & - & 177 \\
\hline 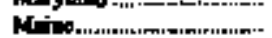 & $\mathbf{W}$ & $1,5 \$ 5$ & $\boldsymbol{w}$ & $1.7 \% 7$ & $=$ & 3.301 & - & 7,628 \\
\hline 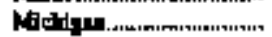 & $w$ & 176 & 10,607 & 130 & - & 2694 & $\mathbf{w}$ & 15,581 \\
\hline H' & 1,283 & w & 316 & 20 & $\mathbf{w}$ & 835 & - & 1, gl: \\
\hline 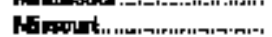 & W & $w$ & $w$ & - & - & $\mathbf{W}$ & - & 33 \\
\hline 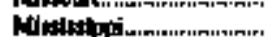 & $w$ & $\vec{w}$ & 691 & - & - & 2048 & - & 2,020 \\
\hline 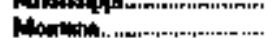 & $w$ & w & $\mathbf{W}$ & $w$ & - & $W$ & - & 615 \\
\hline 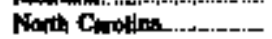 & 6.139 & 256 & 542 & $\ddot{w}$ & $=$ & $1, \pi / 7$ & $w$ & 10,780 \\
\hline North Dabola................. & $\boldsymbol{W}$ & $w$ & $\mathbf{W}$ & - & 一 & W & - & I酶 \\
\hline 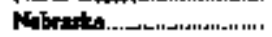 & $w$ & - & $\boldsymbol{\psi}$ & - & - & - & 一 & 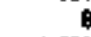 \\
\hline Plen Hopthire............... & - & III & - & 406 & - & 1,062 & 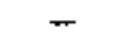 & 1,590 \\
\hline 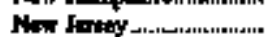 & W & 723 & 14,49 & $w$ & 一 & 1320 & - & I8.815 \\
\hline 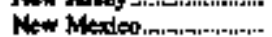 & - & $+w$ & 399 & - & - & $w$ & - & 413 \\
\hline 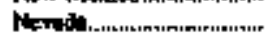 & - & w & 2,428 & $w$ & $1,69 \%$ & - & $\mathbf{W}$ & $\$, 127$ \\
\hline 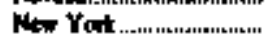 & 2,547 & w & 26,751 & 1,223 & - & 2,399 & $\mathbf{W}$ & 33,502 \\
\hline 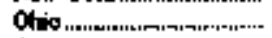 & 74 & 31 & 363 & $w$ & 一 & $\mathbf{W}$ & 一 & 1,551 \\
\hline 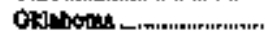 & W & $w$ & $1,3,1$ & - & - & $\boldsymbol{F}$ & - & 5,031 \\
\hline 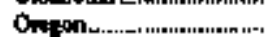 & $\mathbf{W}$ & $\mathbf{w}$ & 285 & 356 & - & 653 & - & 1,321 \\
\hline 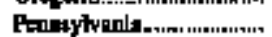 & 10,043 & 559 & 3,801 & $w$ & - & 2513 & $w$ & 17,400 \\
\hline 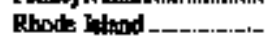 & - & 38 & 3.836 & $w$ & - & $W$ & - & 3,965 \\
\hline 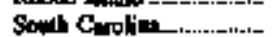 & 561 & 165 & 10 & 65 & - & 1,738 & - & 2,632 \\
\hline South Doluocin_-,...-..-1- & - & - & $\sigma$ & - & - & - & - & $\cdots$ \\
\hline 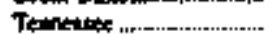 & 1,742 & $\boldsymbol{w}$ & $\mathbf{2 l 0}$ & $w$ & 一 & 600 & $w$ & 3,615 \\
\hline 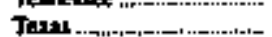 & 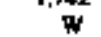 & 3,000 & $\sin 00 \%$ & $-{ }^{n}$ & - & $\mathbf{w}$ & 615 & 53,326 \\
\hline 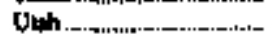 & $w$ & $w$ & $\mathbf{W}$ & $w$ & - & - & - & 740 \\
\hline Vingloin & 4,328 & 56 & 3,587 & $\mathbf{w}$ & - & 2,279 & $w$ & 10,844 \\
\hline Vermont_-_-................... & - & $\mathbf{w}$ & - & 140 & - & $\mathbf{W}$ & - & 347 \\
\hline 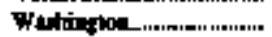 & $\mathbf{W}$ & p & 4.706 & 47 & - & 790 & $\mathbf{w}$ & 6,703 \\
\hline Whónip....-............ & $\$ 311$ & W & 325 & 276 & 一 & 840 & w & 3,066 \\
\hline Wear Vhritis............... & 2,128 & W & 403 & $\mathbf{w}$ & 一 & $\mathbf{w}$ & $\boldsymbol{W}$ & 3,356 \\
\hline Wyodint & $w$ & $\boldsymbol{W}$ & $w$ & $-"$ & - & - & $\mathbf{W}$ & 60 \\
\hline US Tratil. & 57,668 & 16,987 & 210,332 & 14.374 & 13,921 & 56.975 & 3,780 & 374,438 \\
\hline
\end{tabular}

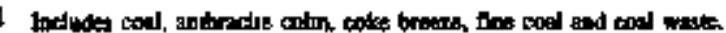

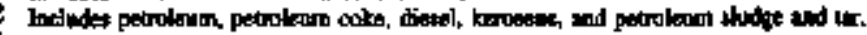

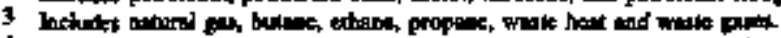

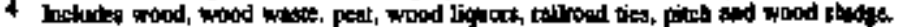

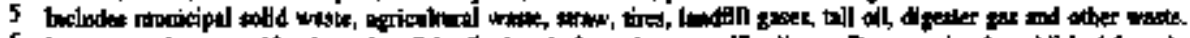


Table 60. Gross Generation at U.S. Nonntillity Gemerating Focilities by Qualifying Facility Status and Census Diviston, 1991 Through 1995

(Million Kilowatthours)

\begin{tabular}{|c|c|c|c|c|c|c|c|}
\hline \multirow[b]{2}{*}{ 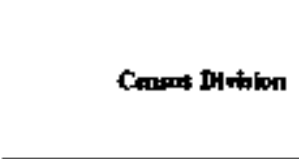 } & & \multicolumn{2}{|c|}{ Q7 Genernith } & \multicolumn{2}{|c|}{ Non-QF Carertion } & \multicolumn{2}{|c|}{ Total Gentanion } \\
\hline & & $\underset{\mathrm{Na}}{\mathrm{Na} \text { or }}$ & 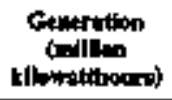 & $\begin{array}{c}\text { star of } \\
\text { Bectilktes }\end{array}$ & 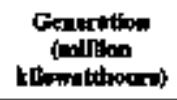 & $\begin{array}{l}\text { Who. of } \\
\text { Focitstites }\end{array}$ & 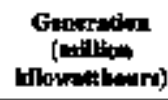 \\
\hline & & \multicolumn{6}{|c|}{ 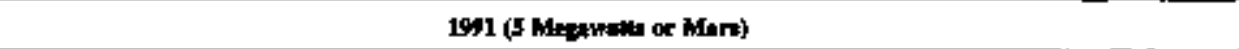 } \\
\hline \multirow[t]{2}{*}{ 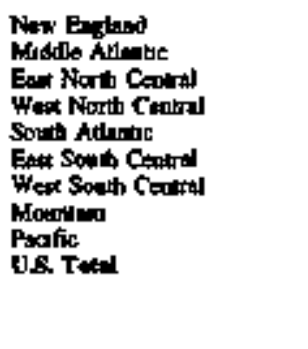 } & & $\begin{array}{r}60 \\
105 \\
38 \\
14 \\
86 \\
16 \\
87 \\
27 \\
276 \\
75\end{array}$ & $\begin{array}{r}15,448 \\
23,202 \\
13,169 \\
1,964 \\
23,952 \\
4,909 \\
61,661 \\
3,673 \\
51,570 \\
139,59\end{array}$ & $\begin{array}{l}22 \\
17 \\
52 \\
22 \\
47 \\
17 \\
30 \\
15 \\
85 \\
30\end{array}$ & $\begin{array}{r}4,899 \\
1,684 \\
8,245 \\
1,331 \\
8,791 \\
4,104 \\
11,743 \\
1,769 \\
6,273 \\
4,149\end{array}$ & $\begin{array}{r}91 \\
122 \\
90 \\
36 \\
133 \\
33 \\
117 \\
43 \\
362 \\
1,407\end{array}$ & $\begin{array}{r}20,347 \\
21,886 \\
21,424 \\
3,316 \\
32,773 \\
9,013 \\
79,404 \\
5,442 \\
57,843 \\
249,448\end{array}$ \\
\hline & & \multicolumn{6}{|c|}{ J92 (1 Megratt or Mot) } \\
\hline \multirow[t]{2}{*}{ 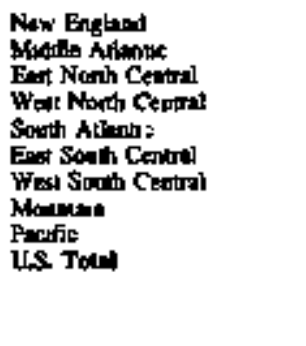 } & & $\begin{array}{r}111 \\
211 \\
95 \\
23 \\
127 \\
23 \\
107 \\
73 \\
407 \\
1,175\end{array}$ & $\begin{array}{r}18,717 \\
38,758 \\
15,683 \\
2,073 \\
28,916 \\
5,413 \\
65,0807 \\
5,507 \\
60,979 \\
241,126\end{array}$ & $\begin{array}{l}75 \\
48 \\
99 \\
44 \\
95 \\
23 \\
59 \\
37 \\
149 \\
94\end{array}$ & $\begin{array}{r}7,354 \\
2,132 \\
8,675 \\
2,398 \\
9,868 \\
4,549 \\
11,970 \\
1,948 \\
6,061 \\
64,875\end{array}$ & $\begin{array}{r}186 \\
259 \\
194 \\
67 \\
282 \\
46 \\
166 \\
110 \\
558 \\
148\end{array}$ & $\begin{array}{r}26,071 \\
44,890 \\
24,358 \\
4,371 \\
38,804 \\
9,962 \\
77,060 \\
7,455 \\
67,040 \\
296,041\end{array}$ \\
\hline & & \multicolumn{6}{|c|}{ Johs (I Mlotwet or Mort) } \\
\hline \multirow[t]{2}{*}{ 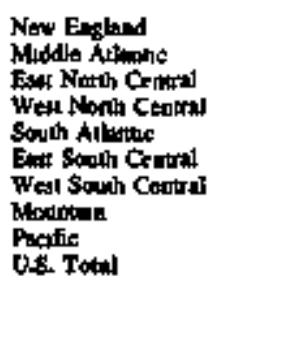 } & - & $\begin{array}{r}116 \\
240 \\
96 \\
25 \\
139 \\
24 \\
107 \\
81 \\
112 \\
1,212\end{array}$ & $\begin{array}{r}20,936 \\
46,602 \\
17,238 \\
2,257 \\
32,132 \\
5,383 \\
68,884 \\
7,391 \\
66,820 \\
2,7,41\end{array}$ & $\begin{array}{r}77 \\
41 \\
101 \\
49 \\
97 \\
30 \\
60 \\
38 \\
142 \\
64\end{array}$ & $\begin{array}{r}7,293 \\
2,103 \\
8,573 \\
2,418 \\
11,488 \\
5,358 \\
11,190 \\
2,181 \\
6,580 \\
6,540\end{array}$ & $\begin{array}{r}189 \\
274 \\
199 \\
74 \\
256 \\
54 \\
167 \\
119 \\
554 \\
1.56\end{array}$ & $\begin{array}{r}28,279 \\
48,706 \\
26,211 \\
1,675 \\
43,620 \\
10,711 \\
84,073 \\
9,572 \\
73,400 \\
30,515\end{array}$ \\
\hline & & \multicolumn{6}{|c|}{ 1904 (1 Meparant of Morn) } \\
\hline \multirow[t]{2}{*}{ 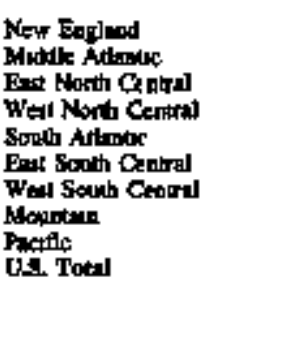 } & - & $\begin{array}{r}117 \\
249 \\
10 \mid \\
26 \\
131 \\
24 \\
107 \\
85 \\
107 \\
1,247\end{array}$ & $\begin{array}{r}21,832 \\
54,274 \\
17,961 \\
2,480 \\
39,312 \\
5,702 \\
70,773 \\
9,089 \\
70,699 \\
192,40\end{array}$ & $\begin{array}{r}75 \\
48 \\
118 \\
51 \\
125 \\
35 \\
61 \\
35 \\
145 \\
140\end{array}$ & $\begin{array}{r}8,093 \\
2,183 \\
11.033 \\
2,597 \\
12,840 \\
7,005 \\
11,217 \\
2,183 \\
5,612 \\
10.046\end{array}$ & $\begin{array}{r}192 \\
296 \\
219 \\
77 \\
280 \\
59 \\
168 \\
129 \\
554 \\
1.58\end{array}$ & $\begin{array}{r}29,915 \\
36,457 \\
28,99,3 \\
5,477 \\
51,152 \\
12,786 \\
81,989 \\
11,273 \\
76,271 \\
364,925\end{array}$ \\
\hline & & \multicolumn{6}{|c|}{ Jess (I Mhapats or Mern) } \\
\hline 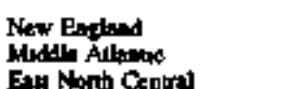 & . & $\begin{array}{l}119 \\
258 \\
112\end{array}$ & $\begin{array}{l}21,681 \\
67,651 \\
19,255\end{array}$ & $\begin{array}{r}73 \\
48 \\
110\end{array}$ & $\begin{array}{l}7,659 \\
2,107 \\
9,132\end{array}$ & $\begin{array}{l}192 \\
706 \\
272\end{array}$ & $\begin{array}{l}29.150 \\
69.768 \\
20.436\end{array}$ \\
\hline
\end{tabular}


Table 53. Inotalled Capacity at U.S. Nonatility Generatiag Facllitied by Foadl Feets, Renewable Enerty Sources, and Census Division, 19,1 Thmough 1995

(Megawatts)

\begin{tabular}{|c|c|c|c|}
\hline Cartas Div'don & Fom Panlel & 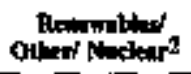 & 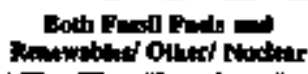 \\
\hline & \multicolumn{3}{|c|}{ 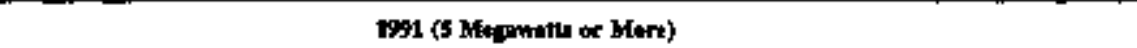 } \\
\hline \multirow[t]{2}{*}{ 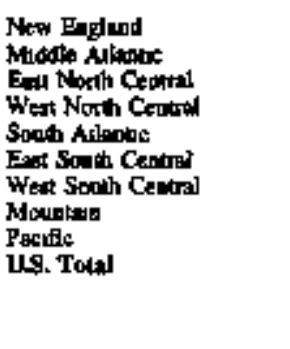 } & $\begin{array}{r}1,842 \\
3,690 \\
3,633 \\
082 \\
3,597 \\
453 \\
10,019 \\
564 \\
5,044 \\
3,004\end{array}$ & $\begin{array}{r}1,180 \\
82] \\
210 \\
105 \\
1,2 \leqslant 0 \\
162 \\
4 ! \\
445 \\
4,508 \\
8,754\end{array}$ & $\begin{array}{r}834 \\
429 \\
054 \\
116 \\
2,416 \\
872 \\
1,996 \\
283 \\
347 \\
8407\end{array}$ \\
\hline & \multicolumn{3}{|c|}{ 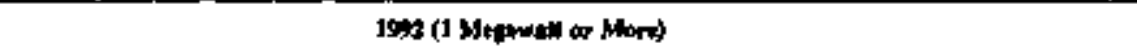 } \\
\hline \multirow[t]{2}{*}{ 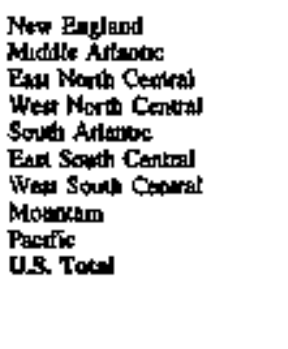 } & $\begin{array}{r}2,115 \\
5,883 \\
4,024 \\
956 \\
5,413 \\
486 \\
10,239 \\
540 \\
6,541 \\
37,000\end{array}$ & $\begin{array}{r}1,429 \\
1,481 \\
3897 \\
141 \\
1.388 \\
188 \\
260 \\
601 \\
5,299 \\
1,9715\end{array}$ & $\begin{array}{r}861 \\
415 \\
1,038 \\
127 \\
2,648 \\
867 \\
2,176 \\
285 \\
668 \\
9,074\end{array}$ \\
\hline & \multicolumn{3}{|c|}{ 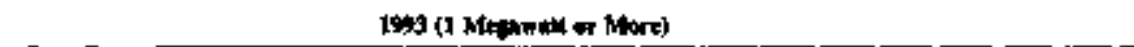 } \\
\hline \multirow[t]{2}{*}{ 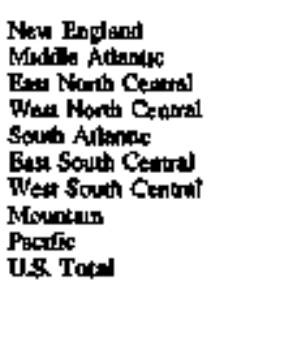 } & $\begin{array}{r}2,369 \\
7,107 \\
4,079 \\
972 \\
6,357 \\
444 \\
10,673 \\
1,042 \\
7,420 \\
4,463\end{array}$ & $\begin{array}{r}1,479 \\
1,089 \\
421 \\
1,43 \\
1,354 \\
253 \\
255 \\
695 \\
5,205 \\
1.345\end{array}$ & $\begin{array}{r}892 \\
335 \\
1,046 \\
146 \\
2.587 \\
1.097 \\
1,742 \\
344 \\
760 \\
3,474\end{array}$ \\
\hline & \multicolumn{3}{|c|}{ 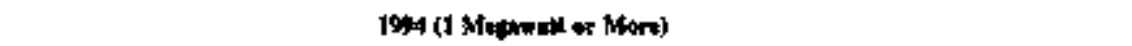 } \\
\hline \multirow[t]{2}{*}{ 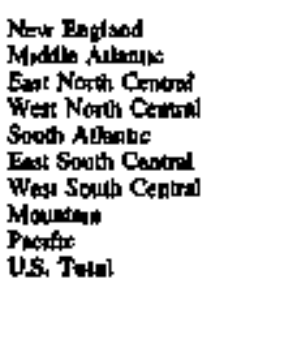 } & $\begin{array}{r}2, \overline{532} \\
9,956 \\
4,476 \\
959 \\
7,778 \\
426 \\
11,339 \\
1,819 \\
7,700 \\
4656\end{array}$ & $\begin{array}{r}1,496 \\
1,215 \\
341 \\
175 \\
1,799 \\
245 \\
245 \\
610 \\
5,092 \\
11,141\end{array}$ & $\begin{array}{r}877 \\
591 \\
1,130 \\
159 \\
1,406 \\
1,418 \\
2,170 \\
753 \\
861 \\
10,344\end{array}$ \\
\hline & \multicolumn{3}{|c|}{1998 (I Mtepwath of Mort) } \\
\hline 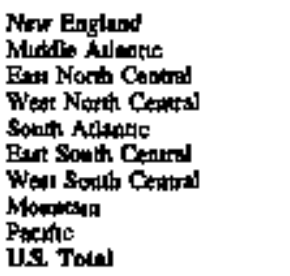 & $\begin{array}{r}2,619 \\
10,617 \\
4,243 \\
918 \\
3,2,42 \\
4,3 \\
11,419 \\
1,890 \\
8,014 \\
40,464\end{array}$ & $\begin{array}{r}1,426 \\
1,269 \\
303 \\
185 \\
2,095 \\
234 \\
261 \\
614 \\
5,014 \\
11,601\end{array}$ & $\begin{array}{r}992 \\
591 \\
1,171 \\
130 \\
2,698 \\
1,418 \\
2,217 \\
253 \\
831 \\
14,29\end{array}$ \\
\hline
\end{tabular}

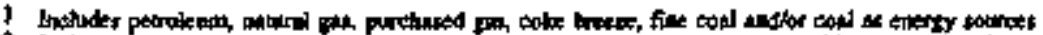

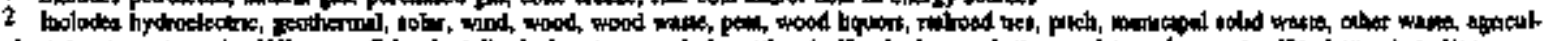

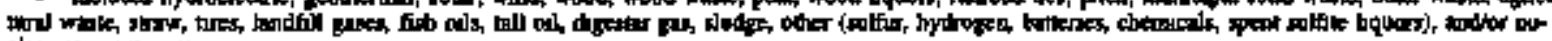

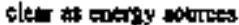

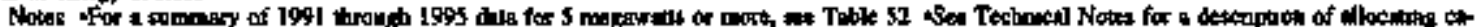

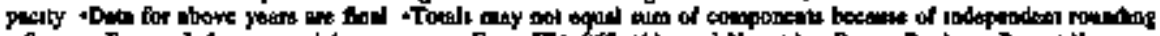

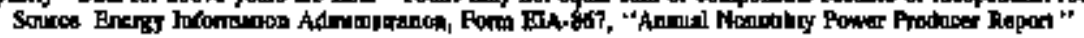


Table 54. Installed Copacky at U.S. Nonutilty Generating Fancitities by Energy Source and Cenous Division, 1991 Through 1995 (Megawats)

\begin{tabular}{|c|c|c|c|c|c|c|c|}
\hline Cennus Dotritikn & Confl & Nated & 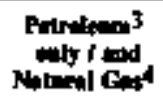 & 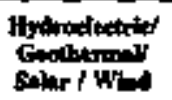 & Hond & $\begin{array}{l}\text { Otinsr? } \\
\text { Nuctener }\end{array}$ & Tent \\
\hline & \multicolumn{7}{|c|}{ S91 (5 Mepentip or Mere) } \\
\hline \multirow[t]{2}{*}{ 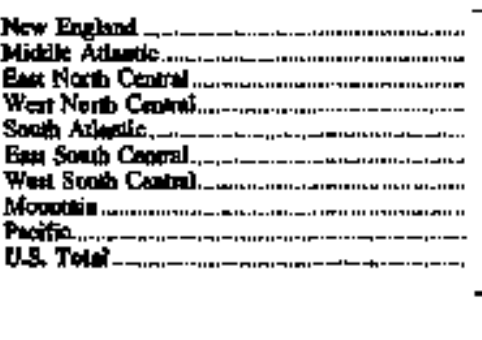 } & 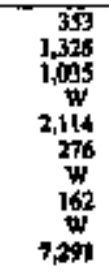 & 年, & 1,036 & $\begin{array}{l}4,32 \\
239 \\
59 \\
55 \\
155 \\
- \\
=363 \\
3,343 \\
4,447\end{array}$ & $\begin{array}{r}1,192 \\
684 \\
577 \\
104 \\
2,809 \\
8,84 \\
1,137 \\
1,99 \\
1,652 \\
7,27\end{array}$ & 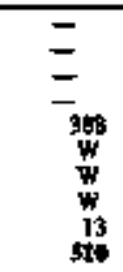 & 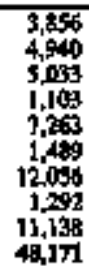 \\
\hline & \multicolumn{7}{|c|}{ 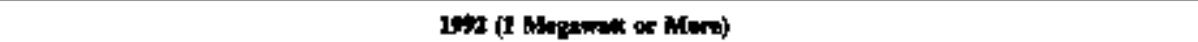 } \\
\hline \multirow[t]{2}{*}{ 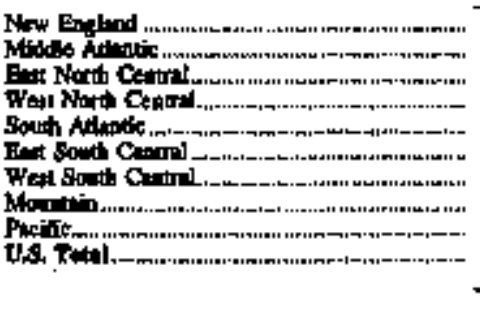 } & 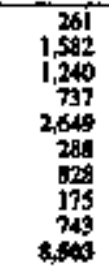 & & 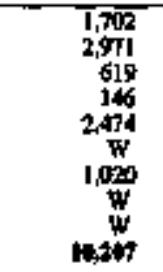 & 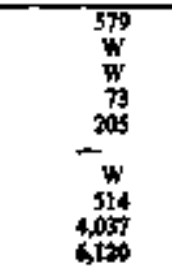 & 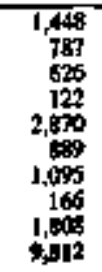 & בw & 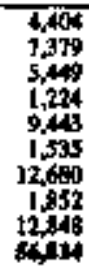 \\
\hline & \multicolumn{7}{|c|}{ 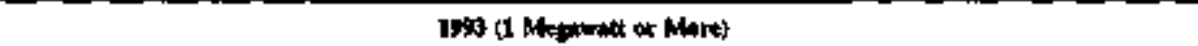 } \\
\hline \multirow[t]{2}{*}{ 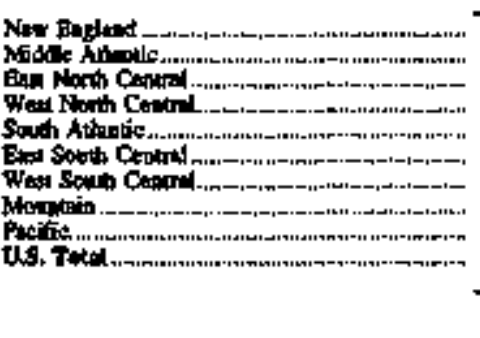 } & 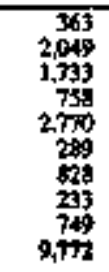 & 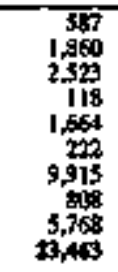 & 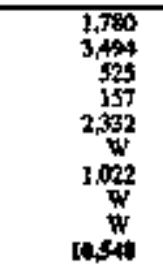 & 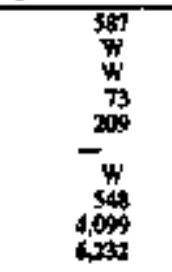 & $\begin{array}{r}1,412 \\
806 \\
646 \\
136 \\
2,958 \\
1,099 \\
1,069 \\
165 \\
1,601 \\
1479\end{array}$ & $\begin{array}{c}\bar{w} \\
\mathbf{w} \\
\mathbf{w} \\
\mathbf{w} \\
\mathbf{w} \\
\mathbf{w} \\
\mathbf{w} \\
\mathbf{w}\end{array}$ & $\begin{array}{r}\overline{1,729} \\
8,730 \\
5,540 \\
1,161 \\
10,303 \\
1,734 \\
13,069 \\
2,030 \\
13,305 \\
64,778\end{array}$ \\
\hline & \multicolumn{7}{|c|}{ 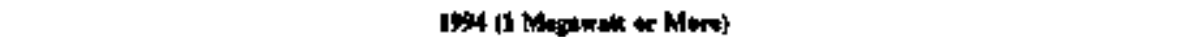 } \\
\hline \multirow[t]{2}{*}{ 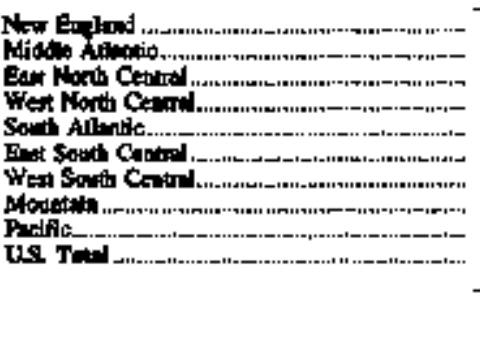 } & 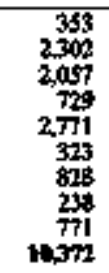 & 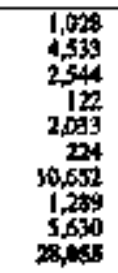 & 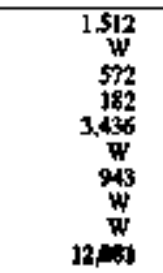 & 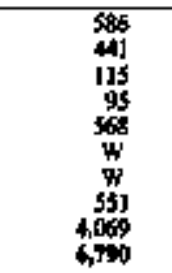 & $\begin{array}{r}1,416 \\
689 \\
658 \\
168 \\
3.197 \\
1,265 \\
1,125 \\
157 \\
1,692 \\
1,405\end{array}$ & $\begin{array}{c}-w \\
-w 79 \\
w \\
w \\
w \\
w \\
w\end{array}$ & $\begin{array}{r}4,695 \\
11,754 \\
5,947 \\
1,296 \\
12,384 \\
2,084 \\
13,764 \\
2,682 \\
13,654 \\
64,461\end{array}$ \\
\hline & \multicolumn{7}{|c|}{ Inest (1 Magined of Mor) } \\
\hline 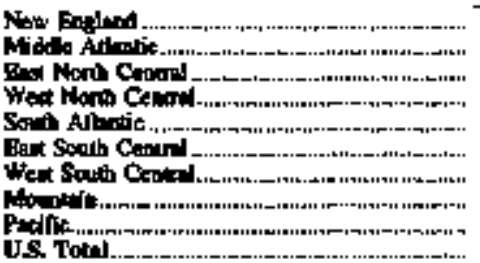 & 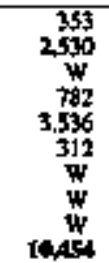 & $\begin{array}{r}1.118 \\
4,713 \\
3,044 \\
33 \\
1,746 \\
225 \\
00,929 \\
1,294 \\
6,151 \\
29,272\end{array}$ & 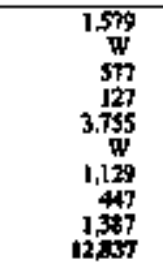 & 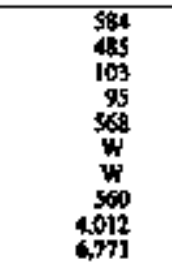 & $\begin{array}{r}1,904 \\
973 \\
690 \\
176 \\
3,610 \\
1,254 \\
1,145 \\
159 \\
1,542 \\
1,347\end{array}$ & 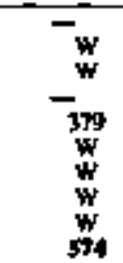 & $\begin{array}{r}5,037 \\
12,077 \\
5,917 \\
1,232 \\
12,995 \\
2,078 \\
13,091 \\
2,757 \\
13,860 \\
7,20\end{array}$ \\
\hline
\end{tabular}

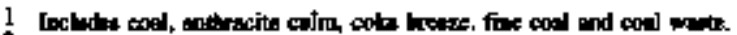

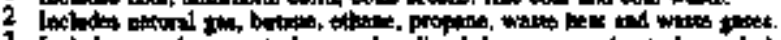

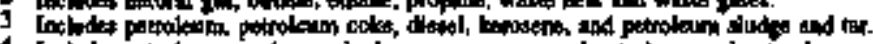

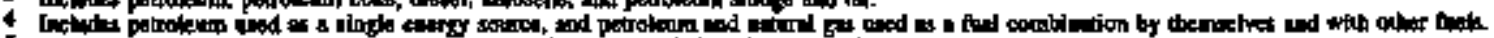

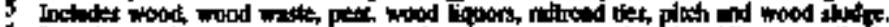

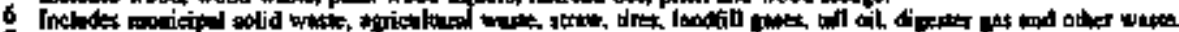

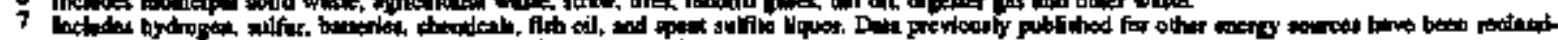

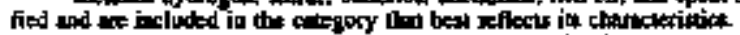

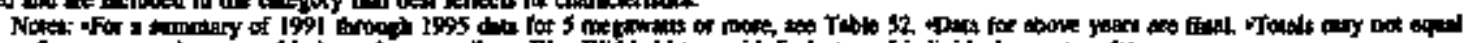

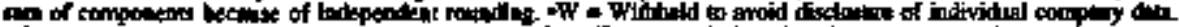

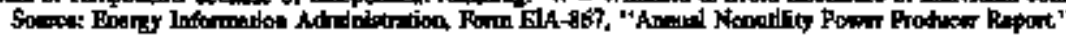




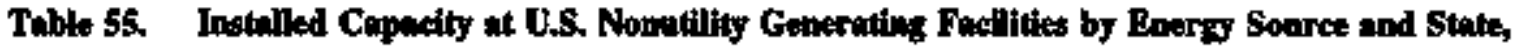
1995 (Megawatts)

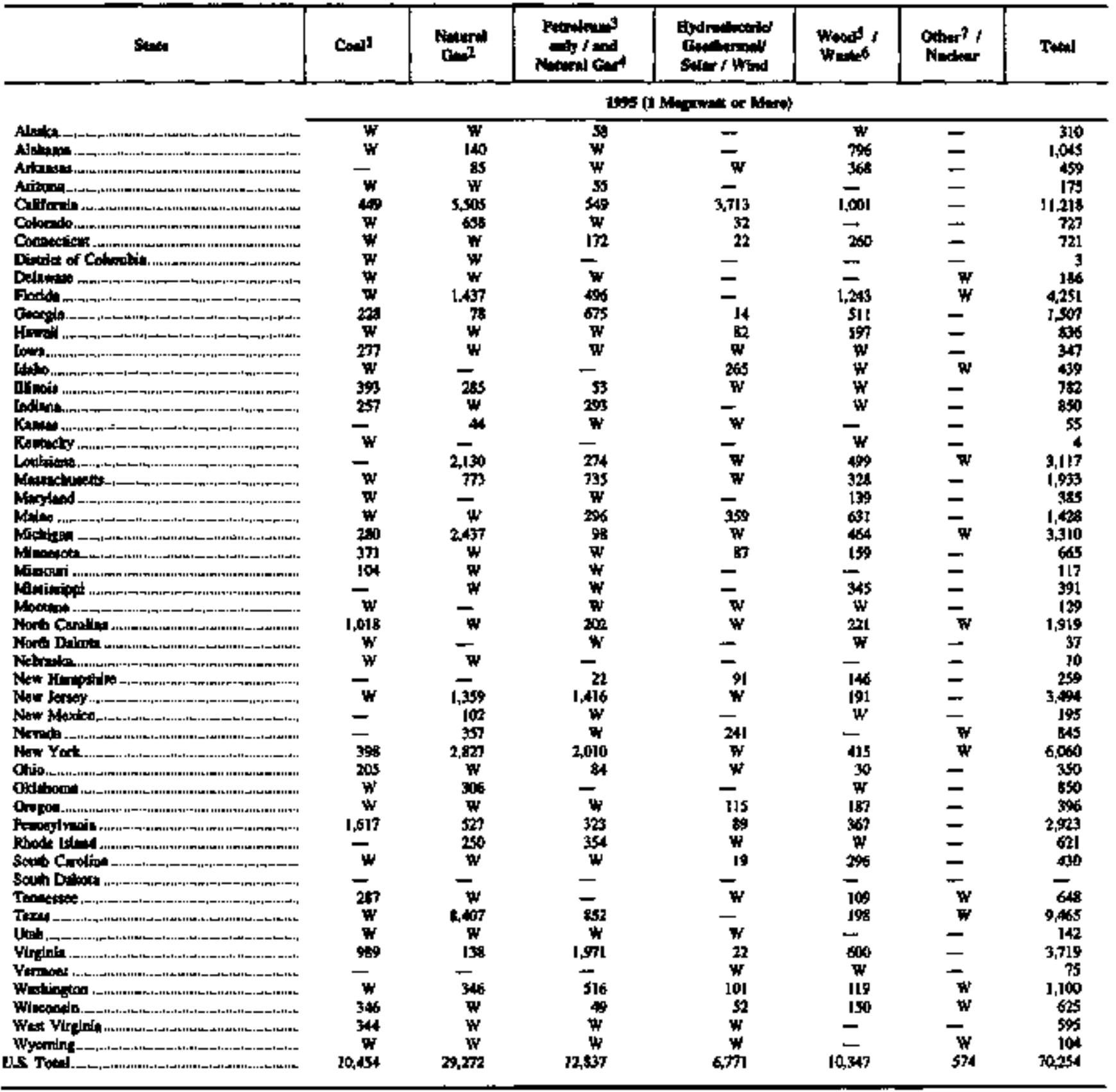

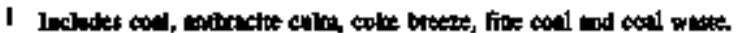

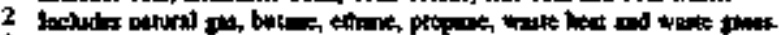

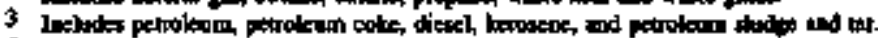

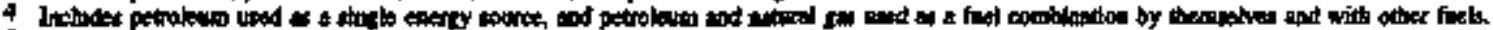

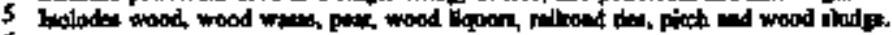

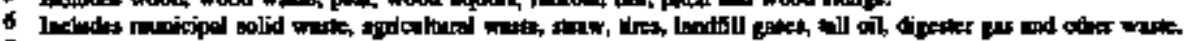

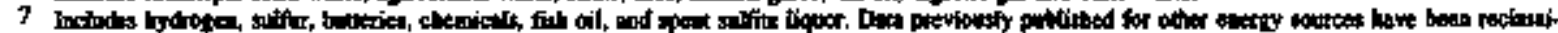

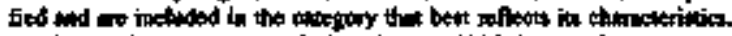

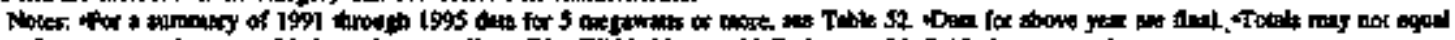

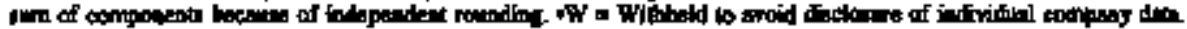

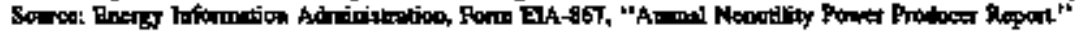


Table 56. Installed Cappecity at U.S. Nonutility Geoerating Focilities by Qualifyhing Facillty Status and Census Division, 1991 Through 1995

(Megawarts)

\begin{tabular}{|c|c|c|c|c|c|c|}
\hline \multirow[b]{2}{*}{ Cerent Dhtoder } & \multicolumn{2}{|c|}{ CF Cepacity } & \multicolumn{2}{|c|}{ Now-QF Crindty } & \multicolumn{2}{|c|}{ Tot Cupodity } \\
\hline & 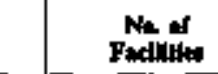 & Capadty & Fintititas & Canodity & Ma. of & 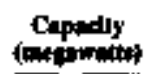 \\
\hline & \multicolumn{6}{|c|}{ IF9] if Bsegentits or MAte) } \\
\hline \multirow[t]{2}{*}{ 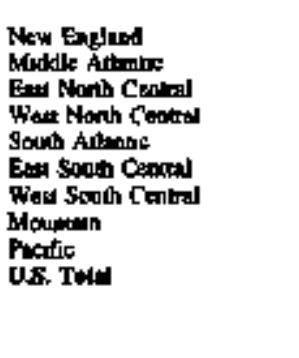 } & $\begin{array}{r}69 \\
105 \\
38 \\
14 \\
86 \\
16 \\
87 \\
28 \\
276 \\
76\end{array}$ & $\begin{array}{r}2,719 \\
4,674 \\
3,080 \\
478 \\
5,149 \\
753 \\
10,016 \\
543 \\
9,458 \\
36,969\end{array}$ & $\begin{array}{l}27 \\
17 \\
52 \\
12 \\
17 \\
17 \\
30 \\
15 \\
8 \\
34\end{array}$ & $\begin{array}{r}1,137 \\
467 \\
1,954 \\
625 \\
2,113 \\
736 \\
2,040 \\
409 \\
1,681 \\
1,202\end{array}$ & $\begin{array}{r}91 \\
127 \\
90 \\
36 \\
133 \\
33 \\
117 \\
43 \\
362 \\
1,007\end{array}$ & $\begin{array}{r}3,845 \\
4,940 \\
5.033 \\
1.109 \\
7,263 \\
1,489 \\
12,056 \\
1,292 \\
11,139 \\
40,171\end{array}$ \\
\hline & \multicolumn{6}{|c|}{ IPS (1 Mriputit ar Mare) } \\
\hline \multirow[t]{2}{*}{ 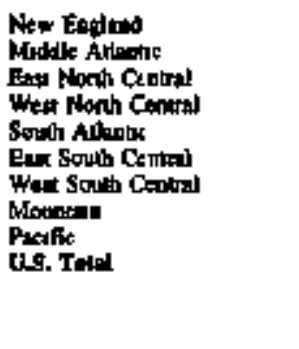 } & $\begin{array}{r}111 \\
211 \\
95 \\
23 \\
127 \\
23 \\
107 \\
73 \\
409 \\
109\end{array}$ & $\begin{array}{r}5,077 \\
6,924 \\
3,341 \\
505 \\
6,2,56 \\
5,22 \\
10,551 \\
1,513 \\
10,972 \\
4,760\end{array}$ & $\begin{array}{r}75 \\
48 \\
99 \\
44 \\
95 \\
23 \\
59 \\
37 \\
149 \\
699\end{array}$ & $\begin{array}{r}1,327 \\
455 \\
2,108 \\
720 \\
3,187 \\
713 \\
2,128 \\
540 \\
1,876 \\
13,404\end{array}$ & $\begin{array}{r}186 \\
269 \\
194 \\
67 \\
222 \\
46 \\
166 \\
110 \\
558 \\
158\end{array}$ & $\begin{array}{r}4,404 \\
7,379 \\
5,449 \\
1,224 \\
9,443 \\
1,535 \\
12,680 \\
1,859 \\
12,849 \\
6,814\end{array}$ \\
\hline & \multicolumn{6}{|c|}{ Fss (1 Mejowntt or Mord) } \\
\hline \multirow[t]{2}{*}{ 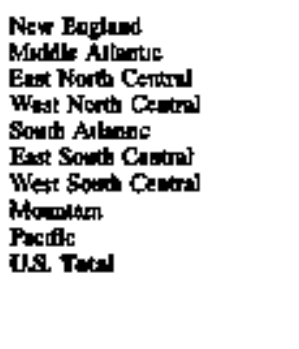 } & $\begin{array}{r}116 \\
280 \\
98 \\
24 \\
195 \\
24 \\
107 \\
81 \\
412 \\
1732\end{array}$ & 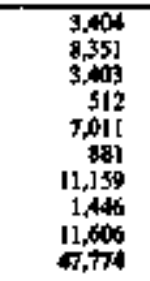 & $\begin{array}{r}13 \\
44 \\
101 \\
49 \\
97 \\
30 \\
60 \\
38 \\
142 \\
94\end{array}$ & $\begin{array}{r}1,325 \\
374 \\
2,143 \\
749 \\
3291 \\
653 \\
1.910 \\
574 \\
1,779 \\
13,04\end{array}$ & $\begin{array}{r}189 \\
274 \\
199 \\
74 \\
236 \\
54 \\
167 \\
119 \\
554 \\
1.04\end{array}$ & $\begin{array}{r}4,729 \\
8,730 \\
3,546 \\
1,261 \\
10,20,7 \\
1,734 \\
13,069 \\
2,020 \\
13,385 \\
4.775\end{array}$ \\
\hline & \multicolumn{6}{|c|}{ 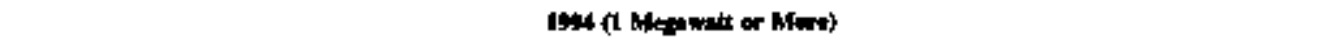 } \\
\hline \multirow[t]{2}{*}{ 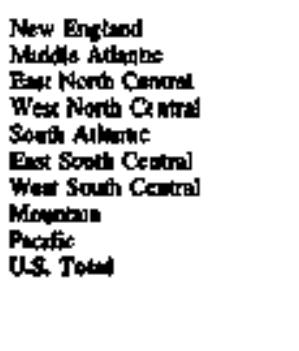 } & $\begin{array}{r}117 \\
248 \\
101 \\
26 \\
151 \\
24 \\
107 \\
85 \\
109 \\
1,267\end{array}$ & 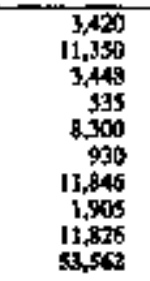 & $\begin{array}{r}75 \\
18 \\
118 \\
51 \\
129 \\
.15 \\
61 \\
19 \\
146 \\
701\end{array}$ & $\begin{array}{r}1,475 \\
402 \\
2,496 \\
760 \\
4,033 \\
1,139 \\
1,917 \\
776 \\
1,928 \\
1490\end{array}$ & $\begin{array}{r}192 \\
296 \\
219 \\
47 \\
280 \\
59 \\
168 \\
127 \\
554 \\
1964\end{array}$ & $\begin{array}{r}4,999 \\
11,752 \\
5,947 \\
1,296 \\
12,384 \\
2,048 \\
13,764 \\
2,692 \\
13,654 \\
65,461\end{array}$ \\
\hline & \multicolumn{6}{|c|}{ 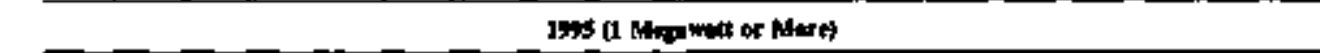 } \\
\hline 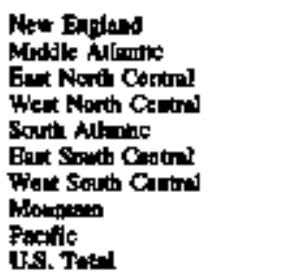 & $\begin{array}{r}119 \\
248 \\
112 \\
28 \\
160 \\
28 \\
100 \\
53 \\
400 \\
103\end{array}$ & $\begin{array}{r}3,478 \\
12,087 \\
3,712 \\
575 \\
9,060 \\
1,143 \\
12,165 \\
1,980 \\
11,940 \\
9,14\end{array}$ & $\begin{array}{r}77 \\
49 \\
110 \\
57 \\
125 \\
31 \\
59 \\
38 \\
139 \\
674\end{array}$ & $\begin{array}{r}1,560 \\
390 \\
2,055 \\
658 \\
3,929 \\
945 \\
1,726 \\
777 \\
1,920 \\
1496\end{array}$ & $\begin{array}{r}192 \\
306 \\
228 \\
80 \\
285 \\
59 \\
167 \\
120 \\
519 \\
1973\end{array}$ & $\begin{array}{r}5,037 \\
12,411 \\
5,917 \\
1,232 \\
12,995 \\
2,058 \\
13,991 \\
2,757 \\
1,3,060 \\
70,234\end{array}$ \\
\hline
\end{tabular}

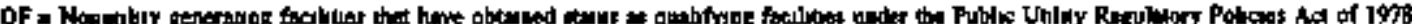

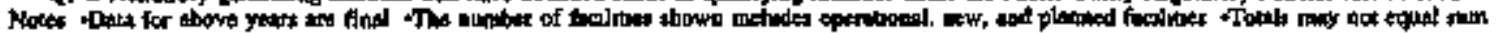

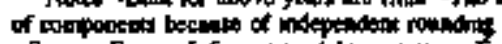

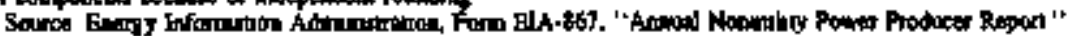


Table 57. Installad Capacity at U.S. Nomatilitios Attributed to Major Indaitry Growps and Cenias Divinions, 1991 Througth 1995

(Megawarts)

\begin{tabular}{|c|c|c|c|c|c|c|c|}
\hline 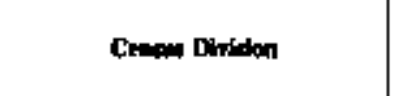 & Menofinginthis & 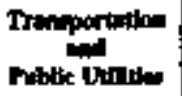 & Serriean & Mrint & & 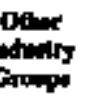 & Thet \\
\hline \multirow{3}{*}{ 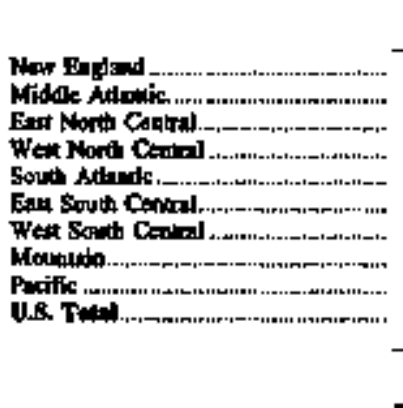 } & \multicolumn{7}{|c|}{ tsol (s Megmitti a Mort) } \\
\hline & $\begin{array}{r}7,925 \\
3,320 \\
4,027 \\
647 \\
3,474 \\
1,466 \\
11,291 \\
493 \\
3,588 \\
32,767\end{array}$ & 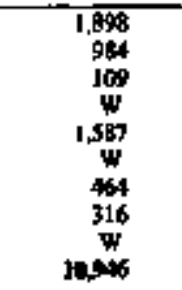 & $\begin{array}{r}33 \\
194 \\
193 \\
130 \\
124 \\
w \\
w \\
w \\
w 111\end{array}$ & $\begin{array}{c}-w \\
-w \\
-w \\
w \\
w \\
w \\
w\end{array}$ & $\begin{array}{l}=w \\
= \\
-w \\
-w \\
4 \\
w\end{array}$ & $={ }_{260}^{-}$ & $\begin{array}{r}3,656 \\
4,540 \\
5,033 \\
1,103 \\
7,269 \\
1,469 \\
1,066 \\
1,292 \\
11,138 \\
4,171\end{array}$ \\
\hline & \multicolumn{7}{|c|}{ lows (I Migumin of Mar) } \\
\hline 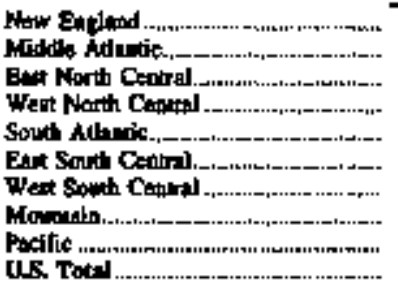 & $\begin{array}{r}2,120 \\
5,112 \\
4,864 \\
695 \\
6,376 \\
1,497 \\
11,365 \\
746 \\
4,39 \\
37,612\end{array}$ & $\begin{array}{r}2,267 \\
1,395 \\
253 \\
w \\
2,324 \\
w \\
442 \\
474 \\
6,200 \\
12,55\end{array}$ & $\begin{array}{c}\text { W17 } \\
410 \\
299 \\
138 \\
150 \\
7 \\
193 \\
157 \\
239 \\
1645\end{array}$ & $\underset{w}{W}$ & $\underset{w}{w}$ & $\begin{array}{c}-162 \\
\text { W } \\
-61 \\
- \\
278 \\
7182\end{array}$ & $\begin{array}{r}4,404 \\
7,379 \\
5,449 \\
1,224 \\
9,443 \\
1,535 \\
12,640 \\
1,864 \\
12,848 \\
86,814\end{array}$ \\
\hline & \multicolumn{7}{|c|}{ 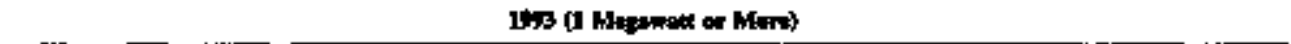 } \\
\hline 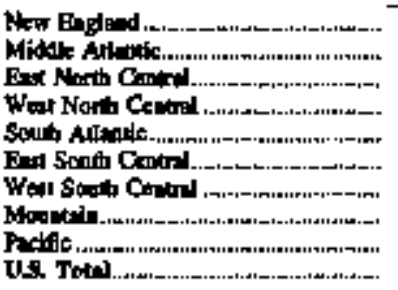 & $\begin{array}{r}2,248 \\
5,707 \\
1,85 t \\
702 \\
6,925 \\
1,676 \\
12,245 \\
777 \\
4,678 \\
3,044\end{array}$ & $\begin{array}{r}2,369 \\
1,969 \\
301 \\
184 \\
2,914 \\
18 \\
442 \\
566 \\
5,532 \\
24,46\end{array}$ & $\begin{array}{c}W \\
511 \\
271 \\
165 \\
158 \\
w \\
209 \\
158 \\
324 \\
1,50\end{array}$ & $\begin{array}{c}-w \\
w \\
w \\
w \\
w \\
w \\
240 \\
2459 \\
3245\end{array}$ & 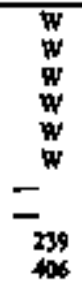 & 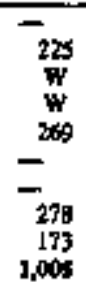 & $\begin{array}{r}4,729 \\
8,730 \\
5,546 \\
1,261 \\
10,306 \\
1,734 \\
13,069 \\
2,020 \\
13,395 \\
10,7 \%\end{array}$ \\
\hline & \multicolumn{7}{|c|}{ 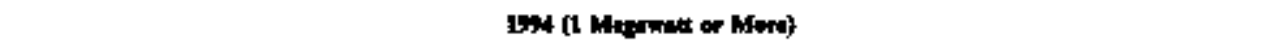 } \\
\hline \multirow[t]{2}{*}{ 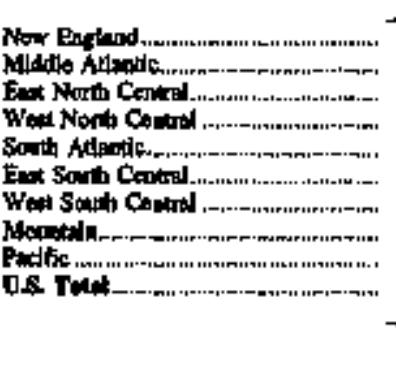 } & 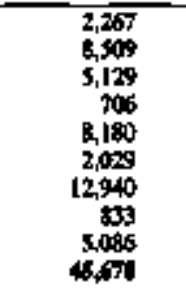 & $\begin{array}{r}2,499 \\
2,168 \\
373 \\
213 \\
3,85 \\
18 \\
42 \\
179 \\
5,307 \\
15,601\end{array}$ & 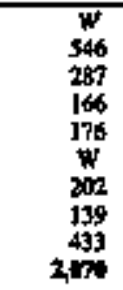 & 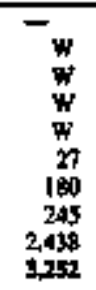 & $\begin{array}{c}-w \\
w \\
w \\
w \\
-w \\
-w 9 \\
\mathbf{w a g}\end{array}$ & $\begin{array}{l}124 \\
90 \\
-97 \\
- \\
686 \\
151 \\
1,134\end{array}$ & 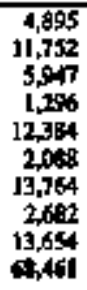 \\
\hline & \multicolumn{7}{|c|}{ 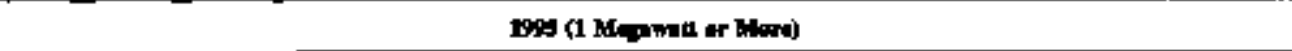 } \\
\hline 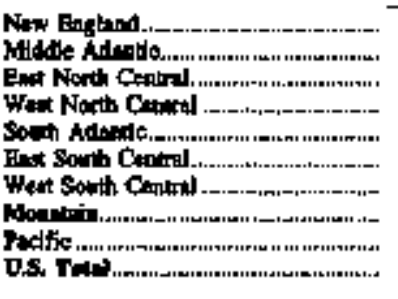 & $\begin{array}{r}2,261 \\
9,201 \\
5,086 \\
735 \\
3,842 \\
2,027 \\
1,297 \\
806 \\
5,250 \\
4,406\end{array}$ & $\begin{array}{r}2,602 \\
2,074 \\
3,66 \\
104 \\
3,704 \\
w \\
W \\
\$ 23 \\
5,258 \\
15,144\end{array}$ & $\begin{array}{c}W \\
\$ 43 \\
353 \\
164 \\
149 \\
w \\
202 \\
132 \\
435 \\
2,164\end{array}$ & $\begin{array}{c}- \\
w \\
w \\
w \\
w \\
27 \\
177 \\
245 \\
2,498 \\
345\end{array}$ & 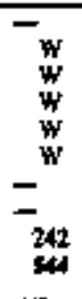 & $\begin{array}{c}w \\
225 \\
w \\
w \\
204 \\
-w \\
w \\
176 \\
136\end{array}$ & $\begin{array}{r}5,037 \\
12,477 \\
5,917 \\
1,237 \\
12,995 \\
2,058 \\
13,091 \\
2,797 \\
13,860 \\
7,140\end{array}$ \\
\hline
\end{tabular}

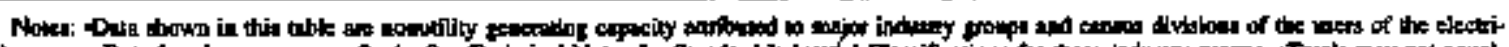

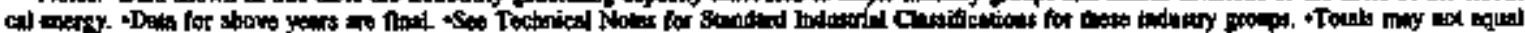

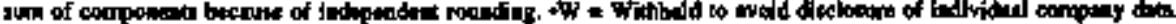

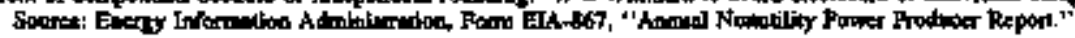


Table 58. Grass Generation for US. Nomstilty Power Producess by Energy Source and Census Division, 1991 Through 1995

(Milion Kilowanhours)

\begin{tabular}{|c|c|c|c|c|c|c|c|c|}
\hline 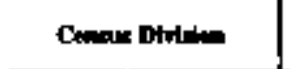 & Cenall & Futrelong & Nobured Gua & Byilyoletertt & 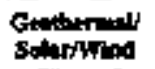 & Wowd4 & $\begin{array}{l}\text { Optors i } \\
\text { Nodtar }\end{array}$ & Thant \\
\hline & & & & Len is Mor & malle of Moral & & & \\
\hline \multirow[t]{2}{*}{ 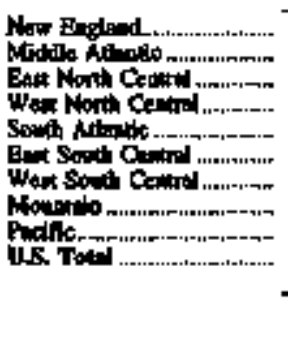 } & $\begin{array}{r}2,57 ? \\
7,741 \\
5,156 \\
1,641 \\
13,504 \\
2,005 \\
5,459 \\
1,044 \\
3,009 \\
4,5167\end{array}$ & & $\begin{array}{r}6,710 \\
31,060 \\
12,173 \\
345 \\
3.706 \\
2,132 \\
60,093 \\
1,932 \\
32,796 \\
131,340\end{array}$ & $\begin{array}{l}2,264 \\
8 \pi 7 \\
256 \\
227 \\
760 \\
- \\
- \\
511 \\
0,337 \\
6,213\end{array}$ & 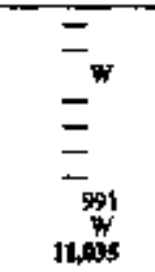 & $\begin{array}{r}7,353 \\
3,933 \\
3,094 \\
466 \\
12,991 \\
4,735 \\
5,404 \\
755 \\
8,920 \\
4,741\end{array}$ & $\frac{-}{-w}$ & $\begin{array}{r}20,347 \\
24,946 \\
21,424 \\
3,316 \\
32773 \\
9,013 \\
73,404 \\
5,442 \\
57,843 \\
24,44\end{array}$ \\
\hline & \multicolumn{8}{|c|}{$1 \sin$ (1 $\mathrm{k}$ (1) } \\
\hline \multirow[t]{2}{*}{ 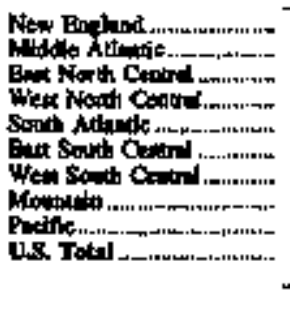 } & $\begin{array}{r}2,397 \\
9,747 \\
6,397 \\
2,364 \\
13,327 \\
2,152 \\
5,354 \\
1,131 \\
4,317 \\
4,343\end{array}$ & 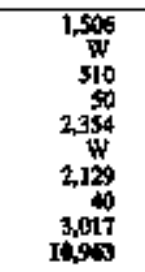 & 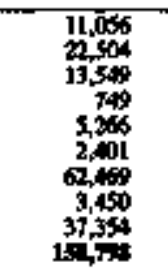 & 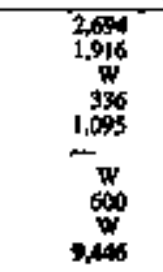 & $\begin{array}{l}= \\
= \\
= \\
= \\
\overline{1,214} \\
1,006 \\
12,211\end{array}$ & $\begin{array}{r}8,418 \\
5,244 \\
3,166 \\
8,00 \\
14,936 \\
5,163 \\
5,506 \\
816 \\
9,007 \\
51,007\end{array}$ & 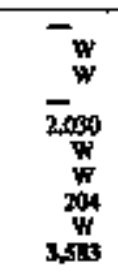 & 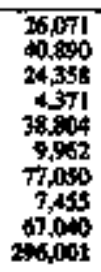 \\
\hline & \multicolumn{8}{|c|}{ E9S (1 Mefumit \& Mart) } \\
\hline \multirow[t]{2}{*}{ 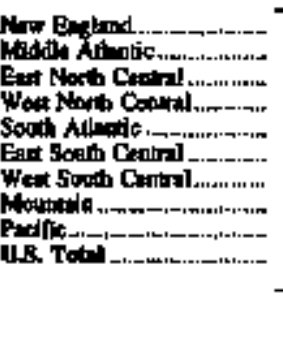 } & $\begin{array}{r}2,417 \\
10,560 \\
7,138 \\
2,852 \\
15,460 \\
2,289 \\
5,798 \\
1,317 \\
5,140 \\
5,34\end{array}$ & $\begin{array}{r}1.764 \\
w 27 \\
63 \\
2,774 \\
1,269 \\
112 \\
2,905 \\
13,964\end{array}$ & $\begin{array}{r}12,460 \\
2,351 \\
14,274 \\
687 \\
7,866 \\
2,170 \\
6,1677 \\
4,638 \\
40,708 \\
174,214\end{array}$ & $\begin{array}{c}2536 \\
1.724 \\
w \\
336 \\
963 \\
- \\
w \\
948 \\
11.511\end{array}$ & $\begin{array}{l}= \\
= \\
= \\
= \\
\overrightarrow{1,5183} \\
12,110 \\
13,610\end{array}$ & $\begin{array}{r}9,002 \\
5,714 \\
3,602 \\
737 \\
14,821 \\
6,019 \\
5,804 \\
767 \\
9,220 \\
5,144\end{array}$ & 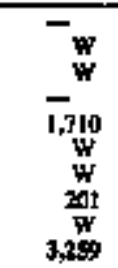 & $\begin{array}{r}28,229 \\
48,706 \\
26,211 \\
4,675 \\
43,640 \\
10,741 \\
0,073 \\
9,572 \\
73,400 \\
34,204\end{array}$ \\
\hline & \multicolumn{8}{|c|}{ 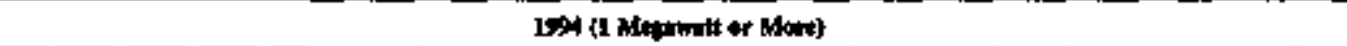 } \\
\hline \multirow[t]{2}{*}{ 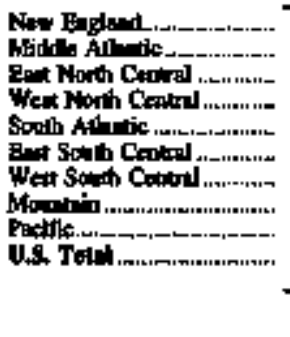 } & $\begin{array}{r}2,573 \\
12,169 \\
3,652 \\
3,111 \\
17,122 \\
2,325 \\
6,227 \\
1,567 \\
5,215 \\
5,151\end{array}$ & & $\begin{array}{r}13,917 \\
3,178 \\
15,139 \\
726 \\
11,348 \\
2,246 \\
4,768 \\
6,131 \\
6,762 \\
1+216\end{array}$ & 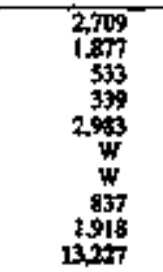 & $\begin{array}{l}= \\
= \\
= \\
= \\
12,752 \\
14 \times 28\end{array}$ & 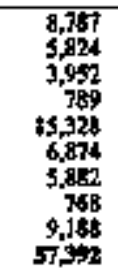 & 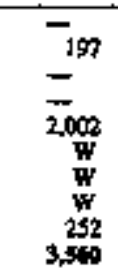 & 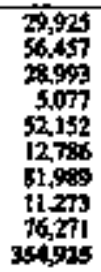 \\
\hline & \multicolumn{8}{|c|}{ 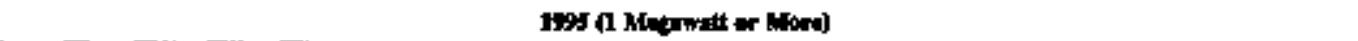 } \\
\hline 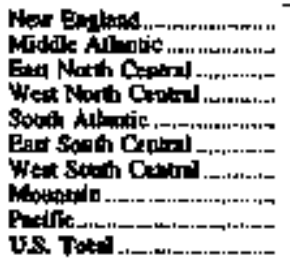 & $\begin{array}{r}2,464 \\
14,603 \\
6,813 \\
2,690 \\
18,891 \\
2,375 \\
3,796 \\
1,511 \\
4,404 \\
57,640\end{array}$ & (1781 & $\begin{array}{r}19,418 \\
45,191 \\
16,063 \\
690 \\
15,135 \\
2,151 \\
64,547 \\
6,828 \\
43,692 \\
210,38\end{array}$ & $\begin{array}{c}2,561 \\
1,5 \% \\
w \\
2,793 \\
w \\
w \\
1,171 \\
4,070 \\
14,794\end{array}$ & 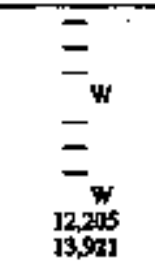 & $\begin{array}{r}8,555 \\
6,230 \\
4,304 \\
904 \\
15,445 \\
7,030 \\
5,894 \\
745 \\
7,523 \\
56,915\end{array}$ & 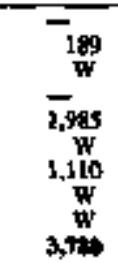 & $\begin{array}{r}29,750 \\
49,766 \\
28,436 \\
4,702 \\
57,624 \\
12,700 \\
83,172 \\
12,260 \\
76,415 \\
374,154\end{array}$ \\
\hline
\end{tabular}

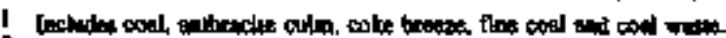

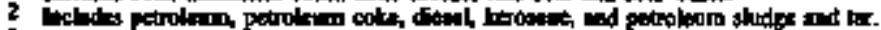

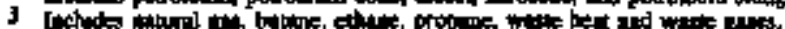

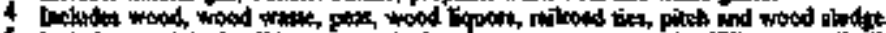

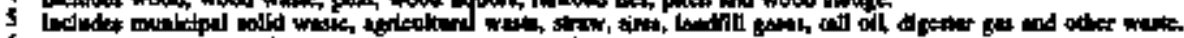

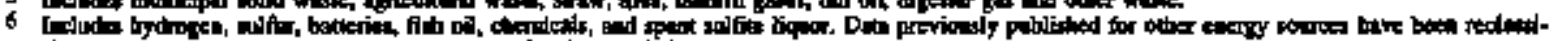

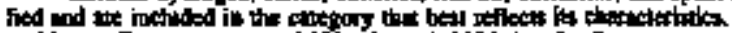

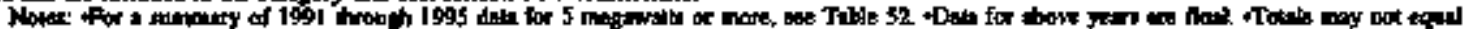

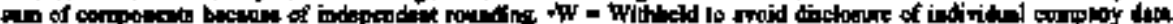

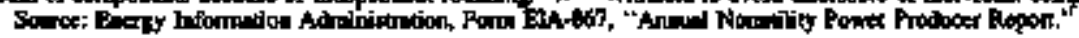


Table 59. Gross Generation for U.S. Nonutifity Power Produeens by Energy Sooret and Stote, 19\%5

(Million Kilowathours)

\begin{tabular}{|c|c|c|c|c|c|c|c|c|}
\hline State & الإC & 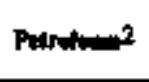 & Nont Go:3 & 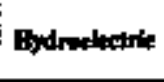 & 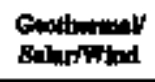 & Whod & $\begin{array}{l}\text { Oturot } \\
\text { Nude: }\end{array}$ & Tall \\
\hline & \multicolumn{8}{|c|}{ 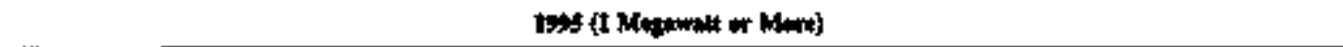 } \\
\hline 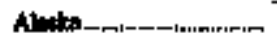 & $w$ & 139 & $\boldsymbol{F}$ & - & - & $\bar{w}$ & - & 1,52 \\
\hline 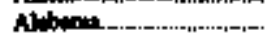 & 565 & 106 & 1,200 & - & 一 & 4,313 & 一 & 6,260 \\
\hline 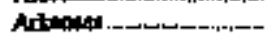 & $w$ & $w$ & 912 & $\rightarrow$ & - & 1,634 & $w$ & 2618 \\
\hline 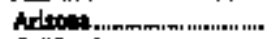 & $\boldsymbol{w}$ & 20 & $6 \pi$ & - & عـ & $W$ & 一 & 878 \\
\hline 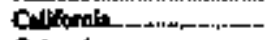 & 2.979 & 1,904 & 375063 & $w$ & 11,042 & 5,253 & $\mathbf{w}$ & 6202 \\
\hline 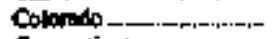 & $w$ & $w$ & 2666 & Es & - & $\mathrm{W}$ & - & $3,0,0 ?$ \\
\hline 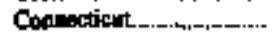 & $\mathbf{W}$ & I.t & 1,257 & $\mathbf{w}$ & - & 1,600 & - & 1,812 \\
\hline Dituick of Cohronhth & - & $\rightarrow$ & - & - & - & - & - & - \\
\hline 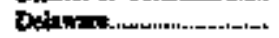 & $\boldsymbol{W}$ & $w$ & $\mathbf{w}$ & - & 一 & - & $w$ & 750 \\
\hline 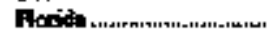 & 4,153 & 640 & 8064 & 一 & 一 & 5.839 & 1,702 & 21,197 \\
\hline 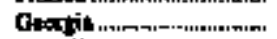 & 1,129 & 640 & 1,304 & \$I & - & 3,133 & - & 6,284 \\
\hline Hown & $w$ & 1,751 & $\Psi$ & 8 & $\mathbf{W}$ & 603 & $\mathbf{w}$ & $4,3-27$ \\
\hline buen. & 1,002 & 9 & jos & $w$ & - & W & 一 & 1.177 \\
\hline 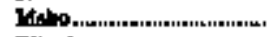 & $\mathbf{w}$ & $w$ & W & 996 & 一 & 531 & $\mathbf{W}$ & 1,623 \\
\hline 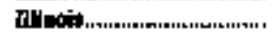 & 1,901 & $\mathbf{W}$ & $i, 604$ & $w$ & - & $\mathbf{w}$ & - & 3,952 \\
\hline 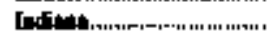 & 950 & $\mathbf{w}$ & 3,100 & 一 & 一 & $\mathbf{W}$ & 一 & 4281 \\
\hline 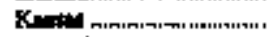 & - & $\mathbf{w}$ & 1) 1 & & 一 & - & 一 & 195 \\
\hline Xeducly & 一 & $\mathbf{w}$ & - & - & - & $\mathbf{w}$ & 一 & 4 \\
\hline Lonidikte-,-,-,_, ............. & $w$ & $\mathbf{w}$ & 14.099 & $w$ & - & 2,915 & $\mathbf{W}$ & 20,195 \\
\hline 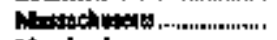 & $w$ & 20 & $\$ 310$ & $w$ & 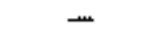 & 2,156 & 一 & 11,022 \\
\hline Mbyland ..._-_................. & $\mathbf{W}$ & $\mathbf{w}$ & $w$ & - & - & 708 & 一 & $\{.773$ \\
\hline 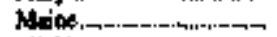 & $w$ & 1,558 & Y & 1,77 & 一 & 3,741 & 一 & 7,625 \\
\hline 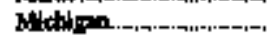 & $w$ & 176 & 10,667 & 130 & 一 & 2,694 & $w$ & IS.5.7. \\
\hline Minomate.................. & $1,2.7$ & $w$ & 316 & 280 & w & KS & - & 2,803 \\
\hline Mianowd___._......,-,-_-_, & $\nabla$ & $\mathbf{W}$ & $W$ & 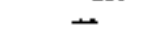 & - & W & 一 & 333 \\
\hline 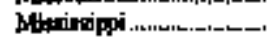 & $\mathbf{w}$ & $w$ & 69I & - & - & 2,048 & - & 2,820 \\
\hline 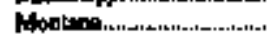 & $\mathbf{w}$ & $w$ & 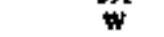 & $w$ & - & W & - & 617 \\
\hline Nerth Corotine............... & 6,139 & 256 & 542 & $\mathbf{W}$ & - & 1,787 & $\boldsymbol{W}$ & 10,780 \\
\hline 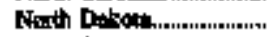 & $W$ & $\mathbf{W}$ & $\mathbf{w}$ & - & $m$ & $\mathbf{w}$ & - & 186 \\
\hline 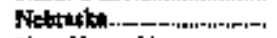 & $w$ & - & $\mathbf{W}$ & - & - & - & 一 & 6 \\
\hline 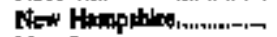 & 一 & 111 & $\rightarrow$ & 4hos & 一 & 1,062 & - & 1500 \\
\hline 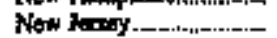 & $\boldsymbol{W}$ & 72 & 14,545 & $\mathbf{W}$ & 一 & 1,320 & - & IB.815 \\
\hline 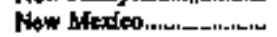 & - & $\vec{W}$ & 399 & - & 一 & $W$ & - & 413 \\
\hline 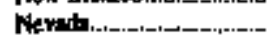 & - & $w$ & 2428 & $w$ & 1,649 & - & $\mathbf{W}$ & 4,127 \\
\hline NAw Yot & 2,547 & $w$ & 26,751 & 1,23 & - & 2,797 & $\mathbf{W}$ & $33,3+2$ \\
\hline Ohio,_,_, & 747 & 31 & 365 & $\Psi$ & 一 & W & - & 1,551 \\
\hline 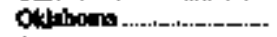 & $w$ & $\mathbf{W}$ & $|, 51|$ & - & 一 & $w$ & - & 5,031 \\
\hline 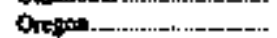 & $\mathbf{W}$ & $\mathbf{w}$ & 285 & 356 & - & 65 & - & 1,321 \\
\hline Penacytyends. & 10,043 & 559 & 3,881 & $W$ & - & 2,513 & $w$ & 17,450 \\
\hline Rhode lsland & - & 38 & 3,806 & $w$ & - & W & - & 3,960 \\
\hline Sowth Crobing.......... & \$5) & 165 & 102 & 63 & - & 1,738 & - & 2,632 \\
\hline Sowth Ditrohe............... & 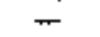 & - & 一 & & 一 & - & عשد & - \\
\hline Tenmotese _.................... & I.TA? & W & 210 & $\mathbf{W}$ & 一 & 660 & $\mathbf{W}$ & 3,615 \\
\hline 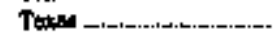 & $\mathbf{W}$ & 3,0N0 & 50,090 & مع & 一 & $w$ & 615 & 53,326 \\
\hline 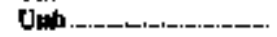 & $\boldsymbol{W}$ & $w$ & $\mathbf{W}$ & $\Psi$ & - & - & - & 744 \\
\hline 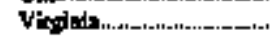 & 4,328 & 366 & 3,589 & $W$ & 一 & 2,279 & $w$ & 10,844 \\
\hline Yemont........................ & - & $w$ & - & 140 & 一 & W & 一 & 347 \\
\hline 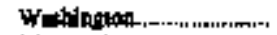 & $\boldsymbol{w}$ & $\mathbf{w}$ & 4,706 & $47 ?$ & 一 & 790 & $W$ & 6,700 \\
\hline Whiconde & 1,311 & $\mathbf{w}$ & 325 & 276 & 一 & 140 & $\mathbf{w}$ & 3,066 \\
\hline 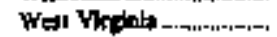 & 2,128 & W & $\$ 03$ & $\mathbf{W}$ & 一 & $w$ & $w$ & 3,356 \\
\hline Wyoning & W & $\mathbf{W}$ & $\mathbf{w}$ & - & - & - & w & EDA \\
\hline DE. Total & 57,668 & 16,987 & 210,332 & 14774 & 13,921 & 56,975 & 3,780 & 374,438 \\
\hline
\end{tabular}

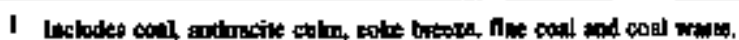

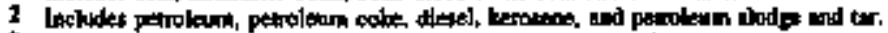

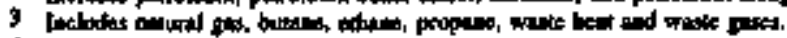

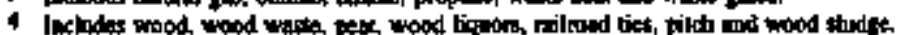

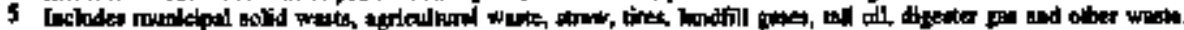

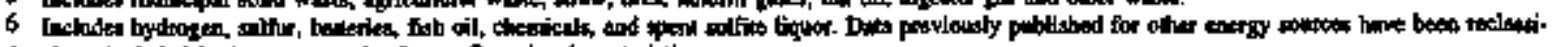

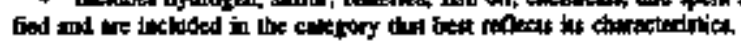

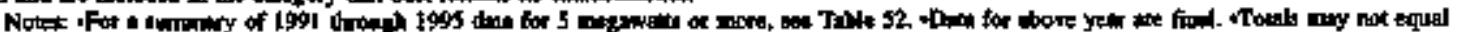

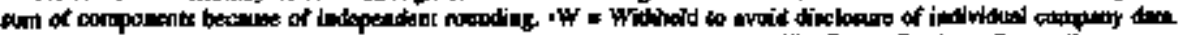

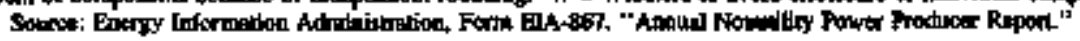


Table 60. Gross Generation at U.S. Nomutlity Gegerating Faclities by Qualifying Faclity Status and Census Divistom, 1991 Through 1995

(Mulion Killowatthours)

\begin{tabular}{|c|c|c|c|c|c|c|}
\hline \multirow[b]{2}{*}{ 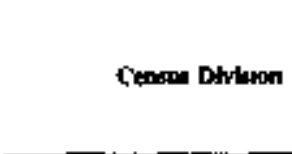 } & \multicolumn{2}{|c|}{ QF Gevintos } & \multicolumn{2}{|c|}{ Noo-QF Ganestlon } & \multicolumn{2}{|c|}{ Total Generritlon } \\
\hline & Fuditina & 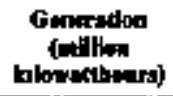 & Fin of & 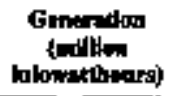 & Fochtor of & 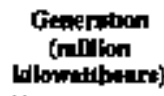 \\
\hline & \multicolumn{6}{|c|}{ 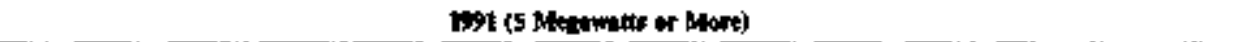 } \\
\hline \multirow[t]{2}{*}{ 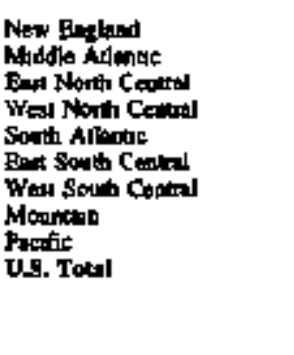 } & $\begin{array}{r}68 \\
105 \\
38 \\
14 \\
806 \\
16 \\
87 \\
28 \\
276 \\
79\end{array}$ & 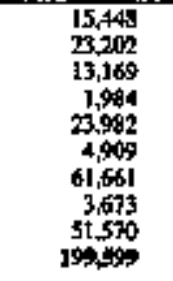 & $\begin{array}{l}27 \\
17 \\
52 \\
27 \\
47 \\
17 \\
30 \\
15 \\
96 \\
30\end{array}$ & $\begin{array}{r}4,899 \\
1,684 \\
8,253 \\
1,371 \\
8,791 \\
4,104 \\
11,743 \\
1,769 \\
6,273 \\
4,048\end{array}$ & $\begin{array}{r}9 k \\
122 \\
90 \\
36 \\
133 \\
33 \\
117 \\
43 \\
362 \\
1,027\end{array}$ & $\begin{array}{r}20,397 \\
24,886 \\
21,424 \\
9,316 \\
32,773 \\
9,013 \\
77,404 \\
5,442 \\
57,843 \\
240,444\end{array}$ \\
\hline & \multicolumn{6}{|c|}{ 19i2 (I Mepawed of Mort) } \\
\hline \multirow[t]{2}{*}{ 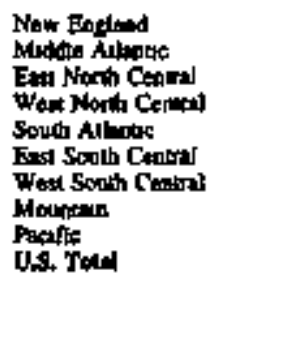 } & $\begin{array}{r}111 \\
251 \\
95 \\
27 \\
127 \\
23 \\
107 \\
73 \\
409 \\
109\end{array}$ & $\begin{array}{r}15,717 \\
30,798 \\
15,6693 \\
2,4773 \\
25,916 \\
5,413 \\
65,0980 \\
5,567 \\
60,979 \\
21,126\end{array}$ & $\begin{array}{l}75 \\
48 \\
99 \\
4 \\
95 \\
27 \\
59 \\
37 \\
149 \\
699\end{array}$ & $\begin{array}{r}7,354 \\
2,132 \\
3,675 \\
2,298 \\
9,858 \\
4,549 \\
11,910 \\
1,945 \\
6,061 \\
54975\end{array}$ & $\begin{array}{r}186 \\
259 \\
194 \\
67 \\
222 \\
46 \\
166 \\
110 \\
558 \\
1.848\end{array}$ & $\begin{array}{r}26,071 \\
40,390 \\
24,358 \\
4,371 \\
38,801 \\
9,952 \\
7,040 \\
7,455 \\
67,040 \\
296,0101\end{array}$ \\
\hline & & & $19 \%$ (1 H & ( ar Mace) & & \\
\hline \multirow[t]{2}{*}{ 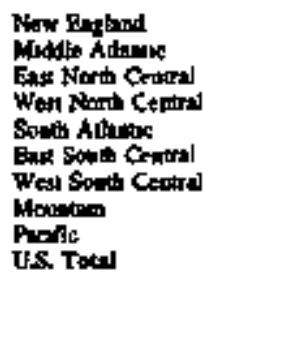 } & $\begin{array}{r}116 \\
230 \\
98 \\
24 \\
139 \\
24 \\
101 \\
81 \\
412 \\
1,212\end{array}$ & 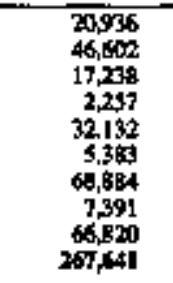 & $\begin{array}{r}71 \\
44 \\
101 \\
49 \\
97 \\
30 \\
60 \\
38 \\
142 \\
634\end{array}$ & $\begin{array}{r}7,293 \\
2,102 \\
3,971 \\
2,418 \\
11,488 \\
5,358 \\
11,190 \\
2,181 \\
6,560 \\
57,544\end{array}$ & $\begin{array}{r}199 \\
274 \\
199 \\
74 \\
296 \\
54 \\
167 \\
119 \\
554 \\
1,805\end{array}$ & $\begin{array}{r}28,229 \\
48,705 \\
26,211 \\
4,675 \\
43,6201 \\
10,741 \\
00,013 \\
9,572 \\
73,400 \\
325,726\end{array}$ \\
\hline & \multicolumn{6}{|c|}{ Le4 \{1 Mhprent or Hort } \\
\hline \multirow[t]{2}{*}{ 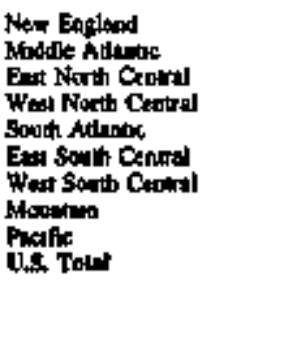 } & $\begin{array}{r}117 \\
248 \\
10 ! \\
26 \\
251 \\
24 \\
10 ! \\
55 \\
40 ! \\
1,267\end{array}$ & $\begin{array}{r}21,532 \\
54,274 \\
17,561 \\
2,490 \\
19,312 \\
5,702 \\
70,753 \\
9,049 \\
70,699 \\
21,041\end{array}$ & $\begin{array}{r}75 \\
43 \\
115 \\
51 \\
129 \\
95 \\
61 \\
38 \\
145 \\
701\end{array}$ & $\begin{array}{r}8,099 \\
2,183 \\
1,033 \\
2,597 \\
12,840 \\
3,065 \\
11,217 \\
2,183 \\
5,612 \\
6,184\end{array}$ & $\begin{array}{r}1 \overline{2} \\
296 \\
219 \\
77 \\
280 \\
59 \\
169 \\
123 \\
554 \\
1.46\end{array}$ & $\begin{array}{r}29,925 \\
56,457 \\
26,991 \\
3,077 \\
52,152 \\
12,796 \\
91,996 \\
11,272 \\
70,271 \\
354,925\end{array}$ \\
\hline & \multicolumn{6}{|c|}{ 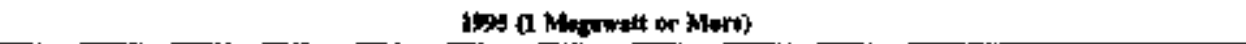 } \\
\hline 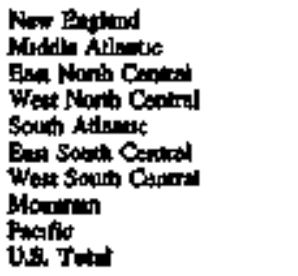 & $\begin{array}{r}119 \\
258 \\
112 \\
28 \\
160 \\
28 \\
109 \\
85 \\
400 \\
109\end{array}$ & $\begin{array}{r}21,681 \\
67,661 \\
19,235 \\
2,377 \\
44,77 \\
7567 \\
73,116 \\
10004 \\
69.168 \\
318,124\end{array}$ & $\begin{array}{r}78 \\
48 \\
110 \\
32 \\
125 \\
31 \\
58 \\
78 \\
799 \\
674\end{array}$ & $\begin{array}{r}7,669 \\
2,107 \\
9,152 \\
2,325 \\
13,348 \\
5,148 \\
10,056 \\
2,239 \\
7,247 \\
5,394\end{array}$ & $\begin{array}{r}192 \\
306 \\
228 \\
80 \\
285 \\
59 \\
167 \\
123 \\
539 \\
1973\end{array}$ & $\begin{array}{r}29,350 \\
69,768 \\
28,466 \\
4,702 \\
57,624 \\
12,768 \\
83,172 \\
12,263 \\
76,415 \\
374,438\end{array}$ \\
\hline
\end{tabular}

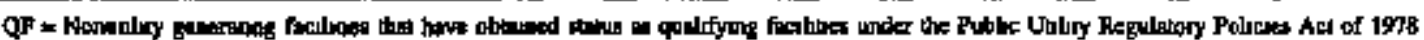

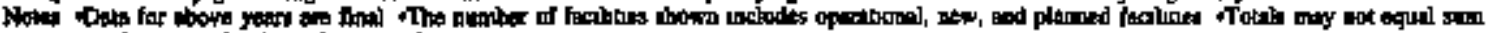

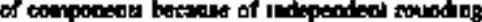

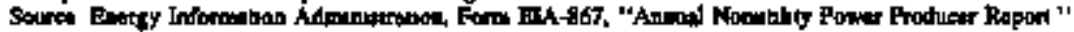


Toble 61. Groes Generation of U.S. Nonatillties Attributed to Major Industry Groups and Cenang Divisions, 1991 Through 1995

(Million Kilowatthours)

\begin{tabular}{|c|c|c|c|c|c|c|c|}
\hline 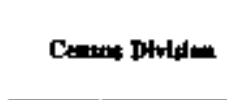 & Whofictentes & Traptiolon & Sorvices & Mles & Pable & 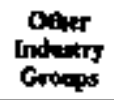 & Total \\
\hline & \multicolumn{7}{|c|}{ 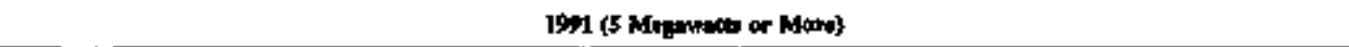 } \\
\hline \multirow[t]{2}{*}{ 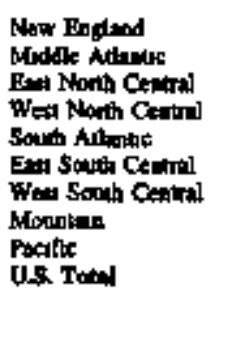 } & $\begin{array}{r}9,513 \\
26,413 \\
19,332 \\
2,587 \\
27,959 \\
4,843 \\
69,739 \\
2,260 \\
20,786 \\
177,472\end{array}$ & $\begin{array}{r}10,670 \\
4,376 \\
791 \\
w \\
4,401 \\
w \\
2,258 \\
1,705 \\
24,0096 \\
43,508\end{array}$ & $\begin{array}{c}1 \overline{4} \\
844 \\
510 \\
w \\
131 \\
-w \\
w \\
w \\
W\end{array}$ & $\begin{array}{l}-w \\
-w \\
-w \\
w \\
w \\
w \\
w\end{array}$ & 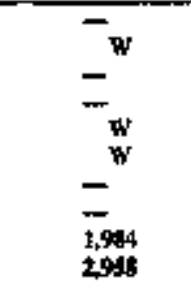 & 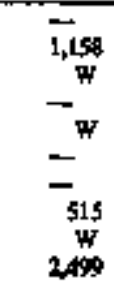 & $\begin{array}{r}20,347 \\
21,856 \\
21,424 \\
3,316 \\
32,373 \\
9,013 \\
73,404 \\
5,442 \\
57,843 \\
210,46\end{array}$ \\
\hline & \multicolumn{7}{|c|}{1992 (1 Mreprote or Mor) } \\
\hline \multirow[t]{2}{*}{ 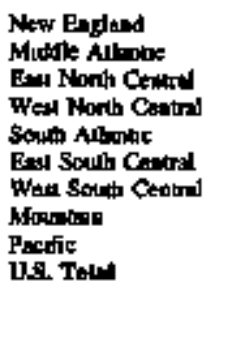 } & $\begin{array}{r}12,165 \\
27,482 \\
21,838 \\
2,758 \\
31,290 \\
9,752 \\
73,695 \\
3,564 \\
24,944 \\
24,758\end{array}$ & $\begin{array}{r}13,444 \\
7,330 \\
1,366 \\
1 \\
6,739 \\
1, \\
1,697 \\
2,156 \\
27,233 \\
64,115\end{array}$ & 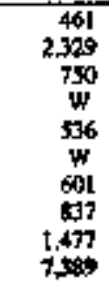 & 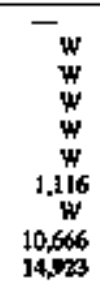 & $\begin{array}{l}-w \\
w \\
w \\
w \\
w \\
- \\
- \\
2,091 \\
9,0145\end{array}$ & 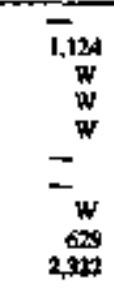 & $\begin{array}{r}26,071 \\
40,890 \\
24,358 \\
4,371 \\
38,001 \\
9,060 \\
73,460 \\
7,459 \\
67,040 \\
24,401\end{array}$ \\
\hline & \multicolumn{7}{|c|}{ 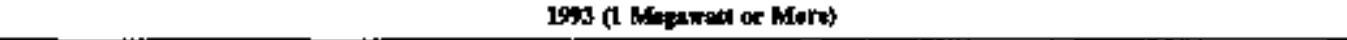 } \\
\hline \multirow[t]{2}{*}{ 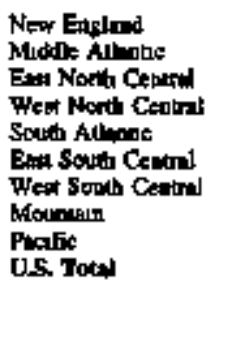 } & $\begin{array}{r}12,644 \\
31,368 \\
23,015 \\
2,983 \\
33,179 \\
10,531 \\
76,103 \\
4,620 \\
26,889 \\
21,464\end{array}$ & $\begin{array}{r}15,120 \\
11,669 \\
1,698 \\
, 341 \\
8,461 \\
77 \\
2,232 \\
2,699 \\
25,056 \\
67,549\end{array}$ & $\begin{array}{c}466 \\
2,800 \\
987 \\
W \\
657 \\
W \\
611 \\
975 \\
2,038 \\
8,5 m\end{array}$ & 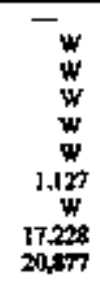 & $\begin{array}{c}-w \\
w \\
w \\
w \\
w \\
-1.530 \\
2.691\end{array}$ & 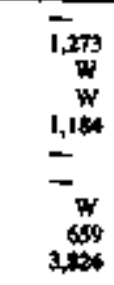 & $\begin{array}{r}2,209 \\
46,705 \\
26,211 \\
4,675 \\
43,620 \\
10,741 \\
80,073 \\
9,572 \\
73,460 \\
55,226\end{array}$ \\
\hline & \multicolumn{7}{|c|}{ 19s4 (I Mrepent or Blote) } \\
\hline \multirow[t]{2}{*}{ 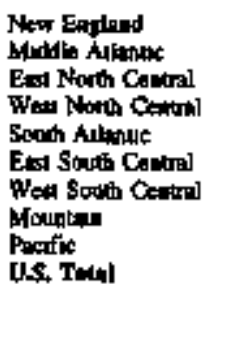 } & $\begin{array}{r}13,64] \\
37,382 \\
24,909 \\
3,150 \\
41,152 \\
12,478 \\
78,974 \\
5,096 \\
31,053 \\
247,536\end{array}$ & $\begin{array}{r}15.343 \\
12,009 \\
2,415 \\
434 \\
10,142 \\
51 \\
2,013 \\
3,173 \\
22,97 t \\
64,0.2\end{array}$ & $\begin{array}{c}W \\
3,395 \\
1,65 ? \\
421 \\
635 \\
w \\
599 \\
954 \\
2,406 \\
7500\end{array}$ & $\begin{array}{c}-w \\
W \\
w \\
w \\
148 \\
454 \\
563 \\
17,757 \\
21,924\end{array}$ & $\begin{array}{l}\overline{1,452} \\
w \\
w \\
w \\
w \\
- \\
-1,523 \\
3,1+12\end{array}$ & $\begin{array}{l}W \\
W \\
254 \\
W \\
- \\
1,496 \\
561 \\
4,411\end{array}$ & $\begin{array}{r}29,923 \\
56,457 \\
28,991 \\
5,077 \\
52,152 \\
12,786 \\
81,949 \\
11,273 \\
76,271 \\
354,926\end{array}$ \\
\hline & \multicolumn{7}{|c|}{1995 (1 Mrgangat or Mort) } \\
\hline 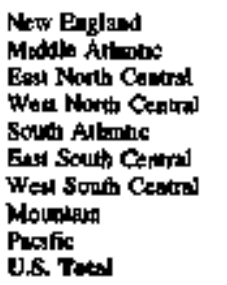 & $\begin{array}{r}13,334 \\
51,313 \\
24,7] 6 \\
3,025 \\
45,772 \\
12,449 \\
30,971 \\
4,976 \\
30,630 \\
297,248\end{array}$ & $\begin{array}{r}15,422 \\
10,349 \\
1,994 \\
w \\
10,998 \\
70 \\
w \\
3,603 \\
23,352 \\
67,695\end{array}$ & $\begin{array}{r}W \\
3,668 \\
1,345 \\
403 \\
657 \\
w \\
614 \\
390 \\
2606 \\
10,775\end{array}$ & 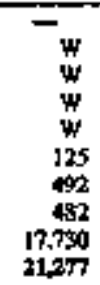 & $\begin{array}{l}- \\
968 \\
w \\
w \\
W \\
W \\
- \\
1,528 \\
2,617\end{array}$ & 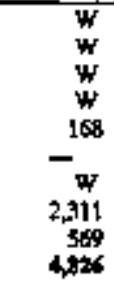 & $\begin{array}{r}29,750 \\
49,368 \\
28,436 \\
4,702 \\
51,624 \\
12,708 \\
83,172 \\
12,253 \\
76,415 \\
374,435\end{array}$ \\
\hline
\end{tabular}

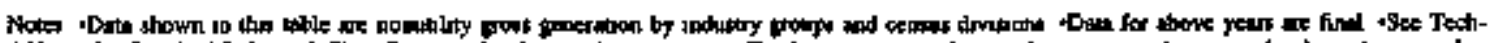

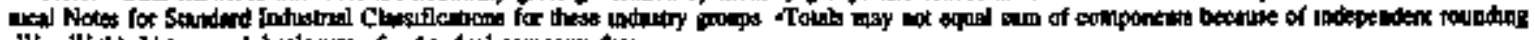

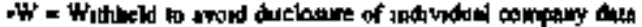

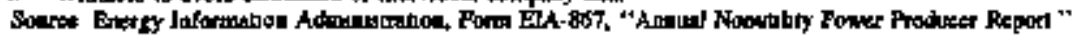


Table 62. U.S. Nonutility Electricity Sapply and Disposition for Facilities by Census Division and State, 1995

(Million Kilowattbours)

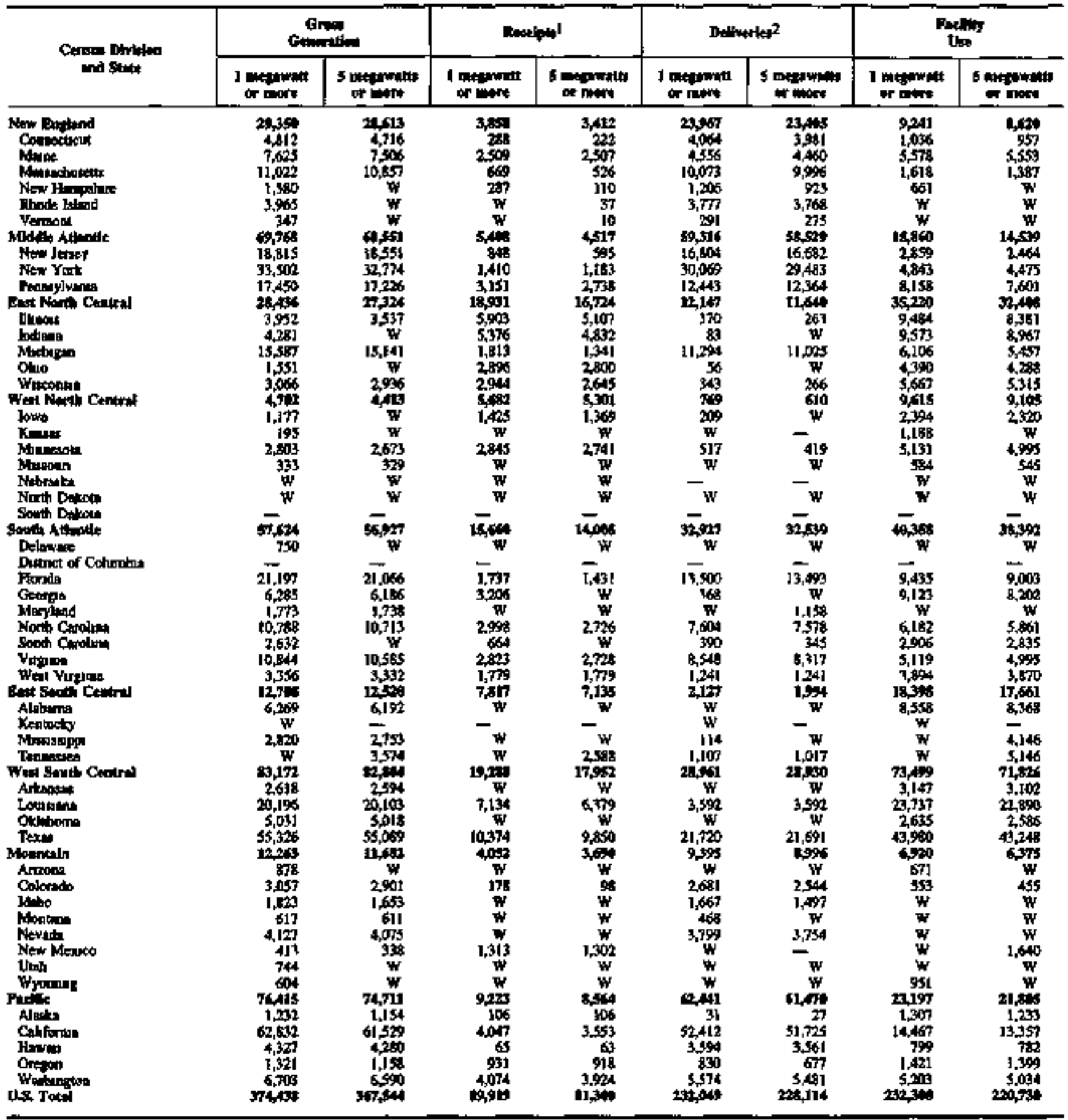

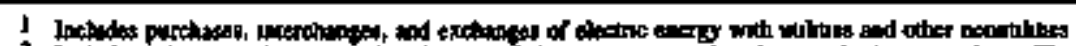

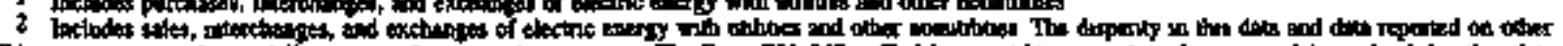

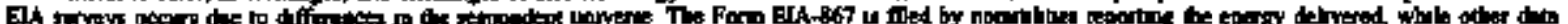

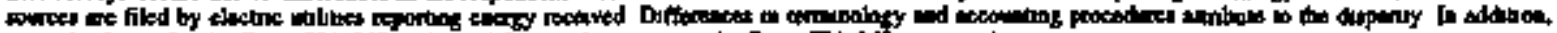

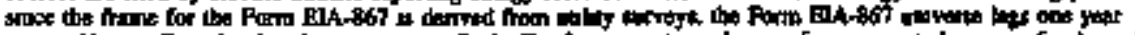

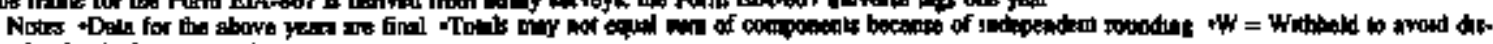

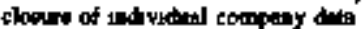

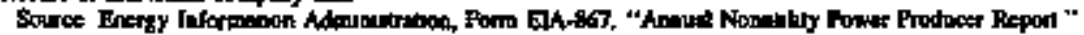


Tabye 63. Estimited Rmissions tram U.S. Nonnutility Power Producers Facilltes by Cenors Division, 1991 Through 1995 (Thousand Stort Tows)

\begin{tabular}{|c|c|c|c|}
\hline Conde Divition & Blth & Ntroger & Ciman \\
\hline \multicolumn{4}{|c|}{ 1951 (6 Meqperrats ar More) } \\
\hline \multirow[t]{2}{*}{ 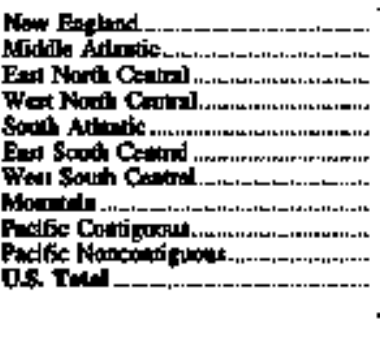 } & $\begin{array}{r}46 \\
95 \\
193 \\
69 \\
343 \\
112 \\
174 \\
20 \\
47 \\
7 \\
1,191\end{array}$ & & $\begin{array}{r}26,464 \\
37,252 \\
78,122 \\
1,290 \\
100,600 \\
3,6,47 \\
94,953 \\
9,771 \\
46,466 \\
4,277 \\
44,467\end{array}$ \\
\hline & & 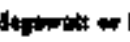 & \\
\hline \multirow[t]{2}{*}{ 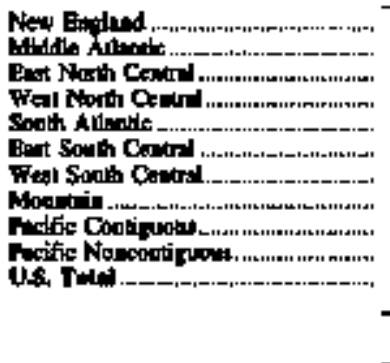 } & $\begin{array}{r}39 \\
89 \\
201 \\
60 \\
384 \\
119 \\
297 \\
21 \\
45 \\
13 \\
1,70\end{array}$ & $\begin{array}{r}45 \\
156 \\
275 \\
37 \\
231 \\
70 \\
258 \\
29 \\
107 \\
15 \\
1,219\end{array}$ & 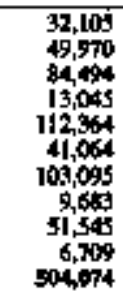 \\
\hline & & egdrint or & \\
\hline \multirow[t]{2}{*}{ 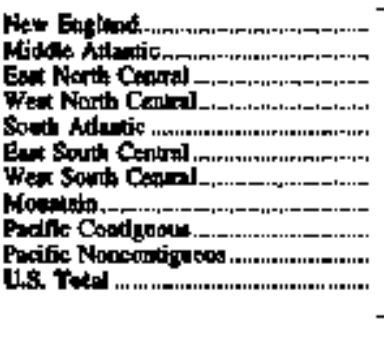 } & 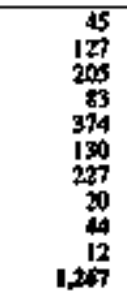 & $\begin{array}{c}19 \\
168 \\
307 \\
250 \\
75 \\
250 \\
35 \\
111 \\
15 \\
13\end{array}$ & 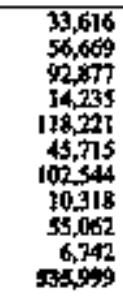 \\
\hline & & learowat of & \\
\hline \multirow[t]{2}{*}{ 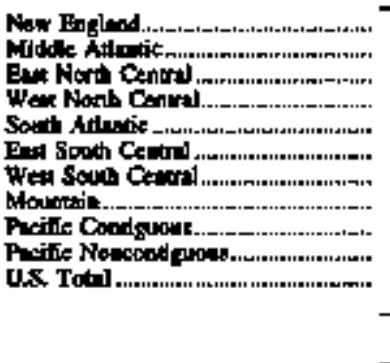 } & $\begin{array}{r}18 \\
124 \\
291 \\
68 \\
104 \\
138 \\
269 \\
212 \\
52 \\
14 \\
194\end{array}$ & $\begin{array}{r}48 \\
172 \\
325 \\
45 \\
273 \\
73 \\
233 \\
37 \\
109 \\
15 \\
1,395\end{array}$ & $\begin{array}{r}39,509 \\
59,731 \\
101,517 \\
14,790 \\
134,675 \\
51,625 \\
\$ 00,721 \\
12,045 \\
55,069 \\
2,309 \\
5 \times 7,201\end{array}$ \\
\hline & & 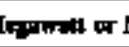 & \\
\hline 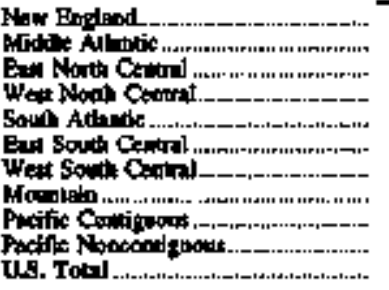 & $\begin{array}{r}45 \\
118 \\
227 \\
77 \\
390 \\
94 \\
194 \\
26 \\
44 \\
12 \\
t, 217\end{array}$ & $\begin{array}{r}65 \\
206 \\
295 \\
15 \\
299 \\
68 \\
242 \\
61 \\
140 \\
19 \\
1.440\end{array}$ & $\begin{array}{r}40,427 \\
61,567 \\
89,212 \\
16,020 \\
175,217 \\
43,404 \\
93,760 \\
17,514 \\
51,453 \\
7,747 \\
\$ 50,344\end{array}$ \\
\hline
\end{tabular}

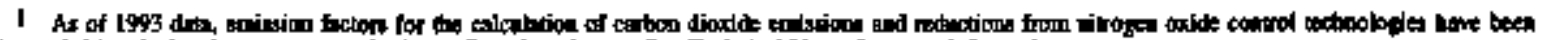

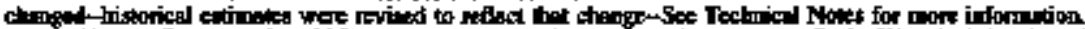

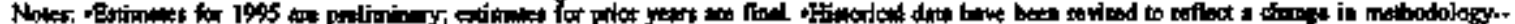

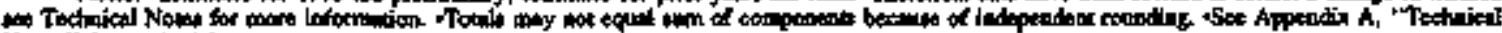
Nowe:" tor netbridology.

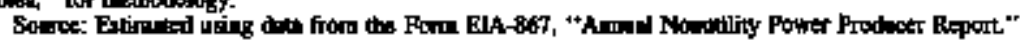



Appendix A

\author{
Technical \\ Notes
}





\section{Technical Notes}

\section{Sources of Data}

The Electric Power Annuel Volume $n$ is prepared by the Coal and Electric Data and Renewables Division; Office of Coal, Nuclear, Electric and Altermate Fuels; Evergy Information Admínistration (EIA); U.S. Department of Energy (DOE). Data publisbed in the Electric Power Annual Volune II are compiled from six forms filed annually by electric utilities and one form filed ansually by nonutility power producers. Those forms are: the Form EIA-861, "Annual Electric Utility Report"; the Federal Energy Regulatory Commission (FERC) Form 1, "Anaust Report of Major Electric Utilitłes, Licensees, and Others"; the Form EIA-412, "Annual Report of Public Electric Utilities": the Form ElA-767, "Steam-Electric Plant Operation and Design Report"; the Form EIA-867, "Annta] Nonutility Power Producer Report"; the Department of Energy, Office of Emergency Planning Form ELA-4I], "Coordinated Bulk Power Supply Program Report"; and the Departenent of Energy, Office of Fuels Programs, Fossil Energy Form FE-781R, "Annual Report of International Electric Export/Import Data." Each form is summarized below.

\section{Form ElA-861}

The Form EIA-861 is a mandatory census of electric utilities in the United States, its territories, and Pverto Rico. The Form EIA-861 data contained in this publication are for the United States only. The survey is used to collect information on power production and sales of electricity and demand-side management information from approximately 3,200 electric utilities. The data collected are used to update the electric utility frame data base maintained by the EIA. This data base supports queries from the Executive Branch, Congress, other public agencies, and the general public. Summary data from the Form ElA-861 are also contained in the Electric Power Monthly; the Electric Sales and Revenue; the Financial Statistics of Major U.S. Investor-Owned Electric Utilities; the Finantial Statistics of Major U.S. Publicly Owned Electric Utilifies; the Annual Energy Ontlook; the U.S. Electric Utility Demand-Side Management: and the Electric Trade in the United States. These reports present aggregate totals for electric utilities on national, State, and regional levels by ownership type.
Demand-side management data collected on the Form EIA-861 are estimated by electric utilitios based on engineerigs data or statistical analysis. The utilities also use a variety of verification methodologies for these estimates. The Energy Policy Act (EPACT) of 1992, Section 171(a), mandated that ELA verify DSM data estimates and the methodologies used for estimation and verification. In response to this mandate. EIA conducted a study of DSM estimation methodologites and DSM verification methodologits. The report describes typical estimation methodologies and DSM verification methodologies, as well as the difficulties in reaching broad conclusions conceruing the quality of savings estimates reported to EIA. The report is featured in the EIA publication, U.S. Electric Utiliny Demond-Side Management 1993 , released in July 1995.

Instrument and Design History. The Form ELA-861 was implemented in January 1985 to collect data as of year-end 1984. The Federal Administration Act of 1974 (Public Law 93-275) defines the Eegislative authority to collect these data.

Data Processing. The Form EIA-861 is mailed to the respondents to collect data as of the end of the calendar year. The completed forms are to be returned to the EIA by April 30. The data are entered into the interactive on-line systern. Internal edit checks are performed to verify that current data total across and between schedules and are comparable to data reported the previous year. Edit checks are also pertormed to compare data reported on the Form EIA-861 and similar data reported on the Forms EIA-826, "Monthly Electric Utility Sales and Revenue Report with Stale Distributions, ${ }^{-}$the FERC Form 1, and the Form EIA-412. These are utility-levol checks. Respondents are telephoned to obtain clarification of reported data and to obtain missing data.

\section{FERC Form 1}

The FERC Form 1 is a mandatory restricted-universe census of major investor-0wned electric utilities in the United States having, in each of the last 3 consecutive years, sales or transmission service that exceeds one or more of the following: (1) 1 million megawatthours of total annual sales, (2) 100 megawatthours of annual sales for resale, (3) 500 emgawathours of annual power exchanges delivered, or (4) 500 megawatthours 
of annust wheeling for others (deliveries plus losses). All major U,S. investor-owned electric ntiljties, licensees, or others subject to the Federal Power Act of 3935 must submit this fors annually to the FERC. Classification of such entities is provided in the FERC Uniform System of Accounts Presctibed for Public Utilities and Licensees Subject to the Provisions of the Federal Power Act. Approximately 179 electric utilities are classifjed as major. Excluded from the summary data are the independent power producers and cooperatives jurisdictional to the FERC. The FERC has determined that seven independent power producers (IPP's): Catalyst Old River Hydrotelectric Limited Partnership. Entergy Power Incorporated, Hardee Power Partners Limited, Medina Powes Company, Nevada Sun-Peak Limited Partnership, Ocean State Power, and Ocean State Power II gre under FERC jurisdiction. These IPP's must therefore submit the FERC Form I. The FERC bas also determined that Golden Spzead Electric Cooperative. Midewest Energy, Incorporated, Old Dominion Electric Cooperative, People's Electric Cooperative, and Rayburu Country Electric Cooperative should file a FERC Form 1 under Section 201 of the Federal Power Act. Data from these five entities were not included since they are classified as cooperative electric utilities on the Form EIA-861.

The FERC Form 1 is used to collect data on income and earnings, taxes, depreciation and amortization, distribution of salaries and wages, electric operating revenues, electric maintenance expenses, gentrating planl statistics, planned construction data, yeat-end balance sheets, and geperal corporate information. Respondents are required to report data on historical plant cost and power production expenses for their hydroelectric plants with a generator nameplate capacity of 10 or more megawatts; each steam-electric plant with a generator nameplate capacity of 25 or more megawaits; and each gas-turbine plant with a generaldr nameplate capacity of 10 of more megawatts. Less detailed data are required for other plants.

This data base supports queries from the Execulive Branch, Congress, other public agencies, and the general public. Summaty and detailed data from the FERC Form 1 are also contained in the State Energy Data Report; the Financial Statistics of Major U.S. Investor-Owned Electric Utilities; the State Energy Price and Expenditure Report; the Annual Energy Review; and the Electric Trade in the United States. These reports pressent aggregate totals for electric utilities on a national leve], by Siate, and by ownership type.

Instrument and Design History. The Federal Power Commission's (FPC) Form 1, the predecessor of the FERC Form 1, was implemented in 1935 by the FPC. When the FPC was merged with the DOE in October 1977 , the processing of data on the survey becant the responsibility of the ElA. In 1991, the collection responsibitity reverted to the FERC. This mandatory survey is conducted in accordance with the FERC Uniform System of Accounks Prescribed for Private Utilities and Licensees.
Data Processing. The completed surveys, both hard copy and diskettes, are returned to the FERC on or before April 30, containing data for the preceding calendar year. A copy of each suryey and diskette is forwarded to the EIA for processing. Manual editing of the reported data is completed prior to data entry. Additional edit checks of the data are performed through computer programs. The program edits include both deterministic checks, in which records are checked for the presence of data in required fields. and statistical checks, in which the data are checked against a range of values based on historical data values and for logical or mathematical consistency with data elements reported in the survey. Discrepancies found in the data, as a result of these checks, are resolved either by the processing office or by further information obtained from a telephone call to the respondeot company.

\section{Form ElA-412}

The Porm EIA-4!2 is a restricted-universe census used annually to collect accounting, financial, and operating data from major publicly owmed electric utilities in the United Siates. Those publicly owned electric utilities engaged in the generation, transtrission, or distribution of electricity which had 120,000 megawatuhours of sales to ultimate consupters and/or 120,000 megawattbours of sales for resale for the 2 previous years, as reported on the Foran EJA-861, "Annual Electric Utility Report," must submit the Form EIA-412. The criteria used to select the respondents for this survey results in approximately 500 publicly owned electric utilities.

Federal electric utilities are required to file the Form EIA-412. The financial data for the U.S. Army Corps of Engineers (except for Saint Mary's Falts at Sault Ste. Marie, Michigan); the U.S. International Boundary and Water Commission; and the U.S. Department of Interior, Bureau of Reclamation were collected on the Form BIA-412 from the Federal power marketing adoinjstrations.

Instrument and Design History. The FPC cteated the FPC Form $\mathrm{tM}$ in 1961 as a mandatory survey. It became the responsibility of the EIA in October 1977 when the FPC was merged with DOE. In 1979, the FPC Form IM was superseded by the Economic Regolatory Administration (ERA) Form ERA-412, and in January 1980 by the Form EJA-412.

This data base supports queries from the Executive Branch. Congress, other public agencies, and the general public. Summary and detail dacs from the Form EIA-412 are also containod in the Financial Statistics of Majot U.S. Publicly Owned Electric Utilities; the State Energy Price and Expenditure Report; the and the Electric Trade in the United States. These reports present aggegate totals for electric atilities on a national level, by State, and by ownership type. 
Data Processing. The processing of data reported on this survey is the responsibility of the Coal and Electric Data and Renewables Division withjn the Office of Coal, Nuclear, Electric and Alternate Fuels. The compleled surveys are due in this office on or before April 30. Nonresponse follow-up procedures are vsed to attain to0-percent response. Manual editing of the reported data is completed prior to data entry. Additional edit checks of the data are performed through computer programs. The progran edits include both deterministic checks, in which records are checked for the presence of data in required fields, and statistical checks, in which the data are checked against a range of values based on histortcal data values and for logical or mathematical consistency with data elemeuts reported in the survey. Discrepancies found in the data, as a result of these cbecks, are resolved either by the processing office or by further information obtained from a telephone call to the respondont company.

\section{Form EIA-767}

The Form EIA 767 is a mandatory restricted-universe census of all electric power plants with a tosil existing or planned organic- or puclear-fueled steanelectric generator nameplate ratiog of 10 or more megawatts. The entire form is filed by approximately 700 power plants with a nameplate capacity of 100 or more megawatts. An additional 200 power plants with a uameplate capacity belween 10 and 100 megawatts submit information only on futel consumption/quality, boiler/generator configuration, and flue-gas desulfurization equipment, if applicable. The Form ElA.767 is used to collect data annually on plant operations and equipment design (including boilet, generator, cooling system, flue gos desulfurization, flue gas particulate collectors, Bnd stack data). Data from the Form EIA-767 are used for economic, regulatory, and environmental anslyses conducted by the $\mathrm{DOE}_{+}$the FERC, the Environmental Protection Agency, and the Depariment of Commerce.

This data base supports queries from the Executive Branch, Congress, other public agencies, and the general public. Summary and dotail data from the Form EfA-767 are also contained in the Electric Power Annual Volume I; and the Coal Industry Annual. These reports present agsregale totals for electric utilities on a national level, by State, and by ownership type.

Instrument and Design History. The Federal Energy Administration Act of 1974 (Public Law 93-275) defines the legislative authority to collect these data. The predecessor form, FPC-67, "SteamElectric Plant Air and Water Quality Control Data," was used to collect data from 1969 to 1980 , when the form number was changed to Form BIA.767. In 1982, the form was completely redesigned and given the name Form ELA-767, "Steam-Electric Plant Operation and Design Report." In 1986, the respondent universe of 700 was increased to 900 to inctude plants with nameplate capacity from 10 megawatts to 100 megawates. Respondents for these 200 additional plants complete only pages 1, 5, 6, and, if applicable, 13 , and 14.

Data Processing. The Form EIA-767 is mailed to respondents in January to collect data as of the end of the preceding calendar year. The completed forms are to be teturned to the EJA by May 1. Equipment design data for each respondent are preprinted from the appijicable data base. Respondents are instructed to verify alt preprinted data and to supply missing data. The data are manually reviewed before being keyed for automatic data processing. Computer programs containing additional edit checks are run. Respondents are telephoned to obtain cortection or clarification of reported data and to obtain missing data, as a result of the manual and automatic editing process.

\section{Form ElA-867}

The Form ElA-867 is a mandatory survey of all existing and planned nonutitity electric generating facilities in the Unjted States with a total geperator nameplate capacity of 1 or more megawatts. In 1992. the reporting threshold of the Form EIA-867 was lowered to include all facilities with a combined nameplate capacity of 1 or more megawatts. Previously, data were collected every 3 years from facilities with a nameplate capacity between 1 and 5 megawatts. Planned generators are defined as a proposal by a company to instalf electric generating equipment at an existing of planned facility. The proposal is based on the ownter having obtained (1) all environenental and regulatory approvals, (2) a contract for the electric energy, or (3) finsncial closure on the facility. The Form cossists of Schedules I, "Identification and Certification;" Schedule II, "Facility Information"; Schedule HI. "Standard Industrial Classification Code Designation"; Schedule IVA, "Facility Fuel Information"; Scbedule IVB, "Facility Thermal and Generation Information"; Schedule V, "Facility Enviconmental Isformation"; and Schednle VI, "Electric Generator Information."

Submission of the Form EIA-867 is required from all facilities that have a combined facility nameplate capacity of 1 megawatt or more. Schedule V, "Facility Environmental Information" is only roquired of those facilities of $\mathbf{2 5}$ megawatis or more.

The form is used to collect data on the instalied capacity, energy consumption, generation, and electric enerby sales to electric utilities and other nonutilitios by facility. Additionally, the form is used to callect data on the quality of fuels burned and the types of enviropmental equipment used by the respondent.

Instrument and Dasign History. The Form EIA-867 was implemented in December 1989 to collect data as of year-ead 1989. The Federal Energy Administration Act of 1984 (Public Law 93-275) defines the legislative authority to collect these data. 
Data Processing. The Form EIA-867 is mailed to the respondents in January to collect dace as of the end of the preceding catendar year. Static data for each respondent are preprinted from the previous year, and the respondents are instructed to verify all preprinted information and to supply the missing data, The completed forms are to be returned to the EIA by Apri] 30. The response rate for all facilities that addresses were confirtmed was 100 percent. The data are manually ediced before being keyed for autoratic data processing. Computer programs containing addjtional edit cbecks are run. Respondents are telephosed to obtain corrections or clarifications of repotted data and to obtain anissing data as a result of the goanual and automated editing.

Data Qually. The Manufacturing Energy Consumption Survey (MECS) produces detailed estimates of manufacturing electricity generation by industry and Census Division on a triennial basis. The data are published in the Manufacturing Entrgy Consumption Survey, Consumption of Energy. Gross generation by nonutitity power producers by major industry groups, and Census division, for 1991 through 1995 presented in this report, are reasonable given the growth in manufacturting on site generation.

Data for the Form EIA-867 are collected from all exjsting and planned nonutility generating faciljties in the United States with a total generator nameplate eapacity of 1 or more megawats. These data are aggregated to provide geographic totals for selected States and at the Censos division and national tevels. Since the Form EIA-867 data are considered contidential, suppression of some data is necessary to protect the confidentiality of the individnal respondent data. See "Confidentiality of the Data" in this section for further information on the nondisclosure of dats.

Allocating Capacity. The installed capactty for nonutility generating units is allocated to one energy source using the following algorithms:

- For generating units using a single fossil energy sourca, the capacity is allocated totally to that energy source.

- For generating units that use hydraulic, geothermal, solar, biomess, or wind energy, the capacity is allocated to that energy source (even if a secondary fuel is burned).

- For generatiog units using a combination of fossil energy and renewable enerisy sources, capacity is classified as fossil or tenewable based on the greatest percentage of Btu consumed when sumined.

- To allocate capacity by fuel within the fossil energy and renewable energy sources, the single fuel within that energy source with the greatest percentage of Btu constrmed is usted.
Allocating Generation. The generation for nonutility facilities is atlocated to one energy source usiag the following algoritbus:

- For generating units that use energy sources that are sot butned (hydranlic, geothermal, nuclear, solar, or wind energy), the generation is allocated to that energy source (even if a secondary fuel is burned).

- For facilities having generating anits using energy sources that art burped, the generation is allocated based on the percentage of Btu consumed. This algorithm assumes that unit efficiency is the saine for all encrgy sources.

A comparison of installed capacity for facitities of $I$ megawatts or more of EIA's data with data published by Edison Etectric Institute (EEI) in Capacity and Generation of Non-Utitity Sources of Energy shows a difference of approximately 1 percent.

\section{Gross-to-Net Generation Conversion} Methodology. Gross electricity genoration data from the Form EIA-867, reported by generator, are aggregated to provide totals by energy source and geographic area. Nonutility power producers report gross electricity generated on the Form EIA-867, unlike electric utilities that report net generation on various EIA and FERC forms. Nonutilities generally do not measure and record electrical consumption used solely for the production of electricity. Nonuitity generalors and associated auxiliary equipurent are often an integral part of a manufacturing or other industrial process and individual watthour meters are not generally instalIed on suxiliary equipment.

Estimated values for net generation from nonutility power producers were developed by EIA using gross generation, prime mover, fuels, and type of air pollution control data reported on the Form EIA-867. The difference between gross and net generation is tho electricity consumed by auxiliary equipment and eavironmental control devices such as pumps, fans, coal pulverizers, particulate collectors, and flue gas desulfurization (FGD) units. The difference between gross and oet generation is sometimes called parasitic joad. In smaller power plants rotating avxiljaries are almost ajways efectric motors. In large power plants that produce steam, rotating auxiliaries cha be powered by eitber steam turbines or electric motors and somelimes both because of cold startup require. ments.

This methodology for estimating net generation from gross generation is based on determining typical energy consumption for auxiliary electrical equipment associated with electrical generators. For instance. wind turbines have none of the auxiliaries common to a coal-burnigg power plant such as a coll po]verizers. fans, and emission controls. On the other hand, wiedfarms do consume electricity since automatic. computer-based control systems are used to control blade pitch and speed thereby affecting generntor electricity output. 
Shown below are the conversion factors used to estiwated nel generation by nonutility generators. The factors are typical of a madern electric power plunt but could vary significantly between individual plants. Net generation is calculated by multiplying the appropriate conversion factor by the reported gross electrical generation.

\begin{tabular}{|c|c|}
\hline Prine Irow Tr:2 & 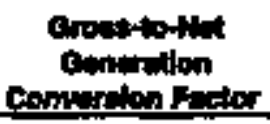 \\
\hline 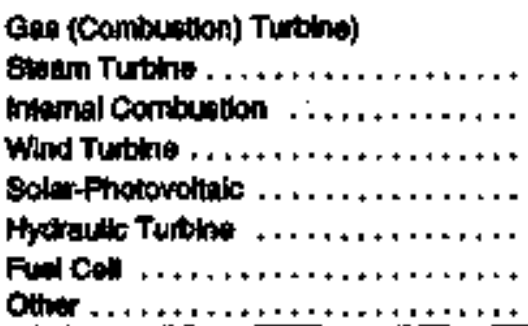 & $\begin{array}{l}98 \\
.87 \\
.89 \\
89 \\
89 \\
.87\end{array}$ \\
\hline
\end{tabular}

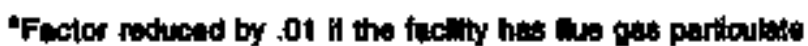

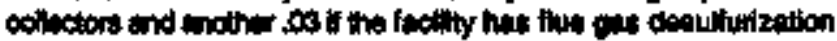

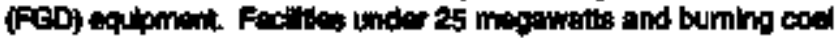

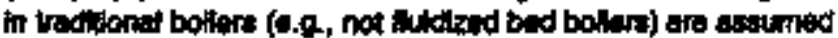
to heve paticulate and FGD equipment

These conversion factors were estimated by the staff of the Office of Coal, Nuclear, Electric and Alternate Fuels, Enetgy Information Administration. The primary reference nsed in developing the conversion factors was Steam, Its Generation and Dse, 40th Edition, Bebeock \& Wilcox, Barberton, Ohio.
Emissions for the Production of Electricty Mefhodology. Emíssions for nonutility power producers include emissions from cogeneration facilities that produce electric power as an istegral part of a manufacturing or other thermal consuming procest. Emissions are directly proportional to the quatities of fuels consumed. To calculate emissions for the production of elextricity, a methodology was developed to estimate the consumption of fuel associated for the prodaction of electricity by cogeperation facilities. The methodology is based on net geceration heat trates by primary fuef and prime-mover. The primary fuel is the predominant energy source for the generntor based on fuel consumption at the facility expressed in total Btu by fued type. The beat rates were estimated by the staff of the Office of Coal, Nuclear, Electric and Atternate Fuels: Energy Informetion Administration. The pridary reference used in developing the conversjon factors was TAG--Technical Assessment Guide. Volume 1: Electricity Supply--1986, Electric Power Research Institute, Palo Alto, California, December 1986. The procedure to estimate the fuel consutred for the production of electricity is to calculate net generation by primary fuel and prime-mover (see gross+to-net generation methodology), multiply the net generation by the appropriate herat rate to obtain total Btu consumed for the prodoction of electricity, and spportion by the total Btu weighted by entrgy source.

Net generation heat rates by primary fuel and prime mover are as follows:

\begin{tabular}{|c|c|c|c|c|}
\hline \multirow[b]{2}{*}{ Pdme:Mover. } & \multicolumn{4}{|c|}{ Heat Rote (Btukwh - not) By Pulmay Fued } \\
\hline & Cor: & Potroleum & Naturol Gas & Other. \\
\hline $\begin{array}{l}\text { Gess (Combuetion) Turbine } \\
\text { Gingle Cycte } \ldots \ldots \ldots \ldots \ldots \ldots \ldots \ldots \ldots \ldots \\
\text { Combinad Cyole } \ldots \ldots \ldots+\ldots \ldots \ldots \ldots \ldots\end{array}$ & $\begin{array}{l}\text { N/A } \\
\mathbf{N A}\end{array}$ & $\begin{array}{r}14,000 \\
8,100\end{array}$ & $\begin{array}{r}14,500 \\
8,200\end{array}$ & $\begin{array}{l}\text { NA } \\
\text { NA }\end{array}$ \\
\hline 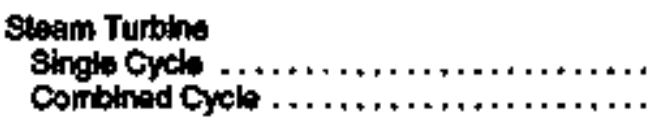 & $\begin{array}{r}10,200 \\
9,000\end{array}$ & $\begin{array}{l}9,600 \\
9,000\end{array}$ & $\begin{array}{l}9,600 \\
0,000\end{array}$ & $\begin{array}{l}16,500 \\
10,500\end{array}$ \\
\hline Internet Combustion $\ldots \ldots \ldots, \ldots \ldots \ldots \ldots$ & $N / 4$ & 11,700 & 11,700 & $\mathbf{N} / \mathbf{A}$ \\
\hline Other $\ldots \ldots$ & 10,200 & 11,700 & $t 1,700$ & 10,600 \\
\hline
\end{tabular}


Nameplate Capacity to Summer Capability Conversion Methodology. Form EIA-867, "Anzal Nonutility Power Producer Report," collects nameplate capacity for electric generating units. Estimated values for net summer capability from nameplate capacity are aggregated to provide a U.S. total. The methodology used for estimatiog summer capability from nameplate capacity is the same methodology shown in this Appendix for the Form ElA-860.

Business Classification. The nonutility industry consists of all manufacturing, agricultural, forestry, transportation, fnnance, service and administrative industries, based on the Office of Management and Budget's Standard Industrial Classification (SIC) Manual, th The following is a list from the Forn EIA-867 of the main classifications and the category of primary business activity within each classification.

Agricultere, Forestry, and Fisbing

01 Agriculture production-crops

02 Agriculture production, livestock and animal specialties

07 Agricultural services

OB Forestry

OS Fishing, hunting, and trapping

Mining

10 Metal mining

12 Coal mining

13 Oil and gas extraction

14 Mining and quarrying of nobmetallic minerals except fuels

\section{Censtruction}

15 to 17

Manutactaring

20 Food and kindred produets

21 Tobacco products

22 Textile and mill products

23 Apparel and other finished products made from fabrics and similar materials

24 Lumber and wood products, except furniture

25 Furniture and fjxtures

26 Paper and allied products (other than 2621 or 2631)

2621 Paper milts, except building paper

2631 Paperboard mills
27 Printing and publisting

28 Chemicals and allied products (other than $2819,2821,2869$, or 2873 )

2819 Industrial Inorganic Chemicals

2821 Plastics materials and resitss

2869 Industrial organic chemicals

2873 Nitrogenous fertilizers

29 Petroleum refining and related industrites

(other than 2911)

2911 Petroleum refining

30 Rtubber and miscellaneous plastic products

31 Leatber and leather products

32 Stone, clay, glass, and concrete products (other than 324 i)

3241 Cement, hydraulic

33 Primary metal industries fother than 3312 or 3334)

3312 Blast furnaces and steel mitts

3334 Primary aluminum

34 Fabricated metal products, except machinery and trabsportation equipment

35 Industsia and contmercial equipment and components except computer equipment

36 Electronic and other electrical equjpment and components except computer equipment

37 Transportation equipment

38 Measuring, anslyzing, and controlling instruments, photographic, medicat, and optical goods, watches and clocks

39 Miscellantous manufacturing industries

Transportation and Public Utilities

40 Railroad transportation

41 Local and suburban transit and interurban highway passenger transport

42 Motor freight transportation and warehousing

43 United States Postal Service

44 Water transportation

45 Transportation by air

46 Plpelines, except natutal gas

47 Transportation services

48 Compunications

49 Electric, gas, and sanitary services

Wholestle Trodte

50 to 51

Retatl Trade

52 to 59

Finance, Instrance, ond Real Estate

60 Deposttory Institutions

61 Nondepository credit institutions

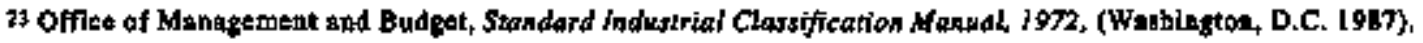


62 Security and commodity brokers, dealers. exchapges, and services

63 Insurance carriers

64 Insurance agents, brokers, and services

65 Real estate

67 Holding and other investment offices

Services

70 Hotels

72 Personal services

73 Business services

75 Automotive repair, services, and parking

76 Miscellanecus repaír services

78 Motion pictures

79 Amusement and recreation services

80 Health services

81 Legal services

82 Education services

83 Social services

84 Museums, art galleries, and botanical

and 2oological gardens

86 Membership organizations

87 Enginectīng, accounting, research,

management, and related services

88 Private households

89 Miscelianeous services

Public Administrotion

91 to 97

Other (explain):

Historically, (Tables 57 and 61) show cogeneration faciljties reporting the Standard Classification Code (SIC) that identified the user of the electric and/or thermal energy. Beginning in 1993, the SIC code was broadened to include the SIC code(s) of the producing facility based on the facilities consumption. This revision provides an alternative method of comparing power needs and utilization within the nonutility power industry. Tables AI and A2 show the installed capacily and gross generation of electricity by the producing energy group, respectively.

\section{Form EIA-411}

The Form EIA-4l] is filed anpually as a voluntary report. The information reported includes: (1) actual energy and peak demand for the preceding year and 10 additional years; (2) existing and future generatiog capacity; (3) scheduled capacity transfers; (4) projections of capacity, demand, purchases, sales, and scheduled maintenance; and (5) bulk power system maps. These data supporl queries from the execuljue branch. Congress, other public agencies, and the general public. These reports present various council aggregate totels for their member electric utilities, with some nonmember information included.

Instrument and Design Hisfory. The Form BIA-4IJ program was initisted under the Federal Power Conmission Docket R-362, reliability and adequacy of electric service, and Orders 383-2, 3\$3-3, and 383-4.
The Department of Energy, established in Octoher 1977, assumed the respousibility for this activity. This form is considered voluntary under the authority of the Federal Power Act (Public Law 88-280), The Federal Energy Administration Act of 1974 (Pub]ic Law 93-275), and the Department of Energy Organization Act (Public Law 95-91). The responsibility for collecting these data had been delegated to the Office of Emergency Planning and Operations within the Department of Energy and was returned to EIA for the reporting year 1996.

Data Processing. The Form ELA-41 is filed anoually on June 1 by the ten North American Electric Reliability Councils. The forms are compiled from data furnished by electric utilities and nonutilities (members, associates, and for nonmembers) within the council areas.

\section{Form FE-781R}

The Form FE-781R, "Annual Report of International Electrical Export/Impor1 Data" is used to collect on an asnual basis, monthly information on the gross amounis of electrical energy received and delivered and the costs and revenue associated with these transactions. The use of the format contained in Form FE-781 $R$ is optional for reporting purposes; bowever, submission of the data is mandatory.

Instrument and Design History. The atthority to issue presidentisl peruits pursuant to Executive Order Number 10485 was transferred to the Secretary of Energy by Executive Order Number 12038 (43 FR 4957 February 7, 1987). Thjs responsibitity was delegated by the Secretary to the Econonic Regulatory Administration (DOE Delegation Order Number 0204-04, October 1, 1977). The authority was redelegated (DOE Delegation Order Number 127) to the Office of Fuels Programs, Fossi! Energy, (54 FR 11436 March 20, 1990). The survey universe is defined under Title 10 of the Code of Federal Regp. lations, Sections 205.308 and 205.325 to include at] public utilities or other entities subject to the Department of Energy jurisdiction under Part II of the Federal Power Act engaged in the export of electric entergy across the international borders of the United States with Conada and Mexico. It also includes those engaged in the transmission of electrical energy across these borders who hold a presidential permit.

Data Processing. The Form FE-781R is mailed to the respondents to collect annually, the monthly dita for the preceding calendar yesr. The completed forms are to be returned to the DOE by February 15. The receipts are monually edited and the data used for the Presidential Perruit Program are entered into a machine readable format. 


\section{Quality of Data}

The Office of Coal, Nuclear, Electric and Alternate Fuels (CNEAF) is responsible for routine data improvernent and quality assurance activities. All operations in this office are done in accordance with formal standards established by the EIA. These standards are the measuring rod necessary for quality staistics. Data inprovernent efforts include verification of data-keyed input by automatic computerized methods, editing by subject matter specialists, and follow up on nourespondents. The CNEAF office supports the quality assurance efforts of the data collectors by providing advisory reviews of the structure of information requirements, and of proposed designs for new and revised data collection forms and systems. Once implemented, the actual performance of worktng data collection systems is also validated. Computerized respondent data files are checked to jdentify those who fail to tespond to the survey. By taw, nonrespondents may be fined or otherwise penalized for not filing \& mandatory EIA data form. Before inroking the law, the BIA tries to obtain the reguired information by enconraging cooperation of nontespondents.

Completed forms received by the CNEAF office are sorted, screened for completenoss of reported information, and keyed onto computer tapes for storage and transfer to randorn access data bases for computer processing. The information coded on the computer tapes is manually spot-checked agsinst the forms to certify accuracy of the topes. To ensure the quality standards ettablished by the EIA, formulas that use the past history of data values in the data base bave been designed and jimplemented to check data input for errors automatically. Data values that fall outside the ranges prescribed in the formulas are verifjed by telephoning respondents to tesolve any discrepancies.

\section{Data Editing System}

Data from the form surveys are edited using automated systems. The edit includes both deterministic checks, in which records are checked for the presence of required fields and their valldity; and statistical check, in which estimation techniques are used to validate data according to their behavior in the past and in comparison to other current fields.

\section{Confidentiality of the Data}

In general, the data collected on the forms used for input to this report are not confidential. However, dets from the Forrs EIA-867, "Annual Nonutility Power Producer Report," are considered confldenttal and must adbere to EIA's "Policy on the Disclosure of Indjvidually Identifiable Energy Isformation in the Possession of the ELA" (45 Federal Register 59812
(1980)). In arder to protect the confidentiality of indi. vidual respondent's data, a procedure was developed to suppress the data for publication. The ptacedure is described as follows.

\section{Disciosure of Data}

Date reported on the Form ELA-867, "Annud Nonutility Power Producer Reprort," are confidential. In order to protect the confidentiality of dala for an indjvidual respondent, a policy was implemented to ensure that the reporting of survey data would not associate those data with a particular company. The final phase in the data quatity assurance and control procedures is to dotermine which data must be suppressed (withheid) during publication to provide the necessary confidentiality for respondents that operate in small reporting areas. These procedures are performed as follows:

- Primary Withholding Based on the Number of Respondents in a Cell--All cells with three or fewer respondents are suppressed.

- Residual Withholding Dominance Rule--All cells containing four or more respondents are tested using a linear sensitjvity rule.

- Complementary Suppression+-All tables bre reviewed to identlfy cells that should have dats withheld to prevent disclosure of already suppressed cells. An example of this concept, when U.S. totals are available, would be the complementary suppression of a second State in order to prevent the derivation of an initially suppressed Stale.

The withholding/suppression of data is performed as an adjunct to Quality Assurance (QA) procedures. The work is perforthed by survey editors and the $Q A$ staff and is reviewed by the atrvey manager before being submitted to the division level QA review.

All sensitive cells identified in the withholding analysis are denoted with the symbol/letter "W" The use of the symbol/hetter applies to primary, complementary and inter-labte suppressions as well as all with. held data.

\section{Rounding Rules for Data}

Given a number with $\mathrm{r}$ digits to the left of the decimal and $d+t$ digits in the froction part, with $d$ being the place to which the number is to be rounded and $t$ being the remeining digits which will be truscated. this number is rounded to $r+d$ digits by adding 5 to the $(r+d+1)$ th digit when the number is positive or by subtracting 5 when the aumber is negative. The : digits are then truscated at the $(r+d+1)$ th digit. The symbol for a rounded number truncuted to zero is ("). 


\section{CNEAF Data Rovision and Pollcy}

The Office of Caal, Nuclear, Electric and Alternate Fuels has adopted the following policy with respect to the revision and correction of recurront dats in energy publications:

1. Annual survey data collected by this office are published either as preliminary or final when first appearing in a data report. Date initially relessed as preliminary will be so noted in the report. These data wil] be revised, if necessary, and declared final in the next pablication of the data.

2. All monthly and quarterly survey data collected by this office are published as preliminaty. These data are revised only after the completion of the 12 -month cycle of the data. No revisions are made to the published data before this upless approved by the Office Director.

3. The magnitude of changes due to revisions experienced in the past will be included in the data reports, so that the reader can assess the accuracy of the data.

4. After data are published as final, corrections will be made only in the event of a greater than one percent difference at the national level. Corroctions for differences that are less than the before-nentioned threshold are left to the discretion of the Office Director.

The Electric Power Annual Volume $I I$ presents the most current annual data available to the EIA. The statistics may differ from those published previously in EIA publications due to corrections, revisions, or other adjustments to the data subsequent to its orjginal release. On a chapter basis, the status (prelimiasry versus fiazl) of the data contained in the BPA follows:
- U.S. Flectrle Utility Retail Sales and Revenue Data on bales, revenue, and average revenue per kilowatthour from the Form EIA-861 for 1995 are prefiminary. The data are rovised and dectared final in the Electric Sales and Revenue 1995. A comparison of preliminary versus final anaual data at the national level for 1995 will be provided in the Electric Power Annual Volume II 1996.

- U.S. Eletetric Utilty Fizancial Statistics Financial data from the Federal Energy Regulatory Commission Form 1 and the Form EIA-4 I2 for 1995 are final.

- U.S. Electric Utility Enpironaneutal Statistics Data from the Form EIA-767 for 1994 are final. The methodology for calculating emissions of sulfur dioxides, nitrogen oxides, and carbon dioxide has been revised. As a result, final data for 1994 at the national level differ from the prelinunary by 10.0 percent for sulfur dioxide, 25.0 percent for nitrogen oxides, and 3.0 percent for carben dioxide. Date for 1995 are preliminary. A conparison of preliminary versus final data at the national level for 1995 will be provided in the Electric Power Annital Volume II 1996.

- U.S. Electric Power Transactions

All data from the Fotmis EIA-4IJ and FE-718R are final. Data from the Form EIA-861 for 1995 are preliminary; Form ELA-861 data for prior years are finat. Data from the Form EIA- 860 are final.

- U.S. Electric Utillty Demand-Side Management Data on demand-side management from the Form ElA-861 for 1994 are final. Data for 1995 are preliminary. A comparison of preliminary versus final data at the national level for 1995 will be provided in the Electric Power Annual Volume $I$ 1996.

- U.S. Nonutility Power Producers Data from the Form ELA-867 for 1991 through 1995 are final. 



\section{Formulas and Calculations}

\section{Average Heat Content}

In order to determine the Btu value per unit of consumption for each of the fossil fut ls collected on the Form EIA-759, the beat content values contained on the FERC Form 423 were used. Data on the FERC Forn 423 represent approximately 85 percent of the total gentrator nameplate capacity for all electric utilities.

\section{Percent Difference}

The following formula is used to calculate percent differences.

Percent Difference $=\left(\frac{x\left(t_{1}\right)-x\left(t_{1}\right)}{x\left(t_{1}\right)}\right) \times 100$,

where $x\left(t_{1}\right)$ and $x\left(t_{2}\right)$ denote the quantity at year $t_{1}$ and subsequent year $h$.

\section{Form E/A-861}

Data for the Form EIA-861 are collected at the utility level from all electric utilities in the United \$tates, its territories, and Puerto Rico. Forrin ElA-\$61 data in this putblication are for the United States only. These data are then aggregated to provide geographic totals at the State, NERC region, Census division, and national level. Sources and disposition of data ase also provided by utility class of ownership and relail consumer class of service. Average revenue (nominal dollars) per kilowathour of electricity solo is calculated by dividing total annual retaij revenue (nominal dollars) by the total annual retail sales of electricity.

Average reveuue per kilowatchour is defined as the cost per unit of electricity sold and is calculated by dividing retail electric reveatse by the corresponding sales of electricity. The average revenue per kilowatthour is calculated for all consumers and for each sector (residential, commercial, industrial, and other sales).

Electric utilities typically employ a number of rate schedules witbin a single sector. These alternative rate schedules reflect the varying consumption levels and patterms of consumers and their associaled impact on the costs to the electric utility for providing electrical service. The average revenue per kilowathour reported in this publication by sector represents a weighted sverage of consumer revenue and sales within that sector and across sectors for all consumers.

The electric revenve used to derive the average revenue per kilowatthour is the operating revenue reported by the electric utility. Operating revenue includes energy charges, demand charges, consumer service charges, environmental surcharges, fuel adjustments, and other miscellaneous charges.

Electric utility operating revenues cover, among other costs of service. State and Federal income taxes and taxes other than income taxes paid by the utility. The Federal component of these taxes are, for the most part, "payroll" taxes. State and local authorities lax the value of plant (property taxes), the arnount of revenues (gross recejpts taxes), purchases of materials and services (sales and use laxes), and a potentially long list of other items that vary extensively by taxing authority. Taxes deducted from employees' pay (such as Federal income taxes and employees' share of social secunity taxes) are not a part of the utility's "tax costs," but are paid to the caxing authorities in the name of the employees. These taxes are included in the utility's cost of service (for example, revenue requirements) and ate included in the amounis recovered from consumers in rates and reported in operating revenues.

Ejectric utilities, like many olher business enterprises, are required by various taxing authorities to collect and remit taxes assessed on their consumers. In this regiard, the electric utility serves as an agent fot the taxing authority. Taxes assessed on the consumer, suct as a gross recejpts tax or sales tax, are called "pass through" taxes. These taxes do not represent a cost to the utility and are not recorded in the operating revenues of the utilily. However, taxing authorities differ as to whether a specific tax is assessed on the utility or the consumet--wbich, in turn, determines whether or not the tax is included in the operating revenue of the electric utility.

EIA collects Demand-Side Management (DSM) information from all utilities with DSM programs. Uftilities with sales to ultimate consumers or sales for resale greater than or equal to 120,000 merawat thours report their incremental peak load reductions and energy savings for the reporting year (1994), annual peak load reductions and energy savings for the reporting year and first- and fifth-forecast years (1995 and 1999), and direct and indirect utility costs and nonistility tost attribulable to DSM programs for all 3 years. Annual and incremental effects for the reporting year are reported by consumer sector (residentíal, commercial, industrial, other) for each program category (energy efficiepcy, direct load control, intersuptible Iosd, other load managoment, other DSM programs, and load building). Forecast peak reductions and energy savings are reported by program category with all cossumer sectors conbined. Utilities with sales to ultimate consumers and sales for resale less than 120,000 megawatthours report incremental peak load reductions and energy savings. They also report total utility cost, total nonutitity cosi, and total DSM cost for the reporting year and first and fifth forecast years. In yoars prior to 1992, utilities with sales less than 120,000 megawatthours did not report on DSM activities. 


\section{FERC Form 1 \\ Composte Financlal Indlcatore for Major Investor-Owned Electrle Utillities}

All Enancial monetary data in this report are expressed in nominal terns. The following formulas are used to calculate composite financial indicators.

\section{Electric Fixed Asset (Net Plant) Tornover *}

$$
\frac{\sum_{i}\left(E O R_{i}\right)}{\sum_{i}\left(U_{i}\right)}
$$

where $E O R_{i}$ is the Electric Operating Revenue for the $i^{\text {ith }}$ major utility, and $U_{t}$ is the Electric Utility Plant

-- Net for the inajor utility.

\section{Total Asset Turnover $=$}

$$
\frac{\sum_{i}\left(O R_{i}\right)}{\sum_{i}\left(A_{i}\right)}
$$

where $O R$ is the Operating Revenue for the in major utility, and $A_{i}$ are the Total Assets for the it major utility.

\section{Current Assets to Current Liabillties =}

$$
\frac{\sum_{i}\left(C A A_{i}\right)}{\sum_{i}\left(C A L_{i}\right)}
$$

where CAA, are the Current and Accrned Assets for the in major utility, and $C A L_{1}$ are the Current and Accrued Liabilities for the it major utility.

Long-term Debt to Capitalizalion =

$$
\frac{\sum_{i}\left(L T D_{i}\right)}{\sum_{i}\left(C_{i}\right)} \times 100
$$

where $\angle T D_{i}$ is the Long-term Debt for the $i^{\text {it }}$ major utility. and $C_{i}$ is the Capitalization for the ith major utility.

Preferred Stock to Cepitalization =

$$
\frac{\sum_{i}\left(P S_{i}\right)}{\sum_{i}\left(C_{i}\right)} \times 100
$$

Where $P S_{t}$ is the Preferred Stock for the $f^{\mathrm{H}}$ major vitility, and $C_{y}$ is the Capitalization for the major utility.

\section{Common Stock Equity to Capitalization =}

$$
\frac{\sum_{i}\left(C S E_{j}\right)}{\sum_{i}\left(C_{i}\right)} \times 100
$$

where CSE is the Common Stock Equity of the in uajor utility; and, $C_{i}$ is the Capitalization for the $t^{*}$ major wtility.

\section{Total Debt to Total Assets =}

$$
\frac{\sum_{i}\left(L T D_{i}+S T D_{\mathrm{j}}\right)}{\sum_{i}\left(T A_{i}\right)} \times 100
$$

where $L T D_{i}$ is the Long-term Debt of the $i^{\text {in }}$ major utility; $S T D_{i}$ is the Short-term Debt of the major utility; and, $T A_{4}$ are the Total Assets of the $j^{\text {th }}$ major atility.

\section{Common Stock Equity to Total Assets =}

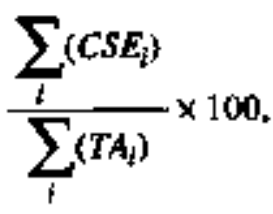

where $\operatorname{CSE}_{i}$ is the Common Stock Equity of the $i^{\text {th }}$ major utility; and, $T A$ are the Total Assets of the $i^{\text {it }}$ major utility.

\section{Interest Coverage Before Taxes Withont AFUDC =}

$$
\frac{\sum_{i}\left(\begin{array}{c}
I B L_{i}+E T T_{i}+G T_{i} \\
+O U T_{i}+T O W D_{i}-A C_{i}
\end{array}\right)}{\sum_{i}\left(I E_{l}\right)}
$$

where $I B I_{i}$ is Total Income Before Interest Charges for the it major utility; $E I T$ are the Electric Income

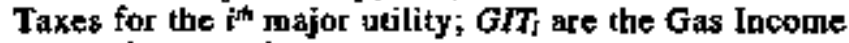
Taxes for the major utility; $O U T_{1}$ are the Other Utllity Income Taxes for the $i^{\text {in }}$ major vatility: TOID;are the Taxes for Other Income and Deductions for the ith major utility; $A C_{J}$ is the Allowance for Other Funds 
Used During Construction for the $f^{\text {ta }}$ major utility; and, $J E_{\mathrm{i}}$ is the Interest Expense for the ${ }^{\mathrm{i}} \mathrm{major}$ utility.

Proflt Margin =

$\frac{\sum_{i}\left(N l_{i}\right)}{\sum_{i}\left(O R_{l}\right)} \times 100$

where $N L_{\text {is }}$ is the Not Income of the major atility; and,

$O R_{r}$ is the Operating Revenue for the is major utility.

Return on Average Common Stock Equity *

$\frac{\sum_{i}\left(N_{i}\right)}{\left(\sum_{i}\left(\operatorname{CSE} B_{i}\right)+\sum_{i}(\operatorname{CSE} E)\right)} / 2 \times 100$

where $N / ;$ is the Net Income of the $\mathrm{i}^{\text {sh }}$ major ntility; $C S E B_{i}$ is the Comman Stock Equity at Beginning of Year, for the $i^{\text {th }}$ major utility, and CSEE. is the Common Stock Equity at Ead of Yetar for the it majot utility.

Return on Jovestment =

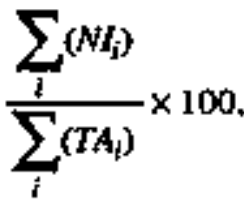

where $N h$ is the Net Incone of the $i^{\text {th }}$ major utility: and,

$T A_{1}$ are the Total Assets of the it major utility.

\section{Form EIA-412}

\section{Composito Fimanclal indlcatore for Major Publiely Owned Electrie Utilities}

Electric Utility Plant per Dollar of Revende =

$$
\frac{\sum_{i}\left(E U P_{i}\right)}{\sum_{i}\left(E O R_{i}\right)}
$$

where EUP is the Electric Utility Plant for the the public atility; and, EOR is the Electric Operating Revenue for the int public utility.

\section{Current Asaets to Corrent Llabilities =}

$\frac{\sum_{i}\left(C A_{i}\right)}{\sum_{i}\left(C L_{l}\right)}$

where $C A_{1}$ are the Current and Accrued Assets for the public utility; and, $C L_{i}$ are the Current and Accrued Liabilities for the $i^{\text {th }}$ public utility.

Electric Utility Plant as a Percent of Total Assets =

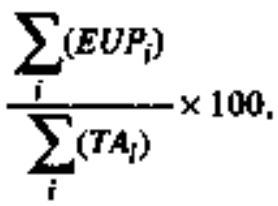

where EUP is the Electric Utility Plant for the It $^{\text {th }}$ public utility: and, $T A_{i}$ are the Total Assets for the $e^{b}$ public utility.

Net Electric Utility Plant as a Percent of Total Assets =

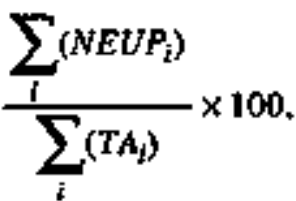

where NEUP is the Net Electric Utility Plant for the $t^{\text {th }}$ public utility; and, $T A$ is the Total Assets for the $i^{\text {it }}$ public utj]ity.

Debt as a Percent of Total Liabilities =<smiles>CCCCC1(C(C)CC)CCCC1</smiles>

where $D_{\text {t }}$ is the Debt for the $i^{\text {ih }}$ public utility; and, $T H$ is the Total Liabilities for the $i^{\text {it }}$ public utility.

Acenmalnted Provision for Depreciation as a Percent of Electric Utality Plant o

$$
\frac{\sum_{i}\left(A P D_{j}\right)}{\sum_{i}\left(E V P_{i}\right)} \times 100
$$

where APD, is the Accumulated Provision for Depreciation for the $i^{\text {th }}$ public utility: and, $E U P$ is the Electric Utility Plant for the ${ }^{\text {th }}$ public utilisy.

Electric Operntion and Moistebonce Expenses as a Percent of Efectric Operating Revenue = 


$$
\frac{\sum_{i}\left(E O M E_{i}\right)}{\sum_{i}\left(E O R_{i}\right)} \times 100
$$

where EOME is the Electric Operation and Maintenance Expenses for the int public utility; and, $E O R_{1}$ is the Electric Operating Revenue for the ith pablic utility.

Electric Deprectation and Amortization as a Percent of Electric Operating Revenat =

$$
\frac{\sum_{i}\left(E D A_{j}\right)}{\sum_{i}\left(E O R_{l}\right)} \times 100
$$

where $E D A$ is Electric Depreciation and Amortization for the $i^{\text {th }}$ public utility; and. $E O R_{i}$ is the Electric Operating Revepue for the ith public utility.

Taxes and Tax Equivalents as a Percent of Electric Operating Reventre =

$$
\frac{\sum_{i}\left(T T E_{i}\right)}{\sum_{i}\left(E O R_{i}\right)} \times 100 .
$$

where $T T E_{t}$ are the Taxes and Tax Equivalents for the $i_{\text {th }}$ public utility; and, $E O R_{\text {; }}$ is the Electric Operating Revenue tor the $i^{\text {th }}$ public utilily.

Interest Expense as a Percent of Electric Operating Revenue $=$

$$
\frac{\sum_{i}\left(I E_{j}\right)}{\sum_{i}\left(E O R_{j}\right)} \times 100
$$

where $I E_{i}$ is the Interest Expense for the $i^{\text {th }}$ public utility; and. EOR is the Electric Operatiog Revonue fot the $i^{\text {th }}$ publics utility.
Net Incoune as a Parcent of Electric Operation Revenues $=$

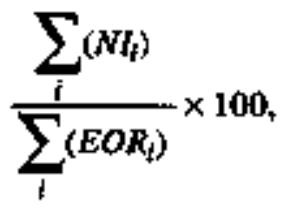

where $N H_{4}$ is the Net Income of the ith public utility: and, $E O R$ is the Electric Operating Revenue for the it public utility.

\section{Purchase Power Cents Per Kilowatthour a}

$\frac{\sum_{i}^{\left(P P C_{i}\right)}}{\sum_{i}\left(P P K_{i}\right)} \times 10$

where $P P C_{i}$ is the Purchase Power Costs (in cents) for the it public utility; and, $P P X_{\text {; }}$ is the Purchased Power Kilowatthours for the $\mathrm{i}^{\text {th }}$ public utility.

\section{Generated Cents Per Kilowatthour =}

$$
\frac{\sum_{i}\left(T G C_{i}\right)}{\sum_{i}\left(T G K_{i}\right)} \times 10
$$

where $T G C_{t}$ is the Total Generation Costs (in cents) for the ith public utility; and, $T G K_{1}$ is the Total Generated Kilowalthours for the $i^{\text {rh }}$ public utility.

Total Power Supply Per Kilowatthour Sold =

$$
\frac{\sum_{i}\left(T P C_{i}\right)}{\sum_{i}\left(T P X_{i}\right)} \times 10
$$

where $T P C_{i}$ is the Total Generation and Purchase Power Cost for the $i^{\text {th }}$ public utitity; and. $T P R$ is the Total Generated and Purchased Power Kilowatthours Sold for the $i^{\text {th }}$ public utility. 


\section{Air Emissions}

This section describes the methodology employed to calculate estimates of sulfur dioxide $\left(\mathrm{SO}_{3}\right)$, titrogen oxides ( $\mathrm{NO}_{s}$ ), and carbon dioxide $\left(\mathrm{CO}_{2}\right)$ enissions from utility and nonutility electric generating plants.

\section{Utility Aly Emlssions}

The following describes the methodology employed to calculate estimates of $\mathrm{SO}_{3}, \mathrm{NO}_{\mathrm{r}}$ and $\mathrm{CO}_{2}$ emissions from power plants operated by electric utilities. These air emissions are estimated using information contained on Form EIA-767, "Steam-Electric Plant Operation and Design Report." Form ELA-767 collecls information anuually for all U.S. power plants with a total existing or planned organic- or nuclear-fueled steam-electric generalor nameplate rating of 10 megawatts (MW) or larger. Power plants with a total generator nameplate rating of $100 \mathrm{MW}$ or more must complete the entire form, providing, among other things, information about fuel consumption and quality, Jegal air emission linits, and five gas desulfurization (FGD) efficiency. Power plants with a total generator nameplate rating from $10 \mathrm{MW}$ to less than $100 \mathrm{MW}$ complete only parl of the form. including infotmation on fuel consuription and FGD sulfur removal efficiency, if applicable.

Uncontrolied Air Pollutant Emissions. Uncontrolled aij pollutant emissions are those emissions that would occur in the absence of any control equipment. Uncontrolled $\mathrm{SO}_{2} \mathrm{NO}_{x_{\mathrm{r}}}$ and $\mathrm{CO}_{2}$ emissious are determined by multiplying the quantity of fuel burned by an emission factor. An emission factor is the average quantity of a pollutant released from a boiler when a unit of fuel is burned.

The source of the $\mathrm{SO}_{2}$ and $\mathrm{NO}_{\mathrm{x}}$ emission factors, when available, is the Environmental Protection Agency teport AP-42, "Compilation of Air Pollutant Emission Factors" (Table A3). ${ }^{\text {i* }}$ Environmental Protection Agency emission factors are based on boiler type. firing configuration, and fuel burned. The methodology for determining emissions of $\mathrm{CO}_{2}$ has been revised since the 199! publication. Emissions of carbon dioxide for 1992 and prior years have been revised using the set of factors shown in Tables $\mathrm{A}$ 3 and $\mathbf{A 4}$.

lo 1992, a special study of the relationsbip between the heat and carbon content of coal was completed by the Energy Information Admipistralion's Analysis and Systems Division of the Office of Coal, Nuclear.
Electric and Alternate Fuels. The hypothesis underlying this study was that the ratio of carbon-to-heat content varies not only by coal tank (i.e., anthracite. bittuminous, subbituminous, and lignite), but also by geograpbic location of the coal. In this study, the hypothesis was tested ant the results of the analysis supported the bypothesis. That is, it was concluded from the analysis that coal rank and location of the coal are significant factors in the variation of the ratio of carbon-to-heal content. After this determination, a set of emission factors, by rank and State were derived on the basis of data contained in EIA's Coat Analysis File. ${ }^{25}$

In editions prior to 1992 of this publication, separate conversion factors by coal rank were published and used to estimate emissions of $\mathrm{CO}_{2}$. The special study by ElA coneluded that siree geographic location of coal in addition to rank of coal is a significant factor in detertmining the carbon/heat content relationship. the use of emission factors that consider both of these elements may yield morc accurate estimates of $\mathrm{CO}_{2}$ emissions. The emission factors for coal were devel. oped in the units of pounds of $\mathrm{CO}_{2}$ per million Btu of coal.

The emission factors for $\mathrm{CO}_{2}$ (Table A4) from coal are applied by power plant, based on the rank, amount of coal recejved, and the State from which the coal originated, as reported in FERC Form 423, "Cost and Quality of Fuels for Electric Utility Plants." Thus, a weighted average emissions factor is obtained by plant and multiplied by the quantity of coal consumed by plant, as reported on Form EIA-767. "Steam. Electric Plant Operation and Desiga Report," to determine the emissions of $\mathrm{CO}_{2}$. The emission factors for $\mathrm{CO}_{2}$ based on 100-percent combustion of the carbon in the firt. Since a smalt percentage of the carbon in the coal is not converted to $\mathrm{CO}_{2}$, this publication assumes 99 percent combustion. The 1 percent of emissions is deducted at the State/National level. The emissions at the State level are based on the State in which the plant is located.

Uncontrolied emissions of $\mathrm{SO}_{2}$ and $\mathrm{NO}_{2}$ do not always accurately depict the guantity of emissions released into the atmosphere because they fail to reflect reductions from control equipment andfor operating technotogies. Conseguendy, controlled emissions are calcuialed to provide a more accurate estimate of actual utility air emissios.

Controlled Sulfur Dioxide Emissions. Because of environmental regulations controlling $\mathrm{SO}_{2}$ emissions, many utilities are requited to install FGD units at their coal-fired plants. ${ }^{26}$ FGD units typically remove between 70 to 90 percent of $\mathrm{SO}_{2}$ from the boiler flue gas although bigher removal efficiencies can be achieved. Electric utilities repott both sulfur removal efficiency (percent) and their most stringent $\mathrm{SO}_{2}$ emis-

24 "Compilation of Air Pollwtant Emistion Factors, Vol. 1: Stationary Point and Arag Sources (A.P-44);" 5th Edition (jncinding Suppleaent A) Research Triag gle Part. North Ciardina, Janoary 1996.

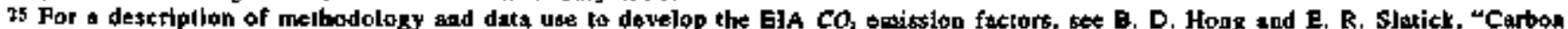
Dipxide Eraission Factors for Coal," Quarteriy Cual Report, Jatuary-Narth 1994, DOEJEIA-0121(9410) (WakhingIan, DC, Augurt I994), Energy Information Administration.

26 Flue gas desulfarizarion units may also redice sulfur dioxide emitsions from jlants that boun oil and petroleom coke. 
sion timits on the Form ElA-767. To determine controlled $\mathrm{SO}_{2}$ emissions, the uncontrolled emissions are reduced by the annual average removal efficiencies reporled on the Form ElA-767. This emission is the controlled enission. As a check, the controlled emission is compared with the most stringent legal limit reported on the Form ELA-767. The controlled emission should be less than the legal limit because research indicates that utilities routunely remove more $\mathrm{SO}_{2}$ than required to assure an operating margin of safely. If the controlled emission is not less than the most stringent legal limit, it impties that the utility is out of legal compliance and could be subject to fines and other penalties.

Utilities are permitted to take credit for sulfur that remains in bottom ash -- ash remaining in the bottom of the furnace after the coal is burned. For example, if a utility is reguired to remove 90 percent of the sulfur in the coal and 3 percent remains in the asb, it bas to remove only 87 percent using scrubbers. This ctedit is included in emissions data in this report. It is 1jkely. however, that in many cases the credit is not taken. In order to take the ash credit, utilities need to monitor the coal consumed on a daily basis; this is both timeconsuming and costly. To the extent that utilities do not take the ash credth, emissions might be slighly overstated.

Sulfur Dioxide Emission Comparison. Title IV of the Cleas Air Act Amendments of 1990 requires annual sulfur dioxide ( $\left.\mathrm{SO}_{2}\right)$ emissions from electric power plants to be reduced 10 million lons below their 1990 level by the year 2010. The Clean Ais Act requised electric utility units covered under the Acid Rajn Program (units 25 megawatts and greater) to be equipped with continuous emission moniloring systems (CEMS). CEMS is the industry standard for measuring and recording hourly $\mathrm{SO}_{2}$, nirogen oxide ( $\mathrm{NO}_{\mathrm{x}}$ ), and carbon dioxide $\left(\mathrm{CO}_{2}\right)$ ernisssions, In 1994, the first 263 utility units covered under the Acid Rain Program were required to install CEMS and submit a year's worth of emissions data to the Environmental Protection Agency (EPA). In 1995, the operators of more than 2,000 additional units were required to measure and report emissions data. EPA published 1994 CEMS emissions data by state and plant in its publication Acid Rain Program. Emissions Scorecard 1994 (EPA430/R-95-012).

Preliminary 1995 CEMS data for about 1,000 power plants was received from EPA just prior to the publication deadline. A comparison was made between $S O_{2}$ emissions data from 719 electic utility plants for which both EPA and EIA collected data for 1995. On a national basis, the data collected by EPA is 5

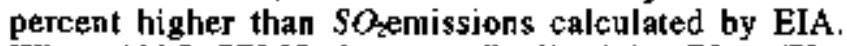
When 1995 CEMS data are finalized by EPA, EIA plans to conduct a plant-by-plant comparison of CEMS and EJA-calculated $\mathrm{SO}_{2}, \mathrm{NO}_{\mathrm{x}}$, and $\mathrm{CO}_{2}$ emissions.

Controlled Nitrogen Oxide Emissions. The controlled $N O_{x}$ emission is calculated by applying the approprtate reduction factor in Table AS. Ptior to 1995 for utidity boilers with regulaled nitrogen oxide emission limirs, the annual controlled estimate used was the lesser of the concrolled estimate or the annual limitation. When more than one control technology is reporled, the highest single reduction factor is used to estimate the annual controlled NOs emission.

Carbon Dioxide Emissions. There are no Federal regulations that limit $\mathrm{CO}_{2}$ emissions. Information pertinent to the estimation of controlled $\mathrm{CO}_{2}$ emissions is not collected on the Form ElA-767; therefore, no estimates of controlled $\mathrm{CO}_{2}$ cmissions are made.

A degtee of complexily is added to this approach, however, because air emission standards are not reported in consistent units. In some rare instances, emission standards are reported in units that cannot be directly compared with estimated uncontrolied emission rates. Examples of such standards are ones that specify the concentration of $N O$ allowed in the flue gas or the ambient concentration of $\mathrm{NO}_{x}$ (parts pet mitlion). In cases where these types of standards ate reported, the uncontrolled emission estimate is used. Such standards are uncommon, however, and do not siguificantly affect the results.

Air Emissions from Small Planis. The Form EIA-767 does not collet data for generators powered by internal combustion engines, gas turbines, combined cycle units (for example, gas turbines with waste heat boilers), and boilers at steam-electric plants with a total namepiale capacity of less than 10 MW. Accordingly, utility air emission from these generators are not estimated by the methodology. An estimate of ais emissions from these generating units based on a similar methodology using 1991 fuel consumption data reported on the Form ELA-759. "Monthly Power Plant Report" was performed. Results of this effort indicate that the emissions of $\mathrm{SO}_{2}, \mathrm{NO}$, and $\mathrm{CO}_{2}$ from utility sources not included on the Form EIA-767, are less than (t.t, 1.2, and 1.1 percent, respectively, of total utility air emissions.

\section{Nonutility Alr Emissions}

The following describes the methodology employed to calculate estimates of $\mathrm{SO}_{21} \quad \mathrm{NO}_{\mathrm{n}}$ and $\mathrm{CO}$ emissions from power plants operated by nonutilities. The emisstons are estimated using information contained on Form EIA-867, "Annual Nonutility Power Producer Report." Form ElA-867 collects infotmalion annuatly from all nonutility power producers with a total generator nameplate raling of 1 megawats (MW) or more, including cogenerators, small power producers, and other nonutility electricity generators. Facilities with a total generator nameplate rating of $1 \mathrm{MW}$ or more must complete the entire form, providing. among other things, information about fuel consumption and quatity. Facilities with a combined nameplate capacily of less than 25 megawatts are not required to complete Schedule V "Facility Envisonmental Information" of the Form EIA-867. 
Unconfrofled Emissions, Uncontrolled air pollutant emissions are those emissions that would occur in the absence of any control equipment, Unconttolled $\mathrm{SO}_{2}$, $\mathrm{NO}_{n}$ and $\mathrm{CO}_{2}$ emissions are determined by multiplyìng the quantity of fuel burned by an emission factor. An emission factor is the average quantity of a pollutant teleased from a boiler when a unit of fuel is burned. As with electric utilities, the source of both the $\mathrm{SO}_{\text {, }}$ and $N O_{x}$ emission factors, when available, is the Environmental Proteclion Agency report AP-42, "Compilation of Air Pollutant Emission Faclors. "27 However, the boiler type and firitg configuration are not reported on the Form EJA-B67 so all boilers are assumed to be large boilers 23 with pulverized coal firing and dry bottons. For other types of prime movers (for example, gas turbines, combined cycle, and internal combustion engines) the same set of emission factors ate used.

The melhodology for determining emissions of $\mathrm{CO}_{2}$ from tonutility electtic power plants has been revised. The new melhodology uses the resulis of the coal study discussed under "Utility Air Emissions." Based on the coal rank, the quality of coal received and its Stace of origin, weighted average emission factors are determined by State for electric utility plants. It is assumed that nonutility plants located in the same State as utility plants obtain coal from the same State. The weighted emission factors by State for utility coal-fired plants are moltiplited by the coal consumption reported for nonutitity plants in the respeetive State on Form ElA-867.

Uneonttolled emissions of $\mathrm{SO}_{2}$ and $\mathrm{NO}_{x}$ do nol always accurately depict the quantily of emissions released into the almosphere because they fail to reflect reductions from control equipment and operating technologies. Consequently, controlled emissions are calculated to provide a more accurate estimate of actual nonutility air emissions.

Controlled Sulfur Dioxide Emissions. The Clean Air Acl of 1971 establisbed Federal emission limits for new fossil-fueled steam generators .. 1.2 pounds of $\mathrm{SO}_{2}$ per mitlion Btu of solid fossil fuel consumed and 0.8 pounds for tiquid fossil fuels. The Clean Air Act of 1978 established even more stringent sulfur dioxide emission limits. The revised law mandates the installation of flue gas desulfurization (FGD) equipment at some new industrial and commercial facilities built after June 19,1984, and requires that these facilities remove 90 percent of the $\mathrm{SO}_{2}$ in the flut gases. Nonutilities report whether they have FGD equipmenl at their facilities and the date of first electrical generation on the Form EIA-867. Air enission limits are based on the date construction began. It is assumed that it takes two years from the start of construction to the date of first electrical generation as rcported on the form.

Controlled $\mathrm{SO}_{2}$ emissions ate calculated for respondents teporting FGD equipment or tluidized bed com- bustion. For facilities reporting first electrical generation before August 1973, no reductions are assumed. For facilities reporting first electrical generation between August 1973 and June 1986, the controlled emission is estimated as the lesser of ejther: the unconttolled emission, or a weighted average of 1.2 and 0.8 pounds of $\mathrm{SO}_{2}$ per mitlion Bte of solid and liquid fossil fuel consumed, respectively. For faciljties reporting first efectrical generation after Jure 1986, the controlled emission is estimated as the lesser of either: the uncontrolled emission reduced by 90 percent, or a weighted average of 1.2 and 0.8 pounds of $\mathrm{SO}_{2}$ per million Btu of solid and liquid fossil fuel consumed, respectively.

Facilities with a total nameplate rating between $5 \mathrm{MW}$ and $25 \mathrm{MW}$ are not required to report whether they have FGD units. Controlled $\mathrm{SO}_{2}$ enissions for these facilities are calculated based on the year electricity was first generated at the facility as reporled on the Form ELA-867. For facilities repotting electrical generation before August 1973, no control equipment is assumed and the controlled $\mathrm{SO}_{2}$ emission is equal to the uncontrolted emission as calculated above. For facilities reporting the dale of their first electrical generation as between August 1973 and August 1980, the controlled $\mathrm{SO}_{2}$ emission is estimated as the lesser of either: the uncontrolled $\mathrm{SO}_{2}$ emission, or 1.2 pound of $\mathrm{SO}_{2}$ per million Btu of fuel consumed. For facilities reporting their first electrical generation after August 1980, the controlled $\mathrm{SO}_{2}$ emission is estimated as the lesser of either: the unconlrolled emission reduced by 80 percent, or 1.2 pounds of sulfur dioxide per mislion Btu of fuel consumed.

Controlled Nitrogen Oxide Emissions. Nonutilitics with a cotal facility nameplate rating of $25 \mathrm{MW}$ or more are required to report on the Form EIA-867 whether they have any $N O_{x}$ control equipment and its type. Controlled $\mathrm{NO}_{\mathrm{x}}$ emissions estimates are based on assumed removal efficienties for the different lypes of $N O_{x}$ control equipment. The percent removal effj. ciencies of the $N O_{x}$ control equipgient and/or operating 1echnologies are shown in Table A5.

The controlled NO, emission is calculated by reducing the uncontrolled emission by the appropriate reduction percentage based on the $N O_{x}$ technology. In cases where more than one type of technology is reported, the highest single reduction percentage of the equipment reported is applied.

Facilities with a total nameplate rating between $5 \mathrm{MW}$ and $25 \mathrm{MW}$ are not required to repon whether they have $N O_{x}$ reduction equipment. However, the Clean Air Act limits NOr emissions to 0.8 pounds per million Btu of fuet consumed. Controlled $\mathrm{NO}_{x}$ emissions for these facilities are calculated based on the year electricity was first generated at the facility as reported on the Form ELA-867. For facilities reporting efectrical gentration before August 1973, no control equipment is assumed and the controlled $N O_{x}$ emis-

71 "Complitation of Air Poltutant Enissinn Factors, Vol. I: Stationary Point and Area Saurces(AP-42)," Sih Edition (tnctuding Supplement A) Research Triangle Park. North Carolina, Japuary 1995.

28 Botlers with a grost heat rate of 100 million Bta per hoor or greater 
sion is estimated to be equal to the uncontrolled emission as calculated above. For facilities reporting the first date of electrical generation after August 1973, the controlled $N O_{x}$ emission is estimated is the lesser of eithes: the uncontrolled $N O_{x}$ emission, or 0.8 pounds of $\mathrm{NO}_{\mathrm{r}}$ per orillion Btu of fuel consumed.
Confralled Carbon Dloxide Emissions. There are no Federal regulations that limit $\mathrm{CO}_{2}$ emissions. Information pertinent to the estimation of controlled $\mathrm{CO}_{2}$ emissions is not collected on the Form ELA-867; therefore, bo estimates of controlled $C O_{2}$ emissions at provided. 


\section{General Information}

\section{Use of the Glossary}

The terms in the glossary have been defined for general use. Restrictions on the definitions, as used in these data collection systems, are included in each definition when necessary to define the terms as they are used in this report.

\section{Obtaining Copies of Data}

Upon EIA approval of the Electric Power Annkat Volkme II these data are available for public use.

Magnetic tapes may be purchased by using Visa, MasterCard, or American Express cards, as well as monty orders or checks payable to the National Technical Information Service (NTIS). Purchasers may ałso use NTIS and Government Printing Office deposit accounts. To place an order, contact:

National Texhuical Information Service (NTIS) Office of Dats Base Services

U.S. Department of Commerce 5285 Port Royal Road

Springfield, Virginia 22161

(703) 487.4650 or Fax (703) 321.8547

Personal computer diskette ( $31 / 2^{n}$ or $51 / 4^{\prime \prime}$ ) may be purchased by using Visa or MasterCard, as well as money orders or checks payable to the U.S. Department of Energy. To place an order, contact:

Offuce of Scientific and Technical Information U.S. Department of Energy

Request Services

P.O. Box 62

Oak Ridge. Tennessee 37831

(615) 576-8401 or Fax (615) 576-2865 
Tabje A1. Installed Capacity at U.S. Nonutility Generating Facilities by Prodocing Energy Groop and Census Division, 1993 throngh 1995

(Megawatts)

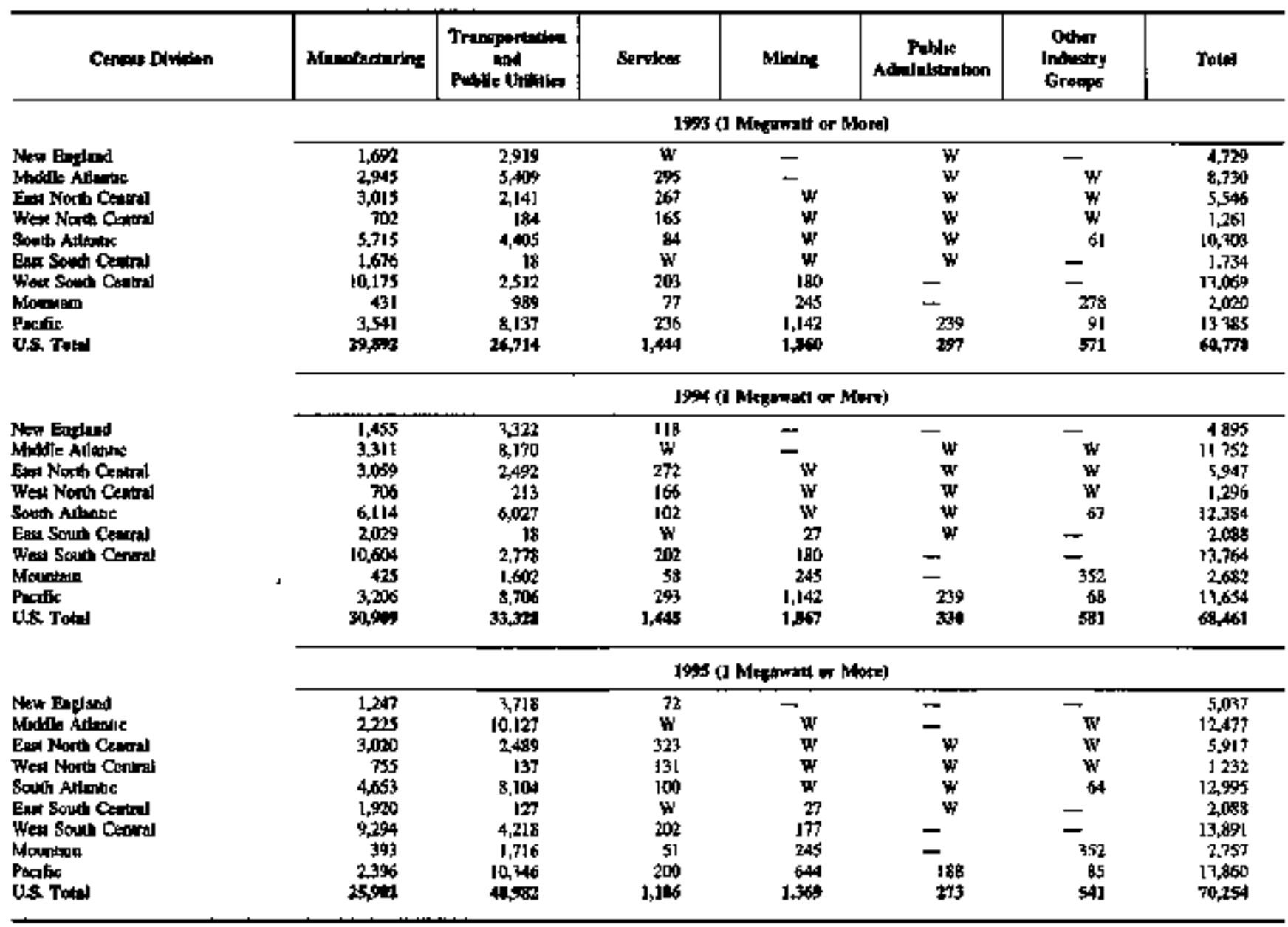

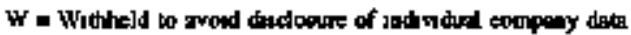

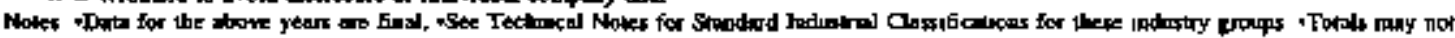

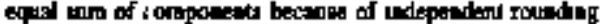

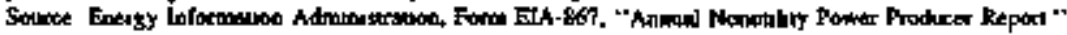


Table A2. Gross Generation by ULS. Nonutility Generating Facilities by Prodocing Energy Group and Census Divisitn, 1993 through 1995

(Million Kilowatthours)

\begin{tabular}{|c|c|c|c|c|c|c|c|}
\hline Censes Dhtion & Monetintarlun & 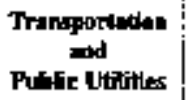 & Servinet & Mitnin & $\begin{array}{c}\text { Punle } \\
\text { Adminlstruthog }\end{array}$ & $\begin{array}{l}\text { Cother } \\
\text { Indopart } \\
\text { Croapa }\end{array}$ & Totol \\
\hline & \multicolumn{7}{|c|}{ 1933 (I Mtoprowt of Mart) } \\
\hline \multirow[t]{2}{*}{ 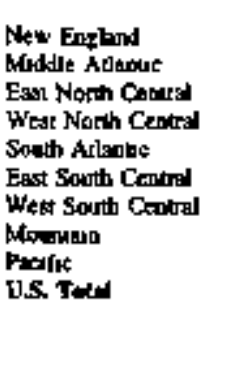 } & $\begin{array}{r}9,933 \\
16,469 \\
14,763 \\
2,993 \\
32,412 \\
10,533 \\
61,308 \\
2,403 \\
20,704 \\
171,145\end{array}$ & $\begin{array}{r}17,9910 \\
30,513 \\
9,981 \\
341 \\
10,769 \\
72 \\
16,627 \\
5,721 \\
41,692 \\
133,627\end{array}$ & $\begin{array}{c}465 \\
W \\
956 \\
403 \\
1,59 \\
W \\
611 \\
11 \\
1,407 \\
5,541\end{array}$ & $\begin{array}{r}- \\
(*) \\
w \\
W \\
W \\
W \\
1,127 \\
523 \\
7,720 \\
146 \% 9\end{array}$ & $\begin{array}{l}(\omega) \\
(\omega) \\
w \\
w \\
W \\
-W \\
-1,530 \\
1,707\end{array}$ & 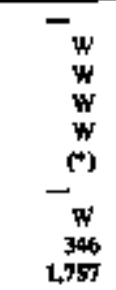 & $\begin{array}{r}28,229 \\
48,705 \\
26,211 \\
4,675 \\
43,620 \\
10,741 \\
80,673 \\
9,572 \\
73,460 \\
325,226\end{array}$ \\
\hline & \multicolumn{7}{|c|}{$190 \mathrm{~d}$ (1 Mrgpart or Mart) } \\
\hline 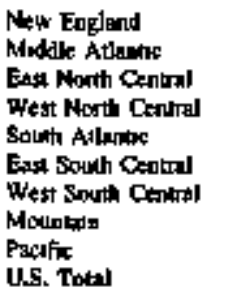 & $\begin{array}{r}7,840 \\
17,948 \\
14,728 \\
3,150 \\
35,043 \\
12,478 \\
62,636 \\
2,473 \\
19,483 \\
175,781\end{array}$ & $\begin{array}{r}21,613 \\
31,167 \\
12,762 \\
434 \\
16,720 \\
81 \\
11,751 \\
7,199 \\
45,393 \\
159,520\end{array}$ & $\begin{array}{c}471 \\
W \\
\$ 99 \\
421 \\
166 \\
W \\
539 \\
336 \\
5,700 \\
5,781\end{array}$ & $\begin{array}{r}- \\
(7) \\
w \\
w \\
w \\
148 \\
464 \\
567 \\
8,069 \\
10,618\end{array}$ & $\begin{array}{l}(v) \\
w \\
w \\
w \\
w \\
- \\
= \\
1,529 \\
1,747\end{array}$ & 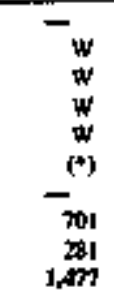 & $\begin{array}{r}29,925 \\
56,457 \\
28,993 \\
5,077 \\
52,152 \\
12,7 \% 6 \\
81,996 \\
11,273 \\
76,271 \\
354,975\end{array}$ \\
\hline & \multicolumn{7}{|c|}{1995 (I Megnewat or More) } \\
\hline 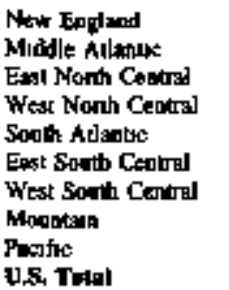 & $\begin{array}{r}6,381 \\
12,831 \\
14,859 \\
3,025 \\
25,931 \\
11,593 \\
57,667 \\
2,1907 \\
12,714 \\
147,392\end{array}$ & $\begin{array}{r}22,593 \\
56,428 \\
32,134 \\
7 \\
31,284 \\
w \\
24,398 \\
3,454 \\
56,952 \\
213,784\end{array}$ & $\begin{array}{r}175 \\
419 \\
1,259 \\
w \\
237 \\
W \\
614 \\
2 \$ 5 \\
1,022 \\
4,196\end{array}$ & $\begin{array}{c}- \\
w \\
w \\
w \\
w \\
125 \\
492 \\
492 \\
4,3,58 \\
6440\end{array}$ & $\begin{array}{l}- \\
-w \\
w \\
w \\
w \\
w \\
w \\
1,104 \\
w \\
w\end{array}$ & 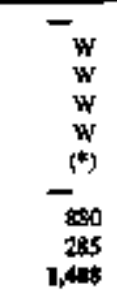 & $\begin{array}{r}29,350 \\
69,768 \\
28,436 \\
4,302 \\
57,624 \\
12,708 \\
89,172 \\
12,263 \\
76,415 \\
374,458\end{array}$ \\
\hline
\end{tabular}

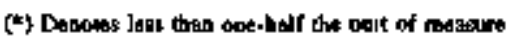

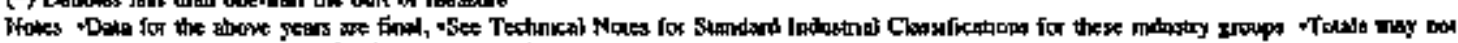

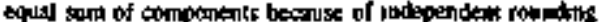

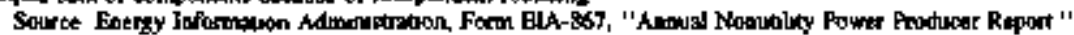


Table A3. Sultur Dioxide, Nitrogen Oxida, and Carbon Dhoxtde Embston Factors

\begin{tabular}{|c|c|c|c|c|}
\hline \multirow{2}{*}{ Fanl } & \multirow{2}{*}{ 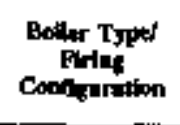 } & \multicolumn{3}{|c|}{ Bmtanin Vector } \\
\hline & & Dimild & 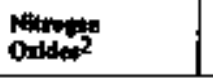 & Diention \\
\hline \multicolumn{5}{|l|}{ ulainy } \\
\hline \multicolumn{2}{|l|}{ Coil nnd Other Seld Furb } & We par in & Thes per ion & Wen par too \\
\hline Bannemours & 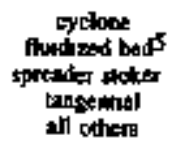 & $\begin{array}{l}3800 \times S \\
3960 \times 5 \\
3 \$ 00 \times S \\
3800 \times S \\
3800 \times 5\end{array}$ & $\begin{array}{r}338 \\
96 \\
137 \\
144 \\
217(34)\end{array}$ & $\begin{array}{l}\text { See Tinble Ad } \\
\text { Set Tatile M4 } \\
\text { See Tuble A4 } \\
\text { See Tuble A4 } \\
\text { See Teble Ad }\end{array}$ \\
\hline Subbotumancest & 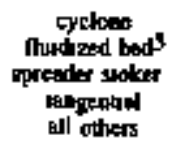 & $\begin{array}{l}3500 \times 5 \\
3960 \times 5 \\
3500 \times 5 \\
3500 \times 5 \\
3500 \times 5\end{array}$ & $\begin{array}{r}338 \\
96 \\
137 \\
144 \\
217(34)\end{array}$ & $\begin{array}{l}\text { See Table A4 } \\
\text { Sat Table A4 } \\
\text { Sa Tuble M4 } \\
\text { See Tabie A4 } \\
\text { Sec Table A4 }\end{array}$ \\
\hline Lanotet & 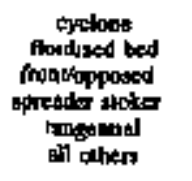 & $\begin{array}{l}3000 \times 5 \\
1000 \times 5 \\
3000 \times 5 \\
3000 \times 5 \\
3000 \times 5 \\
3000 \times 5\end{array}$ & $\begin{array}{r}1250 \\
360 \\
1110 \\
580 \\
730 \\
1190\end{array}$ & 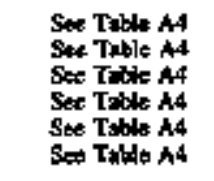 \\
\hline Rerroleon Colnt & $\begin{array}{l}\text { fimduged bed } \\
\text { All ethon }\end{array}$ & $\begin{array}{l}3900 \times S \\
3900 \times 5\end{array}$ & $\begin{array}{r}180 \\
1800\end{array}$ & $5,608)$ \\
\hline Refore & I rypes & 146 & 269 & 2,344 \\
\hline Wood & Il types & 0.08 & 150 & 2,100 \\
\hline \multicolumn{2}{|l|}{ 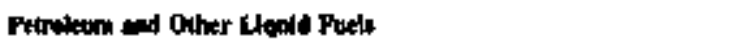 } & اله & In perr $10^{3}$ ent & los per $10^{3}$ \\
\hline Reqdod Oil & 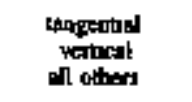 & $\begin{array}{l}16270 \times 5 \\
16270 \times S \\
16270 \times S\end{array}$ & $\begin{array}{l}4700 \\
6700 \\
6700\end{array}$ & $\begin{array}{l}25,445 \\
25,445 \\
25,445\end{array}$ \\
\hline Deullak 007 & topes & $14000 \times \$$ & 2000 & $2,5 \pi$ \\
\hline Methonod & all ipes & 905 & 1740 & 7.603 \\
\hline Propane (1tquds & all iypes & 005 & 1900 & 12.500 \\
\hline Costod bus and & 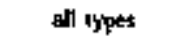 & $18500 \times s$ & 5000 & 2,368 \\
\hline \multicolumn{2}{|l|}{ 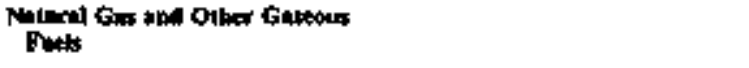 } & lis per I $\phi^{6}$ ef & Wes per $10^{6}$ of & los atr lot of \\
\hline \multirow[t]{2}{*}{ Namal Gos } & trapental & 060 & 27500 & 120,000 \\
\hline & wll okhers & 060 & 55000 & 1200000 \\
\hline Blat Furmenes Gas & with cypar & 060 & 5000 & 920,000 \\
\hline \multicolumn{5}{|l|}{ Nondilliky } \\
\hline Coal wid Ouber Seld Fonts & & her per th & lise per ton & Ihe per lon \\
\hline 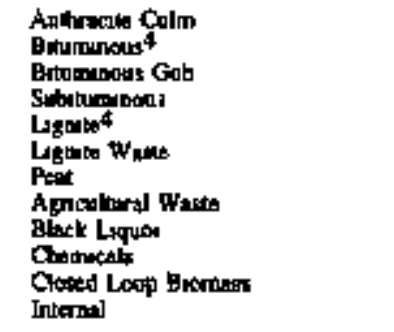 & 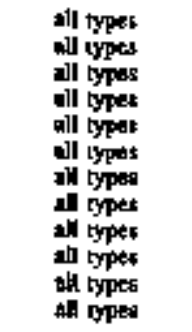 & $\begin{array}{r}3900 \times 8 \\
3600 \times s \\
3800 \times s \\
3500 \times s \\
3000 \times 8 \\
7000 \times s \\
3000 \times s \\
008 \\
700 \\
700 \\
000 \\
008\end{array}$ & 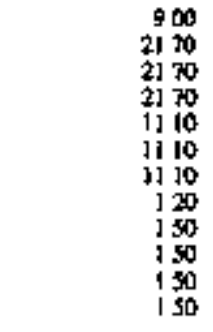 & 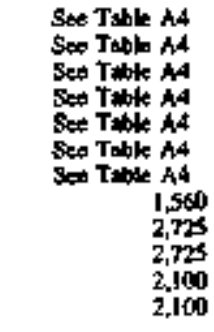 \\
\hline
\end{tabular}

See fooboes at end of ublo 
Table A3. Solfur Dioxide, Nitrocen Oxide, and Carbon Dloxide Emission Factors (Conthned)

\begin{tabular}{|c|c|c|c|c|}
\hline \multirow[b]{2}{*}{ Fived } & \multirow{2}{*}{$\begin{array}{l}\text { Boller Typet } \\
\text { Firing } \\
\text { Cowipurtion }\end{array}$} & \multicolumn{3}{|c|}{ Enderidos Fuctors } \\
\hline & & $\begin{array}{l}\text { Sentur } \\
\text { Dnwaldel }\end{array}$ & $\begin{array}{l}\text { Nirenes } \\
\text { Ondides }\end{array}$ & Conton \\
\hline $\begin{array}{l}\text { Ced and Othar Sald Meld } \\
\text { (Centhed) }\end{array}$ & & los per 10a & the per ton & Ibe per 100 \\
\hline 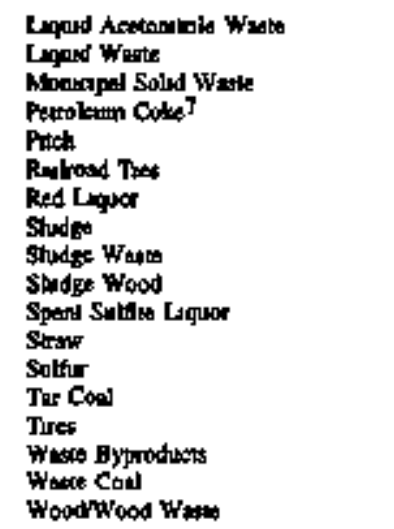 & 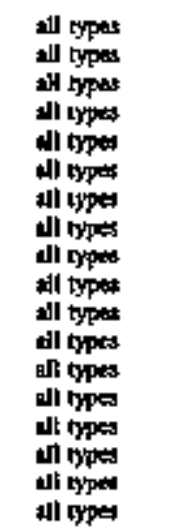 & $\begin{array}{r}700 \\
700 \\
345 \\
3900 \times 5 \\
9000 \times 5 \\
005 \\
700 \\
280 \\
280 \\
280 \\
700 \\
008 \\
700 \\
3000 \times 5 \\
900 \times 8 \\
3846 \\
3800 \times 5 \\
008\end{array}$ & $\begin{array}{r}150 \\
150 \\
260 \\
1800 \\
1110 \\
150 \\
150 \\
500 \\
500 \\
500 \\
150 \\
150 \\
000 \\
1110 \\
21 \% 0 \\
269 \\
2170 \\
150\end{array}$ & 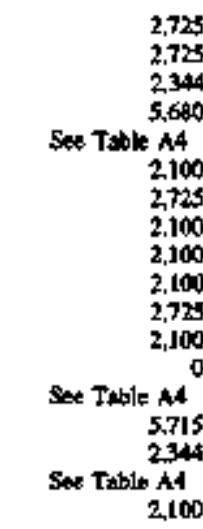 \\
\hline 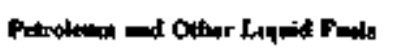 & & 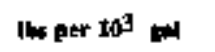 & los in & ba per $10^{3}$ \\
\hline 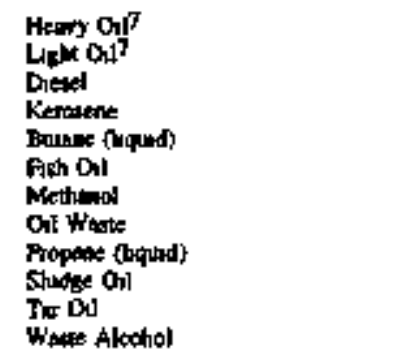 & 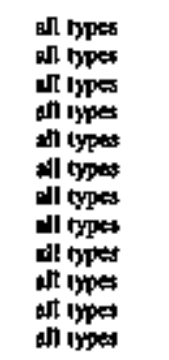 & $\begin{array}{r}16270 \times 5 \\
16270 \times 5 \\
162 \times 0 \times 5 \\
16270 \times 5 \\
060 \\
090 \\
050 \\
1600 \times 5 \\
050 \\
14700 \times 5 \\
16270 \times \$ \\
050\end{array}$ & $\begin{array}{l}6700 \\
2000 \\
2000 \\
2000 \\
2100 \\
1200 \\
1200 \\
1900 \\
1900 \\
1900 \\
6100 \\
1240\end{array}$ & $\begin{array}{r}25,445 \\
22,572 \\
22,572 \\
22,572 \\
14,700 \\
7,603 \\
7,603 \\
20,000 \\
12,900 \\
20,000 \\
25,445 \\
7,003\end{array}$ \\
\hline 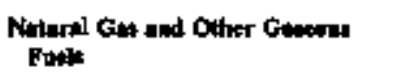 & & be $10^{6}$ a & lod Der Ito et & the per to ef \\
\hline 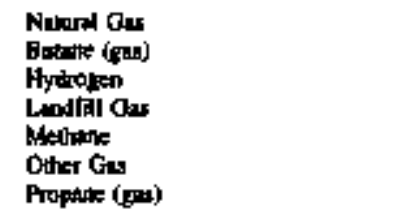 & $\begin{array}{l}\text { all types } \\
\text { all types } \\
\text { all npes } \\
\text { al bpes } \\
\text { ah typen } \\
\text { all types } \\
\text { all types }\end{array}$ & $\begin{array}{l}060 \\
060 \\
000 \\
060 \\
060 \\
060 \\
060\end{array}$ & $\begin{array}{l}55000 \\
55000 \\
550000 \\
55000 \\
55000 \\
55000 \\
55000\end{array}$ & $\begin{array}{r}120,000 \\
479,4,00 \\
0 \\
120,000 \\
116,436 \\
120,000 \\
358,333\end{array}$ \\
\hline
\end{tabular}

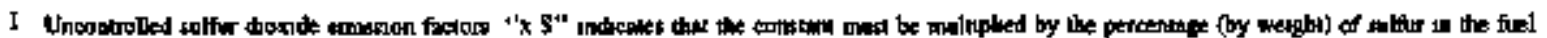

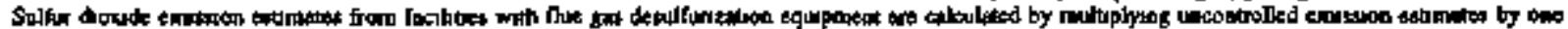

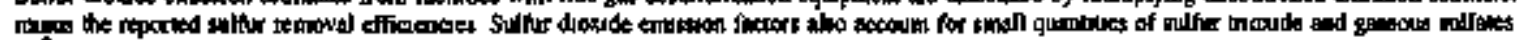

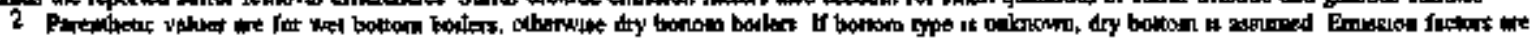

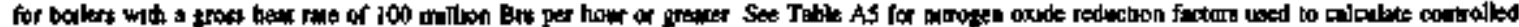

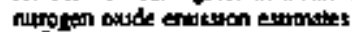

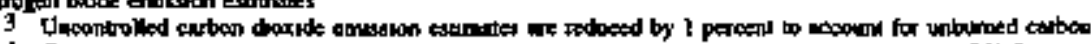

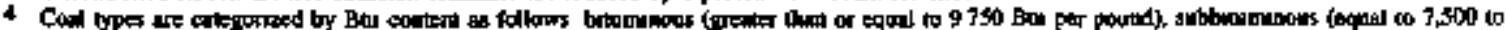

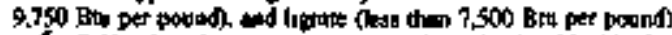

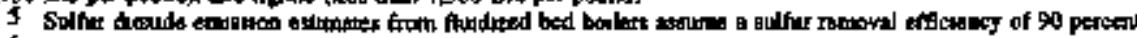

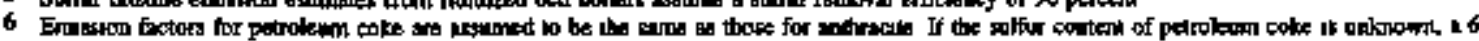

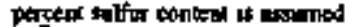

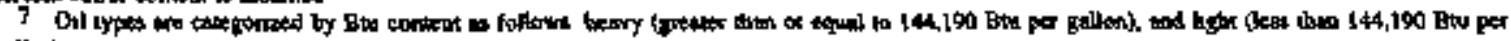
gsloo)

of $=$ Cobuc Foet

gal - US Gallows

ino = Poundt

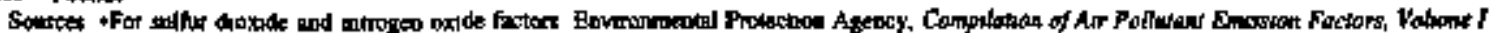

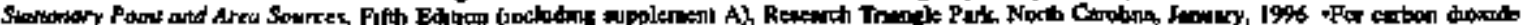

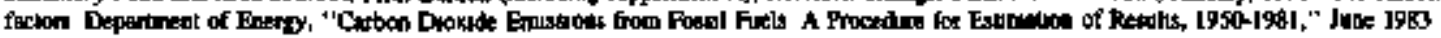


Toble A4. Carbon Dioxide Bmlssion Factors for Cook by Rent and State of Origin

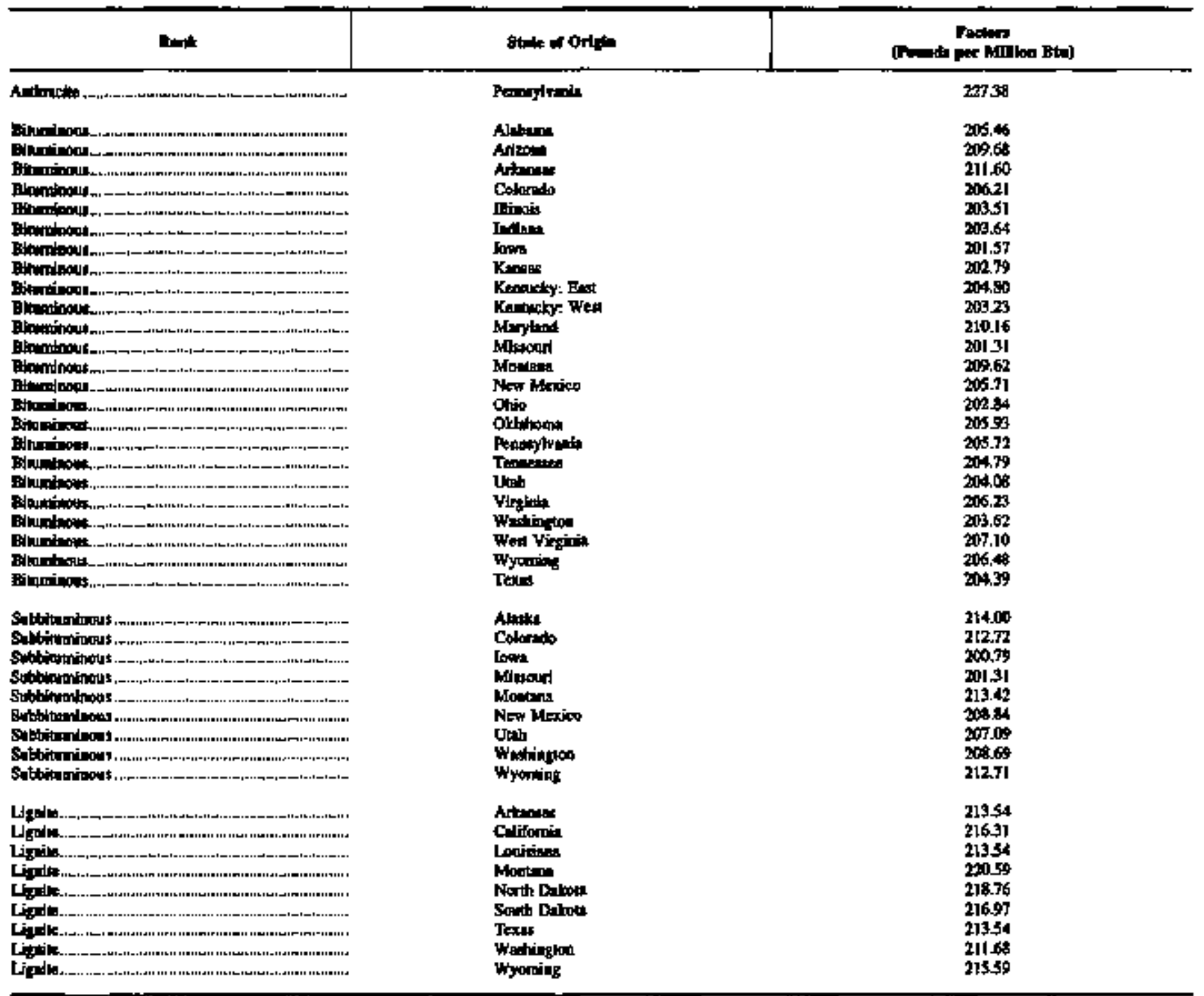

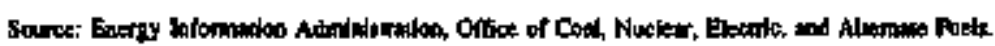


Tahle A5. Nitrogen Onide Reduction Fectors

\begin{tabular}{|c|c|c|c|}
\hline 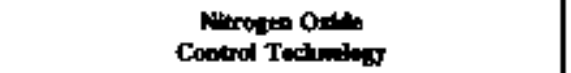 & ELA-76T Coduldi) & .1A-857 Coda(6) & $\begin{array}{c}\text { Redoctlon Pactor } \\
\text { Rertedy }\end{array}$ \\
\hline 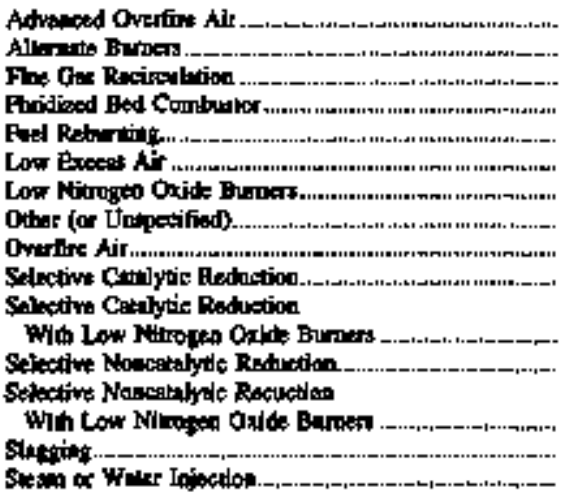 & $\begin{array}{l}\text { PP } \\
\text { FR } \\
\text { CF } \\
\text { FU } \\
\text { LN } \\
\text { OT } \\
\text { OV } \\
\text { SR } \\
\text { SR and IN } \\
\text { SN } \\
\text { SN and } \mathbf{W N} \\
\text { SC } \\
\text {. }\end{array}$ & $\begin{array}{l}\ddot{.} \\
\text { FU } \\
\ddot{\text { LE }} \\
\text { LN } \\
\text { OT } \\
\text { OA } \\
\text { Or } \\
\text { OC and } 1 \text { N } \\
- \\
- \\
\text { Sit }\end{array}$ & $\begin{array}{c}301 \\
20 \\
40 \\
20 \\
30 \\
70 \\
201 \\
301 \\
201 \\
201 \\
70 \\
90 \\
50 \\
50 \\
20 \\
20\end{array}$ \\
\hline
\end{tabular}

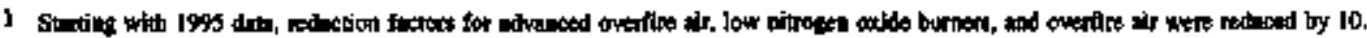

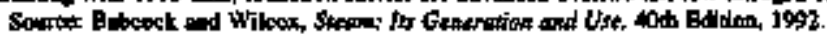

Table A6. Unit-of-Mensure Equivalents

\begin{tabular}{|c|c|}
\hline Untit & Equatent \\
\hline 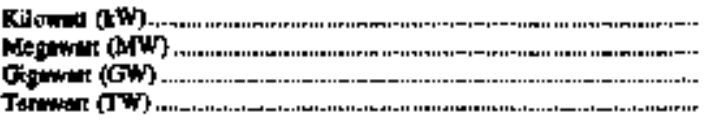 & 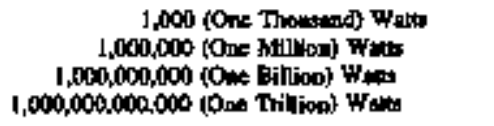 \\
\hline 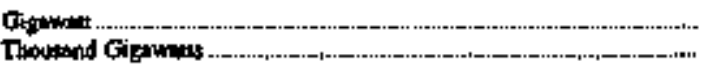 & 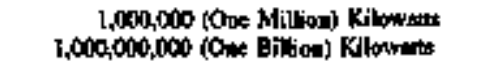 \\
\hline 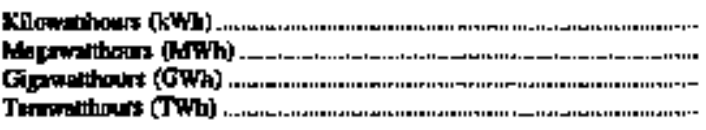 & 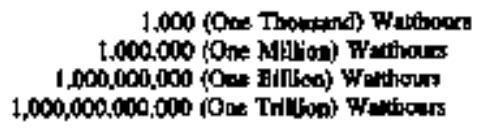 \\
\hline 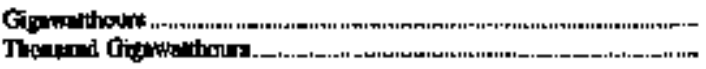 & 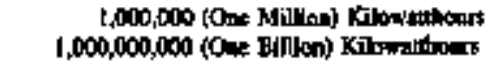 \\
\hline 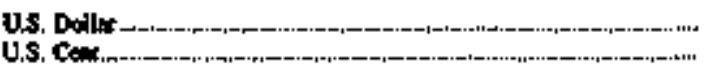 & 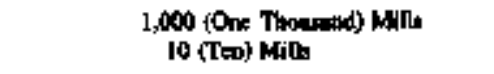 \\
\hline
\end{tabular}

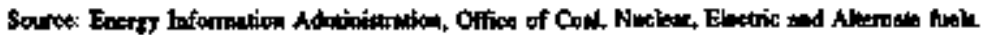





\section{Glossary}

Ackd Rolin: Also called acid precipitation or acid deposition, acid rain is presipitation containing har'mfol amounts of nitric and sulfuric acids formed primarily by nitrogen oxides azd sulfor oxdes released into the atmosphere when fossil fuels are burned. It can be wet precipitation (rain, snow, or fog) of dry precipitation (absorbed gaseous and particulate matter, aerosol particles or dust). Acid rain has a $\mathbf{p H}$ below 3.6. Normal rain bas a $\mathrm{pH}$ of about 5.6, which is slightly acidic. The term $\mathrm{pH}$ is a measure of acidity ot alkalinity and ranges from 0 to 14 . A pH measurement of 7 is regarded as nentral. Measurements below 7 indicate increased acidity, while those above irfjcate increased alkalinity.

Actual Peak Reduction: The actual reduction in annual peak load (measured in kilowatts) achieved by consumers that participate in a utility DSM program. It reflects the changes in the demand for electricily resulting from a utility DSM progtan that is in effect at the same time the utility experiences its antulal perk load, as opposed to the installed peak lond reduction espability (i.e., Potential Peak Reduction). It should account for the regulas cycling of energy efficient units during the period of ansual peak load.

\begin{abstract}
Allawance for Fands Used Daring Construction (AFUDC): A noncash item representing the estimated composite interest costs of debt and a return on equity funds used to finance construction. The allowance is capitalized in the property sccounts and isclưded in income.
\end{abstract}

Ampere: The unit of measurement of electrical current produced in a circuit by I voll acting through a resistance of $1 \mathrm{ohwl}$.

Annual Effects: The total effects in energy use (measured in megawatthours) and peak load (measured is kilowatts) caused by all participents in the DSM programs that are in effect during a given yesr. It includes new and existing participants in existing programs (those implemented in prior years that are in place during the given year) and all participants in new programs (those implemented during the given year). The effects of new participants in existing programs and all participants in new programs should be based on their start-up dates (t.e., if participants enter a program in July, only the effects frotn July to December should be reported). If start-up dates are unkpown and cannot be reasonably estimated, the effects can be annualized (i.e., assume the participants were initiated into the program on January 1 of the given year). The Annual Effects should consider the useful life of efficiency measures, by accounting fot building denolition, equipmept degradation and attrition.
Anthracte: A bard, black lastrous coal, often referred to as hard coal, contajning a high percentage of fixed carbon and how percentage of volatile matter. Couprises three groups classified accordiag to the following ASTM Specification D\$88-84, on a $₫ T y$ mineral-matter-free basis:

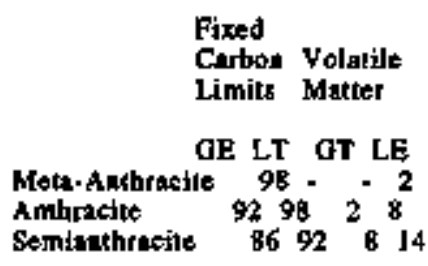

Appliances: Energy Efficiency program promotion of bigh efficiency appliances such as dishwashers, ranges, refrigerators, and freezers in the residential, commercial, and industrial sectors. Includes programs aimed at improving the efficiency of refrigeration equipment and electricsi cooking equjpment. including replacement. It also includes the promotion and identification of high efficiency appliances in retail stores using a labeling system different from the federalty-mandated Energy Guide. Energy Efficiency program promotion of bigh efficiency cooling and heating appliances are included under Cooting System and Heating System, tespectively.

Ash: Impurities consisting of silica, iron, alumina, and other noncombustible matter that are contaired in coal. Asb increases the weight of coal, adds 10 the cost of handling, and can affect its burning characteristics. Ash coptent is measured as a percent by weight of coal on an "as received" or a "dry" (moisture-free, usually part of a laboratory analysis) basis.

Asset: An economic resource, tangible or intangible, which is expected to provide benefits to a business.

Artilable but not Needed Capablity: Net capability of main generating units that are operable bul not considered aecessary to carry load, and cannot be connected to load within 30 minutes.

Averige Revenat per Kilowstthour: The average revenue per kilowathour of electricity sold by sector (residential, commercial, industrial, or other) and geographic area (State, Census division, and national), is calculated by dividing the total montbly revenve by the corresponding total monthly sales for each sector and geographic area.

Barrel: A volumetric unit of measure for crude oil and petroleum products equivalent to 42 U.S. gallons. 
Base Bill: A charge calculated through multiplication of the rate from the appropriate electric rate schedule by the level of consumption.

Baseload: The minimum anount of electric power delivered or required over a given period of tine at a steady rate.

Baseloed Capaclty: The generating equipment normally operated to serve loads on an arotind-theclock basis.

Baseload Plant: A plant, usually housing bighefficiency steam-electric units, which is normally operated to take all or part of the minimum load of a system, and which consequently prodaces electricity at an essentially constant rate and runs conlinuously. Thess units are operated to maximize system mechanictl and therroal efficiency and minimize system operating costs.

Bbl: The abbreviation for batrel.

Bef: The abbreviation for 1 bilfion eubic feet.

Bituminons Coal: The most common coat. It is dense and black (often with well-defined bands of bright and dull material). Its moisture tontent usually is less than 20 percent. It is used for generating electricity, unaking coke, and space heating. Comprises five groups classified according to the following ASTM Specification D388-84, on a dry mineralmatter-free (mmi) besis for fixed-carbon and volatile matter and a moist mmf basis for calorific value.

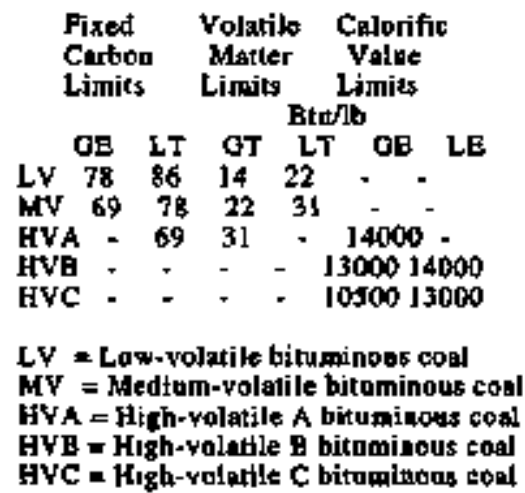

Boiler: A device for generatiog steam for power, processing, or beating purposes or for ptoducing hot water for heating porposes or hot water supply. Heat from an external combustion source is transmitted to a fluid coniained within the tubes in the boiler shell. This fluid is delivered to an end-use at a desired pressure, temperature, and quality.

Bte (British Thermal Unit): A standard unit for measuring the quantity of heat energy equal to the quantity of heac required to raise the temperature of 1 pound of water by I degree Fahreabeit.

Capability: The maximum load that a generating unit. generating station, or other electrical apparatus can earry under specifjed conditions for a given perjod of time without exceeding approved limits of temperature and stress.

Capacity: The amount of electric power delivered or required for which a generator, turbine, transformer, transmission circuit, station, or system is rated by the manufecturer.

Capacity (Purchosed): The amount of energy and capacity available for purchase from outside the system.

Capacity Charse: An elemeat in a two-part pricing method used in capacity transactions (energy charge is the other element). The capacity charge, sometimes called Demand Chage, is assessed on the amount of capacity being purchased.

Capital (Financial): The line items on the right side of a balance sheet, that include debt, preferred stock. and common equity. A net increase in assets must be fjanced by an increase in one or more torcts of capital.

Census Divisions: The nine geographic divisions of the United States established by the Burean of the Census, U.S. Department of Commerce, for the purpose of statistical analysis. The boundaries of Census divisjons coincide with State boundaries. The Pacific Division is subdivided into the Pacific Contigvous and Pacific Noncontiguous areas.

Circuit: A conductor or a system of conducters through which electric current flows.

Coal: A black or brownish-black solid combustible substance formed by the partial decomposition of vegetable matter without access to air. The rank of coal, which includes anthracite, bituminous coal, subbitumizous coal, and lignite, is based on fixed carbon, volatile inatter, and heating value. Cool rank indicates the progressive alteration from ligaite to anthracite, Lignite contains approximately 9 to 17 million Btu per ton. The contents of subbituminous and bituminous conl range from 16 to 24 million Btu per ton and from 19 to 30 million Bto per ton, respectively. Antbracite contains approximately 22 to 28 million Btu per ton.

Cogenerator: A gentrating facility that produces electricity and antother form of useful thermal energy (such as heat or steam), bsed for jndustrial. commercial, heating, or cooling purposes. To receive status as t qualifying facility (QF) under the Public ttility Regulatory Policies Act (PURPA), the facility stust produce electric energy and "another form of useful thermal energy tbrough the seguential use of energy." and buet certain ownersbip, operating, and efficiency criteria established by the Federal Energy Regulatory Commission (FERC). (See the Code of Pederal Regulations, Title 18, Part 292.)

Colncidentel Derand: The sum of two of more demands that oceur in the same time izterval.

Coincldental Peak Lond: The sum of two or more peak loads that occur in the same time interval. 
Coke (Petroleam): A residu high in carbon content and low in hydrogen that is the final ptoduct of thermal decomposition in the condensation process in cracking. This product is reported as martetsble coke or catalyst coke. The conversion factor is 5 barrels (42 U.S. gallous each) per short ton.

Combined Cycle: An electric generating technology in which electricity is produced from otherwise lost waste beat exjting from one or more gas (combustion) turbines. The exiting heat is routed to a conventional boiler or to a beat jecovery steatn generator for utilization by a stear turbine in the production of eloctriclty. This process increnses the efficiency of the electric generating anit.

Conbined Cycle Unit: An electric generating unit that consists of ont or more combustion tubines and one of more boilers with a portion of the required energy input to the boiler(s) provided by the exhaust gas of the combostion torbine(s).

Combined Pumped-Storage Plant: A pumpedstorage hydroelectric power plant that uses both punped water and natural strearaflow to produce electricity.

Commereial: The commercial sector is generally defined as nonmonufacturing business egtablishments. including hotels, motels, restatirants, wholesale businesses, retai] stores, and hesith, social, and educational institutions. The utility may classify commercial service as all consumers whose denand or annual use exceeds some specified limit. The timit may be set by the utility based on the rate schedule of the utility.

Commercial Operation: Commercial operation begins when control of the loading of the generator is turned over to the system dispatcher.

Connection: The physical connection (c.g. transmission lines, transformers, switch gear, etc.) between two electric systems permitting the transfer of electric energy in one or both directions.

Conservatlow and Other DSM: This Depand-Side Management sategory represents the amount of consumer load reduction at the time of system penk dute to utility ptograms that reduce consumer load during many hours of the year. Examples jnclude utility rebate end shared savings activities for the installation of thergy efficient eppliances, lighting and electrical machinery, and weatherization materials. In addition, this cotegory includes all other Demand-Side Manage. ment activities, such as thermal storage, time-of-use rates, fuel substitution, measurentent and evaluation, and eny other utility-administered Demand-Side Management activity designed to reduce demand andfor ejectricity use.

Construction Work In Progresa (CWIP): The balance sbown on a utility's balance sheet for construction work not yet completed but in process. This balance line item may or may not be included in the Iate base.
Comsumption (Nuel): The anount of fuel used for pross generation, providing standby service, start-up and/or flane stabilization.

Contract Price: Price of fuels marketed on a contract basis coveríng a period of 1 or more years. Contract prices reflect market conditions at the time the contract was atgotiated and therefore remain constant througbout the life of the contract or are adjusted through escalation clauses. Generally, contracl prices do not fluctuate widely.

Contract Recelpts: Purchases based on a negotiated agreement that generally covers a period of $I$ of more years.

Cooling System: Eaergy Efflciency program promotion aimed at improving the efficiency of the cooling delivery system, including replacement, in the residential, conmercial, or industrial sectors.

Cooperative Electric Uthity: An electric utilfty legally established to be owned by and operaled for the benefit of those using its service. The vtility company will generate. transmit, and/or distribute supplies of electric energy to a specified area not being serviced by another utility. Such ventures are peneralty exempt fron Federal income tax laws. Most electric cooperatives have been initially financed by the Rural Electrification Administration, U.S, Department of Agriculture.

Cost: The amount paid to acquire resources, such as plant and equipment, fuel, or labor services.

Carrent (Electric): A flow of electrons in an electrical conductor. The strength or rate of movement of the electricity is measured in amperes.

Demand (Electric): The rate at which electric energy is delivered to or by a system, part of a system, or piece of equipment, at a given instant or averaged over any designated period of time.

Demand-Side Management; The plenning, implementation, and monitoring of utility activities designed to encourage consumers to modify patterns of electricity usage, including the timing and level of electricity demand. It refers only to entergy and loadshape modifying activities that are undertaken in response to utility-administered programs. It does not refer to energy and Joad-shope changes arising from the normal operation of the marketplace or from government-mandaced energy-efficleney standards. Demand-Side Management (DSM) covers the complete range of load-shape objectives, including strategic conservation and load management, as well as strategic load growth.

Demand-Side Manozement Closts: The costs incutred by the utility to achieve the capacity and energy savitugs from the Demand-Side Management Program. Costs incurred by consumers or third parttes are to be excluded. The costs are to be reported in nominal dollars in the year in which they are jncurred. regardless of when the savings occur. Program costs include expensed items incurred to implement the 
program, incentive payments provided to consumers to install Demand-Side Management measures, and annual operation and maintenance expenses incurred during the year. Utility costs that are general, administrative, or not specific to a particular Demand-Side Management category are to be included in "other" costs.

Direct Laad Control: Refers to program activities that can interrupt consumer load at the time of annual peak load by direct control of the utility system operator by interupting power suppoly to individual appliances or equipment on consumer premises. This type of control usually isvolyes residential consumers, Direct Load Control excludes Interruptible Load and Other Load Management effects. (Direct Load Control, as defined here, is synonymous with Direct Load Control Managemeat reported to the North American Electric Reliability Council on the voluntary Office of Energy Emergency Operations Form OE-411, "Coordinated Regional Bulk Power Supply Program Report," with the exception that annual peak load effects are reported here and seasenal (i.e., summer and winter) peak load effects are reported on the OE-411.)

Direct Utillity Cost: A utility cost that is identified with one of the DSWA program categories (i.e. Energy Efficiency, Direct Load Control, Interiruplible Load, Other Load Management, Other DSM Programs, Load Bujlding).

Diatillate Fuel Oil: A general classification for one of the petroleum fractions produced to conventional distillation operations. It is used primarily for space heating, on-and-off-highway diesel exgine fuel (including railtoad engine fuel and fuel for agriculture machinery), and electric power generation. Included are Fuel Oils No. 1, No. 2, and No. 4; and Diesel Fuels No, 1, No. 2, and No. 4.

Distribution System: The portion of an electric system that is dedicated to dejuering electric energy to an end user.

Diversity Dxchange: An exchange of capacity or energy, or both, between systems whose peak loads occor at different times.

Electric Plant (Physical): A facility containing prime novers, electric generators, and auxiliary equipment for converting mechanical, chennical, and/or fission energy into electric energy.

Electric Rate Schedule: A statement of the electric rate and the terms and conditions governing its spplication, including attendane contract terms and conditions that have been accepted by a regulatory body with appropriate oversite authority.

Electric Utility: A corporation, person, agency, anthority, or otber legal entily or instrumentatity that owns andfor operates facilities witbin the United States, its territories, or Puerto Rico for the generation, transmission, distribution, or sale of electric energy primarily for use by the public and files forms listed in the Code of Federal Regulations, Title 18 , Part 141. Facilities that qualify as cogenerators or small power producers under the Public Utility Regulatory Policies Act (PLRPA) are not considered electric utilities.

Energy: The capacity for doing work as measured by the capability of doing work (poiential entrgy) of the conversion of this capability to motion (kinetic energy). Energy has several forms, some of which are easily convertible and can be changed to another form useful for work. Most of the world's convertible energy comes from fossil fuels that are burned to produce heat that is then used as a transfer medium to mechanical or other means in order to accomplish 1asks. Electrical energy is usually measured is kilowatthours, while beat energy is usually measued in British thermal units.

Energy Chinge: That portion of the charge for electric service based upon the electric energy ( $\mathrm{kWh}$ ) consumed or biljed.

Eneray Deliveries: Energy generated by one electric utility system and delivered to another system through one or more transmission lines.

Enerty Effects: The changes in aggregate electricity use (measured in megawatthours) for customers that participate in a utility DSM program. Energy Effects should represent changes at the consumer uneter (i.e. exclude transioission and distribution effects) and teflect only activities that are undertaken specifically in response to utility-kdministered programs, including those activities implemented by thírd parties under contract to the utility. To the extent possible, Energy Effects should exclude non-progran related effects such as changes in energy usage attributable to nonparticipants, government-mandated energyefficiency standards that Iegislate improvements in bojlding and appliance energy usage, changes in consumer behavior that result to greater energy use after initiation in a DSM program, the natural operations of the marketplace, and weather and business-cycle adjustments.

Energy Efitclency: Relers to programs that are aimed at reducing the energy used by specific end-use devices and systems, typically without affecting the services provided. These programs reduce overall electricity consumption (reported in megawatthours), often without explicit consideration for the timing of program-induced savings. Such savings are generally achjeved by substituting technically more advanced equipment to produce the same level of end-ust services (e.g. lighting, heating, motor drive) with fess electricity. Examples include high-afficiency appliasces, efficient lighting programs, high-efificiency heating, ventilating and air conditioning (HVAC) systems or control modifications, efficient building design, advanced electric motor drives, and heat recovery systerms.

Energy Recelpts: Energy generated by one electric utility system and received by another system through one or more transmission lines. 
Energy Source: The primary source that provides the power that is converted to electricity through chemical, mechanical, or other means. Energy sources include coal, petrolenm and petroleum products, gas, water, uranizm, wind, sunlight, geothermal, and other sources.

Equity Capilal: The sum of capital from retained earbings and the issuance of stocks.

Expenditure: The incurrence of a liability to obtnin an asset or service.

Facllity: An existing or planned lacation or site at which prime movers, electric generators, and/or equipment for converting mechanical, chemica!, and/or nuclear energy into olectric energy are situated, or will be situated. A facility may contain more than one generator of either the same or different prime mover type. For a cogenerator, the facitify includes the industrial or commercial process.

Federal Energy Regutatory Commission (FERC): A quasi-jndependent regulatory agency within the Department of Energy having jurisdiction over inter* state electricity sales, wholesale electric tates, hydrodectric licensing, natural gas pricing, oil pipeline rates, and gas pipeline certification.

Federal Power Act: Enacted in 1920, and amended in 1935, the Act consists of three parts. The first part incorporated the Federal Water Power Act administered by the former Federal Power Commission, whose sctivities were confined almost entirely to licensing non-Federal bydroeIectric projects. Parts II and III were added with the passage of the Public Utility Act. These parts extended the Act's jurisdiction to include regulating the interstate transmisstion of electrical energy and rates for its sale as wholesale in interstate commerce. The Federal Energy Regulatory Commission is now charged witb the administration of this law.

Pederal Power Commission: The predecessor agency of the Federal Energy Regulatory Commission. The Federal Power Commission (FPC) was created by an Act of Congress under the Federal Water Power Act on June 10, 1920. It was charged originally with regulating the electric power and natural gas industries. The FPC was abolished on September 20, 1977, when the Department of Energy was created. The functions of the FPC were divided between the Department of Energy and the Federal Energy Regulatory Commission.

EERC: The Federal Energy Regulatory Commission.

Firm Gas: Gas sold on a continuous and generally long-ternl coatract.

Firm Pawer: Power or power-producing capacity Intended to be available at all times duting the period covered by a guaranteed comtmitment to deliver, even under adverse condjtions.

Flue Gas Desulfarization Unit (Scrubber): Equipment used to remove sulfur oxides from the com- bustion gases of a boiler plant before discharge to the atmosphere. Chemicals, such as linte, are used as the serubbing medis.

Free Gas Particnlate Collectors: Equipment used to remove fly ash from the combustion gases of a boiler plant before discharge to the atmosphere. Particulate collectors include electrostatic precipitators, mechanica! collectors (cyclones), fabric filters (baghouses), and wet scrubbers.

Fly Ash: Particule matter from coal ash in which the particle diameter is less than $1 \times 10^{-4}$ meter. This is removed from the flue gas using flue gas particulate collectors sucb as fabric filters and electrostatic precipitators.

Forced Outuge: The shutdown of a generating unit, transmission line or other facility, for emertency reasons or a condition in which the generating equipment is unavailable for load dise to unanticipated breakdown.

Fossll Fuel: Any naturally occurring organic fuel, such as petooleurn, coal, and natural gas.

Fossil-Fuel Plant: A plant using coal, petroleusa, or gas as its soutce of energy.

Fuel: Any substance that can be burned to produce heat; also, materiais that can be fissioned in a cbain reaction to produce heat.

Fuel Expenser: These costs inclade the fuel used in the production of steam or driving another prime mover for the generation of electricity, Other associated expenses include unloading the shipped fael and all handling of the fuel up to the point where it enters the first bunker, hopper, bucket, tank, or holder in the boiler-bouse structuro.

Full-Forced Ontage: The net capability of main genterating units that is ungvailable for load for emergency reasons.

Gas: A frel burted under boilers and by internat conbustion engines for eloctric generation. These include natural, manufactured and waste gas.

Gas Turbive Plant: A plant in which the prime mover is a gas turbine. A gas turbine consists typically of an axiat-flow air compressor, one or more conbustion chambers, where liquid or gaseous fuel is burned and the bot gases ate passed to the turbine and where the hot gases expand to drive the generator and are then used to run the compressor.

Generating Unit: Any combination of physically conpected generator(s), reactor(s), boiler(s), combustion furbine(s), or other ptime mover(s) operateo together to profuce electric power.

Generation (Electricity): The process of producing electric energy by transforming other forms of energy; also, the amount of electric energy produced, expressed in watthours (Wh). 
Gross Generation: The total amount of electric energy produced by the generating units at a generating station or station, measured at the generator terminals.

Net Generation: Gross generation less the electric energy consumed at the generating station for station use.

Generator: A machine that cosverts mechanical energy into electrical onergy.

Generator Nameplate Capacity: The full-load continuous tating of a generator, prime mover, or other electric power production equjpment onder speciftc conditions as designated by the manufacturer. Installed generator nameplate rating is usually indicated on a nameplate physically attached to the generator.

Geothermal Plant: A plant in which the prime mover is a steam turbine. The turbine is driven either by steam produced from hot water or by natural steam that derives its energy from heat found in rocks or fluids at various depths beneath the surfact of the eartb. The energy is extracted by drilling and/or pumping.

Gigawatt (GW): One billion watts.

Glgawalthour (GWh): One billion watthours.

Greenhouse Effect: The increasing mean global surface temperature of the earth caused by gases in the atmosphere (including carbon dioxide, methune. ritrous oxide, ozone, and chlorofluorocarbon). The greenhonse effect allows solar radiation to penetrate but absorbs the infrared radjation retureing to space.

Grid: The Jayout of an electrical distribution system.

Gross Generation: The total amount of electric energy produced by a generating facility, as measured at the gentrator terminals.

Heating Systera: Energy Efficiency program promotjon aimed at inproving the efficiency of the heating delivery system, including replacement, in the residential, commercial, or industrial stectors.

Heavy Otl: The fuel oils remaining ofter the lighter vils have been distilled off during the refining process. Except for start-up and flane stabilization, virtually all petroleum used in steam plants is heavy oil.

Hydroelectric Plant: A plant in which the torbine generators are driven by falling water.

Incremental Effects: The annual effects in energy use (measured in megawatthours) and peak load (monsured in kilowatts) caused by new participants in existing DSM programs and all participants in new DSM programs during a given year. Reported Incre: mental Effects should be annualizad to indicate the propram effects that would have occurred bad these participants been initiated into the program on January I of the given year. Incremental effects are not simpty the Annual Effects of a given year minus the Annual Effects of the prior year, since these net effects would fail to account for program attrition, degradation, demolition, and participant droponts.

Indirect Utillty Cost: A utility cost that may not be meaningfully identified with any particular DSM program category. Indirect costs could be attributable to one of several accounting cost categorjes (i.e., Administrative, Marketing, Monitoring \& Evaluation, Utility-Earned incentives, Other). Accounting costs that are known DSM progran costs should not be reported under Indirect Utility Cost, rather those costs shonld be reported as Direct Utility Costs under the appropriate DSM program category.

Industriel: The industrial sectot is generally defined as manufecturing, construction, mining agriculture, fishing and forestry establishments Standard Industrial Classification (SIC) codes 01-39. The uttlity may classify industrial service using the SIC codes, or based on demand or annual usage exceeding some specified limit. The limit may be set by the utility based on the rate schedule of the utility.

Interdepartmeatal Service (Electric): Interdepartmental service includes amounts charged by the electric department at tariff or other specified rates for electricity sapplied by it to otber utility departments.

Intermediate Load (Electric System): The range from base load to a point between base load and peak. This point may be the midpoint, a percent of the peak load, or the load over a specified time period.

Internal Combostion Pinnt: A plant in which the prime mover is an interna! combustion engine. An internal combustion engine bas one or more cylinders in which the process of combustion takes place, converting energy released from the rapid burning of a fuel-air mixture into mechanical energy. Diesel or gas-fired engines are the principal types used in electric plants. The plant is usually operated during periods of high demand for electricity.

Interruptble Gas: Gas sold to customets with a provision that permits curtailment or cessation of service at the discretion of the distributing company under certain eircutnstances, as specified in the service contract.

Interroptible Lodd: Rofers to progran activitios that, in accordance with contrectual arrongements, can intertupt consumer load at times of seasonal peak load by direct control of the utility system operator or by action of the consumer at the direct request of the system operator. It usually involves commercial abd industria] consumers. In some instances the load reduction may be affected by direct axtion of the system operator (temole tripping) after notice to the consumer in accordance with contractual provisions. For example, loads that can be interrupted to fulfill plannins or operation reserve reguirements should be reported as Interruptible Load. Interruptible Load as defined bere axcludes Direct Load Control and Other Load Management. (Interruptible Load, is teported bere, is synonymous with Interruptible Demand 
reported to the North American Electric Reliability Council on the voluntary Office of Energy Emergency Operations Form OE-4]1, "Cootdinated Regional Bulk Power Supply Program Report." with the exception that annual peak load effects are reported on the Form E1A-861 and seasonal (i.e., summer and winter) peak load effects are reported on the OE-411).

KHowett (tw): One thoasand watts.

Kilowatthour (kWh): One thousand watthours.

Leveroge Rotlo: A measure that indicates the financial ability to meet debt service requirements and increase the value of the investment to the stockholders. (i.e. the ratio of total dobt lo total assets).

Llabilty: An anount payable in dolkars or by future services to be rendered.

Light Oil: Lighter fuel oils distilled off during the refining process. Virtually all petroleum used in internal combustion and gas-turbine engines is light oil.

Lignite: A brownish-b]ack coal of low rank with bigh inherent mojsture and volatile matter (used almost exclusively for electric power generation). It is also referred to as brown coal. Comprises two groups classified according to the following ASTM Specification D388-84 for calorific values on a moist material-matter-free basis:

Limits Btu/b.

$\underset{6300}{\text { OE }} \frac{1 T}{8300}$

Load (Electric): The amount of electric power deliv. ered or required at any specific point or points on a system. The requirement originates at the entrgyconsuming equipment of the consumers.

Lood Bulding: Refers to programs that are aimed at increasing the usage of existing electric equipment or the addition of electric equipment. Examples include industrial technologies such as induction heating and melting. direct are furbaces and infrared drying; cooking for commercial establishments; and heat pumps for residences. Load Building should include programs that promote electric fuel substitution. Load Buifding effects should be reported as a negative number, shown with a minus sign.

Marketing Cost: Expenses directy associated with the preparation and implementation of the strategies designed to encourage particlpation in a DSM program. The cattgory oxcludes general market and loat research costs.

Monitoring \& Evaluation Coat: Expenditures associated with the planning. collection, and analyzis of data used to assess program operation and effects. It includes the activities such as load metering, custorter surveys, new technology testing, and program evalu- ations that are intented to establish or improve the ability to monitor and evaluate the impacts of DSM programs, collectively or individually.

Maximom Demend: The greatest of all demands of the load that has occurted within a specified period of time.

Mcf One thousand cubic feet.

Mogowatt (MW): One million watts.

Megawatthour (MWh): One million watthours.

MMef: One million cubic feet.

Natural Gas: A naturally oecurring mixture of hydrocarbon and nonbydrocarbon gases found in porous geological formations beneath the tartb's surface, often is association with pettoleum. The principal constituent is methane.

Net Capability: The maximum Joad-carrying ability of the oquipment, exclusive of station use, under speciffed conditions for a given time interval, independent of the characteristics of the load. (Capability is determined by destign characleristics, physical conditions, adequacy of prime mover, energy supply, and operating limitations such as cooling and circulating water supply and temperature, headwator and tailwater elevations, and electrical use.)

Net Generation: Gross genteration minus plant use from all electric utility owned plants. The energy required for pumping at a pumped-storage plant is regarded as plant use and must be deducted from the gross generation.

Net Sammer Capability: The steady hourly output. which generating equipment is expected to supply to system load exclusive of auxiliary power, as demonstrated by tests at the time of summer peak domand.

Net Winter Copmbility: The steady hourly output which generating equipment is expected to supply to system load exclusive of auxiliay power, as demonstrated by tests at the time of winter peak demand.

New Conatruction: Entrgy-efficiency program promotion to encourage the building of now homes. buildings, and plants to exceed standard governmentmandated energy efficiency codes; it msy include major renovations of existing facilities.

Noncotncidental Peak Lagd: The sum of two or more peak loads on individual systems that do not occur in the same time interval. Meaningful onfly when considering loads within a limited period of time, such as a day, week, month, a heating or cooling season, and usually for not more then 1 yeat.

Non-Firm Power: Power or power-producing capacity supplied or available under a commitment huving línited or no assured availebility.

Nonutility Power Prodncer: A corporation, person, agency, authority, or otber legal entity or 
instrumentalisy that owns electric generating capacity and is not an electric utility. Nonutility power producers include qualifying cogenerators, qualifying small power prodtucers, and other nonutility generators (including independent power producers) witbout a designated franchised service area, and which do not file forms listed in the Code of Federal Regulations, Title 18. Part 141.

North American Electric Reliability Council (NERC): A council formed in 1968 by the electric utility iodustry to promote the reliability and adequacy of bulk power supply in the eleetric atility systems of North America. NERC consists of ten regional reliability councils and encompasses essenlially all the power regional of the contiguous United States, Canada, and Mexico. The NERC Regions are:

ASCC - Alaskan Systea Coordination Counci!

ECAR - East Central Area Reliability Coordination Agreement

ERCOT - Electric Reliability Council of Texas

MAIN - Mid-America Interconnected Network

MAAC - Mid-Atlantic Area Council

MAPP - Mid-Continent Area Power Pool

NPCC - Northeası Power Coordinating Council

SERC - Southeastem Electric Reliability Council

SPP - Soutbwest Power Pool

WSCC - Western Systems Coordinating Council

Noclear Fut: Fissionable materiais that have been enriched to such a composition that, when placed in a nuclear reactor, will support a self-stustaining fission chain reaction, producing heat in a conirolled manner for process use.

Noclear Power Plont: A facility in which heat produced in a reactor by the fissioning of nuclear fuel is used to drive a steam turbine.

Ort-Peak Gas: Oas that is to be delivered and taken on demand when demand is not at its peak.

Ohw: The unit of measurement of electrical resistance. The resistance of a circuit in which a potential difference of 1 volt produces a current of $I$ ampere.

Operable Noclear Unit: A nuclear unit is "operable" after it completes low-power testing and is granted auborization to operate al full powet. This occurs when it receives its full power amendment to its operating license from the Nuclear Regulatory Commission.

Other Cost: A residual category to capture the Indjrect Costs of DSM programs that canoot be meaningfully included in any of the other cost categories listed and deftned hetein. Included are costs such as those incurred in the research and development of DSM technologies.

Other DSM Programs: A residual catcgory to capture the effects of DSM prograpis that cannot be meaningfully included in any of the program categoties listed and defined herein. The energy effects attributable to this category should be the net effects of all the residual programs. Programs that promote cossumer's substitution of electricity by otber energy types should be included in Other DSM Programs. Also, self-generation should be included in Other DSM Programs to the extent that it is not accounted for as backup generation in Other Load Management or Interruptible Load categories.

Other Incentives: Energy Efficiency programs that offer cash or noocash awatds to electric energy efficiency deliverers, such as appliance and equipment dealers, bujlding contractors, and architectural and engineering firms, that encourage consumer partic. jpation in a DSM program and adoption of recommended measures.

Other Load Management: Refers to programs othet thas Direct Load Control and Interraptible Load that limit or shift peak load from on-peak to off-peak time periods. It includes tecbnologies that primarily shift all or part of a toad from one time-of-day to another and secondarily may have an impact on energy consumption. Examples include space heating and water heating storage systems, cool storage systems, and losd limuiting devices in energy management systems. This category also includes programs that aggressively promote time-of-use (TOU) rates and other innovative rates such as teal ttme pricing. These rates are intended to reduce consumer bills and shift hours of operation of equipment from on-peak to off-peak periods through the application of time-differentiated rates.

Outege: The period during which a generating unit, transmission line, or other facility is out of service.

Peak Demand: The maximum load during a specified period of time.

Peak Load Plant: A plant usually housing old, lowefficiency steam units; gas iurbines; diesels; or pumped-storage hydroelectric equipment normally used during the peak-load periods.

Peaking Capacity: Capacity of generating equipment normally reserved for operation during the bours of highesi dajly, weekjy, or seasonal loads. Some generating equipment may be operated at certain times as peaking capacity and at other times to serve loads on an around-the-clock basis.

Percent Difference: The relative change in a quantity over a specified time period. It is calculated as follows: the current value bas the previous value subtracted from it; this new number is divjed by the absolute vatue of the previous value; then this new number is multiplied by 100 .

Petroleum: A mixture of hydrocarbons existing in the liquid state found in natural anderground reservoirs, often associated with gas. Petroleum includes fuel oil No. 2, No. 4, No. 5. No. 6; topped crude; Kerosene; and jet fuel. 
Petroleum Coke: See Coke (Petroleum).

Petroleom (Crude Oil): A naturally occuring, oily, flanmable liquid composed principally of bydrocarboes. Crudo oil is occasionally found in springs or pools but usually is drilled from wells beneatb the earth's surface.

Planned Generator: A proposal by a company to install electric generating equipment at an exjsting of planned facility or site. The proposal is based on the owner having obtained (1) all environmental and reg. ulatory approvals, (2) a signed contract for the electric energy. or (3) financial closure for the facility.

Plant: A facility at which are located prime movers, electrtc generators, and auxiliary equipment tor converting mechanical, chemical, and/or nuclear energy into electric energy. A plant may contain more than one type of prime mover. Electric utility plants exclude facilities that satisfy the definition of a qualifying factility under the Public Utility Regulatory Policjes Act of 1978 .

Plant Use: The electric energy used in the operation of a plant. Included in this definition is the energy required for pumping at purnped-storage plants.

Plant-Use Electricity: The electric energy psed in the operation of a plant. This energy total is sublracled from the gross energy production of the plant; for reporting purposes the plant energy production is then reported as a net figure. The energy required for pumping at pumped-storage plants is, by definition, subtracted, and the energy prodpction for these plants is then reported as a net figure.

Potential Peak Reduction: The potential annual peak load reduction (measured jn kilowatts) that can be deployed from Direct Load Control, Interruptible Load, Other Load Management, and Other DSM Program activities. It represents the load that can be reduced either by the direct controt of the ntility system operator or by the consumer in response to a utility request to curtajl load. It reflects the installed load Jeduction capability, as opposed to the Actual Peak Reduction achieved by participants, during the time of annual system peak load.

Power: The rate at which energy is transferred. Electrical energy is usually measured in watts. Also used for a measurement of capacity.

Power Pool: An association of two or more interconnected electric syslems having an agreement to coordinate operations and planuing for improved reliability and efficiencies.

Power Marketers: Power marketers are business entitjes engaged in buying and sellibg electricity, but do not ow gentratiog or transmission facilities. Power marketers, as opposed to Brokers, take owner. ship of the electricity and are involved in interstate trade. These entities file with FERC for status as a power matketer.
Price: The amount of money or consideration-inkind for which a service is bought, sold, or offered for sale.

Prime Mover: The engine, turbine, water wheel, or similar machine that drives an electric generator; or, for reporting purposes, a device that converts enersy to elextricity directly (e.g., photovoltaic solar and fuel cell(s)).

Process Heating: Energy Efficiency prograsn promotion of increasted electric energy efficiency applications in industrial process heatiog.

Profft: The income remaining after all business expenses are paid.

Public Authority Service to Pnblic Authorities: Public anthority service includes electricity supplied and services rendered to municipalities or divisions or agencies of State or Federal governments, under special contracts or agreements or service classtfications applicable only to public authorities.

Public Street and Highway Lighting: Public street and highway lighting includes electricity supplied and services rendered for the purposes of lighting streets, bighways, parks, and other public places; or for traffic or other signal system service, for municipalities, or other divisions or agencies of Slate or Federal governments.

Pumped-Storage Hydroelectric Plant: A plant that usually generates electric energy during peak-load periods by using water previously pumped into an televated storage reservoir during off-peak periods when excess generating capacity is available to do so. When additional generatiag capacity is needed, the water can be released from the reservoir through a conduil to turbine generators located in a power plant at a lower level.

Porchased Power Adjustment: A clause in a rate schodule that provides for adjustments to the bill whes energy from another electric system is acquired and it varies from a specified unit base amount.

Phre Pumped-Storage Hydroelectric Plant: A plas: that produces power only from water that has previously been pumped to an upper reservoir.

Qualifying Factlity (QF): A cogeneration or small power prodnction tacility thal meets certain ownership, operation, and effreiency criteria establisted by the Federal Energy Regulatory Commission (FERC) pursuant to the Public Utility Rogulatory Policies Act (PURPA). (See the Code of Federal Regulations, Title 18, Part 292.) Part 292.

Rallroad and Raliway Services: Railroad and railway services include electricity supplied and services rendered to railroads and interurban and stret railways, for general reilroad use, including the propulsion of cars or locomotives, where stch electricity is stupplied under separate and distinct rate schedules. 
Rate Base: The value of property upos which a utility is permitted to earn a specified rate of returo as established by a regulatory authority. The rate base generally represents the value of property used by ate utility in providing service and may be calculated by any one or a combination of the following accounting methods: fair value, prudent investment, reproduction cost, of original cost. Depending on which method is used, the rate base includes cash, working capital, materials and supplies, and deductions for accumulated provisions for depreciation, contributions in aid of construction, customer advances for construction. accumulated deferred income taxes, and accumglated doferred investment lax credits.

Rateralyng Anthority: A utility comunission's legat authority to fix, modify, approve, or disapprove rates, as determined by the powers given the commission by * State or Federai legislature.

Recelpts: Purchases of fuel.

Regulation: The governmental function of controlling or directing economic entities through the process of rulenaking and adjudication.

Reserve Margin (Opernting): The amount of unused available capability of an electric power system at peak load for a utility system as a percentage of total espability.

Residential: The residential sector is defized as private housebold establishments which consume energy primarily for space heating, water heating, eir conditioning, lighting, refrigeration, cooking and clothes drying. The classification of an individual consumer's account, where the use is both residentis] and comretcial, is based on principal oste. For the residential class, do not dupticate consumer accounts due to multiple metering for special services (water, heating, elc.). Apartment houses are also included.

Residual Foel Oil: The topped coude of refinery operation, includes No. 5 and No. 6 fuel oils as defined in ASTM Specification D396 and Foderel Specification VV-F-815C; Navy Special fuel oil as defined in Miljtary Specification MIL-F-85\%E including Amendment 2 (NATO Symbol F-77); and Bunker C fuel oil. Rerjidual fuel oil is used for the production of electric power, space heating. vessel bunkering, and various industrial purposes. Imports of residual fuel oil include imported crude otl burned as fuel.

Restructed-Universe Census: This ts the complete enumeration of data from a specifically defined subset of entities including, for example, those that txceed a tiven level of sales or genterator nameplate capacity.

Retall: Sales covering electrical energy supplied for residential, commercial, and industrial end-use purposes. Other small classes, such as agriculture and street lighting, also are included in this category.

Revenue: The cotal amount of money received by a firm from sales of its products and/or services, gains from the sales or exchange of assets, interest and divi- dends earned on investments, and other increases in the owner's equity except those arising from capital adjustments.

Running and Qualck-Start Capability: The aet capability of generating units that carry load or have quick-start cspability. In general, quick-start capability refers to generating units that can be available for load within a 30-minute pertiod.

Sales: The amount of kilowatthonrs sold in a given period of time; ustaliy grouped by classes of service, such as residential, commercial, industrial, and otber. Other sales include public street and highway lighting, other sales to public authorities and tajiways, and interdepartmental sales.

Sales for Regale: Energy supplied to other olectric utilities, cooperatives, municipalities, and Federal and State electric agencies for resale to ultimate consumers.

Schedoled Outage: The shutdown of a kenerating unit, transmission line, or other facility, for inspection or majntenance, in accordance with an advance schedule.

Short Ton: A unit of weight equal to 2,000 pounds.

Small Power Prodncer (SPP): Under the Public Utility Regulatory Policies Act (PURPA), a snall power production facility (or small power producer) generates electricity using waste, renewable (water, wind and solar), or geothermal entergy as a primary energy source. Fossil fuels can be used, but renewable resource must provide at least 75 percent of the total energy input. (See Code of Federal Regulations, Title 18, Part 292.)

Spinoing Reservet That reserve generating capacity running at a zero load and synchronized to the electric system.

Spot Perchases: A single shipment of fuel or volumes of fuel, purchased for delivery within 1 year. Spot purchases are often mado by a user to fulfill a certain portion of energy requirements, to meet unanticipated energy needs, or to take advantage of lowfuel prices.

Stability: The property of a system or element by virtue of which its output will ultimately attain a steady state. The amount of power thet can be transferred from one machine to another following a dis. turbance. The stability of a power system is its ability to develop restoring forces equal to or greater than the disturbing forces so $2 s$ to maintain a state of equilibrium.

Standard Industrial Clasaifleation (SIC): A set of codes developed by the Office of Mapatement and Budget. which categorizes business into groups with similar econoric activities.

Standby Focllity: A facility that suppotts otility systen and is generally running under no-load. It is 
avatilabte to replace or supplement a facility rormally in service.

Standby Service: Support service that is availatle, as beeded, to supplement a consomer, a vtility system, or to another utility if a schedule or an agreement authorizes the transaction. The service is not regularly used.

Steam-Electric Plant (Conventional): A plant in which the prime mover is a steam turbine. The steam used to drive the turbine is produced in a boiler where fossil fuels are burned.

Stocks: A supply of fuel accumulated for future ust. This includes coal and fuel oil stocks at the plant site, in coal cars, tanks, or barges at the plant site, or at separate storage sites.

Subbituminous Cos: Subbituminous coal, or black lignite, is dull black and generally contains 20 to 30 percent moisture. The heat content of subbitominous coal ranges from 16 to 24 miltion Btu per ton as received and averages about 18 million Btu per ton. Subbituninous coal, mined in the western coal fields, is used for generating electricity and space beating.

Substation: Facility equipment that switches. changes, or regulates olectric voltage.

Sulfinr: One of the elements present in varying quantities in coal which contributes to environmentel degradation when coel is burned. In terms of sulfur content by weight, coal is genejally classifjed as low (less than or equal to 1 percent), medium (greater than 1 percent and less than or equal to 3 percent), and high (greater than 3 percent). Sulfur content is meastred as a percent by weight of coal on an "as received" or a "dry" (moisture-free, usually part of a laboratory analysis) basis.

Switching Station: Facility equjpment used to tie logether two or more electric circuits through switches. The switches are selectively arranged to permit a circuit to be disconnected, or to change the electric connection between the circuits.

System (Electric): Physically connected generation, transmission, and distribution facilities operated as an integrated unit under one central managethent, or operating supervision.

Total DSM Cost: Refers to the sum of total utility cost and bontutility cost.

Total DSM Programs: Refers to the total net effects of all the uttlity's DSM programs. For the purpose of this survey, it is the sum of the effects for Energy Effitioncy, Direct Load Control. Interruptible Load, Other Load Management, Other DSM Programs, and Load Building. Net growth in energy or load effects should be reported as a negative number, shown with 2 minus signt.

Total Nonutllity Cost: Refers to total cash expeadjtures incurred by consumers and trade allies that are associated with participation in a DSM program, but that are not remobursed by the utility. The noututility expenditures should include only those additional costs necessary to purchase or instatl an efficient measure relative to a less efficient one. Costs are to be reported in nominal dollars in the year in which they are incumed, regardless of when the actual effects occur. To the extent possible, provide the best estimate of nonutility costs if actual costs are uravail. able.

Total Utility Cost: Refers to the sum of the total Direct and Indirect Utility Costs for the year. Utility costs stould reflect the total cash expenditures for the year, reported in uominal doltars, that flowed ont to suppott DSM programs. They should be reported in the year they are incurred, regardless of when the actual effects occur.

Transformer: An electrical device for changing the voltage of alternating current.

Transmission: The movement or transfer of electric ebergy over an interconnected group of lines aud associated exujpment between points of supply and points at which it is transformed for delivery to consumers, or is delivered to other electric systems. Transmission is considered to end when the energy is transformed for distribution to the consumer.

Transmission System (Electric): An interconnected group of olectric transmission lines and associated equiputent for moving or transferring electric energy in bulk between points of supply and points at which it is transformed for delivery over the distribution system lines to consumers, or is delivered to other jectric systems.

Turbize: A machine for generating rotary mechanical power from the energy of a stream of fluid (such as water, steam, or bot gas). Turbines convert the kinetic energy of fluids to mechanical energy through the principles of impulse and reaction, or a mixture of the two.

Uniform Systen of Acconnts: Prescribed financial rales and recullations established by the Federal Energy Regulatory Commission for utílities subject to its jurisdiction under the authority granted by the Federal Power Act.

Useful Thermal Outpat: The thermal energy made available for use in any industrial or commercial process, or used in any healing or cooling application, i.e., total thetan enetgy made avajlable for processes and applications other than electrical generation.

Utitty-Earned Incentives: Costs in the form of incentives paid to the utility for achievement in consumer participation in DSM programs. These financial incentives are intended to influence the utility's consideration of DSM as a resource option by addressing cost recovery, lost revenue, and profitability.

Voltage Reduction: Any intentional reduction of system voltage by 3 percent or greater for reasons of maintaining the continuity of service of the bulk electric power supply system. 
Water Heating: Energy Efficiency program promolion to increase efficioncy in water heating. including low-flow shower heads and water heater insulation wraps. Cottd be applicable to residential, contmercial, or industria] consumer sectors.

Watt: The electrical unit of power. The rate of energy transfer equivalent to 1 ampere flowing onder a pressure of 1 volt at unity power factor.

Watthonr (Wh): An electrical energy unit of measure equal to 1 watt of power supplied to, or taken from, an elestric citcuit steadily for 1 hour.
Wheeling Service: The movement of electricity from one system to another over transmission facilities of intervening systems. Wheeling service contracts can be established between two or more systems.

Wholesele Soles: Energy supplied to other electric utilities, cooperatives, municipals, and Federa! and State electric agencies for resale to ultimate con. sumers. 